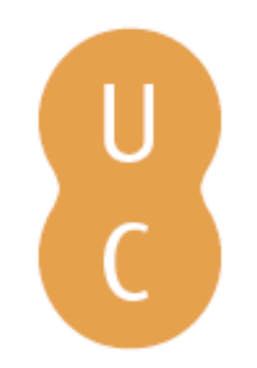

\title{
pommalina
}

\section{Nomos, Kosmos \& Dike in Plutarch}

$\begin{array}{ll}\text { Autor(es): } \quad \text { Ferreira, José Ribeiro, coord.; Leão, Delfim F., coord.; Jesus, Carlos A. } & \text { Martins de, coord. }\end{array}$

Publicado por: Imprensa da Universidade de Coimbra

URL

persistente: URI:http://hdl.handle.net/10316.2/32868

DOI: $\quad$ DOI:http://dx.doi.org/10.14195/978-989-721-012-9

Accessed : $\quad$ 26-Apr-2023 08:06:03

A navegação consulta e descarregamento dos títulos inseridos nas Bibliotecas Digitais UC Digitalis, UC Pombalina e UC Impactum, pressupõem a aceitação plena e sem reservas dos Termos e Condições de Uso destas Bibliotecas Digitais, disponíveis em https://digitalis.uc.pt/pt-pt/termos.

Conforme exposto nos referidos Termos e Condições de Uso, o descarregamento de títulos de acesso restrito requer uma licença válida de autorização devendo o utilizador aceder ao(s) documento(s) a partir de um endereço de IP da instituição detentora da supramencionada licença.

Ao utilizador é apenas permitido o descarregamento para uso pessoal, pelo que o emprego do(s) título(s) descarregado(s) para outro fim, designadamente comercial, carece de autorização do respetivo autor ou editor da obra.

Na medida em que todas as obras da UC Digitalis se encontram protegidas pelo Código do Direito de Autor e Direitos Conexos e demais legislação aplicável, toda a cópia, parcial ou total, deste documento, nos casos em que é legalmente admitida, deverá conter ou fazer-se acompanhar por este aviso.

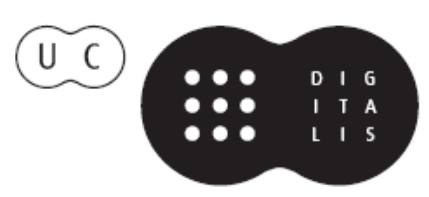




\section{Nomos, Kosmos \& Dike in Plutarch}

José Ribeiro Ferreira, Delfim F. Leão \& Carlos A. Martins de Jesus (eds.) 
(Página deixada propositadamente em branco) 


\section{Nomos, Kosmos \& Dike in Plutarch}

José Ribeiro Ferreira, Delfim F. Leão

\& Carlos A. Martins de Jesus (eds.) 
Each volume in this series is first submitted to a panel of independent referees.

\section{EDITORS}

José Ribeiro Ferreira, Delfim F. Leão \& Carlos A. Martins de Jesus

Tithe

Nomos, Kosmos E Dike in Plutarch

Publisher

Imprensa da Universidade de Coimbra

Centro de Estudos Clássicos e Humanísticos da Universidade de Coimbra (1 $\left.1^{\text {st ed. }} / 2012\right)$

Academic Co-ordinator

Maria do Céu Fialho

EDITORIAL BOARD

José Ribeiro Ferreira, Maria de Fátima Silva, Francisco de Oliveira and Nair Castro Soares

Technical Director of the Collection

Delfim F. Leão

DESIGN

Rodolfo Lopes, Nelson Ferreira

\section{Printed BY}

Simões \& Linhares, Lda. Av. Fernando Namora, n. ${ }^{\circ} 83$ Loja 4. 3000 Coimbra

ISBN: 978-989-721-011-2

Digital ISBN: 978-989-721-012-9

Legal Deposit: $365274 / 13$

DOI: http://dx.doi.org/10.14195/978-989-721-012-9

(C) IMPRENSA DA UNIVERSIDADE DE COIMBRA

CCentro de Estudos Clássicos e Humanísticos da Universidade de Coimbra

(C) Classica Digitalia Vniversitatis Conimbrigensis (http://classicadigitalia.uc.pt)

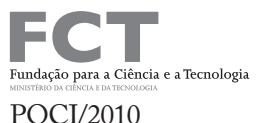

All rights reserved. No part of this publication may be reproduced, stored in a retrieval system, or transmitted, in any form or by any means, electronic, photocopying, or otherwise, without the written permission of the publisher, except for educational purposes, namely e-learning environments. 


\section{CONTENTS}

Preface

Delfim F. Leão (Universidade de Coimbra)

\section{STATESMEN AND LAWGIVERS}

NOMO $\Sigma$ como criterio de valoración ética en las Vidas Paralelas

Aurelio Pérez Jiménez (Universidad de Málaga)

Pericles, cun modelo de $\triangle \mathrm{IKAIO \Sigma YNH}$ ?

Mónica Durán Mañas (Universidad Complutense de Madrid)

O sentido de dike nas biografias de Aristides e Catão Censor

Joaquim Pinheiro (Universidade da Madeira)

Plutarco y su interpretación de algunas leyes griegas

concernientes a la familia y propiedad

Inés Calero Secall (Universidad de Málaga)

Political reforms in the Lives of Lycurgus and Numa: divine revelation or political lie?

Ália Rodrigues (Universidade de Coimbra)

\section{NoMOS AND KOSMOS}

Kosmos and its derivatives in the Plutarchan works on love

Carlos A. Martins de Jesus (Universidade de Coimbra)

Nomos e kosmos na caracterização do António e da Cleópatra de Plutarco

Nuno Simões Rodrigues (Universidade de Lisboa)

The Daimon in Timarchus' Cosmic Vision (Plu. De Genio Socr. 22, 590B-592E)

Aldo Setaioli (Università degli Studi di Perugia)

Un nomos atopos? Gli Efori e i baffi degli Spartani. Nota esegetica a De sera num. vind. 4.550B

Stefano Amendola (Università degli Studi di Salerno) 


\section{THE PATH TO DIKE}

La nozione di giustizia nel suo sviluppo storico: la giustizia come valore primario del pensiero etico e politico di Plutarco

Francesco Becchi (Università degli Studi di Firenze)

La giustizia del saggio: una polemica di Plutarco contro gli Stoici

Paola Volpe Cacciatore (Università degli Studi di Salerno)

Dike y otras deidades justicieras en la obra de Plutarco

Miguel Herrero de Jáuregui (Universidad Complutense de Madrid)

La giustizia nel Grillo e la conclusione del dialogo

Angelo Casanova (Università degli Studi di Firenze)

Animali parlanti e giustizia in Plutarco ed Omero

Marcello Tozza (Universidad de Málaga)

\section{CONCEPTUAL TENSIONS AND JUSTICE IN THE AFTERLIFE}

Eunomia in heaven and on earth. Plutarch's nomos between rhetoric and science

Luc Van der Stockt (Katholieke Universiteit Leuven)

Ordre et désordre dans la pensée de Plutarque. Réseaux lexicaux et problématiques philosophiques autour de

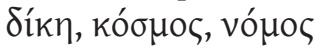

Françoise Frazier (Université de Paris Ouest - Nanterre La Défense)

Jueces, premios y castigos en el Más Allá de Plutarco

Ana Isabel Jiménez San Cristóbal (Universidad Complutense de Madrid) 


\section{PREFACE}

In September 2002, the University of Coimbra hosted, for the first time, a conference of the Réseau Thématique Plutarque, a research network created by several European universities in order to promote regular annual meetings of junior and senior scholars who share a common interest in Plutarch's work. The Coimbra meeting of 2002 was devoted to the fragments of Plutarch, and the results of that event were published one year later, in a volume edited by José Ribeiro Ferreira and Delfim Leão, under the title Os fragmentos de Plutarco e a recepção da sua obra (Coimbra, 2003). During the following years, many other universities organized conferences of the Réseau on a rotating basis, until the event came back to Coimbra, where the Portuguese section of the International Plutarch Society (SoPlutarco) hosted, from 16 to 18 June 2011, the twelfth meeting of the network, devoted this time to the subject "Nomos, kosmos and dike in Plutarch".

The present volume comprises most of the contributions presented during the Coimbra meeting, after having been submitted to a process of revision, which involved the direct collaboration of the several regional sections of the Réseau. Although the volume kept the multilingual diversity of the participants in the conference, its structuring elements were composed in English, in order to reinforce the coherence of the book and to enlarge the number of potential readers.

In its final form, the volume is organized in four different sections. The first one is devoted to statesmen and lawgivers, and comprises five contributions. Aurelio Pérez Jiménez (Málaga), in "Nomos como criterio de valoración ética en las Vidas Paralelas", explores the concepts of law and justice as literary expedients, used by Plutarch to highlight the virtuous or despotic character of such legislators as Lycurgus, Numa and Solon. Mónica Durán Mañas (Madrid), in "Pericles, cuun modelo de dikaiosyne?", discusses the ambivalent interpretation of the term dikaiosyne, with a particular focus 
on the Life of Pericles. Joaquim Pinheiro (Madeira), in "O sentido de dike nas biografias de Aristides e Catão Censor", analyzes the idea of dike (and other terms with the same etymological root, especially dikaiosyne) in the shaping of Aristides' and Cato's ethos, considering their respective roles as individual citizens and as members of a wider community. Inés Calero Secall (Málaga), in her study "Plutarco y su interpretación de algunas leyes griegas concernientes a la familia y propiedad", discusses the part of Solon's legislation that deals with family affairs and with damages inflicted by animals, suggesting that Plutarch's mistakes in interpreting them are due to a lack of chronological or juridical accuracy. Ália Rodrigues (Coimbra), in "Political reforms in the Lives of Lycurgus and Numa: divine revelation or political lie?", examines the way the topos of divine inspiration is used by Plutarch in the presentation of the legislative activity of Lycurgus and Numa (a trait also detectable in the tradition of personalities like Minos, Zaleucus and Zoroaster), concluding that they correspond to an artificial way of legitimating authority rather than to a genuine expression of divine intervention.

The second section is dedicated to the relation between nomos and kosmos. Carlos A. Martins de Jesus (Coimbra) devotes his study "Kosmos and its derivatives in the Plutarchan works on love" to the different meanings of kosmos (and other etymologically related terms), seeking to reach an integrated understanding of them in Plutarch's works dealing more directly with love. Nuno Simões Rodrigues (Lisboa), in "Nomos e kosmos na caracterização do António e da Cleópatra de Plutarco", analyzes the way the characterization of Mark Antony and Cleopatra is reflected in the reluctance to use words related with law and order throughout this biography. Aldo Setaioli (Perugia), in "The daimon in Timarchus' cosmic vision (Plu. De Genio Socr. 22, 590B-592E)”, examines Plutarch's efforts to harmonize the different perspectives of Plato concerning the personal daimon, in a way that foreshadows later developments unfolding in Plotinus. Finally, Stefano Amendola (Salerno), in his study "Un nomos atopos? Gli Efori e i baffi degli Spartani. Nota esegetica a De sera num. vind. $4.550 \mathrm{~B}$ ", analyzes an 'atypical law' concerning the Spartan Ephors by applying an exegetic approach to this passage in comparison with two other fragments (Aristotle fr. 539 Rose and Plu. fr. 90 Sandbach).

The third section is organized under the topic of the path to Dike. Francesco Becchi (Firenze), with the paper "La nozione di giustizia nel suo sviluppo storico: la giustizia come valore primario del pensiero etico e politico di Plutarco", studies the ideal of justice, a principle that is present in Greek thought since Homer, and finds its most elaborated expression in Plato and Aristotle, whose doctrines are interpreted by Plutarch, through the lens of modern Stoicism and posterior Aristotelianism, in order to present dike as one of the most perfect virtues and highest expressions of humanity. Paola Volpe 
Cacciatore (Salerno), in "La giustizia del saggio: una polemica di Plutarco contro gli Stoici", discusses as well the virtues of justice and their interpretation by Plutarch (especially in fragments 35-35 Sandbach), in comparison with Plato, Aristotle, and Stoic philosophy. Miguel Herrero de Jáuregui (Madrid), in "Dike y otras deidades justicieras en la obra de Plutarco", analyses the use of Greek divinities that personify the idea of justice throughout Plutarch's œuvre (mainly in the Lives), especially those who are perceived as dynameis of divine origin personified as daimones (such as Erinis, Poine, Nemesis and Dike). Angelo Casanova (Firenze), in "La giustizia nel Grillo e la conclusione del dialogo", argues that the absence of a section on justice in this dialogue is not necessarily a sign that it is incomplete, suggesting on the contrary that it may have been planned and written with this structure in mind. Marcello Tozza (Málaga), in "Animali parlanti e giustizia in Plutarco ed Omero", examines the way the Homeric poems are used by Plutarch, in the dialogue Bruta animalia ratione uti, as an ironic device to place animals above men (from a physical, ethical and rational perspective).

The last section of the volume is devoted to the topic of conceptual tensions and justice in the afterlife. Luc Van der Stockt (Leuven), in "Eunomia in heaven and on earth. Plutarch's nomos between rhetoric and science”, analyzes how the Platonist Plutarch uses the rhetorical concept of persuasion in order to express the god's creation of the harmonious cosmos as a result of the way divine persuasion overcame the laws of nature. Françoise Frazier (Paris Ouest - Nanterre), in her study "Ordre et désordre dans la pensée de Plutarque.

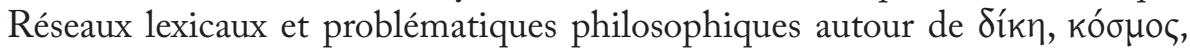
vónos", explores the concepts of dike, kosmos and nomos (together with their opposites and other related terms) as a background to discuss Plutarch's own ideas on Dike and Theodicy, as well as his perspectives on the good political order and the good ruler. Finally, Ana Isabel Jiménez San Cristóbal (Madrid), in "Jueces, premios y castigos en el Más Allá de Plutarco", examines the motifs and traditional background on which Plutarch may have based his imagery when depicting the implementation of the idea of justice in the netherworld.

The volume also includes a final Index Locorum, structured in English, despite the multilingual nature of the studies presented. This demanding work was performed by Carlos de Jesus, who is also responsible for most of the editing process.

Special thanks are also due to José Ribeiro Ferreira, former Director of the Portuguese section of the International Plutarch Society (SoPlutarco), and to Maria do Céu Fialho, Coordinator of the Centre of Classical and Humanistic Studies, without whose support it would not have been possible to organize the XII International Conference of the Réseau Thématique Plutarque. Our gratitude also goes to the Editorial Board of Classica Digitalia and to 
Nelson Ferreira and Rodolfo Lopes, who made possible the publication of the book, as well to Manuel Tröster for his advice in revising the English of the global structure of the volume.

Coimbra, October 2012

Delfim Leão

Director of the Portuguese section of the International Plutarch Society 


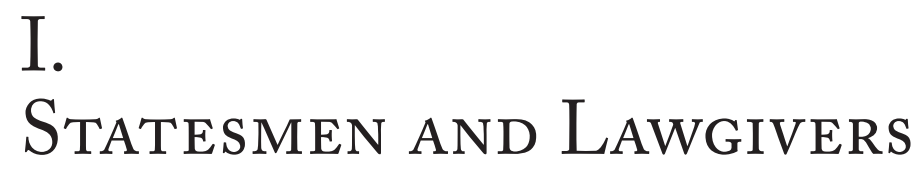


(Página deixada propositadamente em branco) 


\title{
NOMO $\Sigma$ COMO CRITERIO DE VALORACIÓN ÉTICA EN LAS VIDAS \\ PARALELAS
}

\author{
Aurelio Pérez Jiménez \\ Universidad de Málaga
}

\begin{abstract}
Law and justice in Plutarch are not only philosophical or technical concepts, but also literary expedients. Sometimes the political behaviour of Plutarch's heroes moves on the border between law and convenience. It is in these situations that Plutarch uses vó $\mu$ o the virtues or the despotical nature of his characters. In this paper we try to clarify the nature of legislative activity by men such as Lycurgus, Numa, or Solon as well as the circumstances in

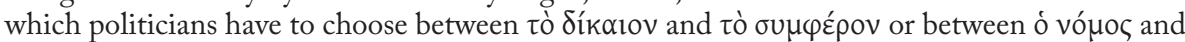
other unavowable interests, according to Plutarch's biographical design of these figures.
\end{abstract}

Cuando Solón estaba ocupado en la redacción de sus leyes, Anacarsis, de paso por Atenas, acudió a su puerta con la intención de trabar amistad con él. Ante la insistencia del sabio, Solón lo recibió y su encuentro se ha hecho célebre, no sólo como ejemplo de la polémica sobre la eficacia de la norma oral frente a la escrita, sino también porque evidencia el carácter práctico del legislador ateniense:

Pues bien, Anacarsis, al enterarse de ello, se reía del empeño de Solón, porque intentaba frenar las injusticias y abusos de los ciudadanos con letras que en nada se diferencian de las telas de araña, sino que, como aquéllas, de los que caen, aprisionan a los débiles y pequeños; pero son rotas por los poderosos y ricos. A esto, dicen, Solón respondió que los hombres respetan los pactos cuando para ninguna de las dos partes contratantes es ventajoso violarlos y que él estaba ajustando las leyes a los ciudadanos de tal modo que les demostraba que era mejor para todos actuar con justicia que en contra de la ley (Sol. 5.4-5).

La anécdota, que se ha convertido en un tema recurrente en la tradición literaria occidental y que ha dejado ejemplos muy bellos en la emblemática europea de los siglos XVI-XVII, es una buena presentación para este trabajo nuestro, en el que nos proponemos ilustrar cómo vó $\mu$ o es con cierta frecuencia en las Vidas Paralelas un expediente para la caracterización biográfica. En el caso que hemos referido, el relativismo de las leyes, ajustadas a la conducta del hombre y no a una idea platónica de justicia política, evidencia tal vez la ingenuidad de un personaje en general bien valorado por el biógrafo. La opinión de éste es concluyente: 
Pero el resultado fue más como conjeturó Anacarsis que según las esperanzas de Solón (5.6).

No es el único caso en que Plutarco señala la insuficiencia de la legislación política en su conjunto y de las leyes concretas cuando su vocación de futuro no trasciende los intereses privados del legislador o las tendencias de aquellos a los que han de aplicarse, sin ajustarse a principios absolutos, como puedan ser la justicia, el bien común o la verdad ${ }^{1}$.

Y no faltan, por cierto, reflexiones teóricas sobre la importancia, la aplicabilidad y las limitaciones de la ley política, que es la que aquí nos interesa. En la Vida de Rómulo leemos, por ejemplo, que cuanto los hombres dignifican o controlan por ley se opone a los bienes necesarios y a las leyes de la naturaleza ${ }^{2}$; y se da por sentado que, para el progreso metafísico de los hombres hacia la divinidad, no juega ningún papel la ley, enfrentada en este caso a la verdad ${ }^{3}$.

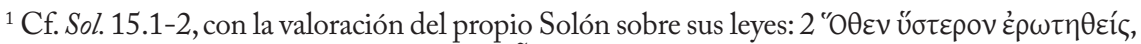

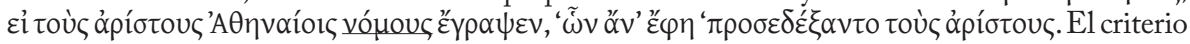
de adecuación a los ciudadanos se indica en diversos lugares, relacionados con las leyes concretas

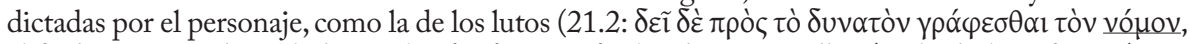

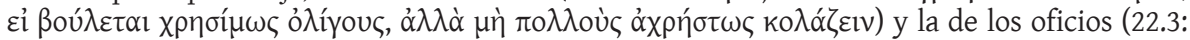

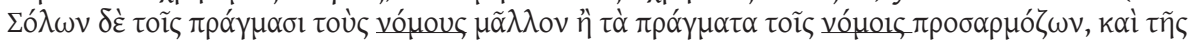

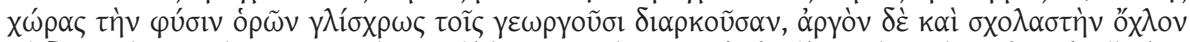

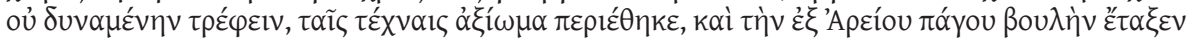

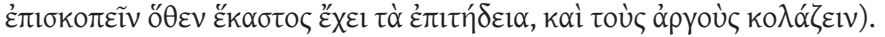

${ }^{2}$ En Rom. 11.2, en el comitium depositan los romanos los principios de las cosas que son

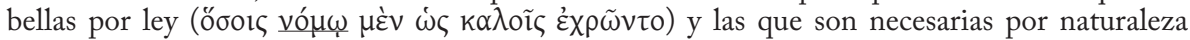

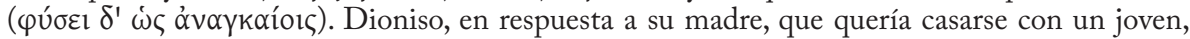
reconoce que él, como tirano, ha disuelto las leyes de la ciudad, pero no puede hacer lo mismo con las de la naturaleza (Sol. 20.7). También Temístocles se hace eco de esta diferencia cuando distingue entre las leyes distintas de los pueblos, que consideran bellas cuestiones diferentes y lo que todos consideran bello, como es, en este caso, el principio de conservación de lo propio

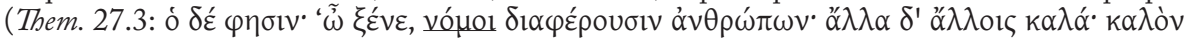

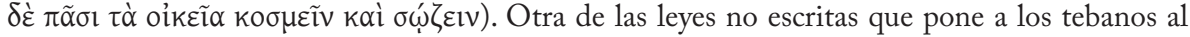
servicio de Pelópidas es la que hace que un pueblo que necesita ser salvado se someta al que

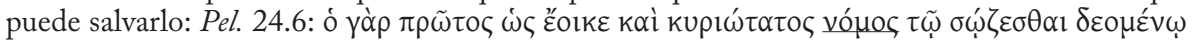

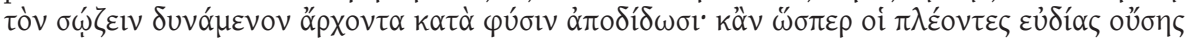

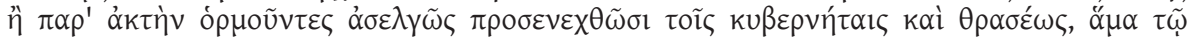

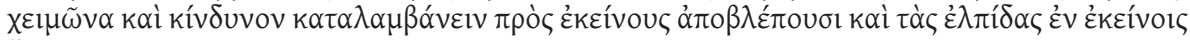

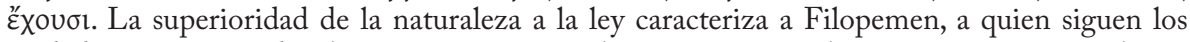
ciudadanos en su ayuda a los mesenios por ser el mejor por naturaleza y sin esperar a que lo sea

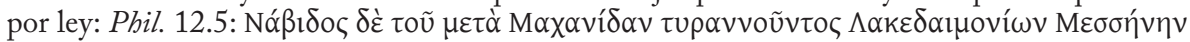

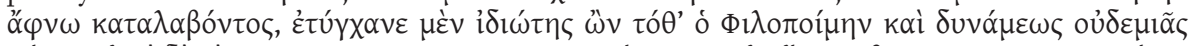

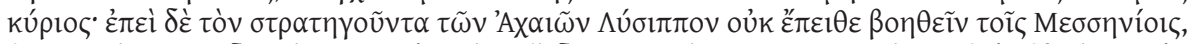

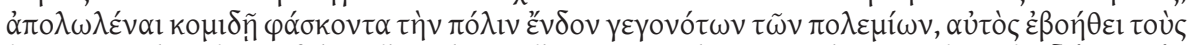

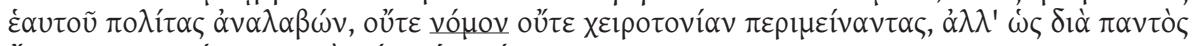

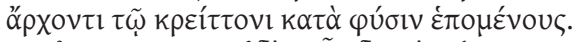

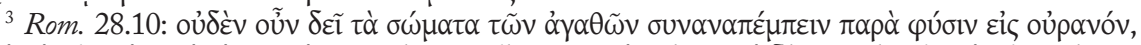

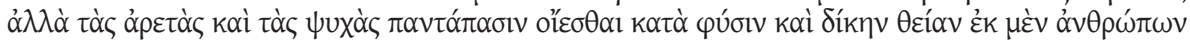

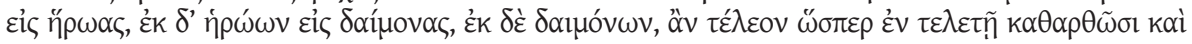


Pero la alta consideración en que tiene Plutarco la ley como fundamento de cohesión social se manifiesta no sólo en los casos concretos de actuación de los personajes, que le hacen reflexionar sobre su sometimiento a las leyes (cf. Cic., 13.1), sino también cuando se asocia la ley a la justicia, la más divina de las virtudes humanas. A este respecto, es significativo el pasaje del Demetrio y de otros lugares de Moralia donde se reivindica la expresión pindárica sobre la ley reina de todo ${ }^{4}$, así como las opiniones de los sabios recogidas en el Septem Sapientium convivium 5 .

Que la ley es condición para el orden público, es un principio asumido por Plutarco, que la asocia, de acuerdo con la doctrina del ateniense en las Leyes de Platón, a la justicia y al interés público ${ }^{6}$, dos referentes continuos en la valoración ética de las Vidas Paralelas. Ahora bien, si en el diálogo platónico la rectitud de la ley depende de que se dicte pensando en el bien común, para Plutarco la justicia es el objetivo de la ley y, ésta, tarea del gobernante, como se dice en Ad princ. ind. $780 \mathrm{E}^{7}$, con lo que la ley se convierte en un expediente biográfico de primer orden. La actitud de los personajes ante ella y ante el conflicto entre el binomio ley/ justicia e interés público, prioridad del buen político, ofrecen un campo extraordinariamente rico de análisis moral del que Plutarco no se desentiende en sus relatos biográficos ${ }^{8}$.

Pasando ya al terreno estrictamente biográfico, hay que hacer una distinción entre los personajes cuya actividad es en esencia legislativa y aquellos otros más comprometidos en las luchas políticas de sus pueblos.

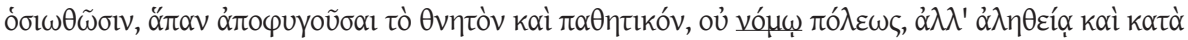

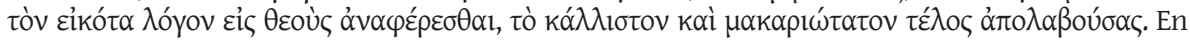
otro ejemplo, esta vez de Dión, vuelve a oponerse la ley, que fija poder vengarse antes que ser el primero en ofender, a la naturaleza que identifica como debilidad ambas actitudes: Dio 47.8: ci $\delta$ '

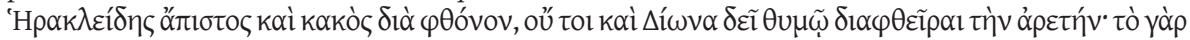

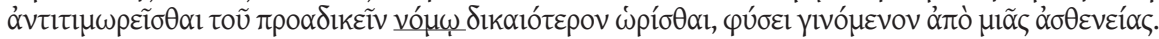

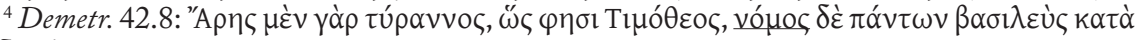
Пívઈapóv. Cf. Ad princ. ind. $780 \mathrm{C}$.

${ }^{5}$ Por ejemplo, Bías considera la mejor democracia aquella en la que los ciudadanos temen

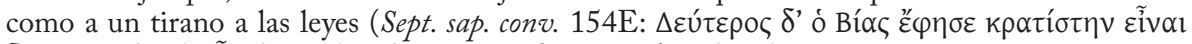

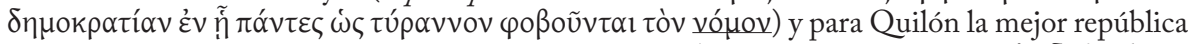

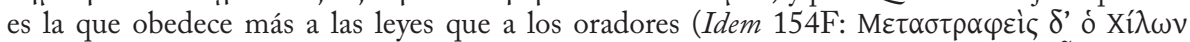

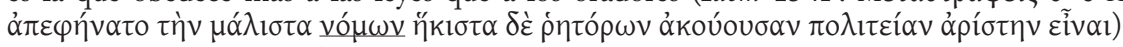

${ }^{6}$ Praec. ger. reip. 808A 9, donde los tres figuran como los principios que ponen límite a los

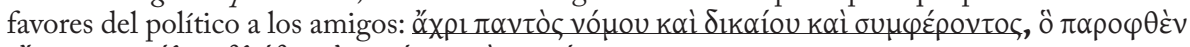

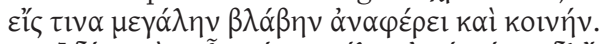

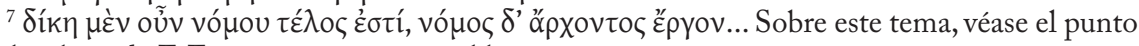
2 del trabajo de F. Frazier en este mismo libro.

${ }^{8}$ Remitimos al reciente trabajo de J. R. Ferreira 2011, que maneja otros conceptos complementarios del héroe respetuoso con la legalidad (en este caso Catón el Joven) como es la educación y la afabilidad. 
Lógicamente, en el caso de los legisladores, la naturaleza de las leyes y la importancia que el personaje concede a ciertos aspectos de aquellas dice mucho sobre su personalidad. En este punto, Plutarco es claro sobre sus preferencias: aunque tanto Licurgo, como Solón y Numa encarnan la imagen del buen político que se ajusta a las condiciones propuestas por Platón en la República el Queronense se inclina más a favor del espartano, que inculcó las leyes en su pueblo mediante la educación, que de los otros $\operatorname{dos}^{10} ;$ a estos les critica, de forma más o menos explícita, que trataran de ligar a los ciudadanos con leyes escritas, como ya hemos visto, sobre el primero, en la anécdota de Anacarsis. En este caso, el carácter práctico y utilitario de Solón, evidente desde el comienzo de la biografía, queda reflejado en sus leyes: las acomoda a los intereses privados de los ciudadanos, buscando un respeto que se basa en el interés de aquéllos y no en el de la ciudad en su conjunto; y la insistencia en aspectos sociales y económicos, sin contar los políticos, que regulan, denota ese carácter práctico. Frente a él, las leyes de Licurgo y de Numa se acercan más a las exigencias de la república ideal platónica, donde los sabios identifican el bien común con su propia idea de Estado y legislan y gobiernan para educar a los ciudadanos y orientarlos en esa dirección; ambos héroes encarnan el prototipo del legislador que se ha trazado este platónico que es Plutarco; pero mientras Numa escribe sus leyes en piedra y no en el espíritu de los romanos, el programa de Licurgo es esencialmente educativo. El sabio espartano graba las leyes en el alma de los jóvenes, que es la forma más eficaz para salvaguardarlas, puesto que su conocimiento genera la voluntad de cumplirlas ${ }^{11}$; eso las hizo perdurables ${ }^{12}$, y para ello él mismo se sacrificó con el destierro, atando a los espartanos con el juramento.

Dos cuestiones son importantes aquí, a propósito de la valoración biográfica del legislador. La primera es la superioridad de la ley grabada en el alma ( $\varepsilon \mu \psi \cup x \circ \varsigma$ vó $\mu \circ \varsigma)$ frente a la ley escrita, pues identifica en cierto modo la

9 Para Solón y Licurgo, remitimos a las reflexiones de L. DE Blois 2008: 318-321, J. P. Hershbell 2008: 495-496 y J. Vela Tejada 2008: 505. E. Koulakiotis 2008: 409-410 establece, por su parte, una interesante equiparación entre Licurgo y Alejandro, como legisladores educadores de su pueblo, que los hace superiores a Numa.

${ }^{10}$ Cf. A. Pérez Jiménez 1991.

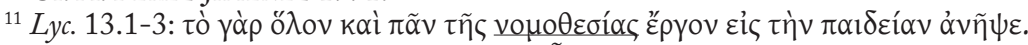

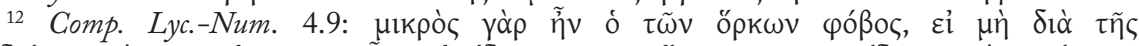

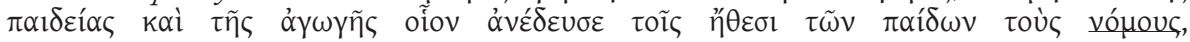

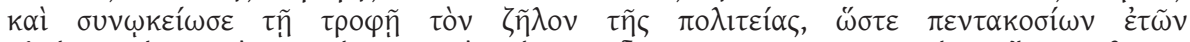

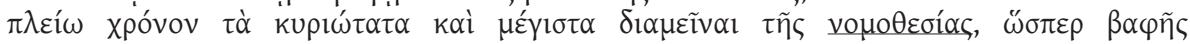

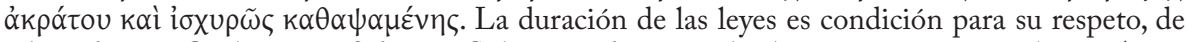
tal modo que Quilón se enfadó con Solón por decir que las leyes tenían que cambiarse (Sept.

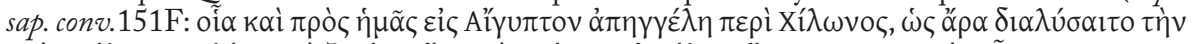

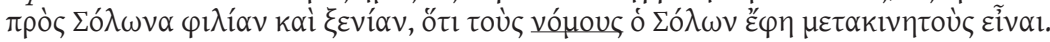


ley con la razón ${ }^{13}$. Y la segunda tiene que ver con el compromiso de los legisladores con su propia obra. En lo primero, Licurgo es sin duda el preferido de Plutarco; y, en lo segundo, son superiores Licurgo y Numa a Solón; pues al marcharse éste de Atenas nada más promulgar sus leyes, sin controlar su puesta en práctica con la propia autoridad, facilitó el camino a la tiranía de Pisístrato. Tal vez la clave de esa actitud de Solón esté en su poca fe respecto de la inmutabilidad de las leyes, que, como se cuenta anecdóticamente en el Septem sapientium convivium, le llevó a perder la amistad de Quilón ${ }^{14}$. Este defecto del legislador ateniense no es simple apreciación nuestra, sino que ya Plutarco lo señala en la Comparación, al dar la preferencia a Publícola; pues, aunque las leyes del romano imitan las del ateniense, aquél sí que se preocupó de las suyas, permaneciendo en Roma hasta la muerte ${ }^{15}$. En cuanto a Timoleón, su ordenación política de los sicilianos, tras liberarlos de los tiranos, pasa a formar parte del bagaje personal del héroe para quien esa actividad se considera un ejemplo más de su fortuna que, en este caso, pervive en la felicidad de los propios sicilianos ${ }^{16}$.

Estos legisladores, diríamos profesionales, a los que concierne la ingente tarea de civilizar políticamente a los pueblos, sacándolos de una situación de caos general (como en el caso de Licurgo o Solón) o cambiando su orientación histórica (como en el de Numa) o adaptándolos a una nueva situación política (como en el de Rómulo, Publícola, Timoleón y las leyes de Lúculo a los cireneos), identifican su personalidad generosa y desinteresada con las constituciones creadas por ellos.

${ }^{13}$ Cf. Ad princ. ind. 780F. Indirectamente Plutarco mantiene esa crítica a las leyes de Solón cuando en Max. cum princ. 779B compara los áxones de Solón con las almas de los gobernantes en las que los filósofos graban sus palabras que adquieren así la fuerza de las leyes.

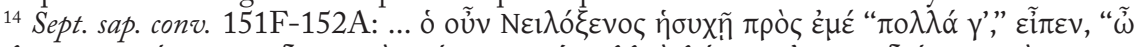

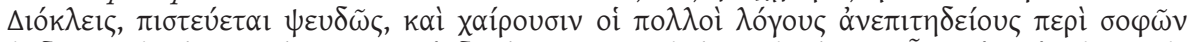

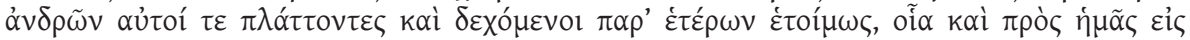

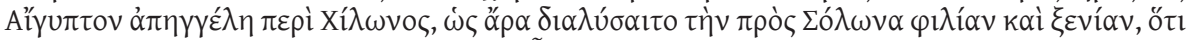

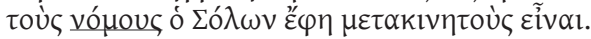

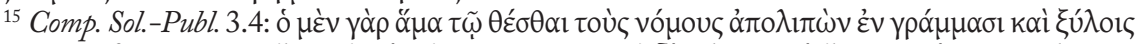

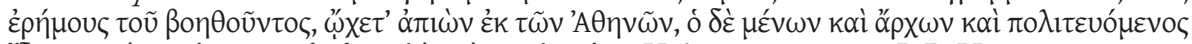

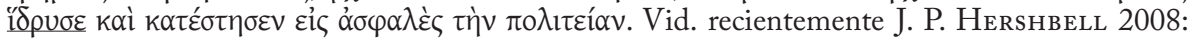
496-498.

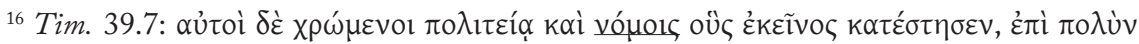

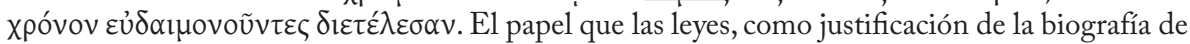
Timoleón, juega en el planteamiento biográfico de Plutarco y en la elección de este personaje ha sido subrayado por S.-T. Teodorsson 2005: 223: "We may plausibly assume to the contrary that Plutarch was highly interested in Timoleon as a persona and that he admired his steadfast anti-tyranic conviction, his unyielding struggle against unlawful Greek rulers and Carthaginian invaders in Sicily, his consistent commitment to regulated democracy and lawfulness, and his remarkable lack of greed for power. I believe that Plutarch considered Timoleon a person especially worthy of being adopted in his series of biographies." Una posición, que sale al paso de la falta de interés por el personaje que le atribuye J. Geiger 1981: 101, seguido por F. E. BRENK 1987: 312. 
En cambio, para el resto de personajes (reyes, generales y políticos), que deben adaptar su conducta pública y privada a las leyes o, excepcionalmente, adecuar aquellas a ésta, la ley política deja de ser en principio norma que dicta un sabio para civilizar a su pueblo y con vocación de futuro. Es cierto que hay, en parte, algunas excepciones, como Timoleón, cuya organización política de los siracusanos (por lo demás no realizada directamente por él, sino por medio de expertos legisladores) culmina la semblanza personal del protagonista. Se trata de un personaje caracterizado por la aceptación de las leyes y la justicia frente al comportamiento de los tiranos; pero la felicidad alcanzada por los sicilianos con su constitución no apunta hacia sus virtudes como legislador, sino que es un argumento más para ilustrar su fortuna. En cuanto a las leyes que dio Lúculo a los cireneos, a Plutarco le interesa sólo su eco platónico ${ }^{17}$.

Al margen de estos dos casos, los demás agentes públicos de las Vidas se encuentran las leyes ahí, limitando los márgenes de su actividad, y el biógrafo aprovecha la actitud de los personajes hacia ellas como un expediente para trazar sus perfiles ético-políticos. Es el terreno en que Plutarco ilustra con la práctica los principios platónicos de la ley como reina de los gobernantes y de la disociación entre las leyes dictadas por intereses de partido y la justicia o el bien común ${ }^{18}$. En ellos la actitud del personaje ante las leyes ilustra positiva o negativamente su conducta moral, y descubre ante nosotros una parte importante de sus defectos y de sus virtudes.

\subsection{El buen político}

El hombre virtuoso, el buen político, acepta y respeta las leyes (escritas y no escritas), consciente de que ellas forman parte de la distinción entre los pueblos civilizados y los bárbaros. Plutarco formula en varias ocasiones este principio que considera necesario para la cohesión social y pertinente para la condición ejemplar del estadista que merece una biografía. El respeto a las leyes implica la capacidad de obediencia que nuestro moralista considera necesario para el gobernante:

La ley que reina sobre todos, mortales e inmortales, como dijo Píndaro, que no está escrita en el exterior en libros ni en tablas, sino que es una palabra con vida propia en su interior, que siempre vive con él, lo vigila y jamás deja a su alma desprovista de gobierno ${ }^{19}$.

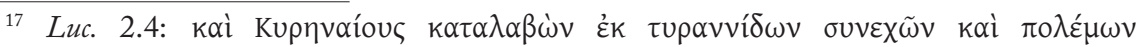

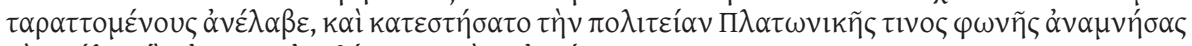

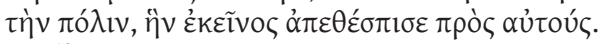

${ }_{18}^{18}$ Un principio que deja claro el ateniense en P1., Lg. 715b.

${ }^{19}$ Ad princ. ind. $780 \mathrm{C}$ (trad. Helena Rodríguez Somolinos). Cf. An seni resp. 784D: "La actuación política, conforme a los principios de la democracia y de la ley, de un hombre que 
Ese respeto está por encima de los intereses personales y, a veces, incluso lleva al héroe a aplazar la solución de los conflictos que trae entre manos. Camilo, por ejemplo, lo sabe, y prefiere cumplir con las leyes naturales antes que manchar el buen nombre de la patria. Lo expresa él mismo para justificar su decisión con el maestro de Faleros; en efecto, el general romano proclama la existencia de unas normas de conducta humana que rigen incluso en la guerra y su observación le sirve al biógrafo para exaltar la virtud del héroe:

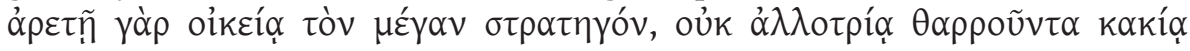

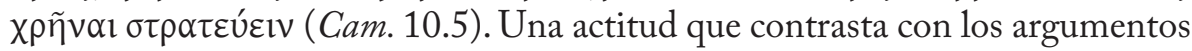
esgrimidos por Breno ante los embajadores romanos de Clusio (Cam. 17.4). Aquí el galo (que escuda su conducta en comportamientos anteriores de los romanos) hace suya la ley del más fuerte, vigente entre los dioses y los animales; pero, aunque tiene razón en este punto $^{20}$, el hombre ni es dios ni es fiera y sin duda Plutarco piensa que semejante conducta no es propia de hombres civilizados y las palabras del galo lo presentan ante los embajadores romanos como un hombre violento e incoercible.

Que el respeto a las leyes (sean naturales o sociales) es un principio básico de la pedagogía de Plutarco relativa a la virtud (aplicable, por tanto, a su esquema biográfico) está claro desde las páginas del De liberis educandis donde incluye la obediencia a aquellas entre las acciones bellas que nos enseña la filosofía ${ }^{21}$. Es ese sentido pedagógico el que lo lleva a aceptar el temor a la ley como clave de su eficacia. En efecto, a propósito de la existencia en Esparta de un templo a Phobos y del temor que, como primera medida de su mandato, tienen por costumbre infundir los éforos en los ciudadanos jóvenes, afirma que el miedo a las leyes los hace valientes ante los enemigos y que no temen los sufrimientos quienes temen el reproche ${ }^{22}$; con ello no hace otra cosa el

acostumbra a mostrarse no menos útil cuando es mandado que cuando manda, proporciona a su muerte una mortaja verdaderamente bella, la gloria que ha obtenido en vida".

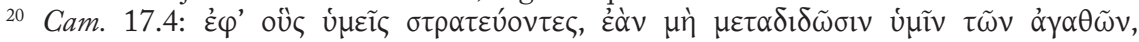

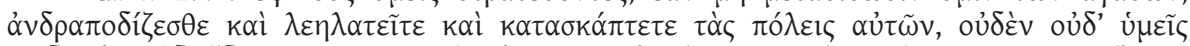

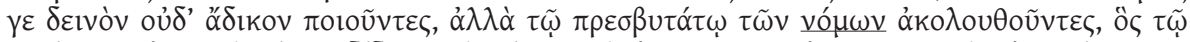

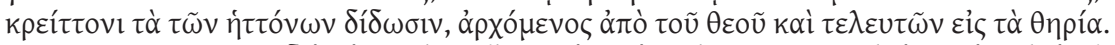

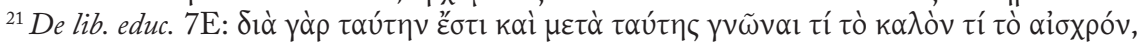

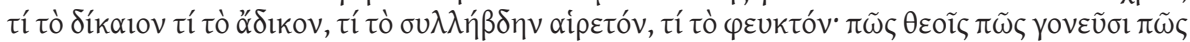

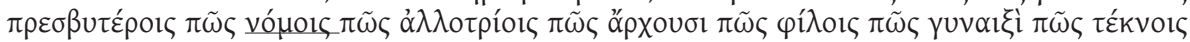

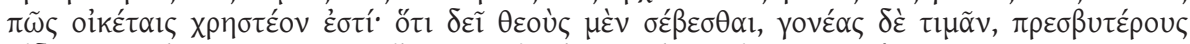

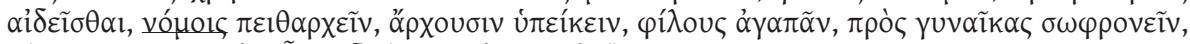

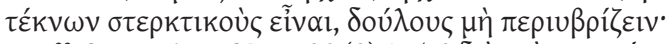

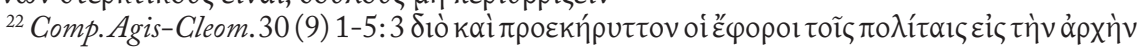

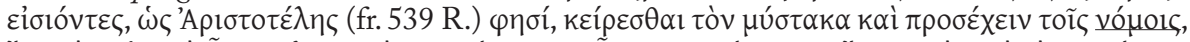

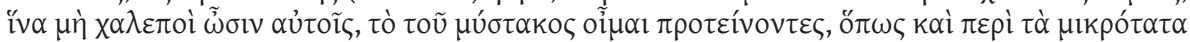

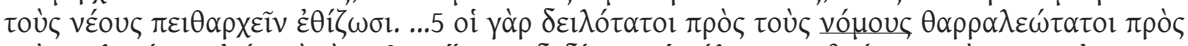

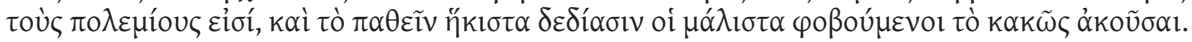


Queronense sino fundir en una las dos respuestas que Bías y Cleobulo dieron a la pregunta de ¿cuál es la mejor ciudad? Pues para Bías era aquella "en la que todos temen a la ley como a un tirano" y para Cleobulo aquella "donde los ciudadanos temen más el reproche que la ley"23.

Tal vez en este grupo haya que incluir aquellos personajes que respetan las leyes de la ciudad por convicción y coherencia, como le ocurre a Catón el Menor. Del tema ya se ha ocupado J. R. Ferreira 2011 y por ello nos limitaremos a unas cuantas referencias. La defensa a ultranza de las leyes justas, pero incluso el respeto incondicional a las que existen, sean justas o no, describen bien su semblanza moral en Plutarco. Se opone con todas sus fuerzas y con obstinación a las leyes injustas propuestas por los déspotas y demagogos del momento (César, Clodio, Metelo, Trebonio, etc.), se niega a jurarlas con riesgo de su propia integridad, y es el único que ya desde los comienzos de su carrera política se somete siempre y voluntariamente a las prescripciones legales. Plutarco, en el cap. 8, cuando asimila nuestro personaje al Catón anterior, señala este rasgo con motivo de su petición del tribunado militar en tiempos de la Guerra de Espartaco ${ }^{24}$; y sin duda es por miedo al reproche de su fama por lo que subordina los intereses privados al respeto a las leyes, cuando Escipión y Varo le proponen el mando en África. Rechaza la oferta, porque aquellos tenían la autoridad legal, y los anima a no quebrantar ellos las leyes siendo así que están empeñados en una guerra contra quien las quebranta (César) ${ }^{25}$. La eficacia literaria del recurso es evidente: pues la conducta del personaje le gana el respeto de sus propios enemigos, como se lee en el capítulo 21. En él Murena, despues de su nombramiento como cónsul, al que se oponía Catón, lo trata con respeto, reconociendo su seriedad y justicia. Y Plutarco atribuye a los valores y virtudes del personaje la causa de ese respeto:

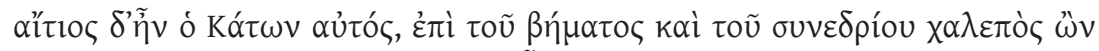

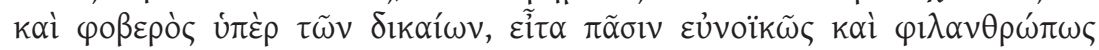

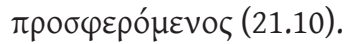

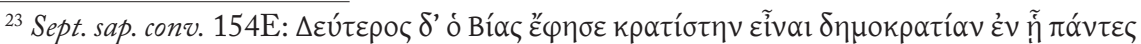

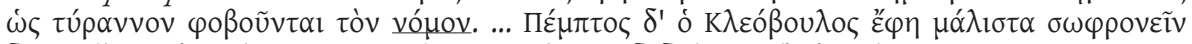

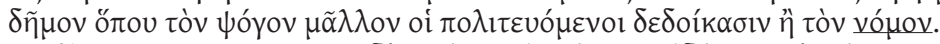

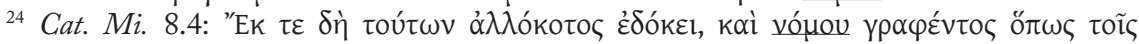

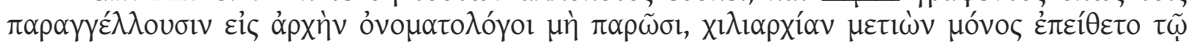

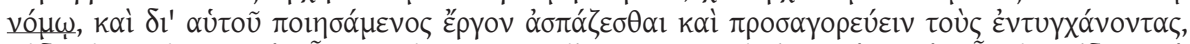

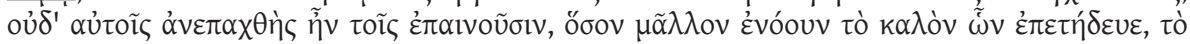

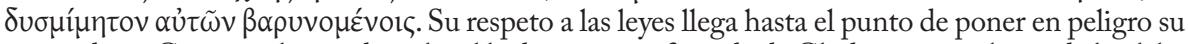
amistad con Cicerón, al considerar legal la designación forzada de Clodio como tribuno de la plebe (ya que el pueblo había permitido su paso de los patricios a los plebeyos). Cf. Cat. Mi. 40, Cic. 34.

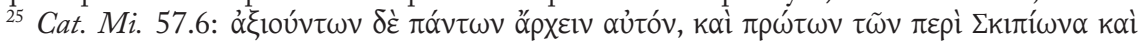

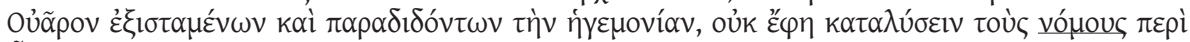

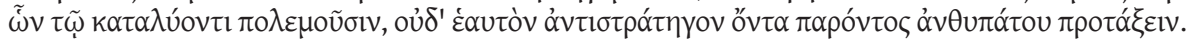


Por supuesto, el biógrafo encuentra casi siempre los datos en las fuentes, pero el enfoque es responsabilidad del biógrafo. Recordemos de nuevo, y a propósito de esto, el caso de Camilo, sobre el que ha llamado la atención Françoise Frazier. Cuando los romanos de Veyes le ofrecen el mando para liberar Roma de su asedio, nos dice Plutarco, no quiso aceptarlo antes de que lo

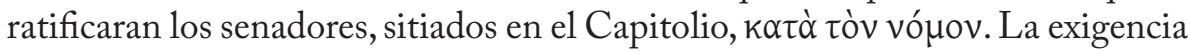
de este requisito está en Plutarco y en Tito Livio, pero éste no la atribuye al propio personaje, sino a romanos de Veyes cuando le hacen el ofrecimiento ${ }^{26}$.

\subsection{E1 transgresor de las leyes}

En el otro extremo está el mal político, transgresor sin escrúpulos de las leyes. En esa situación, Plutarco las utiliza para caracterizar a los personajes negativos secundarios (tiranos y demagogos) frente al héroe principal, defensor de las normas. A veces, como la acusación de Camilo contra Manlio (Cam. 36.3), se trata de situaciones puntuales en la actividad del personaje. Pero en ejemplos como el de Timoleón, el respeto a las leyes, transgredidas por los tiranos, es un tema de referencia continuo, que forma parte de la estructura literaria de la biografía. Al aceptar la misión que le encomiendan los corintios en él pesa ante todo la vocación restauradora de las leyes violadas por los gobernantes tiránicos de Sicilia ${ }^{27}$. Pues bien, muchas veces la ley sirve como criterio de oposición entre personajes secundarios, tiranos y demagogos que la transgreden, y el personaje principal cuya virtud se exalta precisamente por el respeto a la ley. El ejemplo más significativo es la conducta de Bruto, el asesino de César. Frente a quienes son partidarios de matar a Antonio cuando hayan asesinado a César, Bruto esgrime el respeto a las leyes como argumento contra esa conducta política y moralmente reprobable; pues, dice, una acción que se hace por defender las leyes y la justicia debe estar al margen y limpia de toda injusticia ${ }^{28}$. En la propia Vida de Bruto Plutarco vuelve a insistir en su legalidad y justicia por su comportamiento en el juicio a uno de sus soldados, contrastado con la sentencia de Casio. Éste le echa en cara su exceso de legalidad

${ }^{26}$ Cam. 24.4. La intervención del biógrafo sobre la tradición histórica en este caso es clara, como ha puesto de manifiesto F. Frazier 1996: 161. Livio atribuía este requisito no a una exigencia de Camilo, sino de los propios romanos en Veyes (5.46.7-8); Plutarco, en De fort. Rom. lo atribuye a Camilo, pero con otras intenciones (para que no pareciera que se aprovechaba de la situación y que creía que el estado se encontraba abatido, 324E-F); en la biografía el respeto a

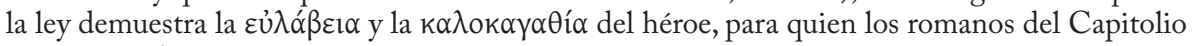
representan la patria.

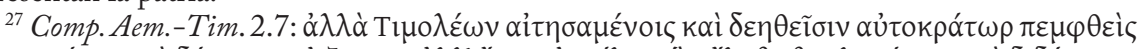

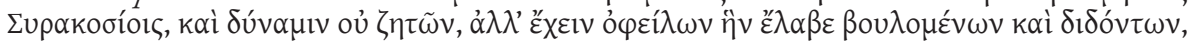

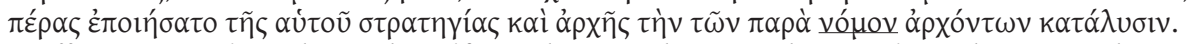

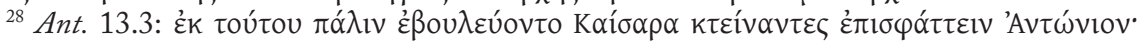

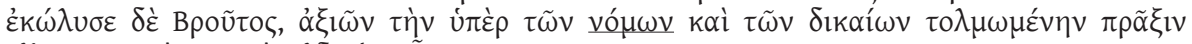

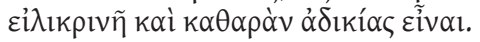


en momentos difíciles y él responde diciendo que el respeto a las leyes debe observarse en cualquier situación y más con los amigos que con los enemigos ${ }^{29}$. Se contrapone a Casio e incluso a Pompeyo, siendo admirado por su justicia $y$ rectitud ${ }^{30}$. Tiranos, ya lo hemos visto, y demagogos - especialmente en los convulsos períodos de las guerras civiles romanas - se caracterizan básicamente por su falta de escrúpulos ante las leyes. En relación con el comportamiento de los romanos a propósito de los bienes culturales de Grecia, una cuestión para la que Plutarco es especialmente sensible, contrapone el respeto hacia ellos por parte de los generales romanos en épocas anteriores (la de Emilio, Escipión o el propio Marcelo) y el pillaje a que son sometidos en tiempos de Sila y Mario que utilizan esos bienes para beneficio propio. La clave de esa conducta moral está precisamente en el respeto a las leyes ${ }^{31}$ de lo que no son modelo estos personajes. De hecho uno de los argumentos que baraja Plutarco para preferir a Lisandro frente a Sila es que aquél mantuvo su poder sin transgredir las leyes $^{32}$, mientras que en época de éste las leyes se dictaban a hierro y fuego ${ }^{33}$.

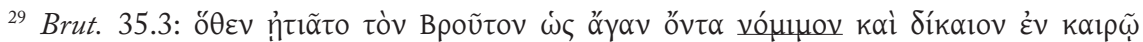

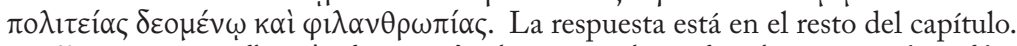

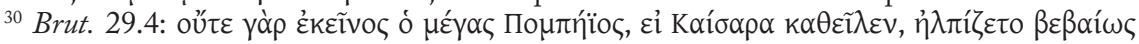

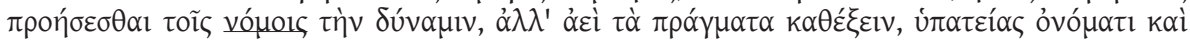

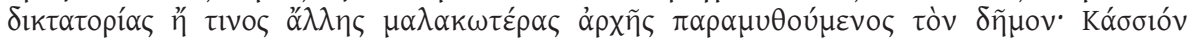

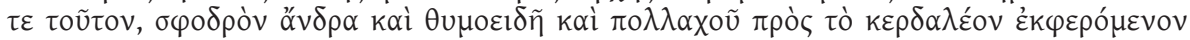

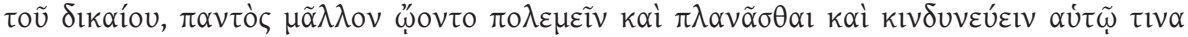

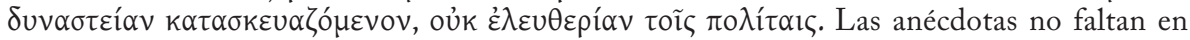
las que se ilustra este respeto a las leyes puesto incluso por encima de su seguridad personal:

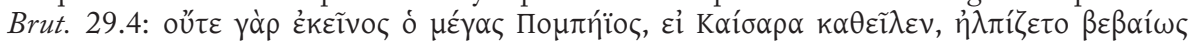

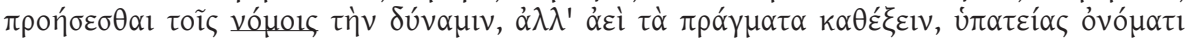

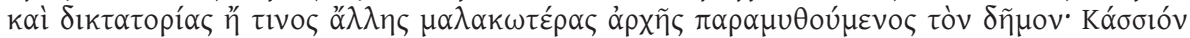

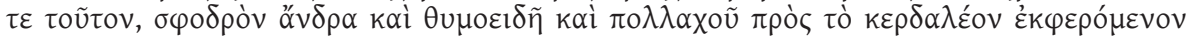

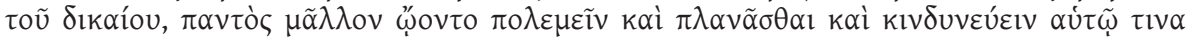

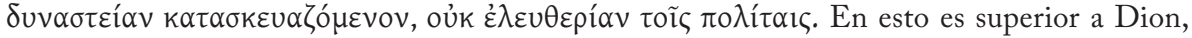
que a veces incluso colaboró con Dionisio, mientras que a Bruto le hizo ser amigo de Pompeyo y enemigo de César la libertad de la patria: Importante en este sentido Comp. Dio-Brut. 3.6:

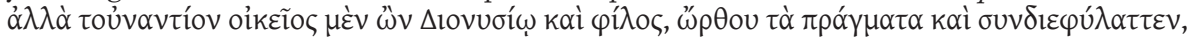

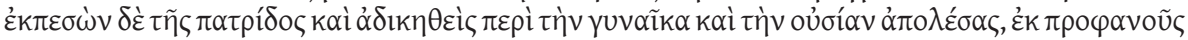

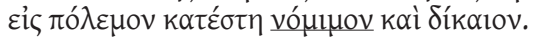

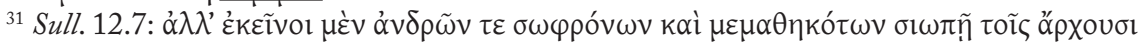

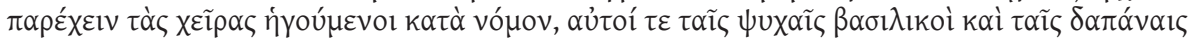

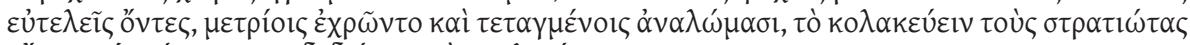

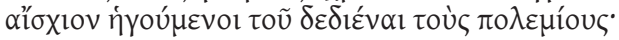

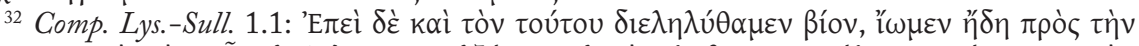

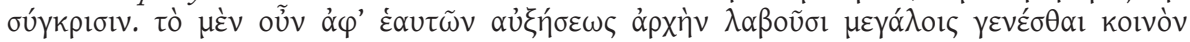

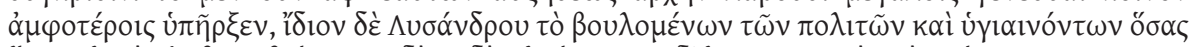

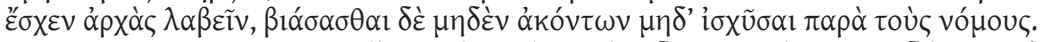

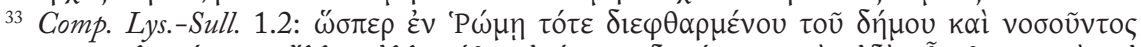

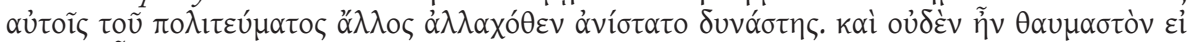

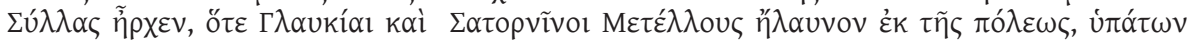

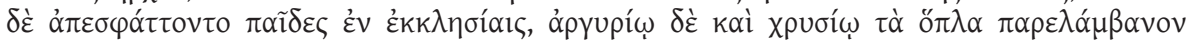


Sila nos recuerda a los gobernantes sectarios de que hablaba el ateniense de las Leyes. Estos malos legisladores y transgresores sin escrúpulos de las leyes violan incluso las que dictan ellos mismos (como Censorino, un esbirro de Sila) y dictan otras por intereses privados o de partido ${ }^{34}$. También Sila se salta sus leyes sobre gasto y moral ${ }^{35}$, mientras que Antonio, César y otros caracteres autoritarios del momento hacen aprobar leyes ajustadas a sus propios intereses que sólo encuentran oposición en hombres decentes como Catón, Cicerón, Bruto, etc. En casi todos estos ejemplos Plutarco recurre al expediente de la ley propuesta para ilustrar la escasa calidad moral de algunos personajes. Basta una muestra: Cuando Mario, a propósito de la ley de Saturnino favorable a la plebe, exige al Senado que la jure, demuestra su carencia de virtud y su falsedad. Primero dice que es un deshonor para el Senado jurarla y que él no la jurará (para que Metelo no la jure) y luego, cuando llega el momento, la jura. Plutarco se sirve de esta ley para contrastar el carácter inflexible y virtuoso de Metelo con el interesado y mentiroso de $\mathrm{Mario}^{36}$.

Estos son los casos extremos: exceso de celo en el cumplimiento estricto de las leyes o total desprecio por ellas. En medio encontramos otras situaciones en que las leyes dificultan el progreso personal de los héroes o impiden sus actividades o bien obligan al personaje a decantarse por una suspensión puntual

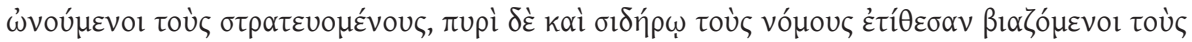

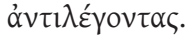

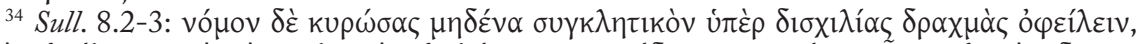

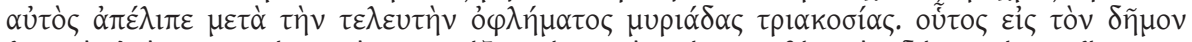

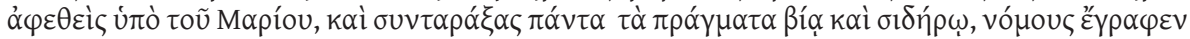

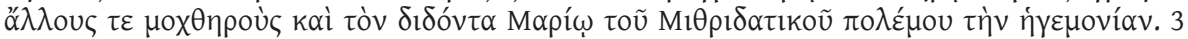

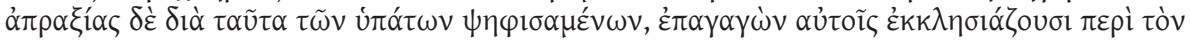

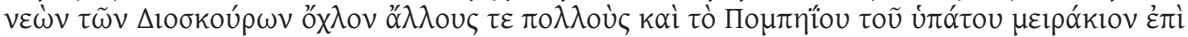

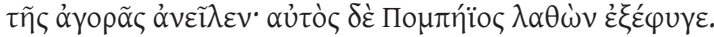

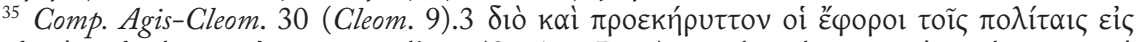

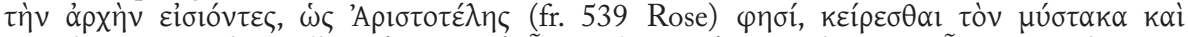

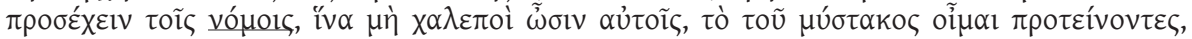

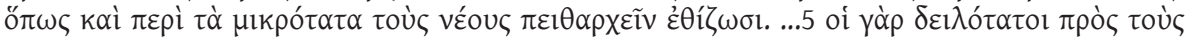

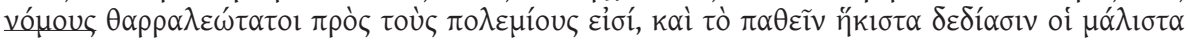

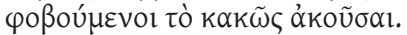

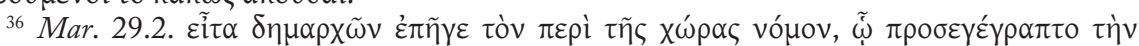

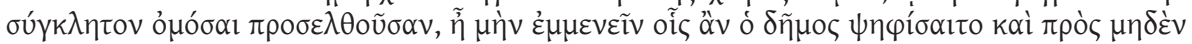

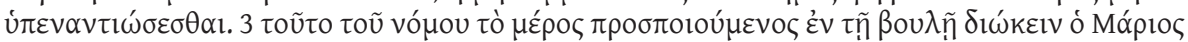

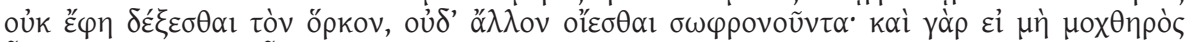

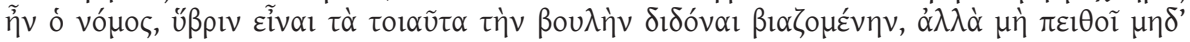

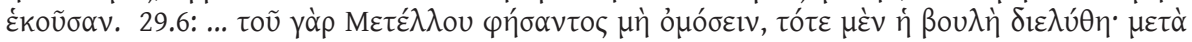

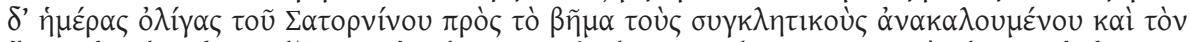

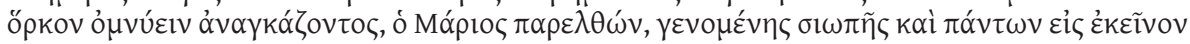

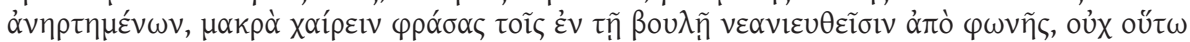

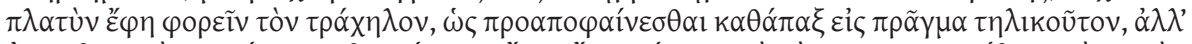

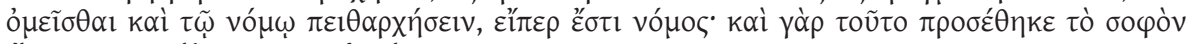

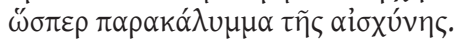


de su cumplimiento. En semejantes circunstancias, la forma de resolverse el conflicto es un expediente literario con que se subraya el prestigio del biografiado o la naturaleza de sus prioridades, morales, políticas o religiosas.

a) De lo primero, tenemos al menos dos ejemplos en los que las leyes se oponen a la carrera política del héroe, en un caso, y al protagonismo que le corresponde por sus méritos en otro. En efecto, Mario, como Escipión antes de la destrucción de Cartago, aspira por segunda vez al consulado, cuando la ley vigente entonces impedía el nombramiento para un segundo consulado inmediatamente después del primero, sin haber pasado un cierto tiempo. Lo extraordinario de la situación hace que el pueblo lo elija contra esa ley, existiendo el precedente de Escipión, nombrado por segunda vez cónsul para destruir Cartago, cuando ahora es la misma patria la que estaba en peligro ${ }^{37}$. Ya aquí el interés general de los ciudadanos justifica la transgresión de la norma, aunque en este caso no es opción del personaje, sino del pueblo, que ve en él su tabla de salvación. En otras situaciones, los espartanos no se saltan las normas, pero recurren a otros expedientes para rodearla. Precedentes hay de esta actitud de los espartanos, como cuando Pericles dijo a los embajadores de Esparta que una ley impedía destruir la tablilla en la que se había escrito el decreto de Mégara y Polialces le propuso que, entonces, tan sólo le diera la vuelta ${ }^{38}$. Ahora se trata de poner en manos de Lisandro los asuntos de Asia, ante la insistencia de los aliados. Pero como no era posible nombrarlo general por impedir la ley ser navarca por dos veces, los espartanos nombraron general a otro y mensajero de derecho, pero navarca de hecho, a Lisandro ${ }^{39}$.

b) Mario nombra ciudadanos en contra de las leyes a los mil camarinos que lucharon en su favor ${ }^{40}$. En otro caso simula respeto a aquellas, por lo que, al haber sido desterrado por una ley, pide a su regreso que se decrete otra

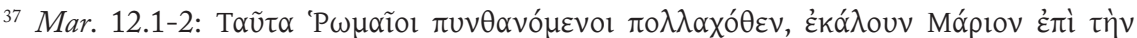

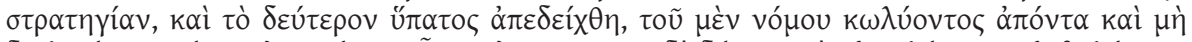

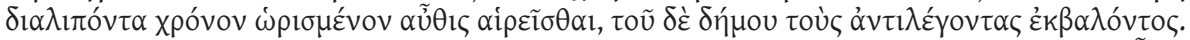

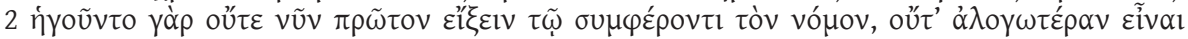

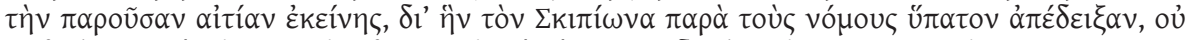


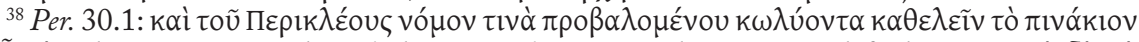

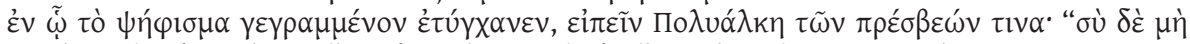

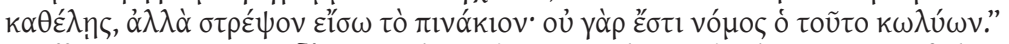

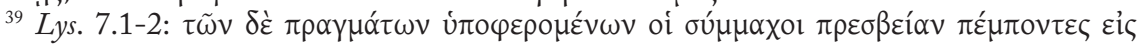

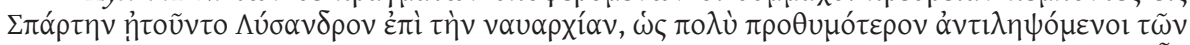

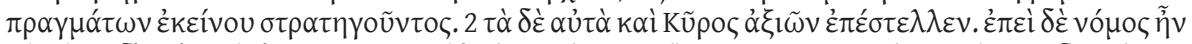

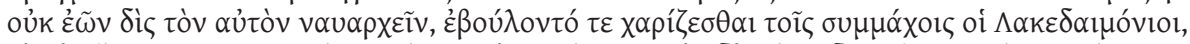

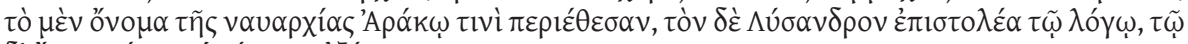
' '

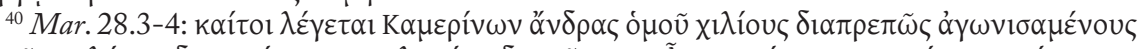

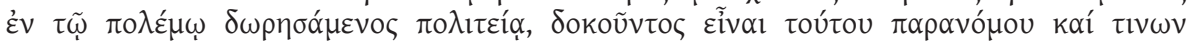

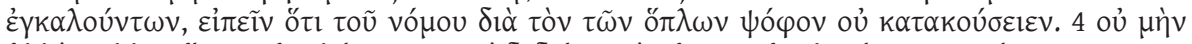

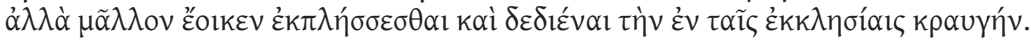


anulando aquella, como si él las tuviera en cuenta ${ }^{41}$. César se apodera del dinero del erario, en contra de Metelo, su custodio, que trataba de evitarlo esgrimiendo las leyes, alegando que un tiempo es el de las leyes y otro el de la guerra ${ }^{42}$. El paso del Rubicón se entiende por Plutarco como una remoción de todas las leyes de la República, que queda en total desorden y zozobra ${ }^{43}$. César en su consulado legisla en contra de los intereses de la República, para favorecer a la plebe y sin estar a la altura de su mando. Trata de conseguir la aprobación de sus leyes por la fuerza ${ }^{44}$.

\subsection{Transgresiones oportunas}

Por último, el caso más significativo de actuación política es el de los personajes que incumplen o olvidan puntualmente las leyes por patriotismo o preocupación por el bien común ${ }^{45}$, contraviniendo el principio teórico de que la ley humana no puede justificar acciones injustas del gobernante ${ }^{46}$ : La prevalencia del bien común sobre las leyes se acepta en los praecepta gerendae reipublicae (817C-E), donde Plutarco propone que el hombre de estado compita en interés, previsión y preocupación por el bien común. La ley, en estos casos, concede la primacía en el gobierno a quien hace lo justo y sabe lo que es útil (817D) y recuerda el ejemplo de Filopemen que, sin esperar órdenes, se lanzó al ataque y liberó la ciudad de Mesene.

Con frecuencia Plutarco se hace eco del conflicto entre la actuación moral y los preceptos legales contemplado por Platón en el Político, cuando en la misma obra explica que el buen político puede contravenir las leyes

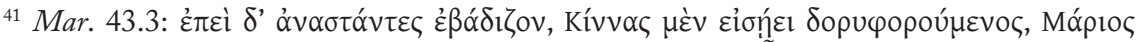

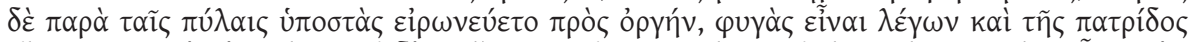

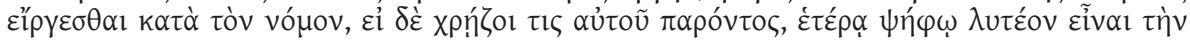

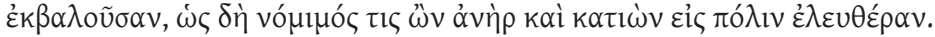

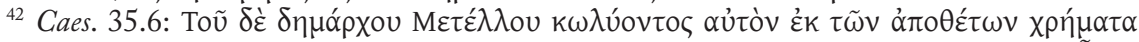

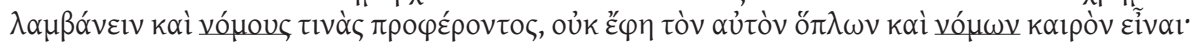

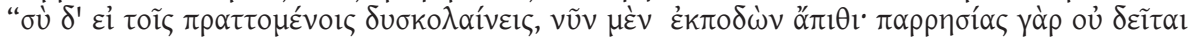

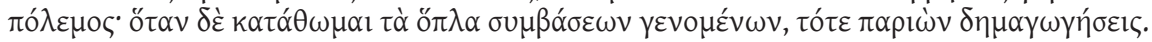

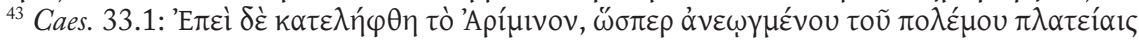

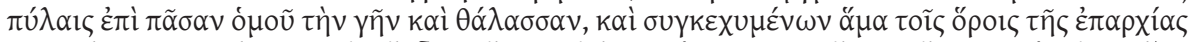

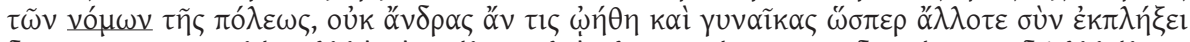

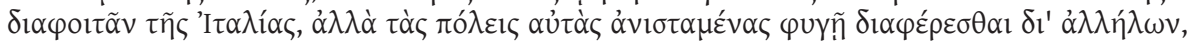

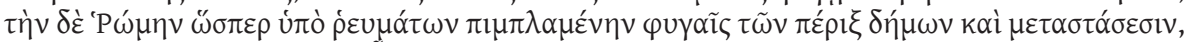

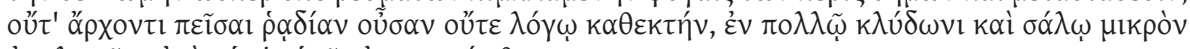

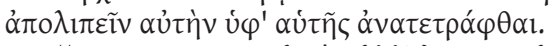

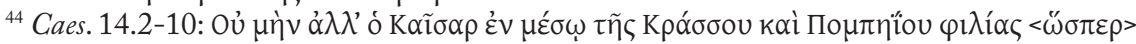

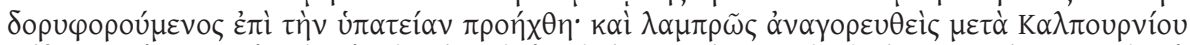

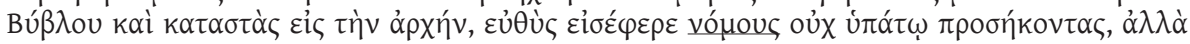

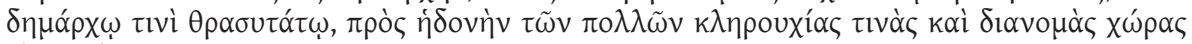

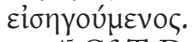

${ }^{45}$ Cf. T. Duff 1999: 131-132.

${ }^{46}$ L. VAN DER STOckT 2004: 148-149. 
si con ello se asegura la justicia y la utilidad ${ }^{47}$. Pelópidas y Epaminondas se desentienden de la ley para llevar a buen término sus campañas ${ }^{48}$ y Filopemen salva la situación entre la Confederación y Laconia tomando la iniciativa para eliminar los conflictos que habían motivado la intervención de aquella en esta, con un acto "que no era ni legal ni rigurosamente justo, pero grande y digno de un gran corazón” ${ }^{49}$. Plutarco aprueba que Agesilao no castigue a los desertores de Leuctras: Al dejar dormir las leyes un solo día salvó su país y las propias leyes (Ages. 30.2-6 y comp. Ages.-Pomp. 2.3-4). Catón, cuando, ante la anarquía creada por Escipión, Hipseo y Milón, pedían algunos que presidiera Pompeyo los comicios, se opuso al principio, argumentando que no tenía que venirles a las leyes la seguridad de Pompeyo, sino a éste de las leyes. Pero como se prolongaba la situación de anarquía, cambió de parecer, juzgándolo conveniente como la menor de las ilegalidades ${ }^{50}$. En cambio, el excesivo celo por el cumplimiento de las leyes puede arruinar el Estado, como ocurrió con Mario y Cinna que tomaron Roma en el 87 a.C. por el celo legal de sus contrarios

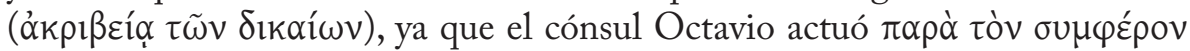
al descuidar lo que era necesario (Mar. 42.4) ${ }^{51}$. Sin duda alguna para Plutarco en determinadas circunstancias el fin justifica los medios $^{52}$, pues la injusticia y la ignorancia de las leyes son aconsejables cuando el resultado beneficia al Estado $^{53}$. Por ello nuestro biógrafo aplaude el rapto de las sabinas por Rómulo (comp. Thes.-Rom. 6.2-3) o el ataque de Craso a Partia (comp. Nic.-Crass. 4.3-4). Lo mismo ocurre, en el caso de Aristides, con su decisión de no arrestar a los sospechosos de complot para salvar la democracia en 479 a.C. (Arist. 13.2) $)^{54}$

${ }^{47}$ Cf. F. Frazier 1996: 160.

${ }^{48}$ Pel.25.2 Cf. Praec. ger. reip. 817F, donde se justifica la ilegalidad de prorrogar la permanencia en el cargo de beotarca durante cuatro meses en los que invadió Laconia y liberó Mesenia: "De manera que, aunque recaida alguna acusación o censura sobre dicho comportamiento, tenemos la necesidad como defensa de la acusación o, como consuelo del peligro, la grandeza y la gloria de la hazaña."

${ }^{49}$ Phil.16.3. Como concluye F. Frazier 1996: 161, "si la lettre de la loi a souffert, le résultat est là: Lacédémone rentre dans la Confédération comme par le passé”. Otra ilegalidad alabada por Plutarco es Phil. 12.4, 6 (cf. Comp. Phil.-Flam. 3 y Ages. 30.5, 32.11).

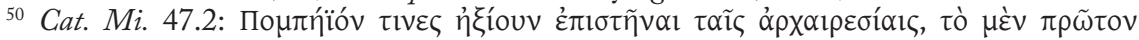

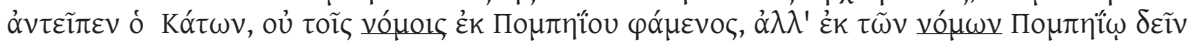

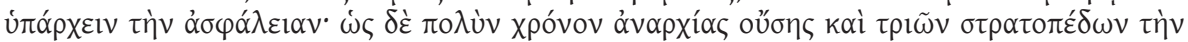

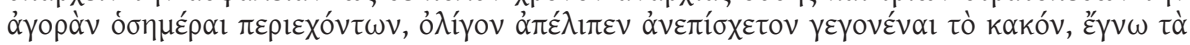

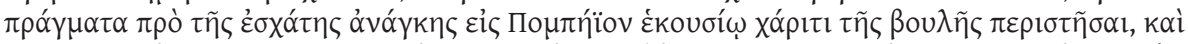

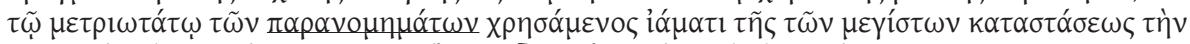

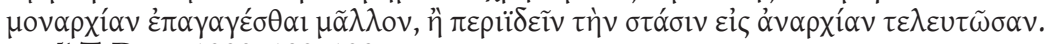

${ }^{51}$ T. Duff 1999: 132, 129.

52 Ejemplos en A. G. Nikolaidis 1995.

${ }^{53}$ T. Duff 1999: 132, F. Frazier 1996: 155-160 y 165-170, A. G. Nikolaidis 1995: 311312, A. Pérez Jiménez 2004: 131-135.

${ }^{54}$ A. Pérez Jiménez 1980: 147-153, F. Frazier 1996: 161-164, T. Duff 1999: 132. 
o cuando opone legalidad a conveniencia a propósito del plan de Temístocles (Arist. 22.3-4) o en el trato de los aliados (Arist. 25.1-3). Algo similar se expone en la comparación de Filopemen con Flaminino. Al contrastarlos, Plutarco destaca la natural disposición de aquél al mando diciendo que era capaz de mandar no sólo de acuerdo con las leyes, sino también controlando las leyes para lo conveniente ${ }^{55}$. En cambio al cónsul Octavio, y con ello concluimos, sus escrúpulos en la observación de la justicia le hicieron perjudicar los intereses de su partido, cuando no quiso servirse como fuerza de los esclavos, aunque muchos se lo pedían ${ }^{56}$.

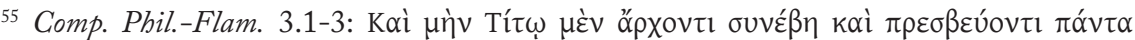

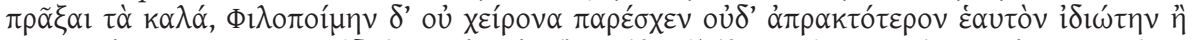

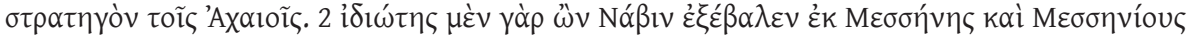

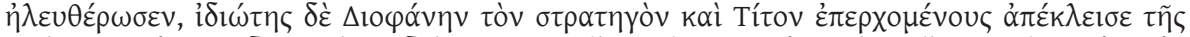

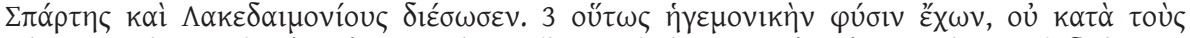

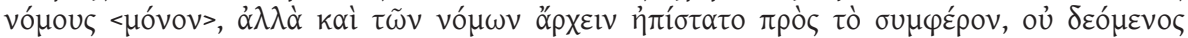

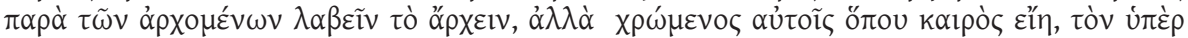

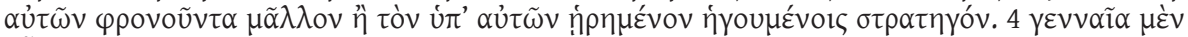

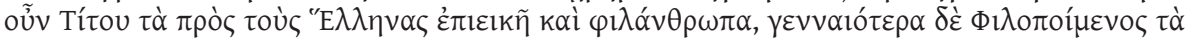

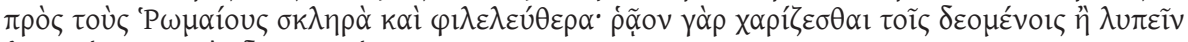

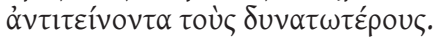

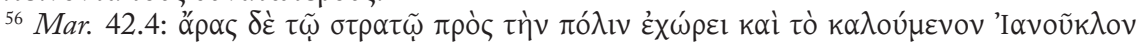

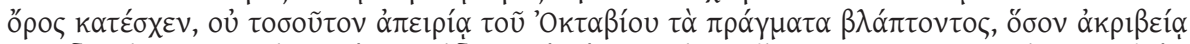

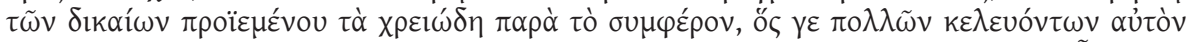

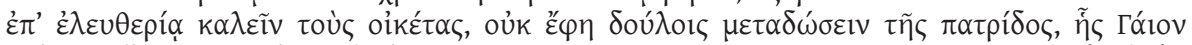

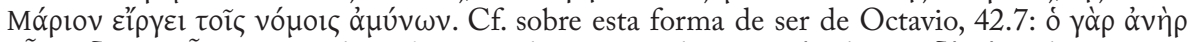

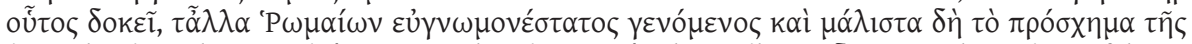

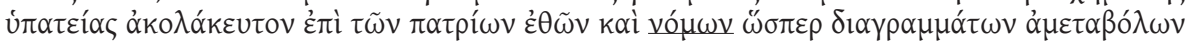

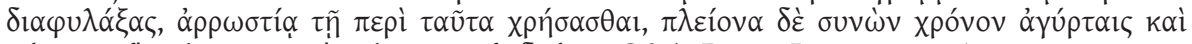

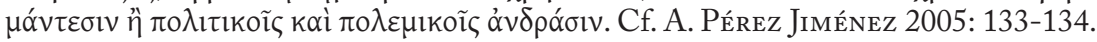




\section{Referencias bibliográficas}

Brenk, F. E., "An Imperial Heritage: The Religious Spirit of Plutarch of Chaeronea", ANRW, II.36.1, Berlin-New York, 1987: 248-349.

De Blois, L., "The Ideal Statesman: A Commonplace in Plutarch's Political Tratises, His Solon, and His Lycurgus", in A. G. Nikolaidis (ed.), The Unity of Plutarch's Works, Berlin-New York, 2008: 317-324.

Duff, T., Plutarch's Lives. Exploring Virtue and Vice, Oxford, 1999: 131ss.

Ferreira, J. Ribeiro, "O respeito da lei e os valores da liberdade e da moderação no Cato Minor", in J. Ma Candau Morón, Fco. J. González Ponce \& A. L. Chávez Reino (eds.), Plutarco transmisor, Sevilla, 2011: 253-265.

Frazier, F., Histoire et morale dans les Vies parallèles de Plutarque, Paris, 1996.

Geiger, J., "Plutarch's Parallel Lives: The Choice of Heroes”, Hermes, 109, 1981: 85-104.

Hershbell, J. P., "Plutarch on Solon and Sophia", in A. G. Nikolaidis (ed.), The Unity of Plutarch's Works, Berlin-New York, 2008: 489-499.

Koulakiotis, E., "Greek Lawgivers in Plutarch: A comparison between the Biographical Lycurgus and the Rhetorical Alexander", in A. G. Nikolaidis (ed.), The Unity of Plutarch's Works, Berlin-New York, 2008: 403-422.

Nikolaidis, A. G., "Plutarch's Heroes in Action: Does the End Justify the Means?”, in I. Gallo \& B. Scardigli, Teoria e prassi politica nelle opere di Plutarco (Atti del V Convegno plutarcheo, Certosa di Pontignano, 7-9 giugno 1993, Napoli, 1995: 301-312.

Pérez Jiménez, A., "Pobreza, justicia y patriotismo en la Vida de Aristides de Plutarco", Sodalitas 1, 1980: 147-153.

Pérez Jiménez, A., "La Debilidad Política de Solón en Plutarco", L. Ferreres (ed.), Actes del LXè Simposi de la Secció Catalana de la SEEC. Treballs en Honor de Virgilio Bejarano, Barcelona, 1991: 687-696.

Pérez Jiménez, A., "Los héroes de Plutarco y su elección entre la justicia y la utilidad", in L. De Blois, J. Bons, T. Kessels \& D. M. Schenkeveld, The Statesman in Plutarch's Works, Leiden-Boston, 2004: 127-136.

Teodorsson, S.-T., “Timoleon, the fortunate general”, in L. De Blois, J. Bons, T. Kessels \& D. M. Schenkeveld, The Statesman in Plutarch's Works, vol. II, Leiden-Boston, 2005: 215-226.

VAn der Stockt, L., “'With followeth Justice always' (Plato, Laws 716a). Plutarch on the 'Divity' of Rulers and Laws", in L. De Blois, J. Bons, T. Kessels \& D. M. Schenkeveld, The Statesman in Plutarch's Works, vol. I, Leiden-Boston, 2004: 137-149. 
Vela Tejada, J., "El Banquete de los Siete Sabios y la Vida de Solón de Plutarco: mito político y contexto literario", in A. G. Nikolaidis (ed.), The Unity of Plutarch's Works, Berlin-New York, 2008: 501-514. 
(Página deixada propositadamente em branco) 


\title{
Pericles, ¿̇un modelo de $\Delta$ IKAIOEYNH?
}

\author{
Mónica Durán Mañas \\ Universidad Complutense de Madrid
}

\begin{abstract}
At the beginning of Plutarch's Life of Pericles, Plutarch says that Pericles is, above all, a model

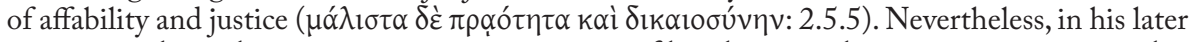
exposition, the author comments on some aspects of his character that invite us to question his impartiality, at least in judicial matters. For this reason, we aim to explore the meaning of the term $\delta$ ikaloбúv $\eta$ in the context of the Life of Pericles in order to understand why the statesman is a prototype of this virtue for our author.
\end{abstract}

Todos tenemos una idea, más o menos vaga, de lo que implica la noción de justicia, pero basta con revisar mínimamente la literatura para darse cuenta de que no es fácil ofrecer una buena definición de este concepto. De hecho, no hay consenso en cuanto a su significado, que cambia según las diferentes culturas y épocas y que incluso puede llegar a depender de cada punto de vista particular. Los antiguos griegos personificaron esta abstracción con la forma de una diosa, Dike, que según Hesíodo (Th. 901-2) era una de las Horas, hijas de Zeus y Temis y hermana de Eunomía y Eirene. Más tarde, en el clima filosófico de la Atenas del s. V a.C., la justicia se convirtió en un elemento central de la política griega que ha pervivido hasta nuestros días, pues es evidente que el hombre, por naturaleza, anhela vivir en una sociedad justa, del mismo modo que siente la necesidad, a veces imperiosa, de ver reparadas las afrentas que se han cometido contra él. Por este motivo, quizás, Plutarco califica a menudo de justos a los protagonistas de sus biografías, en su mayoría personajes públicos de notable presencia en el marco político de su tiempo. Ahora bien, llegados a este punto, nos preguntamos si nuestro autor, renombrado moralista, emplea la justicia ( de autoridad o si cuando habla de esta virtud lo hace con pleno conocimiento de causa, es decir, porque observa que la trayectoria vital de su personaje se ve realmente imbuida de esta cualidad ${ }^{1}$. Pues una cosa es que Plutarco afirme que la justicia regía la vida de estos hombres y otra muy distinta el que el lector pueda corroborar, a través de la descripción de estos mismos personajes y sus actos, su justa virtud. Para responder a esta cuestión, hemos escogido una obra de Plutarco, la Vida de Pericles, ya que en ella se propone al estadista ateniense como modelo de moderación y de justicia (Per. 2.5.5), si bien podríamos

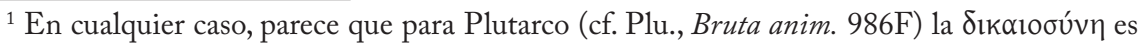
una virtud exclusivamente humana. Vd. J. Bouffartigue 2009: 11. 
haber optado igualmente por la Vida de Arístides, al comienzo de la cual se

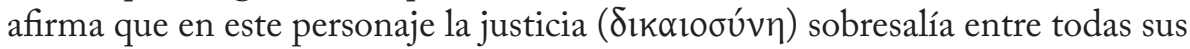
virtudes. Pero, dejando a un lado a Arístides, tratado en este mismo encuentro por el Prof. Joaquim Pinheiro, vamos a centrar nuestra atención en el enfoque plutarqueo de la justicia de Pericles.

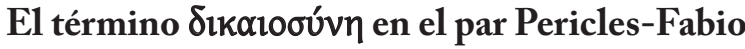

La Vida de Pericles comienza con una digresión introductoria sobre la virtud, tras la cual Plutarco expone los motivos que le han llevado a escribir acerca del par Pericles-Fabio (Per. 2.5.1-9):

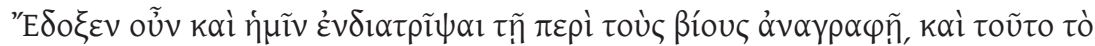

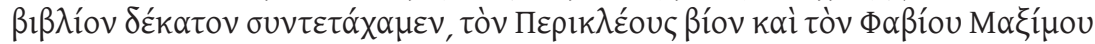

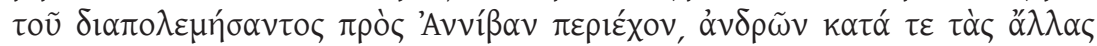

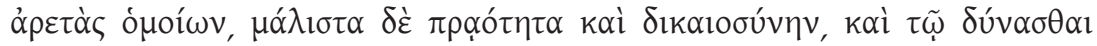

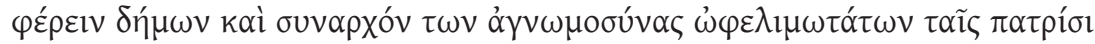

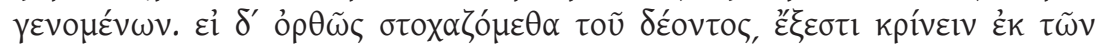

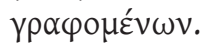

Decidimos, por tanto, también nosotros emplearnos en la escritura de las Vidas y hemos compuesto como décimo este libro que contiene la Vida de Pericles y la de Fabio Máximo, el que combatió contra Aníbal. Estos hombres se asemejaron en las demás virtudes, pero sobre todo, en autocontrol y justicia; y, por su capacidad para asumir las imprudencias de sus pueblos y colegas en el mando, fueron del mayor provecho para sus patrias. Si acertadamente apuntamos en la dirección correcta, se puede juzgar por nuestro relato².

Como acabamos de señalar, uno de los motivos que justifica el tratamiento conjunto de estos personajes es, según el autor, su semejanza

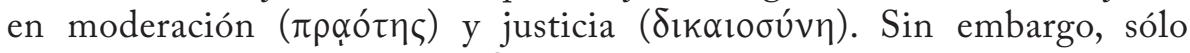

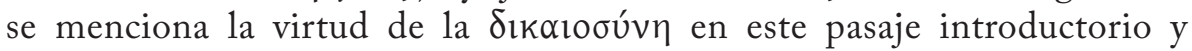
no reaparece ni en la Vida de Pericles ni en la de Fabio, de suerte que, entendemos, Plutarco deja libertad al lector para ir desgranando por sí mismo a lo largo del texto esta afirmación, tal y como parece sugerir en las líneas precedentes ${ }^{3}$. Con esta idea en mente, leemos la Vida de Fabio y

${ }^{2}$ Todas las traducciones de la Vida de Pericles están tomadas de A. Pérez Jiménez 1996.

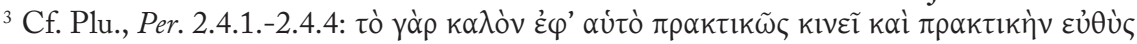

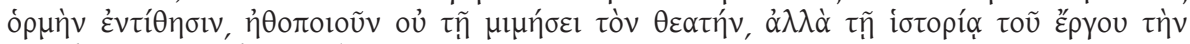
$\pi \rho o \alpha i ́ p \varepsilon \sigma \mathrm{lv} \pi \alpha \rho \varepsilon \chi o ́ \mu \varepsilon v o v$ ("La belleza auténtica atrae activamente hacia ella y crea dentro de nosotros un impulso hacia la acción, formando el carácter del espectador no con la imitación, sino con el conocimiento profundo de su obra, que induce a preferirla”). 
no encontramos más que una referencia muy general a la fragilidad de la justicia en los tiempos que corren $(F a b .21 .3 .7)$, pero el término empleado

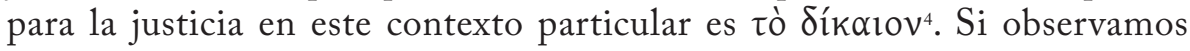
la Vida de Pericles, hallamos, al menos, varios términos pertenecientes a

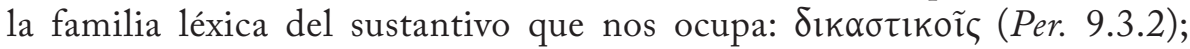

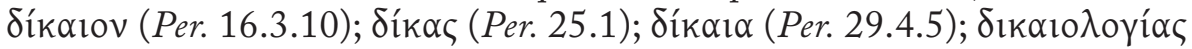

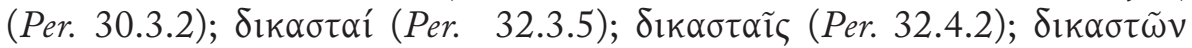

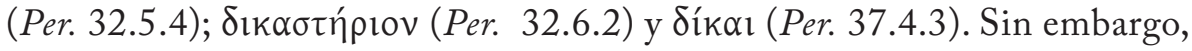
si nos adentramos en su contenido, no parece que Plutarco se refiera con estos términos a la misma justicia que anuncia al comienzo de su opúsculo. No olvidemos que, aunque en nuestra lengua a menudo traducimos como

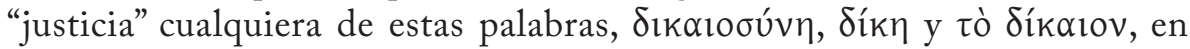
griego se aplican a realidades diferentes ${ }^{5}$. En efecto, la $\delta i k \alpha ı \sigma u ́ v \eta$ es la virtud de la justicia y, por lo tanto, su práctica pertenece al ámbito de lo

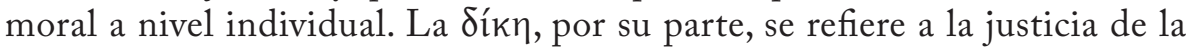
polis que vela por el cumplimiento de lo justo y conforma una institución reglada mediante leyes, de suerte que, según vemos en Aristóteles (Pol.

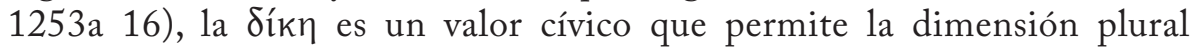

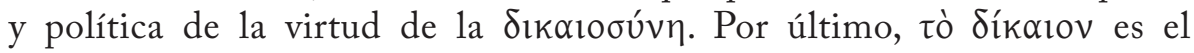
concepto más general y constituye una suerte de medida de lo justo, en tanto que mantiene el equilibrio de las relaciones entre los individuos ${ }^{6}$. Por consiguiente, ninguno de los términos antes reseñados redunda en la

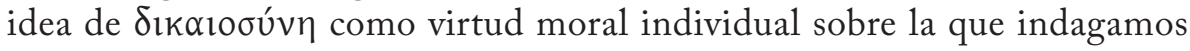
a propósito de la Vida de Pericles. Así las cosas, nos vemos en la necesidad de profundizar en el concepto que el de Queronea pudiera tener acerca de esta virtud.

Para la configuración de su idea de justicia, es muy probable que Plutarco, como en tantos otros asuntos, se viera influido por las doctrinas de Platón ${ }^{7} \mathrm{y}$

${ }^{4}$ También encontramos en la misma Vida otro término vinculado etimológicamente a

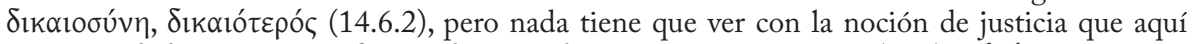
tratamos, dado que aparece formando parte de una construcción con el verbo cíuí.

${ }^{5}$ Vd. G. Vlastos 1947: 174-178, P. Cartledge 2000: 6 y A. Ladikos 2006: 74.

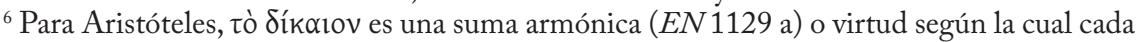
uno tiene lo propio y según la ley (Arist., $R h .1366$ b 9-10) y, en consecuencia, se refiere tanto a lo legal como a lo equitativo. Vd. J. Corral Genicio 2002/2003: 150.

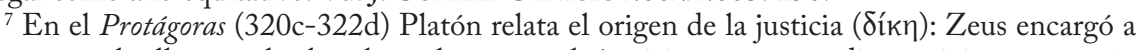
Hermes que les llevara a los hombres el respeto y la justicia para que pudieran vivir en armonía;

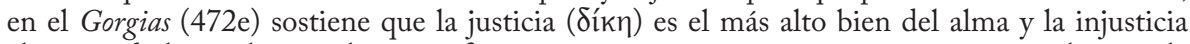
el mayor de los males, por lo que sufrir una injusticia siempre es mejor que cometerla; y en la

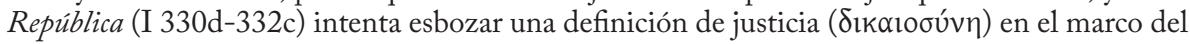
individuo sin llegar a una solución satisfactoria. Por este motivo, en el libro II Sócrates propone indagar sobre el mismo concepto, pero a nivel de la comunidad. Para Platón, lo que conforma un Estado justo es el que cada uno se dedique plenamente y con exclusividad a las funciones 
de Aristóteles ${ }^{8}$. Para el primero (P1., R. 433a; cf. P1., Smp. 209a), la justicia debe presidir a todas las demás virtudes y así parece reflejarse también, por ejemplo, en el comienzo de la Vida de Arístides a la que antes hacíamos

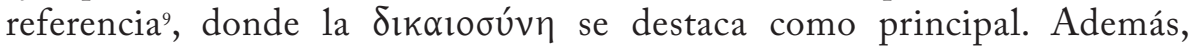
Plutarco incluye en otras Vidas (e.g. Demetr. 1.4; Ages. 23.5; Dio. 47.6-7)

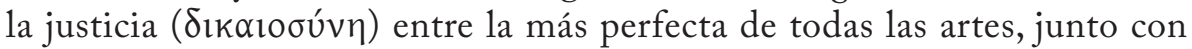
la templanza ( $\sigma \omega \varphi \rho o \sigma u ́ v \eta)$ y la prudencia $(\varphi \rho o ́ v \eta \sigma r \varsigma)^{10}$. Para Platón, la justicia es una virtud estrechamente vinculada a la convivencia social ${ }^{11}$ que consiste en un ajuste, de acuerdo con el cual cada parte del alma y cada miembro de la ciudad debe cumplir la función que le es propia a fin de

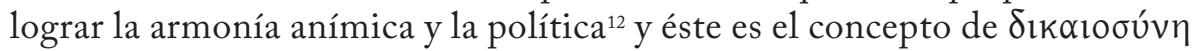
que asumirá el Estagirita, para quien la justicia de la ley es toda la virtud (cf. Arist., $R h$. 1366b). Desde esta perspectiva ideológica parece encajar

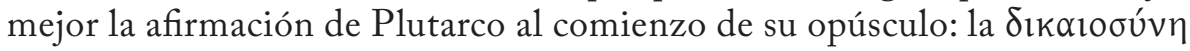
encabeza efectivamente el texto porque es una virtud imprescindible en el gobernante y de esta manera la justicia, al menos a nivel conceptual, "preside" a las demás virtudes, aunque luego no se vuelva a hacer referencia a ella.

propias de su clase (P1., Rh. 434c), lo cual proporciona un equilibrio que asegura la unidad. Ahora bien, dado que se establece en esta obra un paralelismo entre el individuo y el Estado (“... el hombre justo en tanto que es justo no se diferenciará en nada de un Estado justo, sino que es perfectamente semejante a él”, $R$. 435a), resulta que la justicia en el individuo consistirá en que las distintas partes del alma cumplan su respectiva función, de suerte que, finalmente, se establezca el gobierno de la razón. En todo caso, la justicia es un bien moral sujeto a la decisión personal, por lo que sólo puede llegar a ella quien posea el conocimiento adecuado, esto es, el sabio, el filósofo.

${ }^{8}$ Para Aristóteles, la justicia es una de las virtudes más útiles para el logro de la felicidad. Cf. notas 6 y 11 .

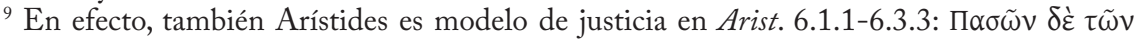

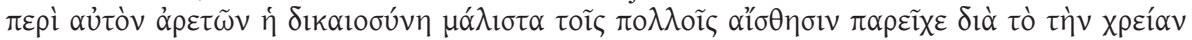

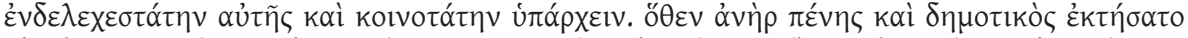

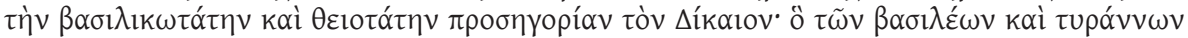

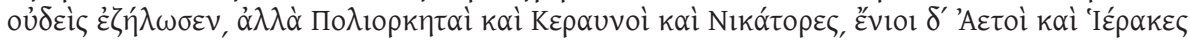

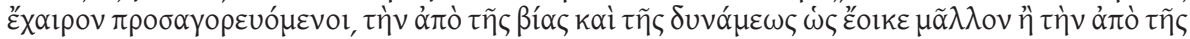

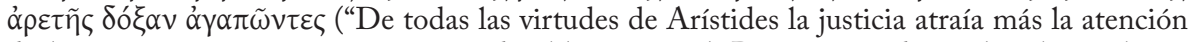
de la mayoría por ser su uso más perdurable y general. Por eso, siendo un hombre pobre y plebeyo adquirió el título más regio y divino de Justo, lo que ningún rey ni tirano envidió, sino que se complacían en ser denominados Poliorcetes, Ceraunos y Nicátores, y algunos Águilas y Halcones, prefiriendo, según parece, la reputación de la violencia y la fuerza más que la de la virtud"). Trad. de J. M. Guzmán Hermida 2007.

${ }^{10}$ Vd. el estudio de F. Frazier 1996: 177-195 en el que trata de las cuatro virtudes cardinales

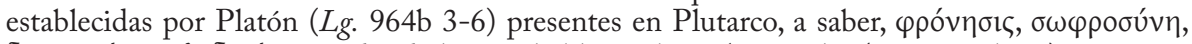

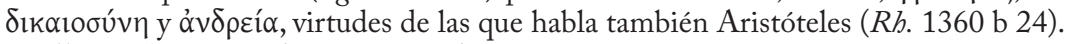

${ }^{11}$ Para Aristóteles (Ret.1362 b 28) la justicia es un bien porque es conveniente a la comunidad.

${ }^{12}$ Vd. M. B. Foster 1984: 42 y 64, J. L. López Aranguren 1990: 249-255 y P. Azara 2007: 215 . 


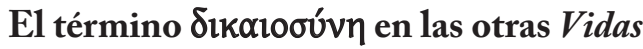

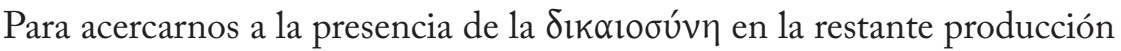
biográfica de Plutarco, nos serviremos de los trabajos de M. Cerezo 1996 y F. Frazier 1996 principalmente, pues ambos se han dedicado al estudio de esta virtud, aunque - y esto parece significativo - no se han detenido en la Vida de Pericles. Según M. Cerezo 1996: 130, en Plutarco la justicia define por lo general el comportamiento del gobernante - como también en Platón - y de ella destaca el estudioso los siguientes aspectos (M. Cerezo 1996: 130-131): a) utilidad (Arist. 6.1); b) un lugar pequeño no es óbice para su existencia (Dem. 1.2); c) convicción interna en la acción de la justicia (Tim. 6.2); d) debe gobernar quien por naturaleza es justo (Comp. Lys. Sull. 2.1); e) es una paideía y un servicio divino; f) su ausencia es causante de la guerra (Pyrrh. 22.3); g) el gobernante tiene que ser justo, pero no blando; h) tema de la justicia excesiva como defecto; i) la justicia atrae la envidia; j) su falta produce añoranza; $\mathrm{k}$ ) posee distintos grados de intensidad; 1) tema de la guerra justa; $m$ ) tema tradicional de hacer el bien posible al amigo, pero también todo el mal posible al enemigo y n) anteposición del interés común al propio.

Con todo, si tomamos estos ítems como punto de referencia para contrastar la idea de justicia en la Vida de Pericles, observamos que en ella no aparecen, a no ser el punto m) en Per. 19.3.6) y parcialmente el 1) en Per. 18.1; 21.1 y 22.2) ${ }^{13}$. Siendo así, no sólo Plutarco no vuelve a mencionar el término $\delta$ ı $\alpha 10 \sigma u ́ v \eta$, sino que tampoco desarrolla a continuación su contenido, al menos de manera expresa. De hecho, no vemos a lo largo de la obra que

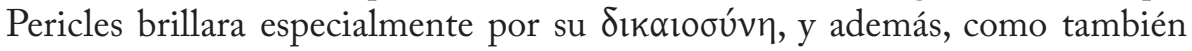
señala C. Mossé 1996: 212-222 no sin cierta parcialidad ${ }^{14}$, es fácil entrever las reiteradas críticas que Plutarco recoge a propósito de su personaje $\mathrm{e}^{15}$. Para comenzar, Pericles recibió enseñanzas de dos maestros afectados por una imagen negativa ${ }^{16}$, Damón y Zenón de Elea (Per. 4.1-5); se muestra vengativo al disminuir los poderes del Areópago como consecuencia del rencor que guardaba por no haberse sentado allí, pues nunca había sido arconte, tesmotetes, rey ni

${ }^{13}$ Donde Plutarco deja claro que Pericles era comedido en la guerra.

${ }^{14}$ Aunque C. Mossé observa bien estas críticas, presenta un análisis sesgado al no tener en cuenta las cualidades positivas que Plutarco también elogia de su personaje.

15 Tampoco J. García López 2008: 89 tiene claro que Pericles sea un modelo de virtud, ya que observa igualmente que Plutarco reconoce grandes defectos en este personaje. Con todo, el mismo auctor afirma que Plutarco destaca en reiteradas ocasiones el autocontrol y la justicia de Pericles, opinión que, al menos en el caso de la justicia, no compartimos.

${ }^{16} \mathrm{Si}$ bien gozó asimismo de las enseñanzas de Anaxágoras de Clazómenas, a quien Plutarco (Per. 4.6-6.1) describe como un hombre prudente, inteligente, con grandes conocimientos en asuntos físicos, comedido, paciente, imperturbable y alejado de la superstición. 
polemarco (Per. 9.4); gracias a él ${ }^{17}$, el pueblo adquirió malos hábitos a causa de la institución de salarios públicos con los cuales, de sabio y trabajador que era, se hizo gastador e indisciplinado ${ }^{18}$ (Per.9.1); corrompió a la multitud con el dinero de los espectáculos y la paga de los juicios y con otros salarios y ayudas (Per. 9.3); Plutarco destaca la responsabilidad de Pericles en el ostracismo de Cimón ${ }^{19}$ del año 461 a.C. e incide en que todos los amigos de éste, a los que el estadista había acusado de apoyar a Esparta, fueron aniquilados sin excepción, lo cual produjo un gran arrepentimiento entre los atenienses $(P e r .10 .3)^{20}$ que motivó a Pericles a decretar su regreso ${ }^{21}$; Plutarco recoge su fama de grosero al comienzo de la biografía donde dice que el poeta Ión de Quíos afirmaba que "el trato de Pericles era presuntuoso y algo vanidoso y que con sus jactancias se combinaba un gran desdén y desprecio por los demás” (Per. 5.3), actitud ${ }^{22}$ que luego vuelve a ponerse de relieve en la descripción de su respuesta a Elpínice, lo cual contrastaba con Cimón, de quien el autor alaba el tacto y la delicadeza (Per. 5.3); Plutarco recuerda las acusaciones formuladas por sus adversarios que consideraban que Grecia era "víctima de una terrible injusticia y una tiranía manifiesta" (Per.12.2), así como las críticas de los poetas cómicos acerca de su política, más semejante a una tiranía que a una democracia (Per. 16.1) o las acusaciones de promiscuidad ${ }^{23}$ que giraban en torno a su persona (Per. 13.15 y 13.16); Plutarco cuenta, además, que Pericles decidió apoyar a los milesios

${ }^{17}$ Además, Plutarco pone de relieve el hecho de que, siendo aristócrata, se acercó al pueblo, lo cual se hallaba en aparente contradicción con los intereses de su clase. Vd. Per.7.3-6.

${ }^{18}$ En este punto, Plutarco se dispone a analizar el cambio que se produjo en la sociedad ateniense a fin de dilucidar si se debía realmente a los privilegios (fiestas, espectáculos, comidas, etc.) que Pericles concedió al pueblo. En relación con estos últimos, el de Queronea recoge el testimonio de Aristóteles (Ath. 27.4), según el cual recurrió para ello al reparto de los bienes públicos por consejo de Damónides de Ee, aunque probablemente se tratara de Damón, hijo de Damónides.

19 Plutarco no oculta sus preferencias por Cimón, el hijo de Milcíades, al relatar el enfrentamiento entre éste y Pericles.

${ }^{20}$ También Tucídides alude a esta gran carnicería acaecida durante la batalla de Tanagra en el 457 a.C.

${ }^{21}$ Plutarco (Per. 10.4) añade otra versión según la cual Pericles habría pactado secretamente con Cimón por mediación de la hermana de éste, Elpínice, de suerte que en realidad Cimón habría zarpado con doscientas naves al mando de las operaciones en el exterior, en tanto que Pericles se habría quedado al mando de la ciudad.

22 Paradójicamente, Plutarco afirma también que Pericles tenía una voz agradable y una lengua rápida y ágil en la conversación (Per. 7.1), ya que consultaba a Anaxágoras para lo relativo al lenguaje y la dicción (Per. 8.1) y no tomaba parte en los asuntos de gobierno por miedo al ostracismo (Per. 7.2). Hallamos de nuevo esta aparente contradicción en Per. 8.4, donde el de Queronea recuerda que los comediógrafos llamaban a Pericles "olímpico" porque "tronaba" y "relampagueaba" al hablar y porque llevaba "un terrible rayo en su lengua" (Ar., Ach. 530), frente a Plu., Per. 8.6, donde afirma que el estadista era sumamente precavido en el decir.

${ }^{23}$ En esto el propio Plutarco reconoce que, pasado el tiempo, es difícil conocer la verdad, ya que, a veces por envidia y mala voluntad, o bien por complacencia y adulación, se tergiversa la verdad (Per. 13.16). 
contra los samios para complacer a Aspasia, pues ella era originaria de Mileto ${ }^{24}$ (Per.24.2 y 25.1) y añade que los cómicos acusaron a Pericles de haber hecho votar el famoso decreto de Mégara porque los megarenses habían raptado a dos cortesanas que pertenecían a Aspasia (Per. 30.4) ${ }^{25}$. Como resultado de este cúmulo de virtudes, Plutarco afirma que la desgracia familiar que afectaba a Pericles, a saber, la muerte de sus dos hijos a consecuencia de la peste, era según los atenienses "la justa pena por aquella soberbia y orgullo" (Per. 37.5).Y, a modo de colofón de su mal hacer, recuerda que al final de sus días se volvió ridículamente supersticioso (Per. 38.2), pese a las buenas enseñanzas de su maestro Anaxágoras (Per. 6.1).

Así pues, el de Queronea transmite una imagen ambigua ${ }^{26}$ del estratego, ya que tras contarnos tantos defectos, la Vida de Pericles concluye con alabanzas: "un hombre semejante merece nuestra admiración por la moderación y la afabilidad que siempre conservó...” (Per. 39.1). De este modo, siendo ésta la obra que, junto a la Historia de la guerra del Peloponeso de Tucídides, más ha contribuido a la imagen postrera de Pericles ${ }^{27}$, hemos de atribuir la visión positiva que de él ha llegado hasta nosotros a un efecto tanto de primacía como de recencia ${ }^{28}$.

\section{La justicia de Pericles}

Volviendo al tema de la justicia en nuestro personaje, hay dos aspectos importantes sobre los que reflexionar: su relación con el sistema judicial y la justicia de su proceder político. Con respecto a lo primero, Plutarco refiere varios momentos significativos de la vida del estadista vinculados a contextos judiciales en los que se aprecian, más que la virtud del personaje en cuestión, las carencias del sistema de justicia ${ }^{29}$ de época clásica. Así, a propósito del pacto acaecido entre Pericles y Cimón por intercesión de la hermana de éste, Elpínice, el Queronense recuerda que ya antes esta misma mujer había suavizado los ánimos del estadista cuando Cimón hubo de defenderse imputado en una

${ }^{24}$ Cf. Duris de Samos, FGrHist.76F 65, a quien Plutarco se refiere en Per. 28.2.

${ }^{25}$ Cf. Ar., Ach. 524-527.

${ }^{26}$ Cf. Plu., Per. 10.10.7 donde el autor reconoce que Pericles no fue del todo irreprensible, pues tuvo un espíritu generoso y un alma apasionada por la gloria.

${ }^{27}$ Así, por ejemplo, V. VANoyeke 2000: 51-66 se centra únicamente en las cualidades positivas del estratego narradas por Plutarco y Tucídides y considera a Pericles víctima de las críticas negativas de sus enemigos. Sobre el redescubrimiento de Pericles y su imagen en la posteridad, vd. C. Mossé 2006: 225-245.

${ }^{28}$ Los efectos de 'primacía' y de recencia' se refieren a la intensidad de la huella que deja un recuerdo en la memoria, de suerte que es más probable recordar la información aparecida en primera y última posición, respectivamente. Para una definición de estos conceptos, vd. Z del R. Santalla Peñaloza 2000: 158-159 y 223-225.

${ }^{29}$ Vd. L. SAncho Rocher 2009: 210-211 y 278. 
causa capital. En aquella ocasión, Pericles era uno de los acusadores propuesto por el pueblo y Elpínice acudió a él y le suplicó por su hermano. Aunque, según Plutarco, Pericles no se mostró muy amable con ella, en el momento del juicio, y probablemente como consecuencia de estos precedentes, Pericles "sólo se levantó una vez a hablar, con el fin de justificar su nombramiento, y luego se marchó, siendo el que menos perjudicó a Cimón de los acusadores"(Per.10.6). Ahora bien, pese a que el de Queronea introduce esta anécdota sin tomar partido

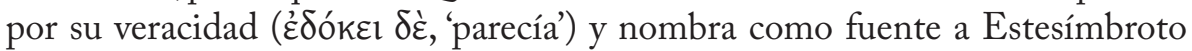
de $\operatorname{Tasos}^{30}$, tampoco descarta su verosimilitud. En efecto, cuando nuestro autor tiene una opinión contraria, no vacila en descreditarla como de hecho hace cuando poco después introduce la acusación de Idomeneo $^{31}$ en relación con el asesinato de Efialtes: “¿Pues quién con esto podrá dar crédito...?” (Per. 10.7). Lo que sí parece cierto es que Pericles se vio influido de algún modo por la petición de Elpínice y de ser el más violento de los acusadores, según dice el propio Plutarco (Cim. 14.5), se mostró para la ocasión sumamente benigno. Claro que los juicios de época clásica carecían del rigor que hoy consideramos indispensable y a los jueces había que persuadirlos empleando toda suerte de recursos al alcance. Así, en otro pasaje (Per. 32.5), dice el de Queronea que el poeta cómico Hermipo llevó a juicio a Aspasia por un delito de impiedad, al tiempo que Fidias y Anaxágoras también fueron procesados a causa de un arranque de los adversarios de Pericles. Pero éste, "a fuerza de $1 \operatorname{lorar}^{32}$ por ella y de suplicar ${ }^{33}$ a los jueces durante todo el proceso" logró que Aspasia fuera absuelta. De este modo, si uno conseguía conmover a los jueces, podría salir indemne de casi cualquier causa judicial. Pero el que Pericles llore por su amada no debe resultarnos tan impropio de un político como verlo promoviendo una guerra por motivos personales. En efecto, Plutarco afirma en Per. 32.6: "Y cuando a causa de Fidias (Pericles) tuvo problemas con el pueblo, por miedo, avivó el fuego de la guerra que ya estaba a punto de empezar y humeante con la esperanza de que disiparía las acusaciones y quitaría fuerza a la envidia, cuando la ciudad en medio de importantes asuntos y peligros se pusiera sólo en sus manos en razón de su prestigio y autoridad". Tanto si el motivo era

30 Vd. Plu., Cim. 14.5.

${ }^{31}$ En este caso no es evidente que Pericles fuera inocente y de hecho los estudiosos no se ponen de acuerdo. Vd. A. PÉrez Jiménez 1996: 435, n. 90.

${ }^{32}$ Esta anécdota parece contradecir el relato del final de su Vida (Per.36.9), donde Plutarco afirma que Pericles, ante la muerte de sus hijos, su hermana y amigos, en el momento de colocar una corona sobre el cadáver de su hijo rompió a llorar derramando muchas lágrimas, cosa que nunca había hecho antes.

${ }^{33}$ Paradójicamente, en los juicios el acusado debía hablar por sí mismo y no se permitían intervenciones ajenas, por lo que era habitual aprenderse de memoria defensas preparadas por profesionales, los logógrafos. 
éste ${ }^{34}$ como si era el de evitar una rendición de cuentas, como sugiere Diodoro Sículo (12.39.3), cabe preguntarse si un hombre justo promovería una guerra para distraer la atención pública de un asunto personal, aunque siempre cabe la posibilidad de pensar que esto no sea sino mera ficción o deformación literaria ${ }^{35}$.

Sea como fuere, esta anécdota nos impulsa a observar la justicia del proceder político de Pericles que a menudo se ve imbuido de intereses particulares ${ }^{36}$. Así, en la línea del ejemplo anterior y según hemos visto más arriba, Plutarco relata que a causa de una sola mujer, Aspasia, Pericles hizo la guerra contra los de Samos (Per. 25.1). Con esta afirmación, se pone de manifiesto que el estadista no es precisamente un modelo de justicia, sino de parcialidad y, de hecho, el de Queronea parece incluso criticar a su protagonista al sintonizar con la opinión de Elpínice, quien, después de la rendición de los samios tras nueve meses de encarnizada lucha, le reprocha diciéndole: "Estos hechos son admirables y dignos de coronas, oh Pericles, tú que nos llevaste a la muerte a muchos y nobles ciudadanos, no en combate con los fenicios ni con los medos, como mi hermano Cimón, sino conquistando una ciudad aliada y de nuestra misma raza" (Per. 28.6). Así, poco a poco, Plutarco va dibujando una imagen de Pericles que, si bien no se dice en ningún momento que carezca de justicia - sino todo lo contrario, según hemos visto al principio -, sí contiene pinceladas aquí y allá de un proceder poco acorde con lo que esperaríamos de un político justo. En efecto, ante la descripción de cualquier personaje, tendemos a hacernos una idea global de su personalidad, de suerte que si se nos dice que se trata de una persona justa, tenderemos a pensar que sus acciones también lo son. Sin embargo, hay ciertas actitudes en el Pericles de Plutarco que no encajan bien con esta idea que se adelanta al comienzo de la obra y que debería presidir la vida de nuestro personaje. Para empezar, relata Plutarco (Per.15.1) que cuando el estadista ya no tuvo rival político planteó un gobierno aristocrático y que, a veces con persuasión e instrucción y a veces con firmeza y violencia, puso mano en todo lo que le parecía útil, valiéndose según la ocasión de la esperanza y del miedo. De igual modo, nos preguntamos si es un modelo de justicia moral la persona que le entrega, tan sólo y a propósito, diez naves

${ }^{34}$ Como recuerda F. J. Frost 1964: 70, gracias al escolio al v. 605 de la Paz de Aristófanes, deducimos que el proceso contra Fidias (438/7) no coincide cronológicamente con el inicio de la guerra (432/1 a.C.).

${ }^{35}$ Cf. A. R. Burn 1962: 18-19, quien observa que la imagen predominantemente negativa del estratego en Plutarco se debe a que sus fuentes para la Vida de Pericles pertenecen fundamentalmente al ámbito de la comedia. Incluso hay quien considera esta actuación como una invención de Esquines, de quien Plutarco toma la anécdota. Vd. A. PÉrez Jiménez 1996: 499, n. 336.

${ }_{36}$ Actuación contraria al pensamiento de Aristóteles ( $R h$. 1367a 17-22), para quien la justicia es más provechosa a los demás que a uno mismo. 
a Lacedemonio, el hijo de Cimón, con el fin de que no pueda hacer gran cosa con ellas y sea así posible acusarle de laconismo (Per. 29.1-2); o la que emplea el soborno como estrategia política ${ }^{37}$. En esta misma línea, Pericles gastaba diez talentos anuales que justificaba en las cuentas oficiales en concepto de "lo que hacía falta" ${ }^{38}$, aunque, según Plutarco (Per. 24.1-2), Teofrasto refería que con este dinero que gastaba misteriosamente en realidad compraba la paz mientras se iba preparando para hacer mejor la guerra. En cuanto a la administración de las finanzas estatales, es bien sabido que Pericles embellece la ciudad de Atenas a la par que genera puestos de trabajo con el dinero de la Liga de Delos bajo el pretexto de garantizar la seguridad contra los bárbaros (Per. 12.1) ${ }^{39}$. Pero los restantes griegos opinan que son víctimas de un terrible abuso y que Grecia se halla sometida a la voluntad de un tirano, como es natural (Per. 12.2). ¿Podemos decir que esta estrategia es propia de un gobernante justo? Incluso, como señala F. Frazier 1996: 163-4 en su perspicaz trabajo, a propósito de este acto de los más controvertidos del imperialismo ateniense, Arístides hace esta reflexión: "no es justo, pero es útil" ${ }^{40}$. Pero a continuación Plutarco introduce un detalle inverosímil: aunque los oradores partidarios de Tucídides (Per. 14.1) lo acusaban de dilapidar el dinero público, no tardaron en mudar de opinión hasta el punto de que, como por arte de magia "empezaron a dar gritos animándolo a gastar los fondos públicos y hacer provisión sin escatimar nada”. Así, el relato de Plutarco destaca los aspectos positivos de la política económica ${ }^{41}$ de Pericles, de suerte que, pese a su discutida gestión del erario público, prevalece finalmente su incorruptibilidad, muy superior a los atractivos del oro, pues no se quedó con nada para sus hijos (Per.15.3).

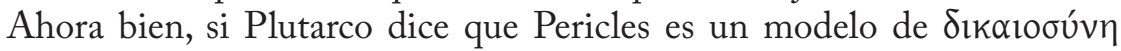
debe ser por alguna razón y no fruto de un mero capricho. Pero, como bien ha visto M. Cerezo 1996: 126, Numa y Solón ${ }^{42}$ son los auténticos pilares que sustentan la idea de justicia en la obra de nuestro autor y también Arístides -pero no Pericles. Aunque con respecto a Arístides, el de Queronea (Comp. Arist. Cat. Ma. 3.3) afirma que desacreditó con su pobreza a la justicia por

${ }^{37}$ Cuenta Plutarco (Per. 22.2-3) que Pericles sobornó a Cleándridas, el asesor del joven rey lacedemonio Plistonacte, para que persuadiera a los suyos de que se marcharan del Ática. Como consecuencia, los lacedemonios pusieron una multa al rey y a Cleándridas lo condenaron a muerte. Cf. Th. 1.114 .2 y 2.21 .1 .

${ }^{38}$ Cf. Ar., Nu. 858-859; Éforo, FGrHist.70F 193; Suda, s.v. Déov.

39 Sobre el conocimiento de esta polémica actuación de Pericles por Plutarco, vd. W. S. Ferguson 1904: 5-20. Para un análisis de la política financiera de Pericles, vd. G. H. Stevenson 1924: 1-9 y J. Philippoussis 2000: 277-281.

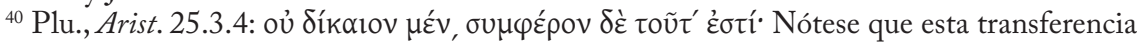
de fondos tuvo lugar después de la muerte de Arístides, aunque este detalle parece no importarle al moralista.

${ }^{41}$ Para los detalles de esta política, vd. V. Vanoyeke 2000: 117-128.

${ }^{42}$ Sobre la justicia de Solón, vd. G. Vlastos 1946: 65-83. 
haberla convertido en destructora de la casa, productora de mendigos y más útil para los demás que para los que la poseen. Con estas palabras, parece sugerir Plutarco que la riqueza y la justicia son términos contrapuestos, pero no es así y lo vemos, por ejemplo, en Arist. 25.3-10, donde el autor incide en la justicia de su personaje: su integridad, su desprecio del dinero y su nobleza ante la desgracia de su adversario Temístocles ${ }^{43}$. Por otra parte, siendo Solón un modelo de justicia por antonomasia ${ }^{44}$, no es improbable que Plutarco tuviera en mente esta figura cuando escribía su Vida de Pericles. En cierto modo el de Queronea, como también aquél, entiende que la posición del político no es nada fácil y que complacer a todos es imposible. En este sentido, existe cierta semejanza de contenido entre el texto de Plutarco (Per.33.7.1-8.3) ${ }^{45}$ y el poema $24 \mathrm{D}^{46}$ de Solón en el que el propio poeta dice haber actuado "uniendo

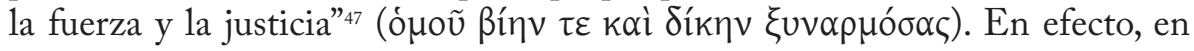
ambos pasajes el político se ve comprometido por amigos y enemigos, pero sin acabar de complacer a nadie. Y como también aquél, parecía ir en contra de los intereses de su clase al conceder ciertos privilegios, de los que ya antes hablamos, al pueblo. Si esto es así, la idea de justicia se hallaría implícita en el texto a través de una asociación Solón-Pericles ${ }^{48}$ que, sin embargo, su autor no llega a plasmar explícitamente.

\section{Pericles y la justa administración de las riquezas}

En alguna ocasión, hay quien (e.g. C. Mossé 2006: 208) ha querido ver en la ascendencia materna de Pericles, mencionada por Plutarco (Per. 3.2),

${ }^{43}$ Vd. F. Frazier 1996: 164.

${ }^{44}$ Cf. Arist., Ath. 9. 63-68; Pol. 1256 b-1274 a.

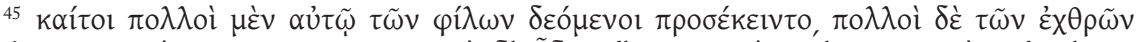

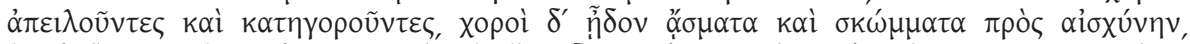

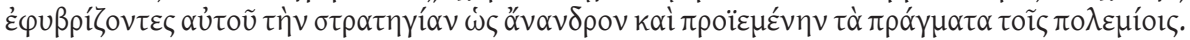

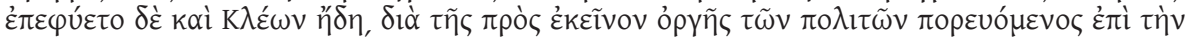
$\delta \eta \mu \alpha \gamma \omega \gamma i ́ \alpha v$ ("En verdad muchos de sus amigos acudían a él con ruegos y muchos de sus enemigos con amenazas y acusaciones; y los coros entonaban cantos y burlas para escarnio suyo, echándole en cara que su forma de llevar la guerra era cobarde y dejaba la situación en manos de los enemigos. Ya le acosaba como un perro también Cleón, en marcha hacia el liderazgo del pueblo aprovechando la irritación de los ciudadanos contra aquél...").

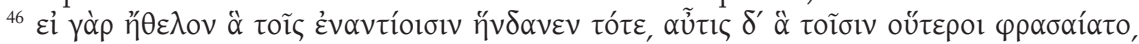

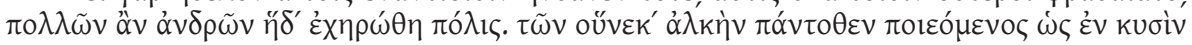

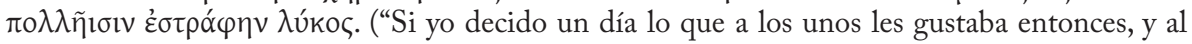
otro lo que planeaban sus contrarios, esta ciudad habría quedado viuda de muchos hombres. Frente a eso, sacando vigor de todos lados, me revolví como un lobo acosado por perros". Trad. de C. García Gual 1993.

${ }^{47}$ Esta idea se desarrolla a lo largo de los vv. 15-27, que es la parte más importante de la composición. Vd. E. García Novo 1979-1980: 201-202.

${ }^{48}$ También Solón, al igual que el Pericles de Plutarco, insiste en sus poemas en la necesidad de que las riquezas se adquieran con justicia. Vd. J. A. Clúa Serena 2005: 128. 
un evidente complemento de la moderación y el sentido de la justicia de Pericles. Sin embargo, el vínculo entre la justicia del estadista y el equilibrio y la concordia de su pariente lejano Clístenes ${ }^{49}$ no resulta tan evidente a tenor de lo que dice Plutarco ni tampoco que estas cualidades, el equilibrio y la concordia, sean efectivamente un complemento esencial de la justicia. Ahora bien, si ser justo significa, como parece desprenderse del texto de Plutarco, no dejarse eclipsar por las ganancias, entonces tal vez sí podamos hablar con propiedad de justicia, aunque quizás sería más exacto, al menos en castellano, hablar de honradez. Pero no olvidemos que en griego el adjetivo dík $\alpha$ los también puede significar 'honrado'.

Con esta idea en mente, retomamos, de los términos antes mencionados que aparecen en la Vida de Pericles y que se hallan etimológicamente relacionados

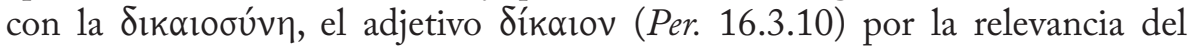
contexto en el que aparece. Se trata de un pasaje en el que Plutarco incide sobre la relación del estratego con los bienes materiales (Per. 16.3.4-5.1):

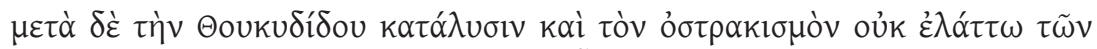

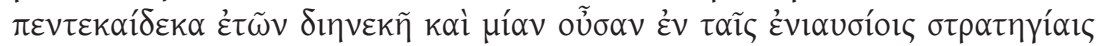

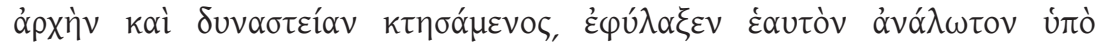

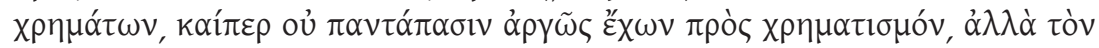

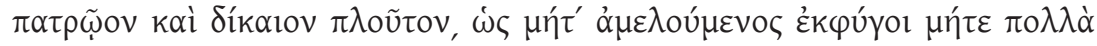

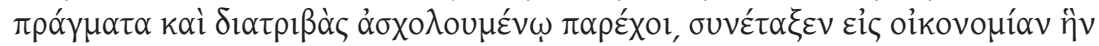

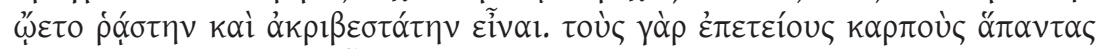

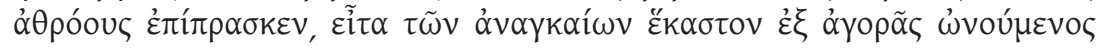

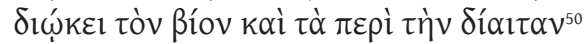

En estas líneas, el adjetivo Síkolos hace referencia a la idea de que la riqueza de Pericles, que era heredada y no adquirida por su propia actividad, es una riqueza justa, es decir, legítima. Esta cuestión es de suma importancia y Plutarco aprueba la austeridad del gobernante en su vida privada, concepto que encontramos también en Platón. De hecho, en relación con este asunto, no podemos evitar el recuerdo del final del libro III de la República platónica ${ }^{51}$,

${ }^{49}$ Vd. M. Durán Mañas 2010: 145.

50 "Y aunque, después de la caída y ostracismo de Tucídides, durante no menos de quince años estuvo de manera continuada y en solitario en posesión del mando y de la autoridad en las campañas anuales, se mantuvo inaccesible al dinero; sin embargo, no era por completo indolente ante los negocios, sino que para evitar la pérdida por descuido de su patrimonio familiar y legítimo y que no le diera muchos quehaceres y distracciones cuando nunca tenía tiempo, lo organizó en una administración que a su juicio era muy fácil y transparente. Vendía junta toda la cosecha anual de una vez y luego gobernaba su vida y lo de su casa, comprando en el ágora cada uno de los artículos imprescindibles”.

${ }^{51} \mathrm{Pl}$., R. 416d-417b: "En primer lugar, nadie poseerá bienes en privado, salvo los de primera 
donde el filósofo deja claro que la afección por los bienes materiales es adversa para la consolidación del Estado, siendo la ambición material de los políticos especialmente dañina, por lo que propone separar el poder político del poder económico a fin de que la única ambición del que gobierna sea la de ejercer sus funciones con rectitud. En sintonía con este pensamiento, Plutarco retrata a Pericles como un hombre que, a diferencia de su maestro Anaxágoras ${ }^{52}$, no abandona su hacienda a su suerte, sino que se la encomienda a su esclavo Evangelo para que lleve las cuentas, al carecer él mismo de tiempo. Así, Plutarco alaba del estadista su forma de administrar los bienes privados y lo cataloga como un modelo de sensatez, pues saca de lo material el provecho justo para lo necesario. En este sentido, su modo de vida resulta un ejercicio diario de la virtud del político (Per. 16). Y Plutarco insiste una y otra vez en este aspecto de su biografiado: es un orador que cuenta con el apoyo del pueblo y su comportamiento se opone a la imagen del demagogo que, según la tradición, era un orador popular y fácil de comprar ${ }^{53}$. Así, en Per. 5.1., el de Queronea habla de las enseñanzas de Anaxágoras de Clazómenas, que hicieron de Pericles un hombre comedido; en Per. 15.3, afirma que era desinteresado e incorruptible; en Per. 25. 2-3, recuerda que también en el caso de Samos rechazó el dinero que le ofrecían los notables samios que tenía por rehenes e igualmente rechazó las 10000 estateras de oro que le había enviado el sátrapa de Sardes, Pisutnes, para tratar de que cediera ante los samios; además, en Per. 33.3 se dice que declaró públicamente, cuando el rey Arquidamo se disponía a invadir el Ática, que si sus bienes eran respetados por los vínculos de hospitalidad que le unían al lacedemonio, él mismo los donaría a la ciudad;

necesidad. En segundo lugar nadie tendrá una morada ni un depósito al que no pueda acceder todo el que quiera. Con respecto a las vituallas, para todas las que necesitan hombres sobrios y valientes que se entrenan para la guerra, se les asignará un pago por su vigilancia, que recibirán de los demás ciudadanos, de modo tal que durante el año tengan como para que no les sobre ni les falte nada. Se sentarán juntos a la mesa, como soldados en campaña que viven en común. Les diremos que, gracias a los dioses, cuentan siempre en el alma con oro y plata divina y que para nada necesitan de la humana, y que sería sacrílego manchar la posesión de aquel oro divino con la del oro mortal, mezclándolas, ya que muchos sacrilegios han nacido en torno a la moneda corriente, mientras que el oro que hay en ellos es puro. En el Estado, por consiguiente, únicamente a ellos no les estará permitido manipular ni tocar oro ni plata, ni siquiera cobijarse bajo el mismo techo que éstos, ni adornarse con ellos, ni beber en vasos de oro o plata. Y de este modo se salvarán ellos y salvarán al Estado. Si en cambio poseyeran tierra propia, casas y dinero, en lugar de guardianes serán administradores y labradores, en lugar de asistentes serán déspotas y enemigos de los demás ciudadanos, odiarán y serán odiados, conspirarán y se conspirará contra ellos, y así pasarán toda la vida, temiendo más bien y mucho más a los enemigos de adentro que a los enemigos de afuera, con lo cual se aproximarán rápidamente a la destrucción de ellos mismos y del Estado.”Trad. de C. Eggers Lan 1986.

${ }^{52}$ Paradójicamente, Pericles, preocupado por sus quehaceres, descuidó a su maestro. Como es natural, nadie puede estar en todo.

${ }^{53}$ Vd. C. Mossé 2006: 211. 
y, por último, en la comparación entre Fabio y Pericles (3.5.1-3.6.5) reitera Plutarco la misma idea:

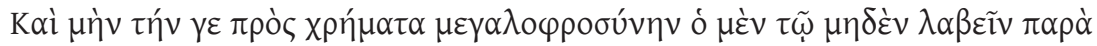

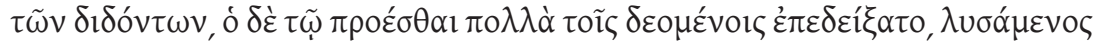

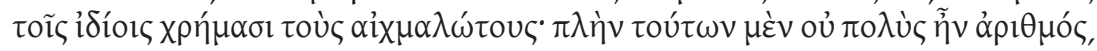

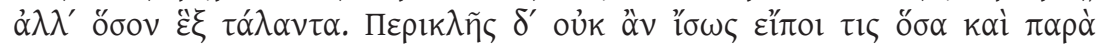

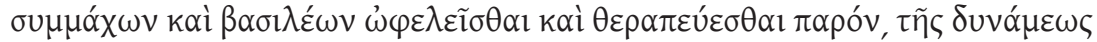

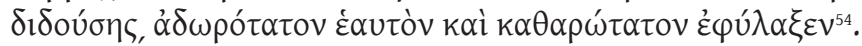

Pero tampoco aquí reaparece el término díkaıı ni ninguno de su familia léxica. Por este motivo, nos preguntamos si estas características del estadista no se vinculan mejor a la otra virtud manifestada por Plutarco al comienzo de su vida: la $\pi \rho \alpha o_{\text {ó}} \eta \varsigma^{55}$. Este término, tradicionalmente traducido como 'afabilidad', en las Vidas expresa la evitación de cualquier exceso mediante el control de uno mismo ${ }^{56}$ $\mathrm{y}$ así ha sido traducido recientemente en nuestro idioma como 'autodominio' o 'autocontrol' ${ }^{57}$. De este modo, además de significar una resistencia interior a la cólera y a la violencia, una placidez tendente a la inercia, como señala bien F. FrAZIER 1996: 232-233, puede igualmente aplicarse a la moderación en materia

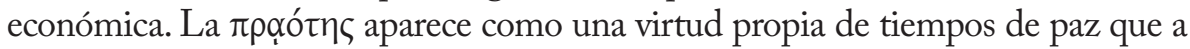
menudo ocupa junto con la justicia ${ }^{58}$ la cima de la escala de valores que conforman un ideal político. Así, como moderadora, constituye un freno al comportamiento, aunque también pueda tener en alguna ocasión un componente negativo ${ }^{59}$. En todo caso, Plutarco pone de relieve la buena administración de Pericles, sobre todo

54 "Respecto a la grandeza de alma ante las riquezas, aquél (Pericles) la demostró con no coger nada de las que le ofrecían, y éste (Fabio) con dar muchas a los necesitados, cuando liberó con su propio dinero a los prisioneros. Es verdad que en este caso la suma no era elevada, sino unos seis talentos. Pero de Pericles tal vez nadie pueda decir cuánto provecho y favores pudo sacar de aliados y reyes, gracias a su influencia, y en cambio se mantuvo incorruptible y sin tacha”. Trad. de A. PÉrez Jiménez 1996: 587.

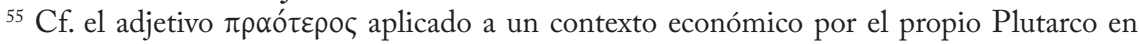
Gracch. 9.2.2.

${ }^{56}$ Vd. H. Martin 1960: 65-73 y 1961: 334, n. 30: "In the Lives, praotes is basically a selfrestraint which avoids excess of every kind, whether physical or emotional, whether within the individual or in his relations with other people. It manifests itself in the dignity of a person's appearance, his control of an emotional impulse, and the forbearance with which he treats another".

${ }^{57}$ Vd. A. Pérez Jiménez 1996: 415-416 y J. García López 2008: 89.

${ }^{58}$ La $\pi \rho \alpha o ́$ tn, unida a la justicia, permite a Numa apaciguar y embrujar a los romanos (Numa 20.4). Vd. también Lyc. 28.13.

${ }^{59}$ Por ejemplo, se atribuye el fin trágico de Agis a su praotes y a su juventud en Plu., Agis 21.5. Vd. F. Frazier 1996: 233. 
a partir del capítulo 15, desviándose en determinados momentos de sus fuentes ${ }^{60}$.

En suma, podemos decir que de las dos cualidades anunciadas al comienzo

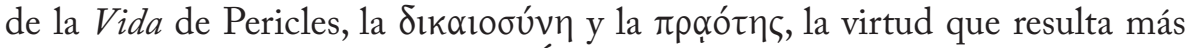
manifiesta es la de la moderación. Ésta se materializa sobre todo en su forma comedida de administrar la hacienda privada -no la del Estado-, si bien tampoco este proceder queda exento de críticas, dado que produce descontento en el seno de su propia familia y una enconada animadversión por parte de sus hijos. Pero, además, esta virtud no se restringe al plano de lo económico, ya que en la recapitulación de lo que fue la vida de Pericles, Plutarco (Per. 39.1.12.1) insiste nuevamente en su equidad y su autodominio, no en relación con el dinero, sino con los enemigos:

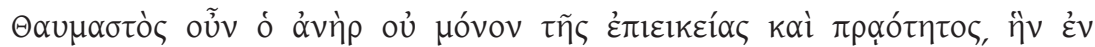

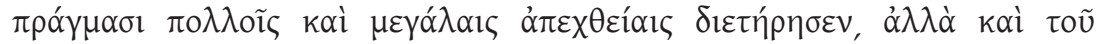

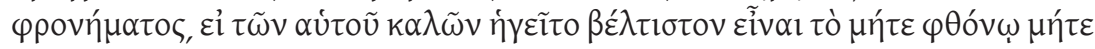

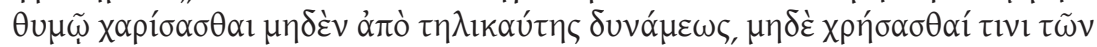

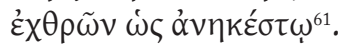

En cualquier caso, es evidente que ambas virtudes van de la mano, pues

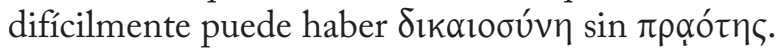

\section{Conclusiones}

Como hemos ido viendo a lo largo de nuestra exposición, Plutarco no desarrolla en la Vida de Pericles el tema de la justicia, pese a su afirmación inicial de que era un gobernante destacable a causa de esta virtud. En consecuencia,

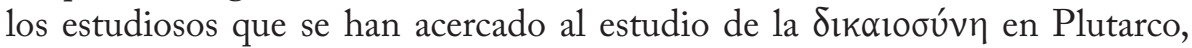
ni siquiera mencionan esta biografía. Tampoco a partir de la imagen global que se desprende de las acciones del personaje puede extraerse ninguna conclusión acerca de su justicia e incluso en no pocas ocasiones su proceder político resulta rayano en lo injusto o, cuando menos, movido por intereses particulares. Por ejemplo, nos preguntamos si un político como Pericles que, al no disponer de tanto dinero como su rival Cimón, recurre a la repartición de los caudales públicos, puede ser considerado como imbuido de la virtud moral

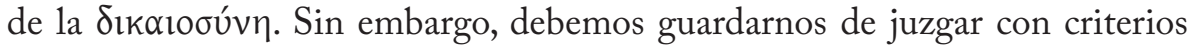
modernos $^{62}$ una política que tal vez sólo pretendía la mayor gloria para su

\footnotetext{
${ }^{60}$ Vd. A. Pérez Jiménez 1996: 453, n. 153.

61 "Es sin duda admirable este hombre no sólo por su ecuanimidad y serenidad, de las que hizo gala en medio de muchos asuntos y grandes rencores, sino también por su nobleza, si es que, de entre sus bellas acciones, consideraba la mejor no haber cedido ni a la envidia ni a la ira con semejante poder, ni haber tratado a ninguno de sus enemigos como irreconciliable".

${ }^{62}$ Cf. L. Sancho 1991: 81.
} 
ciudad. En todo caso, tal vez sí podamos hablar de justicia en la actuación de Pericles en materia económica, pues hemos visto que, en efecto, administraba justamente una hacienda heredada a su vez con justicia. Sin embargo, esta

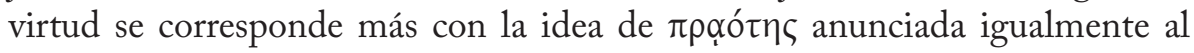

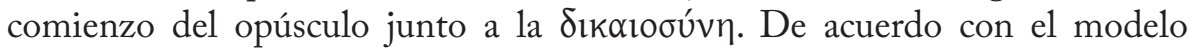
platónico, la justicia es una virtud fundamental del gobernante y es probable que por este motivo Plutarco se la atribuya inicialmente a Pericles aunque

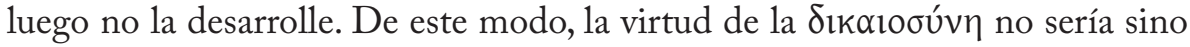
un tópico presente también en otros autores de la época o, incluso, Plutarco podría estar pensando en ciertas características comunes entre Pericles y Solón que le llevarían a trasladar al primero las cualidades del segundo, habida cuenta de que Solón sí es un auténtico modelo de justicia en Plutarco. 


\section{Referencias bibliográficas}

Azara, P., "Al compás de la templanza: sôfrosyne y edificación en Platón", Eikasia. Revista de Filosofía 12, Extraordinario I, 2007: 201-218.

Bouffartigue, J., "La notion d'animal vertueux dans l'Antiquité grecque", Schedae 1/1, 1-14, 2009. (http://www.unicaen.fr/services/puc/ecrire/ preprints/preprint0012009.pdf).

Burn, A. R., Pericles and Athens, New York, 1962.

Cartledge, P., "Spartan Justice? Or "The State of the Ephors"?", Dike 3, 2000: 5-26.

Cerezo, M., Plutarco. Virtudes y Vicios de sus héroes biográficos, Universitat de Lleida, 1996.

Clúa Serena, J. A., "Solón o la historicidad de la comunicación elegíaca: la Elegía a las Musas y otros fragmentos: problemas actuales", Norba. Revista de Historia 18, 2005: 119-135.

Corral Genicio, J., "La noción de justicia en la Retórica de Aristóteles", Revista Telemática de Filosofía del Derecho 6, 2002/2003: 137-166.

Durán Mañas, M., “Las mujeres en la Vida de Pericles” en Van der Stockt, L.; Titchener, F.; Ingenkamp, H. G.; Pérez Jiménez, A. eds., 2010: 143-162.

Eggers Lan, C., Platón. Diálogos IV. República, Madrid, 1986.

Ferguson, W. S., "Historical Value of the Twelfth Chapter of Plutarch's Life of Pericles", TPAPA 35, 1904: 5-20.

Foster, M. B., The political philosophies of Plato and Hegel, New York, 1984 (reimpr. de 1935).

Frazier, F., Histoire et morale dans les Vies parallèles de Plutarque, Paris, 1996.

Frost, F. J., "Pericles and Dracontides”, JHS 84, 1964: 69-72.

García Gual, C., Antología de la poesía lírica griega, Madrid, 1993.

García López, J., "Estructura formal y elementos religiosos en las Vidas de Plutarco: Pericles", Myrtia 23, 2008: 87-99.

García Novo, E., "Fuerza y justicia. Comentarios al fragmento 24D de Solón”, CFC 16, 1979/1980: 199-213.

Guzmán Hermida, J. M.; Martínez García, O., Plutarco: Vidas Paralelas IV, Madrid, 2007.

Ladikos, A., "The Pursuit of Justice in Plato's Republic", Phronimon 7/2, 2006: 73-88.

López Aranguren, J. L., Ética, Madrid, 1990. 
Martin, Jr. H., “The Concept of Praotes in Plutarch's Lives”, GRBS 3, 1960: 65-73.

Martin, JR. H., “The Character of Plutarch's Themistocles”, TPAPA 92, 1961: 326-339.

Mossé, C., Pericles, el inventor de la democracia, Madrid, 2006.

Pérez Jiménez, A., Plutarco: Vidas Paralelas II, Madrid, 1996.

Philippoussis, J., "The Periclean Notions of Justice, Excellence and Citizenship", Phronimon 2, 2000: 275-294.

Racionero Carmona, Q. Aristóteles. Retórica, introducción, traducción y notas, Madrid, 1990.

SANCho,L.,"TO METEXEIN TH $\Sigma \Pi O \Lambda E \Omega \Sigma$. Reflexiones acerca de las condiciones de pertenencia ciudadana entre Solón y Pericles", Gerión 9, 1991: 59-86.

Sancho Rocher, L., ¿Una democracia "perfecta”? Consenso, justicia y demokratía en el discurso político de Atenas (411-322 a.C.), Zaragoza, 2009.

Santalla Peñaloza, Z. Del R., El sistema de memoria humano: memoria episódica y semántica, Caracas, 2000.

Stadter, Ph. A., A commentary on Plutarch's Pericles, North Carolina, 1989.

Stevenson, G. H., “The Financial Administration of Pericles”, JHS 44.1, 1924: 1-9.

Van der Stockt, L.; Titchener, F.; Ingenkamp, H. G.; Pérez Jiménez, A. (eds.), Gods, Daimones, Rituals, Myths and History of Religions in Plutarch's Works, Málaga, Utah, 2010.

Vanoyeke, V., Pericles, Madrid, 2000.

Vlastos, G., "Solonian Justice”, CP 41.2, 1946: 65-83.

Vlastos, G., "Equality and Justice in Early Greek Cosmologies", CP 42.3, 1947: 156-178. 


\title{
O Sentido de dike nas biografias de Aristides e Catão CENSOR
}

\author{
Joaquim Pinheiro \\ Universidade da Madeira
}

\begin{abstract}
The biographic pair Aristides-Cato-the-Elder allows a comprehensive analysis of the meaning of dike and other words with the same etymological root. Given the context in which these terms are used, we propose to evaluate their sense in shaping the profile of both characters as members of a community, and the ways in which Plutarch combines the individual level of analysis with the need for society to identify and respect the principles related to the dike.
\end{abstract}

A análise do sentido de dike e de vocábulos que pertencem ao mesmo campo lexical, em particular a dikaiosyne, no par biográfico Aristides-Catão Censor, leva-nos a ter em conta, por um lado, o seu contributo para a definição do ethos do herói e da sua actividade política e, por outro, o valor da dike no contexto da polis. Ambas estão interligadas, uma vez que aquele que agir com respeito pela justiça merece ser elogiado e imitado. Aliás, parece ser um dos requisitos de quem exerce funções públicas o escrupoloso respeito pela justiça

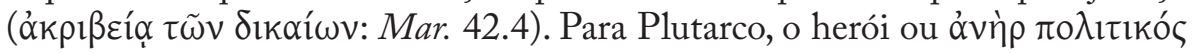
deve constituir um modelo de virtude para os cidadãos e inspirar neles uma conduta de vida exemplar. É desta forma que se gera a proairesis política ${ }^{1}$, como se lê no bios de Numa, em que o sentido de justiça (dikaiosyne) e a moderação (metriotes) contribuem para uma vida melhor (Num. 20.11-12):

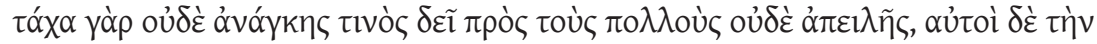

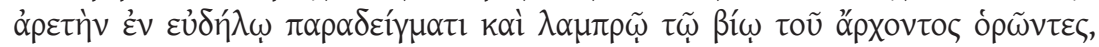

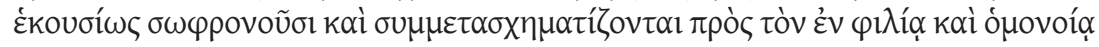

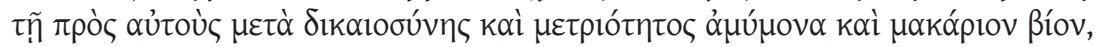

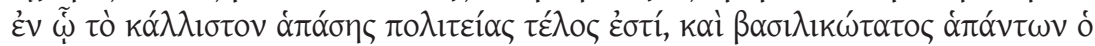

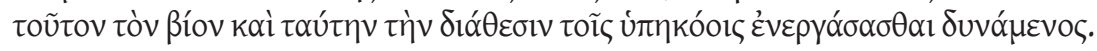

De imediato, não é necessário qualquer uso da força contra a multidão, nem de ameaça, pois os próprios cidadãos observando a virtude no claro exemplo e na vida insigne do governante, espontaneamente se tornam moderados e se configuram com uma vida irrepreensível e feliz na amizade e na concórdia mútuas, mediante a justiça e a moderação, já que nesta vida está o fim mais belo de todo o Estado, e é o melhor rei de todos o que pode inspirar este estilo de vida e esta disposição aos súbditos.

\footnotetext{
${ }^{1}$ Cf. Praec. ger. reip. 800B-C; sobre a proairesis política, vide A. PÉrez Jiménez 1995: 363-381.
} 
Nas Vidas Paralelas e nos Tratados Morais, a arete surge associada à philanthropia, à praotes, à phronesis, à sophrosyne, à andreia e também à dikaiosyne, entre outros valores ${ }^{2}$, sendo muito difícil encontrar num Grego ou Romano todas as aretai. Por exemplo, Agesilau, Lisandro, Nícias e Alcibíades foram excelentes e vitoriosos comandantes, mas que não souberam usar o seu sucesso para desenvolver acções generosas. A própria estrutura paralelas das vidas, como Plutarco refere no tratado Mulierum virtutes (243B-D), ao evidenciar as semelhanças e as diferenças (ópoló confronto as virtudes, que estão sujeitas a alterações e a diferenciações, graças

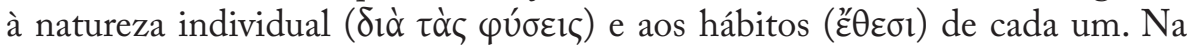
biografia de Fócion (3.7-8), Plutarco demonstra que uma mesma qualidade pode apresentar diferenças de indivíduo para indivíduo, mantendo o carácter (karacter), a forma (morphe) e a cor (chroma), pois parece que se misturam em igual medida (" $\left.\sigma \omega \omega \mu \varepsilon \varepsilon^{\prime} \tau \omega\right)$ as virtudes, de tal maneira que se torna complexo encontrar as diferenças.

No caso particular da dikaiosyne, F. Frazier 1996: 177 ss. inclui-a na lista das virtudes mais importantes das Vidas Paralelas, a par da phronesis, da andreia e da sophrosyne, relacionando-as com a tradição, pois Platão, nas Leis 631c, designa-as como bens superiores. A. Pérez Jiménez 2004: 127, por sua vez, sustenta que a justiça é a mais importante das virtudes, ideia que é partilhada por J. RibEIRo Ferreira 2005: 570 que considera: "Nas Vidas Paralelas, o herói não é um homem só, mas surge como responsável por outros, um chefe que deve velar pela salvação do exército e do estado, cuja prudência protege e cuja resolução galvaniza os outros. Talvez por isso a virtude suprema nas Vidas seja a dikaiosyne, que se aproxima da philanthropia, mas também do que exprimem adjectivos como demotikos e hellenikos (e suas substantivações) - ou seja cultura, afabilidade, humanidade, benevolência, sociabilidade". S-T. TEOdorsson 2005: 659, contudo, defende que a dikaiosyne é um conceito central na ética de Platão, mas, em Plutarco, é a philanthropia que ocupa esse lugar. Certamente que as intervenções deste Colóquio nos ajudarão a enquadrar o valor da dike na obra de Plutarco.

Quanto às biografias de Aristides e Catão Censor, elas corroboram, em particular a do Ateniense, as palavras de Plutarco na biografia de Flaminino

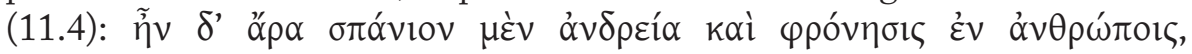

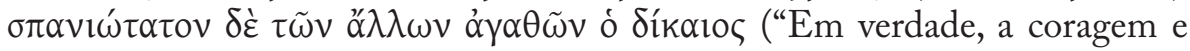
a sabedoria eram raras entre os homens, mas o bem mais raro de todos era um homem justo”). Este passo reforça, sem dúvida, o valor da dikaiosyne na

\footnotetext{
${ }^{2}$ No tratado Diálogo sobre o Amor 769B-C, Plutarco resume, desta forma, as principais qualidades da mulher, a temperança (sophrosyne), a inteligência (synesis), a fidelidade (pistis), o sentido de justiça (dikaiosyne), a coragem (andreia), e a grandeza de espírito (megalopsychia), que são, lato sensu, as virtutes que uma polis deve possuir.
} 
caracterização ética e política do herói. Só por si, a dikaiosyne não é, de modo algum, suficiente para tornar o indivíduo um cidadão exemplar e activo na sociedade. Daí que, em Plutarco, a dikaiosyne surja quase sempre associada a outros valores que a complementam ou reforçam o seu sentido. Por exemplo, foram virtudes como a epimeleia, a praotes e a dikaiosyne que valeram a Cícero a nomeação para questor (cf. Cic. 6.1), em 75 a. C., embora o seu carácter não fosse isento de alguns excessos que desviam o homem de uma vida modelar, tais como o desejo de receber elogios e a paixão pela glória, que provocam o

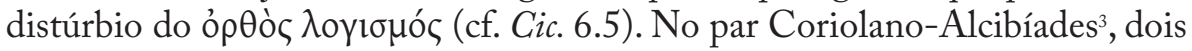
homens em que muitas vezes o vício se sobrepõe à virtude, refere Plutarco que da mesma maneira que o médico ${ }^{4}$ ou o músico precisam, respectivamente, de prestar atenção à doença e aos sons dissonantes, também não se pode ser indiferente às kakiai para expor a verdadeira arete, uma vez que, para se conhecer

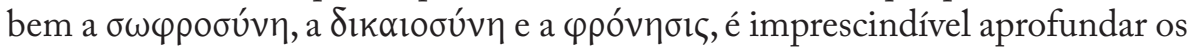
seus contrários. Esse é o princípio que Plutarco defende no início da biografia de Demétrio (1.4) $)^{5}$, ao afirmar que a sophrosyne, a dikaiosyne e a phronesis não julgam apenas o bom (kalos), o justo (dikaios) e o útil (ophelimos), mas também o prejudicial (blaberos), o ignominioso (aischros) e o injusto (adikos).

Neste quadro ético-moral, em que se interliga virtude e conhecimento, na linha do pensamento tradicional helénico, aquele que pratica a arete tem poder para distinguir o que deseja assimilar e o que prefere censurar e rejeitar. Os leitores, ao verem os paradeigmata, devem sentir, interiormente, o apelo por

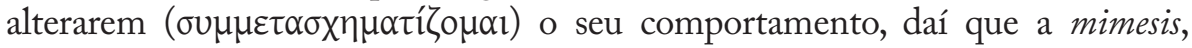

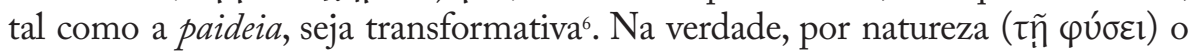
homem não possui o conhecimento do valor da justiça e, por isso mesmo, terá de recorrer à paideia, exigindo este processo entrega e esforço (ponos, spoude). Esse esforço está bem ilustrado por Hesíodo, no poema Trabalbo e Dias (289 ss.), que Plutarco considera a mais antiga declaração de prokope (De prof. virt. 77D).

\section{Aristides-Catão Censor}

No par Aristides-Catão Censor, os vocábulos do campo lexical do substantivo dike apoiam a ideia, absolutamente central em toda a narrativa, de que o homem

${ }^{3}$ Sobre o par Coriolano-Alcibiades, vd. D. Russel 1963, ${ }^{2} 2001: 108$ e T. Duff 2002r: 205-240.

${ }^{4}$ Sobre o uso do médico como referente educacional, vide J. Martín del Pozo 1996: 185-192.

${ }^{5}$ Cf. Ages. 23.5 e Dio 47.6.1-7.1.

${ }^{6}$ Distanciando-se, neste caso, dos preceitos platónicos, em De aud. poet. 26A, defende que o estudante não deve apenas aprender aquilo que se deve imitar, até porque a poesia não representa apenas o que é bom, mas caracteres excessivos e longe da perfeição. Este princípio aumenta a responsabilidade da paideia, no papel que tem em educar a interpretação textual, havendo o risco de a poesia não ser devidamente analisada em meios menos cultos, o que não era o caso das elites greco-romanas. 
se distingue pelo exercício da virtude na vida pública. Nesse sentido, ser justo é

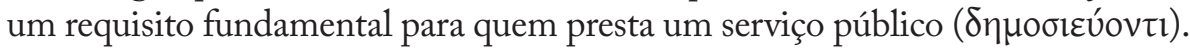
Se para Aristóteles a ética está relacionada com o esforço empregue para se atingir a excelência no modo de viver (cf. EN, II 1103b e 1114b.), Plutarco, de igual modo, descreve acções concretas, na defesa de uma virtude ética que se consubstancia nas atitudes e actividades quotidianas.

Aristides e Catão Censor, duas figuras históricas que surgem algumas vezes associadas nos Tratados Morais (e.g. De coh. ira 463E, An seni resp. 797A e Praec. ger. reip. 805E), tiveram, segundo Plutarco, uma entrada tranquila na vida política $^{7}$ e viveram momentos decisivos para as suas pátrias. A forma louvável como se entregaram ao serviço da pátria merece ainda maior reconhecimento pelo facto de não terem ocupado o poder muitas vezes, como Plutarco realça em An seni respublica gerenda sit 797A. Aristides participou activamente nas Guerras Medo-Persas e Catão Censor na Hispânia, na Segunda Guerra Púnica ou na Batalha das Termópilas (191 a. C.), tendo sido tribuno militar (214 a. C.), questor (204), edil (199), pretor (198), cônsul (195)8 e censor (184), as magistraturas do cursus honorum ${ }^{9}$. No caso de Catão, por ter vivido 85 anos (234-149 a. C.), assiste e participa em vários acontecimentos que ditariam o domínio do espaço mediterrânico por Roma. Apesar disso, as duas biografias concentram-se na análise ética, em particular na qualidade moral do exercício da politeia, abordando também na biografia de Catão Censor a relação entre os tradicionais valores romanos e a paideia grega. Além de uma intensa actividade política, Aristides e Catão têm em comum o modo simples e frugal como viveram. Se na biografia de Catão essa qualidade não surge de forma evidente associada à dikaiosyne, o mesmo não se passa na de Aristides. O filho de Lisímaco, de espírito adverso à luxúria e à ostentação (5.6; 24.1; 25.3-9; 27.1-7; Comp. Arist.-Cat. Ma. 3-4) ${ }^{10}$, poderia até ser criticado pelas consequências da sua penia, uma vez que ela colocou em causa a autarkeia privada (Comp. Arist.-Cat. Ma.3.2-4). Esta crítica parece ser também dirigida aos que pensam, como os Sofistas (cf. Pl. Grg. 482e-483d, Prt. 300c e R. $343 \mathrm{c}-\mathrm{e})$, que a justiça só serve para beneficiar os que governam e mesmo os injustos, prejudicando quem pratica a pobreza, como é o caso de Aristides. $\mathrm{Na}$ sequência do pensamento hesiódico ( $O p .286$ ss.), é digno de louvor para o biógrafo aquele que consegue conciliar a economia doméstica com a justiça,

${ }^{7}$ Em Praec. ger. reip. 805E, Plutarco explica que ambos cresceram junto de homens célebres e experientes, Aristides junto de Clístenes e Catão de Máximo (Cf. Arist. 2.1 e Cat. Ma. 2.3, 3.4).

${ }^{8}$ Depois de cônsul, serviu novamente como tribuno militar por sua vontade (cf. Cat. Ma. 12.1).

${ }^{9}$ Cf. Cat. Ma. 3.3: Plutarco faz referência ao cursus honorum e como Catão Censor partilhou com Valério Flaco as mais elevadas magistraturas.

${ }^{10}$ Parece evidente que reuniu as duas vidas, a de Aristides e de Catão Censor, pelo facto de ambos levarem uma vida simples e frugal. 
pois acredita-se que a organização do Estado se começa a construir no seio da família, o que leva Plutarco a censurar o facto de Aristides ter deixado a sua própria família na miséria. Ainda assim, a pobreza voluntária de Aristides é, para Plutarco, um valor, enquanto testemunha do ethos incorruptível de quem ocupou magistraturas ou obteve vitórias, fruto da sorte ou do mérito, e conseguiu manter a simplicidade (apheleia), pois a nobreza de espírito vale mais do que qualquer quantia em ouro ${ }^{11}$.

Realça Plutarco que Aristides foi companheiro de Clístenes, o autor de importantes reformas constitucionais (cf. Arist., Ath. 21-22), respeitou e imitou Licurgo, o mais conhecido legislador espartano, e, acima de tudo, manteve uma acesa disputa (philonikia) política com Temístocles, que segundo Aríston de Ceos (fr. $20 \mathrm{~W}$ ), peripatético do séc. III a. C. que Plutarco refere, teria origem numa disputa amorosa ${ }^{12}$. Também Aristóteles, na Constituição dos Atenienses (23.3), diferencia Temístocles de Aristides, aquele por ser mais dotado para os assuntos militares ( $\tau \grave{\alpha} \pi \circ \lambda \hat{\varepsilon} \mu \imath \alpha$ ), e este por ser hábil nas questões políticas

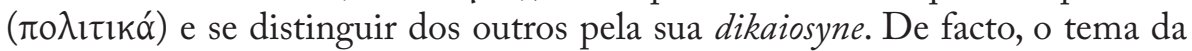
philonikia entre Aristides e Temístocles, domina uma parte substancial da biografia e acaba por remeter o paralelismo com Catão para segundo plano, sobretudo quando a intenção é entender o significado da justiça. Plutarco discorre sobre as diferenças de carácter entre ambos, em especial o uso que fazem do poder. Enquanto Temístocles não conseguiu desempenhar de forma imparcial o seu poder, Aristides foi, em geral, intransigente na defesa da imparcialidade e evitou cometer injustiças ( $\sigma u v \alpha \delta i k \varepsilon \tilde{v})$, mesmo quando se tratava de interesses de pessoas que lhe eram próximas ou de pessoas que o tinham apoiado no seu percurso político (Arist. 2.6):

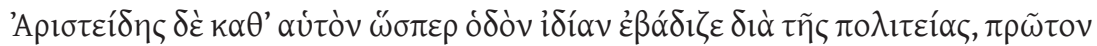

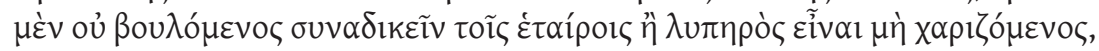

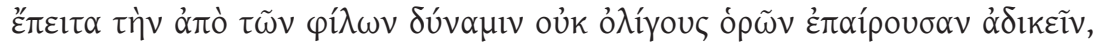

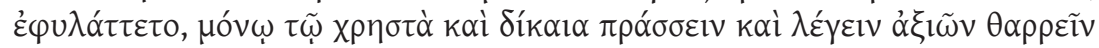

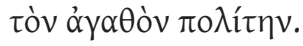

Aristides, pela sua parte, seguiu a actividade política por ele mesmo, como se fosse o seu próprio caminho, sem querer, em primeiro lugar, cometer injustiças

${ }^{11}$ P. A. STADTER 1997: 75-78 reflecte, de forma interessante, sobre a riqueza e a pobreza no contexto específico da participação na vida pública por parte de Aristides e de M. Pórcio Catão, o bios romano escolhido por Plutarco para estabelecer um paralelo.

${ }^{12}$ Cf. Arist. 2.3-4; Them. 2.2; T. Duff 2002: 97 afirma: "Similarly, Plutarch mentions the youthful passion ( $\pi \alpha \dot{\theta} \theta \circ)$ of Aristeides and Themistokles over the favours of a certain Stesilaos

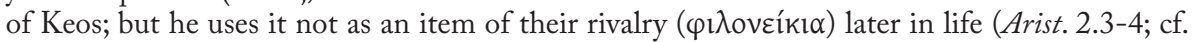
Them. 2.2). Sexual conduct is rarely included as an indicator of character in its own right; it does not itself play a very large role in Plutarch's estimation of a statesman's worth in the Lives." 
com os companheiros ou ser molesto por não condescender com eles, e depois, ao ver que o poder dos amigos impulsionava não poucos a cometer injustiças, manteve-se vigilante, julgando digno de ser bom cidadão somente aquele que praticasse e proferisse coisas virtuosas e justas.

A propósito destes apoios políticos, note-se que Aristides sempre teve consciência dos seus inconvenientes, uma vez que a sua ascensão política, ao contrário da de Temístocles, foi conseguida de forma muito solitária, por não querer participar em injustiças nem dar expectativas de futuros benefícios aos seus apoiantes. Para Aristides, o bom cidadão deve esforçar-

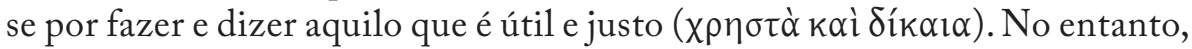
o exercício da política testemunha que nem sempre o que é justo se torna, necessariamente, útil.

Essa é uma das temáticas mais relevantes ao longo da biografia de

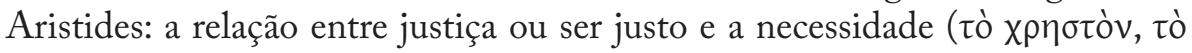

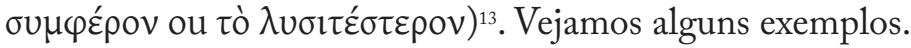

\section{Aristides e a conspiração aristocrática (Arist. 13)}

Conta Plutarco que alguns aristocratas, com a batalha de Plateias, perderam influência e reputação, além de verem dia-a-dia a sua riqueza diminuir, e, por isso, decidiram conspirar contra a democracia, de modo a fragilizar as estruturas estatais e a entregá-las aos inimigos. Aristides, apercebendo-se desta conjura e não querendo negligenciar os intentos aristocráticos, ponderou sobre a utilidade de um possível castigo e a necessidade de aplicar a justiça. Assim, moveu uma acusação contra oito dos implicados; deixou outros partir em liberdade e aos que julgavam não terem sido descobertos permitiu-lhe que se arrependessem, sugerindo-lhes Aristides que, como diz Plutarco, "se queriam escapar de forma recta e justa às acusações para com a pátria tinham a guerra como grande tribunal” (13.3). Embora a referência a esta conspiração aristocrática careça de provas históricas, na verdade este episódio revela como Aristides opta por uma intervenção que se ajusta às circunstâncias e às necessidades do momento, em detrimento de uma inquirição judicial, certamente penosa e de difícil exequibilidade.

\section{Aristides e o plano de Temístocles (Arist. 22.3-4)}

Um outro episódio emblemático, também referido na biografia de Temístocles (20.1-2), trata-se da recusa de Aristides em apoiar o plano de

${ }^{13}$ Sobre esta temática vd. A. PÉrez Jiménez 1980: 147-143, A. Nikolaidis 1995: 301-12 e F. Frazier 1996: 161-164. 
Temístocles, que projectava incendiar o porto dos Gregos, para, dessa forma, criar condições para a supremacia de Atenas na Grécia ${ }^{14}$. Aristides afirma, perante o povo, "não existir outra acção mais útil nem mais injusta" ( $\mu$ ń $\varepsilon$

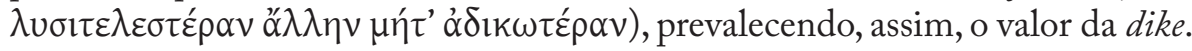
A posição de Aristides será, aliás, secundada pelo demos, o que leva Plutarco a adjectivar o demos de philodikaios, e a realçar que a rejeição do povo ao plano de Temístocles se deve ao facto de Aristides ser uma homem com credibilidade

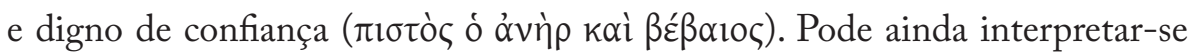
a recusa de Aristides como um sinal do sentimento pan-helénico, da mesma forma que Plutarco elogia Agesilau por não concordar com a entrega de algumas cidades aos Persas pelos Espartanos ${ }^{15}$.

\section{Como a mudança das circunstâncias dita uma alteração na acção política (Arist. 25.1-3)}

Apesar de ter feito jurar os Gregos e de ele próprio ter jurado em nome dos Atenienses, Aristides, por causa da mudança das circunstâncias, viu-se obrigado

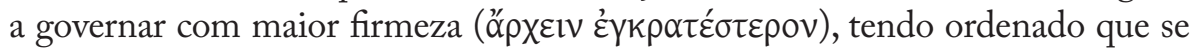

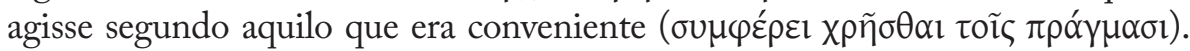
Para reforçar este traço do perfil de Aristides, Plutarco recorre à descrição que Teofrasto faz do Ateniense: "este homem em assuntos da sua vida pessoal e com os cidadãos foi extremamente justo, e nos assuntos públicos agiu muitas vezes de acordo com os princípios da pátria, o que exigia com frequência a injustiça”.

Estes três exemplos, elucidativos dos conflitos que se geram entre a justiça, o interesse pessoal e a utilidade pública, permitem-nos afirmar que Aristides ${ }^{16}$,

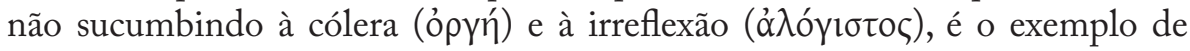
quem analisa o contexto político e toma uma decisão em proveito da causa pública, uma vez que "era o mais vigoroso a opor-se, em defesa do que é justo, não apenas à parcialidade e ao benefício, mas à cólera e à inimizade" (Arist. 4.1). Ao longo do $4^{0}$ capítulo $^{17}$ contam-se algumas histórias que testemunham como Aristides, nos processos judiciais, não permitia que se subvertessem as garantias legais a que os acusados e acusadores tinham direito. Segundo Idomeneu, o próprio Aristides terá sido alvo de uma acusação (katadike) movida por Temístocles, por causa dos bens públicos, mas que os aristocratas desvalorizaram. Esse processo terá criado um profundo desgosto em Aristides,

${ }^{14}$ Cf. A. Pérez Jiménez 2004: 134-135.

${ }^{15}$ Cf. Ages. 23.2-3, ou seja, a paz de Antálcidas.

${ }^{16}$ Cf. Praec. ger. reip.. 817D. Em De coh. ira 458C, ao tratar das acções que se executam em estado colérico, Aristides, juntamente com Camilo, Q. Cecílio Metelo e Sócrates, é mencionado como um exemplo de benevolência e moderação.

${ }^{17}$ Vários vocábulos pertencentes ao campo semântico do processo legal, em particular, com o

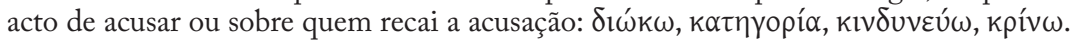


de tal forma que deixou de preocupar-se com aqueles que roubavam o erário público, não compreendendo como antes era motivo de escárnio por ser íntegro na forma como governava e, agora, que se mantinha alheado, era considerado

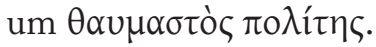

Pelo valor que atribuía à justiça e pelas suas virtudes, Aristides ganharia o epíteto de 'o Justo'. Note-se, porém, que ele não ganhou o cognome "o justo" por ter sido responsável por alguma constituição legal ou por ser um legalista, mas antes pela probidade que imprimiu à sua carreira e por ter sabido conciliar a justiça com a necessidade da polis. Além disso, este cognome deve-se a uma conduta paradigmática, bem diferente de outros cognomes atribuídos a reis e tiranos, que resultam do uso da força e da violência, como "Raio", "Águia”, "Falcão", entre outros (cf. Arist. 6.2).

Um homem com estas características, como facilmente se consegue prever, suscita o apoio de alguns e o ódio de muitos. Temístocles, seu rival, começou a difundir a ideia entre os Atenienses de que os tribunais tinham perdido a sua função por causa da determinação de Aristides em julgar tudo. Para Temístocles, estava-se a preparar, na clandestinidade, uma monarquia sem vigilância. Como reagiu o povo? Embalado pelas vitórias e achando-se merecedor de honrarias, não apreciava o facto de Aristides gozar de uma reputação superior à da maioria.

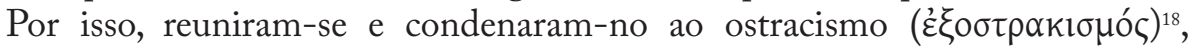
provavelmente no ano de 482 a. C. Segundo Plutarco, Aristides sofreu esta condenação por duas razões: a inveja ( $\varphi \theta$ óvo $)$ pela sua reputação e o receio de que Aristides instaurasse a tirania. Aristóteles, porém, justifica a condenação com o facto de Aristides, defensor de uma economia mais conservadora, se ter oposto ao plano de construção de trirremes proposto por Temístocles, com o objectivo de desenvolver novas formas económicas ${ }^{19}$.

${ }^{18}$ Para Aristóteles (Pol.1284a), o ostracismo é, basicamente, uma forma de banir e exilar da cidade todos os que se tornam uma ameaça, por causa de usufruírem de muito poder. Apesar de não haver entre os estudiosos uma posição unânime, atribui-se a Clístenes a criação deste procedimento legal ateniense, em 508-7 a. C.. Trata-se de uma medida preventiva que exilava por um período de 10 anos um cidadão incómodo, ou seja, com excesso de poder e que poderia tornar-se um tirano. $\mathrm{O}$ povo escrevia em pedaços de cerâmica (os ostraka) o nome daquele que queriam ver condenado. Cada ano a assembleia (ekklesia) votava a continuidade ou não da condenação. Não se confunda este procedimento com o desterro, uma vez que este previa a apreensão dos bens do condenado. De acordo com a tradição, o último condenado ao ostracismo foi Hipérbolo, provavelmente em 417 a. C.

${ }_{19}$ Cf. Ath. 22.7: "No terceiro ano após estes acontecimentos durante o arcontado de Nicodemo, foram descobertas as minas de Maroneia e a exploração rendeu à cidade um encaixe de cem talentos. Alguns aconselharam que os porventos fossem repartidos pelo povo, mas Temístocles opôs-se e, sem revelar que destino daria ao dinheiro, defendeu que se emprestasse um talento a cada um dos cem Atenienses mais ricos; depois, se o investimento agradasse, a despesa ficaria a cargo da cidade; caso contrário, o dinheiro seria retirado a quem havia contraído o empréstimo. Assim que recebeu o dinheiro nestas condições, tratou da construção de cem trirremes (a cada um dos cem cidadãos cabia construir uma) e com elas se combateram os 
Assinale-se que posteriormente, em 471 a. C., o próprio Temístocles será condenado ao ostracismo e o único que não o acusou nem se alegrou com a adversidade do seu rival foi... Aristides, atitude que denota bem o seu carácter. De facto, os episódios relacionados com o notável exercício de Aristides na Liga Délica ${ }^{20}$, a sepultura de Aristides e o apoio da polis à sua família reforçam a primazia que durante a vida deu à moralidade e à ética no exercício de funções públicas, não deixando fortunas como herança aos seus descendentes, mas a sua reputação de homem justo, indulgente e patriótico, qualidades que já haviam merecido de Heródoto um elogio digno de nota: "o melhor e mais justo homem em Atenas" (8.79.1).

Quanto a Catão Censor, ficou conhecido por ser um homem conservador e por tentar defender os valores e os costumes ancestrais dos Romanos, numa época em que Roma começava a estabelecer o seu poder imperial. Por causa da sua capacidade oratória, que lhe valeu o epíteto de "Demóstenes romano" (Cat. Ma. 4.1), Catão participou em vários processos como advogado, defendendo ( $\sigma u v \delta ı \tilde{\omega} v: 1.5)$ quem solicitava os seus serviços ou participando em processos de acusação (katadike). Procurava, na sua actividade pública, agir com rectidão (ő $\rho \theta ı c:$ 6.4) e de forma justa (dikaios). Apesar disso, Plutarco critica o comportamento, por vezes, excessivamente severo de Catão com aqueles que o rodeavam (escravos ou outros), e, por isso, considera que a "bondade ocupa um espaço mais amplo do que a dikaiosyne"

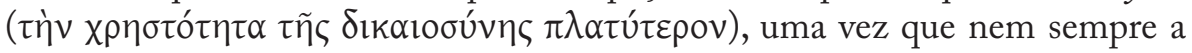
condição humana se circunscreve ao nomos ou ao dikaios (5.2).

Podemos, assim, verificar que no bios de Catão Censor o sentido de justiça não é estruturante na narrativa biográfica, nem surge como um elemento fundamental da caracterização do romano. Não se conclua destas palavras que a dikaiosyne é um valor exclusivo dos Gregos. Bastaria lembrar o que Plutarco afirma de Marcelo, um romano que nasceu cerca de quarenta anos antes de Catão Censor (Marc. 20.1) ${ }^{21}$ :

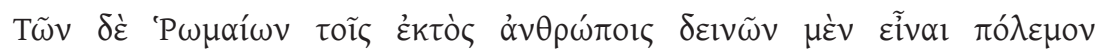

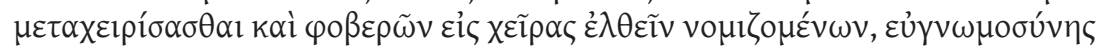

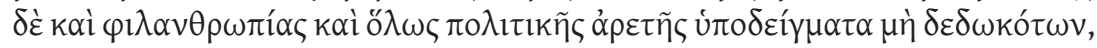

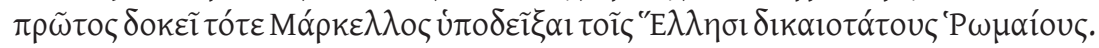

bárbaros, em Salamina. Por esta razão, foi ostracizado Aristides, filho de Lisímaco”. (trad. de D. F. LEÃo 2003).

${ }^{20}$ Pelo facto de os aliados de Atenas louvarem o tributo fixado por Aristides (quatrocentos e sessenta talentos; cf. Th. 1.96), Plutarco compara, de forma algo exagerada, esta época à de Cronos, ou seja, à Idade de Ouro (cf. Arist. 24.3).

${ }^{21}$ Políbio condena os actos de Marcelo (9.10). 
Para os estrangeiros, os Romanos eram considerados hábeis na condução da guerra e terríveis na luta, não tendo dado provas de benevolência, de humanidade e, em geral, de virtude política. Marcelo parece ter sido o primeiro a mostrar aos Gregos que os Romanos eram particularmente justos.

Tendo em conta, sobretudo, o sentido de justiça na biografia de Aristides, podemos afirmar que, tal como outros valores, ele adquire uma dimensão moral, filosófica e ética, quer em relação à formação do indivíduo, quer pela sua valorização no contexto da polis. Associada à pobreza, ao amor à pátria ${ }^{22}$ ou à conduta cívica, a justiça, como processo legal ou judicial, ou como valor em si mesma, merece da parte do biógrafo de Queroneia realce especial na composição do bios de Aristides. Não como valor abstracto, mas como virtude prática, fundada na razão, que brota da actividade pública do herói. Daí que a interiorização individual do sentido de justiça seja importante, bem como o seu aprofundamento e contínuo processo de actualização, mas de pouco valerá esse esforço se não existir uma consequência colectiva. Por isso, Plutarco dirige os maiores elogios ao herói que souber harmonizar as suas convicções pessoais com os objectivos do colectivo, tal como Aristides fez ao esquecer o processo que o condenou ao ostracismo, continuando a lutar pelos Gregos contra os Persas, em prol de uma Hélade livre e justa.

${ }^{22}$ Cf. A. Pérez Jiménez 1980. Note-se que para este estudioso o patriotismo é a qualidade mais realçada por Plutarco; podemos encontrar um argumento a favor desta tese em An seni

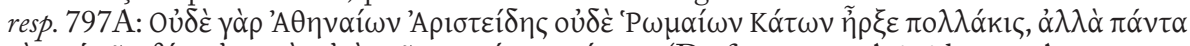

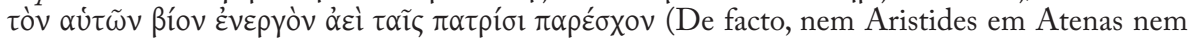
Catão em Roma tiveram muitas vezes o poder, mas entregaram a sua vida inteira ao serviço da pátria); a philopatria é, sem dúvida, um valor apreciado por Plutarco, mas quando o patriotismo se torna exacerbado é muitas vezes nocivo e inoportuno, como prova a biografia de Fócion; em J. Pinheiro 2006: 23-24 desenvolvemos alguns dos traços do carácter de Aristides. 


\section{Bibliografia}

Duff, T., Plutarch's Lives. Exploring Virtue and Vice, Oxford, 2002r.

Frazier, F., Histoire et Morale dans les Vies parallèles de Plutarque, Paris, 1996.

Leão, D. F., Aristóteles. Constituição dos Atenienses, Lisboa, 2003.

Nixolaidis, A., "Plutarch's heroes in action: does the end justify the means?", in I. Gallo \& B. Scardigli (eds.), Teoria e Prassi Politica nelle Opere di Plutarco, Atti del V Convegno plutarcheo (Certosa di Pontignano, 7-9 giugno 1993), Napoli, 1995: 301-312.

Pérez Jiménez, A., "Pobreza, justicia y patriotismo en la Vida de Arístides de Plutarco", Sodalitas 1, 1980: 145-153

Pérez Jiménez, A., "Proairesis: las formas de acesso a la vida pública y el pensamiento politico de Plutarco", in I. Gallo \& B. Scardigli (Eds.), Teoria e Prassi Politica nelle Opere di Plutarco, Atti del V Convegno plutarcheo (Certosa di Pontignano, 7-9 giugno 1993), Napoli, 1995: 363381

Pérez Jiménez, A., "Los Héroes de Plutarco y su Elección entre la Justicia y la Utilidad", L. de Blois et al. (eds.), The Statesman in Plutarch's Greek and Roman Lives, Leiden \& Boston, 2004: 127-136.

Pinheiro, J., "O exercício da virtude na vida pública: o exemplo de Aristides", Classica 25, 2006: 23-34.

Ribeiro Ferreira, J., “Demotikos e demokratikos na paideia de Plutarco”, in M. Jufresa et al. (eds.), Plutarc a la seva època: Paideia i societat (Actas dels VIII Simposio Internacional de la Sociedad Española de Plutarquistas, Barcelona, 6-8 nov. 2003), Barcelona, 2005: 569-576.

Russel, D., "Plutarch's Life of Coriolanus”, JRS 52, 1963: 21-28.

Russel, D., Plutarch, foreword and bibliography by Judith Mossman, London, ${ }^{2} 2001$.

Stadter, P. A., "Plutarch's Lives: the statesman as moral actor", in C. Schrader et al. (eds.), Plutarco y la Historia. Actas del V Simposio Español sobre Plutarco (Zaragoza, 20-22 de junio de 1996), Zaragoza, 1997: 65-81.

Teodorsson, S.-T., "El programa de Plutarco para la conducta social”, in M. Jufresa et al. (eds.), Plutarc a la seva època: Paideia i societat (Actas dels VIII Simposio Internacional de la Sociedad Española de Plutarquistas, Barcelona, 6-8 nov. 2003), Barcelona, 2005: 659-664. 
(Página deixada propositadamente em branco) 


\title{
Plutarco y su interpretación de leyes griegas CONCERNIENTES A LA FAMILIA Y PROPIEDAD ${ }^{1}$
}

\author{
Inés Calero Secall \\ Universidad de Málaga
}

\begin{abstract}
This paper looks at certain Greek laws mentioned by Plutarch, in order to examine whether they were interpreted with complete juridical rigour. Thus, the following laws are analysed: the nomoi agamiou, Solon's law concerning to the exemption of the filial duty of feeding the father, the illegitimacy of children of mixed marriages and the law of damages due to animals. This study reveals that Plutarch committed certain mistakes because of chronological errors or lack of juridical accuracy.
\end{abstract}

A Plutarco hay que concederle el mérito de haberse convertido en una importante fuente de información sobre hechos políticos o sociales de la antigüedad clásica. Gracias a su investigación sobre personajes históricos de la época griega y romana hemos podido conocer multitud de aspectos del mundo clásico que no hubiéramos conocido o que habrían caído en el olvido. La erudición con la que reviste su obra nos ayuda a entender mejor o completar nuestro conocimiento sobre detalles ya conocidos o, aún más, sobre algunos desconocidos que él nos ha hecho llegar.

Lo mismo podríamos decir cuando aborda temas legales de épocas pasadas. Sus obras también están sembradas de referencias a leyes y situaciones legales que aportan luz al conocimiento del derecho griego anterior ${ }^{2}$.

Sin embargo, es sabido que en las Vidas paralelas prevalece sobre todo el interés por transmitir mensajes morales más que una profunda investigación histórica ${ }^{3}$. Y si esto ocurre con hechos históricos, también sería posible detectar alguna falta de rigor en sus noticias sobre cuestiones legales de sus antepasados.

Pues bien, una lectura pausada de estas referencias me ha permitido constatar que Plutarco en más de una ocasión no se ajusta a la realidad jurídica

${ }^{1}$ Este trabajo se incluye en el marco del proyecto FFI2008-00326: "Familia y propiedad en el derecho griego antiguo”, financiado por el Ministerio de Ciencia e Innovación.

${ }^{2}$ No es desacertado bucear por la literatura griega para investigar temas jurídicos, porque en el mundo griego la ciencia jurídica no era un aspecto separado de otros campos. La mayor parte de nuestra información del sistema jurídico procede de este tipo de fuente griega. Sobre las diferencias entre romanistas que hacen distinción entre "fuentes jurídicas" y "no jurídicas" y los estudiosos del derecho griego que no lo hacen, cf. la introducción que hace Eva Cantarella en E. Cantarella; L. Gagliardi 2007: 9-10, quien expone los dos métodos de investigación en esta relación entre literatura y derecho: Law in Literature y Law as Literature.

${ }^{3}$ Apud A.Pérez Jiménez 1985: 71. El propio Plutarco dice en Nic. 1.5 que su pretensión era componer una historia que sirviera para comprender el carácter y la conducta de los personajes. 
de antaño. Es por ello que este trabajo se va a orientar a examinar esos desajustes para averiguar qué grado de inexactitud jurídica tienen las informaciones plutarqueas sobre cuestiones concernientes a la familia y propiedad. Pero además en el análisis se intentará indagar las razones que motivaron esa discordancia con la realidad antigua.

Huelga decir que las leyes de Solón tienen una importante presencia en la obra de Plutarco y máxime cuando a su figura está dedicada una de sus biografías. Es sabido que Solón emprendió reformas de los más variopintos asuntos, pero entre ellos destacamos la regulación de la familia y, por ende, el matrimonio. La mayoría de los datos aportados por Plutarco al respecto son ciertos, pero en su interpretación convergen juicios que vienen dictados desde su propia perspectiva.

\section{El matrimonio y las nómoi agamíou}

El matrimonio fue considerado por Plutarco como una simbiosis espiritual entre los esposos en una sympatheia y una koinonia pantos tou biou ${ }^{4}$, donde prima el amor y el respeto mutuo más que la unión física de una pareja con vistas a procrear hijos legítimos. Estos rasgos con los que definió el matrimonio, Plutarco los aplicará en la exégesis de las leyes nupciales de Solón sin darse cuenta de que el amor conyugal no fue el fin perseguido en las prescripciones solonianas sobre el matrimonio. Su objetivo primordial fue la procreación de hijos legítimos que heredaran el patrimonio. Así, por ejemplo, ocurre con su comentario a la disposición legal sobre la obligación de mantener relaciones sexuales con la heredera por lo menos tres veces al mes (cf. Sol. 20.4).

En las leyes solonianas sobre el matrimonio de la heredera lo que hay es un gran poso de interés patrimonial para beneficiar al oikos, que escapa a los ojos de Plutarco. La perpetuación del patrimonio familiar fue uno de los principios en los que se basó la institución griega del epiclerato. Para lograr tal fin la hija huérfana estaba obligada a proporcionar un heredero, de ahí la prescripción de la frecuencia de encuentros sexuales ${ }^{5}$.

Sin embargo, no es probable que Solón dictase normas para combatir el celibato y algunas dudas nos sugiere la atribución al legislador de la $\gamma \rho \propto \varphi \eta ́$ àyouíov, "acción pública por celibato", que, según Plutarco, introdujo en sus normas matrimoniales. Pocos estudiosos aceptan que una acción de este tipo procediera de Solón, mientras que es opinión general que esta graphe fue contemplada por la legislación espartana por motivos claramente patrióticos,

\footnotetext{
${ }^{4}$ Sobre ello, cf. la introducción de Plutarco. Deberes del matrimonio de C. Morales Otal; J. García López 1986: 173. Y también Plu., Coning. Praec. 138D; 140E.

${ }^{5}$ Para el análisis más extenso de estos temas matrimoniales solonianos que trató Plutarco, remito a mi trabajo: I. Calero Secall 2008: 520 ss.
} 
con objeto de acrecentar el número de ciudadanos que lucharan para la patria. Aquellos ciudadanos que no contraían matrimonio eran castigados con la pérdida de ciertos derechos. Esta disposición espartana es corroborada por Plutarco que la atribuye a Licurgo. Los solteros eran privados de honores como el respeto y atención de los jóvenes (Lyc. 15.2). Esta normativa seguía vigente en la Esparta del s. V.a. C., porque por el pasaje de la Vida de Lisandro 30.5 , nos enteramos de que al morir el general y dejar a sus hijas en la más absoluta indigencia, sus yernos las abandonaron, cuando descubrieron que su suegro era pobre. Entonces fueron castigados con una multa, de acuerdo con la

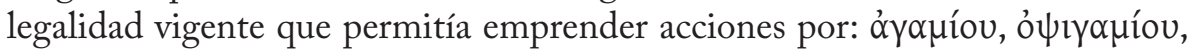

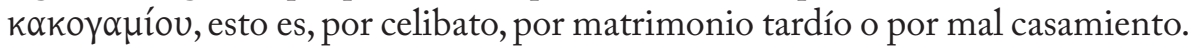

Sin embargo, en De amore prolis (493E) Plutarco introduce el nombre de Solón junto a Licurgo, dictando de la misma manera las vópor ỏyauíou y ó $\psi$ ıүauíou para los ciudadanos atenienses y se expresa en tales términos:

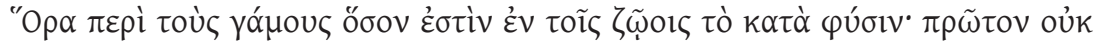

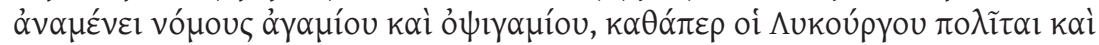

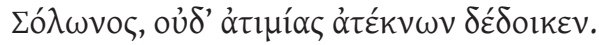

Fíjate cómo es la naturaleza de los animales respecto a sus uniones. En primer lugar, no soportan las leyes del celibato ni las del matrimonio tardío, como los ciudadanos de Licurgo y Solón, ni temen la privación de derechos ciudadanos por no tener hijos.

Hasta ahora Plutarco no había consignado noticia alguna respecto a esa normativa soloniana ni siquiera en la Vida de Solón; incluso no tenemos constancia de que otro autor antiguo la haya mencionado. Si Plutarco estaba convencido de que los atenienses también contaban con una graphe agamiou, cabe la posibilidad de que o bien cometió un descuido y se olvidó de referirlo en la vida o bien pensó que esta situación legal que critica en De am. prol. 493E debía cubrirla con un velo de silencio, porque desmerecía la figura de Solón. Parece que Plutarco no estaba de acuerdo con esta medida, porque él defendía que en el matrimonio se debía dejar actuar a las leyes de la naturaleza, lo mismo que hacen los animales, y no imponer castigos por no procrear.

Sin embargo, es posible encontrar razones a esta atribución soloniana, porque de sobra eran conocidas las reglas del epiclerato ático que estaban encaminadas a buscar un heredero que mantuviese la propiedad familiar. De hecho las sociedades antiguas, y no tan antiguas, ponían en valor la procreación; por ejemplo Calias, el hermano de la esposa de Alcibíades, incentivó a su cuñado con diez talentos más como dote si tenía descendencia (Alc. 8.3). Habría un deseo social de procrear, pero de ahí a emprender acciones públicas con el castigo de la atimia, como dice Plutarco, media una gran distancia. Además la 
atimia en época soloniana conllevaba efectos jurídicos mucho más rigurosos que en época clásica ${ }^{6}$ y, aún más, en la sociedad contemporánea de Plutarco. De implicar la idea de ser proscrito, la atimia pasó a significar la privación de los derechos de ciudadanía. Al decir Plutarco que recaía la atimia sobre los atenienses de época soloniana por estar célibes es no entender el alcance de este castigo.

También pudo ocurrir que Plutarco sacara sus propias conclusiones al consultar a los autores que le precedieron e hiciera retrotraer esta norma a Solón. Quizás se haga eco de la propuesta de Platón que prescribe en sus Leyes castigar a los que no se habían casado antes de los treinta y cinco años (Lg. 774a), pero el castigo platónico no tenía la importancia de una atimia. Se imponían sanciones pecuniarias y se excluía de los honores por parte de los más jóvenes a quienes se mantuvieran solteros.

\section{Ley sobre la exención a los hijos del deber de alimentar al padre}

Un poco confusa se presenta la ley concerniente al cuidado de los padres mayores, la cual pudo ser distorsionada por Plutarco. El autor atribuye a Solón una ley (Sol.22.1), en virtud de la cual "un hijo no tenía obligación de alimentar

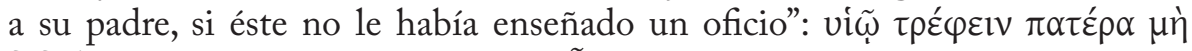

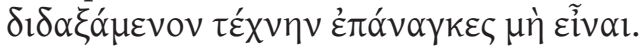

Esta ley contrasta con el omnímodo poder primitivo del padre. Es posible que el ius vitae necisque del que gozaba el padre no perdurase en tiempos de Solón, pero hemos de ver que todavía permitía vender a la hija si descubría que no era virgen (Sol.23.2).

Es sabido que respecto a la figura del padre el hijo tenía muchas obligaciones como proporcionarle alimento en la vejez o darle sepultura. E1 quebranto de estas obligaciones entrañaba la posibilidad de emprender contra él acciones públicas por maltrato. Precisamente se autorizaba a cualquier ciudadano a perseguir al hijo por incumplimiento del deber filial mediante una

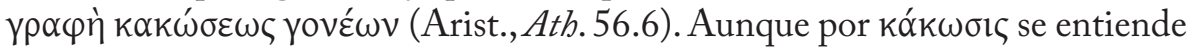
maltrato físico, comprende también la desatención de los padres mayores tanto en su alimentación como en su cuidado personal.

Que existía entre los atenienses esta prescripción soloniana de que los hijos alimentaran y cuidaran de sus padres en la vejez queda constatado por los testimonios aportados por otros autores griegos (cf. D.L. 1.55; Lib. Decl. 11.1,14; Ael. NA. 6.61). Y un hijo que no cumpliera con estos deberes hacia sus padres era castigado más que con pena de cárcel, como dice Demóstenes (D. 24 (C. Tim.). 103), con la atimía (D.L. 1.55) o pérdida de los derechos cívicos,

\footnotetext{
${ }^{6}$ Sobre los dos tipos de atimia, cf. A. Biscardi 1982: 84-86.
} 
por lo que entre otras cosas, sería excluido de hablar en la asamblea (Aeschin. 1 (C. Tim.).28). Y tan arraigada estaba esta obligación que en la anakrisis de los tesmótetas, cuando un ciudadano iba a ocupar un cargo, una de las preguntas formuladas al aspirante versaba sobre el trato que daba a sus padres (Arist. Ath.55.3).Y si el hijo no cuidaba de su padre era excluido de las magistraturas (Xen. Mem. 2.2.13).

Es más, Iseo, además de detallar incluso el número de mayores a los que el hijo debía alimentar, no sólo al padre y a la madre, sino también a los abuelos, indica que sin dejar ninguna fortuna a su hijo, el padre debía ser cuidado y alimentado (Is. 8.32).

Frente a estos deberes filiales, cobra pleno sentido que las leyes matrimoniales a su vez protegieran a los hijos, exigiendo a los padres su

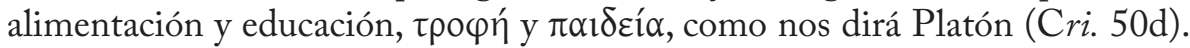
Extraña, por tanto, que la información de Plutarco connote la obligación de

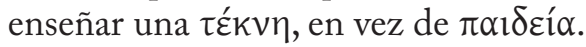

Es difícil pronunciarse por los motivos que favorecieron la interpretación de Plutarco. Es ampliamente conocido que hubo un eximente en la obligación filial de alimentar al progenitor, pero en casos cuando el hijo hubiera sido prostituido por él (Aeschin. 1 (C. Tim.). 13), no pudiéndose ejercer una graphe kakoseos goneon contra el hijo, si no lo atendía. Pero cuesta entender que se le eximiera del deber de gerotrophia por no haber sido instruido en un oficio.

Considero que cabrían dos modos de explicar las palabras de Plutarco. Por un lado, sostengo que en algún período de la vida ateniense se estimó conveniente castigar la desidia de un padre por no enseñar un oficio a su hijo con la privación de alimento en la vejez, pero tal vez no tengamos que remontarnos hasta Solón. Vitrubio (6. pref. 3) se hace eco de esta ley ática que contrasta con las dictadas por los demás griegos, que exigían a los hijos alimentar a los padres, frente a los atenienses que solo obligaban a aquellos que habían sido instruidos en las artes. Pero, fijémonos, Vitrubio no menciona a Solón. Además, estas sanciones a los padres con la privación de su cuidado

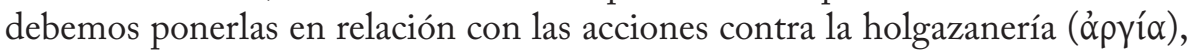
pues esta preocupación por combatirla fue constante en Atenas. El propio Plutarco atribuye a Sólón (Sol. 22.3) la nomos argias y es posible que esta ley procediera de Solón, aunque las fuentes antiguas no se ponen de acuerdo, unos la atribuyen a Dracón ${ }^{7}$, otros a Solón y también a Pisístrato ${ }^{8}$. Pero se ha de tener en cuenta también que más tarde en tiempos de Demetrio de Falero

${ }^{7}$ Cf. D. F. LEÃo 2001b: 107, para quien es posible que la nomos argias estuviese ligado a Dracón y entonces Solón se aprovechase de esta disposición de su antecesor, aunque tuvo la preocupación de alterar las penas y de que la ley pasara a ser competencia del Areópago.

${ }^{8}$ Cf. E. Caillemer, s. v. Argias Graphè, en H. Daremberg \& E. D. M. Saglio, Dictionnaire des antiquités grecques et romaines, Graz, 1969, p. 412 y A. PÉrez Jiménez 1996: 145. 
se recrudeció esa lucha contra la holgazanería y se dictaron leyes muy severas contra la moral pública. Sabemos que los areopagitas fueron autorizados a investigar casos de holgazanería9. Según la historia que Ateneo ha tomado de Filócoro y Fanodemo, en ese tiempo los areopagitas castigaban a los derrochones y a los que no vivían de sus propios recursos. Se cuenta que a los filósofos Menedemo y Asclepíades les exigieron que explicaran el modo de ganarse la vida, y ellos hubieron de responder que iban a trabajar a un molino por la noche por dos dracmas (cf. Ath. 4.65).

No es de extrañar que esta severidad legal que impulsaba tanto el trabajo y la moral se tradujera en la introducción de nuevas normas en la existente nomos argias $^{10}$. Estas pudieron afectar a las relaciones familiares e imponer este duro castigo a los padres que no habían dado un oficio a sus hijos. Y quizás esta cláusula sobre el cuidado de los padres citada por Plutarco procediera de esta época, 317 a. C. aproximadamente y no del tiempo de Solón, cuando el poder paterno estaba aún en todo su vigor.

Por otro lado, habría otra posibilidad de interpretar este pasaje y dar la razón a A. R. W. Harrison 1968: 79 que considera esta alteración de la letra de la ley como buscada deliberadamente por Plutarco, con el fin de diferenciar a Solón de Licurgo. En efecto, tal como el queronense refiere, el legislador lacedemonio había procurado que los ciudadanos disfrutaran de mucho tiempo libre, puesto que no permitía que se ocupasen en oficios manuales ni en actividades comerciales, porque el dinero no tenía interés (cf. Plu. Lyc. 24.2). Esto parece que no debía de ser del agrado de Plutarco. Y quizás con el fin de introducir consejos morales alentando el amor al trabajo y al esfuerzo como defendía la corriente estoica que admiraba, Plutarco atribuyera a su estimado legislador situaciones que fueron posteriores.

\section{La ilegitimidad de los hijos de matrimonios mixtos}

Los hijos nacidos de matrimonios mixtos, es decir, de la unión de ateniense y extranjero fueron considerados ilegítimos. Por ello Plutarco atribuye la calificación de vó$\theta$ os a Temístocles (Them. 1.1). En efecto, la primera noticia que nos transmite en la biografía es su condición de vó $\theta$ os por parte de madre, aunque su padre Neocles era ateniense originario del demos de Freario. Fuera su madre de Tracia y de nombre Habrótono, como la opinión más generalizada consideraba, o de Caria (Them.1.1), como suponía Fanias, el caso es que no era ateniense, sino extranjera. En efecto, Temístocles era un $\mu \eta \tau \rho o ́ \xi \varepsilon v o \varsigma$, igual que Cimón ${ }^{11}$.

\footnotetext{
${ }^{9}$ Cf. R. W. Wallace 2005: 372.

${ }^{10}$ En Demóstenes se hace mención de una nomos argias en la que estaba incurso Eubúlides, cf. D., 57 (C.Eub.). 32.

${ }^{11}$ Su madre Hegesípila era tracia. Cf. Plu., Cim. 4.1.
} 
Pero es sabido que no en todas las épocas los nacidos de un progenitor extranjero fueron considerados vó $\theta$ or en Atenas, pues hay que recordar que la noción de legitimidad fluctuó en los distintos períodos de la historia griega. En época homérica o soloniana eran legales las uniones matrimoniales entre extranjeros que más tarde quedaron fuera del marco de la legalidad, cuando Pericles definió la ciudadanía ateniense. Su decreto de 451/450 a. C. reconocía como ciudadano "al nacido de padre y de madre ateniense" (cf. Plu., Per. 37.3; Arist.,Pol. 1275b; Arist.,Ath. 26.3), cuya consecuencia no fue otra que convertir en ilegítimos a los hijos nacidos de esos matrimonios, a fin de disminuir el número de ciudadanos ${ }^{12}$. La derogación de esta norma se produjo, sin embargo, con la llegada de la oligarquía en 411, pero volviendo de nuevo a entrar en vigor con más severidad a partir del arcontado de Euclides (403/402 a. C.), puesto que los períodos demagógicos siempre fueron muy rígidos respecto al acceso a la ciudadanía ${ }^{13}$.

Por tanto, esta atribución de ilegitimidad parece falsa y puede ser imputable a un error cronológico, porque si nos fijamos en el tiempo que Temístocles ocupó el arcontado en 493/492 a. C. todavía no se había promulgado el decreto de Pericles y los hijos de uniones entre atenienses y extranjeros no estaban excluidos de la vida política de la ciudad. Entonces en la Atenas pre-periclea

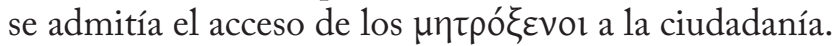

Es comprensible que Plutarco incurriera en ese error por la dificultad de averiguar con exactitud las fechas de antaño y de calcularlas, cuando esta exigencia de la doble ciudadanía de los padres para acceder a ella era conocida también en otras zonas griegas, pues, según refiere Plutarco, había una ley antigua que no permitía a los Heraclidas engendrar de una mujer extranjera (cf. Plu., Agis y Cleom. 11.2).

De ahí, se podrá deducir que la historia que Plutarco cuenta sobre la participación de Temístocles en el gimnasio Cinosarges y, sobre todo, la interpretación que hace de ello no se apoya en cimientos verdaderos ${ }^{14}$. Según el queronense, acudían a ese gimnasio solo las personas ilegítimas, como consecuencia de haber sido consagrado a Heracles, que no era de sangre enteramente divina, al nacer de madre mortal. Y por ser Temístocles ilegítimo, en opinión de Plutarco, invitaba a los legítimos a que le acompañaran al gimnasio a fin de acabar con las barreras que discriminaban a los nothoi (Them. 1.3)

${ }^{12}$ Cf. J. M. Hannick 1976: 146.

${ }^{13}$ Cf. J. M. Hannick 1976: 147.

${ }^{14}$ Según A. R. W. Harrison 1968: 65, n. 2, esta historia parece apócrifa y no es probable que los beneficiarios del gimnasio fueran los no ciudadanos.

${ }^{15}$ En Amatorius (750F) Plutarco vuelve a referirse al Cinosarges como un lugar de reunión de ilegítimos, cuando define el amor de un hombre que se casa por placer con una mujer perversa. 


\section{Ley de daños causados por los animales}

Del acervo plutarqueo recogemos también una ley soloniana en materia de propiedad sobre los daños causados por los animales, cuya exposición no se ajusta a la reglamentación jurídica griega para estos casos. Hablamos de la

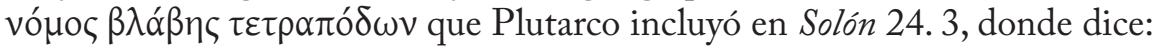

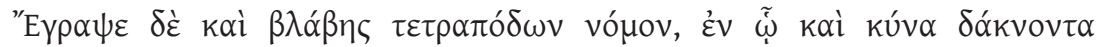

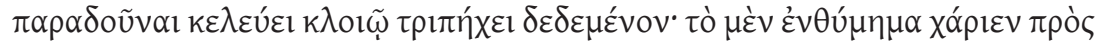

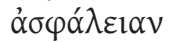

Él también redactó la ley sobre los daños causados por los animales cuadrúpedos, en virtud de la cual se ordena que sea entregado el perro que muerde atado con una cadena de tres codos. La inteligente medida nació por cuestión de seguridad.

Al decir que no se ajusta a la regla jurídica no es considerar que Plutarco estuviese equivocado, porque noticias parecidas sobre los perros que muerden son suministradas por el historiador Jenofonte ( $H G$ 2.4.41), sino intentar subrayar la falta de rigor en su modo de exponer la redacción de esta ley.

Solón legisló sobre situaciones de daños ocasionados a otras personas. Para ello fijó una sanción pecuniaria al doble o al simple, si los daños eran voluntarios o involuntarios. Pero también legisla sobre casos concretos de daños provocados no solo por animales, como recoge Plutarco, sino también

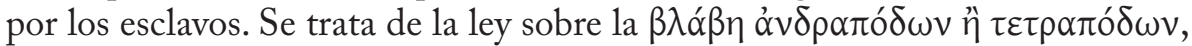

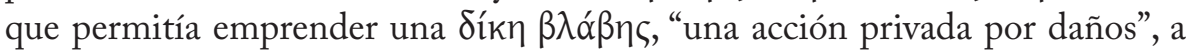
fin de obtener la reparación.

Que los daños y los delitos perpetrados por los esclavos fueron también regulados por Solón está testimoniado por Hipérides (Ath. 10.11-16) que, citando al legislador, confirma que los delitos ${ }^{16}$ del esclavo debían ser reparados por su dueño.

Sin embargo, en esta materia parece que Plutarco prefiere correr un tupido velo y silenciarlo, mientras que nos presenta la ley a medias sobre los daños causados por los animales.

No se equivoca Plutarco cuando afirma que, si un perro muerde, había de ser entregado, pero no parece que así fuera la cláusula completa de esta ley soloniana. Al afirmar la exigencia de la entrega del animal no se nos oculta que estamos ante lo que se conoce como "el abandono noxal", una de las dos maneras de resolver el conflicto en una situación de daños.

Es un amor bastardo que acaba en el Cinosarges.

${ }^{16}$ 'A $\_$$\kappa \eta ́ \mu \alpha \tau \alpha$ (lectura de Jensen). 
Resulta de claridad meridiana la conflictividad que surgía, cuando los animales o los esclavos hacían estropicios, del grado que fuera, a la propiedad de otro. Estos daños no quedaban impunes, pues la responsabilidad de esas acciones desastrosas recaía en el propietario del animal o del esclavo. Entonces al dueño se le ofrecían dos posibilidades de elección para zanjar el problema: entregar su animal que había causado el daño o pagar una indemnización a la persona perjudicada.

Que ambas alternativas fue un principio general en el mundo antiguo ${ }^{17}$ para resolver los problemas causados por los animales domésticos y por los esclavos queda corroborado por diferentes testimonios tantos griegos como romanos.

El propio Platón, cuyas leyes tienen como modelo disposiciones áticas y espartanas ${ }^{18}$, pero también cretenses ${ }^{19}$, dedica algunos preceptos a ambas situaciones. El pasaje de Leyes $936 \mathrm{~d}$ reza así:

$\mathrm{Si}$ un esclavo o una esclava $[\ldots]$ dañara cualquier bien ajeno, sin que tenga culpa el propio perjudicado, que el dueño del que haya hecho el daño, pague una indemnización suficiente o entregue al causante del daño.

$\mathrm{Y}$ en caso de animales como "una mula, un caballo, un perro o cualquier otro animal”, Platón exige que se indemnice por los daños al perjudicado en las mismas condiciones (P1. Lg. 936e $)^{20}$.

Se podrá rebatir que las leyes de Platón son solo una propuesta, pero Lisias testimonia la indemnización doble que habría de pagarse por los daños del esclavo (Lys. 10 (Theom. I). 19).

Pero la fuente de información más extensa sobre una y otra vertiente nos las ofrecen unas leyes cretenses del s. V a. C., cuyo contenido revela que Gortina tuvo prevista la misma manera de resolver los conflictos por daños, por lo que estos documentos sirven para confirmar que antes de la llegada de Alejandro hubo en los sistemas legales de la Grecia arcaica y clásica, si no un derecho común, al menos en el ámbito del procedimiento rasgos significativos compartidos ${ }^{21}$.

Es así que, en caso de animales la ley cretense se pronuncia por las dos posibles vías de reparar el daño, como en Atenas. En el llamado segundo código

${ }^{17}$ Para R. Sealey 2006: 482, refiriéndose al tema, hubo un conjunto de ideas comunes esenciales que según él son indoeuropeas.

${ }^{18}$ Cf. A. Wilson Nightingale 1999: 100.

${ }^{19}$ Sobre esa afinidad, cf. I. Calero Secall 2011: 92.

${ }^{20}$ Aristóteles (Ath. 52.2) también hace alguna alusión a los procesos por causa de los esclavos y animales.

${ }^{21}$ Cf. M. Gagarin 2005: 40, quien sugiere que se puede hablar de la unidad de derecho griego o, al menos, de la unidad de procedimientos legales griegos. 
cretense se prescribe que, cuando se hubieran causado daños a animales, su dueño podía cambiar su bestia herida o maltratada por aquella que causó el daño o, por lo menos, recibir una indemnización, si era su voluntad (IC IV 41. I 1-7; I 12-17-II 2).

Se constata, por tanto, como vimos en Platón, las dos alternativas: la entrega del animal o la indemnización.

Además, se conserva otra inscripción cretense, IC IV 47.1-8, donde se recogen también disposiciones concernientes a delitos causados por los esclavos. Su disposición hace evidente la ley de Gortina: los perjuicios que provoque el esclavo en su propio provecho serán responsabilidad de su dueño. Así pues, en Gortina asistimos también a una ley sobre la responsabilidad noxal que recae sobre el dueño del esclavo, igual que prescribe Platón.

Hemos de recordar que también la ley romana de las XII Tablas admitió la actio noxalis en razón de los daños causados por uno y por otro y contempla las dos posibilidades de resarcir el daño, bien con la entrega del esclavo o del animal o con el pago del valor en que se hubiera estimado el daño ${ }^{22}$.

Ante todos estos testimonios, estamos en condiciones de afirmar que, además de legislar sobre los daños de animales, Solón debió de dictar normas sobre los delitos perpetrados por los esclavos, sobre lo cual Plutarco guarda absoluto silencio.

Es difícil esgrimir las razones que motivaron esa omisión plutarquea, pero conociendo su tendencia moralista, se puede aventurar que esta supresión obedece a las pautas éticas que presiden su vida. Situar al esclavo en el mismo nivel que los animales, como hemos visto en Platón, no debería ser atribuido a Solón, parece decir Plutarco cuando la filosofía le enseñaba a "no tratar con insolencia a los

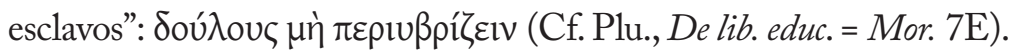

Por otro lado, en lo que respecta al texto que leemos en Solón 24.3, cabría preguntarse por qué Plutarco sólo menciona a los perros y no a todos los animales. Cuesta aceptar que Solón legislara solo sobre el daño de los perros. Platón se refiere a todos los animales cuadrúpedos, incluso perros y las posibles restituciones y lecturas de la inscripción cretense ${ }^{23}$ puede llevarnos a la misma conclusión.

Es posible que al principio no todos los animales entraran dentro del régimen de acción noxal y se distinguiesen los domésticos de los demás. Precisamente en el derecho romano, diferenciaban entre animales domésticos y feroces, cuyos daños daban lugar a emprender dos tipos diferentes de acciones,

${ }^{22}$ Respecto a los animales precisa que debían ser cuadrúpedos, cf. Ley de las XII Tablas (VIII. 6). Sobre los esclavos, cf. Ley de las XII Tablas (XII 2.b).

${ }^{23}$ Cf. H. Van Effenterre; F. Ruzé 1995: 236. 
la actio pauperie $e^{24}$ y la acción edilicia, la cual se emprendía respecto a los feroces, entre ellos los perros ${ }^{25}$.

Quizás Plutarco sufriera alguna confusión a tenor de su conocimiento del derecho romano que lo tenía más próximo y atribuyera a Solón solo la ley de daños causados por los animales feroces y no por los domésticos. Pues si examinamos la descripción plutarquea de la ley, es posible intuir en la precisión de 'perros que muerden' un indicio de que Plutarco se refería a estos animales como feroces. Y esto explicaría que no nombre las dos vías claves que facilitará la ley para la reparación del daño, al entender que los perros no eran animales susceptibles de acción noxal, puesto que, como legislaba el derecho romano en tiempos de la república, no habría lugar a una actio noxalis, pues estos animales no tendrían propietario.

Sin embargo, los testimonios griegos vistos con anterioridad nos llevan a pensar que los perros considerados domésticos entrarían en la ley soloniana dentro de los animales, cuyos daños habían de ser reparados. Es probable que Plutarco al reproducir los términos de la ley, por interpretarla de otro modo, no entendiese que la entrega, $\pi \alpha \rho \alpha \delta o v \tilde{v} \alpha 1$, a la que se aludía, se trataba del abandono noxal ${ }^{26} \mathrm{y}$, por tanto, no mencionase a quien debía efectuarse la entrega del animal e ignorase la indemnización pecuniaria.

De ahí que aduzca razones de seguridad, $\alpha \sigma \varphi \alpha \lambda \varepsilon i ́ \alpha$, como el principio que origina la entrega. Pero este no era el principal fin en situaciones antiguas de noxa, sino el derecho de la víctima a ser resarcida. Con la entrega del animal provocador del daño al propietario perjudicado se pretendía proporcionarle una compensación con el valor del animal. Hay incluso otros matices en el análisis del "abandono noxal", como el de Sealey quien entiende que con esta norma se buscaba la simple restitución o también la privación de la propiedad ${ }^{27}$. El dueño que había sido perjudicado adquiría entonces la propiedad de la cosa, el animal.

Pero si Plutarco entendió mal la ley de daños soloniana como aplicada solo a los animales y entre ellos a los feroces, era razonable, entonces, que adujera la seguridad como el objetivo que motivó esta ley.

De todos modos en esta limitada y sesgada exposición de la ley sobre daños, se

${ }^{24}$ Cf. E. Cuq, s.v. Noxalis actio, en H. Daremberg \& E. D. M. SAglio, Dictionnaire des antiquités grecques et romaines, Graz, 1969: 114.

${ }_{25}$ Cf. J. Adame Goddard 2009: 358. Sabemos que en una de las Sentencias de Paulo (parece de s. III d. C) se menciona una ley romana Lex Pesolania que aplicó las reglas noxales también a los daños causados por los perros. Esta ley ha llevado a sostener desde hace tiempo que se trata de una lectura corrupta de la ley soloniana que cita Plutarco. Cf. J. Adame Goddard 2009: 361.

${ }^{26}$ Siguiendo las leyes de responsabilidad por los daños causados por los animales, considero, de modo diferente a D. F. LEÃo 2001a: 355, que los perros debían ser entregados a la víctima, con la intención de que ello sirviera como reparación del daño.

${ }^{27}$ Cf. R. Sealey 2006: 482. 
vislumbra en Plutarco un pobre bagaje jurídico o, por lo menos, una actitud menos interesada en la exactitud legal de antaño que en la transmisión anecdótica.

Pues bien, tras el examen de las informaciones que prodiga Plutarco sobre los temas legales estudiados, cabe concluir que las inexactitudes encontradas obedecen a errores cronológicos o son originadas por su tendencia a interpretar los datos, siguiendo los parámetros tanto propios como contemporáneos. Da la impresión de que Plutarco no ha llegado a penetrar en la idiosincrasia de la época antepasada ni a captar el espíritu de la ley soloniana y, por tanto, lo que busca es silenciar todo lo que desmerezca al personaje. 
Plutarco y su interpretación de leyes griegas concernientes a la familia y propiedad

\section{Referencias bibliográficas}

Adame Goddard, J., Comentario al libro primero de las sentencias de Paulo, México, 2009.

Biscardi, A., Diritto greco antico, Varese, 1982.

Calero Secall, I., "Las Vidas frente a los Moralia en las alusiones plutarqueas sobre Solón", en A. G. Nikolaidis (ed.), The Unity of Plutarch's Work, Berlin-New York, 2008: 512-532.

Calero Secall, I., "Las Leyes de Platón: Afinidades con las prescripciones de Gortina sobre el matrimonio", in A. Pérez Jiménez; I. Calero Secall

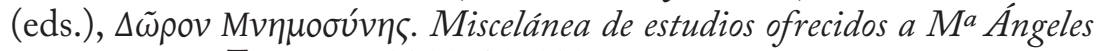
Durán López, Zaragoza, 2011: 91-102.

Cantarella, E; Gagliardi, L. (eds.), Diritto e Teatro in Grecia e a Roma, Milano, 2007.

Gagarin, M., “The unity of Greek Law”, in M. Gagarin; D. Cohen (eds.), The Cambridge Companion to Ancient Greek Law, Cambridge, 2005: 29-40.

Hannick, J. M., "Droit de cité et mariages mixtes dans la Grèce classique", $A C$ 45, 1976: 133-148.

Harrison, A. R. W., The Law of the Athens. The Family and Property, London, 1968.

LEÃo, D. F., Solon. Ética e política, Lisboa, 2001a.

LeÃo, D. F., "Nomos Argias”, Logo, 1, 2001b: 103-108.

Morales Otal, C.; García López, J., Plutarco. Obras morales y de costumbres, Madrid, 1986.

Pérez Jiménez, A., Plutarco. Teseo-Rómulo. Licurgo-Numa, Madrid, 1985.

Pérez Jiménez, A., Plutarco. Solón-Publicola. Temistocles-Camilo. Pericles-Fabio Máximo, Madrid, 1996.

Sealey, R., "Athenaion Politeia 57, 4: Trial of Animals and Inanimate Objects for Homicide”, CQ 56, 2006: 475-485.

Van Effenterre, H.; Ruzé, F., Nomina. Recueil d'inscriptions politiques et juridiques de l'archaïsme grec II, Roma 1995.

Wallace, R. W., "Law, Attic Comedy, and the Regulation of Comic Speech", in M. Gagarin; D. Cohen (eds.), The Cambridge Companion to Ancient Greek Law, Cambridge, 2005: 357-373.

Wilson Nightingale, A., "Plato's Lawcode in Context: Rule by written Law in Athens and Magnesia", CQ 49, 1999: 100-122. 
(Página deixada propositadamente em branco) 


\title{
Political Reforms in the LiVES OF LyCURGUS AND NUMA: DIVINE REVELATION OR POLITICAL LIE? ${ }^{\text {1 }}$
}

\author{
Ália Rosa Rodrigues \\ Universidade de Coimbra
}

\begin{abstract}
This paper aims to analyze the political importance of divine inspiration for Spartan and Roman political reforms carried out by Lycurgus (c. 650 BC?) and by Numa Pompilius (715-673 BC). In the former case, the constitution is supposed to have been transmitted to Lycurgus by the Delphic oracle and consequently it was called Rhetra, a "ceremonial utterance" or an "agreement" (Lyc. 6). Similarly, in the Life of the Roman counterpart, the goddess Egeria (Num. 4.2) inspires the second king of Rome to carry out a profound religious reform. In fact, this is not a specific feature of these Lives, since several other lawgivers were credited with divine assistance, such as Minos, Zaleucus or Zoroaster. The discussion of this issue is designed to reveal the argument that may lie behind these legends: divine inspiration or an artificial way of legitimating the lawgiver's power? In fact, despite all the effort made in order to sacralise these ancient political institutions, Plutarch himself seems to accept the latter theory. This strategy can be seen as a kind of political lie which had previously been accepted by Plato as an instrument for legitimizing constitutional reforms ( $R .389 \mathrm{~b})$.
\end{abstract}

In the synkrisis of Lycurgus and Numa, Plutarch stated four reasons to justify the placing of these two lives in parallel: "their wise moderation ( $\sigma \omega \varphi \rho \circ \sigma u ́ v \eta)$,

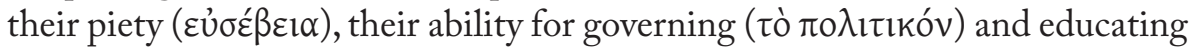

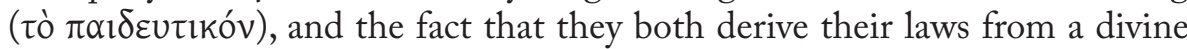
source ( $\tau \tilde{\omega} v \theta \varepsilon \tilde{\omega} v$... $\lambda \alpha \beta \varepsilon \tilde{i} v)$ ". While these first three features are related to their characters, the fourth concerns their political activity: both reforms were credited with divine assistance. Both reforms were intended to resolve a stasis: in the former, people "felt that their kings were such in name and station merely" (4.5) and in the second, "it is indeed true that it was the pleasure of all to have a king, but they wrangled and quarreled". Each lawgiver would establish eunomia for his community; nevertheless, while Spartan eunomia would last 500 years (Lyc. 29.6), the peace of Numa would last only until his death. However, such profound reforms would not have been accepted by people without divine sanction, even though they consist of positive laws, rules and institutions that are postulated by men among men, a matter of convention.

This paper focuses upon the Plutarchean argument that lies behind the legitimacy of the political reforms carried out by Lycurgus and Numa, the

\footnotetext{
${ }^{1}$ An earlier version of this paper was given in Coimbra (Nomos, Kosmos and Dike in Plutarch, 2011). I am grateful to the audience for their interesting comments and suggestions. I wish to thank to Professor Christopher Pelling for reading an earlier version of this text and for offering many valuable remarks as well as for having improved the English text. I'm also grateful to the scholar Anton Powell and Professor Delfim Leão for theirs readings and helpful suggestions.
} 
argument that they were undertaken in order to achieve the best interests

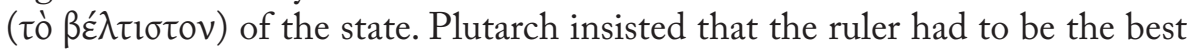
of craftsmen and the maker of lawfulness and justice, as well as being the educator who would discipline an unstable people (Praec. ger. reip. 814A-C).

\section{Divine assistance, a topos in the legends of Greek lawgivers}

In central Italy, the first lawgivers were actually gods - Janus and Saturnus, Picus and Faunus - as B. Liou-Galle 2000: 177 stated: "ces rois anciens représentent à leur manière le passage du monde sauvage à la civilization"2. Accounts of the lives of early lawgivers of Greece, such as Zaleucus, Charondas, Lycurgus, and Solon, have always been filled with a rich mixture of myth and invention. In 1893, Julius Beloch, based on the general Indo-European belief in the divine origin of law, argued that Zaleucus and Charondas were personifications of sun gods. In a similar way, Eduard Meyer and Wilamowitz identified "Lyko-orgos" with the ubiquitous figure of the Arcadian wolf-god Zeus Lykaios and the Arcadian light-God Lykaon. Thus, the cult of Lycurgus (like the cults of Helen, Menelaus...) was a relic of the ancient Laconian religion that had survived the early invasions.

The scarce historical data about early Greek lawgivers has led to a process of "infiguration", as Cornford ${ }^{3}$ put it, when "facts shift into legend, and legend into myth". Thus, as A. Szegedy-Maszad 1978: 210 has pointed out: "This concept of infiguration allows us to treat the stories as a genre, unified and controlled by certain conventions." In fact, this scholar identified some topoi that became attached to the names of great legislators: firstly, the state's progress from initial anomia to eunomia; secondly, the main methods of acquiring instruction, i.e. extensive travel and study with a great philosopher; thirdly, when the lawgiver is selected to establish order, he must apply all the knowledge he has acquired on his travels as well as his acquaintance with philosophers. In addition, some of the lawgivers were credited with divine assistance $^{4}$. The material provided by this tradition can be summarized in this schema: at an initial stage, there is a crisis in the state and a man rises due to his virtue, education and experience; secondly, there is an intermediate stage, when the crisis is suspended; finally comes the last phase, when the code is firmly established and the lawgiver departs 5 .

\footnotetext{
${ }^{2}$ On this matter, see the chapter of B. Liou-Galle 2000.

${ }^{3}$ Thucydides Mythistoricus. London, 1907 (repr. New York 1969); apud A. Szegedy-Maszad 1978: 210.

${ }^{4}$ See A. Szegedy-Maszad 1978: 204-205.

${ }^{5}$ This reflects a dynamic of physis: one is born, grows up, and declines. The biological model is applied to the forms of government succession by Polybius (6. 8.10). See also J. Romilly 1991: 9-12.
} 
This pattern is one that we can see in Lycurgus and Numa. Lycurgus had traveled in Crete, Egypt and maybe Libya and Iberia to study their various forms of government, making the acquaintance of distinguished men like the poet and lawgiver Thaletas; Numa had lived in the country, far away from the city, and passed his days with a $\delta \alpha^{\prime} \mu \omega \nu$, the goddess Egeria, and might have been a pupil of Pythagoras ${ }^{6}$. Besides, both legitimise their reforms through a divine source, the former with Apollo's blessing and the latter with Egeria's wisdom.

Despite all the energy expended in order to make sacred the first Spartan institutions and Roman religious reforms, Plutarch sought to rationalize this notion of divine inspiration as a source of law:

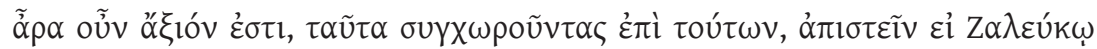

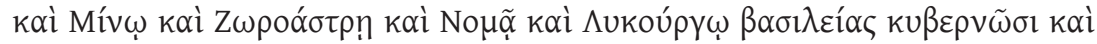

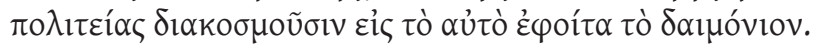

Is it worth while, then, if we concede these instances of divine favour, to disbelieve that Zaleucus, Minos, Zoroaster, Numa, and Lycurgus, who piloted kingdoms and formulated constitutions, had audiences with the Deity? (Num. 4.7)

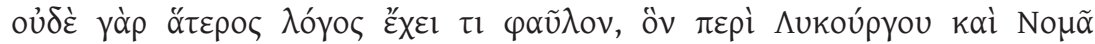

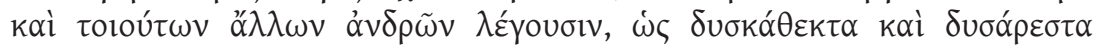

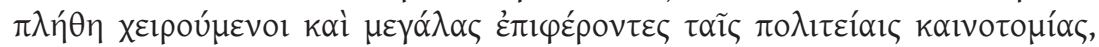

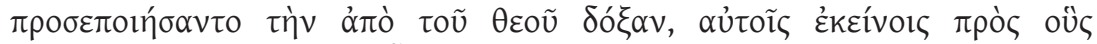

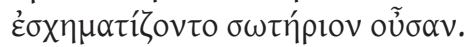

Indeed there is no absurdity in the other account which is given of Lycurgus and Numa and their like, namely, that since they were managing headstrong and captious multitudes, and introducing great innovations in modes of government, they pretended to get a sanction from the god, which sanction was the salvation of the very ones against whom it was contrived. [emphasis added] (Num. 4.7-8)

At this point, Plutarch was seeking to justify this legend about Egeria and its traditional credibility, as well as other divine inspirations of earlier constitutions. According to Plutarch, if it is hard to believe in Numa's celestial marriage, it is equally doubtful that lawgivers who managed to resolve a stasis would not have attributed their political measures to a divine source. From this very point we therefore understand how Plutarch takes this divine inspiration

\footnotetext{
${ }^{6}$ On this matter, see R. M. Ogilvie 1978: 89. On the Pythagorean tradition in Rome and its influence on the legend of Numa, see Ferrero 1955: 109-174 and Marino 1999.

${ }^{7}$ All translations are from The Loeb Classical Library with some modifications.
} 
- as something that was probably an invention, one that was necessary in order to carry through the planned political reform. Despite Plutarch's disapproval of $\delta \varepsilon l \sigma i \delta \alpha \iota \mu \nu$ ía, "an emotion engendered from false reason" (de superst. 165C) or "the most impotent and helpless is superstitious fear" (de superst. 165E), some scholars such as A. Pérez Jiménez 1987, 1996, D. Babut 1969: 428 and T. Duff 2005: 131, have already explored the approval of political manipulation through superstition in order to achieve a greater $\mathrm{end}^{8}$. Besides the frequent use of superstition, especially in Numa's case (cf. A. WARDMANn 1974: 88-89), we will argue that the well-known Platonic instrument, the noble lie, is behind these political reforms of both lawgivers. In fact, if we take a look at the lives of Lycurgus and Numa, we will see that political artifice is present from the very beginning.

\section{I.1 Lycurgus, "beloved of the gods, and rather a god than a man"(Lyc. 4.5)}

Lycurgus, "the best example of a lawmaker" (De lat. viv. 1128F) as Plutarch describes him elsewhere, after his travels returns to his people, who sees in him "a nature fitted to lead" ( $\varphi$ oı v $\dot{\gamma} \varepsilon \mu o v \imath k \eta v)$, and a "power to make men follow

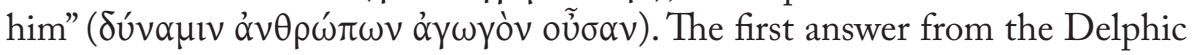
oracle legitimised him as a legislator and promised him a "constitution, which should be the best of all". Blessed with Apollo's approval ${ }^{9}$, Lycurgus ordered thirty of the chiefs to strike terror into those of the opposite party, and therefore both kings (Charilaus and Archelaus) accepted the new political institution:

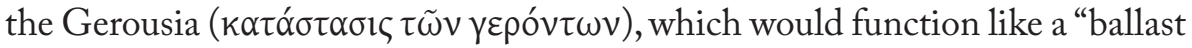

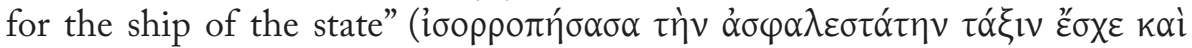

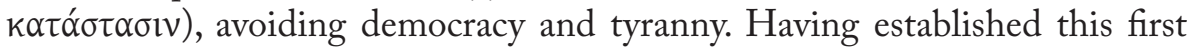
institution, there would be a second oracle from Delphi, which was the socalled "rhetra". This oracle established that the people should be divided into groups, some into phylai and obai; the council of the elders (gerousia) was also confirmed, including the two kings (archagetai)". Although the people could not initiate a motion, they had the power to accept or reject the proposals of the Gerousia. Later, however, when the people perverted this political mechanism, senators and kings made a proposal which would increase their power: they could dissolve the session when the people did not ratify the vote

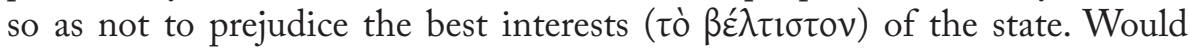
Apollo, the first author of this constitution, allow this correction? Plutarch

\footnotetext{
${ }^{8}$ Fab. 4.4-5.1; Dion 24.1-10; Non posse suav. 1101D. Contra M. Cerezo 1996: 162-163 argues that the description of people's manipulation through superstition by Numa Pompilius represents an aggressive criticism against this kind of political practice.

${ }^{9}$ On the way in which Plutarch and his erudite circle saw Apollo in the first (and second) century A.D., see A. G. Nikolaidis 2009.
} 
answered that both kings "were actually able to persuade the city that the god

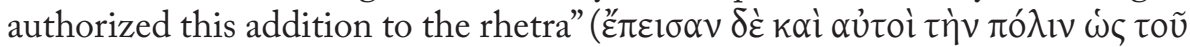

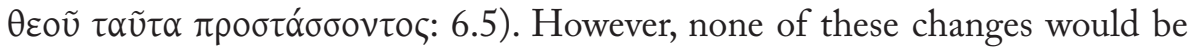
more definitive than the educational reform, "which he regarded as the greatest and noblest task of the law-giver" (14.1). According to Plutarch (21.1), the contents of law would be revealed during this public education, by examples of social behaviour, poetry and music, whose "themes were serious and edifying". In fact, it is very suggestive that Lycurgus' first measure to initiate his political reform would be the invitation of the Cretan poet Thaletas, who was also a Cretan lawgiver, as J. D. Lewis 2007: 50 states, "he is said to have brought certain norms of justice to Crete through his poetry and his music, perhaps using choral lyric poetry with dance to promote aristocratic norms". Only a highly regulated and demanding educational system for both sexes, from birth until adulthood and even older, would obviate the need for written laws: the law would have its origin in each Spartiate, but also in each free woman; each one should sanction the practice and guarantee the endurance of the law. In fact, one rhetra had forbidden the writing of the laws (13.1). We may regard this process as a way to naturalize a political program in order to become a matter of custom, which is traditionally stronger than positive law: the rhetra should become an $\dot{\varepsilon} \theta$ เouós (29.1) and take its place among those hallowed by age $^{10}$. Furthermore, we might suggest another political motivation to justify the preference for unwritten law, because if it is not written, it can change whenever political power desired ${ }^{11}$. In fact, that would happen, when senators and both kings changed the voting process; this therefore became another strategy to secure the lasting success of a reform.

When the primitive lawgiver saw that his main institutions were firmly fixed and that his civil policy had grown enough to preserve itself, he rejoiced

${ }^{10}$ One of the most distinguishing features of natural right/custom consists in the fact that it is unwritten, but inscribed in the memory of the community and revealed by its practices and social sanctions. Concerning the superiority of custom unwritten law over the positive law, we can mention Antigone's well-known discourse in the discussion with Creon, symbol of legality of the state (vv. 495-508). We do not intend to discuss here the complex semantic sphere of agraphoi nomoi. On this matter, see J. Romilly 1971. On the traditional idea of the divine origin of justice from Hesiod onwards, see the text of $\mathrm{F}$. BECCHI in this volume.

${ }^{11}$ M. Flower 2002: passim demonstrated that many traditional Spartan features were actually invented in order to legitimise specific political reforms, such as: the ban on the ownership of precious metals by a group hostile to Lysander (p. 193), the whole concept of inalienable and indivisible lots of equal size (p. 196), the abolition of debts (p. 197) were invented by the King Agis, the general ban on foreign travel (ibidem) which is mentioned by several fourth-century sources (Xenophon, Isocrates, Plato and Aristotle), but there more specific restrictions are elsewhere unattested and finally the re-evaluation the role played by Sphaerus, a friend and advisor to King Cleomenes, in reinventing the agoge (pp. 199-200), among others. 
at seeing his "cosmos come into being and have its first motion", just as the Platonic demiurge ( òv $\left._{\theta \varepsilon o ́ v}\right)^{12}$. Then, in order to make his system of laws

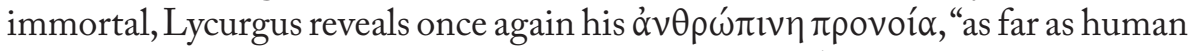

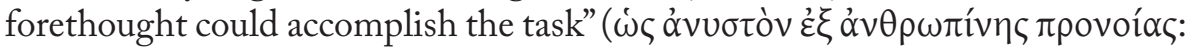

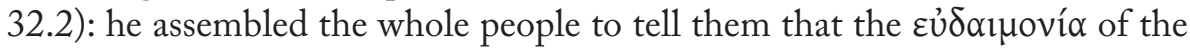
city depended on their respect for those institutions, which should remain unchangeable until his return. Thus, the shape of the Spartan constitutional cosmos would depend on the observance of this original archetype.

Finally, there came the third and last inquiry to Apollo, who gave the final ratification of the Lycurgean constitution. The lawgiver would never return home and his civil policy would last for five hundred years ${ }^{13}$. Thus the people were misled one more time.

\section{I.2. Numa Pompilius, "honoured with a celestial marriage" (Num.4.6)}

Plutarch does not engage in such historical polemics with the second king of Rome as he does with Lycurgus ${ }^{14}$, even if the only historical fact about this figure is his own name: it is even possible to study the stages by which his legendary biography was constructed ${ }^{15}$. Recently, some archeological evidence has come to support his existence, namely, the discovery made by Clementina Panella in $2007^{16}$. The excavation team led by this archeologist from Rome's Sapienza University uncovered a temple or sanctuary (probably dedicated to the Goddess of Fortune), which, accordingly to Panella, dated from the period of Numa Pompilius ( $8^{\text {th }} 7^{\text {th }} \mathrm{BC}$ ). In addition, no statues or figures were found, a fact that Panella explains by the suggestion that it has to do with the prohibition of images of the gods in his temples. In fact, Plutarch in the Life of

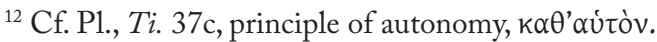

${ }^{13}$ Modern scholarship is increasingly convinced that Sparta did change profoundly over the four centuries $\left(6^{\text {th }}-3^{\text {th }}\right.$ BC), culturally as well as demographically. See A. Powell 2010: 87, 129 n. 5 .

${ }^{14}$ According to Plutarch (Num. 3.4), this man of Sabine descent was born in the very day

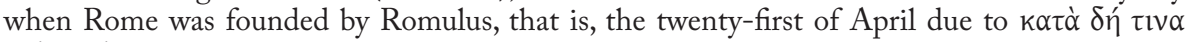

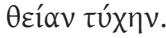

${ }^{15}$ See R. M. Ogilvie 1978: 88.

${ }^{16}$ The archaeological campaign began in 2006, with the help of 130 students and volunteers, and has been led by this archeologist, who had been also excavating in the Forum for twenty years. According to this scholar, the wall of the temple was found seven meters below the surface and lies between the Palatine and Velian hills, close to the Colosseum, the Arch of Titus and Via Sacra. Besides the temple, were also found two wells, both full of thousands of objects, such as votive offerings and cult objects, including the bones of birds and animals, ceramic bowls and cups. In 2006, Andrea Carandini, Professor of Archeology at La Sapienza, announced that he had discovered the remains of a royal palace dating to the time of Romulus, which had a monumental entrance, ornate furniture and tiles, having ten times the size of ordinary homes of the period. Sources: Richard Owen, Times Online (October 8, 2007). 
Numa $(8.7)^{17}$ does ascribe this practice to Numa, regarding it as a Pythagoric influence. Still, even if this important discovery seems to confirm this ancient religious Roman practice in a period which legend attributes to Numa's reign, it is not yet truly definitive concerning the historical existence of Numa himself.

After Romulus' disappearance, the city had been plunged into stasis and the oligarchical element had become predominant, although "it was the pleasure of all to have a king". Then, both factions, those who had built the city with Romulus and the Sabines, agreed to appoint the Sabine Numa Pompilius as king, well-known for his abilities as a "judge", or "counsellor" and for his "rational contemplation of gods' $(\theta \varepsilon \tilde{\omega} v)$ nature and power" $(3.8)^{18}$. At first Numa declined the kingdom, but eventually did not resist the people's appeals, which were even ratified by auspicious omens. In fact, Numa would subdue the people's minds by means of fear of the gods ( $\delta \varepsilon 1 \sigma 1 \delta \alpha \iota \mu o v i ́ \alpha)$ and by the practice of religious events (sacrifices, processions, religious dances), accompanying them with strange signs, such as vague terrors, apparitions, threatening voices (8.3). In the last stage of Numa's rule, the religious reform had accomplished its purpose: "the city became so tractable (...) that they accepted his stories, though fabulously strange, and thought nothing incredible or impossible

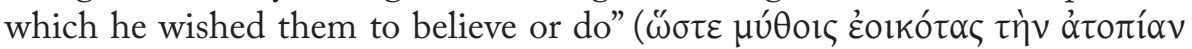

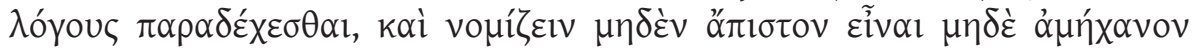

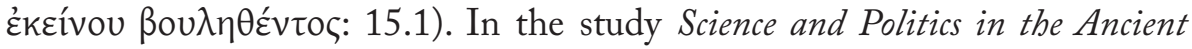
world, B. FARRINGTON 1939 aims to identify the obstacles to the spread of a scientific outlook in the ancient world and claims that one of these obstacles consisted in popular superstition. He argues that this popular superstition had two different sources: popular ignorance and deliberate political deceit. In this narrative, the political lie through religion and Numa's exploitation of religious effects on people can be seen as an example of superstition imposed upon the people.

In contrast to his Greek counterpart, Numa wrote down his laws, "as the Greek lawgivers their tablets", taught them to the priests and asked for them to be buried with his body ${ }^{19}$. Nevertheless, since he did not create a

17 "And in like manner Numa forbade the Romans to revere an image of God which had the form of man or beast. Nor was there among them in this earlier time any painted or graven likeness of Deity, but while for the first hundred and seventy years they were continually building temples and establishing sacred shrines, they made no statues in bodily form for them, convinced that it was impious to liken higher things to lower, and that it was impossible to apprehend Deity except by the intellect" [emphasis added].

${ }^{18}$ After Tatia's death, Numa was determined to live in country places, passing his days with a goddess $(\delta \alpha i \mu \omega v)$ and, according to Plutarch, "the goddess Egeria loved him and bestowed herself upon him a life of blessedness and wisdom more than human." (4.2).

${ }^{19}$ In this case, Plutarch justifies his option as an instance of Pythagorean influence, which established that precepts should "implant the memory and practice of them in living disciples worthy to receive them" (22.3-4). 
highly controlled educational system similar to the Lycurgean agoge, the peace generated by Numa would die with him and a new stasis began. His religious institutions, however, would represent an identifying feature for the entire Roman people ${ }^{20}$. In fact, the paired contrast of the warrior-king (Romulus) and the priest-king (Numa) lies in the very heart of the Indo-European thought - similar to the antithesis of Varuna and Mitra in Vedic Literature -, as Dumézil (1958: 80) illustrated: "Numa complétant l'oeuvre de Romulus, donnant à l'idéologie royale de Rome son second pole, aussi nécessaire que le premier" 21 .

\section{The noble lie as a ruling instrument}

In the third book of the Republic (389c-d), Plato accepts the act of lying only when it is done by city leaders for the people's benefit: "The rulers then of the city may, if anybody, fitly lie on account of enemies or citizens for the benefit of the state".

Before Plato, there are two important texts on the political function of religion: the fragment from a drama by the oligarch Critias, and Isocrates' epideictic essay Busiris (24-25) written as a eulogy of Busiris, the mythical king of Egypt ${ }^{22}$. The fragment of the former consists of an explanation of the origin of the laws and a rationalist theory of the origin of religion, describing it as just a political expedient by a "shrewd and wise-thoughted man" ( $\pi$ uvvó

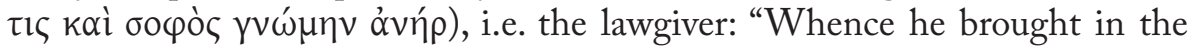
divinity ( this discourse he introduced the most welcome of teachings hiding the truth

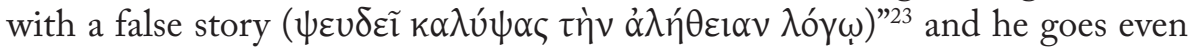
further, arguing: "in my opinion, someone first persuaded mortals to think that there is a race of deities". Regarding this passage, B. FARRINGTON 1939: $88-106$, who traces the part played by this concept in the formulation of

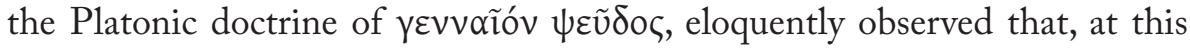
point, Critias was clearly confusing the political function of religion with its

${ }^{20}$ As Polybius (6.56.2-13) demonstrated: "the quality in which the Roman commonwealth is most distinctly superior is in my opinion the nature of their religious convictions. (...) I mean superstition which maintains the cohesion of the Roman State". See also F. W. Walbank's commentary on this passage (1957: 741).

${ }^{21}$ R. M. Ogilvie 1978: 88. For a recent revision of Dumézil's perspective on the early history of Rome, see D. BRIQUEL 2006.

${ }^{22}$ See also Iambl. VP 179 and X. Mem. 1.4. The idea of the divine origin of law as a socially useful concept can be found in the Pythagorean literature: on this matter see A. Delatte 1974: 44-46.

${ }^{23}$ Fr. 19 Snell (Eleg., Trag. et Phil., Fragmenta). This is an excerpt from Whittaker's translation (21925, Priests, philosophers and prophets. London, p. 77). 
genesis. Regarding the second text, the rhetorician Isocrates is mentioning the intentions of the religious legislator of Egyptians who guaranteed people's obedience by introducing little pious practices, ensuring that the mob would obey important commands given to them by their superiors ${ }^{24}$.

Based on the idea that all systems of government were, without exception, bad $(R .497 \mathrm{c}-\mathrm{d})$, Plato always sought the construction of a system of belief and a system of education ${ }^{25}$, which would guarantee the well being of the State. In fact, regarding Plato's condemnation of poets' tales, he does not object to them for being untrue, but for not being unedifying ${ }^{26}$. Thus, Plato's political lie should be so skilfully adapted that it should become a kind of "second nature" 27 , because it should appear as truth to the subjects and, according to Socrates, even to rulers $(R .414 \mathrm{~d}, 459 \mathrm{~d}-\mathrm{e})$. In fact, the general belief in myths is a proof that it is possible to make people believe anything, from which the legislator would take advantage, as Plutarch also pointed out about Numa (15.1): "they accepted his stories, though fabulously strange, and thought nothing incredible or impossible which he wished them to believe or do".

Polybius, regarding the Roman use of religion and superstition, also approves its use for disciplinary purposes (16.12.9-11), but as F. W. WALbank 1967: 515 noted: "his interpretation of Roman religio is that of the Greek rationalist, not of the native Roman”. In fact, Polybius' religious scepticism is linked with a tendency towards Euhemerism, which, based on the mythographer Euhemerus' view of religion, established a rationalist and humanistic approach to the interpretation of myths during the $3^{\text {th }}$ century BC. In his tenth book, Polybius (10.2.8-10), comparing Scipio to Lycurgus, stated that both made their political scheme more acceptable and credible by appealing to superstition: "For neither must we suppose that Lycurgus drew up the constitution of Sparta (...) solely prompted by the Pythia, nor that Scipio won such an empire from his country by following the suggestion of dreams and omens. (...) That everything he did was done with calculation and foresight, and that all his enterprises fell out as he had reckoned (...)"28. Based on this passage, M. Guelfucci 2010: 147 has highlighted Scipio's features

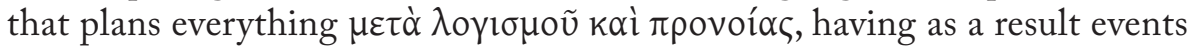

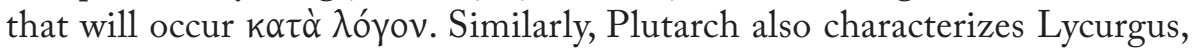

${ }^{24}$ B. Farrington 1939: 89-90.

${ }^{25}$ On the influence of Sparta on Plato's Laws, see G. Morrow 1960. On the resemblances between non-argumentative techniques of persuasion and modes of rule used by the Spartan authorities and the elements of Plato's Laws, see A. Powell i994.

${ }^{26} \mathrm{Pl}$., R. 10, 602b: "Yet still he will nonetheless imitate, though in every case he does not know in what way the thing is bad or good. But, as it seems, the thing he will imitate will be the thing that appears beautiful to the ignorant multitude".

${ }^{27}$ B. FarRington 1939: 93.

${ }^{28}$ Translation by W. R. PAton 1976: 105. 


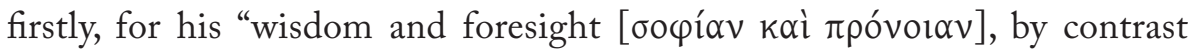
with the factions and misgovernment of the people and kings of Messenia and Argos, who were kinsmen and neighbours of the Spartans" (Lyc. 7.2) and then, when he planned the best way to keep the Spartan constitution unchangeable, for having desired "so far as human forethought ( $\alpha v \theta \rho \omega \pi i ́ v \eta \varsigma$ זpovoías) could accomplish the task, to make it immortal, and let it go down unchanged to future ages" (Lyc. 29.1). Thus, the lie of such a ruler, if in the best interest of community, may well be seen as a political result of the faculty of human pronoia, which is also shared by the divine being ${ }^{29}$. Later, Cicero (Div. 18.42) refers very clearly that the use of superstition through divinatory practices had become particularly useful for the manipulation of the masses in his own day.

In these Lives, Plutarch is also seeking to rationalize this traditional material and come up with an explanation, because only "duller minds are content with history if they learn the mere general drift and upshot of the matter" (De gen. Socr. 575C). As Plutarch himself stated in the well known and commented beginning of the Life of Theseus (1.3), "may I therefore succeed in purifying Fable, making her submit to reason and

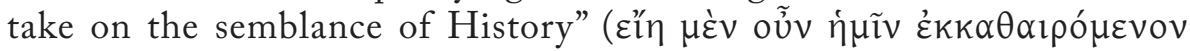

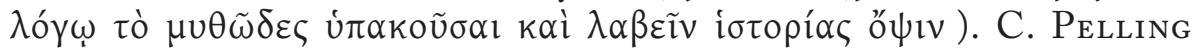
2011 has already studied the way in which Plutarch treats his historical sources according to their periods, analysing how this rationalization process works specially in the Lives of Theseus and Romulus, which aims to attribute "credibility" ( $\tau$ ò $\pi \imath \theta \alpha v o ́ v)$. Accordingly to C. Pelling 2011: 174-175, two different kinds of rationalization can be distinguished: the first can be found in Herodotus and consists of "how a story could develop, it explains away a legend" and the second, the so-called Thucydidean, works by secularizing the historical fact, i. e., Agamemnon gathered the Trojan expedition because of his power, not because of any oaths (1.9). In this case of the pair of Lives, and from what has been argued, there is a Thucydidean rationalization of this mythical material that also follows that thread of Greek thinking about religion, which was eloquently expressed by Critias.

In fact, in the case of Numa, Plutarch clearly does not believe in the legend of Egeria, as he makes clear in De fortuna Romanorum: "For the tale that a certain Egeria, a dryad and a wise divinity, consorted in love with the

${ }^{29}$ As F. Frazier 2010: VIII stated: "On trouve, situées ici au niveau divin, des qualités d'intelligence qui interviennent pareillement chez les hommes: dans les Définitions transmises

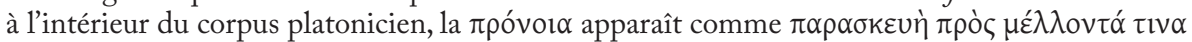
(414a)". This scholar (1996: 209) does not recognize "une prudence expectionelle" in the case of Lycurgus, but just a "banale" pronoia. 
man, and helped him in instituting and shaping the government of his State, is perhaps somewhat fabulous. (...)”. Regarding this passage, D. BAвUт 1969: 428 suggested that, even though divine filiation is an invention, it is actually "une invention intéressée pour exploiter à des fins politiques la crédulité publique”. Therefore Plutarch does not exclude the other possibility of special favours occurring between god and men that are distinguished by their moral value ${ }^{30}$. D. BAвut 1969: 467-469 also noted the textual concordance between this passage (4.4) and the text of In the sign of Socrates (593A) which establishes that

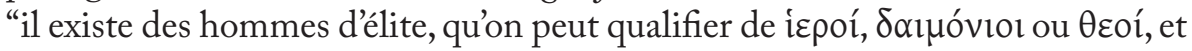
que la Providence gratifie d'avertissements ou de prémonitions extraordinaires, parce que leur pureté morale les rend aptes à entrer en contact avec le divin” (p. 469).

We see, then, that Plutarch's interpretation of the political reforms carried out by Lycurgus and Numa consists of another example of the political function of religion, that idea which we found eloquently expressed before Plato by the oligarch Critias as early as the $5^{\text {th }}$ century. However, by the time that he wrote these Lives, Plutarch was already a priest of Delphi ${ }^{31}$. Was he then devaluing the oracle function, reducing it to a mere instrument of politics? In fact, on the On the Sign of Socrates (580A), Galaxidorus also reveals a pragmatic view, accepting that a politician is likely to exploit the people's superstitiousness in dealing with them: "For men engaged in public affairs and compelled to live at the caprice of a self-willed and licentious mob this may have its use - to treat the superstition of the populace as a bridle, and thereby pull them back to the profitable course and set them right" ${ }^{32}$. In addition, Plutarch's political vision of the people is clearly derogatory, presenting it as a multitude that must be controlled or deceived in order to be saved. A recent study by S. SAID 2005: 7 has identified a notable consistency in the treatment of the demos in Plutarch's work, conditioned by his Platonism ( $R .493$ a-e): "As a rule, these members of the elite refrain from awarding the common people any significant place in their writings and, when they did bother to mention them, it was mostly with disdain. Plutarch (...) is no exception".

${ }^{30}$ Another testimony is Cicero who also manifests his incredulity on these tales and justifies it with the necessity to mix history and poetry, because while in the former, "everything that is judged is the truth", in the second "it is generally the pleasure one gives" (N.D. 3.91).

${ }^{31}$ Accordingly to C. P. Jones 1966, Plutarch becomes priest of Apollo at Delphi after 96 or possibly earlier and the composition of this pair of Lives is located between c. 96 and c. 120 .

${ }^{32}$ G. J. D. H. Wzn. Aalders 1982: 50. 


\section{Conclusion}

Having arrived at this point, we can summarize this approach by distinguishing two different links with a divine entity. The first regards the connection between the lawgiver and the divinity, which is transmitted by tradition and becomes a topos usually attached to the names of great legislators $^{33}$. The figure of the lawgiver is traditionally attached to the image of a divinity since his activity, the postulation of a political order, requires this sacred authority so that it can be observed. This first type of link therefore also projects a genuine divine source for these political constitutions. However, the political reforms of Lycurgus and Numa are different, in that they are rules and institutions postulated by men among men, like a convention: and this provides our second type of link, where the divine sanction is itself a further human postulate, a fabricated claim made by the lawgivers because such profound political reforms would not have been accepted without divine sanction ${ }^{34}$.

The political lie and the use of superstition represent only useful devices as expressed in the Republic (389c-d) and before that in Critias' fragment - to establish eunomia and for it is both likely and acceptable that rulers will take advantage of this divine influence over people's minds for the common good. Besides, the rationalized version of these traditional mythoi was attested, as has been noticed, by Polybius (10.2.8-10), Dionysius of Halicarnassus (2.61.2) and Livy (1.18-21). Being probably inspired by a Pythagorean principle, Numa did wish to replace the "metus hostilis by the metus deorum as unifying force in the State" 35 . While in the case of Numa Plutarch clearly does not believe in the legend of Egeria, in the Life of Lycurgus he would pick up the most divinized version of the tradition ${ }^{36}$ and rationalize it by resorting to a Platonic instrument of rule, comparing Lycurgus twice to a physician $(4.3,5.2)$, just like the Platonic frequent physician/ lawgiver parallell (Grg. 464b-465e; $R$. 405a-410b).

Regarding the Spartan Life, the topos of the divine assistance, however, has to be integrated and analysed in a larger historical perspective: the "Spartan talent for official lying and myth-making" as described by A. Powell 2010: 12837. Regarding Spartan internal affairs, this scholar (2010: 126-127)

${ }^{33}$ A. Szegedy-Maszad 1978 and B. Liou-Gille 2000: 174-177.

${ }^{34}$ See also Praec. ger. reip. 813B-C.

${ }^{35}$ R. M. Ogilvie 1978: 90 and A. Walbank 1967: 741.

${ }^{36}$ Diodorus Siculus 7.12; [Xenophon], The Polity of the Lacedaemonians I. 2; Ephorus ap. Strabo 10.14.19 (= FGrHist 70F 149).

${ }^{37}$ M. FLOwER 2002 has made penetrating observations on the construction of the Spartan 'mirage' through a process of invention of tradition, i. e., "traditions invented, constructed and formally instituted at a specific point in time and for a specific purpose", for instance, every time the Spartans changed something in their society, they attributed the change to Lycurgus. 
presented the full list of the royal rulers of the Agiad and Eurypontid houses over the period 500-395 BC, demonstrating that "most (seven out of eleven) royal rulers of Sparta were either killed, enduringly exiled or threatened with exile". Thus, the use of divine sanction in secular matters became an effective political device used by kings in times of insecurity, such as from the reign of Kleomenes until Agesilaus. Thus, the so-called Spartan stability and internal concordance was actually no more than a convenient image, successfully "sold" to the wider Greek world at the same time as Sparta was beset by striking internal conflicts.

On the contrary, in the case of the Roman counterpart, religion played an important role within the Roman collective memory ${ }^{38}$ as well as in the political field, as Polybius (6.56.2-13) said: "the quality in which the Roman commonwealth is most distinctly superior is in my opinion the nature of their religious convictions. (...) I mean superstition which maintains the cohesion of the Roman State". However, unlike the Spartan lawgiver, Numa participates in the order created by him, while Lycurgus, being so external to his own order, must depart in order to force the people to obey the laws without the force of his personality ${ }^{39}$. Thus, if Lycurgus is superior to Numa due to his educational reform ${ }^{40}$, "the greatest and noblest task of the lawgiver" (Lyc. 14.1),

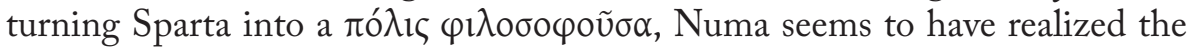
Platonic ideal of philosopher-king long before Plato's Republic: "the power of a king should be united in one person with the insight of a philosopher, thereby establishing virtue in control and mastery over vice" (Num. 20.7) ${ }^{41}$. In the work To an Uneducated Ruler (780C), Plutarch alludes to the Hellenistic theory of the king as divine living law ${ }^{42}$ (vó $\mu \circ \varsigma$ है $\mu \psi \cup \chi 0 \varsigma^{43}$ ), according to whom the ruler should follow the law of reason which will lead his rule to the necessary stability: "not law written outside him in books or on wooden tablets or the like, but reason endowed with life within him." As Plutarch puts it, and the ruler can only reach this lofty ideal through philosophy ${ }^{44}$.

To sum up, there is no real contradiction between Plutarch's general disapproval of superstition and the religious and political lie, which legitimated both reforms of Lycurgus and Numa. In fact, they were just techniques that

In fact, he argued that this device was used so often that he concluded that "any synthetic history of Spartan institutions is impossible" (idem, p. 192), as the tradition of the "ancestral" (i.e. Lycurgean) iron currency, for instance.

${ }^{38}$ See also G. DuméziL 1958.

${ }^{39}$ J. D. Lewis 2007: 63.

${ }^{40}$ On this matter, see P. Desiredi 2002.

${ }^{41}$ Cf. P1., R. 487e, Lg. 711E.

${ }^{42}$ See also G. J. D. H. Wzn. Aadalers 1982: 45 and D. Babut 1969: 85-87.

${ }^{43}$ Cf. Plu, De Alex. fort. aut virt. 1,330D; Alex. 52.5 and Art. 23.5.

${ }^{44}$ G. Roskam 2002: 180. 


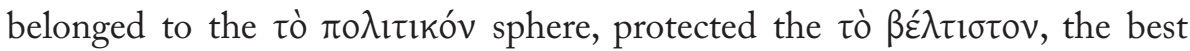
interest of the state and intended to "pull them [the mob] back to the profitable course and set them right" (De gen. Socr. 579F).

In these Lives, the political lie may be seen as an expression of pronoia, i. e., an exceptional ability to analyse his own present circumstances, just as in that Polybian example of Scipio (10.2.8-10) or even the Plutarchean Fabius Maximus (Fab. 7.2) ${ }^{45}$. On the other hand, Plutarch, in the path of Greek skeptical, rationalist and humanist view eloquently expressed by Critias, admits the use of political lie as a likely origin of these political reforms, which is related to his often derogatory treatment of the demos, already present in Plato (Saï, 2005). Although Plutarch has recognized that "for Philosophy such outward seeming appears not only unseemly but in open conflict with her claims" (De gen. Soc. 580A-B) ${ }^{46}$, he accepts the use of superstition with some leniency for political purposes.

${ }^{45}$ The contrary can be found also in Plutarch, Comp. Per.-Fab. 2.4.

${ }^{46}$ Contra De superst. and De Is. et Os. 2, 68, 71. 


\section{References}

Aalders, G. J. D. H. Wzn., Plutarch's Political thought. Amsterdam, 1982.

Babut, D., Plutarque et le stoicisme, Paris, 1969.

Briquel, D., "Les rois de Rome selon G. Dumézil: corrections et complements", in F. Delpech \& M. V. García Quintela (eds.), Vingt ans après Georges Dumézil, 1898-1986. Budapest, 2006: 21-44.

Cartledge, P., Agesilaus and the crisis of Sparta. London, 1987.

Cerezo, M., Plutarco: virtudes y vicios de sus héroes biográficos, Lleida. 1996.

Delatte, A., Études sur la littérature pythagoricienne. Genève, 1974: 44-46.

Desiredi, P., "Lycurgus: the Spartan ideal in the age of Trajan", in P. Stadter

\& L. van DER StockT, (eds.), Sage and Emperor. Plutarch, Greek Intellectuals and Roman Power in the Time of Trajan (98-117 A.D.). Leuven, 2002: 315-327.

Dumézil, G., L'idéologie tripartie des Indo-Européens, Bruxelles, 1958.

Duff, T., Plutarch's Lives: Exploring Virtue and Vice. Oxford, 2005.

Farrignton, B., Science and Politics in the Ancient World, London, 1939.

Ferrero, L., Storia del Pitagorismo nel mondo romano. Torino, 1955.

FLOwer, M., "The invention of tradition in classical and Hellenistic Sparta”, in A. Powell \& S. Hodkinson (eds.), Sparta. Beyond the Mirage. Swansea, 2002: 193-219.

Frazier, F., Histoire et Morale dans les Vies Paralleles de Plutarque, Paris, 1996.

Frazier, F., "Introduction”, in F. Frazier \& D. Leão (eds.), Tychè et Pronoia. La marche du monde selon Plutarque, Coimbra, 2010: III-XXIII.

Guelfucci, M., "Polybe, la Túxך et la marche de l'Histoire", in F. Frazier ; D. Leão (eds.), Tychè et Pronoia. La marche du monde selon Plutarque. Coimbra, 2010: 141-168.

Hodkinson, S., Property and Wealth in Classical Sparta. Swansea, 2000.

Jones, C. P., “Towards a Chronology of Plutarch's Works”, JRS 56.1-2, 1966: 61-74.

Koulakiotis, E., "Greek lawgivers in Plutarch: A comparison between the biographical Lycurgus and the Rhetorical Alexander" in A. G. Nikolaidis (ed.), The Unity of Plutarch's Work: "Moralia" Themes in the "Lives", Features of the "Lives" in the "Moralia". Millennium-Studien 19. Berlin/New York, 2008: 237-253.

Lewis, J. D., Early Greek Lawgivers, Bristol, 2007. 
Liou-Gille, B., "La figure du Législateur dans le monde antique", in Revue belge de philologie et d'histoire 78.1, 2000: 171-190.

Marino, A. S., Numa e Pitagora. Sapientia constituendae civitatis. Napoli, 1999.

Morrow, G., Plato's Cretan City. Princeton, 1960.

Nikolaidis, A. G., "What Did Apollo Mean to Plutarch?”,in L.Athanassaki, R. Martin, and J. F. Miller (eds.), Apolline Politics and Poetics. Athens, 2009: 569-586.

Ogilvie, R. M., A commentary on Livy. books 1-5. Oxford, 1978.

Paton, W. R., Polybius. The Histories. Cambridge, Mass., 1976.

Pelling, C., “'Making myth look like History': Plutarch's Theseus-Romulus”, Plutarch and History, Swansea, 2011: 171-206.

Pérez Jiménez, A., "La religión como instrumento político en Plutarco", Actas del II Congreso Andaluz de Estudios Clásicos, vol. II, Málaga, 1987.

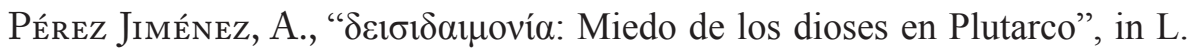
VAn Der Stockt (ed.), Plutarchea Lovaniensia. A Miscellany of Essays on Plutarch. Lovaina, 1996: 195-225.

Perrin, B., Plutarch's Lives: Lycurgus/Numa/Solon, vol. I. Cambridge, Mass., 1914.

Powell, A., "Plato and Sparta: modes of rule and non-rational persuasion in the Laws", A. Powell \& S. Hodkinson (eds.), The Shadow of Sparta. London and New York, 1994: 273-321.

Powell, A., "Divination, royalty and insecurity in Classical Sparta", in A. Powell \& S. Hodkinson (eds.), Sparta. The Body Politic. Swansea, 2010: 85-135.

Romilly, J., La Loi dans la pensée grecque des origins à Aristote, Paris, 1971.

Romilly, J., The Rise and Fall of States According to Greek authors. Ann Arbor, 1991.

Rosкam, G., "A ПАI $\Delta$ EIA for the ruler. Plutarch's dream for collaboration between philosopher and ruler", in P. STAdTer \& L. van der StockT (eds.), Sage and Emperor. Plutarch, Greek Intellectuals and Roman Power in the Time of Trajan (98-117 A.D.). Leuven, 2002: 175-190.

Rosкam, G., Plutarch's Maxime cum principibus philosopho esse disserendum: An Interpretation with Commentary. Leuven, 2009.

VAn Stockт, L., "With followeth justice always (Plato, Laws 716A). Plutarch on the 'divinity' of rulers and laws", in L. de Blois; J. Bons; T. Kessels; Dirk M. Schenkeveld (eds.), The Statesman in Plutarch's Works, Proceedings of the Sixth International Conference of the International Plutarch society I, Leiden-Boston, 2005: 137-149. 
Political reforms in the Lives of Lycurgus and Numa: divine revelation or political lie?

SAïD, S., "Plutarch and the people in the Parallel Lives", in L. De Blois, J. A. E. Bons, T. Kessels \& D. M. Schenkeveld (eds.), The Statesman in Plutarch's Works II. Leiden - Boston, 2005: 7-25.

Szegedy-Maszak, A., "Legends of the Greek Lawgivers", GRBS 19, 1978: 199-209.

Walbank, F.W., A historical commentary on Polybius. Oxford, 1999.

Wardmann, A., Plutarch's Lives, Michigan, 1974. 
(Página deixada propositadamente em branco) 
II.

NOMOS AND KOSMOS 
(Página deixada propositadamente em branco) 


\title{
kozmos and its derivatives in the Plutarchan Works on love
}

\author{
Carlos A. Martins de Jesus \\ Universidade de Coimbra
}

\begin{abstract}
This paper aims to explore the different meanings of the word kó $\mu \circ \varsigma$ and its derivatives, also looking for a unified understanding of them in the Plutarchan works on love, namely Amatorius, Amatoriae Narrationes, Coniugalia Praecepta, Mulierum Virtutes and Consolatio ad Vxorem. By analyzing first a more general and primordial meaning of 'cosmical organization' and then a more domestic one - that of female cosmetics -, as well as others, an attempt is made to understand Plutarch's use of those words, as well as the moral and philosophical principles they imply.
\end{abstract}

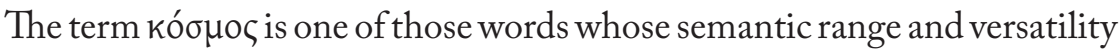
most surprises philologists, since even words which are etymologically derived from it can be seen to bear the imprint of its diversity. When Plutarch, in the second century $\mathrm{AD}$, uses it to characterize the position of women in the context of a loving relationship, especially marriage - and I refer mainly to the works Conjugalia Praecepta, Consolatio ad Vxorem and Amatorius -, there is already an immeasurable philosophical and linguistic tradition conveyed by

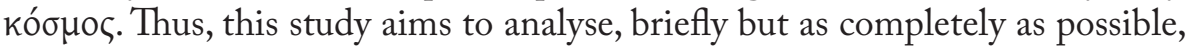
the appropriation and manipulation of this term by Plutarch.

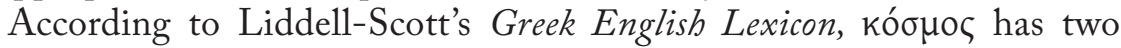
primary meanings: (1) "order", that corresponds to the semantic value of $\tau \alpha \xi_{1 \zeta}$ (cf. Latin ordo) ${ }^{1}$, and, also related to the previous one, (2) "ornament" or "adornment" (cf. Latin ornamentum, ornatus). In fact, they both came to signify the same idea of aesthetical organization of unrelated elements and it is actually difficult to detect which one comes first in Greek language and literature. In relation to its more concrete and scientific sense still used nowadays - "cosmos" or "cosmic order" - it is traditionally ascribed first to Pythagoras (apud Placit. 2.1.1, D.L. 8.48; cf. [Philol.] 21) and Parmenides (Thphr. ap. D.L. 1.c.), although it is already found in the fragments of their predecessors, such as Anaximander (fr. 12A 10 Diels) and Anaxymenes (fr. 13B 2 Diels). Nevertheless, it must have reached this meaning, in a definitive way, by the time of Empedocles (fr. 134 Diels)². However, Greek literature

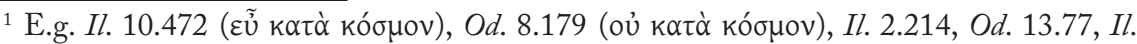
12.225; Hdt. 2.52, cf. 7.36; Ar. Av.1331; Pi. P. 3.82; A. Ag. 521; Hdt. 8.86, 9.59, 9.66; Th. 3.108; A. Pers. 400. It also started to relate to the specific order of States (e.g. Th. 4.76, cf. 8.48, 67; Hdt. 1.65).

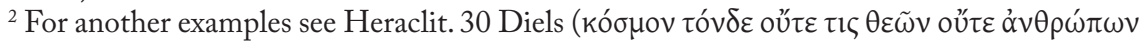


shows that it soon gained moral connotations related to attitudes and conducts in several areas, the ones listed in the Thesaurus Linguae Graecae under the category of "modo et ratione omnia facere" and "decens habitus"3.

In fact it is within this last sense that we must place the Plutarchan use of the term and its derivatives, especially when referring to female conduct in the context of a loving relationship, preferably marriage. Lamprias'

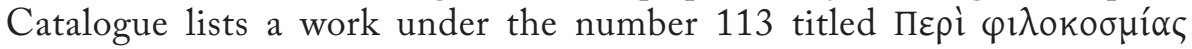
("On the love for adornments"), which, despite the lack of testimonies or fragments 4 , we can reasonably conceive that it might also advocate the value of other type of adornments, those that enrich a woman's soul and make her an example to other women. Regarding female conduct, the entry of the Thesaurus is clear when considering "quod ad ornatum muliebrem transtulit Plutarchus (Mor. 141E)". It refers to one passage of the Conjugalia Praecepta (141E), which is very elucidative of Plutarch's linguistic use of this term, going as follows:

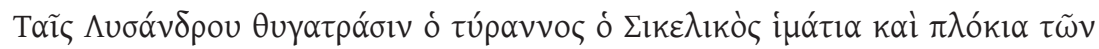

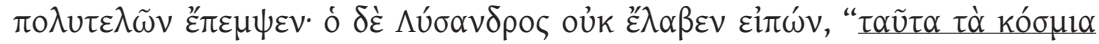

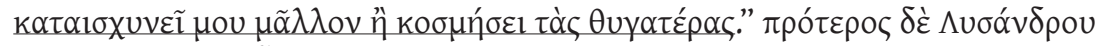

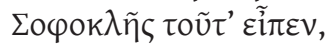

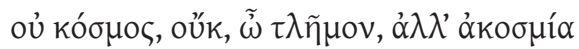

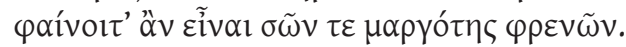

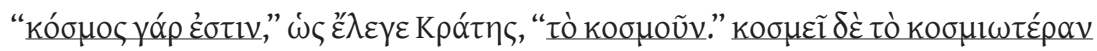

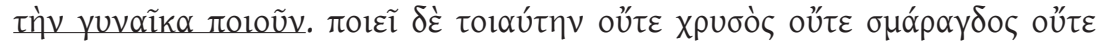

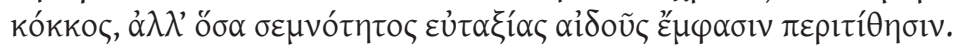

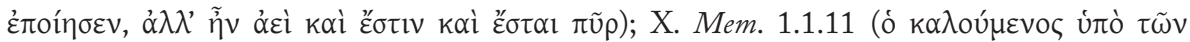

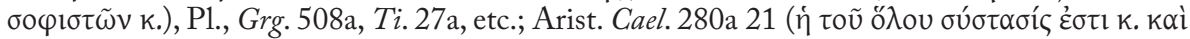
oủpavó(); Epicur. Ep. 2 p.37 U, Chrysipp. Stoic. 2.168, etc. For other derivated meanings see Posidon. ap. D.L. 7.139, Isoc. 4.179, Arist. Mete. 339a 20, Herm. ap. Stob. 1.49.44, [P1.], Epin. 987b, Anaximand. et alii ap. Placit. 2.1.3, etc.

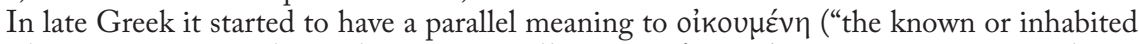

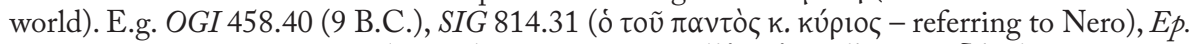

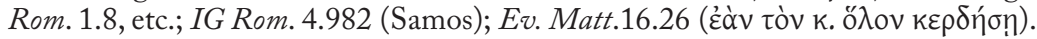

${ }^{3}$ E.g. Il. 2.214, 5.759, 8.12, 8.179; Od. 3.138. See also Hdt. 8.60, 142; Ar. Nu. 914; Th. 1.5; D. 60.36; X. Cyr. 6.4.3; Arist. EN 1124a 1. Therefore, it opposes to ókoouía, as expressed in the fragment of Sophocles (Soph. fr. 762, cit. Plu. Conj. praec. 141E). In fact, in a popular passage

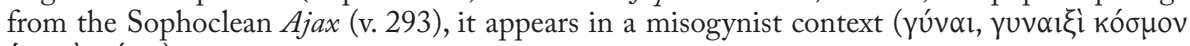

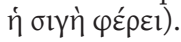

${ }^{4}$ In the Conjugalia Praecepta (145A) Plutarch alludes to a similar themed work (with no mention to the title) that had supposedly been written by his wife, Timoxena. U. Wilamowitz-Moellendorf F 1962: 655 suggested that this authorship was fictional and that it was, in fact, written by Plutarch himself. 
The Sicilian despot sent clothing and jewellery of the costly kind to the daughters of Lysander; but Lysander would not accept them, saying, "These adornments will disgrace my daughters far more than they will adorn them." But Sophocles, before Lysander, had said this:

Adornment! No, you wretch! Naught that adorns

'Twould seem to be - your crazy mind's desire.

For, as Crates used to say, "adornment is that which adorns", and that adorns or decorates a woman which makes her more decorous. It is not Gold or precious stones or scarlet that makes her such, but whatever invests her with that something which betokens dignity, good behaviour, and modesty ${ }^{5}$.

By telling this tale ${ }^{6}$ about the gifts that might have been received by the daughters of Lisander, the Spartan general of the V-IV centuries BC to whom he dedicated an entire biography, Plutarch plays with the double meaning of

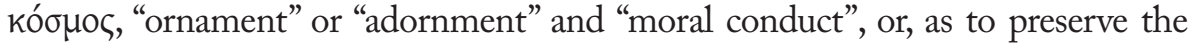
ambiguity of the Greek expression, "moral ornament". This can be inferred from the statement that such adornments ( $\tau \dot{\alpha}$ kó $\sigma \mu l \alpha$, stricto sensu), more than "adorning"

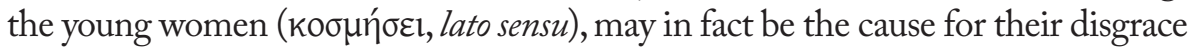

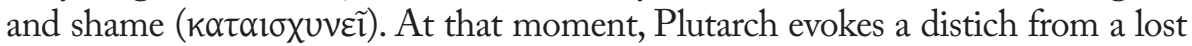
Sophoclean play (fr. $762 \mathrm{Nauck}^{2}$ ), in which the same opposition is expressed by the

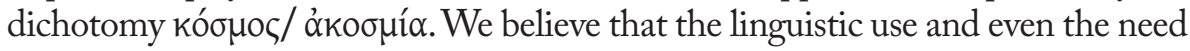
of summoning not one but two ancient definitions reveal the acknowledgement that a delicate matter is being discussed, mostly due to the semantic ambiguity of the term in use. The ambiguity is not even solved by Crates' very simple

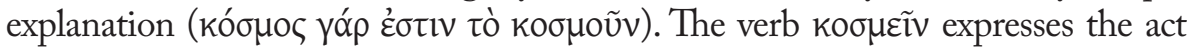

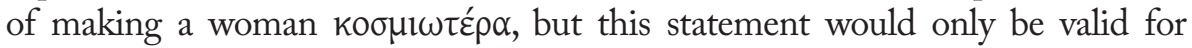
physical adornments. Thus it becomes necessary to clarify that the "cosmetics" being discussed - the one that Plutarch prescribes to Eurydice, the bride to whom the speech is addressed - is not made of gold, gems or lavish fabrics but, instead,

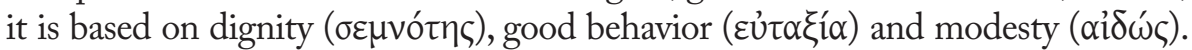
Those are the adornments that make a woman innerly "organized" and "balanced", those are the accessories of her moral cosmetics.

The same characterization of the ideal woman in the context of marriage comes later in the same work, when the final advice to the grooms is being given $(145 \mathrm{E}-\mathrm{F})$ :

\footnotetext{
${ }^{5}$ All English translations, unless otherwise is mentioned, are from the Loeb Classical Library.

${ }^{6}$ It was probably a legendary story, suitable to different characters. Therefore Plutarch applied it also to Archidamus (Apopht. Lac. 218E).
} 


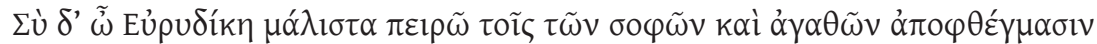

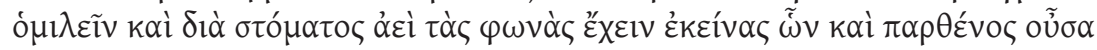

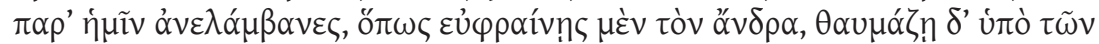

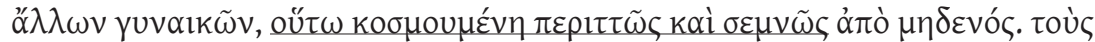

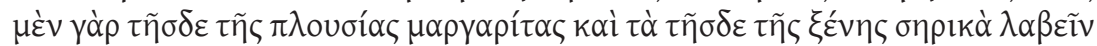

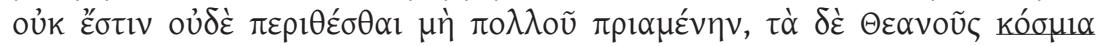

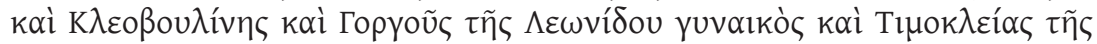

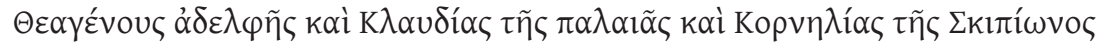

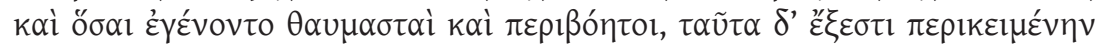

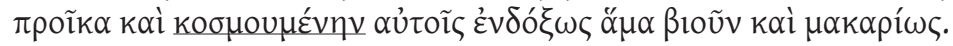

As for you, Eurydice, I beg that you will try to be conversant with the sayings of the wise and good, and always have at your tongue's end those sentiments which you used to cull in your girlhood's days when you were with us, so that you may give joy to your husband, and may be admired by other women, adorne, as you will be, without price, with rare and precious jewels. For you cannot acquire and put upon you this rich woman's pearls or that foreign woman's silks without buying them at a hight price, but the ornaments of Theano, Cleobulina, Gorgo, the wife of Leonidas, Timocleia, the sister of Theagenes, Claudia of old, Cornelia, daughter of Scipio, and of all other women who have been admired and renowned, you may wear about you without price, and, adorning yourself with these, you may live a life of distinction and happiness.

Once again use is made of the image of female cosmetics' precious adornments, pearls of moral conduct that, being materially more accessible, enable a woman to give joy to her husband and commend herself to the admiration of other women. The use of specific examples, common in the Plutarchan works - in this case simple allusions that appear in accumulation - aims at making a series of conduct paradigms linger in the bride's mind, stories that shift from truth and legend, which, in fact, fulfill a valuable paradigm ${ }^{7}$. Common in epideictic rhetoric ${ }^{8}$, two key levels that contribute to

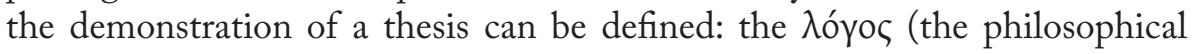

7 The models presented by Plutarch are the following: Theano, Pythagoras' wife, referred once again later (142C); Cleobuline, daughter of Cleobulus - one of the Seven Sages -, supposedly the author of some enigmas in hexameter whom, in the Banquet of the Seven Sages, Thales calls a philosopher; Gorgo, daughter of Cleonomes, king of Sparta, and wife of Leonidas. About Gorgo it is told in the Mulierum Virtutes (225A, 227E-F) that, being asked why only Spartan women were said to have power over their husbands, she replied that only they were mothers of true men; Timocleia, whose story of courage and virtue is also told in the Mulierum Virtutes (259D-260D); Claudia, a Roman vestal that, after being accused of having been defiled, dragged alone a boat that was carrying a statue of Cybele to the city; Cornelia, mother of the Gracchi and Scipio the Africanus, that once referred to her sons as "jewels".

${ }^{8}$ Several Greek authors theorize about how indispensable exempla are to achieve persuasive purposes: e.g. P1. Plt. 277d 1-2, Arist. Rh. 1357b 27-30. 
discussion itself), which is continuously helped by a series of $\mu \tilde{v} \theta$ or or $\pi \alpha \rho \alpha \delta \varepsilon i ́ \gamma \mu \alpha \tau \alpha$ with distinct levels of narrative development. As has been well perceived by J. A. Clúa Serena 19979, we are in the presence of a clear purpose of the $\lambda$ óyoc: to present, by resorting to $\mu \tilde{v} \theta$ oc, the most suitable themes in the range of the eikós (the plausible) ${ }^{10}$.

The conduct implied in the female kó $\mu \iota \propto \alpha$ prescribed by Plutarch is built on the concepts of order, modesty and silence, as can be seen in two passages of another brief Plutarchan work, the so-called Consolatio ad Vxorem. It presents itself in the narrative structure of a letter that Plutarch himself may have written to his wife, Timoxena, on the death of their only daughter, named after her mother, the last of their five children (608C). This work does not actually prescribe the proper conduct of a future wife, as Timoxena is repeatedly presented as being already the complete prototype of a perfect wife; however, Plutarch praises the decorum and silence of her attitude towards the death of her daughter, stating that "everything was

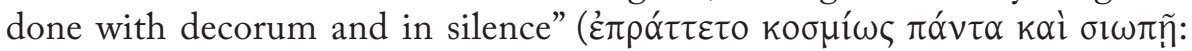
$608 \mathrm{~F}$ ) and emphasizing "the self-possession with which [she] kept order in [her] house-hold at the time that gave full scope to disorderly confusion"

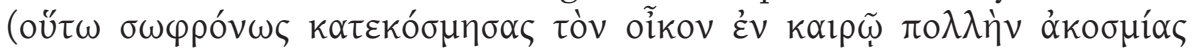

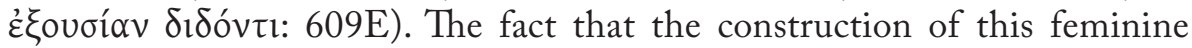
profile depends, in a large scale, on the husband's character is supported by Plutarch in another passage of the Conjugalia Praecepta (140C), based on an interesting linguistic game:

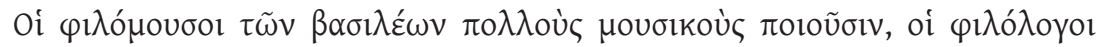

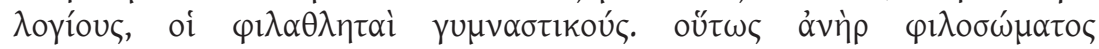

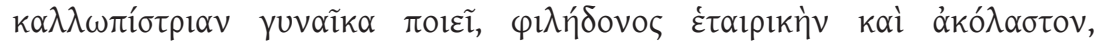

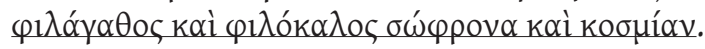

Kings fond of the arts make many persons incline to be artists, those fond of letters make many want to be scholars, and those fond of sport make many take up athletics. In like manner a man fond of his personal appearance makes a wife all paint and powder; one fond of pleasure makes her meretricious and licentious, while a husband who loves what is good and honourable makes a wife discreet and well-behaved.

\footnotetext{
${ }^{9}$ The author studies the narratives (realia) presented in another work, the De sera numinis vindicta, a compilation of the life stories of a few tyrants in the hands of the Providence.

${ }^{10}$ In relation to the structure and function of this type of shorter exempla, true autonomous narratives with a similar paradigmatic function, see F. Frazier 2005 and M. Valverde SÁNCHEZ 2007.
} 
R. M. Aguilar 1990: 316 correctly assumes that statements such as this one, more than misogynistic, are in fact the result of the social evolution of women's status in the Hellenistic and Roman world, as silence and modesty are only prescribed to the moments when a woman is alone, without her husband ${ }^{11}$.

It is however in the Amatorius - perhaps the most popular, disseminated and imitated of all the Moralia - that Plutarch made the highest investment in terms of philosophical and moral precepts about love and female conduct in marriage, since that is the main subject of the dialogue. The "dramatic" situation is clear: Plutarch and his wife had gone to Helicon to make sacrifices to Eros, at the time when an astonishing local event dominated the conversations: Ismenodora, a mature widow, desired to marry Bacon, a young and single man. Then, two inhabitants, Anthemion and Pisias, approach Plutarch with opposing opinions on the matter, clearly advocating each side of the discussion - paederastic versus conjugal love. Hence it aims to philosophically legitimize heterosexual love and to acknowledge the decisive role of women in the pursuit of true love, as she may also be able to foster and inspire the effects triggered by true Eros. Plutarch puts the reader before an extreme situation as Ismenodora, more than a random woman, is a mature widow, being beforehand more experienced than Bacon, the young man that she desires. Therefore, the manipulation of traditional philosophical arguments on love, mostly Platonic ${ }^{12}$, is clear throughout the whole dialogue.

Indeed, regarding philosophical theories on love, the Banquet and the Phaedrus are the most direct models of the Amatorius, alongside noticeable influences of passages from the Phaidon, the Republic or the Laws. By recalling Plato's notion that Eros is the guide of souls to supreme Beauty, the Polygraph shows the evolution of coeval thinking and strips the original misogyny of the Platonic theory, by giving woman a determinant role and - as well stated by $\mathrm{M}$. B. CRAwFord 1999: 290 - by rescuing marriage from a linear and anti erotic conception $^{13}$. At other moments, several philosophical doctrines merge to address the same subject, but Plato is indeed to be seen as the main inspiration.

${ }^{11}$ This becomes clearer in another passage from the Conjugalia Praecepta (139C), by resorting

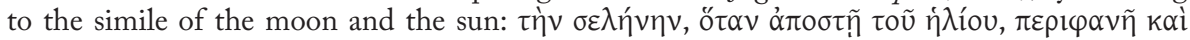

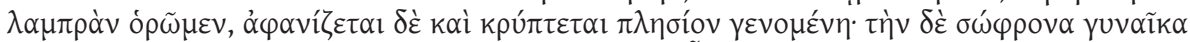

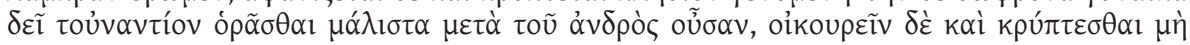

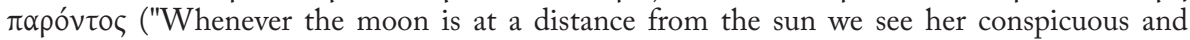
brilliant, but she disappears and hides herself when she comes near him. Contrariwise a virtuous woman ought to be most visible in her husband's company, and to stay in the house and hide herself when he is away").

${ }^{12}$ From the many titles focused on the Platonism in Plutarch, especially in relation to the love theme, see H. Martin 1984, F. Frazier 1999, 2008a, A. Billaut 1999, J. Boulogne 1999, M. B. Crawford 1999, J. M. Rist 2002 and P. Gilabert Barberà 2007.

${ }^{13}$ See also F. E. Brenk 1988, who reaches a similar conclusion. 
Plato had also used the term kó $\sigma \mu$ ○ and its derivatives in the philosophical legitimization of paederastic love in order to refer himself to the conduct of the ideal lover, as a vehicle to achieve Beauty and Good, the aim of the true Eros. An unequivocal example appears in the Symposium (187d-e), after the distinction between two Eros and two Aphrodites (180d-182a), a subject recapped by Plutarch in his dialogue (764B-765D). The Platonic text goes as follows:

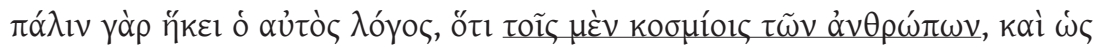

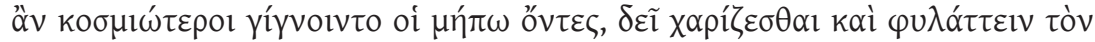

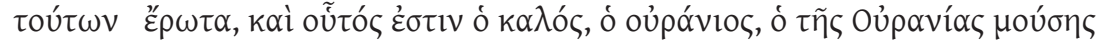
"Е $\rho \omega \varsigma^{\circ}$

Round comes the same conclusion: well-ordered men, and the less regular only so as to bring them to better order, should be indulged in this Love, and this is the sort we should preserve; this is the noble, the Heavenly Love, sprung from the Heavenly Muse.

To another level, in Plato's Symposium references to the value of

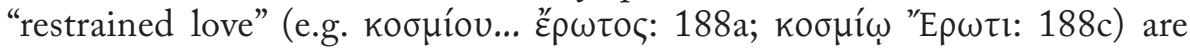
frequent, and one may come to accept that Plutarch might have used the same linguistic expression in his works on that subject. Nevertheless, the kó $\mu_{1} \alpha$ that Plato uses as an ethical, moral and even political value in the masculine ${ }^{14}$ will appear in Plutarch with new drapery and, deliberately, in the feminine. Thus, it is our belief that the rhetoric interrogation to which

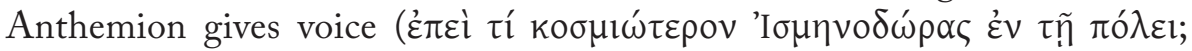
Amat. 755D) is intentional, since the whole discussion of the dialogue aims to attempt a proper answer to it.

In order to inspire true love, Ismenodora's conduct should not reduce itself to the kó $\tilde{\mu l \alpha}$ of a woman who stays at home with all her decency and modesty,

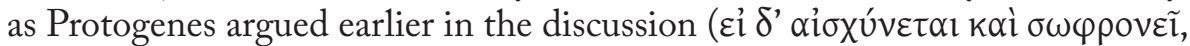

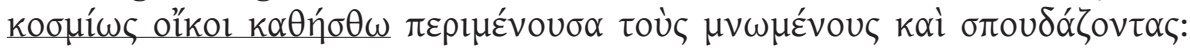
$753 \mathrm{D})$. The Platonic discussion on love $(766 \mathrm{E}-768 \mathrm{~F})$ is carried on against this unambiguous misogyny, aiming to demonstrate, by recurring to the same arguments used by Plato, that true Eros does not obey gender issues. It only

${ }^{14}$ There are several Platonic passages in which the ethical sense of this term and its derivatives

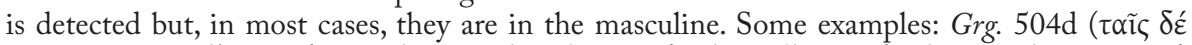

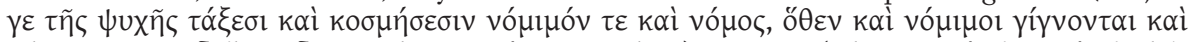

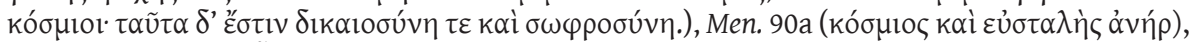

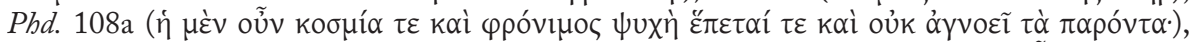

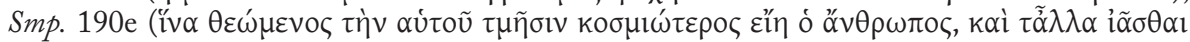

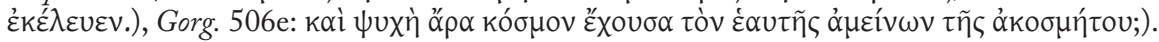


leads a person to make his/her choice by the beauty and virtue of other being (767A):

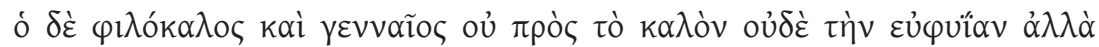

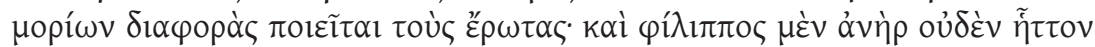

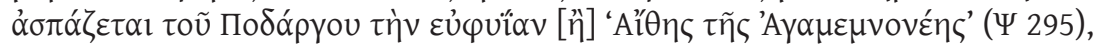

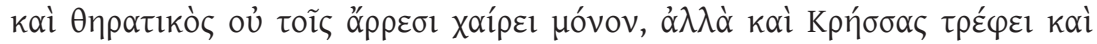

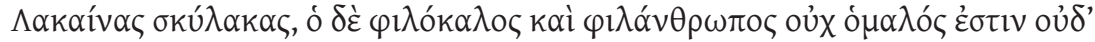

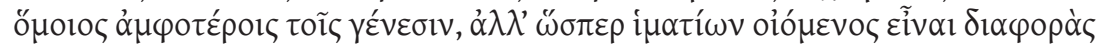

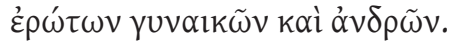

... the noble lover of beauty engages in love wherever he sees excellence and splendid natural endowment without regard for any difference in physiological detail. A lover of horses takes pleasure in the excellent qualities of Aethê, Agamemnon's mare no less than in those of the horse Podargus. The hunter has no special preference for male dogs, but also keeps Cretan and Laconian bitches. So to will not the lover of human beauty be fairly and equably disposed toward both sexes, instead of supposing that males and females are as different in the matter of love as they are in their clothes?

Therefore, the Platonic inspired argumentation in Plutarch is to be understood as the amplification of Plato's own arguments on love for both genders, instead of being a gender shift. It intends to legitimize conjugal love, first philosophically, then ethically. The afore mentioned amplification is based on the defense of the ideal $\ddot{\eta} \theta$ os of true love, notwithstanding its gender:

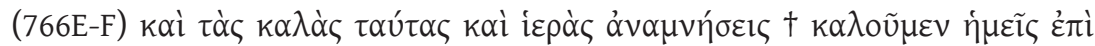

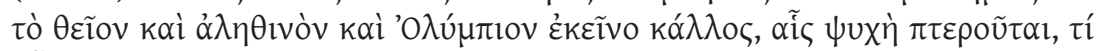

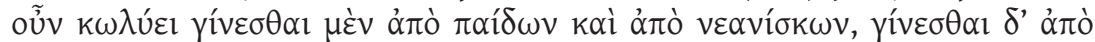

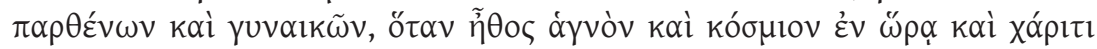

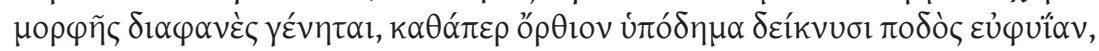

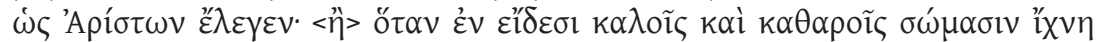

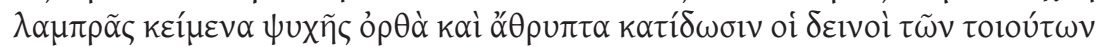

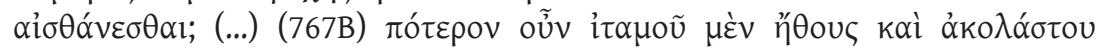

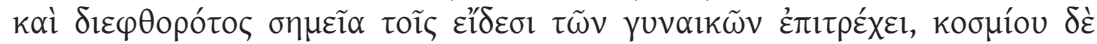

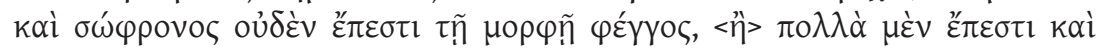

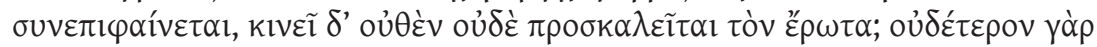

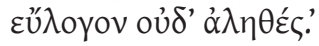

(766E-F) And those beautiful and sacred passions which we call recollections of the divine, the true, the Olympian beauty of the other world, by which the soul is made winged -why should they not spring from maidens and women, as well as from boys and striplings, whenever a pure and disciplined character shines through from within a beautiful and charming outward shape... or 
whenever the clear-cut traces of a shining soul stored up in beautiful forms and pure bodies are perceived undistorted, without a flaw, by those capable of such perceptions. (...) (767B) Do the 'signs' betokening a flight, unchaste, and corrupt character overrun women's faces, while no luster is added to a female's beauty by a chaste and modest character? Or are there many 'signs' of the latter, which 'present themselves in combination', yet nevertheless do not move or evoke our love? Neither position is well taken or true.

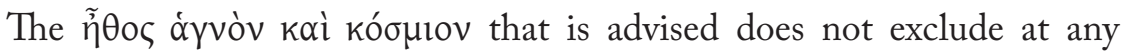
moment the role of physical pleasure and $\operatorname{sex}^{15}$, as they should always be moderated and calculated ${ }^{16}$; instead, it tries to elevate pleasure to a superior stage, to the Platonic supreme Good. At that stage, there is no great difference to the paederastic love advocated by Plato, in which modesty and decency of the young male lover was also recommended. The implied decorum in the кó $\sigma \mu l \alpha$ of the lover is more related to a conduct that inspires total fidelity and concentration on one being, as it can be concluded in the following passage (767E-F):

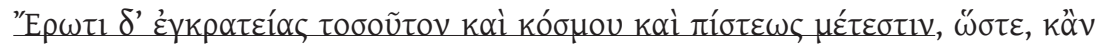

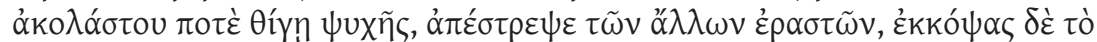

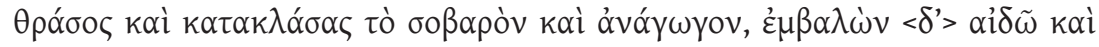

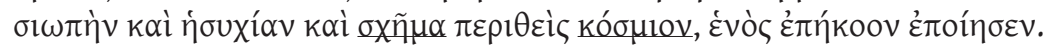

Love, however, has in himself enough self-control, decorum and mutual trust, so that if he ever but touches the heart even of a profligate, he turns him from his other lovers, drives out insolence, humbles pride and intractability, and brings in modesty, silence, calm. He clothes him with the robes of decorum and makes him deaf to all appeals but one.

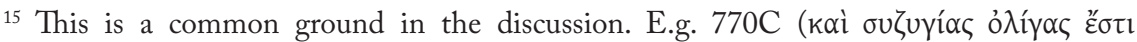

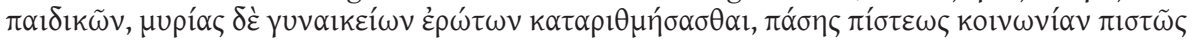

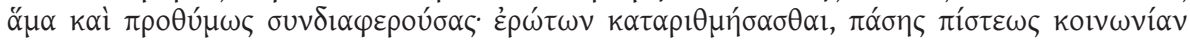

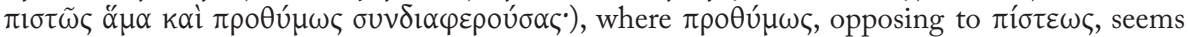
to allude to the physical part of a conjugal relationship. Therefore, it reminds and compliments the Solonian law according to which spouses should have sexual intercourse at least three times a month, as Plutarch says, "definitely not by the pleasure itself but - in the same way that cities, from time to time, renew the pacts that they have among each other - because they wanted to revitalize the marriage from the complaints that accumulates day by day with such a display of

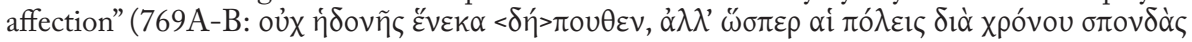

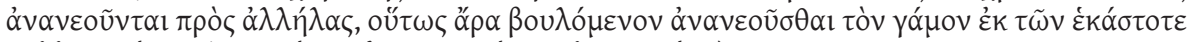

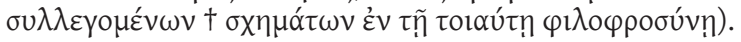

${ }_{16}$ J. F. Martos Montiel 1990, 1999a, 1999b: 111-125 developed the notion of calculation of pleasure by the conception of a $\mu \varepsilon \tau \rho \tau_{0} \alpha \varepsilon \varepsilon 1 \alpha$ that gathers Platonic, Aristotelian and Epicurean influences, and departs from the stoic ó $\pi_{\alpha} \alpha \dot{\theta} \varepsilon 1 \alpha$. About the reception of Epicurism in Plutarch, mainly in the Amatorius, see A. BARIgazzi 1988. 


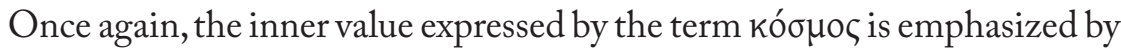
the image of exterior clothing, with garments of nobility and decorum existing

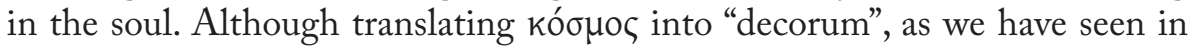
the just quoted passage, may seem too moralizing, several different translations that we found, once compared, prove that its main sense is that of "moral adornment or cosmetics". Moreover, it may be said that both Plutarch and his translators seem to agree on keeping this ambiguity within the cosmetics' semantic range, the exterior and interior ones.

Taking into account the above-explained argumentative logic, according to which a finished theory demands exemplary illustration, we are presented with the story of Lais (767F-768A). She was a famous courtesan from Corinth who might have been intimate with Aristippus of Cyrene, a philosopher of Socrates' circle, known for being the founder of the Cyrenaic school of Philosophy and one of the predecessors of Epicurism. The story concerns the love that she might have dedicated to the Thessalian Hipollocus, for whom she abandoned the profession of courtesan, her homeland and, finally, her own life, as other women's jealousy came to be responsible for her death. In fact, the conclusion of her story is categorically paralleled to the previous argument: "escaping secretly from the vast throngs of her other lovers and from the great

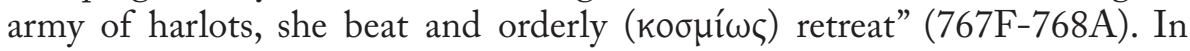
this specific passage, our opinion diverges from the translation of the Loeb

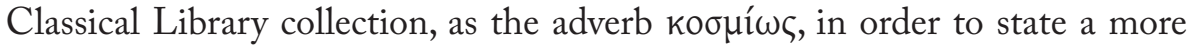
direct identification between the argument and the exemplary illustration, should have also a moral sense in the case of Lais, instead of the most concrete one that describes only her "orderly retreat". We would thus translate the adverb as "virtuously" or, as we actually did in our Portuguese translation of the Amatorius, "covered with honour".

An attentive reading of the works that we discussed seems to prove that Plutarch focuses on the characterization of the female kó $\sigma \mu l \alpha$ to reinstate women as a determinant element in love relationships, especially in a conjugal one. Implied or explicit characteristics as silence, decorum, modesty or fidelity

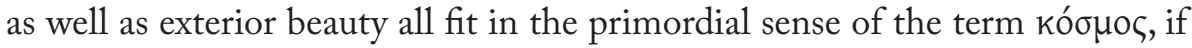
understood as "organization" or "balance" of pre-existing elements. Therefore, the woman who is kóoun, as intended by Plutarch, is the one that shows, both innerly and externally, the presence of adornments at the right amount and disposition, in the same way that the Pythagoreans stood for the barmonia as the principle of all cosmic (universal) organization. Taking the subject further, one may still read in Plutarch the influences of the Platonic theory on kó $\mu_{0}$, mainly the one from Timaios. If such a reading is possible, in the same way that

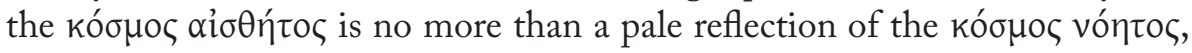
also a woman's external adornments would be nothing other than reflections, 
pale images of those other adornments with which she embellishes her soul. Hence, by comparison, Timoxena - the author's wife - is the ultimate model to work on the descriptions of other historical or legendary examples. The Galatian Camma ${ }^{17}$ (Amatorius 768B-D; Mulierum Virtutes 257E-258C) and Empone $^{18}$ (Amatorius 770D-771C) are perhaps the most polished examples.

However, the question cannot be read in every work that we have discussed in the same terms. F. Frazier 2008b: XX has hit the target when saying: "sans doute n'est-il pas difficile non plus de dégager une certaine 'rhétorique de l'exagération' dans la défense de l'amour conjugal de Plutarque, particulièrement sensible dans sa condamnation des viragos austères (753D), assez différente des propos plus mesurés qu'il tient sur le thème dans ses Préceptes conjugaux." As we have previously mentioned, it is clearly Plutarch's intention, with the Amatorius, to present his readers with a limit situation illustrated by limit examples ${ }^{19}$, and that is why, in this dialogue, Ismenodora is so different from Timoxena's model in the Praecepta. Nevertheless, both these women have an inner ability to inspire true love, the one that lives by the correct combination of pleasure and friendship; a combination already consummated in Timoxena, but also possible in Ismenodora. She may thus be seen, despite her singularities, as a more practical and realistic feminine prototype.

17 The character of Camma was studied by F. Frazier 2005 and F. E. Brenk 2005. She was an authentic romantic heroine. After her husband's death, when his assassin wanted to marry her, she pretended to be interested in him and then killed him, by poisoning, and ended up committing suicide. This story is not transmitted by any other source before Plutarch, being developed in the Amatorius and, and in a greater extent, in the Mulierum Virtutes. Nevertheless, this episode is addressed by Polienus (Strat. 8.39) in a very similar way to Plutarch, mostly to the version portrayed in the Mulierum Virtutes. Therefore, one may come to think that Polienus knew Plutarch's version, the one that influenced at least two tragedies in the Modern Period: Camma, reine de Galatie, of T. Corneille (1661), and The Cup, of Alfred Lord Tennyson (1884).

${ }^{18}$ Other sources are Tac. Hist. 4.67 and D.C. 65.3. We have studied this character ourselves, in a recent paper: C. A. M. Jesus 2011.

${ }^{19}$ The Amatorius is pertinently understood as an exercise of "rhetoric of exaggeration" by F. E. BRENK 2000: 45-60. 


\section{Quoted bibliography}

Aguilar, R. M., "La mujer, el amor y el matrimonio en la obra de Plutarco", Faventia 12-13, 1990: 307-325.

Barigazzi, A., "L'amore: Plutarco contro epicuro", Quad. Giorn. Fil. Ferr. 9, 1988: 141-163.

Billault, A., "Le Dialogue sur l'amour de Plutarque et les Dialogues de Platon sur l'amour", in Aurelio Pérez Jiménez, José García López \& Rosa M. Aguilar (eds.), Plutarco, Platón Y Aristóteles. Actas Del V Congreso Internacional De la I.P.S., Madrid, 1999: 201-214.

Boulogne, J., “Trois Eros? Comment Plutarque réécrit Platon”, in A. Pérez Jiménez et alii (eds.) in Aurelio Pérez Jiménez, José García López \& Rosa M. Aguilar (eds.), Plutarco, Platón Y Aristóteles. Actas Del V Congreso Internacional De la I.P.S., Madrid, 1999: 215-225.

Brenk, F. E., "All for love. The rhetoric of exaggeration in Plutarch's Erotikos", in L. Van der Stockt (ed.), Rhetorical Theory and Praxis in Plutarch. Acta of the IVth International Congress of the International Plutarch Society, Louvain-Namur, 2000: 45-60.

Crawford, M. B., "Amatorius: Plutarch's Platonic departure from the Perigamou literature”, in A. Pérez Jiménez, José García López \& Rosa M. Aguilar (eds.), Plutarco, Platón Y Aristóteles. Actas Del V Congreso Internacional De la I.P.S., Madrid, 1999: 287-298.

Frazier, F., "La 'prouesse de Camma' et la fonction des exempla dans le Dialogue sur l'Amour", in A. Pérez Jiménez \& F. Titchener (eds.), Historical and Biographical Values of Plutarch's Works. Studies Prof. P. A. Stadter, MálagaUtah, 2005: 197-211.

Frazier, F., "Éros, Arès et Aphrodite dans l'Érotikos. Une reconsidération de la réponse à Pemptidès", in J. Ribeiro Ferreira, L. Van der Stockt \& M. Céu Fialho (eds.), Philosophy in Society - Virtues and Values in Plutarch, Leuven-Coimbra, 2008a: 117-136.

Frazier, F., "Introduction", in Plutarque. Éroticos, Dialogue sur l'Amour. Texte établi et traduit par Robert Flacelière. Revu, introduit et annoté par Françoise Frazier, Paris, 2008b.

Gilabert Barberà, P., "El amor en Plutarco: la necesaria corrección platónica de Platón”, in J. M. Nieto Ibáñez \& R. López López (eds.), El Amor en Plutarco. IX Simposio Internacional de la Sociedad Española de Plutarquistas, León, 2007: 123-132.

Jesus, C. A. M., "Semíramis y Émpone. Dos historias de amor y desamor en el Amatorius de Plutarco", in J. M. Candau Morón (et alii, eds.), Plutarco Transmisor, Sevilla, 2011: 69-80. 
Martin, H., "Plutarch, Plato and Eros," CB 60, 1984: 82-88.

Martos Montiel, J. F., "Anotaciones al tema del placer en los Moralia de Plutarco", in J. García López (et alii, eds.), Estudios sobre Plutarco: Paisaje y Naturaleza. Actas del II Simposio Español sobre Plutarco, Madrid, 1990: 67-71.

Martos Montiel,J.F., "Platonismo y Aristotelismo en el concepto plutarqueo del placer”, in A. P. Jiménez et alii (eds.), in Aurelio Pérez Jiménez, José García López \& Rosa M. Aguilar (eds.), Plutarco, Platón Y Aristóteles. Actas Del V Congreso Internacional De la I.P.S., Madrid 1999a: 111-125.

Martos Montiel, J. F., El tema del placer en la obra de Plutarco, Zaragoza, 1999b.

Rist, J. M., "Plutarch's Amatorius: a commentary on Plato's theories of love?", CQ 51, 2002: 557-75.

Teodorsson, S.-T., "Plutarch's views on Love”, Ploutarchos 2, 2004/2005: 105122.

Valverde Sánchez, M., "Tipología del exemplum en el Erótico de Plutarco”, in J. M. Nieto Ibáñez \& R. López López (eds.), El Amor en Plutarco. IX Simposio Internacional de la Sociedad Española de Plutarquistas, León, 2007: 67-82.

Wilamowitz-Moellendorff, U., Kleine Schriften. Herausgegeben von den Akademien zu Berlin und Göttingen. IV, Berlin, 1962. 
(Página deixada propositadamente em branco) 


\title{
Nomos E Kosmos Na CARACTERIZAÇÃo do ANTÓNIO E DA Cleópatra de Plutarco
}

\author{
Nuno Simões Rodrigues \\ Universidade de Lisboa
}

\begin{abstract}
Although words like nomos and kosmos are almost absent in Plutarch's biography of Antony and Cleopatra, the concepts they imply support the author's construction of the Life. The "bigamist" relationship between Antony, Octavia and Cleopatra as well as Antony's uncontrollable passion for Cleopatra are examples of the absence of law and order in Mark Antony's life.
\end{abstract}

As palavras gregas que definem "lei"1 e "ordem" estão praticamente ausentes do relato plutarquiano da relação de António com Cleópatra. Referimo-nos à Vita Antonii (36.7), na qual, ainda assim, se verificam excepções, como a forma nomous, que ocorre como referência às leis de Sólon, numa metonímia que pretende aludir à condenação do adultério em Atenas. Como nota C. Pelling 1994: 220, esta referência evoca um debate presente nos séculos IV e V a.C., quando alguns heróis foram idealizados por seguirem a sua physis ignorando os nomoi humanos artificiais. O próprio Plutarco refere essas leis, na Vita Solonis (22.4), assinalando que tais normas negavam os direitos paternos em relação aos filhos nascidos fora do casamento legítimo3. Outra excepção é o uso do termo kosmos no passo em que se faz a apresentação de Cleópatra, mas com o sentido de "adorno", que a rainha teria usado para se preparar para o encontro com António, em Tarso (Ant.25.6).

Este dado não significa, porém, que os conceitos ou ideias a ele associadas, não estejam presentes no espírito e, por conseguinte, na narrativa de Plutarco, quando compõe a vida de Marco António e, em particular, descreve a relação do tribuno com a última rainha do Egipto lágida. Em suma: que essas noções façam parte da mensagem que o autor grego pretende cunhar nas representações das personagens que caracteriza neste contexto.

Para percebermos o alcance do texto plutarquiano, há que ter presentes os dados em jogo, designadamente: a união de António a Cleópatra; o casamento do romano com Octávia, irmã de Octávio; e ainda a relação entre os dois generais, bem como as repercussões que teve na política romana da segunda metade do século I a.C.

Em 40 a.C., António casou-se com Octávia, com o objectivo de firmar o

\footnotetext{
${ }^{1}$ Nomos, que segundo A. BAIlly 1950: 1332, pode também significar “costume” ou "regra".

${ }^{2}$ Kosmos, que segundo A. BAilly 1950: 1125, pode também significar "o que é conveniente ou adequado", "disciplina" ou "organização". A problemática em torno da semântica destes termos é desenvolvida no texto de Carlos A. Martins de Jesus, neste mesmo volume.

${ }^{3}$ Ver o comentário em D. F. LEÃo 1999: 96, n. 71.
} 
tratado de Brundísio, que dividia os territórios controlados por Roma: Octávio passava a controlar o Mediterrâneo ocidental, enquanto António controlaria o oriental ${ }^{4}$. Há ainda que ter presente que o acordo de Brundísio vinha na sequência do assassinato de Júlio César em 44 a.C. e da guerra civil que entretanto eclodira em Roma e que opusera a facção republicana à cesarista.

O casamento de conveniência celebrado entre António e a irmã de Octávio fora favorecido pelo facto de o primeiro ter enviuvado de Fúlvia, nesse mesmo ano de 40 a.C., sendo que esta tivera um papel importante nas lutas políticas que se sucederam à morte de César e das quais o próprio Plutarco dá testemunho (Ant. 10.5-10; 28.1; 30.1-6; 31.3). Mas em 41 a.C., António encontrara-se com Cleópatra VII do Egipto em Tarso, na Cilícia, numa reunião que motivou a Plutarco algumas das mais belas páginas da sua obra (Ant.25-28). A relação encetada com a macedónia foi interrompida pelo casamento celebrado com Octávia, o qual terá por certo seguido as normas romanas que legitimavam uma união desta natureza perante a ordem social. As circunstâncias e o estatuto dos nubentes exigiam-no. Mas em 37 a.C., o tribuno romano reencetou os contactos com Cleópatra, ao regressar ao Oriente, com o objectivo, entre outros, de combater os Partos. Na verdade, acima de tudo, e não negando quaisquer eventuais factores emotivos (porque esses escapam mais facilmente ao historiador), a relação de António com Cleópatra baseava-se numa componente política substancial: com esta ligação, a rainha do Egipto assegurava o trono enquanto o general romano ficava com recursos significativos à sua disposição para controlar todo o Oriente mediterrâneo e, por conseguinte, fortalecer a sua posição em Roma.

Os acontecimentos, todavia, não se revelaram como António esperava. A campanha de 36 contra os Partos foi um desaire e a saída de Emílio Lépido do triunvirato pouco depois conduziram ao aumento da rivalidade entre Octávio e António. A partir de 34, António instala-se em Alexandria e assume-se qual monarca de tipo oriental. Na base da construção dessa nova imagem está, como é evidente, o apoio de Cleópatra. $\mathrm{O}$ casal comporta-se agora como tal, sendo que Marco António transforma as regiões orientais em reinos que distribui pela rainha lágida e seus filhos, três dos quais nascidos já da relação com o tribuno romano.

Em 32 a.C., António divorcia-se de Octávia, num processo tacitamente

${ }^{4}$ A importância de Octávia neste processo político pode averiguar-se por Plu. Ant. 35.

${ }^{5}$ Sobre esta questão, ver C. Pelling 1994: 202, e S. Treggiari 2002. As diligências legais referidas por Plu. Ant. 31.5 sugerem que tudo terá sido tratado com o maior cuidado legal. Certamente um casamento in manum, eventualmente na forma de confarreatio. Na verdade, as vicissitudes de Octávia aquando da separação de António, bem como a forma como Octávio agiu em relação à irmã, levam-nos a tratar estas questões com cautela, nomeadamente se a forma de casamento teria sido cum manu ou sine manu. Octávia começou por se recusar a abandonar a casa do marido, quando o irmão lho pediu. Vd. S. Treggiari, 2002: 468-469. 
desejado por Octávio, que ao mesmo tempo reúne argumentos para declarar guerra a Cleópatra. Mas o seu principal objectivo é, naturalmente, afastar de vez a concorrência de António ao poder em Roma. A batalha de Áccio no ano seguinte, em 31 a.C., abriu caminho para a invasão romana do Egipto, no ano seguinte, marcada pelos suicídios de António e Cleópatra.

O que nos interessa destacar neste processo, de modo a salientar os conceitos de nomos e kosmos, atem-se precisamente à relação dúbia que se estabeleceu entre o tribuno romano e a rainha do Egipto no período em que durou o casamento daquele com Octávia. Como assinalámos, as diligências tomadas aquando da união de António com a irmã de Octávio levam a crer que o matrimónio então celebrado se terá pautado pelas regras que faziam do casamento romano um consórcio legítimo, i.e., de acordo com o nomos, pois só desse modo teriam todos os seus derivados (heranças e transmissão de propriedade, descendência, e até mesmo o exercício do poder) sido igualmente legítimos (vd. Ant. 54.1). De outra forma, essa teria decerto sido uma união desacreditada e por conseguinte politicamente nula.

Já o processo de divórcio, habilmente usado por Octávio nas suas pretensões políticas, não terá sido pacífico, inclusive por mercê da resistência de Octávia a separar-se do marido (vd. Ant. 54.1) ${ }^{6}$. O facto é que a atitude de Octávio para com a irmã denuncia também o ultraje de que ela fora alvo e que foi publicamente reconhecido. O divórcio de António e Octávia terá dado, aliás, que falar entre os Romanos, como se depreende da anedota transmitida por Séneca-o-Velho nas Suasoriae. Conta-se que, precisamente porque se achava casado com Octávia ao mesmo tempo que coabitava com Cleópatra, alguém em Roma terá escrito na base de uma estátua que o representava: "Octávia e Atena para António; e leva o que é teu" (Sen. Suas. 1.6)7.

Esta nota indica que, entre os Romanos, se considerava a união de António e Cleópatra, pelo menos, ilegítima. Na mesma linha discursiva e a julgar pelas informações dadas por Plutarco, quando em 37 a.C. António voltou ao Oriente, a paixão (sintomaticamente, Plutarco usa eros) por Cleópatra, que parecia adormecida e "enfraquecida pela presença de melhores influências", reacendeuse de forma violentíssima, acabando por levar à vivência comum, marital mesmo, de ambos, à qual decerto, frisamos, não terá sido estranha uma forte motivação política (Plu. Ant. 36.1). Plutarco chega mesmo a evocar a célebre metáfora do Fedro de Platão, para descrever o que acontecera com António por

\footnotetext{
${ }^{6}$ Cf. C. Pelling 1994: 248.
}

${ }^{7}$ Trata-se de uma frase escrita em grego (Oktaouia kai Athena Antonioi) e em latim (res tuas tibi habe), correspondendo esta segunda parte à fórmula do divórcio romano. $\mathrm{O}$ cônjuge que desejava o divórcio informava o outro, oralmente, por escrito ou por um mensageiro, de que devia recolher os seus bens pessoais e abandonar o domicílio comum. Ver S. Treggiari 2002: 446-448. 
causa da rainha oriental ${ }^{8}$. Mas essa ilegitimidade, que na perspectiva romana terá sido uma anomia, não seria coincidente com o que então se vivia na cidade de Alexandria. Com efeito, muito provavelmente, na perspectiva oriental, essa mesma relação seria entendida como um casamento. Parece-nos evidente que, na perspectiva romana, não se trataria de tal. Apesar de numa carta transcrita por Suetónio na Vita diui Augusti, António parecer referir-se a Cleópatra como sua $u x o r^{9}$, o próprio Plutarco afirma que embora o romano não negasse as suas relações com a "egípcia", "não se considerava casado" (Ant. 31.3). Mas o facto é que, segundo as descrições plutarquianas, António coabitaria com Cleópatra como se fosse seu marido e as alegorias hierogâmicas que na biogria plutarquiana associam os pares divinos Dioniso/ Afrodite e Osíris/ Ísis ao casal parecem vir em abono dessa tese ${ }^{10}$. E se perspectivarmos a relação pela óptica oriental, a mesma seria muito certamente entendida como um casamento, uma vez que, no Egipto, o matrimónio não parece ter sido assinalado por qualquer tipo de cerimónia civil ou religiosa, mas antes por um mútuo consentimento entre as partes envolvidas a que se associava a coabitação ${ }^{11}$. Não excluímos, porém, a hipótese de a natureza desta relação estar próxima do que em Roma se entendia por casamento por usus, ainda que o mesmo não fosse adequado a indivíduos do estatuto social de António e Cleópatra. C. Pelling 1994: 219 chega mesmo a afirmar que "se António não fosse casado e se ambos fossem de um estatuto social inferior, até mesmo os Romanos os teriam entendido como casados" ${ }^{12}$.

Também na síncrese que avalia o par Demétrio/António, Plutarco refere que o tribuno romano estivera "casado com duas mulheres ao mesmo tempo, aquilo a que nunca antes nenhum romano se atrevera" (Ant.91(4).2). Aparentemente, o que Plutarco faz neste passo é assumir a posição orientalista da questão, porque convém ao seu objectivo (construir uma imagem negativa de António) e porque, como também afirma o mesmo Plutarco, "apesar da relação com Cleópatra, António não se considerava casado com ela” (Ant. 31.3), tal como estipulava a lei romana. E num outro passo, o biógrafo afirma que "Octávia se unira a António por questões políticas, por causa do irmão, desfrutando assim do título de esposa (to tes gametes onoma karpousthai), ao passo que Cleópatra, rainha de tantos súbditos, era chamada de amante

${ }^{8}$ Trata-se da famosa metáfora do cavalo da alma: P1. Phdr. 254a.

${ }^{9}$ Suet. Aug. 69.2: quid te mutauit? Quod reginam ineo? Vxor mea est. A interpretação do passo, porém, não é pacífica, pois algumas lições lêem uma interrogativa, uxor mea est?, o que altera o sentido do texto, e não uxor mea est. Esta fonte é portanto problemática nesta questão.

${ }^{10}$ Vd. Plu. Ant. 26; 71-85. Cf. F. E. Brenk 1992b: 159-182; N. S. Rodrigues 2002.

${ }^{11}$ P.W. Pestman 1961: 6-52. Trata-se de algo semelhante ao que em Roma se entendia por casamento por usus.

${ }^{12}$ Cf. D. C. Braund 1984: 179-180. 
de António (eromenen kaleisthai), não rejeitando tal designação ou sequer achando-a indigna" (Ant. 53.9-10). Como foi já notado, parece estar-se aqui perante a dialéctica entre a amica e a uxor, que aparece igualmente na poesia elegíaca romana, sendo que Cleópatra insinua a primeira enquanto Octávia representa a segunda ${ }^{13}$.

Como complemento, podemos citar ainda a Eneida, em que, como se tem salientado, a figura de Dido parece ter sido decalcada de Cleópatra ${ }^{14}$. É por isso sintomático que, no poema, Vergílio represente a rainha oriental como acreditando estar casada com Eneias, enquanto o herói troiano nega tal relação ${ }^{15}$. Por outro lado, e numa contradição já familiar, num passo adiante, o poeta chega ao ponto de chamar a Cleópatra Aegyptia coniunx, a "esposa egípcia" (Aen. 8.688).

Seja como for, a união de António a Cleópatra, quer pelo estatuto dos indivíduos nela implicados quer pelas características da figura feminina, em particular o facto de ser uma estrangeira, dificilmente teria sido entendida como legítima nos vários círculos sociais romanos, incluindo as elites, e, como tal, considerada algo à margem do nomos. Com a agravante de que António era uma importante figura do Estado. Terá sido precisamente esse factor a contribuir para a elaboração de um processo propagandístico, que veio a beneficiar Octávio, no qual a definição das personae non gratae se fez com base na imagem de caos político-social desencadeado pelos protagonistas do episódio, i.e., uma ausência de kosmos que radica nos actos e posições políticas de António e Cleópatra. Por esta ordem de ideias, a consequência dessa ausência de ordem ou akosmia teria sido a guerra, que desembocou em Áccio, na derrota dos da "vida inimitável” (Ant.28.2) e na conquista do Egipto. Que essa ideia dominava os espíritos coevos pode ser atestado pelo termo que Vergílio usa na écfrase do canto VIII da Eneida para se referir a Cleópatra: nefas, i.e., "sacrilégio", "abominação" ou "aquilo que é proibido por lei divina" (Aen. 8.688). Em contrapartida, quando em 30 a.C. o Egipto se transformou em província romana, foi como se a ordem ou kosmos regressasse ao mundo tal como era então percebido e, uma vez, mais graças à pax romana.

Pela forma como escreve a biografia de António, Plutarco parece manter estas ideias subentendidas. Um dos argumentos que podemos trazer à colação para o confirmar é a forma "simpática" e "positiva" com que trata a figura de Octávia, por oposição à forma "antipática” e "negativa” com que constrói o

\footnotetext{
${ }^{13}$ C. Pelling 1994: 247.

${ }^{14}$ Sobre esta problemática, ver M. H. Rocha Pereira ${ }^{3} 2002: 260$; J. Griffin 1999: 194; C. Pelling 1994: 220.

${ }^{15}$ Verg.Aen. 4.125-126,172, 338-339, em que Eneias afirma: "nunca empunhei as tochas de noivo ou cheguei a tais compromissos".
} 
carácter de Cleópatra VII ${ }^{16}$. A própria tragédia de António, que se desenvolve ao longo desta biografia, parece ser fortemente determinada por essa mesma ausência de ordem, de que Cleópatra é uma das principais causas ${ }^{17}$.

Tal akosmia é reevocada de forma exemplar no final da $V i t a$, num passo que contrasta precisamente com aquele que introduz a rainha e que citámos no início deste estudo como uma dos poucos casos em que, no contexto em causa, Plutarco usa o termo kosmos (Ant. 25.6). Trata-se do parágrafo 83, no qual se conta que, após a morte de António, Octávio visitou Cleópatra com intenção de a consolar. Como em quase toda esta biografia, a narrativa é uma vez mais teatral, intensamente dramática. Diz Plutarco que o general romano a encontrou "deitada no chão e que ele, ao vê-lo, correu para ela, usando apenas uma túnica, lançando-se-lhe aos pés, com a cabeça e o rosto terrivelmente desalinhados" (Ant. 83.1). Estamos perante uma metáfora do caos que tomara conta do destino da última rainha do Egipto e que contrasta na perfeição com o kosmos que a caracteriza aquando da sua entrada em cena.

\footnotetext{
${ }^{16}$ Cf. C. Pelling 1994: 219.

${ }^{17}$ Sobre António como figura intensamente dramática, ver F. E. BREn K 1992ª 4347-4469.
} 


\section{Bibliografia}

Bailly, A., Dictionnaire Grec-Français, Paris, 1950.

Braund, D. C., Rome and the Friendly King: the Character of Client Kingship, London, 1984.

Brenk, F. E., "Plutarch's Life "Markos Antonios": a Literary and Cultural Study", $A N R W$ II.33.6, 1992a: 4347-4469.

Brenk, F. E., "Antony-Osiris, Cleopatra-Isis: the End of Plutarch's Antony", in P. A. Stadter (ed.), Plutarch and the Historical Tradition, London-New York, 1992b: 159-182.

Griffin, J., Latin Poets and Roman Life, London, 1999.

LeÃo, D. F., Plutarco, Vida de Sólon, Lisboa, 1999.

Pelling, C. B. R., Plutarch, Life of Antony, Cambridge, 1994.

Pestman, P. W., Marriage and Matrimonial Property in Ancient Egypt: a Contribution to establishing the Legal position of the woman, Leiden, 1961.

Rocha Pereira, M. H., Estudos de História da Cultura Clássica II - Cultura Romana, Lisboa, ${ }^{3} 2002$.

Rodrigues, N. S., "Plutarco, historiador dos Lágidas: o caso de Cleópatra VII Filopator", in J. Ribeiro Ferreira (coord.), Actas do Congresso "Plutarco educador da Europa», Porto, 2002: 127-149.

Treggiari, S., Roman Marriage. "Iusti Coniuges» from the time of Cicero to the time of Ulpian, Oxford, 2002. 
(Página deixada propositadamente em branco) 


\title{
The Daimon in Timarchus' cosmic vision (Plu. De Gen. Socr. 22, 590B-592E)
}

\author{
Aldo Setaioli \\ Università di Perugia
}

\begin{abstract}
In the Timarchus myth in Plutarch's De genio Socratis, the daimon is conceived as the highest part of the human soul, currently referred to as "intellect" (voũc) and wrongly believed to be internal. By contrast, in the two speeches preceding and following the myth (by Simmias and Theanor, respectively), the daimon is a superior entity assisting each man in multiple ways. This is Plutarch's way to harmonize Plato's different pronouncements concerning the personal daimon - an attempt anticipating later developments found in Plotinus.
\end{abstract}

One of the most controversial of Plutarch's Moral Essays is the one

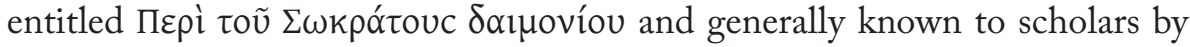
the Latinized title De genio Socratis. This is a dialogue set at the time of the overthrow of the Spartan-backed oligarchic government of Thebes in 379 BC by a conspiracy involving the return of some Theban exiles and the killing of the oligarchs. Several of the characters introduced by Plutarch are Thebans taking an active part in the conspiracy, though Epameinondas, who figures prominently in the dialogue, refuses to shed the blood of fellow-citizens, in spite of his patriotic and anti-Spartan leanings.

One of the speakers in the dialogue is Simmias, one of Socrates' pupils, whom we know from Plato's Phaidon; another is Theanor, a Pythagorean adept who has come from southern Italy to bring back the remains of Lysis, another Pythagorean, who had died at Thebes. At one point in the dialogue the issue of the nature of Socrates' guiding daimon is brought up, and different views are presented by three speakers: Galaxidorus, Simmias, and Theanor; the two latter characters do not limit themselves to the specific problem, but offer general doctrines concerning daimones, with particular emphasis on those that accompany each man as personal guardians.

The question of how the two parts of the dialogue, namely the historical and the doctrinal aspects, relate to each other has been the object of a great deal of controversy. It is not our purpose to tackle this problem at this time; it will suffice to remark that the prevailing trend in scholarship seems to favor the dialogue's unity by pointing out several links connecting the two parts, and to refer to the essays by Babut and Barigazzi, which provide a detailed survey of this long-standing discussion. ${ }^{1}$

\footnotetext{
${ }^{1}$ D. Babut 1984; A. Barigazzi 1988, now collected in A. Barigazzi 1994: 213-234. The
} 
The most striking section of the part devoted to the nature and essence of daimones, and in particular to each man's personal daimon, is the Timarchus myth $(22,590 \mathrm{~B}-592 \mathrm{E})$, related by Simmias, concerning the former's descent into Trophonius' grotto at Lebadeia and the vision he experienced while there. This is preceded, in an earlier section of the dialogue, by Galaxidorus' rationalistic attempt to reduce Socrates' daimon to commonplace divination, such as the omens one could draw from sneezes or various fortuitous occurrences, although he does not expressly deny the existence of daimones $(12,581 \mathrm{~F}-582 \mathrm{C})$. The myth comes immediately after a speech by Simmias, in which the latter expresses his own opinion about Socrates' daimon and on daimones assisting humans $(20,588 \mathrm{C}-589 \mathrm{~F})$. It is only at the insistence of one of the other speakers, the soothsayer Theocritus, that Simmias goes on to relate Timarchus' myth $(21,589 \mathrm{~F}-590 \mathrm{~B})$. The myth is then followed by a speech by Theanor (24, 593A-594A), in which this Pythagorean character adds his own point of view concerning the daimones which assist men during their lives.

Some of the most interesting ideas on the subject are found, in my opinion, in the myth of Timarchus. Though he had gone down into Trophonius' grotto to inquire about Socrates' daimon, the revelation he receives concerns daimones in general. It should be noticed, in the first place, that Timarchus experiences his vision through his soul ( $\psi \cup x \eta$ - but we shall come back to the ambiguity of this term) in a state of separation from the body $(22,590 \mathrm{~B}$ : $\delta o ́ \xi \alpha l ~ \gamma \varepsilon \tau \tilde{\eta} c k \varepsilon \varphi \alpha \lambda \tilde{\eta} c$

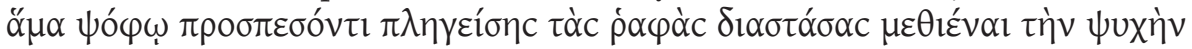
$\kappa \tau \lambda$.), pretty much like Thespesius in the De sera numinis vindicta $(23,563 \mathrm{E})$.

At first he experiences a vision of the cosmos, in which the celestial bodies appear to him as colorful islands in an equally colorful sea. Plutarch adds many astronomical details, for whose explanation we may refer to Hani's edition and to other scholars who have studied this part of the myth. ${ }^{2}$

The section that most closely interests us begins at the moment Timarchus turns down his gaze to a huge circular gulf, "like a sphere cut in

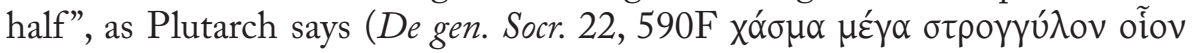

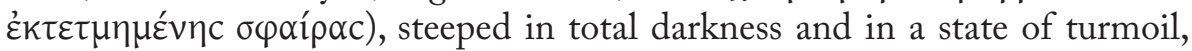
from which rose cries of animals, babies, men, and women. According to $\mathrm{Hani}^{3}$ this sphere cut in half represents the earth's lower hemisphere, on which the hereafter was located according to some widespread conceptions. ${ }^{4}$ But,

Belles Lettres editor of the dialogue, J. Hani 1980: 60-62, also favors the dialogue's unity.

2 J. Hani 1980: 226-228. See also A. PÉrez Jiménez 1996, with the bibliography quoted and discussed. For the Timarchus myth in general see e.g. W. Hamilton 1934; G. MÉautis 1950; J. Hani 1975 (mainly about the shamanistic elements in the myth); R. M. Aguilar 1996; I. GALLO 2001.

${ }^{3}$ J.Hani 1980: 228. According to G. MÉautis 1950: 208 the sphere cut in half is the earth itself.

${ }^{4}$ Cf. e.g. F. Cumont 1942: 35-103. 
as Cumont already remarked, ${ }^{5}$ the earth, or its lower hemisphere, would not appear as a hollow gulf to anyone looking at it from above, but rather as a convex bulge. In my opinion, this sphere cut in half is the lower celestial, rather than the lower terrestrial, hemisphere. The stars of the southern sky shine over the abode of the dead in some famous Virgilian lines too (G. 1.242-243): bic vertex nobis semper sublimis, at illum/ sub pedibus Styx atra videt Manesque profundi ("the celestial pole of our hemisphere is always overhead, but the one below is visible to black Styx and the spirits of the deep"). I will not try to solve, for lack of time, the problem of whether the cries rising up from the dark gulf are those of souls who have been forced to reincarnate in our world as people or beasts, or come from the abode of the dead. In particular, are the cries of babies Timarchus hears those of newly born infants or of children who died before their time, like Virgil's untimely dead, the äw $\omega$ por of the sixth book of the Aeneid (6.426-429)? ${ }^{6}$ Plutarch may well have fused the conception of Hades as the earth's lower hemisphere with another widespread eschatological idea identifying our life on earth as the real Hades, so that the earth's lower hemisphere (placed under the stars of the southern sky) could be regarded in turn both as the abode of the dead after life on earth and, symbolically, as the very location of our terrestrial life.

Be that as it may, the part concerning the fate of the souls and the conception of the daimones, holding the greatest interest for us, begins at this point. Now, also, a new character enters the scene: Timarchus' mysterious, invisible guide, who will instruct him without ever being perceived by his

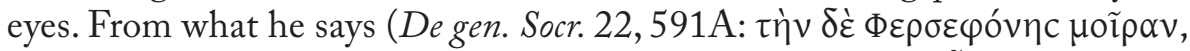

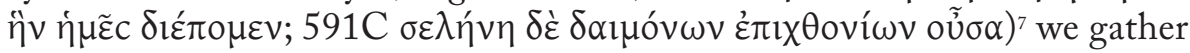

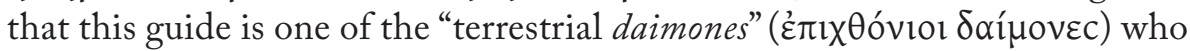
dwell on the moon. His explanations still concern, at first, cosmic details, such as the four principles (life, movement, generation process, decay) dividing the cosmos into three zones, each presided over by one of the three Fates. ${ }^{8}$ But now the cosmological picture is closely connected with the fate of the human soul and the doctrine concerning the daimon.

${ }^{5}$ F. Cumont 1942: 56 n. 2.

${ }^{6}$ F. Cumont 1949: 315 thinks that both in Virgil and in Plutarch the crying babies have died before their time. G. MÉAutis 1950, followed by J. Hani 1980: 229, believes these are newly born babies; according to F. E. BRENK 1987: 287 "these are souls returning from life on earth".

${ }^{7}$ The guide cannot reach the regions higher than the moon (591A). Cf. G. MÉAutis 1950: 207. The moon is, in fact, the realm of Persephone: cf. Plu. De fac. lun 28, 943B; 29, 944C. The

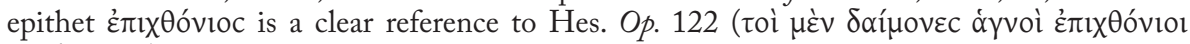
$\tau \varepsilon \lambda \varepsilon^{\prime} \theta$ ov

${ }^{8}$ Plu. De gen. Socr. 22, 591B. Cf. De fac. Iun 30, 945C-D, where the three Fates are differently arranged. They come of course from Plat. R. $617 \mathrm{c}-\mathrm{d}$. 
Timarchus sees some stars jerking in sharp motions around the huge circular gulf, while other stars plunge into it and still other come darting up from it. ${ }^{9}$ These stars are human souls, or, as Timarchus' guide puts it, daimones, and come straight from the closing of the myth of Er, in Plato's Republic, as confirmed by the

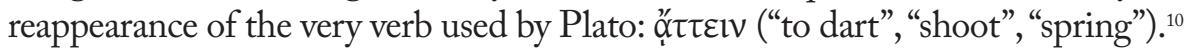

As hinted, the guide explains that these stars are really daimones; but, as we shall see, both this word and the term "soul" $(\psi v x \eta ́)$ are anything but unambiguous. Here are his words: "Every soul partakes of intelligence (voũc) and there is none devoid of reason and intelligence; but what of it gets mixed with flesh and passion undergoes a change and tends to foolishness, as it is affected by pleasure and pain. Not all souls, however, get mixed the same way. Some plunge totally into the body and, falling completely prey to derangement, remain perturbed during their whole life; others get mixed only partially, while partially leaving out their purest element. This is not tugged down with the rest, but floats at the surface, as it were, in connection with the man's head, like a buoy indicating a diver who plunged into the deep; and the soul is kept upright around this emerging part, as far as it obeys reason and is not dominated by passion. The part immersed in the body is called 'soul' ( $\psi v \times \eta$ '), while the part free from corruption is called intellect (voũc) by the mass, and believed to be inside themselves, just as they think what appears as reflection in mirrors to be inside the mirrors themselves; but those who reason correctly call it daimon, as it is outside themselves". ${ }^{11}$

As recognized by several scholars, ${ }^{12}$ the conception of the daimon appearing here must be read in the light of a famous passage of Plato's Timaeus, which states that the highest part or faculty of the human soul has been given by god to each man as a daimon, ${ }^{13}$ whereas elsewhere in Plato the daimon is an external

\footnotetext{
${ }^{9}$ For the movements of the souls cf. Plu. De sera num. vind. 23, 563F-564A.
}

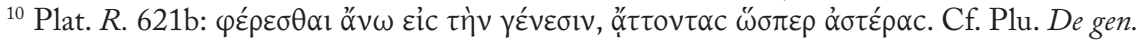

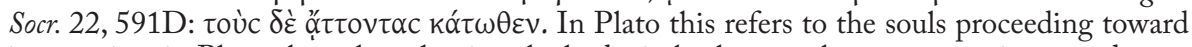
incarnation, in Plutarch to those leaving the body; in both cases the movement is upwards.

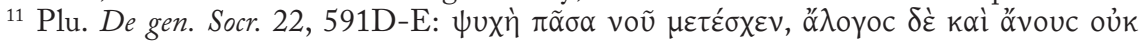

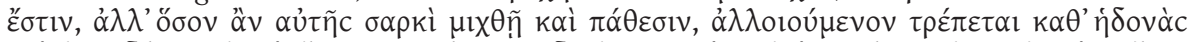

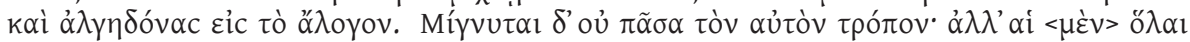

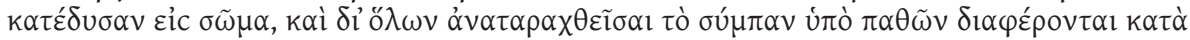

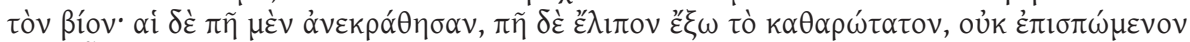

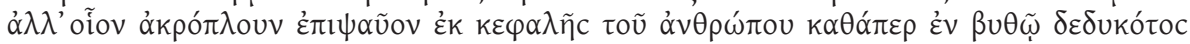

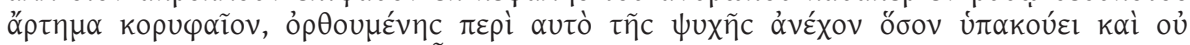

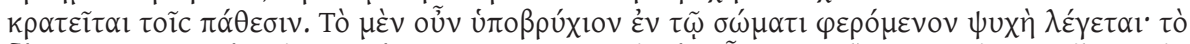

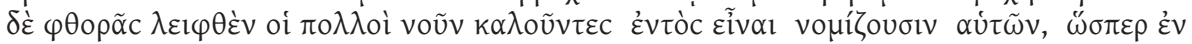

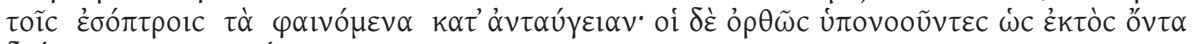

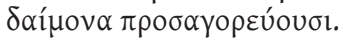

${ }^{12}$ Cf. e.g. W. Hamilton 1934: 181; G. Soury 1942: 160; Y. Vernière 1977 : 128.

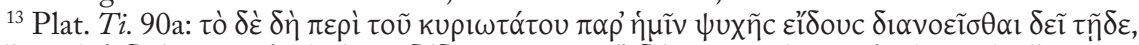

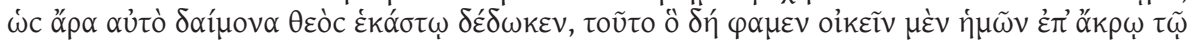

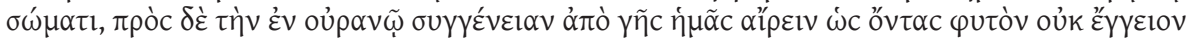


guardian assisting every man, as in the Phaidon (107d; 113d) and the Republic (617d-e; 620d-e), or an entity intermediate between the human and the divine, or the sensible and the intelligible, as in the Banquet (202d-e). The influence of this Timaeus passage is made certain not merely by the conception of the daimon as the highest part or faculty of the soul, but also by the recurrence of such details as the connection of this daimon with the human head and the upright position it ensures. There surely are, in Plutarch's text, echoes from other Platonic dialogues, such as the term úroßpíxiov ("submerged"), which comes from the myth of the Phaedrus 248a (where it is referred to the souls unable to rise high enough to contemplate the intelligible ideas), just like the horsemanship metaphors following upon the passage we have just quoted (Plu. De gen. Socr. 22, 592A-C; cf. Plat. Phdr. 246a-248b); and the pairing of the incarnate soul with an underwater diver is probably borrowed from the Phaidon (109b-e). There is no doubt, however, that the main influence here comes from the Timaeus. We should not miss, at any rate, the main difference between Plato and Plutarch. The daimon identified with the highest part or faculty of the human soul is clearly internal in the Timaeus, but is explicitly said to be external in the De genio Socratis: "those who reason correctly call it daimon, as it is outside themselves".

This is not the time and place to tackle the intricate problem of Plutarch's demonology. We may refer to the comprehensive study by Guy Soury and the more recent essays by father Brenk ${ }^{14}$. It should be noticed, however, that, in the description following the passage we have quoted, this daimon is explicitly called each man's "personal daimon" (oỉkeĩoc $\delta \alpha i ́ \mu \omega v: 22,592 \mathrm{C}$ ) and its action is described, as already hinted, in a way reminiscent of Plato's chariot of the soul in the myth of the Phaedrus, with reason as the charioteer.

Even in the Timarchus myth, however, the daimon identical with the part of the soul that is not sunk in the body is not the only type of daimon. We have seen that Timarchus' mysterious guide is one of the "terrestrial daimones"

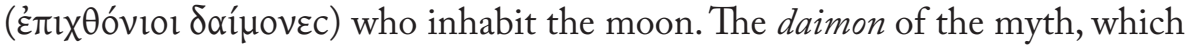
is the purest part of the human soul, but is nevertheless external, should be compared, then, with the other views of the daimones we find in the dialogue.

As already hinted, Galaxidorus gives a rationalistic interpretation of Socrates' daimon. Later on Simmias' speech preceding the myth develops the interesting idea that daimones communicate through an intelligible discourse

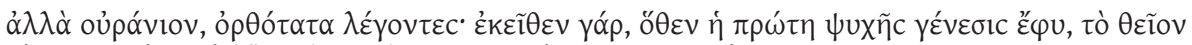

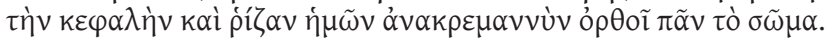

${ }_{14}^{14}$ G. Soury 1942; F. E. Brenk 1973-1974; F. E. Brenk 1977: 49-183; F. E. Brenk 1986: 2117-2130; F. E. Brenk 1987: 275-294. For Plutarch's demonology see also F. Andres 1918: 301-305; C.Zintzen 1976: 644-647; Y. Vernière 1989; C. Santaniello 1996; F. Casadesús Bordoy 2001. 
dispensing with words. The voũc of a higher daimon can thus influence our voũc, which, according to the myth, is our own daimon. ${ }^{15}$ Finally, Theanor describes daimones assisting humans, who are souls who have left the body and are free from reincarnation. ${ }^{16}$ The designation of oikeĩoc $\delta \alpha i ́ \mu \omega v$, or "personal daimon", is employed in reference to these daimones too (24,594A). They seem to be identical with the "terrestrial daimones" inhabiting the moon, ${ }^{17}$ one of which serves as Timarchus' guide. According to father Brenk the conception of the daimon as a disembodied human soul actually reflects Plutarch's genuine opinion, though Cleombrotus, one of the speakers in the De defectu oraculorum, presents his own elaborate, and in many ways different, demonology $(10,414 \mathrm{~F}$; 16, 419A; 21, 420F-421E).

D.BABUt 1983 believes that there is no contradiction in the demonological doctrine of the De genio Socratis. According to him, Galaxidorus' rationalism clears the ground from popular superstitions, and Simmias' and Theanor's speeches can easily be reconciled; as for the difference between the daimon as voũc in the myth and the daimones distinct from the human soul in the speeches preceding and following it, Babut believes it to be Plutarch's way to reconcile Plato's different doctrines, as expressed in the Timaeus, with the daimon as the highest part or faculty of the soul, and in the Phaidon and the Republic, where the daimon is external. I regard this as correct, ${ }^{18}$ but it hardly eliminates the contradiction, which is merely carried over from Plato to Plutarch, although Babut's position has been endorsed by father Brenk. ${ }^{19}$ Recently, an attempt to reconcile the two different elements has been made by J. Boulogne 2010: 77-78, who sees in the joint action of the two daimones of Simmias' speech and the Timarchus myth an "immanent transcendence" and a "transcendent immanence" in the apprehension of thought. It remains, however, that a voũc influenced by a higher voũc is not identical with it; nor is the human voũc the same as the disembodied soul assisting each man in Theanor's speech, although both are referred to as oikeĩoc $\delta \alpha i ́ \mu \omega v$, "personal

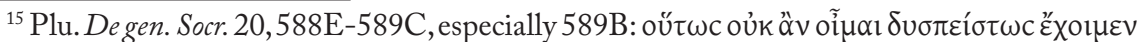

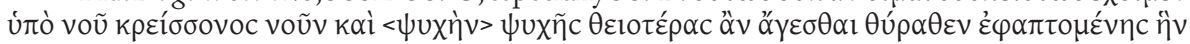

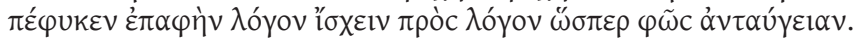

${ }_{16}$ Plu. De gen. Socr. 24, 593D-594A. Cf. 16, 585F-586A, where Theanor says that Lysis has reincarnated and has been entrusted to another daimon, while his former daimon now assists Epameinondas (cf. Pl. Phd. 113d).

${ }^{17}$ As remarked by J. Hani 1980: 229. Cf. the myth of the De facie in orbe lunae, where the Saínovec inhabiting the moon are the souls of the dead (e.g. 30, 944C).

${ }^{18}$ That the conception of the voṽc/ $\delta \alpha i ́ \mu \omega v$ does not rule out the existence of other daimones guarding and protecting humans is emphasized, e.g., by W. Hamilton 1934, 180 n. 1; A. Corlu 1970, 59.

${ }^{19}$ F. E. Brenk 1987: 290-291. F. E. Brenk 1986: 2126 finds it "somewhat surprising to find the nous or daimon external in Plutarch". In my opinion, it is only Plutarch's way to try to reconcile Plato's different doctrines. As we shall see, Plotinus' solution is different. 
daimon". ${ }^{20}$ What Plutarch very probably intended was to present to the reader a gamut of several conceptions concerning the daimon.

Several scholars ${ }^{21}$ believe that the doctrine of the Timarchus myth should be understood in the light of Plutarch's tripartition of man into body, soul, and mind or intellect ( $\sigma \tilde{\omega} \mu \alpha, \psi v x \eta ́, v o \tilde{c})$ ), whose most consistent and developed formulation is found in the De facie in orbe lunae $(28,943 \mathrm{~A}-30,945 \mathrm{E})$. Quite possibly, this idea too was suggested by Plato's Timaeus, ${ }^{22}$ just like the identification of the voũc and the daimon.

It cannot be denied that in the Timarchus myth the soul (or $\psi v x \eta$ ), totally sunk in the body, is clearly distinguished from the voũc, that remains ouside. It must be stressed, however, that, although von Arnim's idea, according to which the distinction between voũc and $\psi v x \eta ́$ begins only at the moment of incarnation, ${ }^{23}$ cannot be accepted, Plutarch's terminology is anything but consistent. In the very passage of the Timarchus myth we have quoted and discussed, as well as in other passages, and also in the myth of the De facie in orbe lunae, the term $\psi v x \eta$ is sometimes referred to the lower part of the human soul, totally sunk in the body, while elsewhere it designates the whole of the human spirit, comprehensive of both the $\psi \cup x \eta$ proper and the higher voṽc undefiled by material contact. We remember reading that "what of the soul gets mixed with flesh and passion" becomes irrational and that some souls "get mixed only partially, while partially leaving out their purest element". ${ }^{24}$ The ambiguity of the term $\psi v x \eta$ has been stressed by several scholars; ${ }^{25}$ but it should be added that the same applies to the term $\delta \alpha i ́ \mu \omega v$, which, in the myth of the De facie in orbe lunae (e.g. 30-31, 944C) sometimes refers to $\psi u x \eta ́$ and voũc while still united, while in the same context the same two unseparated elements are repeatedly referred to as $\psi v x \eta$. And in the Timarchus myth itself, when the daimones of men who are said to possess voũc are described, Plutarch seems to have forgotten the identification of voũc and $\delta \alpha i ́ \mu \omega v$ he has established only a few lines before. ${ }^{26}$

${ }^{20}$ Cf. above, p. 114 ..

${ }^{21}$ Cf. e.g. W. Hamilton 1934: 180; Y. Vernière 1977: 127; J. Hani 1980: 230.

${ }^{22}$ Cf. e.g. Y. Vernière 1977: 128 and notes 3-4 (referring to Pl. Ti. 30b, 69c and 70a); J. HANi 1980: 57 and 230 (referring to P1. Ti. 30b, 31a, 70a).

${ }^{23}$ H. Von Arnim 1921: 31.

${ }^{24}$ Cf. above, p. 112. In the same way, at Plu. De sera num. vind. 24, 564C, Thespesius, who has left the body with the rational part, has left "the rest of the soul" in it.

${ }^{25}$ Cf. e.g. W. Hamilton 1934: 180; G. Soury 1942: 157-158; Y. Vernière 1977: 127.

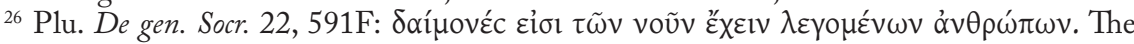
terminological imprecision is pointed out by J. Hani 1980: 230 too. Possibly, however, Plutarch may once more be stressing the incorrectness of the current terminology: these daimones

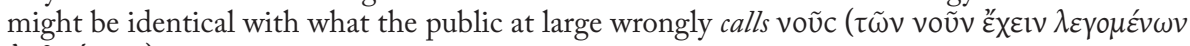

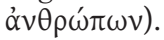


Be this as it may, the conception of the daimon appearing in the Timarchus myth undoubtedly poses some serious difficulties to those who wish to establish the consistency of the demonology put forward by Plutarch in the De genio Socratis. Nevertheless, it is indeed a most stimulating approach to the question. This is confirmed by the development it underwent in Plotinus, who harmonized it with the daimon communicating through intelligible, wordless discourse, which appears shortly before in Plutarch, in Simmias' speech.

In Plutarch, we should remember, both daimones, even the one people

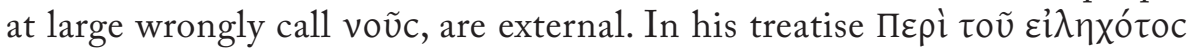

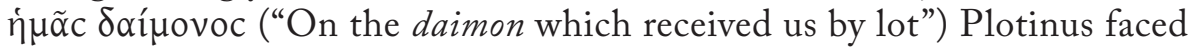
the same problem as Plutarch: reconciling Plato's different statements concerning the personal daimon. Both in the title and in the text he employs the same terminology as the Phaidon, according to which the daimon has received us by lot. ${ }^{27}$ Immediately after, however, he states that the correct conception is the one found in the Republic: we choose our daimon ourselves..$^{28}$ This is because Plotinus identifies the daimon with the psychic faculty immediately superior to the one prevailing in each man, so that, by choosing a type of life, we place ourselves at a definite level, and by doing so we also choose a daimon. Plotinus is of course influenced by the same passage of Plato's Timaeus, which influenced Plutarch, and actually quotes it (Plot. 3.4.5, 19-23; cf. Plat. Tim. 90a); but his conception is more articulated than Plato's; according to him the daimon is not identical with the soul's highest part or faculty, but with the one immediately superior to that which prevails at any given moment; this in turn supposes ever higher daimones, until man has reached the state of perfection (Plot. 3.4.3, 14-21)..$^{29}$

We remember Simmias' higher daimon, communicating through wordless discourse - an idea itself strongly reminiscent of the doctrine of knowledge by

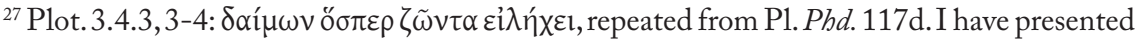
a fuller discussion of the development Plutarch's text receives in Plotinus in a lecture presented on May 6, 2011 at the conference Plato Latinus, which was held at the Palazzo Feltrinelli in Gargnano, on lake Garda, with the title "La citazione di Plotino in Servio, ad Aen. 9.182". This is due to appear in the proceedings of the aforementioned conference and contains full quotations and discussion of the relevant passages.

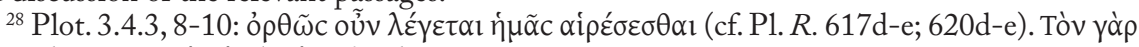

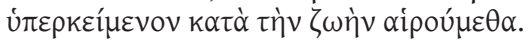

${ }_{29}$ That this is indeed the way Plutarch's text was understood in later times is proved by a commentary to Aristotle's Nicomachean Ethics, which was pointed out to me through the courtesy of Francesco Becchi: Eustratii et Michaelis et Anonyma in Ethica Nicomachea Commentaria,

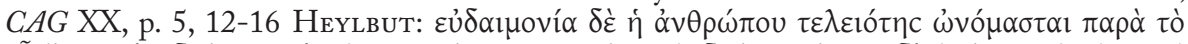

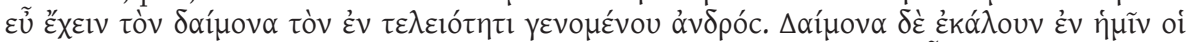

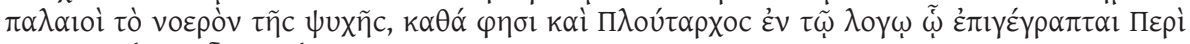

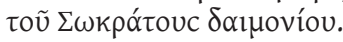


contact, elsewhere developed by Plotinus (5.3.7, 25-28; 6.6.8, 12-14; 6.8.18, 4-7)..$^{30}$ Like Plutarch, Plotinus managed to bring together Plato's different statements about the personal daimon; but whereas Plutarch regards both the daimon identified with the voũc and the one assisting each man as external, Plotinus has connected the one and the other with the human soul and has placed both of them inside the human being.

\footnotetext{
${ }^{30}$ Cf. J. Hani 1980: 225.
} 


\section{Works cited}

Aguilar, R. M, "Elementos religiosos en los mitos de Plutarco", in I. Gallo (ed.), Plutarco e la religione. Atti del VI Convegno plutarcheo (Ravello, 29-31 maggio 1995), Napoli 1996: 285-295

Andres, F., “Daimon”, $R E$ Suppl.b. III, 1918: 267-332

Von Arnim, H., Plutarch über Dämonen und Mantik, Verhand. d. kon. Akad. v. Wetensch. te Amsterdam, Afd. Letterk., N.R. 22, 1921.

Babut, D., "La doctrine démonologique dans le De genio Socratis: cohérence et fonction”, L'Information Littéraire 35, 5, 1983: 201-205.

Babut, D., "Le dialogue de Plutarque Sur le démon de Socrate. Essai d'interprétation", $B A G B$ 1, 1984: 51-76.

Barigazzi, A., "Una nuova interpretazione del De genio Socratis", ICS 13.2, 1988: 409-425.

Barigazzi, A., Studi su Plutarco, Firenze, 1994.

Boulogne, J., "Les fonctions cognitives de la démonologie de Plutarque", in Van Der Stockt, L.; Titchener, F.; Ingekamp, H. G.; Pérez Jiménez, A. (edd.), Gods, Daimones, Myths and History of Religions in Plutarch's Works. Studies Devoted to Professor Frederick E. Brenk, Logan, Utah 2010: 65-84.

Brenk, F.E., “A Most Strange Doctrine'. Daimon in Plutarch”, CJ69,1973-1974:1-11.

Brenk, F. E., In Mist Apparelled. Religious Themes in Plutarch's Moralia and Lives, Leiden, 1977.

Brenk, F. E, "In the Light of the Moon: Demonology in the Early Imperial Period”, $A N R W$ II 16.3, 1986: 2068-2145.

Brenk, F.E., "An Imperial Heritage: The Religious Spirit of Plutarch of Chaironeia”, $A N R W$ II 36.1, 1987: 248-349.

Casadesús Bordoy, F., "La concepción plutarquea de los daimones", in Pérez Jiménez, A.; Casadesús Bordoy, F. (edd.), Estudios sobre Plutarco. Misticismo y religiones mistéricas en la obra de Plutarco. Actas del VII Simposio español sobre Plutarco (Palma de Mallorca, 2-4 de noviembre de 2000), Madrid-Málaga, 2001: 23-34.

Corlu, A., Plutarque. Le démon de Socrate, Paris, 1970.

Cumont, F., Recherches sur le symbolisme funéraire des Romains, Paris, 1942.

Cumont, F., Lux perpetua, Paris, 1949.

Gallo, I., "Il motivo filosofico-religioso nel De genio Socratis di Plutarco", in Pérez Jiménez, A.; Casadesús Bordoy, F. (edd.), Estudios sobre Plutarco. Misticismo y religiones mistéricas en la obra de Plutarco. Actas 
del VII Simposio español sobre Plutarco (Palma de Mallorca, 2-4 de noviembre de 2000), Madrid-Málaga, 2001: 107-110

Hamilton, W., “The Myth in Plutarch's De genio”, CQ 28, 1934: 175-182.

Hani, J., "Le mythe de Timarque chez Plutarque et la structure de l'extase", REG 88, 1975: 105-120.

Hani, J., Plutarque. Euvres morales (Du destin - Le démon de Socrate - De l'exil - Consolation à sa femme), Paris, 1980.

MÉautis, G., "Le mythe de Timarque”, REA 52, 1950: 201-211.

Pérez Jiménez, A., "Elementi astrali nei miti di Plutarco", in I. Gallo (ed.), Plutarco e la religione. Atti del VI Convegno plutarcheo (Ravello, 29-31 maggio 1995), Napoli, 1996: 297-309.

Santaniello, C., "Aspetti della demonologia plutarchea: tra il De defectu oraculorum e altri scritti del Corpus", in I. Gallo (ed.), Plutarco e la religione. Atti del VI Convegno plutarcheo (Ravello, 29-31 maggio 1995), Napoli, 1996: 357-371.

Soury, G., La démonologie de Plutarque. Essai sur les idées religieuses d'un platonicien éclectique, Paris, 1942.

Vernière, Y., Symboles et mythes dans la pensée de Plutarque. Essai d'interprétation philosophique et religieuse des Moralia, Paris, 1977.

Vernière, Y., "Nature et fonction des démons chez Plutarque", in Ries, J.; Limet, H. (edd.), Homo Religiosus 14. Anges et démons. Actes du colloque de Liège et de Louvain-la-Neuve, 25-26 novembre 1987, Louvain-laNeuve 1989: 241-252

Zintzen, C., "Geister (Dämonen). c. Hellenistische und kaiserzeitliche Philosophie”, RAC 9, 1976: 640-668. 
(Página deixada propositadamente em branco) 


\title{
Un nomos atopos? Gli Efori e i bafFi degli Spartani. Nota ESEGETICA A DE SERA NUM. VIND. 4.550B
}

Stefano Amendola

Università di Salerno

\begin{abstract}
At De sera num. vind. 550B, among the examples of atypical laws, Plutarch cites the ban issued by the Spartan Ephors to let the whiskers grow. Witness of this prescription is Aristotle (fr. 539 Rose), specifically mentioned by Plutarch at Cleom. 9.3, where the latter again refers to the odd Spartan law: the text of the biography, however, shows how the same nomos, held as atopos in the aforementioned passage of the treatise, has indeed a precise motivation for Plutarch. Here we propose to discuss some of the ecdotic and exegetic doubts raised by a comparison between the two texts, and further consider the third witness of the Aristotelian quote, Plu. fr. 90 Sandbach.
\end{abstract}

Nel quarto capitolo del De sera numinis vindicta (549D-550C) Plutarco dà inizio al suo primo discorso: l'intervento del Cheronese è presentato come necessario ad evitare che ulteriori dubbi, posti dagli altri protagonisti del dialogo, rafforzino a tal punto le critiche mosse dall'anonimo epicureo contro la provvidenza divina da renderne impossibile la confutazione (549E). Lintero capitolo appare incentrato sulla polarità umano/ divino: in particolare, il Cheronese sembrerebbe proporre una sorta di paragone tra alcune technai umane e quella che Plutarco chiama $\pi \alpha \sigma \tilde{\omega} v$

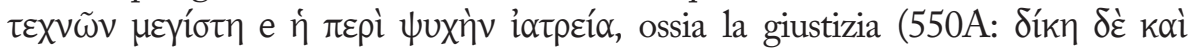

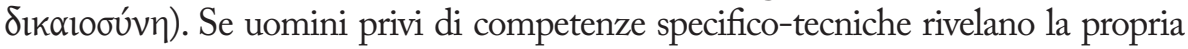
ignoranza intervenendo in campi 'propriamente umani', quali musica, strategia bellica e medicina, un mortale, proprio in quanto mortale, non può comprendere l'operato della divinità, i tempi e i modi con i quali castiga i malvagi, essendo sprovvisto di

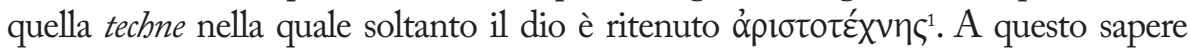
divino è stato invece educato Minosse, figlio e allievo di Zeus: relativamente alla figura del re cretese Plutarco rimanda a Platone' , il quale a sua volta recupera dai poeti epici (Omero ed Esiodo) un'immagine totalmente positiva del sovrano, ben lontana da quella violenta e barbarica offerta dai tragici. Il Cheronese fa riferimento a $\mathrm{Pl}$. $L g$. 614a-b e, in particolare, a [Pl.] Min. 318e-319f: in quest'ultimo dialogo, a partire

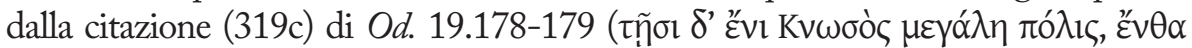

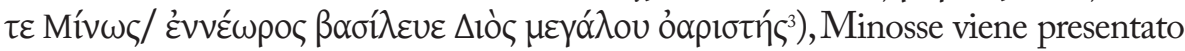

\footnotetext{
${ }^{1}$ Su valore e funzione del termine cf. F. Frazier: 219 in questo stesso volume.

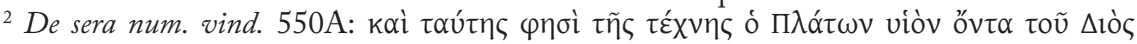

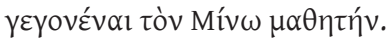

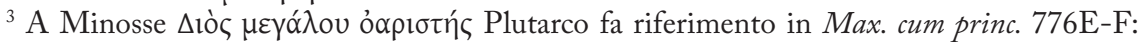

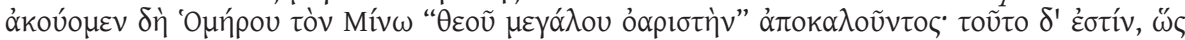

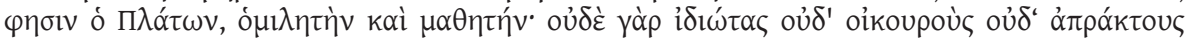


come sovrano in costante contatto con la divinità, educato direttamente dal padre

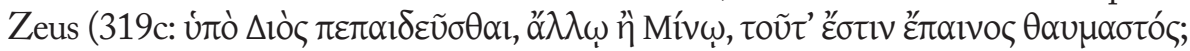

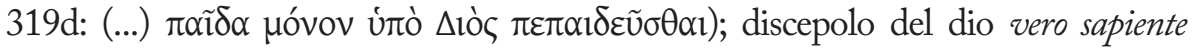

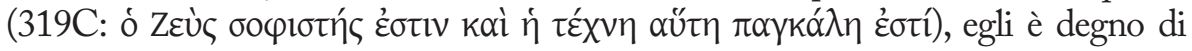
essere rappresentato nella Nekyia odissiaca $(O d .11 .568-571)$ quale giudice infernale

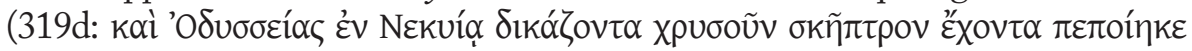
tòv Mív $\omega v)$. In netto contrasto con la citata figura di Minosse, esempio di regnante e legislatore semidivino ${ }^{4}$, Plutarco torna ad evidenziare l'aporia dei mortali che, non solo non sono capaci di comprendere le forme della giustizia divina, ma ignorano anche la ragione di alcune leggi umane, che finiscono per apparire strane e finanche

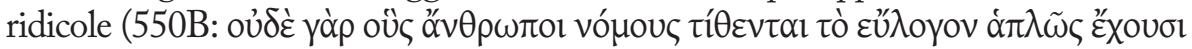

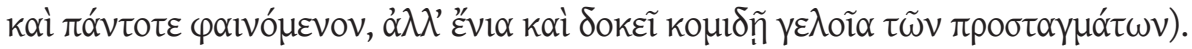
Plutarco avvalora questa affermazione con alcuni esempi storici relativi a leggi, usanze e prescrizioni, vigenti rispettivamente a Sparta (il divieto posto dagli efori di farsi crescere i baffi), a Roma (la manumissio vindicta e il testamentum per aes et libram) e ad Atene (la condanna prevista da Solone per chi, in una guerra civile, non

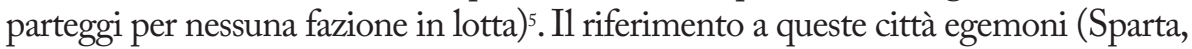
Roma e Atene) sembra assegnare un valore certo e universale a quanto affermato dal Cheronese, il quale al termine del capitolo riafferma, in una sorta di ringkomposition, come la stranezza (atopia) ${ }^{6}$ di tali provvedimenti sia soltanto apparente, da imputarsi interamente all'incapacità umana di cogliere le reali motivazioni dei legislatori.

\section{Arist. fr. 539 Rose: tre testimonianze plutarchee}

Tornando ai tre provvedimenti citati, appare evidente come Plutarco non li giudichi in realtà dei nomoi alogoi e/ a atopoi. Si consideri il primo $\pi \rho o ́ \sigma \tau \alpha \gamma \mu \alpha$, ossia il divieto emanato degli efori sui baffi, menzionato nel De sera e in altri due luoghi dell'opus plutarcheo:

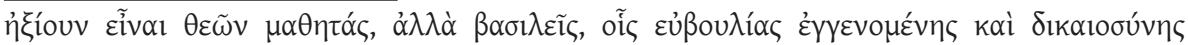

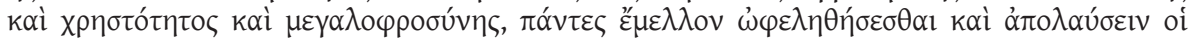

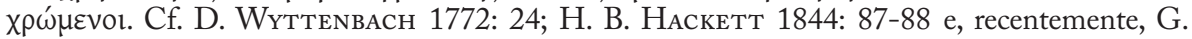
Ros Kam 2009: 91-93.

${ }^{4} \mathrm{Su}$ Minosse e altre figure di sovrani/ legislatori ispirati dalla divinità cf. Plu. Num. 4.11:

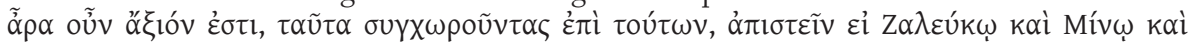

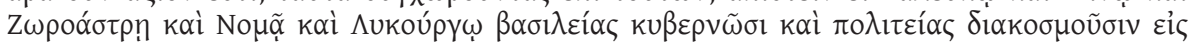

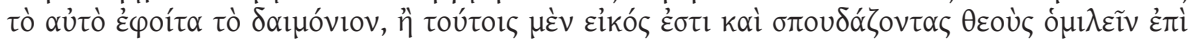

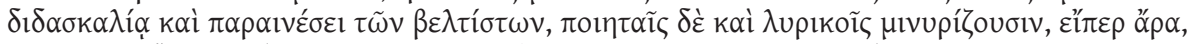

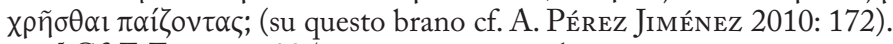

${ }^{5}$ Cf. F. Frazier: 225 in questo stesso volume.

${ }^{6}$ L' atopia è elemento ricorrente nei primi capitoli del De sera num. vind: essa caratterizza immediatamente l'anonimo epicureo, e ốto è ancora considerato Euripide, che nei suoi versi allude ad una Dike che insegue i colpevoli con passo lento

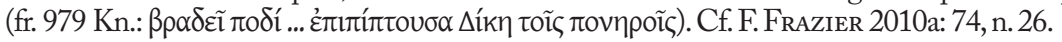


1) De sera num. vind. $4,550 \mathrm{~B}$

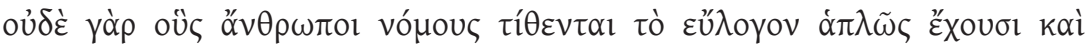

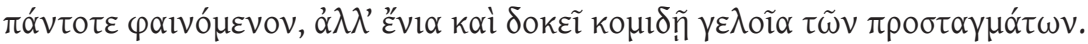

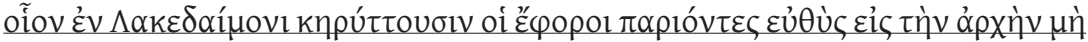

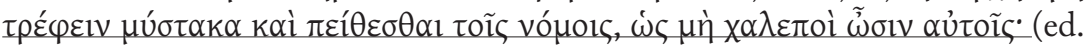
M. Pohlenz 1929: 399-400)7

\section{2) Cleom. 9.3-6}

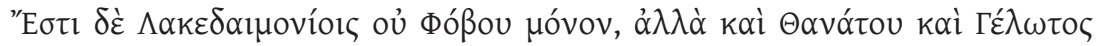

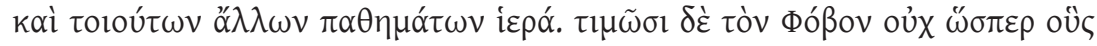

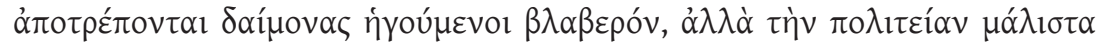

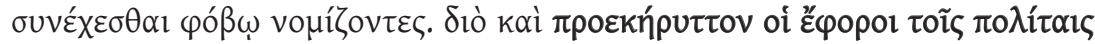

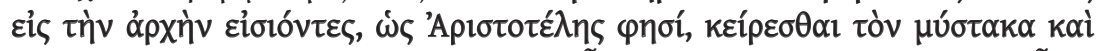

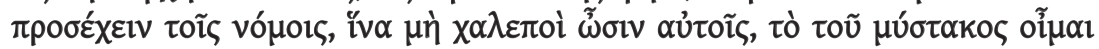

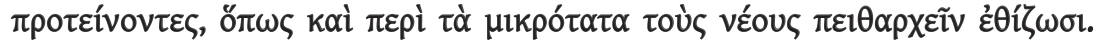

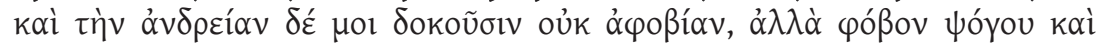

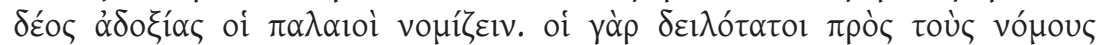

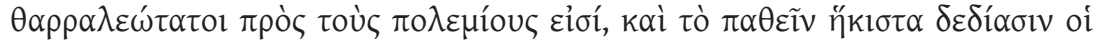

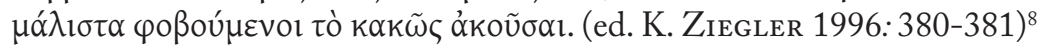

\section{3) Plu. fr. 90 Sandbach (= Schol. Hes. Op. 724-725)9

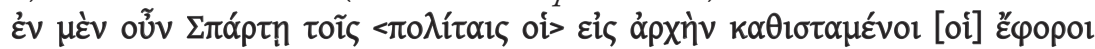

7 "D'altra parte, neppure le leggi che gli uomini si danno sono soggette a un solo criterio di razionalità universalmente manifesto, ma alcune norme sembrano francamente ridicole. $\mathbf{A}$ Sparta, per esempio, quando gli efori assumono la loro carica, proclamano che nessuno si lasci crescere i baffi, ed obbedisca alle leggi affinché queste non siano severe con loro" (trad. di G. Guidorizzi 1982: 132).

8 "Gli Spartani non hanno soltanto il tempio di Timore, ma anche quello della Morte, del Riso, di altri sentimenti del genere. Onorano il Timore non come quegli dei che si vogliono evitare perché ritenuti dannosi, ma perché credono che esso soprattutto tiene unito lo stato. $\mathbf{E}$ per questo che gli efori, entrando in carica, erano soliti ordinare ufficialmente ai cittadini, come dice Aristotele, di tagliarsi i baffi e rispettare le leggi perché esse non fossero aspre verso di loro, mettendo innanzi, io credo, la storia dei baffi per abituare i giovani a obbedire anche nelle minime cose. Per gli antichi il coraggio, mi pare, non consisteva nell'assenza di paura, ma nel timore del biasimo e nel terrore dell'infamia, I più timorosi della legge sono invero i più coraggiosi di fronte ai nemici; quelli che temono al massimo la mala fama temono pochissimo le sofferenze" (trad. di D. Magnino 1991: 193).

${ }^{9}$ Questo scolio fa parte dei cosiddetti scoli procliani, testimonianze di un perduto commentario agli Erga esiodei del neoplatonico Proclo. Questi si sarebbe a sua volta servito di un precedente commento plutarcheo: C. Faraggiana di Sarzana 1987: 22, scrive "Proclus s'est limité, à mon avis, à annoter le úró $\mu v \eta \mu \alpha$ de Plutarque dans les marges de son manuscrit. Il aurait, en d'autres termes, commenté un commentaire, par des observations critiques et par des intégrations". Lesistenza del commento plutarcheo, non menzionato nel Catalogo di Lampria, è confermata da Aulo Gellio in N.A. 20.8 (= fr. 102 Sandbach): Id etiam (...) multo mirandum est magis, quod apud Plutarchum in quarto in Hesiodum commentario legi (...). Sul rapporto tra i commenti esiodei di Plutarco e di Proclo cf., tra gli altri, A. Pertusi 1951:147-159; C. Faraggiana di Sarzana 1978: 17-40; T. Raiola 2010: 263-264, n. 1, con ampia bibliografia precedente. 


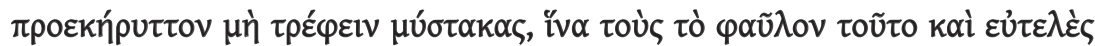

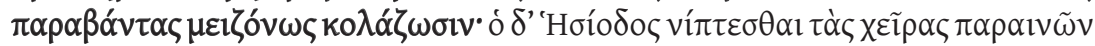

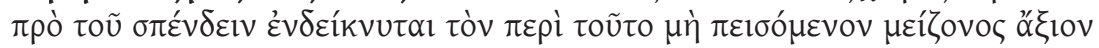

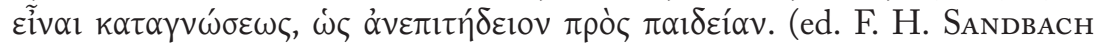
1967: 58 = F. H. SANDBACH 1969: 194) ${ }^{10}$

Dal confronto tra i tre testi (che costituiscono il fr. 539 Rose ${ }^{11}$ di Aristotele, citato esplicitamente da Plutarco solo nella Vita) si può immediatamente notare come la redazione del De sera 1) sia decisamente la più breve; 2) condivida con gli altri brani alcuni elementi fondamentali ${ }^{12}$, che possono essere così schematizzati:

a) il luogo in cui è emanato il $\pi \rho o ́ \sigma \tau \alpha \gamma \mu \alpha:$
De sera num.
Cleom.
fr. 90
ह̉v $\Lambda \alpha \kappa \varepsilon \delta \alpha i ́ p o v l$

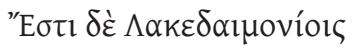

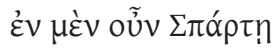

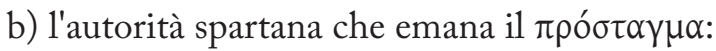

\begin{tabular}{|c|c|}
\hline 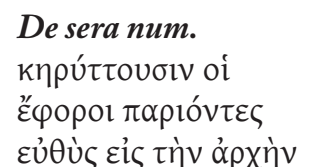 & 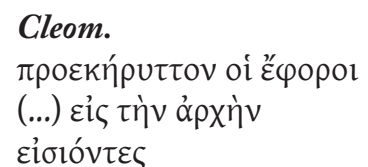 \\
\hline
\end{tabular}

De sera num.

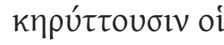

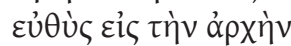

\section{fr. 90}

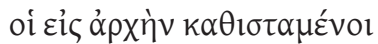

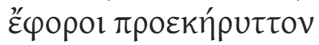

10 "A Sparta gli efori, nell'entrare in carica, proibivano per decreto ai cittadini la crescita dei baffi, col proposito di infliggere severe punizioni a chiunque trasgredisse un'imposizione tanto insignificante. Nell'esortare a lavarsi le mani prima della libagione, Esiodo vuole mostrare che chi è intenzionato a violare questa prescrizione merita una più severa reprimenda, essendo egli refrattario a ricevere un'educazione" (trad. M. De Simone, in P. Volpe 2010: 121).

${ }^{11}$ V. Rose 1886: 332-333.

${ }^{12}$ Un attento confronto tra i tre testi è proposto da B. W. Millis 1997: 575-577. In base alle somiglianze e differenze presenti nelle tre redazioni plutarchee della citazione aristotelica alcuni studiosi hanno congetturato su quale tipo di conoscenza (diretta o mediata da schede ed appunti) Plutarco abbia del testo di Aristotele: cf. G. Marasco 1978: 174, n. 25: "Una prova a sfavore dell'uso di schede e favorevole all'uso diretto potrebbe essere fornita dal ricorrere della stessa notizia sugli efori nel De sera numinis vindicta (550B), con notevoli differenze verbali, ed in un frammento ( 90 Sandbach), dove la prescrizione è spiegata in maniera diversa". Diversamente G. Marasco 1981: 426: "Queste differenze ed il fatto che nei due passi dei Moralia non è citato Aristotele, rafforzano la tesi che Plutarco, nel comporre la biografia di Cleomene, utilizzasse direttamente la $\Lambda \alpha \kappa \varepsilon \delta \alpha \iota \mu o v i ́ \omega v$ ro $\lambda ı \tau \varepsilon i ́ \alpha$ di Aristotele o schede tratte da essa in precedenza"; M. T. Schettino 1999: 649: "La coincidenza ad verbum tra il passo nella biografia di Agide e Cleomene e quello nel De sera numinis vindicta, benché in quest'ultimo non sia menzionato Aristotele, non sembra indicare una citazione a memoria ma tratta da un appunto scritto, che potrebbe derivare di prima mano dalla Lakedaimonion Politeia (...)”. Più in generale, sulla conoscenza dell'opera aristotelica da parte di Plutarco cf. F. H. SANDBAch 1982: 207-232; P. Donini 2004: 255-273; G. Karamanolis 2006: 85-126. 
c) il contenuto del $\pi \rho o ́ \sigma \tau \alpha \gamma \mu \alpha:$

\begin{tabular}{|c|c|c|}
\hline 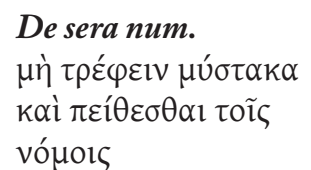 & 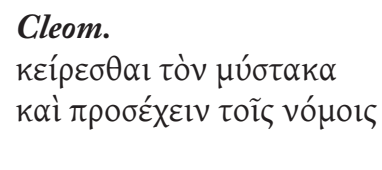 & 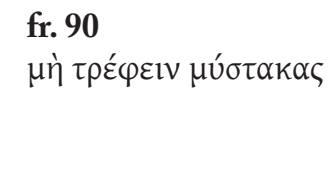 \\
\hline
\end{tabular}

d) l'eventuale sanzione per i trasgressori del $\pi \rho o ́ \sigma \tau \alpha \gamma \mu \alpha$ :
De sera num.
Cleom.
fr. 90

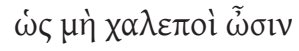

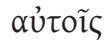

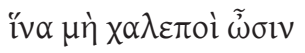

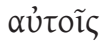

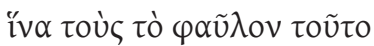

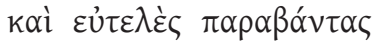

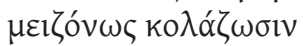

In particolare, quest'ultimo punto (d) richiede una riflessione di carattere esegetico: non appare chiaro, infatti, quale sia il soggetto della proposizione $\dot{\omega} \varsigma$

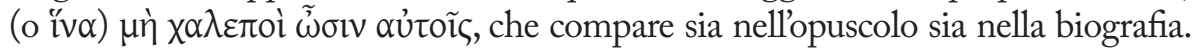
L'esegesi che sembrerebbe maggioritaria (direi canonica per il De sera ${ }^{13}$ ) ricava il soggetto della finale dal precedente toĩ lobbedienza alle leggi (anche a quelle che regolano aspetti di non grandissima importanza) farebbe sì che le stesse leggi non debbano essere più severe (cf. supra le traduzioni di Guidorizzi e Magnino). Due sembrano essere gli elementi a favore

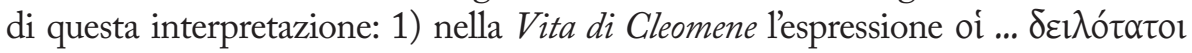

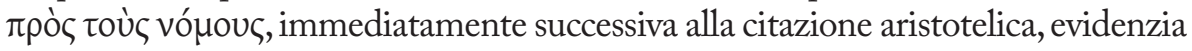

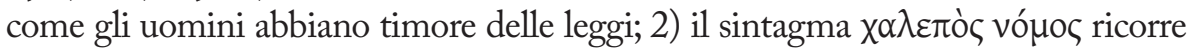
in Conv. sept. sap. 155F, dove è riferito ad una dura legge del saggio Pittaco ( $\Sigma \dot{\varepsilon} \gamma$ $\alpha^{\prime} \rho$,

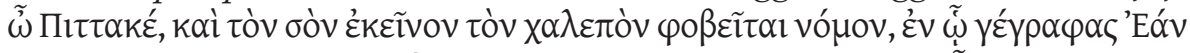

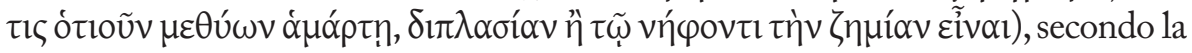
quale veniva raddoppiata la pena per i reati commessi in stato di ebbrezza.

${ }^{13}$ Oltre quella di Guidorizzi (cf. n. 7), cf. le traduzioni di A. O. Prickard 1918: 179 ("In Lacedaemon, for instance, the Ephors, when they first enter office, make proclamation that no one is to grow a moustache, and that men should obey the laws, that the laws may not be hard upon them"); Рh. DE LACY-B. Einarson 1959: 193 ("Thus in Lacedaemon, as soon as they take office, the ephors make a proclamation forbidding the wearing of moustaches and enjoining men to obey the laws, that the laws may not be harsh with them"); R. M. Aguilar 1996: 120121 ("Asi, en Lacedemonia, los éforos, en cuanto toman posesión de su magistratura, proclaman la prohibición de dejarse crecer los bigotes y la obediencia de las leyes, para que éstas no sean severas con ellos"); F. Frazier 2010b: 15 (“Ainsi à Lacédémone les éphores, dès leur entrée en charge, font proclamer l'obligation de ne pas se laisser pousser les moustaches et d'obéir aux

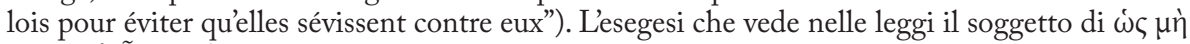

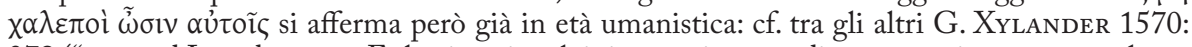
378 ("ut quod Lacedaemone Ephori statim ab inito magistratu edicunt ne quis mystacem alat et ut legibus obtemperent, ne eae ex ipsis sint difficiles observatu”) e J. Амүот 1572: 259 (“comme en Lacedemone les Ephores, aussi tost qu'ils sont instalez en leur magistrat, font publier à son de trompe, que personne ne porte moustaches, et que lon obeïsse volontairement aux loix, à fin qu'elles ne leur soient point dures"). 
Questa non è però la sola lettura possibile. In una nota al volgarizzamento del De Sera, opera dell'umanista Marcello Adriani, F. Ambrosoli scrive: "Questo medesimo riferisce Plutarco nella vita di Cleomene ove il G. Pompei (1816: 328329) tradusse con più verità: Quindiè che gli efori, quando entravano in magistratura, pubblicar faceano dal banditore a' lor cittadini, come dice Aristotele, che si radessero le basette, e che badasser bene alle leggi, acciocché non avesser eglino ad esser rigidi e severi con loro (...)" ${ }^{14}$. Secondo Pompei, che riferisce $\chi \alpha \lambda \varepsilon \pi$ oí agli efori stessi ${ }^{15}$, l'obbedienza alle leggi consentirebbe quindi agli Spartani di evitare la dura punizione degli efori, visti così nella loro funzione di custodi del nomos per conto della città. Un elemento a favore di questa seconda interpretazione potrebbe derivare dal confronto con il fr. 90 Sandbach. Nel commento ai versi degli Erga (a) non si fa menzione dei vó

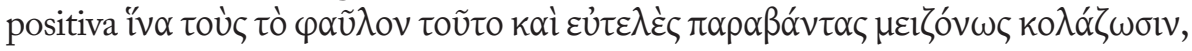
il cui soggetto sono appunto gli efori, che vietavano di portare i baffi con l'idea di punire con maggiore severità chi violasse questo divieto di poco conto e facile da osservare. Si può forse ipotizzare che il testo dello scolio contenga una sorta di parafrasi

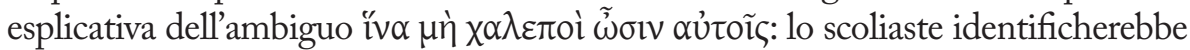
proprio negli efori coloro che sono preposti a punire con severità i trasgressori delle leggi. Questa prerogativa degli efori è inoltre ricordata da Senofonte nell'ottavo capitolo della Costituzione degli Spartani, capitolo dedicato appunto all'eforato e al ruolo svolto da questa magistratura nel fare di Sparta la città in cui maggiormente

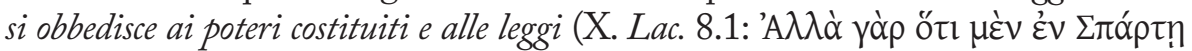

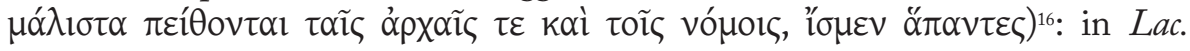
8.4 Senofonte afferma ancora che gli efori puniscono immediatamente chi notino

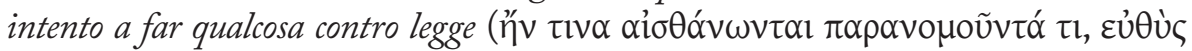

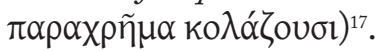

${ }^{14}$ M. Adriani 1827: 559; le traduzioni dell'Adriani furono pubblicate postume da F. Ambrosoli, cui è attribuibile il giudizio positivo sulla traduzione del Pompei.

${ }^{15}$ Simile esegesi, che vede negli efori il soggetto di $\chi \alpha \lambda \varepsilon \pi$ เi $\tilde{\omega} \sigma \mathrm{lv}$, si ritrova in altre traduzioni sempre relative al passo della Vita di Cleomene, e.g. in R. Flacelière 1976: 58 ("C'est pourquoi, quand les éphores entraient en charge, ils faisaient proclamer par le héraut... que les citoyens devaient se raser la moustache et se soumettre aux lois, pour qu'ils n'eussent pas à les punir"); $\mathrm{M}$. Nafissi 1991: 118 ("All'entrata in carica gli efori proclamavano ai cittadini ...di tagliarsi i baffi ed obbedire alle leggi, se non volevano che fossero severi con loro"; cf. inoltre M. NAFissi 2007: 340, che così interpreta Plu. Cleom. 9.3: "All'entrata in carica i "sorveglianti" annunciavano: "tagliatevi i baffi ed obbedite alla legge, se non volete incorrere nella nostra severità"'). Si noti inoltre che lo Xylander nel tradurre il passo della Vita di Cleomene si discosta dalla esegesi adottata per quello del De Sera (cf. supra n. 13), considerando gli efori soggetto anche della proposizione finale negativa: "Ideo etiam Ephori cum magistratum ineunt, civibus edicunt (...) ut superius labrum radant, ac legibus animum advertant, ne molesti ipsis esse cogantur" (G. XYlander 1580: 289).

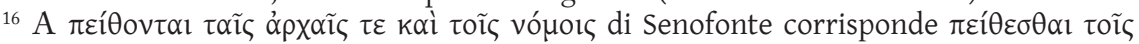
vópors di Plu. De sera num. vind. 550B. Sulle funzioni di controllo esercitate dagli efori a Sparta cf. inoltre L. Thommen 2003: 104.

${ }^{17}$ Sul passo di Senofonte cf. il commento di V. Gray 2007: 166-167. 


\section{Due motivi per una legge "illogica"}

Significative appaiono essere alcune divergenze che differenziano i tre brani plutarchei. In particolare, nella biografia di Cleomene, il Cheronese sembra offrire una 'duplice' spiegazione del proclama degli efori, 'bollato' invece nel De sera come apparentemente immotivato: 1) nel bios la citazione aristotelica è introdotta dalla congiunzione causale $\delta$ ió, che la vincola a quanto appena affermato da Plutarco, ossia che il phobos, la paura, onorata a Sparta come una divinità, sia il principale elemento di coesione della comunità lacedemone ( $\sigma v v \varepsilon ́ \chi \varepsilon \sigma \theta \alpha l)$. In tale ottica, radersi i baffi per timore di una punizione esemplare è testimonianza di come sia proprio il phobos a garantire l'obbedienza alle leggi da parte dei cittadini spartani; 2) è Plutarco a ritenere - oĩ $\alpha$ l sembra rimarcare il carattere soggettivo dell'ulteriore riflessione che segue la citazione di Aristotele - che il divieto degli efori possa svolgere inoltre una funzione paideutica, avendo come fine quello di educare

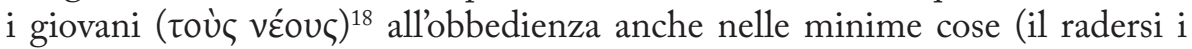
baffi), unobbedienza che poggia appunto sul già citato phobos, sul timore del

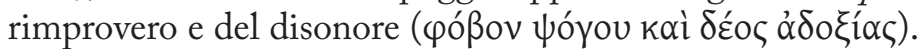

Soffermandosi inizialmente sul raffronto tra il brano della biografia e quello del De sera, è opportuno evidenziare come nell'opuscolo morale Plutarco passi sotto silenzio le ragioni del divieto spartano, esplicitate invece nella Vita di Cleomene. Tale reticenza è probabilmente da considerarsi il frutto di una scelta consapevole dell'autore: nel trattato, omettendo le spiegazioni relative al nomos stabilito dagli efori, il Cheronese può rimarcare maggiormente l'incapacità di alcuni uomini di comprendere la vera ragione di certi nomo ${ }^{19}$. L'aneddoto sui baffi degli Spartani può essere quindi impiegato come efficace esempio del modus operandi di Plutarco, che si serve della stessa citazione o dello stesso episodio storico in opere diverse, riadattandolo ai contesti diversi in cui si trova ad essere collocato ${ }^{20}$. Se nella Vita di Cleomene il divieto sui baffi è testimonianza efficace di come paura e rispetto per le leggi giovino alla città di Sparta, nel $D e$

${ }^{18}$ Per N. Richer 1998: 252-254, riveste grande importanza l'impiego da parte di Plutarco del sostantivo toù véous. In base alle testimonianze di Platone e, soprattutto, di Senofonte (P1. Lg. 6,760c e Xen. Mem. 1.2.35), a Sparta i neoi sarebbero da identificare con uomini di età inferiore ai trent'anni: essi dunque non avrebbero ancora terminato l'agoge e, ancora privi di una piena cittadinanza, non prenderebbero parte all'Apella.

${ }^{19} \mathrm{Cf}$. quanto afferma B. W. Millis 1997: 576-577, relativamente all'impiego di $\mu \eta \dot{~ \tau \rho \varepsilon ́ \varphi \varepsilon ı v ~}$

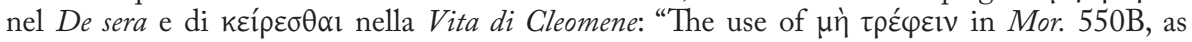

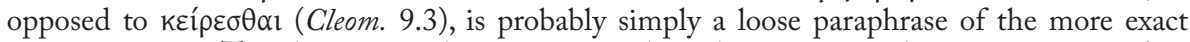
pronouncement. The change may be unintentional carelessness, since he is not interested in the Spartans per se in this passage, or could perhaps be deliberate, designed to highlight the apparent absurdity of the custom and thus strengthen his argument".

${ }^{20} \mathrm{Su}$ tale processo compositivo nelle opere del Cheronese cf. L. VAN DER STOckT 2004: 331-340; P. VOLPE 2007: 117-122. 
sera esso, opportunamente abbreviato e rifunzionalizzato, viene ricordato quale provvedimento apparentemente immotivato, e, quindi, atopos.

Venendo al fr. 90 Sandbach, la citazione della legge spartana è inserita all'interno del commento ai vv. 724-726 degli Erga, dove Esiodo riporta un particolare divieto di carattere religioso: Non offrire mai nell'ora dell'aurora a Zeus il nero vino con mani non pulite, né agli altri immortali. Lo scoliaste collega il precetto esiodeo di purezza rituale al divieto sui baffi decretato dagli efori mediante la

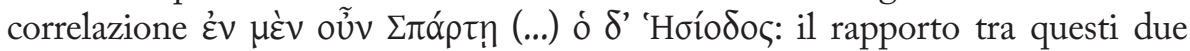
comandi (non libare con mani sudice / non lasciarsi crescere $i$ baffi) sembrerebbe

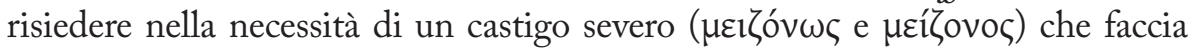
seguito alla mancata obbedienza alle norme ${ }^{21}$. L'impiego nel commento esiodeo

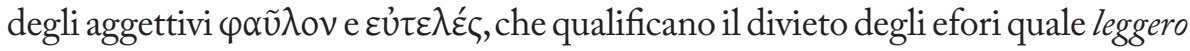
e di poco conto, e l'affermazione conclusiva sul rifiuto della paideia $a^{22}$ da parte di chi

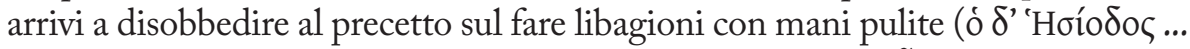

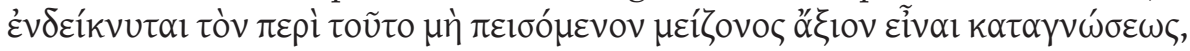

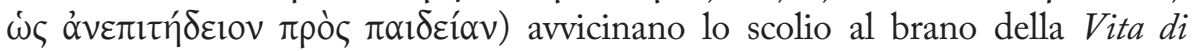
Cleomene: anche nella biografia Plutarco cataloga il comando sui baffi tra $\tau \grave{\alpha}$ $\mu \iota \kappa \rho o ́ \tau \alpha \tau \alpha$, le piccolissime prescrizioni alle quali bisogna comunque obbedire, sottolineandone al contempo la funzione paideutica, che consiste nell'educare i giovani a non trasgredire le norme stabilite dai magistrati, evitandone il castigo.

\section{I destinatari del divieto: problemi ecdotici nel fr. 90 Sandbach}

Un'ulteriore differenza tra $\mathrm{i}$ tre testimoni plutarchei del frammento aristotelico 539 Rose è rappresentata dall'indicazione dei destinatari del proclama degli efori, un elemento che porta con sé alcune difficoltà di carattere sia testuale sia interpretativo. Nella forma riassunta del De sera, infatti, Plutarco impiega il

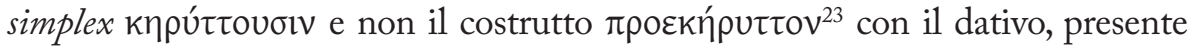
sia nel bios sia nel fr. 90. Nell'opuscolo non viene quindi precisato a chi sia rivolto l'editto dei magistrati spartani: un'omissione, quella dei destinatari, che crea un ulteriore dubbio nel determinare a chi vada riferito il successivo pronome $\alpha$ Ủंoĩ

${ }^{21}$ Cf. il commento allo scolio di P. Marzillo 2010: 359.

${ }^{22} \mathrm{Il}$ contenuto paideutico dello scolio ben si conforma agli interessi di Proclo: C. FAraggiana di SARZANA 1978: 22, sottolinea come i riferimenti negli 'scoli procliani' a determinati aneddoti storici siano impiegati quali "esempio e conferma di un precetto o di una interpretazione etico-pedagogica".

${ }^{23}$ B.W. Millis 1997: 576 evidenzia inoltre come l'impiego da parte di Plutarco dell'imperfetto

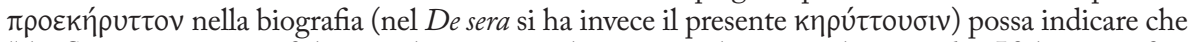
"the Spartan practice of shaving their moustaches was not known in his own day. If the imperfect was Aristotle's, it is possible that it was not a regular practice in his time either, and accordingly it is worth noting that no other reference to the custom exists in the classical period". Cf. inoltre G. Marasco 1981: 427: "In ogni modo, le stesse contraddizioni in cui cade Plutarco nello spiegare i motivi dell'usanza testimoniano che, già ai suoi tempi, i motivi di essa non erano più chiari”. 
della proposizione finale negativa. Le numerose traduzioni del De sera, da quelle umanistiche alle più recenti, appaiono tuttavia concordi (a) nell'individuare nei

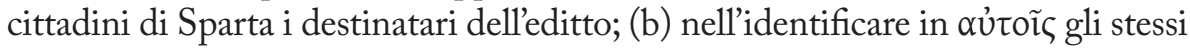
Spartani $^{24}$. Così interpretata, la testimonianza del De sera viene a coincidere

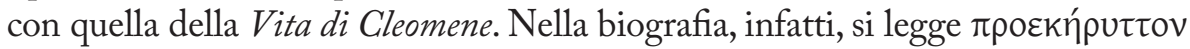
oi

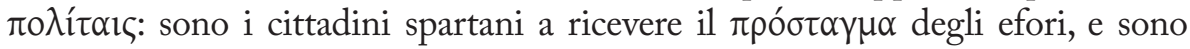
sempre gli stessi cittadini a essere puniti in caso di disobbedienza alle leggi.

Maggiori problemi presenta invece il fr. 90, che fin dalle prime edizioni a stampa è stato fatto oggetto di numerosi interventi, di cui vorrei, in conclusione, valutare opportunità ed efficacia. D. WyтtenвAсн 1800: 797 stampa la porzione di frammento inerente al nomos degli efori, riproducendo prudentemente la paradosi dei manoscritti, ossia

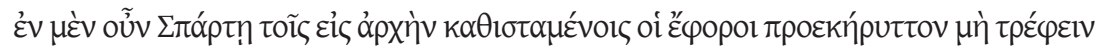

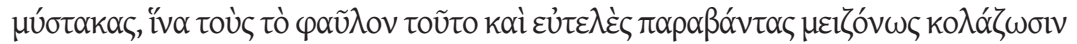

e traduce

Et Spartae quidem Ephori magistratibus, simulatque constituti essent, edicebant ne mystaces, id est barbas infra nares, alerent; ut eos qui leve hoc ac tenue praeceptum neglexissent, gravius punirent ${ }^{25}$.

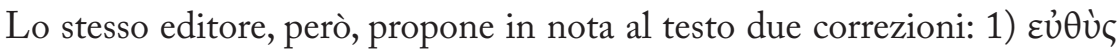

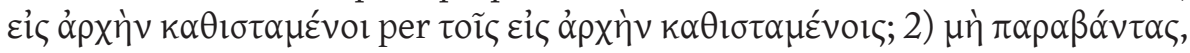

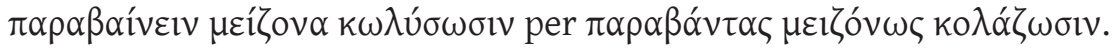

Il primo intervento è menzionato da Wyttenbach già nelle animadversiones che corredano la sua editio singularis del De sera ${ }^{26}$ : nella stessa sede lo studioso ricorda un'altra proposta di D. Ruhnken, il quale suggerisce a sua volta di

${ }^{24}$ Più esplicite a tal proposito appaiono le traduzioni di A.P. Peabody 1885: 9 ("Thus, in Lacedaemon, the Ephori when they come into office make immediate proclamation that no man shall let the beard on the upper lip grow, and that the laws must be so obeyed that they shall never be annoying to the citizens") e di M. Hose 2002: 47 ("In Sparta verkündeten die Ephoren bei Amtsantritt, man solle sich keinen Schnurrbart wachsen lassen und den Gesetzen gehorchen, damit sie ihnen [den Spartiaten] nicht beschwerlich werden".

${ }^{25}$ Cf. la traduzione italiana in D. BAвUт 2003: 545: "A Sparta gli efori vietavano ai magistrati entranti in carica di portare i baffi, con l'idea di punire severamente chi trasgredisse questa prescrizione insignificante e facile da osservare".

${ }^{26}$ Nella nota di commento di D. Wyttenbach 1772: 25 (= D. Wyttenbach 1821: 333), lo scolio procliano viene citato dall'edizione esiodea di D. Heinsius, pubblicata a Leida 1603; nel

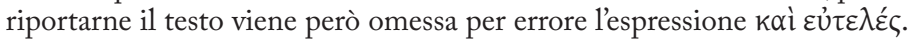




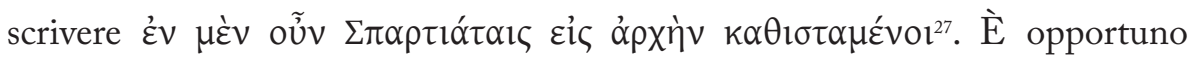
evidenziare come queste correzioni sembrino nascere dal confronto tra il testo del fr. 90 e quelli degli altri due brani plutarchei: se l'avverbio عủ $\theta u ́ c$ compare nel

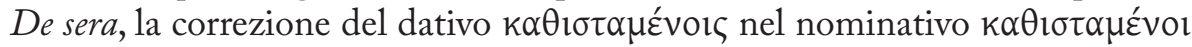
(concordato così con il soggetto oi $\tilde{\varepsilon} \varphi$ opol) appare derivata dalla presenza, sia

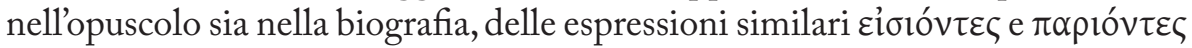

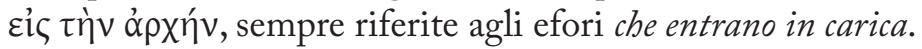

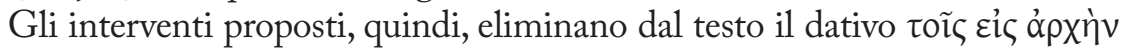

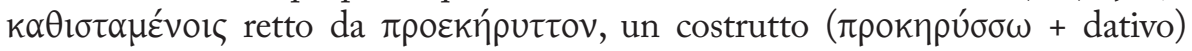
presente, come sopra ricordato, anche nella Vita di Cleomene: gli studiosi non ritengono possibile che destinatari del comando eforale siano alcuni Spartani chiamati a ricoprire qualche altra magistratura o incarico (cf. magistratibus della traduzione di Wyttenbach) sotto il controllo degli efori. Tuttavia, di un possibile potere di sorveglianza dell'eforato su altri magistrati si ha testimonianza nel già

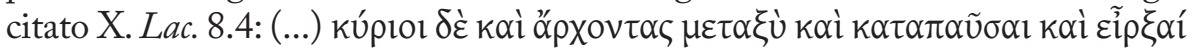

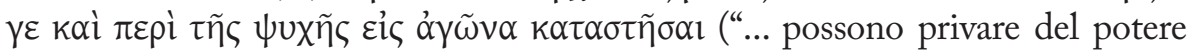
persone che sono ancora in carica per un compito istituzionale, imprigionarle e costringerle a mettere in gioco la loro vita in un processo").

Il 'processo', iniziato da Wyttenbach/ Ruhnken, di assimilazione del testo del commentario esiodeo alle altre due testimonianze plutarchee, che prevede l'eliminazione per via congetturale delle divergenze tra i tre brani, continua nei secoli successivi. Se Gaisford, Dübner, Rose e Bernardakis mantengono anch'essi la paradosi dei manoscritti ${ }^{28}$, A. Pertusi 1955 I: 222, nell'edizione degli scholia vetera agli Erga esiodei, stampa

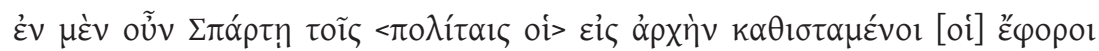

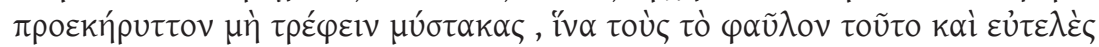

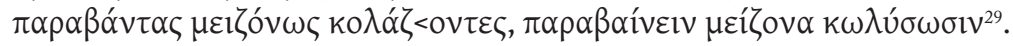

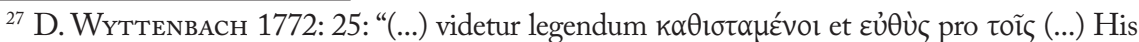
ita in chartam conjectis, eximiam mecum istam animadversionem communicavit Cel. Ruhnkenius:

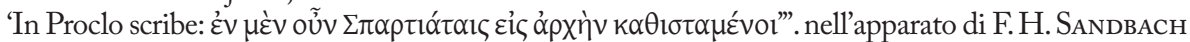

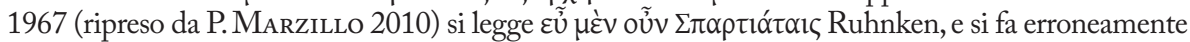
supporre che Ruhnken individuasse negli Spartiati i destinatari della legge eforale ( $\Sigma \pi \alpha \rho \tau$ ́ó $\tau \alpha \iota \varsigma$

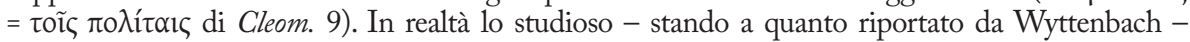

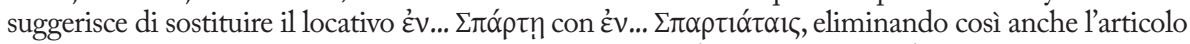

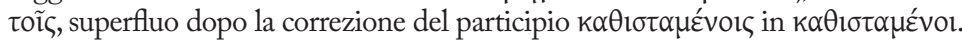

${ }_{28}$ Th. Gaisford 1820: 323; F. DüBner 1855: 30 (che ristampa anche la traduzione di Wyttenbach); V. Rose 1886: 332-333; G. N. Bernardakis 1896: 88-89 (= fr. 72).

29 "A Sparta dunque gli efori, assumendo la loro funzione, ingiungevano preventivamente ai cittadini di non farsi crescere i baffi, affinché, punendo piuttosto severamente i trasgressori di questa banale e insignificante prescrizione, si impedissero maggiori trasgressioni” (trad. di C. CASSANMAGNAGo 2009: 843). Il testo stabilito da Pertusi è accolto da O. Gigon 1987: 668 (fr. 545.3). 


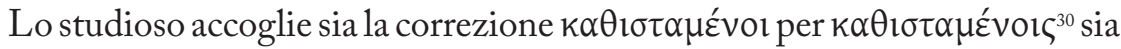

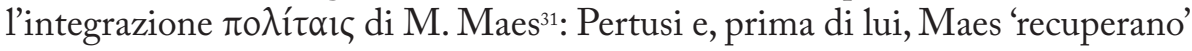

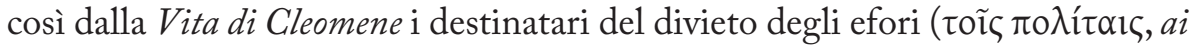
cittadini), dopo che Wyttenbach (con il suo maestro Ruhnken) ha 'eliminato' il

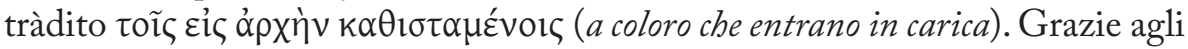
interventi di Pertusi, accolti più recentemente anche da Sandbach (cf. supra) e P. Marzillo 2010: 254, l'inizio del frammento viene a coincidere con il testo della biografia, salvo alcune minime differenze:

\section{fr. 90}

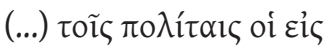

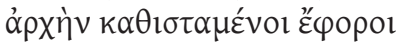

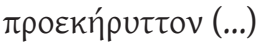

\section{Cleom. 9}

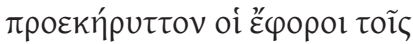

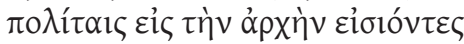

(...)

Al termine di questo breve status quaestionis, resta da interrogarsi sull'opportunità o meno di intervenire sul testo del frammento, che offre un senso accettabile (cf. supra le traduzione dello stesso Wyttenbach e di Babut), al solo fine di uniformarne forma e significato alla testimonianza offerta dalla biografia di Cleomene, ritenuta forse più completa e attendibile. In realtà, una simile operazione sembrerebbe sconsigliabile, data la natura stessa del testo in cui il frammento plutarcheo è collocato, ossia uno scolio assemblato con materiali di varia provenienza e sottoposto nel corso della tradizione a revisione da parte di più redattori. È ipotizzabile che lo scoliaste, oramai ignaro degli originali nomoi spartani, possa aver infine trasmesso una versione diversa (e probabilmente errata) della testimonianza relativa all'editto spartano sui baffi, ma ciò non sembra comunque autorizzare gli editori moderni ad intervenire per ricostruire anche nel frammento plutarcheo quella che essi ritengono la versione canonica ${ }^{32}$, considerato che anche le testimonianze propriamente plutarchee del De sera e della Vita di Cleomene presentano - come si è cercato di dimostrare - alcune specificità e differenze non sempre trascurabili.

${ }^{30}$ L'editore accoglie parzialmente anche la correzione proposta da Wyttenbach per la seconda proposizione del passo (cf. supra): " $\pi \alpha \rho \alpha \beta \alpha i ́ v \varepsilon ı v ~-~ \kappa \omega \lambda u ́ \sigma \omega \sigma ı v ~ p r a e e u n t e ~ W y t t e n b a c h$ correxi” così annota A. Pertusi 1955 II: 196.

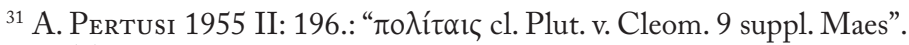

${ }^{32}$ Cf. T. Raiola 2010: 274-275 a proposito del frammento plutarcheo 81 Sandbach, sempre appartenente al commentario esiodeo. 


\section{Abbreviazioni bibliografiche}

Adriani,M.,Opuscolidi Plutarcovolgarizzati daMarcello Adriani,nuovamente confrontati col testo e illustrati con note da Francesco Ambrosoli, III, Milano, 1827.

Aguilar, R.M.,Plutarco, Obras moralesydecostumbres (Moralia), introducciones, traducciones y notas por Rosa María Aguilar, VIII, Madrid, 1996.

Амуот, J., Les cuvres morales et meslées de Plutarque, translatées du grec en françois, par Messire Jacques Amyot, Paris, 1572.

Babut, D., Plutarco e lo stoicismo, edizione italiana a cura di A. Bellanti, Milano, 2003 (titolo originale: Plutarque et le stoïcisme, Paris, 1969).

Bernardakis, G. N., Plutarchi Chaeronensis Moralia recognovit G.N. Bernardakis, VII (Plutarchi Fragmenta vera et spuria), Lipsiae, 1896.

Cassanmagnago, C., Esiodo, Tutte le Opere e i Frammenti con la prima traduzione degli scolii, a cura di C. Cassanmagnago, Milano, 2009.

de Lacy Ph.; Einarson, B., Plutarch's Moralia, with an English Translation by Ph. De Lacy and B. Einarson, VII, London-Cambridge, 1959.

Donini, P., "Plutarco e Aristotele", in I. Gallo (ed.), La biblioteca di Plutarco, Napoli, 2004: 255-274.

Dübner, F., Plutarchi Fragmenta et Spuria cum codicibus contulit et emendavit Fr. Dübner, Parisiis, 1855.

Faraggiana di Sarzana, C., "Il commentario procliano alle Opere e i Giorni”, Aevum, 52, 1978: 17-40.

Faraggiana di Sarzana, C., "Le Commentaire à Hésiode et la 'paideia' encyclopédique de Proclus", in J. Pépin-H.D. Saffrey (eds.), Proclus lecteur et interprète des anciens, Paris, 1987: 21-41.

Flacelière, R., Plutarque, Vies, texte établi et traduit par R. Flacelière et E. Chambry, XI (Agis-Cléomène; Les Gracques), Paris, 1976.

Frazier, F., "Le De sera, dialogue pythique: Hasard et Providence, Philosophie et Religion dans la pensée de Plutarque", in F. Frazier ; D. F. Leão (eds.), Tychè et Pronoia. La marche du monde selon Plutarque, Coimbra, 2010a.

Frazier, F., Plutarque, Sur les délais de la justice divine. texte établi par Yvonne Vernière. Traduction, introduction et notes par F. Frazier, Paris, 2010b.

Gaisford, Th., Poetae minores graeci, praecipua lectionis varietate et indicibus instruxit Th. Gaisford, III, Oxonii, 1820.

Gigon, O., Aristotelis Opera. III, librorum deperditorum fragmenta collegit et annotationibus instruxit O. Gigon, Berlin-New York, 1987.

Gray, V., Xenophon on Government, Cambridge, 2007. 
Guidorizzi, G., Plutarco. Il demone di Socrate (trad. e note di A. Aloni), Iritardi della punizione divina (trad. e note di G. Guidorizzi), introduzione e nota informativa di D. Del Corno, Milano, 1982.

Hackett, H. B., Plutarch on the Delay of the Deity in the Punishment of the Wicked, with notes, by H.B. Hackett, New York, 1844.

Hose, M., Aristoteles, Die historischen Fragmente. Übersetzt und erläutert von M. Hose, (Aristoteles, Werke in deutscher Übersetzung; 20/111), Berlin, 2002.

Karamanolis, G., Plato and Aristotle in Agreement? Platonists on Aristotle from Antiochus to Porphyry, Oxford, 2006.

Magnino, D., Plutarco, Agide e Cleomene, Tiberio e Caio Gracco, introduzione, traduzione e note di D. Magnino, con contributi di B. Scardigli e M. Manfredini, Milano, 1991.

Marasco, G., "Aristotele come fonte di Plutarco nelle biografie di Agide e Cleomene", Athenaeum, 56, 1978: 170-181.

Marasco, G., Commento alle biografie plutarchee di Agide e di Cleomene, Roma, 1981.

Marzillo, P., Der Kommentar des Proklos zu Hesiods 'Werken und Tagen' Edition, Übersetzung und Erläuterung der Fragmente (Classica Monacensia Bd. 33), Tübingen, 2010.

Millis, B.W., "Antiphanes fr.46 K-A and the Problem of Spartan Moustaches", CQ, 47, 1997: 574-578.

NAfissi, M., La nascita del kosmos. Studi sulla storia e la società di Sparta, Perugia, 1991.

Nafissi, M., "Forme di controllo a Sparta", Il pensiero politico, 40, 2007: 329344.

Peabody, A. P., Plutarch on the Delay of the Divine Justice, translated, with an introduction and notes, by A.P. Peabody, Boston, Mass., 1885.

Pérez Jiménez, A., "La Providencia como salvaguarda de los proyectos históricos bumanos en las Vidas paralelas", in F. Frazier; D.F. Leão (eds.), Tychè et Pronoia. La marche du monde selon Plutarque, Coimbra, 2010: 169-181.

Pertusi, A., "Intorno alla tradizione manoscritta degli scolii di Proclo ad Esiodo. IV", Aevum, 25, 1951: 147-159.

Pertusi, A., Scholia vetera in Hesiodi Opera et Dies, recensuit A. Pertusi,Milano, 1955.

Pohlenz, M., Plutarchi Moralia, recensuerunt et emendaverunt W.R. Paton-M. Pohlenz-W. Sieveking, III, Lipsiae, 1929.

Pompei, G., Vite degli uomini illustri di Plutarco, volgarizzate da Girolamo Pompei, VII, Milano, 1816. 
Prickard, A.O., Selected Essays of Plutarch. Vol.II.Translated with Introduction by A. O. Prickard, Oxford, 1918.

Raiola, T., "Plutarco e non Plutarco. Sul frammento 81 Sandbach", in G. Zanetto; S. Martinelli Tempesta (eds.), Plutarco: lingua e testo (Quaderni di Acme 122), Milano, 2010: 263-279.

Richer, N., Les ephores. Etudes sur l'histoire et sur l'image de Sparte (VIII ${ }^{e}-I I^{e}$ siècles avant Jésus- Christ), Paris, 1998.

Rose, V., Aristotelis qui ferebantur librorum deperditorum fragmenta, collegit V. Rose, Leipzig, 1886.

Rosкam, G., Plutarch's Maxime cum principibus philosopho esse disserendum. An Interpretation with Commentary, Leuven, 2009.

Sandbach, F. H., "Plutarch and Aristotle", ICS, 7, 1982: 207-232.

Sandbach, F. H., Plutarchi Moralia, edidit F. H. Sandbach, VII, Lipsiae, 1967.

SAndbach, F. H., Plutarch's Moralia, XV (Plutarch's Fragments), London, 1969.

Schettino, M.T., "Le politeiai aristoteliche nel corpus plutarcheo", in A. Perez Jimenez; J. García López; R. M. Aguilar (eds.), Plutarco, Pláton y Aristoteles, Madrid, 1999: 643-655.

Thommen, L., Sparta. Verfassungs- und Sozialgeschichte einer griechischen Polis, Stuttgart-Weimar, 2003.

VAn Der Stockt,L., "Plutarch in Plutarch: the Problem of the Hypomnemata", in I. Gallo (ed.), La Biblioteca di Plutarco, Napoli, 2004: 331-340.

Volpe, P., "Plutarchus in Plutarcho: de primo frigido e quaest. conv. VI, 4-5", Ploutarchos, 4, 2007: 117-122.

Volpe, P., Plutarco, Frammenti, a cura di P. Volpe Cacciatore, Napoli, 2010.

Wyttenbach, D., Plutarchi liber de sera numinis vindicta, recensuit, emendavit, illustravit D. Wyttenbach, Lugduni Batavorum, 1772.

Wyttenbach, D., Plutarchi Chaeronensis Moralia, id est opera, exceptis Vitis, reliqua. Graeca emendavit, notationem emendationum, et Latinam Xylandri interpretationem castigatam, subjunxit, animadversiones explicandis rebus ac verbis, item indices copiosos, adjecit D. Wyttenbach, V 2, Oxonii, 1800.

Wyttenbach, D., Danielis Wyttenbachii animadversiones in Plutarchi Moralia, Oxonii, 1821.

Xylander, G., Plutarchi Chaeronensis Moralia, quae usurpantur [...] G. Xylandro Augustano interprete, Basileae, 1570.

Xylander, G., Plutarchi Chaeronensis, ... Parallela, id est, Vitae illustrium virorum Graecorum et Romanorum, [...] Gulielmo Xylandro Augustano 
Un nomos atopos? Gli Efori e i baffi degli Spartani.

interprete. [...] Cum indice rerum et verborum copioso, Francoforti ad Moenum, 1580.

Ziegler, K., Plutarchi Vitae parallelae, iterum recensuit $K$. Ziegler, editionem correctiorem cum addendis curavit H.Gärtner, III 1, Stuttgart-Leipzig, 1996. 
(Página deixada propositadamente em branco) 
III.
The Path to Dike 
(Página deixada propositadamente em branco) 


\title{
LA NOZIONE Di GIUSTIZIA NEL SUO SVILUPPO STORICO: LA GIUSTIZIA COME VALORE PRIMARIO DEL PENSIERO ETICO E POlitico di Plutarco
}

\author{
Francesco Becchi \\ Università degli Studi di Firenze
}

\begin{abstract}
Justice is an ideal that characterizes Greek thought throughout its historical development since Homer. It reaches its clearest formulation with Plato, who regarded it as the "virtue of the soul", conceived as summary of its three functions, and with Aristotle, who turned it into the political virtue par excellence, emphasizing its intersubjective character. Plutarch, who interprets the Platonic and Aristotelian doctrine of justice in light of modern Stoicism and posterior Aristotelianism, transforms justice into an ethical and political ideal at the same time: a virtue that springs from the soul, where it has its roots, to seek outside. In this respect, it represents for him one of the most perfect virtues and one of the highest forms of humanity, because it allows the politician - provided with an appropriate education and moral formation - to carry out his activity for the benefit of the members of his community, showing courage in doing and saying what is right and fair.
\end{abstract}

La giustizia non è né di oggi né di ieri, vive da sempre e nessuno sa dire quand'essa sia apparsa ${ }^{1}$. Cosí, dopo un lungo silenzio, recita Antigone innanzi al rappresentante del potere costituito, il re Creonte. $\mathrm{E}$ che la distinzione tra giusto e ingiusto sia ancestrale è stato dimostrato anche da un recentissimo studio di ricercatori svedesi del Karolinska Institut di Stoccolma². Quelle di Antigone sono senza dubbio le più celebri parole del teatro di Sofocle, con cui il poeta di Colono oppone alla giustizia delle leggi umane l' eterna e infallibile giustizia di Zeus ${ }^{3}$.

Ed è con questa giustizia divina che si apre la storia del pensiero greco: essa ancora prima delle ipostasi divine di Themis, la giustizia conforme alle regole in uso, "un costume sancito a livello collettivo", e di Dike, la legge divina, figlia di Themis e di Zeus ${ }^{5}$, è rappresentata dal padre stesso degli dei e degli uomini. La conferma viene da Plutarco che, sulla scia del divino Platone ${ }^{6}$,

${ }^{1}$ Per una storia della nozione di giustizia attraverso i testi degli antichi (P1., R. 1-2; Aristotele, $E N)$, ma soprattutto dei moderni e dei contemporanei vd. S. Maffettone; S. Veca ${ }^{6} 2008$.

${ }^{2}$ Recenti ricerche neurologiche hanno dimostrato che di fronte ad una situazione percepita come ingiusta, il cervello umano attiva aree della amigdala arcaiche e non, come di solito veniva presupposto, la corteccia prefrontale, di più recente formazione. Su questo tema vd. K. Gospic; E. Mohlin; P. Fransson; P. Petrovic; M. Johannesson; M. Ingvar 2011.

${ }^{3}$ Vd. J. Jounnna 2007: 394-395.

${ }^{4}$ Il. 15.87, 93; 20.5; Od. 2.68. Vd. S. Gastaldi 1998: 161.

${ }^{5}$ Cf. Hes., Th. 902; Op. 255-256.

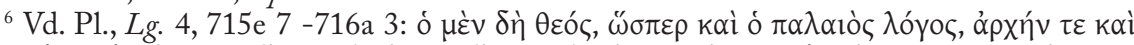

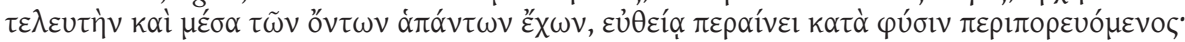

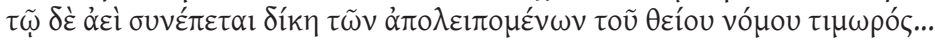


nell' Ad principem ineruditum scrive": "se è lecito congetturare in questa materia Zeus non è assistito dalla Giustizia, ma è lui stesso la Giustizia e il Diritto e

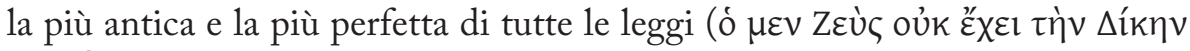

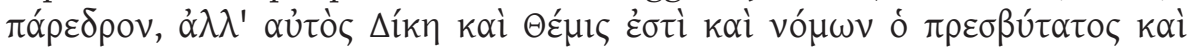

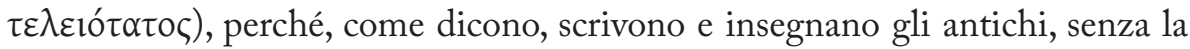
giustizia Zeus stesso non potrebbe ben governare" (Plu., ad princ. ind. 781B ).

Questa sorta di identità, pregnante per il suo valore formale e sostanziale, tra Zeus e la Giustizia costituisce un vero e proprio archetipo del pensiero occidentale nei suoi stretti legami con la religione. Non a caso si assiste ad un travaso o ritrascrizione - con implicazioni di risemantizzazione - di questa identità che dalla cultura classica giunge al cristianesimo e attraversa tutto il Medioevo. Tra le testimonianze più rilevanti basti citare quella di Dante Alighieri che nella Vita Nova (XXVIII i) definisce Dio "segnore de la giustizia" e nella Commedia (Inf. III 4-6) dove, riassumendo l'idea della Trinità di Dio nella "divina potestate" del Padre, nella "somma sapienza" del Figliuolo e nel "primo amore" dello Spirito santo, pone la Giustizia a fondamento della creazione dell'Inferno, quasi a sottolineare l'assoluta necessità sostanziale della pena in relazione al peccato: "Giustizia mosse il mio alto Fattore".

Ritornando all'antico, nei poemi omerici, dove Jíkn non è ancora espressione divina del padre degli dei e tanto meno è una virtù che caratterizza la figura dell'eroe, la giustizia rappresenta comunque la volontà degli dei: nell'Iliade scaccia la giustizia chi agisce con prepotenza (ßín), incurante

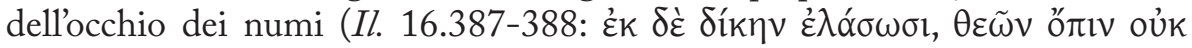

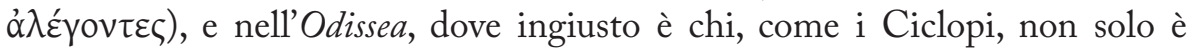
violento $(O d .9 .106)$ e non ha mente pia verso i numi (Od.9.274) ma non

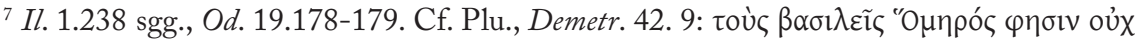

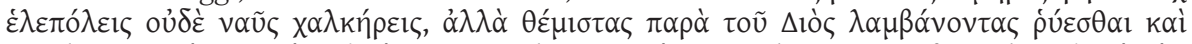

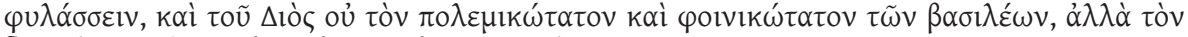

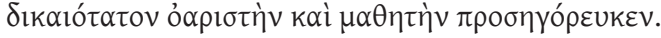

${ }^{8}$ Non è un caso poi che l'ammonimento venga posto da Dante sopra la porta dell' inferno, vera e propria connotazione di quella "città dolente", per la necessaria espiazione di quanto si è commesso contro giustizia. Dante ritornerà sul tema della giustizia e della sua applicazione o del suo inveramento nella legge in vari passi della Commedia: ora condannando la lussuriosa Semiramide che dichiarò lecito, ovvero consentito dalle leggi, ciò che piacesse a ciascuno (Inf. VI 56: "che libito fe' licito in sua legge"); ora con l'intenzione di ribadire la precarietà ed instabilità delle leggi che governano Firenze, esaltando, di contro, le legislazioni di Atene e Sparta, viste come prime fonti del diritto civile (Purg. VI 139-144: "Atene e Lacedemona, che fanno/ l'antiche leggi e furon sì civili...”); ora constatando amaramente la separazione drammatica tra la legge scritta - nei codici e nel cuore - e la sua inattuata applicazione (Purg. XVI 97: "Le leggi son, ma chi pon mano ad esse?"); ora riconfermando, nel richiamo a Giustiniano, vero e proprio esempio e modello di quella monarchia universale, instauratrice di giustizia e, conseguentemente, di progresso civile, auspicata da Dante e da lui teorizzata nel Monarchia, l'intimo legame che lega il laborioso riordino delle leggi con il magistero spirituale della Chiesa (Par. VI 22-24: "Tosto che con la Chiesa mossi i piedi,/ a Dio per grazia piacque di spirarmi”). 
ha neppure leggi (Od. 9.112), la giustizia sembra designare "l'insieme delle prescrizioni, emanate da un'autorità preposta alla regolamentazione dei comportamenti, alle quali pertanto tutti devono adeguarsi", pena di non essere considerati giusti. Poi negli Erga di Esiodo, dove la vergine figlia di Zeus, onorata e venerata dagli dei che abitano l'Olimpo', è discesa sulla terra grazie al dono che il figlio di Crono ha fatto agli uomini, dike rappresenta non solo rispetto degli dei ma assume anche una valenza morale e civile nei rapporti interpersonali regolati da un'idea di giustizia fondata sul senso del limite ${ }^{10}$. Infatti, dopo la stagione dell'epica la giustizia, pur se ancora personificata secondo un modulo esiodeo, serve a caratterizzare un ideale che è ad un tempo

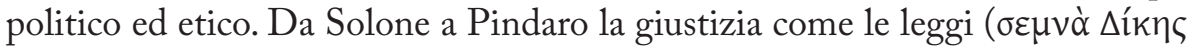
$\theta \varepsilon ́ \mu \varepsilon \theta \lambda \alpha)^{11}$, dono di Zeus agli uomini per il vivere civile, si configurano come

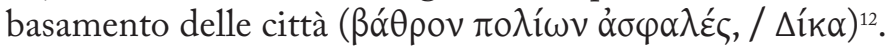

Dunque nel suo significato più antico l'idea di giustizia appare non solo come rispetto degli dei e osservanza dei precetti divini, ma anche come conformità alle regole sociali e obbedienza alle leggi ${ }^{13}$, considerato che anche in greco l'etimologia che corrisponde alla nozione di "giusto" risulta connessa con quella di legge positiva. Si tratta comunque sempre di una modalità del vivere che appartiene all'ordine dei rapporti esterni, retta dal meccanismo della reciprocità, governata dalla regola del contraccambio e fondata sul rispetto del limite e della misura.

Ma è proprio nel secolo di Pindaro, in cui si assiste tra l'altro alla

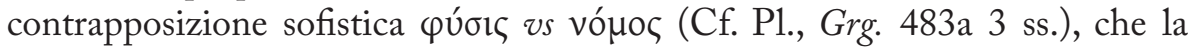
giustizia dal trono di Zeus discende nell'animo dell'uomo e nella letteratura greca compare per la prima volta il termine $\delta ı \kappa \_$ del giusto ${ }^{15}$, cioè una giustizia intesa come pratica di virtù: una nozione questa

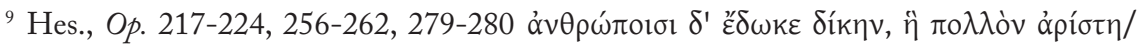

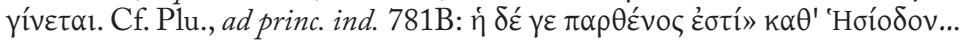

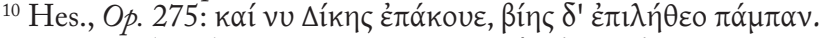

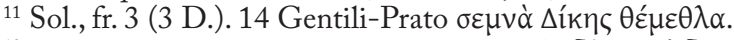

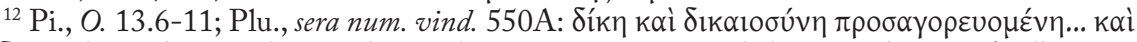

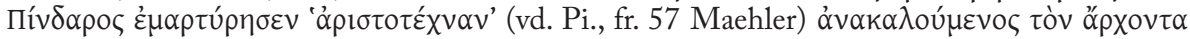

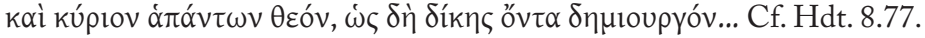

${ }^{13} \mathrm{Vd}$. A. Jellamo 2005: VIII.

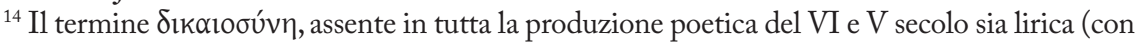
l'esclusione di Teognide (I 145-148) e Focilide) che tragica (sulla legge suprema di giustizia vd. Eur., Hec. 799-801), si rivela assai raro anche nella prosa, dove l'unico autore del V secolo che ne

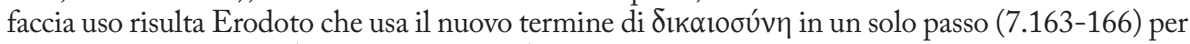
veicolare un' accezione ("senso di giustizia") distinta da quella consolidata di dike. Non è un caso che Platone nel I libro della Repubblica ricorra a due differenti strumenti linguistici per designare

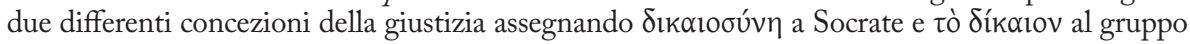
dei suoi interlocutori. Sul tema della giustizia in Platone vd. S. GASTALDi 1998: 159-160.

${ }^{15}$ Sull'origine umana e non divina della giustizia vd. Trasymachos, 85 [78]. B 8, VS II 326. 14-18 D-K. ${ }^{6}$ Vd. P1., Prt. 323a 5-7 ss. 
che sembra avere avuto il suo precursore in Pitagora ([Arist.], $M M$ 1182a 11; Jambl., VP 30.172) e che troverà il suo compimento nell' $E N$ di Aristotele, "il testo canonico - come lo definisce Norberto Bobbio - che ha improntato di sé, in una vicenda plurisecolare, la riflessione filosofica sulla nozione di giustizia" ${ }^{16}$ attraverso un processo di laicizzazione, di cui sono eloquenti testimoni la sofistica per quanto riguarda il pensiero filosofico e la tragedia per quanto attiene alla letteratura.

Al sofista Trasimaco, che contestava la legittimità stessa di una teoria della

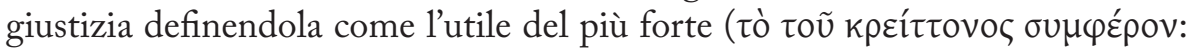
$R .1,338$ e 1 ss.), Platone risponde confutandone le argomentazioni. Tuttavia Platone riconosce con Trasimaco che la giustizia è una prassi con cui si mira a conseguire un utile, ma prende le distanze dal sofista quando precisa che

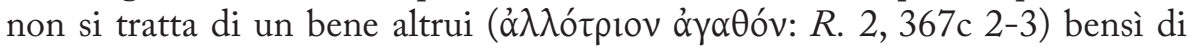
quello proprio che si consegue con un comportamento moralmente corretto. Per Platone, che nella Repubblica istituisce una perfetta homologia tra la dimensione personale e quella interpersonale, tra l'equilibrio dell'anima e quello della polis, dove la giustizia politica risulta una categoria funzionale a definire l'ideale etico - considerato che non si dà giustizia senza sapienza, coraggio

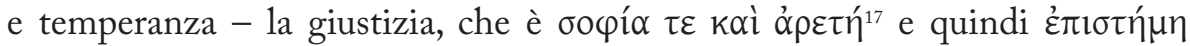
(Tht. 145e 6), corrisponde per l'anima a quella che è la salute per il corpo. Per Platone come per i Platonici essa non rappresenta la quarta virtù accanto alla prudenza, al coraggio e alla temperanza, alle quali pur è legata da uno

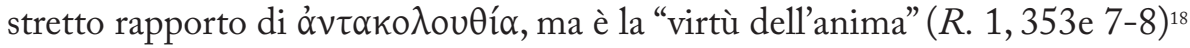
che nasce dall'armonia delle sue tre dimensioni ${ }^{19}$ e rappresenta la funzione stessa dell'anima. Essa, come la definisce Vegetti, è il "prodotto sintetico" o il "precipitato unitario" delle tre funzioni dell'anima ${ }^{20}$.

Aristotele, che si situa "au point d'aboutissement d'une longue histoire au cours de laquelle l'idée de justice n'a cessé de se "laïciser" sans y parvenir cependant tout à fait ${ }^{21}$ avant l'Éthique à Nicomaque", come scrivono Gauthier e Jolif nel loro commento all' $E N$, distingue tra la giustizia come legalità e la giustizia come equità. L'equità ( $\left.\xi_{\pi} \iota \varepsilon i ́ k \varepsilon l \alpha\right)$, che è la giustizia superiore a quella del diritto, di cui è fonte, ha origine dalla legge non scritta della natura ed ha

${ }^{16}$ Vd. G. Zanetti 1993: 18.

${ }^{17}$ Sulla giustizia che in quanto sapienza e virtù rappresenta il più alto valore per l'uomo vd.

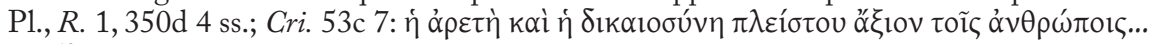

${ }^{18}$ Sul tema della giustizia vd. R. W. Hall 1959: 149-158.

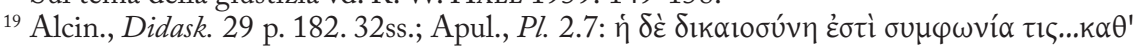

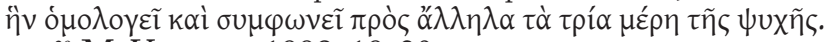

${ }^{20}$ M. Vegetti 1998: 19-20.

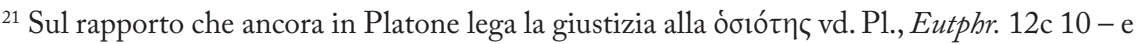
8; R. 1, 331a 4-5; Grg. 507c 1-3. 
un campo di applicazione più vasto di quello della giustizia legale ${ }^{22}$. Anche

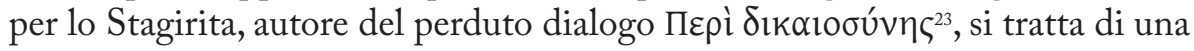

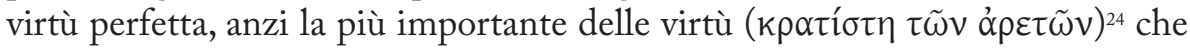
riassume in sé ogni altra virtù, ma non la spiega né come equilibrio dell'anima né come copia dell'armonia cosmica. Essa consiste in uno stato interiore, in una disposizione stabile dell'anima ( $\left.{ }^{\prime} \xi \xi \zeta\right)$ che rende chi è giusto capace di compiere azioni giuste $(\delta 1 \kappa \alpha 10 \pi \rho \alpha \gamma \varepsilon \tilde{v})^{25}$. Sotto questo aspetto essa rappresenta una medietà, anche se una medietà particolare rispetto alle altre virtù in quanto si tratta di una medietà oggettiva e non soggettiva, poiché la giustizia è propria di ciò che sta in mezzo ${ }^{26}$. Ma ciò che distingue la giustizia dalle altre virtù è

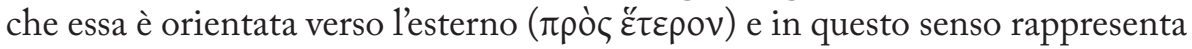

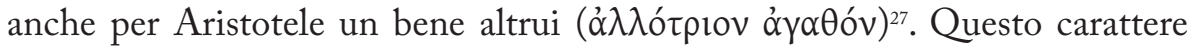
intersoggettivo fa della giustizia anche e soprattutto la virtù politica ${ }^{28}$ per eccellenza che si esercita nel milieu sociale ${ }^{29}$ dove tende a conseguire l'utile di tutti ${ }^{30}$, mentre il suo contrario, l'avidità $\left(\pi \lambda \varepsilon \varepsilon_{0 v \varepsilon} \xi i^{\alpha} \alpha\right)^{31}$, persegue vantaggi che appartengono ad altri o nega ad altri quanto è loro dovuto.

Dopo Aristotele, le moderne scuole di pensiero negarono qualsiasi eticità alla giustizia: gli Stoici interpretandola come diritto naturale che vincola, in quanto logos, tutti gli uomini allo stesso modo e ne determina anche il mondo dello spirito (SVF III 308) alla pari della necessità, del fato e della provvidenza, Epicuro al contrario negando l'esistenza di un diritto naturale, di quella che definisce la giustizia in sé $\left(\kappa \alpha \theta^{\prime} \dot{\varepsilon} \alpha u \tau o ̀ ~ \delta ı \alpha \alpha ı \sigma u ́ v \eta\right)^{32}$ e ammettendo la giustizia solo per la sua utilità (Epic., R.S.XXXI).

L' abbandono della tradizione etico-pratica da parte delle filosofie ellenistiche condusse la riflessione etica in uno stato di prostrazione e in un

${ }^{22}$ R. A. Gauthier; J. Y. Jolif ${ }^{2}$ 1970: 432-434: Nell' $E N$ “l'équité n’y est pas définie comme indulgence, elle n'est pas en dehors de la sphère du droit, elle est au contraire source du droit, et d'un droit supérieur, puisque inscrit dans la nature".

${ }^{23}$ P. Moraux 1977.

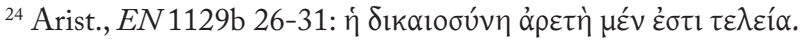

${ }_{25}$ Arist., EN 1133b 30, 1135a 16, 1136a 4, 19, 1172b 24, 1173a 21. Cf. Plu., Sol. 5. 4-5.

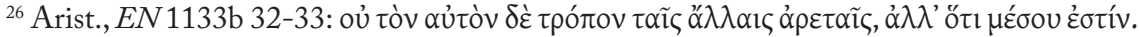

${ }^{27}$ Arist., EN 1130a 3, 1134b 5. Cf. Pl., R. 1, 343c 3. Per la definizione aristotelica di giustizia

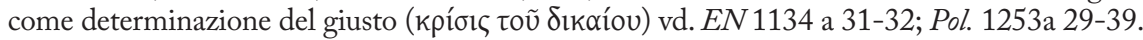

${ }^{28} \mathrm{La}$ giustizia politica non è una nuova forma di giustizia, ma solo un modo diverso di definirla.

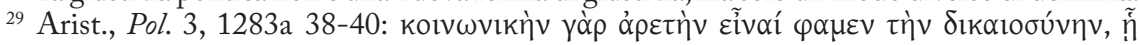

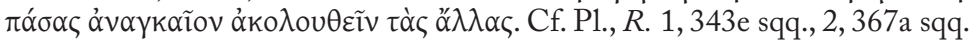

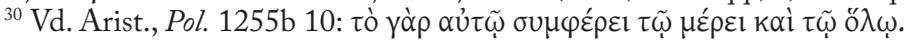

${ }^{31}$ Arist., EN 1129a 32,1130a 26. Cf. Plu., De Alex. fort. virt. I 330F, 332D; T. Gracch. 9. 2-3.

${ }^{32}$ Epic., R.S. XXXIII; cf. Epic. Ethica, fr. 531 Usener = Sen. Ep. 97.15 illic dissentiamus cum Epicuro, ubi dicit nibil iustum esse natura... Tuttavia Epicuro, che riproduce l'antica divisione

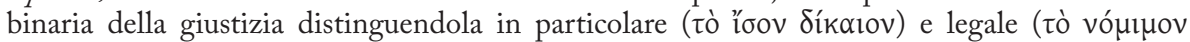

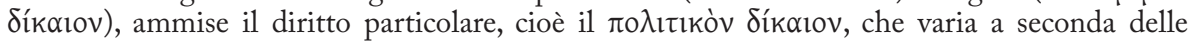
diverse situazioni storiche e ambientali. Vd. Arist., EN1129a 33 ss. 
vicolo cieco con conseguenze di tutta evidenza nella società dei primi secoli dell'età imperiale, dove si rese necessaria la rifondazione di un' etica pratica che si configura come un'assunzione di categorie classiche adattate al mutato contesto socio-politico. A questa opera di rifondazione etica aderì anche Plutarco, che distingue tra la giustizia ( $\delta$ ík $\eta$ ) intesa come osservanza e fine

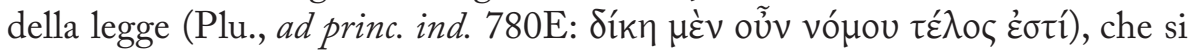
esercita solo all'interno di una comunità fondata sulla ragione, e la giustizia

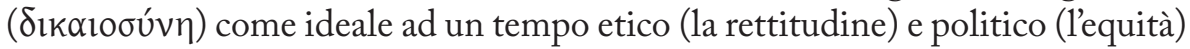
che inerisce all'uomo $\delta$ íkalos, ed ha un campo di applicazione più vasto anche perché si estende agli altri esseri viventi nei riguardi dei quali non vige alcun obbligo di legge.

La giustizia umana ${ }^{33}$ di cui parla Plutarco nei Moralia e nelle Vitae non è una dote o una disposizione naturale (Plu., Arist. 2.2, 23.2; Demetr. 4.5), ma dipende da noi ed è in nostro potere (Plu., Dem. 1.4) perché richiede esercizio. Infatti per diventare giusti e compiere azioni giuste occorre forza di volontà

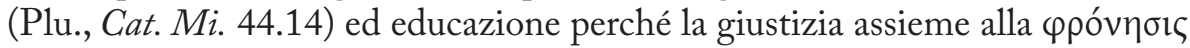

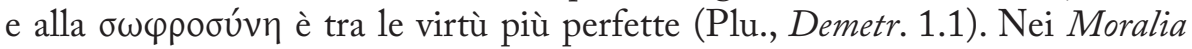
essa è definita sulla scia della filosofia aristotelico-peripatetica come prudenza

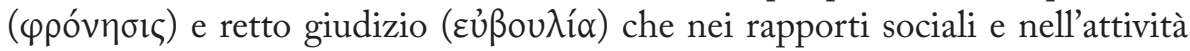
politica non si attribuisce né più né meno di quanto conviene ${ }^{34}$. Una virtù etica

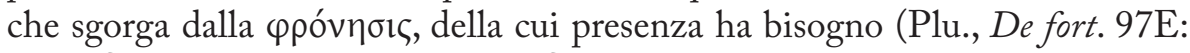

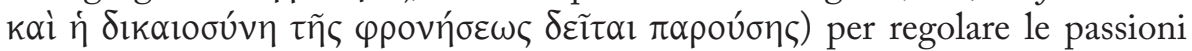

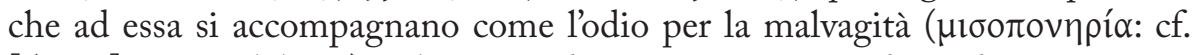
[Arist.], $V V$ 1250b 24) e il giusto sdegno per quanti godono di un successo

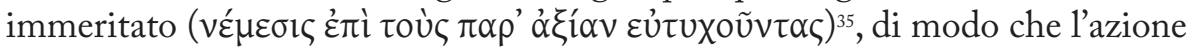
non fallisca il giusto mezzo né per eccesso né per difetto, considerato che l'azione giusta è sempre una medietà tra due eccessi, commettere ingiustizia e subire ingiustizia.

Nelle Vitae, dove assume una connotazione più prettamente politica, che la oppone alla $\pi \lambda \varepsilon \circ v \varepsilon \xi$ ía $^{36}$, che rappresenta l'ingiustizia sociale, la giustizia,

${ }^{33}$ Sulla definizione della giustizia divina come $\pi \alpha \sigma \tilde{\omega} v . . . \tau \varepsilon \chi \nu \tilde{\omega} \nu \mu \varepsilon \gamma i ́ \sigma \tau \eta$ vd. Plu., De sera num. vind. $550 \mathrm{~A}$.

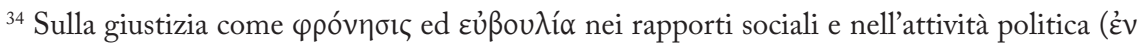

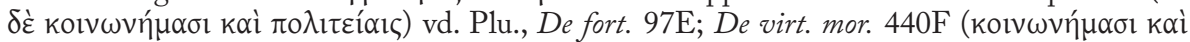

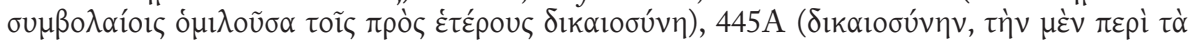

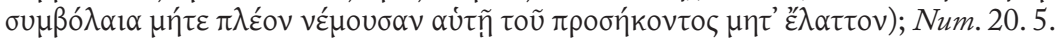

${ }_{35}$ Plu., De virt. mor. 451D-E. Cf. Arist., EE 1234a 31; [Arist.] VV1250b 24; Plu., De Alex. fort. virt. I 330F, 332D; T. Gracch., 9.2-3.

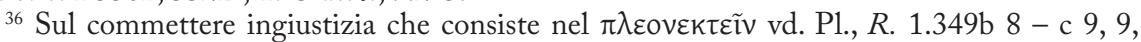
586b 1; Grg. 483c 3 ss.; Lg. 10, 906c 3, Arist., EN 1129a 32; Pol. 1289b 29; [Arist.], VV 1251a

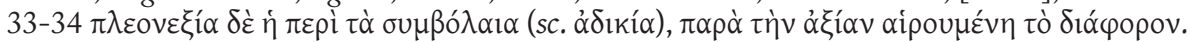

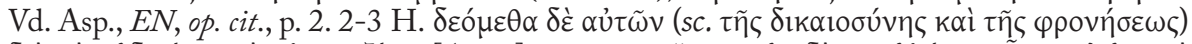

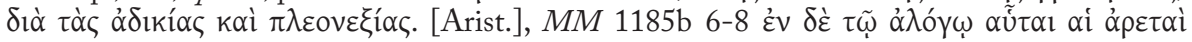


come si evince dal prospetto che segue, risulta secondo i canoni del platonismo e dell'aristotelismo posteriore una virtù egemonica o architettonica nei

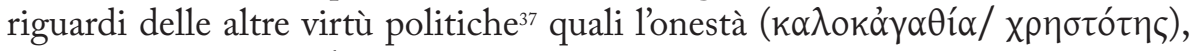

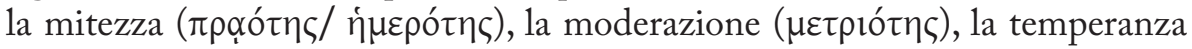

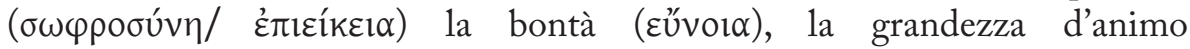
( $\mu \varepsilon \gamma \alpha \lambda \circ \psi v x i ́ \alpha / \mu \varepsilon \gamma \alpha \lambda \circ \varphi \rho \circ \sigma u ́ v \eta)$ e l'umanità ( $\varphi \imath \lambda \alpha v \theta \rho \omega \pi i ́ \alpha)^{38}$ :

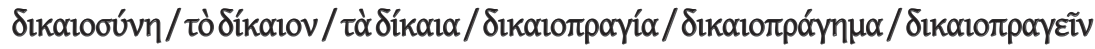

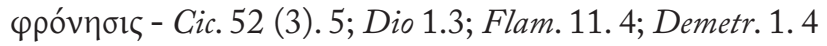
бочía - Cat. Mi. 5. 2, 9.9; Lyc. 3.6

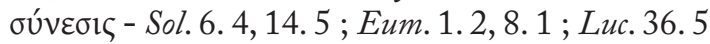

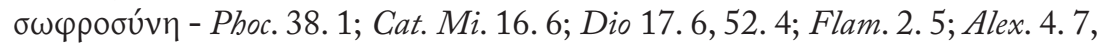
21. 7, 30. 10; Demetr. 1. 4; Pomp. 16. 2; Brut. 32. 2; Marc. 1.3

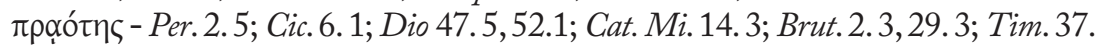

5,41.1; Pel.26.8;DeAlex.fort. virt.I332C;Alex. 4. 8,41.2; Caes. 15.4; Num.20. 4

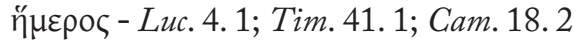

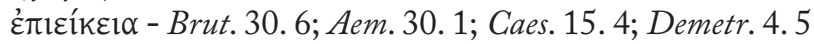

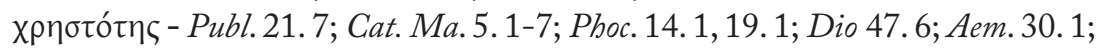

Lys. 30. 6; Tim. 5. 1; Pyrrh. 8.10

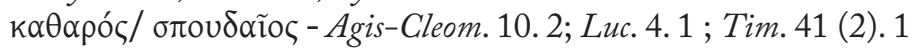

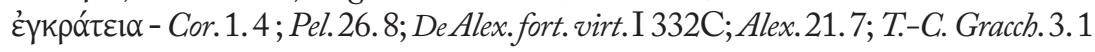

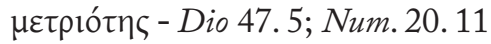

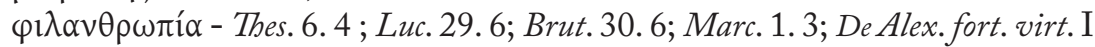

332C ; Phoc. 10.7 ; Arat. 46.1

$\mu \varepsilon \gamma \alpha \lambda$

Cleom. 10. 1; Lys. 7. 1 ; Pel. 25. 4, 26. 8; Tim. 5.1; Dio 4. 3, 7.1, 32.1; Phoc.

36.1; Eum.9.1 Aem. 37. 1; Cat. Mi. 9. 9, 14. 3; Brut.29.3.

Pertanto, adattando un noto detto stoico citato anche dal Cheronese si potrebbe dire che chi esercita la giustizia, agisce secondo tutte le virtù perché la giustizia, quando è la protagonista di un'azione, chiama in aiuto le altre virtù ed insieme ad esse tende verso il fine (De Alex. fort. virt. 1, 332 CD). Essa detiene il primato in quanto rappresenta la virtù più perfetta che l'uomo possa possedere ${ }^{39}$ : ad es. il coraggio non avrebbe alcuna utilità senza la giustizia e viceversa non vi sarebbe alcun bisogno del coraggio se tutti fossero giusti (Ages. 23.8). Tra tutte le virtù è quella che espone maggiormente all'invidia, perché

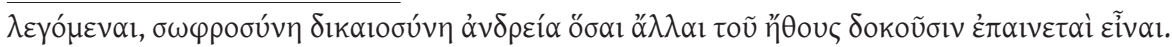

${ }^{37}$ Asp. EN, op. cit., pp. 40.9 e 139. $26 \mathrm{H}$.

${ }^{38}$ Plu., praec. ger. reip. 821B; Max. cum princ. 776 E, 777A.

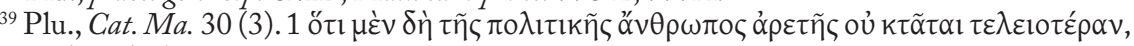

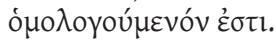


conferisce fama, fiducia e credito a chi la possiede influenzando le masse e non suscita semplicemente stima come il coraggio o ammirazione come la saggezza ma infonde nell'animo coraggio e fiducia (Cat. Mi. 44.12-13) perché il giusto è oggetto di amore. Dall' esercizio della giustizia nasce dunque la benevolenza, l'affetto e la riconoscenza che, anche per il mantenimento del potere, sono vincoli più robusti delle catene adamantine del terrore e della violenza (Dio 10.4).

Questa concezione della giustizia come virtù della medietà (Arist., EN $1133 b 32-33)$ che nei rapporti umani si oppone alla $\pi \lambda \varepsilon \sigma 0 v \xi \xi i \alpha$ trova conferma nelle Etiche aristoteliche (EN 1129a 32-b10, 1133b 32-33) ${ }^{40}$ e nei testi peripatetici ${ }^{41}$.

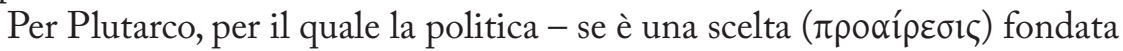
sul giudizio razionale e non su di un impulso nato da un desiderio di vana gloria o di rivalità o dall'assenza di altre occupazioni (Praec. ger. reip. $798 \mathrm{C}$ ) - non consiste nel ricoprire una carica, come pensano i più, ma è un modo di vivere e di agire ( l'attività più degna e più nobile (Praec. ger. reip. $798 \mathrm{E})^{42}$, la giustizia è con il retto giudizio ( $\varepsilon \dot{\beta} \beta o u \lambda i ́ \alpha)$ e la prudenza ( $\varphi \rho o ́ v \eta \sigma \varsigma)$ la virtù che caratterizza l' $' \xi \xi \zeta$ del politico, cui spetta il compito non facile e tanto meno sicuro di

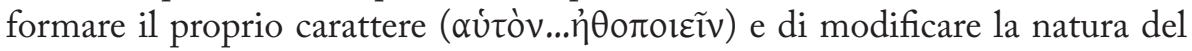
popolo ( $\mu \varepsilon \theta \alpha \rho \mu o ́ \tau \tau \varepsilon ı v ~ \tau o \tilde{~ \delta ́ ́ \mu o u ~ \tau ท ̀ v ~ \varphi u ́ \sigma ı v, ~ P r a e c . ~ g e r . ~ r e i p . ~ 799 B, ~ 800 B) . ~}$ Essa si manifesta nelle opere e nella condotta di ogni giorno ( e rende divina la vita passata in seno al potere (Arist. 6.5), perché le azioni politiche conseguono l'ornamento della bellezza e della grandezza solo se alla potenza e alla fortuna vadano congiunte prudenza e giustizia (Dio 1.3).

Ma se la virtù, che come un pollone forte e resistente mette radici ovunque quando trova una buona natura e un animo cui piace impegnarsi (Dem. 1.4), non è molto diffusa tra gli uomini - perché "la via che mena al vizio è piana e si presta ad essere fatta senza sudore" mentre "Alla virtù dinanzi gli dei immortali il sudore/ Han posto, lungo ed erto è il sentiero che ad essa conduce" come recita Esiodo $(O p$. 287-288) riportato anche da Platone nelle Leggi (4, 718e 5-719a 2) -, tra le virtù

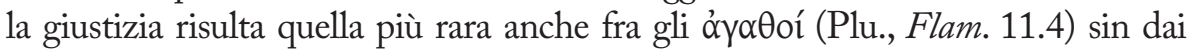
tempi mitici, quando si aveva la convinzione che la verecondia ( $\alpha \hat{i} \delta \omega ́ c)$, la giustizia,

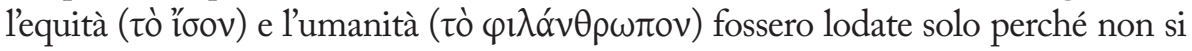
aveva il coraggio di commettere ingiustizia o perché si aveva paura di subirla. La

\footnotetext{
${ }^{40}$ Sulla nozione aristotelico-peripatetica di giustizia come medietà vd. anche Stob. 2.7.25,

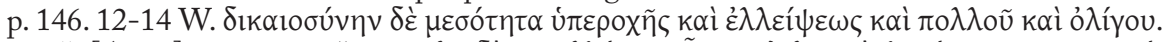

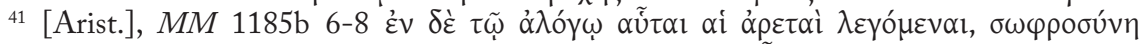

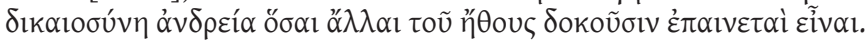

${ }^{42}$ Sull'attività politica che, come la filosofia, si manifesta nelle azioni e nella condotta di ogni giorno vd. Plu., An seni resp. $796 \mathrm{C}$.

${ }^{43}$ Plu., Max. cum princ. 776 E ; An seni resp. 791D, 792D; Praec. ger. reip. 818 A ; Sol. 5. 4-5.
} 
convinzione che le virtù politiche non si addicessero assolutamente a chi era capace di prevalere (Thes. 6.4) e che quindi si potessero curare meglio i propri interessi quanto meno si praticava la giustizia (Pyrrh. 12.12; Arist. 6.3) risulta radicata in epoca storica, dove vige la tendenza a sembrare più che ad essere giusto, che

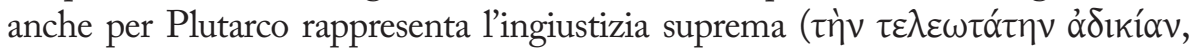
De adulat. $50 \mathrm{E})^{44}$, a magnificare la giustizia solo per trarne vantaggi e a considerare come bene assoluto il proprio interesse personale (Lys. 7.5), mascherando sotto il nome di giustizia comportamenti ingiusti (Pyrrh. 12.4) ${ }^{45}$. Questo spiega perché nessun re e tiranno ha mai invidiato il titolo di giusto. Gli uomini infatti anche se onorano e venerano gli dei per la loro giustizia, a dispetto di ciò aspirano ad adeguarsi e conformarsi a loro più per l' immortalità, che è incompatibile con la natura umana, e per il potere, che dipende nella maggior parte dei casi dalla fortuna; per quanto invece attiene alla virtù, il solo tra i beni divini che dipende da noi, essi lo piazzano all'ultimo posto, molto a torto, perché è la giustizia che rende divina la vita, soprattutto se vissuta in mezzo al potere e ad una grande fortuna, mentre l'ingiustizia la rende bestiale (Arist. 6.5). Anche per questo non sono pochi i personaggi delle Vitae plutarchee che, pur se dotati di buone qualità naturali che hanno loro permesso di distinguersi nelle azioni e nella condotta politica realizzando imprese valorose e di grande successo, non hanno poi saputo per la loro eccessiva ambizione o avidità contemperare le doti militari con le virtù più squisitamente politiche come moderazione, autocontrollo, umanità, grandezza d'animo e giustizia che sono doni della ragione e dell'educazione (Cor. 1.5). Si pensi ad es. a Temistocle, Alcibiade, Timoleonte, Agesilao, Filopemene, che nonostante l'educazione ricevuta fu più dotato di virtù militari che non politiche

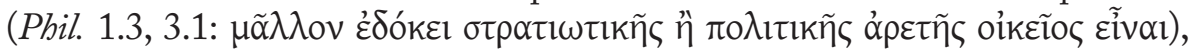
o a Catone il Censore a cui mancarono virtù come la temperanza, la bontà e la magnanimità, virtù che occupano un campo più vasto di quello della giustizia (Cat. Ma. 5.2-7), Coriolano, che respinse ogni moderazione e mitezza (Cor. 15.4), Tito Quinzio Flaminino al quale, pur se riportò la più bella e la più invidiabile delle vittorie occorse per la libertà della Grecia (Flam.1.5), Plutarco rimprovera l'avida ambizione e brama di gloria che gli impedì di mostrare nei riguardi di Annibale quella mitezza e quella grandezza d'animo che aveva contraddistinto a Zama Scipione l'Africano (Flam. 20.1-2, 21.1-2).

Plutarco sa che in generale l'indole naturale ${ }^{46}$, pur essendo nobile e buona, qualora manchi di educazione ( $\lambda$ óyou koì $\pi \alpha 1 \delta \varepsilon i ́ \alpha \varsigma$ ) produce, come la terra d'Egitto (Nic. 9.1), insieme a molti frutti salubri anche molti frutti nocivi,

${ }^{44}$ Cf. P1., R. 2, 361a 5-b 1.

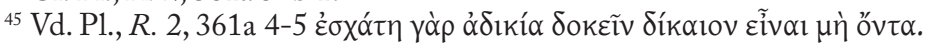

${ }^{46}$ Non mancano eccezioni come quella di Agide e Cleomene che, pur non avendo ricevuto

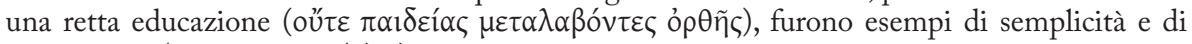
temperanza (C. Gracch. 20 (1).3). 
come accade in agricoltura ad un terreno fertile che non venga coltivato (Cor. 1.3; Arat. 10.5). La mancanza di educazione è la causa prima della debolezza

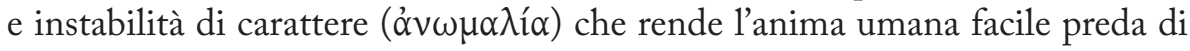
vuote opinioni e falsi giudizi (De superst. 164E-165C; De tranq. an. 465D, 468C-D, 475D; De gen. Socr. 584E; De exil. 600E, 602B; Cons. ad uxor. 609EF; lib. et aegr. c. 6; [cons. ad Apoll.] 102C, 119D). Questi, quando con il tempo e con l'abitudine hanno preso forza e vigore in una cattiva educazione, assillano e umiliano l'anima inducendola a soddisfare passioni acquisite dall'esterno ( $D e$ gen. Socr. 584E), perché l'anima umana, che ha in sé una carica affettiva che la porta per natura ad amare così come a sentire, pensare e ricordare, quando non trovi in sé niente da amare allora si attacca a beni esterni come gli onori e la ricchezza. L'agire umano per essere retto così da lasciare trasparire l'educazione ricevuta ${ }^{47}$ richiede che sia consolidato e rafforzato dal giudizio da cui trae origine $^{48}$, se è vero che il saggio differisce dalla maggioranza degli uomini per

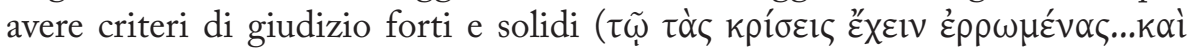
$\pi \varepsilon \pi \eta \gamma v i ́ \alpha c$, De Alex. fort. virt. 1,333B-C).

Questo tuttavia non ha impedito a Plutarco di individuare nella storia greca e romana personaggi che si sono distinti per temperanza, mitezza, umanità e giustizia ( $P$ el. 26.8) e che portarono la loro vita ad un grado di perfezione tale qual è possibile che raggiungano uomini soprattutto giudicati onesti e buoni (Publ. 23.3, 24(1).8) come Solone (Sol. 2.1-3.2,

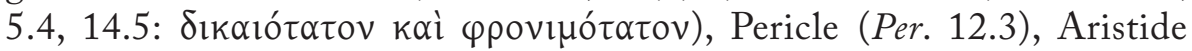
(Arist. 1.1; Cat. Ma. 30(3).2), Lisandro (Lys. 2.6, 30.6), Dione (Dio 52.14), Pelopida (Pel. 4.4, 26.8) ed Epaminonda (Phoc. 30.5; Pel. 26.8; Arat.,

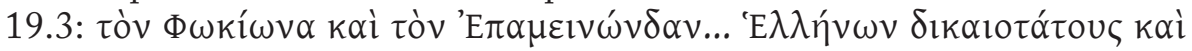

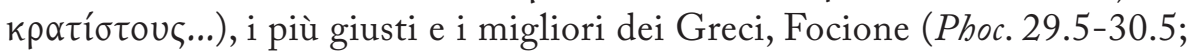
Dem.14.1), Arato (Arat. 14.4), il re Agide, che sarebbe rimasto indignato se l'avessero lodato per non avere preso niente che appartenesse ad altri, lui che offrì ai cittadini i propri beni (comp. Agis Cleom. Gracch. 1.7) e per il mondo romano Numa, Publicola (Publ. 23.3, 24(1).8), Emilio Paolo (Aem. 41(2).8), Marcello (Marc. 20.1-2), che fu il primo a mostrare che i Romani erano più giusti di quanto non si credesse, Tiberio e Gaio Gracco (T. Gracch. 3.1, 9.2-3; C.Gracch. 20(1).2) $)^{49}$, che ricevettero un' eccellente educazione

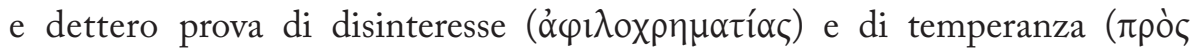

\footnotetext{
${ }^{47}$ Sull'insegnamento filosofico che è naturale traspaia nelle azioni di coloro che sono stati educati, conferendo loro insieme al decoro una certa qual misurata proporzione e armonia vd. Plu., Dio 1.4 .

${ }^{48}$ Sui giudizi degli uomini che vacillano, deviati da elogi e rimproveri, se non ricevono stabilità e forza dall'insegnamento filosofico in vista dell'azione vd. Plu., Tim. 6.1.

${ }^{49} \mathrm{Su}$ Gaio Gracco, che preferì subire ingiustizia piuttosto che commetterla vd. Plu., C. Gracch. 20 (1). 7-8.
} 


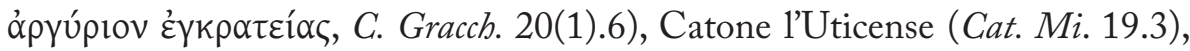
Vitellio (Galb. 22.7). Tutti questi dovettero la loro grandezza morale al fatto che fecero politica senza ricercare mai né la gloria né la ricchezza, ma piuttosto ostentarono la povertà come una virtù ${ }^{50}$ giudicando avidità non solo l'arricchirsi ingiustamente, ma anche possedere più di un altro (C. Gracch. 20(1).7-8). La povertà infatti quando rappresenta una scelta di vita, è segno di una superiorità morale che si manifesta soprattutto nell'esercizio della giustizia. Per questo non è facile imbattersi in chi sappia nobilmente sopportare la povertà, di cui si

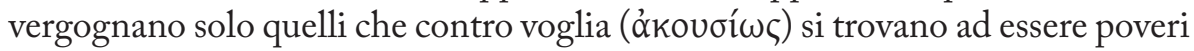
(Arist.25.7-8). Solo l'uomo giusto e onesto va superbo più per la povertà che per la ricchezza, che pur è utile e di per sé non è né disonorevole né disprezzabile ${ }^{51}$.

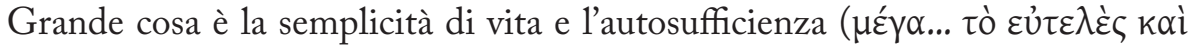

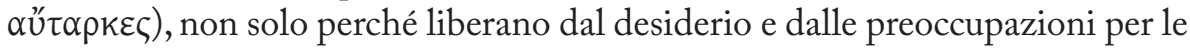
cose superflue (Cat. Ma.31(4).5), ma anche perché non è possibile che compia grandi cose chi ha preoccupazione di quelle piccine, né che possa sovvenire ai bisogni di molti chi ha bisogno lui stesso di molte cose. Bisogna che il possesso dei beni sia proporzionato alle necessità perché chi accumula molte ricchezze non è un uomo indipendente (Cat. Ma.31(4).3) e chi turpemente accumula dissipa poi in spese inutili (Crass. 34(1).4). Grande viatico per la politica non è la ricchezza, ma l'autosufficienza che, con la mancanza di ogni bisogno personale di beni superflui, non frappone alcun ostacolo al compimento del bene pubblico. Dio è assolutamente libero da ogni bisogno, quindi il tipo di virtù umana più perfetta e più vicina a Dio è quello in cui il bisogno è ridotto al minimo (Cat. Ma.31(4).2).

Così, diversamente dagli stolti che accumulano beni esterni prima di avervi posto un solido fondamento con l'ausilio della ragione e dell'educazione e senza così riuscire a soddisfare l'insaziabilità della loro anima (Mar. 46.5), si deve imparare a domare la propria avidità, che è la condizione necessaria per conseguire la giustizia. Solo chi ha imparato a praticare l'aútó $\rho \kappa \varepsilon l \alpha$ avanza con mente pura verso il bene, avendo coscienza nell'animo dei più alti valori ${ }^{52}$.

Se però con l'educazione non si riesce a tenere a freno l'avidità - a cui non pongono limite né i mari né i monti né i deserti e le cui brame non si arrestano neppure dinanzi ai confini che dividono l'Europa dall'Asia (Pyrrh. 12.3) - e ad accontentarsi di quello che si ha e se per arricchirsi si rende

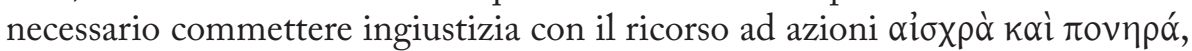

${ }^{50}$ Vd. Plu., Phoc. 29.5 - 30. 5 ; Pel. 3.4 .

${ }^{51}$ Sull'utilità della ricchezza vd. Plu., Per. $16.7 ;$ Pel.3.2.

${ }^{52}$ Plu., De gen. Socr. 584F. Cf. Gal., de propriorum animi... 1.9.13, p. 58 Magnaldi $\pi \circ \lambda \lambda \tilde{\omega}$

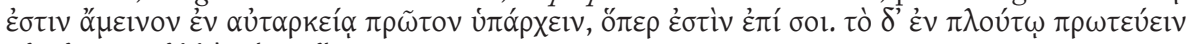

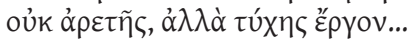


allora bisogna alzare il prezzo dell'ingiustizia e non passare sopra la giustizia alla prima occasione, come sembra facesse Crasso che, avido com'era ${ }^{53}$, trattava male gli alleati, circuiva le donnette e proteggeva i disonesti (Crass.34(1).2; De adulat. $57 \mathrm{C}$ ), quasi che la giustizia fosse qualcosa di meschino o di insignificante (Crass. 37(4).3) oppure pusillanimità e incapacità d'agire (De adulat.57C: $\omega \varsigma \zeta$

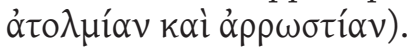

Avviandomi alla conclusione non posso non rilevare come questa riflessione etico-politica sulla giustizia, che ha esiti determinanti per l'assetto di una società, continui ancora oggi ad essere oggetto di indagine non solo nel campo della filosofia politica ma anche da parte di studiosi di economia politica nella profonda convinzione che l'analisi economica possa offrire un contributo all'etica sociale, che sta a fondamento del mondo in cui viviamo.

Dopo la teoria utilitaristica della giustizia, che sulla scia di Trasimaco mira al benessere del più forte, a partire dagli anni Settanta si è assistito alla fioritura di teorie alternative, più attente alla dimensione e alle valenze etiche dei problemi nella società contemporanea ${ }^{54}$. Al di là delle ovvie differenze tra le teorie degli antichi e quelle post-kantiane dei moderni non si può fare a meno di registrare una forte analogia di pensiero almeno nell'individuare e denunciare la causa prima dell'ingiustizia sociale nel comportamento dell'individuo che, mosso dalle proprie passioni, persegue incessantemente e senza compromessi l'utile personale, si accredita - per usare le parole dell'indiano Amarthia Kumar Sen, premio Nobel per l'economia nel '98 - come «un rigido massimizzatore di angusti interessi personali», determinando ieri come oggi società ingiuste.

${ }^{53}$ Sull'avidità come peggiore vizio di Crasso vd. Plu., Crass. 2.1.

${ }^{54}$ Tra queste teorie che hanno mutato l'approccio alla teoria della giustizia meritano di essere ricordate prima quella dell'americano J. Rawls 1971, professore emerito di filosofia politica dell'Università di Harvard, che ha spostato il baricentro dalla ricchezza, considerata un mezzo e non più un fine, all'individuo, poi quelle dell' economista indiano A. K. SEN 2009, repr. 2010 e della statunitense M. Nussbaum 2006, che hanno portato al centro dell'attenzione l'importanza politica ed etica della libertà individuale nell'ambito di una società giusta. 


\section{Bibliografia}

Gastaldi, S. [D], “Dikaion/ dikaiosyne”, in Vegetti, M. 1998.

Gauthier, R. A.; Jolif, J. Y., Aristote, L'Éthique à Nicomaque. Introduction, traduction et commentaire. T. II, Première Partie, Louvain, Paris, ${ }^{2} 1970$.

Gospic, K.; Mohlin, E.; Fransson, P.; Petrovic, P.; Johannesson, M.; Ingvar, M., "Limbic Justice-Amygdala Involument in Immediate Rejection in the Ultimatum Gare", Plos Biology, Maggio 2011.

Jellamo, A., Il cammino di Dike. L'idea di giustizia da Omero a Eschilo, Roma, 2005.

Jounnna, J., Sophocle, Paris, 2007.

Maffettone, S.; Veca, S., L'idea di giustizia da Platone a Rawls, Roma, Bari, ${ }^{6} 2008$.

Moraux, P., À la recherche de l'Aristote perdu: le dialogue «Sur la Justice», Louvain, 1977.

Nussbaum, M., Frontiers of Justice, Cambridge, Mass., 2006.

Rawls, J., A Theory of Justice, Cambridge, Mass., 1971 [Milano, 1982].

Rawls, J., Justice as Fairness: a Restatement, Cambridge, Mass., 2001 [Milano, 2002].

SEn, A. K., The Idea of Justice, Cambridge, Mass., 2009 [Milano 2010].

Vegetti, M., Platone, La Repubblica. Traduzione e commento, Vol. I - Libro I, Napoli, 1998.

Zanetti, G., La nozione di giustizia in Aristotele, Bologna, 1993. 
(Página deixada propositadamente em branco) 


\title{
La giustizia del saggio: una polemica di Plutarco contro gli Stoici
}

\author{
Paola Volpe Cacciatore \\ Università di Salerno
}

\begin{abstract}
This contribution is designed - on the basis of Plutarch's work, and particularly of the fragments 35-39 Sandbach - to emphasize how justice - the highest of civic virtues - can be implemented only in a wise polis (Plato) that is able to respect the laws, if these are not exploited by one part against the other (Aristotle). Far from that we read in the Stoics, this kind of justice is linked to the "regency" of divine logos, as the natural law that in the same way connects all humanity.
\end{abstract}

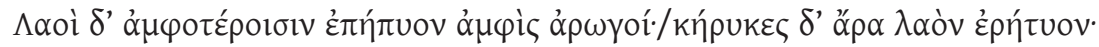

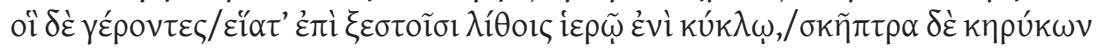

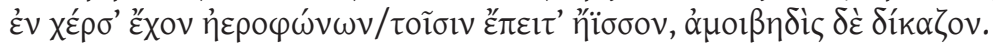

(Il. 18.502-506)

Divisi i favori, la folla si schierava con l'uno o con l'altro/ gli araldi trattenevano intanto la gente e gli anziani/ sedevano in sacro cerchio sui lisci sedili di pietra/ e dagli araldi voci squillanti prendevano in mano/ lo scettro: con esso s'alzavano a turno esprimendo il parere.

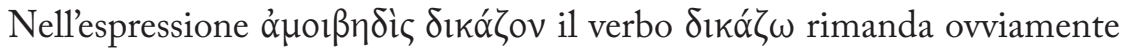
al sostantivo $\delta i ́ k \eta$, donata agli uomini perché essi possano vivere civilmente. Ma $\Delta$ íkn è anche una dea. Figlia di Themis e Zeus, è la dea del giudizio e della decisione ${ }^{1}$ che, allontanata dall'Olimpo per la troppa severità, continuerà a difendere i diritti dei morti e le leggi non scritte 2 . E così Dike, "sempre in simbiosi con la verità, comparirà con molti significati (può indicare il giudizio formulato da un tribunale o più in generale il diritto oppure la giustizia e finanche il costume) ma la sostanza è sempre quella di un atto, l'atto di giudicare, così come la sostanza indicata da Themi è l'atto del consigliare" (C. De Pascale

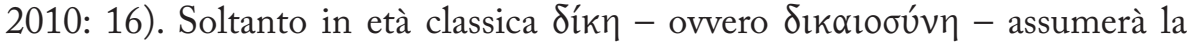
forma della virtù, una virtù che appartiene all'individuo che tende ad una "good life, a life of eudaimonia (...) thought to involve both acting well and being well off"'s La più alta delle virtù, propria dell'uomo che vive in una comunità, in una

${ }^{1}$ Come si legge in $I l .18 .508$.

${ }^{2}$ Lo dirà Antigone ai vv. 450 e ss. dell'omonima tragedia sofoclea: "la legge è male, ma è la legge di Tebe e di Creonte contro la quale un'altra legge soccorre la pietosa sorella”. Cf. P. Piovani, 2006.

3 "Nel mondo di Esiodo, anteriore al regime della città, la dike operava ancora su due piani, come lacerata tra il cielo e la terra: per il piccolo coltivatore beota, quaggiù la dike è una decisione 
polis giusta (Platone) e che sappia rispettare le leggi (Aristotele) $)^{4}$. Dunque una comunità nella quale a buone leggi corrisponda un vivere virtuoso: è quanto richiamato dal fr. 36 Sandbach, nel quale, commentando il v. 240 degli Erga di Esiodo, "Spesso anche un'intera città soffre a causa di un uomo malvagio",

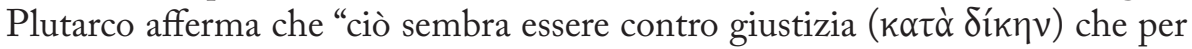
colpa di un solo malvagio sia punita un'intera città". Le ipotesi, continua il Cheronese, possono essere due: o il poeta vuole intendere che la città "stenda su tutta se stessa la malvagità, rendendosi simile a quel solo oppure che per colpa di un unico scellerato tutta la città paghi il fio per non aver arrestato, pur potendo, la malvagità di uno solo". La conclusione cui egli giunge è la seguente - anche alla luce di quanto avvenne in Grecia a causa della üßpıৎ di Agamennone: "non bisogna cedere ai prepotenti né assentire a chi compie una qualche ingiustizia, trascurando, pur avendone la possibilità, di arrestare l'arroganza dei malvagi"'.

La città cioè deve garantire il vó $\mu \circ \zeta^{6} ;$ perché se non vi sono giustizia e il conseguente castigo per chi commette ingiustizia "né i giusti otterranno di più

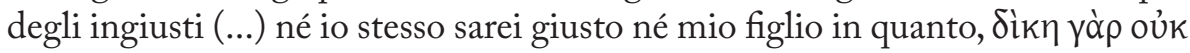

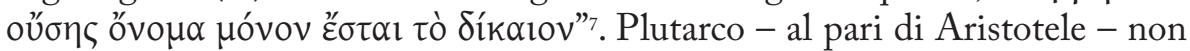
volge la sua attenzione all'individuo - in quanto tale - ma al cittadino ( $\zeta \tilde{\omega} o v$ $\pi 0 \lambda$ i 1 kóv), che vive a contatto con altri uomini, richiamando così ad un concetto di morale non individuale, ma 'collettiva e concreta' ossia "all'insieme di comportamenti virtuosi che vengono posti in essere all'interno di quella comunità politica che è la polis" (C. DE Pascale 2010: 16). In tal modo etica e politica convergono in quanto la seconda essendo "la scienza più direttiva $\mathrm{e}$ architettonica al sommo grado (...) dispone quali delle scienze sono necessarie

che di fatto dipende dall'arbitrio dei re "mangiatori di doni"; in cielo è una divinità sovrana ma lontana e inaccessibile”: J.-P. VERnANT 2007: 44.

4 " $<\mathrm{Ma}>$ la polis, che ancora per Aristotele era il luogo della condivisione familiare, amicale e comunitaria, non viene più considerata un rimedio disponibile. Per la filosofia ellenisticoromana la vita in comune è all'origine, piuttosto, del vizio. 'Non è partecipando alla vita pubblica, dice Seneca (Ep. 7.1-2), che si assimila quel sapere che ci permetterà poi di agire bene"': V. Gessa Kurotschka-S. Maffettone 2000: 83.

${ }^{5}$ La traduzione del frammento è di S. Amendola in P. Volpe 2010: 71.

${ }^{6}$ Cf. Cic. Leg. 1.6.18-19 = SVF III.315: “(...) la legge (...) è ragione suprema, insita nella natura, che comanda le cose da farsi e proibisce le contrarie (...). Ritengono (gli Stoici) che il nome greco che definisce la legge ( che è suo (...). Essa è nata prima del tempo, prima che fosse stata scritta una qualsiasi legge (...)". Cf. ancora Cic. Rep. 3.22, 33 = SVFIII.325: "Ora questo nomos non è un istituto umano; è la giustizia immanente connessa al reggimento del logos divino, è il diritto naturale (...) che vincola tutti gli uomini della terra nello stesso modo. Il diritto positivo è diritto solo nella misura in cui si armonizzi con la legge razionale". Cf. N. O DAhl 2000: 208; M. Pohlenz 2000: 269.

${ }^{7}$ È il fr. 38 che commenta i vv. 270-272 delle Opere: "ora né io sarei giusto tra gli uomini né mio figlio, poiché è un male essere giusti se chi è più ingiusto avrà maggiori diritti” (trad. di S. Amendola in P. Volpe 2010: 73). 
nelle città e quali ciascuna classe di cittadini deve apprendere e fino a che punto" (Arist. EN 1094b). In tal modo Aristotele calava nel mondo reale il progetto platonico della città ideale. A Platone e ad Aristotele si richiamava Plutarco allorquando, in due opuscoli dedicati all'attività politica, che necessariamente deve avere "come supporto stabile e forte, la libera scelta

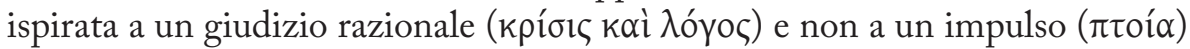
provocato da vanagloria o da qualche rivalità o dalla difficoltà di dedicarsi ad

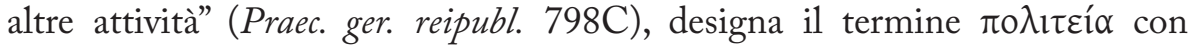

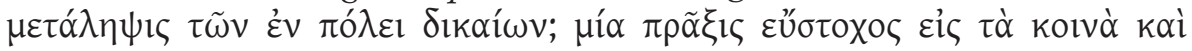

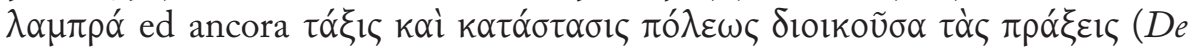
un. in rep. dom. 826C) . A tale definizione segue in Plutarco - come già in Aristotele - l'illustrazione delle tre forme che la politica può assumere e cioè la monarchia, l'oligarchia, la democrazia'. E queste - come avviene nelle scale

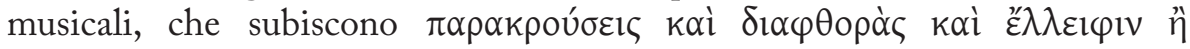

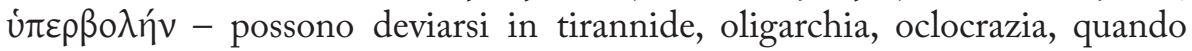
prevalgono űßpıৎ, $\alpha u ̈ \theta \alpha \delta \varepsilon \varsigma, ~ \grave{\alpha} \mu \varepsilon \tau \rho i ́ \alpha$. La giustizia, il rispetto delle leggi, si realizzerà soltanto là dove vi è una $\pi 0 \lambda_{\imath} \tau \varepsilon i ́ \alpha$ corretta, che sappia, in nome del

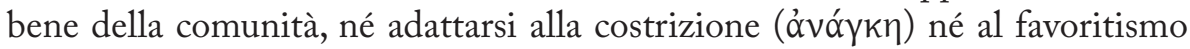

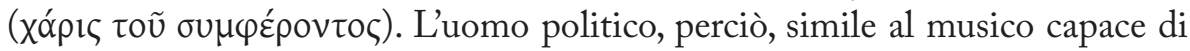
accostare ogni strumento al canto, dovrà usare moderazione in un governo oligarchico e decisione in una democrazia. "Ma se gli fosse concessa la scelta delle costituzioni (...) non preferirebbe altra costituzione se non la monarchia, la sola in grado di sostenere quel "tono" veramente perfetto ed elevato della virtù (...)" ${ }^{\prime \prime}$. Il politico deve, cioè, comportarsi "come il timoniere che cercando di assicurare ciò che è sempre vantaggioso per la nave e per i naviganti, senza stabilire norme scritte, ma disponendo della sua arte come legge, mette in salvo i compagni; allo stesso modo potrebbe avere origine una retta forma di governo (...) amministrando sempre a vantaggio di coloro che vivono nello Stato la perfetta giustizia $(. .)<$. in modo da> metterli in salvo e renderli migliori, per quanto possibile, da peggiori che erano" (P1. Plt. 297d). In tal modo l'uomo politico diviene "educatore" e la sua città ben governata, "precettore e maestro

${ }^{8}$ Alla "politica" intesa come scienza non frammentaria (cf. P1. Lg. 630e: “(...) il dio stabilì le leggi badando non a una parte della virtù (...) ma a tutta la virtù nel suo complesso) spetta il compito di studiare la costituzione migliore in senso assoluto; di studiare la costituzione che si adatta ai diversi popoli, di studiare la costituzione fondata su un certo presupposto ( $\dot{\varepsilon} \xi$

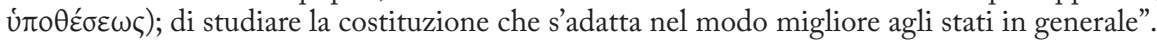

${ }^{9}$ Plutarco non mostra, in verità, di avere una vera preferenza per un regime politico piuttosto che un altro. Seguendo il dogma platonico ritiene superiore la monarchia sulle altre forme di governo (Cf. De un. rep. dom. 827B; An seni resp. 790A) ma, nella sostanza, sembra approvare tanto la costituzione di Licurgo quanto la democrazia soloniana. Cf. D.L. $7.131=$ SVF III.175 von Arnim.

${ }^{10} \mathrm{Il}$ riferimento è a $\mathrm{Pl}$. Plt. 296d-e. 
di equilibrio per i cittadini” (Plu. Lyc. 30.5) sia nella loro vita individuale che in quella della comunità. $\grave{E}$ questo il fine cui deve tendere ogni ordinamento politico in nome della virtù politica della quale, con Licurgo, Plutarco indica come esempio Numa che - quasi a testimonianza della dottrina platonica affermò: "per gli uomini unica tregua e liberazione dai mali è che (...) il potere del re s'incontri col discernimento del filosofo e faccia della virtù la dominatrice e sovrana del male" (Plu. Num. 20.9). ${ }^{11}$ Ma tale liberazione dai mali è possibile solo se si ammette il progresso sulla strada della virtù che prende il nome di "prudenza quando esamina ciò che si deve e non si deve fare, $<$ di $>$ temperanza quando regola il desiderio e definisce la misura e la convenienza nei piaceri, giustizia quando regola i rapporti e le relazioni sociali" (De virt. et vit. 440F-441A). Plutarco, dunque, al pari dei suoi maestri, considera prioritaria "una sana koinonia", ossia una comunanza nella quale tutti, ciascuno nel proprio campo, esercitano una peculiare virtù. Ciascuno, quindi, e non solo il saggio, il quale - secondo quanto affermavano gli Stoici - è l'unico ad avere una virtù perfetta $^{12}$, essendo privo di passioni e di conseguenza non solo alieno da ogni immediato coinvolgimento in una realtà necessariamente distante dalla ragione universale, ma anche del tutto disinteressato a farsi coinvolgere da ciò che deve restargli indifferente: "infatti allorché l'animo (...) si sarà affrancato da ogni timore della morte e del dolore, allorché avrà stabilito con i suoi simili un rapporto sociale fondato sull'amore e avrà considerato tutti i suoi simili congiunti per natura, e si sarà impegnato nel culto agli dei ed in una pura concezione religiosa, ed avrà reso acuta, al pari di quella degli occhi, quella virtù dell'intelletto onde scegliere il bene e rigettare il contrario, virtù che dal prevedere fu denominata prudenza (id est saggezza) che cosa mai si potrà dire o pensare di più felice di lui?" (Cic. Leg. 1.60) ${ }^{13}$. E proprio il saggio, essendo conoscitore del bene e del male, può partecipare alla vita politica perché è l'unico a conoscere la legge "sovrana di tutte le cose, divine o umane. Essa deve sovrastare tutte le realtà buone e cattive e su di essa esercitare potere ed egemonia; deve fissare i canoni del giusto e dell'ingiusto, e, per i viventi che stanno per natura in società, comandare quel che va fatto e vietare quello che non va fatto" (SVF III.314 Arnim-Radice). La legge - farà eco Cicerone (Leg.

${ }^{11}$ Cf. P1. R. 487e; 499b; 501e; Lg. 712a.

${ }^{12}$ Plutarco - al contrario degli Stoici - ammette che la perfezione non è raggiungibile dall'uomo (Plu. Tim. 6.7).

${ }^{13}$ C. De Pascale 2010: 36. Cf. anche Plu., De prof. in virt. 75C-D. È comunque da sottolineare che "quando (...) vogliono parlare realisticamente di quel che accende effettivamente, gli Stoici ammettono che c'è progresso verso la virtù e ammettono che si può essere più o meno lontani da questa e che è meglio esserle il più vicino possibile. I gradi del progresso sono quelli distinti nella teoria del kathekon (...)": P. Donini; F. FERrari 2009: 245 ss. Sulla impassibilità e infallibilità del saggio stoico cf. Gal., Anim. Pass. 5.11K; Alex. Aphr., De fato (Suppl. Arist. II.2.199, 17-18 Bruns = SVF III.658). 
1.5) - non va intesa come consuetudine o usanza, ma come essere eterno, espressione del logos. La legge, cioè, di natura, quella degli uomini, non può che equivalere alla legge di ragione così come vivere secondo natura non significa altro che vivere secondo i dettami della ragione ${ }^{14}$. La legge non era dunque alla base di una kolv $\omega v i \alpha^{15}$ e la giustizia, che di essa era espressione, non poteva intervenire a ristabilire nei rapporti fra gli uomini l'equità violata in nome di un diritto positivo che - secondo gli Stoici - esisteva solo se in armonia con il diritto naturale ${ }^{16}$. Il saggio stoico, pertanto, non solo non può far torto ad alcuno, ma anche semplicemente far danno e, in quanto tale, egli è l'unico che possa mettere a disposizione dello Stato la sua sapienza, perché in lui le due leggi, la positiva e la naturale, convergono. Ma questo comportava una non-trascendenza del divino, un suo mescolarsi "ad una materia che patisce costantemente e a realtà soggette ad ogni sorta di necessità, accidenti e mutamenti” (D. BABut 2003: 103). È quanto afferma il Cheronese nell'opuscolo intitolato $A d$ principem indoctum

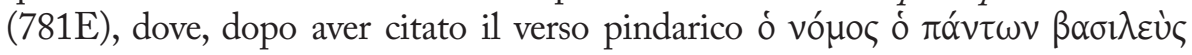

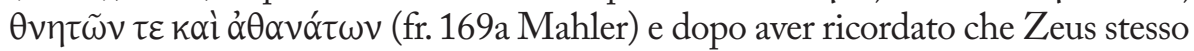

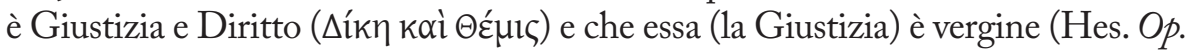
256), è incorruttibile, compagna del rispetto, della temperanza e della semplicità, rinvia a Catone, del quale - nel confronto con Focione - delinea così il carattere: “(...) l'umanità mescolata in misura uguale all'austerità, il coraggio alla cautela; la sollecitudine per gli altri, il disprezzo del pericolo per sé, il rifiuto della turpitudine, la nobile tensione verso la giustizia" (Plu. Cat. Ma. 3, 8). E nonostante tale 'virtù antica', che gli valse rispetto e gloria, Catone non riuscì ad armonizzare il suo comportamento con le esigenze degli altri "poiché la sua austera grandezza non era adatta alle circostanze dell'epoca” (Cat. Ma. 30.3). Come scrive D. BAbut 2003: 406 ss., le idee morali di Plutarco paiono contrapporsi ai principi morali della filosofia stoica, ma il problema era nella diversa concezione del $\operatorname{cosmo}^{17} \mathrm{e}$

${ }^{14}$ Il testo ciceroniano riprende un passo dell' Etica Nicomachea (1134b): "del giusto politico una parte è naturale, un'altra legale. Quella naturale ha dappertutto la stessa efficacia e non dipende dalle nostre opinioni; quella legale è originariamente indifferente se sia così o in altro modo, ma una volta posta non è più indifferente". Cf. anche Arist., $R h .1373 \mathrm{~d}$ : "La legge può essere propria e comune. Propria è quella che ciascuno pone a se stesso e questa può essere tanto scritta quanto non scritta. Comune è quella che è secondo natura". Vi sono dunque regole che derivano dalla natura e sono il diritto naturale, altre regole che derivano dall'arte o dalla convenzione, e sono il diritto positivo: cf. N. Bоввіо 1963: 25-37.

${ }^{15}$ Ossia una moltitudine di uomini che abitano nello stesso luogo e sono governati dalla legge.

${ }^{16}$ Cic. Rep. 3.6: Est quidem vera lex recta ratio, naturae congruens, diffusa in omnis, constans, sempiterna: quae vocet ad officium iubendo, vetando a fraude deterreat (...) Nec vero aut per senatum aut per populum solvi hac lege possumus, neque est quaerendus explanator aut interpres eius alius; nec erit alia lex Romae, alia Athenis, alia nunc, alia posthac, sed et omnes gentes et omni tempore una lex, et sempiterna et immutabilis continebit; unusque erit quasi magister et imperator omnium Deus. Un diritto naturale, perciò, non generato dalla conoscenza occasionale ma immerso nella natura dell'uomo da una vis innata, cioè a dire religio, pietas, gratia, vindicatio, e observantia (Cic., Inv. 3.6).

${ }^{17}$ Presso gli Stoici il mondo ha tre diverse accezioni: a) esso è Dio stesso indistruttibile e ingenerato, 
dell'uomo. Ai suoi occhi "lo stoicismo misconosce due volte la natura umana non più di quanto esista una virtù assolutamente $\operatorname{pur}^{18}$, non esiste neppure una passione in cui non sussista una qualche traccia di ragione" (D. BABUT 2003: 368-369). Questo significa che nessun uomo può essere solo virtuoso o solo perverso anche perché - come si legge in Plu. Tim. 6.7 - se ciò fosse possibile, nascerebbe da una

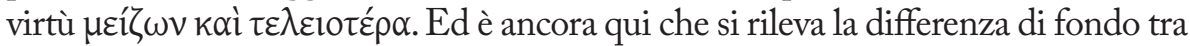
Plutarco e gli Stoici, ovvero "tra il pessimismo morale degli Stoici, associato a un ottimismo metafisico, e l'ottimismo di Plutarco sull'uomo che si coniuga con il pessimismo della sua visione del mondo"(D. Babut 2003: 407). Posto dunque che non esiste un uomo che, in breve lasso di tempo, passa dalla condizione più miserabile alla virtù eccelsa (De profect. in virt. $75 \mathrm{D}-\mathrm{F})^{19}$, al Cheronese si possono attribuire le parole che leggiamo in Seneca (Ben. 3.18): "La virtù non è preclusa ad alcuno, è accessibile a tutti, accoglie tutti, chiama tutti, liberi liberti, schiavi, re, esuli. Non sceglie la casa o il chiuso, si accontenta dell'uomo nudo". Ma ciò in alcun modo può eliminare quell'elemento passionale che è proprio dell'uomo dal momento che egli è anima e corpo, ossia elemento razionale e irrazionale:

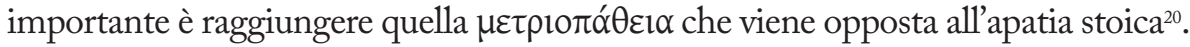

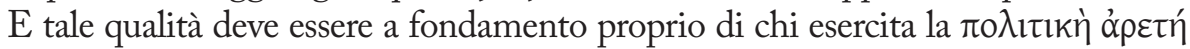
perché "il valore politico degli uomini non si misura esclusivamente dalla loro qualità morale" (D. BABut 2003: 403); non più chiuso nel suo "limbo", il saggio-

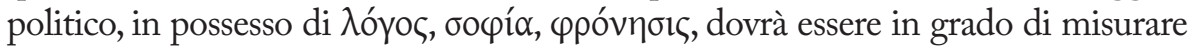
la sua virtù con i 'bisogni umani' (Plu. Per. 16.7), dovrà essere ponderato e mite, giusto in nome della legge, "desideroso di adattare le leggi alle cose, piuttosto che le cose alle leggi”" (Plu. Sol. 22.3) 21.

artefice dellordinamento razionale; b) è ordinamento degli astri; c) è l'unità dei due principi, passivo e attivo.

${ }^{18} \mathrm{Cf}$. An virt. doc. 439B: "(...) non è possibile trovare un risultato perfetto riguardo alla virtù né un carattere privo di passione né una vita intatta da vizio, ma, se anche la natura produce qualcosa di buono spontaneamente, questo è offuscato dal molto che c'è di estraneo, come un prodotto mescolato con materia selvatica e impura?" (trad. A. Barigazzi) Cf. anche De soll. anim. 964D-E; De cap. ex inim. util. 99E.

19 "Quelli che non adattano i principi alla realtà, ma forzano la realtà ad adattarsi contro la sua natura ai loro presupposti, hanno riempito la filosofia di molte aporie, massima delle quali è la dottrina secondo cui tutti gli uomini si trovano nello stesso vizio tranne uno, solo, colui che è perfetto; ragione per cui non si capisce più che cosa possa essere quello che si chiama progresso ...”.

${ }^{20}$ Le virtù etiche sono definite da Plutarco come un "giusto mezzo tra l'eccesso e il difetto che sorge dalla parte irrazionale dell'anima” (cf. Plat. quaest. 9, 1009A-B). In tal modo si sostituisce all'apatheia stoica la metriopatheia peripatetica (per l'uso del termine $\mu \varepsilon \tau \rho 10 \pi \alpha ́ \theta \varepsilon \varepsilon \alpha \mathrm{cf}$. anche $D e$ sera num. vind. 551C e Adv. Col. 1119C).

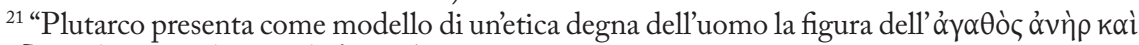

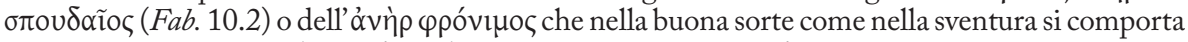

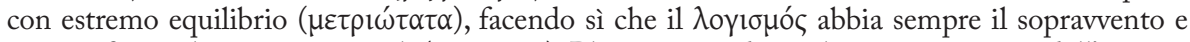
tenga a freno gli istinti passionali (Fab. 24.9). Plutarco quindi con la ricomposizione dell'antitesi ragione-passione segna il ritorno ad un'etica capace di additare reali paradigmi di virtù (De Stoic.

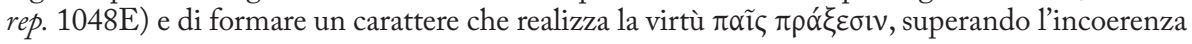


Legge e giustizia sono indissolubilmente legate, ma allora cosa è la giustizia e cosa è l'ingiustizia; cosa significa essere giusti e cosa essere ingiusti? Nel libro IV della Repubblica Platone, dopo aver esaminato le principali dottrine a lui precedenti, afferma che la giustizia consiste in quella virtù per la

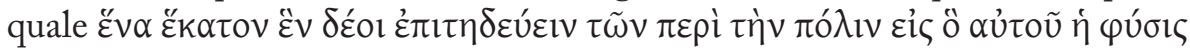

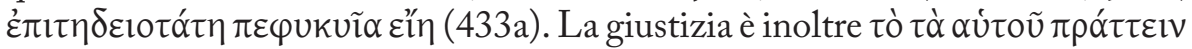

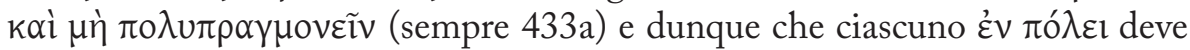
attendere al proprio compito (434c). Ma essa è anche virtù dell'individuo, nel quale si fondano armonicamente le tre parti dell'anima: la 'passione di apprendere', 'l'elemento animoso', 'la brama di godimento' (435e; 435c; 436ab); a ciascuna delle tre parti corrisponde una virtù, ma solo la giustizia "è la consapevolezza critica che è bene essere temperanti tutti, coraggiosi chi deve essere coraggioso, prudente chi deve essere prudente, ponendosi là dove è bene e dove è giusto che sia" (F. Adorno 1975: 207).

Per Aristotele ( $E N 1129 \mathrm{~b})$ la giustizia è la virtù perfetta e, usando anche per essa il metodo matematico-geometrico dell'equidistanza, il comportamento giusto sarà la via di mezzo fra il compiere e il sopportare l'ingiuria (H. Kelsen 1966: 426). È evidente che "chi viola la legge è ingiusto mentre chi la rispetta è giusto e che tutte le azioni che rispettano la legge sono giuste" (Arist. EN $1129 \mathrm{~b}$ ). La giustizia non è solo il possesso della virtù, ma l'uso di essa, e l'habitus virtuoso concerne il rapporto con gli altri. Potremmo allora dire che proprio nell'immanenza della giustizia è la differenza tra Plutarco e la visione stoica, per la quale il saggio non si lascia coinvolgere negli avvenimenti umani: non è partecipando alla vita pubblica - dirà Seneca $(E p .7)$ - che si assimila quel sapere che ci permetterà di agire bene. Ma tale comportamento, fondato sull'impulso all'autoconservazione, non era facilmente spiegabile ed è proprio Crisippo a risolvere il problema in nome dell'oikeiosis e dell' impulso di autoconservazione. E infatti nel De Stoic. rep. 1043B Plutarco ricorda, citando il primo libro della vita di Crisippo, come "il saggio accetterà di buon animo la carica di re ed anche trarrà profitto da essa, e se non potrà regnare di persona, vivrà con il re e combatterà insieme con lui". Dunque non un rifiuto assoluto e così "gli Stoici potranno anche accettare e riproporre il concetto aristotelico dell'uomo come un animale portato all'aggregazione sociale" (P. Donini; F. FERrARI 2009: 259), ma Crisippo, a chi gli chiedeva perché non partecipasse alla vita politica, soleva rispondere "Perché se uno amministra male scontenta gli dei, se amministra bene scontenta gli uomini" (Stob. Flor. 45.29 = SVFIII.174).

Allora in conclusione si potrebbe dire con Aristotele (Arist. Rh. 1375a) che l'osservare le leggi è proprio dell'uomo migliore.

più grave per un filosofo, quella tra teoria e pratica (De Stoic. Rep. 1033A-B)": F. Becchi 2004: 27. 


\section{Bibliografia}

Adorno, F., La flosofia antica, vol. I, Milano, 1975.

Babut, D., Plutarco e lo stoicismo. Presentazione di R. Radice, edizione italiana a cura di A. Bellanti, Milano, 2003.

Bессні, F., "Plutarco e il Peripato: tre esempi di filologia filosofica", Prometheus, 30, 2004: 26-42.

Воввіо, N., Locke e il diritto naturale, Torino, 1963.

Dahl, N. O., "Plato's Defence of Justice", in G. Fine (ed.), Plato. (vol. 2): Ethics, Politics, Religion, and the Soul, Oxford, 1999: 207-234.

De Pascale, C., Giustizia, Bologna, 2010.

Donini P.; Ferrari, F., L'esercizio della ragione nel mondo classico, Torino, 2009.

Gessa Kurotschka, V.; Maffettone, S., Etica individuale e giustizia, Napoli, 2000.

Kelsen H., I fondamenti della democrazia e altri saggi, traduzione italiana di A.M. Castronovo, F. L. Cavazza, G. Melloni, in appendice N. Matteucci, Democrazia e cultura in Hans Kelsen, Bologna, 1966.

Piovani, P., "Per una interpretazione unitaria del Critone", in G. Giannini (ed.), Indagini di storia della filosofia. Incontri e confronti, con una nota di F. Tessitore, Napoli, 2006.

Pohlenz, M., La Stoa. Storia di un movimento spirituale. Presentazione di G. Reale, traduzione di O. De Gregorio, note e apparati di B. Proto, Milano, 2000.

Vernant, J.-P., Le origini del pensiero greco, traduzione di F. Codino, Milano, 2007.

Volpe, P., Plutarco, Frammenti, a cura di P. Volpe Cacciatore, Napoli, 2010. 


\title{
Dike y otras deidades justicieras en la obra de Plutarco
}

Miguel Herrero de Jáuregui

Universidad Complutense de Madrid

\begin{abstract}
This paper deals with Plutarch's use of the Greek deities of justice. While Dikaiosyne, Themis, Nomos and Eunomia are hardly mentioned, other deities more strongly rooted in the mythological tradition appear in several passages not only in citations or comments of ancient poets, but are also incorporated into Plutarch's discourse: Erinis, Poine, Nemesis, and Dike. They are conceived as dynameis of divine origin, which can be perceived as personified daimones. They appear more often in the Lives, but also in some passages from the Moralia which make concessions to traditional mythical language (e.g., the final myth of the dialogue De sera numinis vindicta). These deities of punishment are portrayed by Plutarch as working between the realms of mechanical cosmic compensation and moral retribution of evil deeds, thus contributing to his attempts to find in human history the traces of divine justice.
\end{abstract}

\section{Plutarco y la tradición de personificaciones míticas}

La tradición poética griega desde Hesíodo utilizaba las personas divinas para reflejar con plasticidad los múltiples aspectos de los conceptos abstractos. También las adoptaron filósofos-poetas como Parménides y Empédocles y el propio Platón en sus recreaciones míticas. Poesía, religión y literatura filosófica se encuentran aquí en un campo fértil para la imaginación especulativa. Un terreno abonado para este tipo de figuras míticas era el amplio campo semántico de la justicia, que englobaba muchos conceptos próximos entre sí expresados por palabras como themis, dike o dikaiosyne, alegorizadas como personas distintas pero asociadas: por ejemplo, la colección de Himnos Órficos, datada usualmente en el siglo II d. C., encadena cuatro himnos (6164) a Nemesis, Dikaiosyne, Dike y Nomos, que las presentan como divinidades diferentes, aunque la misma colocación de los himnos juntos muestra su obvia interrelación. En torno a la misma época Plutarco, dentro de su inmensa labor de recepción y reelaboración de la tradición cultural griega, utiliza los recursos de la personificación para definir algunos aspectos de su noción de la justicia cuyos matices se perfilan con gran plasticidad en ciertas figuras míticas. Poco es lo que inventa Plutarco: todas las deidades que vamos a encontrar aparecen en la literatura e iconografía anterior y contemporánea, combinadas de diversos modos $^{1}$. En un volumen dedicado a la idea de justicia en Plutarco, es necesario estudiar el uso de las deidades que la representan en su obra. Este trabajo pretende iluminar, por un lado, el uso del queronense de la tradición religiosa y literaria para ilustrar cuestiones filosóficas según el contexto y la obra de que se

${ }^{1}$ Sobre los conceptos de justicia y sus diversas personificaciones míticas son clásicos insustituibles R. Hirzel 1907, y más reciente, J. RudHARDT 1999. 
trate; por otro lado, ofrece un corpus reducido de textos sobre el que se puede observar en las personas divinas la asociación entre las ideas de destino, justicia y divinidad que se trasluce en muchos otros ámbitos a lo largo de la extensa obra plutarquiana ${ }^{2}$.

Al respecto, conviene recordar algunas cuestiones previas sobre la personificación ${ }^{3}$. Ante todo, que ésta se distingue en las traducciones modernas por el fácil recurso a la mayúscula inicial, que los griegos no utilizaron hasta bien entrado el periodo bizantino. La personificación de un concepto abstracto viene dada por la sintaxis, semántica y contexto de la aparición del sustantivo en cuestión. Por ejemplo, si se ponen palabras en estilo directo en boca de un concepto abstracto, o si el contexto es mitológico-teogónico, se entiende perfectamente que hay una personificación. Pero, como veremos, no es siempre tan claro y hay ocasiones en que el contexto es tan ambivalente que los editores y traductores modernos vacilan entre la mayúscula y la minúscula. Recogeré aquí también esos casos dudosos, pues, como veremos, el primero en explotar esa ambigüedad entre la personificación y el concepto abstracto para reflejar una especie de entes semipersonales, fuerzas (dynameis) o daimones, es el propio Plutarco.

En la obra plutarquea coexisten la transmisión fiel de la tradición poética y religiosa con su reelaboración original. También en lo tocante a las deidades de la justicia encontramos este doble plano. Por tanto, hay que distinguir por un lado las citas o alusiones literarias, y por otro, aquellos pasajes en que habla el propio Plutarco. Y en este segundo caso, a su vez, habrá que diferenciar los pasajes en un tono con más concesiones al mito o la imagen literaria de aquellos en que predomina la racionalidad filosófica. Las personificaciones divinas aparecen sobre todo en el primer tipo de pasajes, que predomina en las Vidas, pero también, como veremos, en ciertos pasajes de las obras morales, pues como Platón y en gran medida por imitación de éste, Plutarco cree en la fuerza plástica del mito para expresar mejor que el logos ciertos conceptos. De hecho, la aparición más espectacular de las deidades de la justicia tiene lugar en el mito final del diálogo más exitoso de Plutarco a través de la historia, De sera numinis vindicta, precisamente el que de modo más directo se ocupa de las cuestiones abordadas en este volumen.

Obviamente cada una de las diosas de la justicia llega a Plutarco con una densa tradición propia, que aquí no voy a tratar ni siquiera de esbozar, pues la bibliografía sobre ellas es numerosa y fácilmente accesible. Tampoco la Quellensforschung de los pasajes plutarqueos, nos ha de interesar ahora. Es un tema de sobra estudiado por autores varios, especialmente Yvonne Vernière, y

\footnotetext{
${ }^{2}$ Cf. e.g. F. E. Brenk 1977: 256-275 sobre la retribución divina en las vidas en relación con la teodicea del De sera. Más específicamente sobre la escatología, cf. e.g. H. G. InGEKAmp 2001.

${ }^{3}$ Sobre personificaciones divinas en literatura y religión griegas, cf. E. STAFFord 2000.
} 
basta con recordar que el tronco principal de la mitopoética plutarquiana es platónico y, en menor medida, también órfico-pitagórico ${ }^{4}$. Tampoco, aunque éste sí es un campo que admitiría ulterior investigación, trataré las relaciones de los pasajes con otras obras de literatura filosófica-religiosa más o menos contemporánea, como la himnología tardohelenística o imperial en que la especulación conceptual se mezcla con el culto real; o como en obras que utilizan la alegoría o la imagen escatológica con intención similar a Plutarco, el Axíoco pseudoplatónico o la Tabla de Cebes, de raigambre pitagórica; o finalmente, con usos libres de la tradición literaria, como las parodias mitológicas de Luciano. Este estudio se concentrará sincrónicamente sólo en los pasajes plutarqueos, para precisar un retrato de cada uno de los conceptos personificados de la justicia que complemente el estudio de su conceptualización no deificada en el resto de los trabajos del volumen.

Señalemos también otra autolimitación de este estudio, que se fija en las deidades explícitamente vinculadas al ámbito de la justicia. Como veremos, una dimensión importante de algunas de ellas es su asociación al dominio de la Tyche: la fortuna, el destino, o la compensación mecánica, tienen sin duda mucho que ver con la justicia cósmica y su plasmación concreta en cada individuo o situación. Las deidades abstractas del destino como las Moiras o Tyche son de gran importancia en Plutarco y se solapan con las de la justicia 5 . Sin embargo, en aras de la profundización, renunciemos aquí a abarcar este campo amplísimo y bien estudiado. Señalaremos en cada caso la vinculación de la deidad justiciera con el ámbito de Tyche.

Por último, cumple abordar ahora una cuestión que inevitablemente surgirá al hilo de los pasajes estudiados: ¿Cree Plutarco en las deidades justicieras cuando habla de ellas? Él mismo se encarga de indicar en la mayoría de los casos que habla dentro de los cánones marcados por la tradición literaria. Como ha señalado Vernière, Plutarco parece compartir con la koiné filosófica de su tiempo la idea de unidad de lo divino que hace a cada una de estas deidades dimensiones de un solo theos. Veremos que en un pasaje de Ad principem ineruditum (781B) sostiene que no es que Dike y Themis sean paredroi de Zeus, es que Zeus es Dike y Themis. Ahora bien, esta unidad fundamental de lo divino no es incompatible con admitir la pluralidad de manifestaciones,

${ }^{4}$ Y. Vernière 1977, esp. pp. 234-241 sobre las divinidades de la justicia. Sobre el pasaje final del De sera, cf. el capítulo de A. Jiménez San cristóbal en este volumen.

${ }^{5}$ Cf. Y. Vernière 1977, S. Swain 1989, y las contribuciones recogidas en F. Frazier; D. LEÃo 2010.

${ }^{6}$ Como señala Y.Vernière 1977: 234, Plutarco parece compartir la identificación profunda que aparece al final del tratado pseudoaristotélico De mundo (401b) sobre que el dios supremo no sólo es Zeus, sino también Ananke, Heimarmene, Pepromene, Némesis, Adrastea, Moira y Aisa. Sobre las creencias de Plutarco sobre lo divino, las primeras contribuciones (W. Burkert, C. Moreschini, G. D’Ippolito) en I. Gallo 1996 ofrecen múltiples orientaciones y bibliografía. 
antes al contrario, es la base de la elaborada demonología plutarquea, estudiada en las últimas décadas hasta la saciedad ${ }^{7}$. Es en este ámbito de los daimones entendidos como fuerzas (dynameis) de origen divino que actúan en relación con los hombres y el cosmos en el que debemos situar una cierta creencia, no en los nombres o descripciones de las deidades justicieras, que Plutarco reconoce que se deben a la tradición, sino en los resultados de su actuación en cada caso concreto y en general, donde Plutarco sí ve las huellas de la actuación divina.

\section{Deidades no mencionadas fuera de las citas}

En primer lugar señalemos, por eliminación, las deidades que, siendo comunes en su época (p. e. cada una recibe un Himno Órfico) no aparecen en la obra plutarquea conservada: Dikaiosyne, Themis, Nomos.

Pese a que usa el término con frecuencia como nombre común, Dikaiosyne como nombre propio aparece sólo en una referencia a Isis "a quien llaman en Hermópolis Dikaiosyne". En De sera numinis vindicta, que como veremos es el tratado que se ocupa de modo más directo de la justicia divina, Plutarco iguala explícitamente dike y dikaiosyne diciendo que "la curación del alma" se

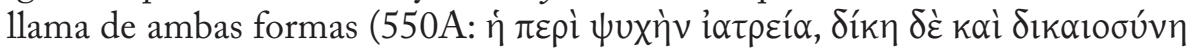

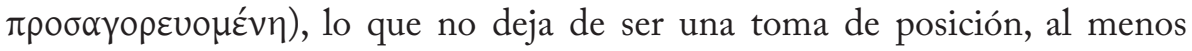
en esta obra, en un tema clásico de la filosofía griega como es la distinción entre dike y dikaiosyne 9 . Pero si como concepto de justicia la segunda es más común, como deidad Dike está muy arraigada y es mucho más frecuente en la tradición griega, por lo que cuando quiere personificar la Justicia, a Plutarco le basta con acudir a ella.

La diosa Themis aparece alguna vez en la obra plutarquea, pero más que como abstracción de un cierto tipo de justicia, como una diosa que recibe culto real: las referencias a Themis como diosa se insertan en general en un contexto

${ }^{7}$ La referencia inexcusable sigue siendo F. E. Brenk 1977. Entre los estudios más recientes, F. Casadesús 2001.

${ }^{8}$ De Is. et Osir. 352A. En De Musica, probablemente auténticamente plutarqueo como demuestra A. Meriani en este volumen, aparece la alegoría de Dikaiosyne junto a Mousike y Poiesis en la cita de un pasaje del cómico Ferécrates (1141 D-F = fr. $145 \mathrm{CAF})$.

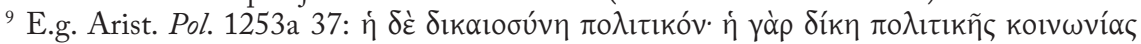

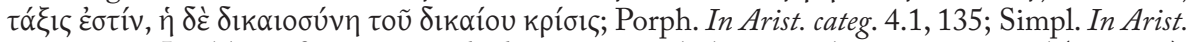
categ. 8.264. Jámblico ofrece una nítida distinción en el plano mitológico-conceptual (VP 9.46):

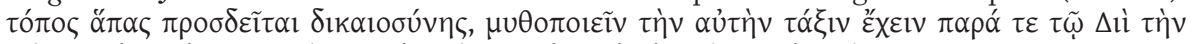

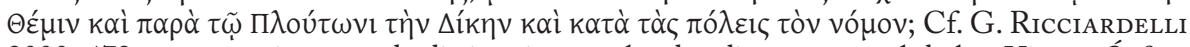
2000: 472 para otros intentos de distinguir entre las dos diosas, como el de los Himnos Órficos. Sobre el pasaje del De sera, cf. F. Frazier en este mismo volumen. 
cultual délfico ${ }^{10} \mathrm{y}$ ateniense ${ }^{11}$, y no como personificación de conceptos como justicia o derecho (para designar los cuales sí aparece con frecuencia como nombre común) ${ }^{12}$. La única excepción es la mencionada cita de Anaxarco (Ad princ. iner. 781B), en que aparece asociada a Dike como paredros de Zeus. Quizá precisamente el arraigo cultual de la diosa Themis en ámbitos cercanos a la actividad sacerdotal de Plutarco fuera óbice para utilizarla como personificación abstracta.

Nomos, diosa de nuevo cuño en los Himnos Órficos (64) sin gran tradición poética anterior, nunca aparece como deidad en Plutarco. Ni siquiera cuando cita el famoso fragmento pindárico sobre el vó

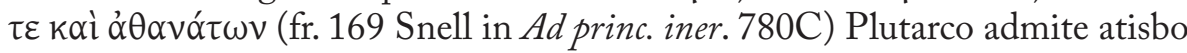
alguno de personalización del nomos, sino que dice que no está escrito fuera en los libros ni en tablas, sino es la razón ínsita en el alma del príncipe (oủk દ̉v

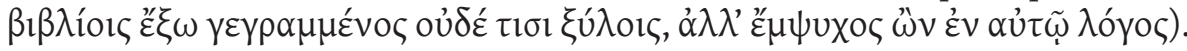
Después (780E) clasifica la nomos y dike del regidor en una frase reveladora de su naturaleza: la justicia es el fin de la ley, la ley es la tarea del soberano, y el

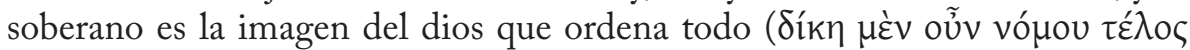

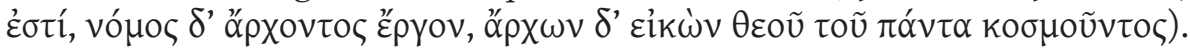
La ley y la justicia tienen origen divino, pero no son diosas ellas mismas (como tampoco el soberano). La tradición permite hablar a veces de la diosa Dike, como revela la referencia a Anaxarco que sigue después, pero Nomos como deidad no es tradicional y por tanto no tiene cabida en la obra plutarquea.

Finalmente, tampoco una diosa más tradicional del buen gobierno como Eunomia aparece más que en dos citas: Una es de Alcmán (fr. 105 Calame), que dice que Tyche es "hermana de Eunomia y Persuasión e hija de Prometea". Si escoge la rara genealogía alcmánica en vez de la habitual hesiodea (Tyche y Persuasión como hijas de Océano y Eunomía como hija de Themis) es porque una descendencia común de Tyche y Eunomía como hermanas le permite asociarlas mejor conceptualmente. Se trata de ilustrar que Tyche, tras sobrevolar los imperios asirio, persa y macedonio, se ha posado sobre Roma

${ }^{10}$ De def. orac. 421C, De Herod. malign. 860D. La única referencia a Themis en el De sera es precisamente en contexto cultual, asociada al trípode de Apolo en Delfos (566D, cf. F. Frazier 2010: 86): A. PÉrez Jiménez 2001: 208 propone una posible identificación implícita de Themis y Ananke, quizás influida por el mitraísmo.

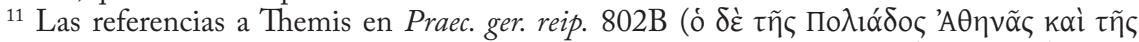

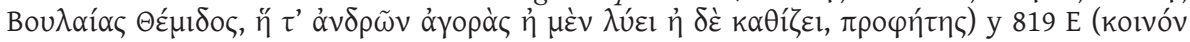

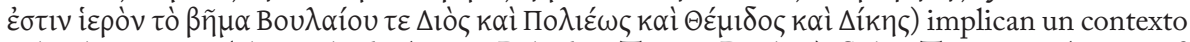
cultual ateniense (el templo de Atenea Poliade y Themis Boulaia). Sobre Themis en Atenas, cf. R. GaGné; M. Herrero de Jáuregui 2009: 270-274.

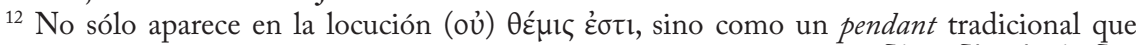

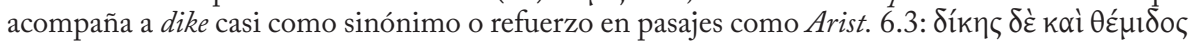

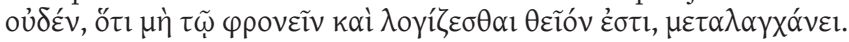




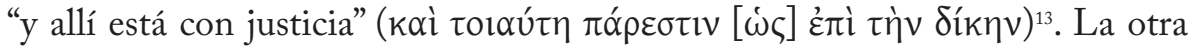
cita, en De Stoic. rep. 1049A, es de la obra Sobre los dioses de Crisipo, quien

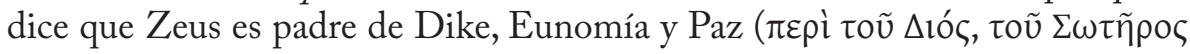

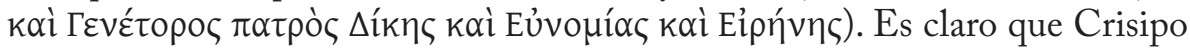
simplemente desarrolla la tradición poética que hacía a las tres Horas hijas de Zeus y Themis (Hesíodo, Th. 900 sq.) y añade dos epítetos acerca de Zeus. Que cite a Crisipo y no directamente a Hesíodo muestra que lo que aquí interesa a Plutarco es Zeus, no las Horas. En cambio, la tradición hesiódica sí puede estar detrás de algunas expresiones en que el "buen gobierno" (eunomia como nombre común sin personalizar) sí está asociado a la paz (Flam.12.6, Luc.23.1, Num. 6.3) o a la justicia (Praec. ger. reip. 807C) ${ }^{14}$.

En suma, lo cierto es que aunque Themis o Eunomia sí tienen una antigua tradición de genealogía mitológica, sólo son nombres y no protagonizan episodios, y Plutarco las trata como a las deidades alegóricas más modernas, Dikaiosyne o Nomos, es decir, se limita a las citas de antiguos poetas y no las integra en su propio discurso. En cambio, hay otras deidades que sí utiliza con más frecuencia: son, en orden de importancia, Adrastea, las Erinis, Poiné, Nemesis, y Dike.

\section{Adrastea}

Adrastea, "la inescapable" es una deidad de tronco platónico y órfico ${ }^{15}$ que aparece sólo dos veces en la obra plutarquea como nombre que también recibe, entre otros, el destino prefijado o Heimarmene. En un pasaje dice que "se aparece como inmóvil e ingobernable e ineluctable, por lo que también se llama Atropo y Adrastea y Ananke y Pepromene, en cuanto que pone límites a

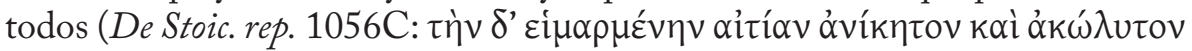

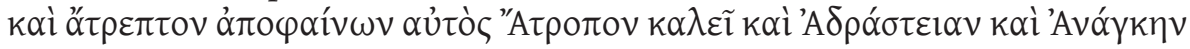

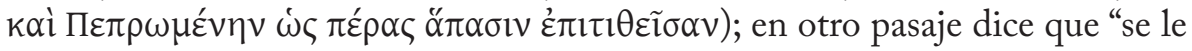
llama también Adrastea porque fuerza el límite a las causas y es ineluctable

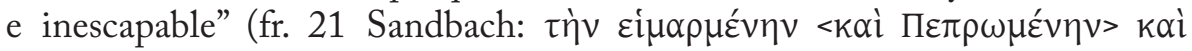

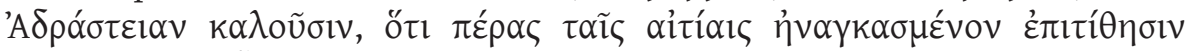

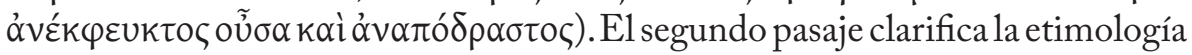
a partir del verbo $\delta 1 \delta \rho \alpha ́ \sigma \kappa \omega$ “correr”. En el mito del De Sera Adrastea encabeza la lista de las deidades justicieras (564F): "Adrastea, hija de Ananke y de Zeus, es la vengadora suprema de todas las injusticias (

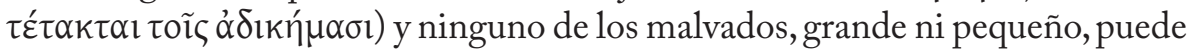

\footnotetext{
${ }^{13}$ De fortuna Romanorum 318A.

${ }^{14}$ Sobre Numa $6.3 \mathrm{cf}$. la propuesta de F. Frazier citada en n. 29 infra.

${ }^{15}$ Cf. Y. Vernière 1977: 235 para las apariciones de Adrastea en la escatología platónica, probablemente como reelaboración de imágenes órficas.
} 


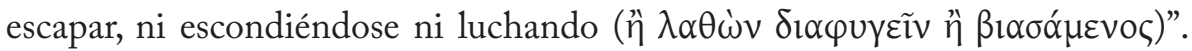
Poiné, Dike y las Erinis son sus tres ayudantes. Si Plutarco la elige para presidir sobre los castigos infernales es sin duda por las connotaciones de su nombre, la inescapable. La genealogía que le otorga refuerza esa cualidad por parte de su madre, Ananke (Necesidad). Pero además, hacerla hija de Zeus coloca toda esta ineluctabilidad bajo la férula del dios supremo garante de la justicia ${ }^{16}$, lo que garantiza la moralidad de todos los terribles castigos que sus ayudantes imponen. Es decir, Adrastea participa por igual de la mecánica ciega de la retribución y de la justicia. Estos son los dos polos entre los que veremos que se van a mover todas las deidades justicieras plutarquianas.

\section{Erinis}

Las Erinis aparecen en primer lugar en las dos citas del célebre fragmento de Heráclito que dice: "El sol no rebasará sus medidas. Pues si no las Erinis,

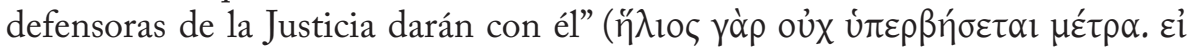

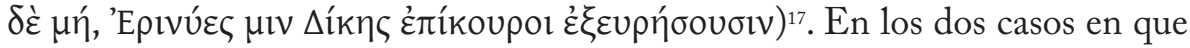
cita esta frase es la armonía cósmica el centro de su interés, y no las Erinis o Dike en cuanto tales. Pero en De exilio (602E) poco antes de citar el fragmento heraclíteo, revela que considera a las Erinis un modo poético de hablar, al mencionar que Alcmeón "huía de las Euménides, como dicen los poetas, pero a mí me parece que aquel huía de perturbaciones políticas, revoluciones y delaciones semejantes a Erinis" (نં

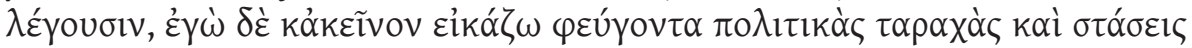

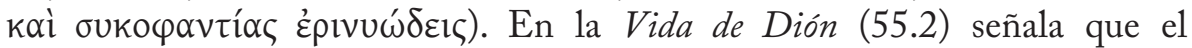
espectro femenino que le anuncia su muerte tiene "rostro y vestimenta nada

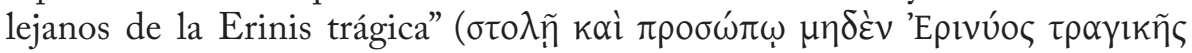

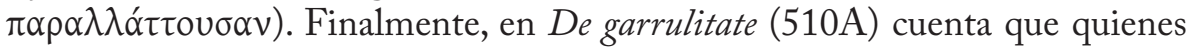
fueron condenados a muerte por irse de la lengua y hablar de su crimen "fueron castigados por su verborrea, como obligados por Erinis o Poiné a confesar el

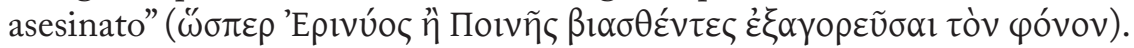

El resultado de estos pocos pasajes es claro. Plutarco circunscribe expresamente la existencia de estas deidades a la poesía y el teatro para representar una persecución terrible. Su asociación con Dike se encuentra en el fragmento de Heráclito, pero el resto de los usos prueba que su dimensión principal es el producir espanto, de acuerdo con su representación habitual en la tradición griega. Que la clave de este espanto está en la asociación con

${ }^{16}$ H. Lloyd-Jones 1971 desmuestra en su obra clásica que Dike está asociada a Zeus con un sentido moral desde sus primeras apariciones en época arcaica.

${ }^{17}$ Heráclito fr. 94 D-K, citado en De ex. 604A y De Is. et Os. 370D. 
la muerte y el castigo de los crímenes es claro también ${ }^{18}$. No es extraño, pues, que en el mito escatológico del De Sera, Erinis aparezca al mismo nivel que Dike y Poiné, pero encargada de una función más terrible $(564 \mathrm{~F})$ : "a quienes son absolutamente incurables, tras rechazarlos Dike, la tercera y más severa

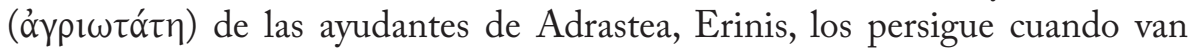
errantes e intentando escapar. De un modo a cada uno, pero siempre doloroso y cruel (oik $\tau \rho \tilde{\omega} \varsigma \delta \grave{\varepsilon} \kappa \alpha i ̀ ~ \chi \alpha \lambda \varepsilon \pi \tilde{\omega} \varsigma$ ), oculta y aprisiona a todos en el lugar

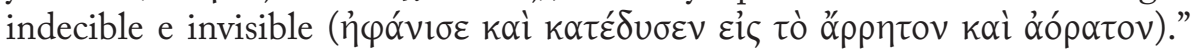
El mito, pues, ni siquiera puede describir los castigos de la Erinis en cuanto imposibles de ver ni de contar, por lo que no parecen cumplir ninguna otra función más que la amenaza de la retribución. No es casual que la Erinis, precisamente aquella deidad cuyo nombre no es una abstracción, sino que surge de la tradición poético-religiosa, sea la figura cuya función es más decorativa y menos conceptual.

\section{Poiné}

Poiné significa "compensación" y se usa frecuentemente como nombre

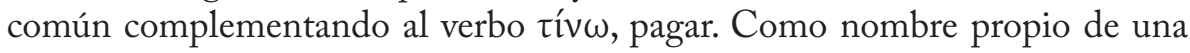
deidad, acabamos de ver un pasaje del De garrulitate (510A) en que Plutarco iguala a la Erinis con Poiné como figuras más bien literarias que obligan a confesar. Encontramos un uso similar en Adversus Colotem 1125F, donde los

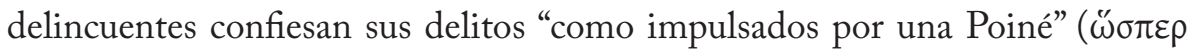

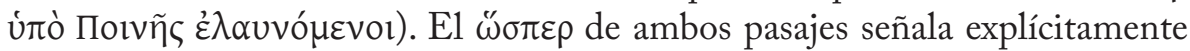
que se trata sólo de una comparación literaria. De hecho, en ocasiones Plutarco niega expresamente la existencia de una deidad tal fuera de la imaginación humana. Así, critica a quienes fomentan la superstición y "presentan la providencia divina como Empusa a los niños o una Poiné terrible y trágica que

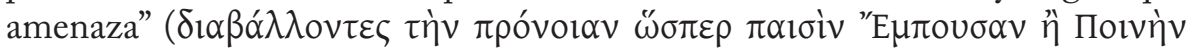

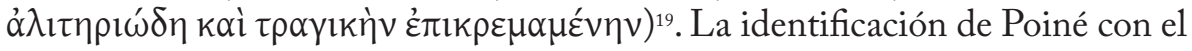

${ }^{18}$ Que las Erinis se conciben en oposición al ámbito del sol y en asociación con la justicia y el mundo subterráneo se deja traslucir en un pasaje narrativo de Amatoriae narrationes (774B) sobre el fin del rey espartano Pausanias (protagonista también de otra anécdota al respecto en De sera 555C, cf. infra): "tendiendo las manos al sol, y a su vez golpeando la tierra, invocaba a las

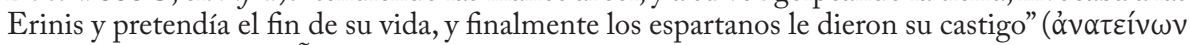

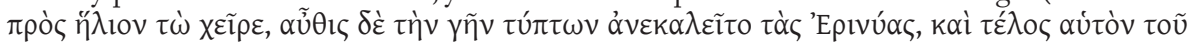

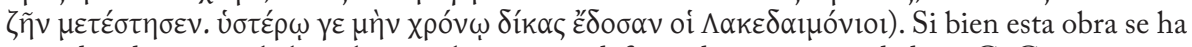
considerado espuria habitualmente, la enérgica defensa de su autenticidad por G. Giangrande 1991, lo ha vuelto a situar para muchos entre las obras plutarqueas.

${ }^{19}$ Non posse suaviter vivi secundum Epicurum 1101C. Empusa es un monstruo femenino que habitualmente se presenta en contextos catabáticos. El pasaje puede indicar que aparece también en contextos de asustar a los niños como "el coco" o bien, más probablemente, que las historias de catábasis son como para niños. Sobre Empusa, cf. J. A. Álvarez-Pedrosa 2011: 291-294. 
“monstruo de las katábasis" Empusa redunda en esta idea de una mera creación literaria. Es difícil distinguir si tiene un sentido personal como nombre propio o simplemente el de "castigo" en un pasaje del De superstitione $(165 \mathrm{~F})$ donde insiste en que la superstición suscita en los sueños "algunas poinai junto a imágenes terribles y apariciones portentosas como si estuviera en el lugar de

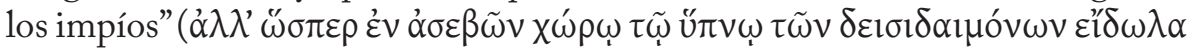

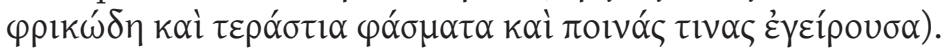

Sin embargo, fuera de las condenas a la superstición que cree literalmente las figuraciones de la tradición, otro pasaje del Aetia Romana et Graeca 277A dice: "los filósofos piensan que Lares romanos son daimones malos que dan vueltas, que los dioses usan como verdugos y castigadores contra los impuros e injustos; así los Lares son unos daimones del tipo de

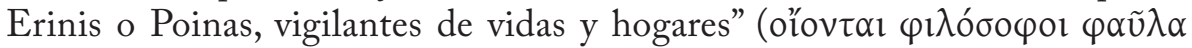

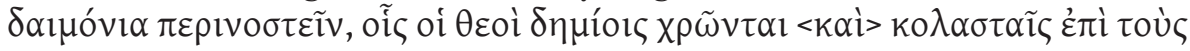

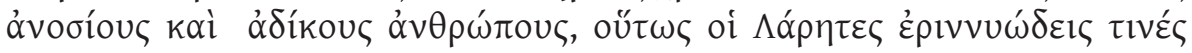

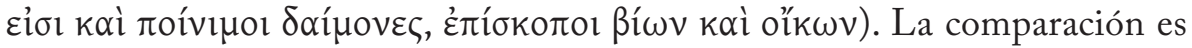
adjetival, lo que implica más distancia que si se usara el sustantivo. Pero en todo caso, parece indicar que Plutarco sí puede llegar a respetar (aunque no explícitamente a compartir) como idea tradicional no condenable que, independientemente de los nombres y apariencias de los poetas, haya ciertos daimones encargados de velar por la justicia en este mundo. Por eso dice con naturalidad en la Vida de Otón (1.3) "los ciudadanos más influyentes habían temido que no fuera un hombre, sino algún demon castigador o Poiné que caía de pronto sobre el Estado" ( $\alpha \lambda \lambda \alpha$ $\tau$ เvo

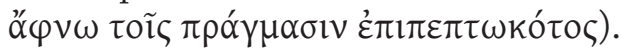

En coherencia con estos usos, en el mito del De sera (564F) Poiné es descrita como la encargada de castigar las faltas con sufrimientos en la propia vida, que es siempre un castigo más ligero que libera de las penas de ultratumba.

La rápida ( $\tau \alpha \chi \varepsilon \tilde{\alpha} \alpha)$ Poiné trata a quienes ya han sido castigados en y por medio de sus cuerpos de un modo suave que deja pasar muchas de las cosas que necesitan purgación; pero aquellos cuya curación de la maldad es un trabajo mayor, el demon los entrega a Dike tras la muerte.

Y sus castigos son así:

De entre los diferentes castigos, decía, el impuesto por Poiné durante la vida se parece a los de los bárbaros, pues así como entre los persas arrancan y azotan los mantos y las tiaras de los castigados, mientras éstos llorando suplican que cesen, así los castigos ejecutados en bienes y cuerpos no tienen contacto vivo ni alcanzan a la propia maldad, sino que la mayoría lo son ante la opinión y los 
sentidos de los castigados. Pero quien llega de allí aquí sin haber sido castigado ni purificado, a ese lo toma Dike...

La elección de Poiné para el primer nivel de castigo en esta vida se puede deber a su significado de "retribución". En los pasajes examinados, el énfasis está en que la Poiné hace sufrir, no en la justicia de este sufrimiento. De hecho, su utilidad es más como amenaza latente que como ejecutora real de un castigo moral que, en el De sera, toca aplicar a las otras deidades.

\section{Némesis}

Paradójicamente, una deidad retributiva de gran importancia en la tradición y entre los contemporáneos de Plutarco, Némesis, está ausente del mito del De sera. Su presencia en la obra de Plutarco ha sido estudiada por Félix Fortea, quien revela que "tiene una naturaleza oculta, velada", como

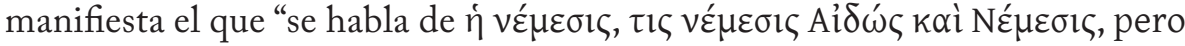

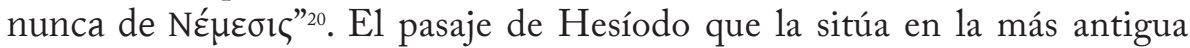
tradición sobre la mitología de la justicia es Op. 197 ss., en que Némesis es compañera de Aidós, y ambos abandonan la tierra al llegar la edad de hierro caracterizada por la total ausencia de justicia. Plutarco cita estos versos una vez como referencia elegante en boca de un personaje que se queja de la falta de atención a los oráculos (De defectu oraculorum 413), pero sobre todo los comenta en su comentario a Trabajos y Dias, donde dice ${ }^{21}$ : "Que Aidós y Némesis dejen nuestra raza es el extremo de los males, pues dominan la desvergüenza y la envidia, que son los opuestos”. Ahora bien,

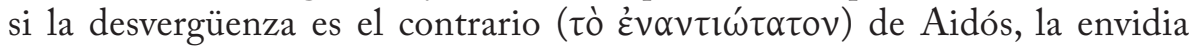

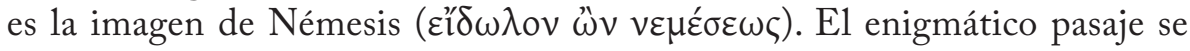
resuelve así: "que es un hecho divino lo muestra que los dioses la usan: la poesía dice que "Hera se enfadó" (Il. 8.198); pero la envidia es ajena a todo el ámbito de lo divino" (ö

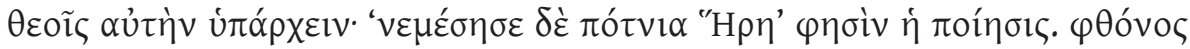

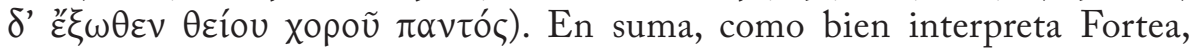
Plutarco viene a decir que "la némesis sería un tipo de envidia que los dioses pueden sentir o manifestar" (F. ForTEa 1994: 563). Sea o no una persona divina, en tanto ligada a los dioses, la némesis es un "hecho divino". Por eso

${ }^{20}$ F. Fortea 1994: 561. Testimonios religioso-literarios de la veneración por Némesis más o menos contemporáneos a Plutarco, que transmiten un retrato similar de retribución entre la compensación cósmica y la justicia moral son el Himno Órfico 61 y el Himno de Mesomedes.

${ }^{21}$ Fr. 31 Sandbach, comentando Hes. Op. 197ss. La cita de Il.13.121 en De aud.poet. 32C es meramente retórica, y además en el pasaje homérico aidós y némesis no tienen valor divino sino guerrero ("vergüenza y pundonor"). 
pone en boca de Paulo Emilio en su Vida el siguiente consejo: "los hombres deben estar siempre atentos hasta ver qué némesis reparte a cada uno el

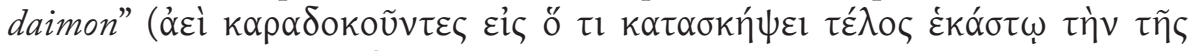

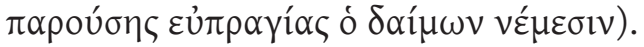

Es difícil precisar, sin embargo (y de ahí la vacilación entre mayúscula y minúscula), si Plutarco concibe esta Némesis que aparece con cierta frecuencia en las Vidas, generalmente con el sentido de "retribución" niveladora, como un daimon personal o como un mero concepto, pues el modo de la nombrarla, $t$ is nemesis, "alguna venganza", igualada a tyche y physis, deja lugar a la ambigüedad ${ }^{22}$. Así la define en la Vida de Mario (23.1): "la que no permite que el placer de los grandes éxitos sea puro y total, sino que mezcla tiñendo de bienes y males la vida humana, sea una fortuna, o némesis, o naturaleza obligatoria de los hechos... (

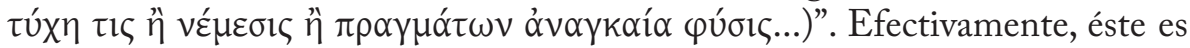

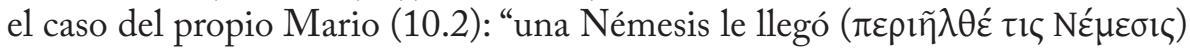
al final de sus hazañas: fue despojado de la gloria de su éxito por Sila, como Metelo lo había sido por él". Tal es también la suerte de Filopemen, que por despreciar a un general capturado vivo por sus enemigos, corrió esta misma suerte: "una Némesis lo derribó como a un atleta que está a punto de vencer en

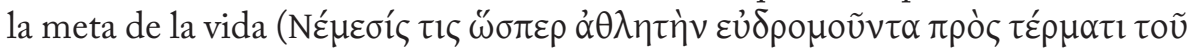

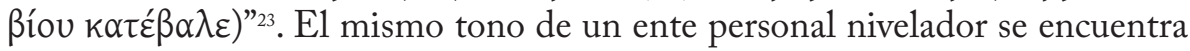
cuando cuenta que Antonio "elevó sus manos al cielo y pidió a los dioses que si debía alguna Némesis acompañar a su fortuna anterior, le llegara a él, pero

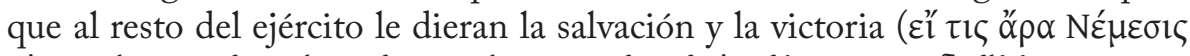

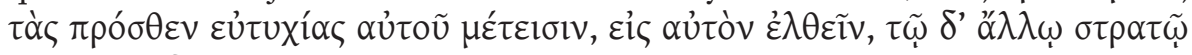

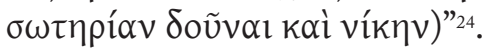

En estos pasajes Némesis no parece implicar tanto una retribución de carácter ético, cuando una recuperación del equilibrio de lo que ha sido excesivo, aunque el sentido moralizante de Plutarco parece implicar que el exceso conlleva cierta carga de hybris que no permite darse cuenta de la desmesura. Por eso la definición anterior la asocia a la fortuna (Tyche) y la necesidad (Ananke), otras dos deidades "conceptuales", como si su principio fuera un mecanicismo ciego. Sin embargo, Némesis también aparece asociada

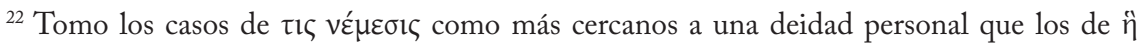

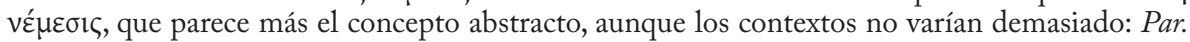
Min.38; Aem.22.3, Mar. 10.2, 22.1, Alex.30.13. El elenco completo de citas en F. ForTEa 1994: 561 n.1.

${ }^{23}$ Phil.opoemen 18.3. F. Fortea 1994: 571 no encuentra la justicia niveladora en la muerte de Filopemen, pero no repara en la injusta crítica que el general aqueo había hecho de otro capturado vivo.

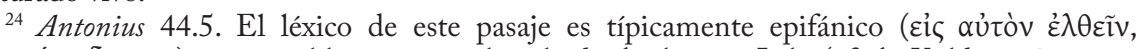

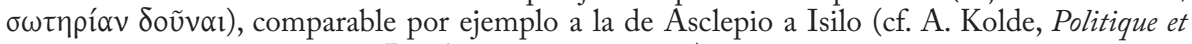
religion chez Isyllos d'Epidaure, Basel 2003, esp. 198-209). 
a Dike en dos pasajes, uno definitorio en las Quaestiones Convivales, y otro narrativo en la Vida de Camilo. En el primero uno de los personajes, Floro, elogiando la proporción geométrica de la constitución oligárquica espartana, frente a la aritmética de las democracias, dice (Quaestiones Convivales 719 B):

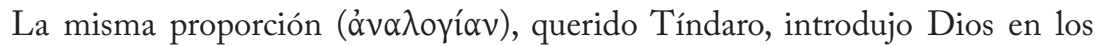
asuntos humanos, que llamó dike y nemesis, y que nos enseña que hay que llamar a lo justo "igual" pero no a lo igual "justo". Pues la igualdad que persiguen muchos es a menudo la mayor de las injusticias, y Dios la evita en lo posible.

\section{Y en la Vida de Camilo (13.1) dice:}

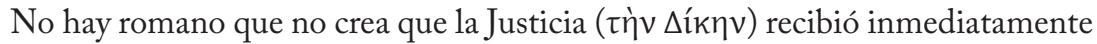
las preces de Camilo, y que éste obtuvo una venganza de su injusticia no dulce,

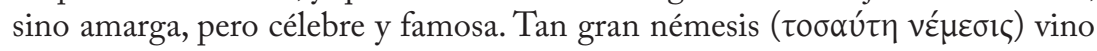
sobre Roma, y tan gran destrucción y peligro junto con desgracia apareció de repente en la ciudad, ya sea porque así fue la fortuna ( $\tau \tilde{\eta} \varsigma \tau u ́ x \eta \varsigma)$, ya porque es

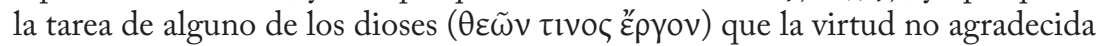
no quede descuidada.

Como se ve en estos dos casos, en contraposición con los anteriores, parece como si Plutarco no tuviera claro si el equilibio que representa Némesis es una balanza ciega o tiene un cierto sentido moral. O como si quisiera moralizar un concepto, la némesis, que de por sí no implica necesariamente la justicia. De nuevo en palabras de Fortea, "las soluciones oscilan entre conceder un significado tradicional, de raíz homerica y/o hesiódica, bien en estructurar un poder entre Tyche y Dike" (F. ForTea 1994: 573). En el fondo la discusión sobre Némesis es la sempiterna discusión sobre la justicia del destino, la que subyace en paralelo a la polaridad entre tyche y pronoia. Por eso no es extraño, antes al contrario, que no aparezca en absoluto en el De sera, ni en el mito final ni siquiera como concepto en la parte anterior, probablemnte porque Plutarco quiere subrayar que el castigo de los dioses, por retardado que sea, no es una retribución ciega y mecánica, sino que tiene una profunda carga moral.

\section{Dike}

Dike es el pilar sobre el que se sustenta todo el diálogo De sera. Curiosamente, en el resto de la obra plutarquea la presencia de Dike como deidad es escasa, salvo en citas literarias: el mencionado fragmento 94 DK de Heráclito sobre las Erinis ayudantes de Dike; la también mencionada alusión (De Stoic. rep. 1049A) a la genealogía de Dike, Eunomía y Paz como hijas de Zeus la obra Sobre los dioses de Crisipo; en el Adversus Colotem (1124F) en defensa de la pronoia divina acumula entre otras citas un verso de tragedia de 
autor desconocido (fr. trag. adesp. $421 \mathrm{~K}$ ) sobre "el ojo de Justicia que todo lo

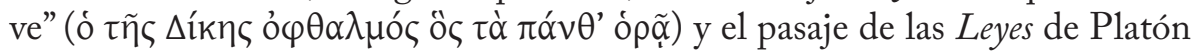
que presenta, en referencia probable de un poema órfico, a Dike siguiendo a

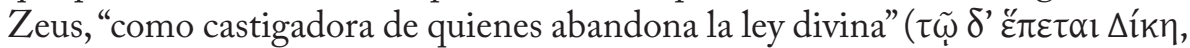

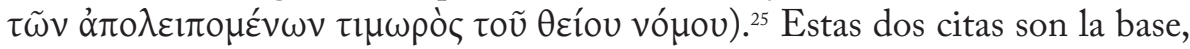
respectivamente, de otros dos pasajes en que Plutarco las incorpora a su propio discurso: en el Banquete de los Siete Sabios (161F) dice en defensa de la pronoia divina, que "no es uno el ojo de la Justicia, sino que Dios vigila en derredor lo

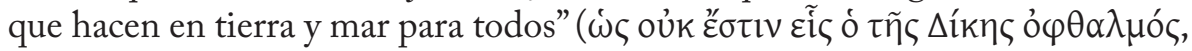

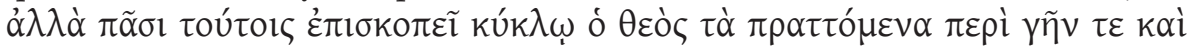
$\theta \alpha ́ \lambda \alpha \tau \tau \alpha \nu)$. Por otro lado, el pasaje platónico aludido está en clara relación con la referencia (Ad princ. iner. 781B) en que recuerda la sentencia del filósofo Anaxarco, quien para consolar a Alejandro, afligido tras haber matado en un arrebato a Clito, le recordó que Zeus tenía a Themis y Dike como consejeros

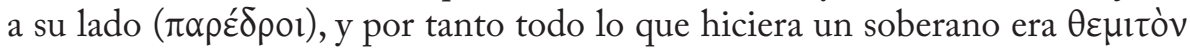

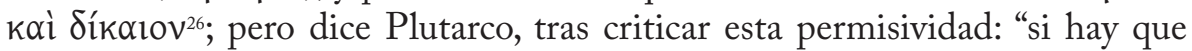
especular sobre esto, Zeus no tiene a Dike como consejera, sino que él mismo

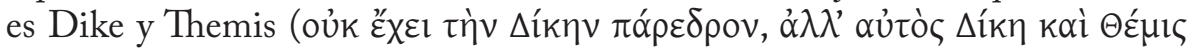

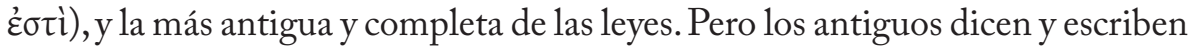

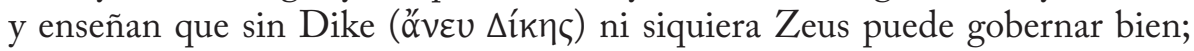
pues "ella es virgen", según Hesíodo, incorruptible, compañera de vergüenza y sensatez y ayuda" 27 .

Aparte de la especulación mitológica en este último pasaje, que él mismo

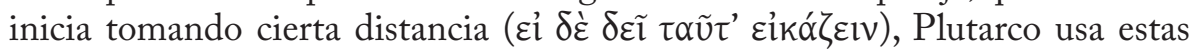
citas más bien como adorno literario, fuera del discurso principal. Sólo en el pasaje antes señalado de la Vida de Camilo (13.1) Plutarco nombra a Dike como si ésta fuera una creencia de los romanos, aunque después apunta su propia opinión, más cauta, con "alguno de los dioses". Quizá también un pasaje de la Vida de Demóstenes 31.4 ( "la justicia por Demóstenes cayó sobre Macedonia") permite ver a esta dike como un ente semipersonificado similar a la poiné o la némesis, aunque el artículo determinado en vez del tis que encontrábamos en estos casos hace preferible mantener la minúscula que la mantiene como concepto abstracto

${ }^{25}$ Lg. 4, 716a. En Orph. Fr. 32-33 Bernabé se comprueba con otros testimonios, además de esta cita platónica, que Dike como acompañante de Zeus se encuentra en la poesía órfica antigua. Además, Platón ha citado justo antes de esta frase los versos sobre Zeus como principio y fin que encontramos en la teogonía de Derveni (Orph. Fr. 14).

${ }^{26}$ Anax. 72A 5 D-K, citado también en Alex. 52.

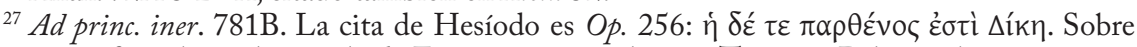
este pasaje, cf. también el capítulo de Frazier en este volumen. Themis y Dike también aparecían asociadas con Zeus en el pasaje de Praec. ger. reipubl. 819E en contexto cultual (cf. n. 11 supra). 
no personal ${ }^{28}$. La misma duda puede suscitar la dike mencionada en la Vida de

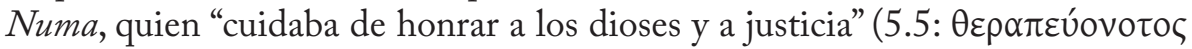

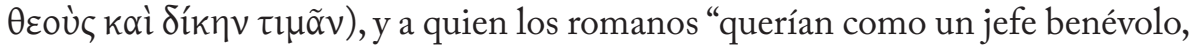

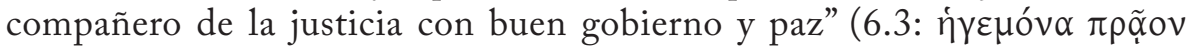

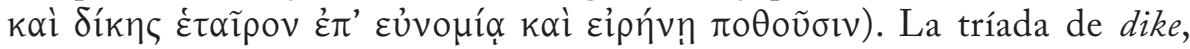
eunomia, eirene tiene una evidente referencia a las Horas hesiódicas, pero el papel pasivo de las tres las mantiene lejos de una personalización como deidades ${ }^{29}$.

En cambio, en el De sera, Plutarco comienza con una cita de Eurípides que no es un mero adorno y acaba con un mito en el que la diosa Dike es central. En la discusión que hay entre medias, también el concepto de la dike es la clave. Al principio del diálogo (549A) el interlocutor de Plutarco, Patrocleas, que se opone a considerar justo el castigo de los dioses sobre los descendientes inocentes, cita unos versos de Eurípides (fr. 979 Kannicht), criticando que "son absurdos para rechazar la maldad":

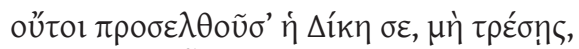

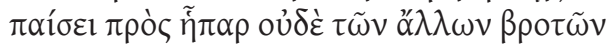

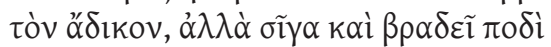

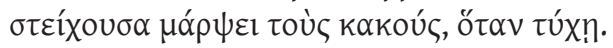

"No tiembles, la Justicia, aunque avanza, todavía no te herirá en el corazón ni entre los demás mortales al injusto, pero viniendo en silencio y con lento pie caerá sobre los malvados cuando llegue el momento.

El castigo retardado es el tema único del diálogo $\mathrm{o}^{30}$, y el pasaje euripídeo que asocia la Justicia a un destino inexorable (el último verso recuerda el dominio de tyche) encuadra como clave de bóveda la entera discusión posterior. Que la cita no es mero adorno, sino la base de la formulación de esta justicia retardada, se comprueba en que el siguiente interlocutor, Olímpico, recuerda el pasaje

${ }^{28}$ S. Swain 1989: 300: "almost an avenging genius".

${ }^{29}$ Cf. Hes. Th. 900 sq. Cf. F. Frazier en este volumen, p. 222: "il est tentant ici de mettre une majuscule à cette $\Delta$ íkn dont le Sabin est compagnon”. Pero es preferible mantener la distinción entre el concepto y la diosa.

${ }^{30}$ La de Plutarco es la primera elaboración con pretensiones de sistematicidad de la noción de la culpa heredada, omnipresente en la poesía arcaica, Heródoto y la tragedia. El tratado tardoantiguo del neoplatónico Proclo, De decem dubitationibus circa providentiam, se basa explícitamente en el De sera. De estas dos obras depende la capital recepción moderna de este concepto en diversas direcciones en la Europa moderna. Cf. R. GAGNÉ, Ancestral Fault in Ancient Greece, Cambridge, en prensa. 
(549D): "Pero esa justicia de Eurípides que inmóvil, “con lento pie y en su momento" cae sobre los malvados, se asemeja más al azar que a la providencia

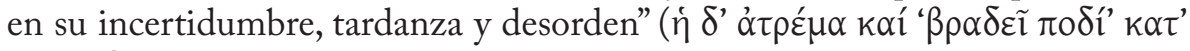

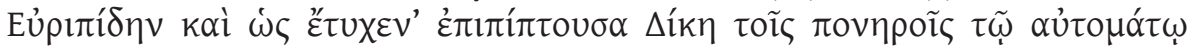

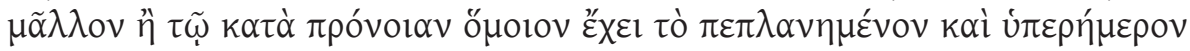

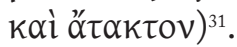

A lo largo del diálogo posterior, se alterna dike en diversas expresiones como objeto directo (dikas o diken didonai, dikas tinein) en que su valor es claramente impersonal, con otros términos para indicar castigo, como kolazein o timoria. Sin embargo, hay algunos pasajes en que dike es sujeto y parece funcionar como ente cuasi-personalizado, como ocurría con nemesis en la sección anterior: así, encontramos que dice que Dios (ho theos) "es el creador de la justicia, a la que toca delimitar el castigo de los malvados" (550A: Jíkn

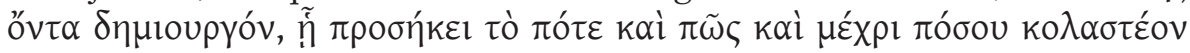

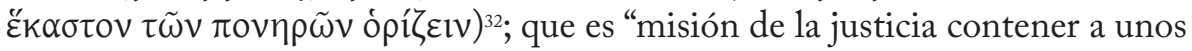

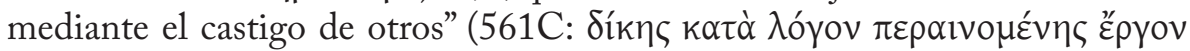

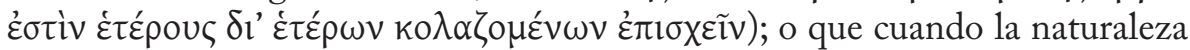
"admite la semejanza familiar, la justicia hostiga y persigue la semejanza en la

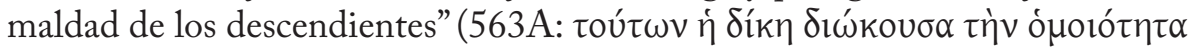

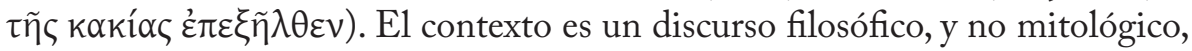
por lo que incluso en estos pasajes dike no parece tanto una divinidad como una fuerza impersonal dirigida por el designio divino: así dice en $558 \mathrm{~F}$ al hablar de "la justicia retardada de las faltas de los delfios y sibaritas que recayó sobre

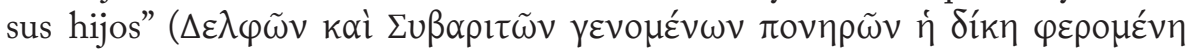

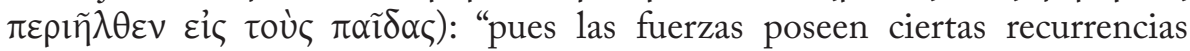
y conexiones desde el final hasta el principio, y las causas de éstas, aunque

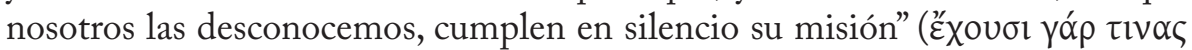

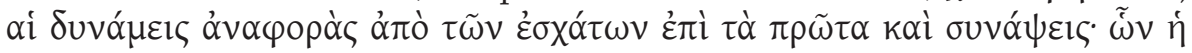

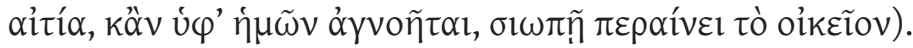

Hay además un pasaje narrativo (555C) en que el papel de dike parece anticipar el mito final: Pausanias el rey de Esparta mató a una doncella, que se le aparecía desde entonces en sueños diciendo "acércate a la justicia, la soberbia

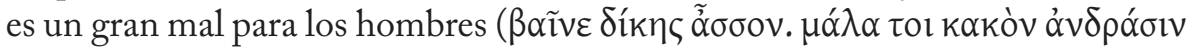
üßpı)". Pausanias "navegó hasta el psychopompeion de Heraclea e invocaba al alma de la joven con ritos expiatorios y libaciones". En este relato, parece como si la dike residiera en la ultratumba, como sucede en el mito final..$^{33}$

${ }^{31}$ Cf. F. Frazier 2010: 74f. sobre la cita euripídea.

32 Esta frase desarrolla el núcleo de lo que L. Van der Stock ha llamado el "Pindar-cluster" en torno a Zeus como demiurgo (cf. F. Frazier en este volumen, p. 174).

${ }^{33}$ La dimensión de ultratumba se hace aún más clara en la versión del relato que transmite la

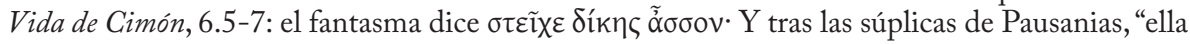


En efecto, tras estos pasajes, el final del De sera presenta a Dike como la encargada principal de la justicia en el Más Allá, flanqueada por Poiné para los castigos más livianos pues las faltas han sido ya purificadas en la tierra, y Erinis para los pecadores incurables. Hay que suponer, pues, que todos los castigos descritos en el mito son los de Dike, porque los de la Erinis se ejecutan "en el lugar invisible e indecible”, y no volvemos a oír hablar de ellos. El principio de los castigos de Dike es la publicidad, contrariamente a los de Erinis, y la purgación del alma, frente a los de Poiné (564F):

Pero quien llega de allí aquí sin haber sido castigado ni purificado, a ese lo toma Dike con el alma desnuda, sin poder huir ni ocultarse en ningún sitio ni disimular su maldad, sino visto por todos y todo en todas partes, y lo muestra primero a los padres buenos, si lo son, y a sus antepasados como un ser despreciable e indigno; si son malos, viéndoles castigados a ellos y siendo visto por ellos, paga su pena durante mucho tiempo siendo despojado de cada una de sus pasiones con dolores y sufrimientos que, en magnitud e intensidad, superan los de la carne tanto como la vigilia es más real que lo del sueño.

La imagen básica es la de una prisión. De la imaginería escatológica de este mito se han ocupado ya otros estudiosos y no es necesario repetirlo aquí. Señalemos sólo que llevado de la libertad que le permite el género, Plutarco describe a unos ejecutores que se suponen subordinados a Dike (566F / 567A):

Los ejecutores de los castigos no le permitían callar y le obligaban a confesar

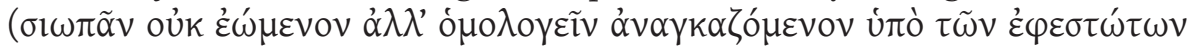

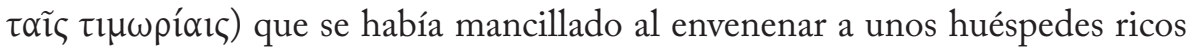
y pasar inadvertido a todos en la tierra; aquí, tras quedar convicto de sus crímenes, ya había sufrido parte de los castigos y le conducían a sufrir el resto...

... veía cómo el tormento de los criminales y convictos castigados en la tierra ya no se ejercía con igual dureza, porque todavía se trataba de la parte irracional y pasional del alma. En cambio, a cuantos vivieron disimulando su maldad y

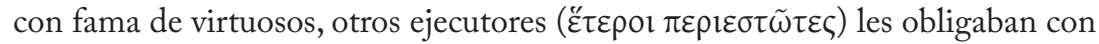
dolorosos esfuerzos a sacar fuera el interior del alma...

No hay nombre para estos ejecutores de castigos, pero su función es clara: hacer confesar, como la Erinis o la Poiné que obligaban a declarar el crimen que hemos encontrado en algunos pasajes anteriores de otras obras plutarquianas ${ }^{34}$.

apareciéndosele, dijo que haría cesar inmediatamente sus males cuando estuviera en Esparta, refiriéndose enigmáticamente, según parece, a su próxima muerte. Esto lo cuentan muchos”.

${ }^{34}$ De garr. 510A y Adv. Col. 1125F, comentadas antes al hablar de Erinis y Poiné. 
Estos nombres ya están usados en el mito con otras funciones distintas y por ello Plutarco les domina vagamente como "otros ejecutores". Sean quienes sean estos démones, esta noción de obligar a la confesión de los crímenes, que aparece en pasajes y contextos diferentes, parece una idea tradicional, dentro de la imagen básica de la prisión ultraterrena, que probablemente ya se encontraba en la tradición escatológica griega, especialmente la órfica ${ }^{35}$.

Así pues, si Adrastea, hija de Ananke, y Poiné representan el principio de inexorabilidad, y Erinis representa la venganza, Dike representa el de la justicia, por lo que su papel central en el mito responde a la lógica interna del De sera. Sin duda el mito es un modo simbólico de hablar, como el propio Plutarco reconoce con frecuencia, pero corrobora, al modo de los mitos platónicos, el razonamiento de los pasajes anteriores, que muestran la idea de una dike cósmica, una cierta fuerza (dynamis) de principio divino, que liga las cosas a lo largo del tiempo y el espacio con un mecanismo compensatorio cuya base última, aunque a veces difícil de percibir, es fundamentalmente moral.

\section{Conclusión}

$¿$ Que resultados proporciona el examen de estos pasajes? Plutarco no pretende ser demasiado innovador en su creación mitopoética. No utiliza como personificaciones más que aquellas deidades consagradas por la tradición poética en sus roles míticos habituales (genealogías, caracterización, contextos), y renuncia al recurso literario de personificar libremente abstracciones de conceptos que usa habitualmente como dikaiosyne, themis o nomos. Incluso cuando acude a la personificación de las deidades míticas de la justicia no lo hace sistemáticamente, sino que sólo usa en ocasiones more platonico como complemento al logos, sirviéndose de modo explícito de las citas e imágenes que la tradición poética le brinda, para presentar como personas divinas lo que él realmente concibe como fuerzas cuyo origen último es divino (dynameis, o en pasajes con más concesiones a la religiosidad tradicional, daimones), y que pueden ser percibidas por los hombres como apariciones personificadas. E1 principio común a todas estas fuerzas es el de retribución que inexorablemente

${ }^{35}$ Platón en $R$. 363a en que critica la imagen del Hades de la poesía órfica se remite a los suplicios de $R$. 362a ("para los que se consideran injustos: ser azotado, torturado, aprisionado y cegado"). La prisión, o incluso simplemente el estar atado, tenía connotaciones de impureza

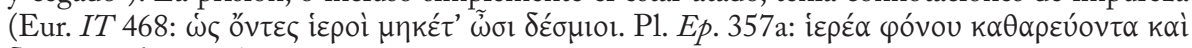
$\delta \varepsilon \sigma \mu o \tilde{v} \kappa \alpha i ̀$ $\varphi v \tilde{\eta} \varsigma)$. Por eso no es extraño que las Erinis aparezcan atando a las almas en la iconografía apulia o en textos de influjo órfico como el pseudoplatónico Axíoco (cf. A. Bernabé 2009). En cambio, las laminillas de Pelina (Orph. Fr. 485-486 Bernabé) instruyen al iniciado, premiado por su pureza con la liberación de toda atadura: "dile a Perséfone que el propio Baco te ha liberado ( $\left.\varepsilon^{\prime} \lambda \cup \sigma \varepsilon\right)$ ". La confesión a la que fuerza el estar atado es el contrario exacto de la declaración que supone la liberación: "cielo" e "infierno" se definen mutuamente por polaridad. 
ha de llegar. Ahora bien, si esta retribución se puede concebir en ocasiones como un mecanismo automático ciego de equilibrio cósmico bajo la férula de Tyche, representado por deidades como Ananke, Adrastea, a veces Poiné y especialmente Némesis, en la gran mayoría de los casos esta compensación tiene un sentido moral ligado a la pronoia divina, como representa sobre todo Dike. Por ello en el diálogo De sera numinis vindicta, Plutarco juega con la multiplicidad de valencias de la palabra dike: sea como deidad en las citas literarias y en los mitos sobre la ultratumba, sea como una dynamis impersonal

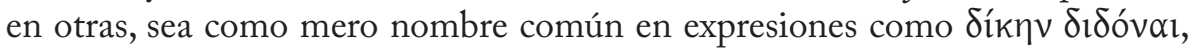
es el centro de una demostración del sentido moral que siempre tiene el castigo divino. Dike cubre todo el espacio conceptual que media entre la imaginación de lo divino y la justicia abstracta en términos humanos, y de este modo es la clave de la teodicea plutarquiana ${ }^{36}$.

${ }^{36}$ Este trabajo forma parte del Proyecto de Investigación “Cosmogonía y escatología en la antigua Grecia. Influjos y paralelos con el Próximo Oriente”, financiado por el MEC (FFI2010-17047). 


\section{Bibliografía}

J. A. Álvarez-Pedrosa, “The Etymology of Gk . "E $\mu$ Tovo $\alpha$ (OF 713-716)”, in M. Herrero de Jáuregui, A. I. Jiménez San Cristóbal, E. R. Luján, R. Martín Hernández, M. A. Santamaría, S. Torallas Tovar, Tracing Orpheus. Studies of Orphic Fragments in Honour of Alberto Bernabé, Berlin, New York, 2011: 291-294.

A. Bernabé, "Imago inferorum orphica", in G. Casadio; P. Johnston (edd.), Mystic Cults in Magna Graecia, Austin, 2009: 95-130.

F. E. Brenk, In Mist Apparelled: Religious Themes in Plutarch's Moralia and Lives, Leiden, 1977.

F. Casadesús, "La concepción plutarquea de los daimones", in A. Pérez Jiménez; F. Casadesús (edd.) Estudios sobre Plutarco: Misticismo y religiones mistéricas en la obra de Plutarco, Madrid, 2001: 23-34.

F. Fortea, "Némesis en la obra de Plutarco de Queronea", in M. García Valdés (ed), Estudios sobre Plutarco: ideas religiosas, Madrid, 1994: 561-574.

F. Frazier; D. Leão (edd.), Tychè et Pronoia, La marche du monde selon Plutarque, Coimbra, 2010.

F. Frazier, "Le De sera, dialogue pythique: hasard et providence, philosophie et religion dans la pensée de Plutarque", in F. Frazier; D. Leão (edd.), Tychè et Pronoia, La marche du monde selon Plutarque, Coimbra, 2010: 69-91.

I. Gallo, Plutarco e la Religione, Napoli, 1996.

R. Gagné; M. Herrero de Jáuregui, “Themis at Eleusis: Clement of Alexandria Protrepticus. 2.25”, CQ 59.1, 2009: 270-274.

G. Giangrande, Plutarco. Narrazioni d'amore, Nápoles, 1991.

R. Hirzel, Themis, Dike und Verwandtes, Leipzig, 1907.

H. G. IngeKamp, "Juridical and non-Juridical Eschatologies and Mysteries", in A. Pérez Jiménez; F. Casadesús (edd.) Estudios sobre Plutarco: Misticismo y religiones mistéricas en la obra de Plutarco, Madrid, 2001: 131-142.

H. Lloyd-Jones, The Justice of Zeus, Berkeley, 1971.

A. Pérez Jiménez, "Plutarco vs. Platón: espacios míticos en el mito de Tespesio", in A. Pérez Jiménez; F. Casadesús (edd.) Estudios sobre Plutarco: Misticismo y religiones mistéricas en la obra de Plutarco, Madrid 2001: 201-210.

G. Ricciardelli, Inni orfici, Milano, 2000.

J. Rudhardt, Thémis et les Hôrai: Recherche sur les divinités grecques de la justice et de la paix, Genève, 1999. 
Miguel Herrero de Jáuregui

M. A. Santamaría, "El motivo literario del viaje al Hades en el mito de Tespesio (Ser. num. vind. 563C-568A)", en J. M. Nieto Ibáñez-R. López López (edd.), El amor en Plutarco, León, 2007: 877-887.

E. Stafford, Worshipping Virtues, Duckworth, 2000.

S. Swain, "Plutarch: Chance, Providence and History", AJPh 110, 1989: 272302.

Y. Vernière, Symboles et mythes dans la pensée de Plutarque, 1977. 


\title{
LA GIUSTIZIA NEL GRILLO E LA CONCLUSIONE DEL DIALOGO
}

Angelo Casanova

Università di Firenze

\begin{abstract}
.
The dialogue lacks a section on justice - one of the four virtues according to Plato and Aristotle (justice, fortitude, prudence and temperance). Several scholars believe the work to be incomplete, with the final part being lost; possibly, though, the author may have intended the work to end as we have it, and given up following through with his paradoxical argumentation.
\end{abstract}

Mi sono occupato altre volte del dialogo Bruta animalia ratione uti, detto anche Gryllus, prima ${ }^{1}$ per precisare l'ambientazione per così dire mitica, cioè il suo riferimento ad Omero (la situazione è quella di $O d$. 12.142, non quella di $O d .10 .135-399$, come si dice di solito), poi $^{2}$ per chiarire che l'Ulisse del dialogo presenta caratteri e motivi valorizzati nella tragedia greca del $\mathrm{V}$ secolo. Oggi vorrei richiamare la vostra attenzione sull'ultima pagina del dialogo e sul vecchio, vecchissimo problema se il dialogo sia concluso e perfetto così comè, oppure se il finale sia andato perduto nel corso della tradizione.

Entrambe le opinioni sono già state autorevolmente sostenute da vari studiosi: ma questo incontro, in cui si parla specificamente dell'importanza della giustizia nelle opere di Plutarco, può essere a mio avviso la sede più adatta per una nuova riflessione in proposito.

Come è noto, si tratta di un dialogo mitico - un caso unico nel corpus plutarcheo - in cui Ulisse prega Circe di concedere che i Greci che si trovano presso di lei, trasformati in animali, possano riprendere le sembianze umane e ritornare con lui in Grecia. Circe acconsente a condizione che accettino gli interessati: a tal fine, ella ridà la parola ad uno di essi, un certo Grillo, ora trasformato in maiale, e si allontana (cap. 1). Subito Grillo dichiara che la vita degli animali è migliore di quella degli uomini e, di fronte alle perplessità di Ulisse, si dichiara pronto a dimostrarlo. Nel cap. 3 (986F) egli dichiara di voler cominciare proprio dalle virtù per cui gli uomini ritengono di essere superiori agli animali, e cioè giustizia, assennatezza, coraggio e tutte le altre (); e passa quindi ad argomentare che l'anima degli animali è più adatta a produrre tali virtù, poiché le produce senza bisogno di ordini e insegnamenti (cap. 3). Per la

${ }^{1}$ Nella relazione fatta all'incontro di Lille, edita come A. Casanova 2005: 97-109; cf. A. Casanova 2005b: 121-131.

${ }^{2}$ Nella relazione tenuta al Convegno di Madrid, 21-24 sett. 2005, edita in Ploutarchos n.s. 4, 2006/2007: 19-28. 
precisione, egli lo dimostra anzitutto (cap.4) per il coraggio, poi per i due campi in cui si manifesta il, e cioè prima (A) per la (cap. 5), cioè per la temperanza, o autocontrollo, la capacità di controllare con la mente gli istinti e le voglie, in particolare la cupidigia, la smania di lusso e di profumi (cap. 6), la bramosia e le perversioni in campo sessuale (cap. 7), e infine la smodatezza nel mangiare e nel bere (cap. 8). Segue (B) la trattazione della , ossia dell'intelligenza, intesa anche come capacità di apprendere le arti e le diverse abilità, come ad esempio l'arte medica (cap. 9) e le altre abilità che dimostrano capacità intellettuali e mnemoniche (cap. 10): e anche in queste varie forme di sapienza - egli argomenta - gli animali risultano superiori agli uomini. A questo punto Ulisse obietta che però agli animali manca la , la percezione che esiste la divinità (meglio che la 'conoscenza di Dio'), e Grillo gli dà una risposta bruciante: ; "Allora non dovremmo neppure dire che tu, Ulisse, così saggio e straordinario come sei, sei nato da Sisifo?”. E così il dialogo si chiude bruscamente (o resta interrotto).

La spiegazione più facile è quella data già da K. ZIEGLer 1965: 131: "Grillo ha appena cominciato a rispondere, ma qui si interrompe il testo... certo per una perdita secondaria. Seguivano indubbiamente altre osservazioni come in De soll. anim. 22 e 35-36, e verosimilmente la dimostrazione della degli animali concludeva il dialogo, e Ulisse si dichiarava persuaso". Questa osservazione è stata variamente ripetuta, variata o ridotta, con spiccata differenziazione tra filosofi e letterati: anzi, si può dire che non c'è un altro punto dell'opuscolo in cui la differenza di lettura dei 'filosofi' e dei 'letterati' venga fuori con altrettanta chiarezza. I primi hanno osservato che il dialogo non può finire senza una trattazione della : particolarmente categorici in proposito erano già H. Usener 1887: LXX ("libello nunc mutilato"), U. Dierauer 1977: 191, D. Russell 1993: 348, ma anche F. Becchi nel suo articolo del 1993: 63³. Incerti (o per lo meno problematici) sono, fra gli editori, sia W. C. НеLmbold 1957 che G. Indelli 1995, mentre C. Hubert 1954 mette indicazione di lacuna con tre asterischi. Oltre tutto - si osserva in genere - la trattazione è stata annunciata nel cap. 3 (come s'è visto all'inizio): cf. in particolare J. A. Fernández Delgado 2000: 175. I 'letterati' invece obiettano che con il duro scambio di battute sulla (percezione o nozione degli dei) il dialogo tocca l'apice della tensione ideologica e dialettica, e che ogni altro finale diverso da questo riuscirebbe fatalmente fiacco e opaco. Ad esempio, Helmbold non segna lacuna finale e annota che è ingegnosa l'interpretazione di Reiske, che si può riassumere così: se chi non conosce dio non possiede la ragione, allora tu difficilmente puoi essere detto figlio di Sisifo! ${ }^{1}$ Il sottinteso, naturalmente, è

\footnotetext{
${ }^{3}$ Vd. anche F. Becchi 2000 e F. Becchi 2001; e cf. A. Barigazzi 1992.

${ }^{4}$ Vd. W. C. Helmbold 1957: 532-533, nota $a$ in calce al testo.
} 
che Sisifo era notoriamente ateo, come si argomentava nella tragedia di Crizia intitolato appunto Sisifo, di cui abbiamo un lungo frammento proprio sulla tematica cara a Sisifo che "gli dei sono soltanto un'utile invenzione" $\operatorname{Tr} G F 1, \mathrm{~F}$ 19 Snell). Anche J. A. Fernández Delgado 2000: 171 osserva che il brusco e inatteso finale fa da pendant con l'inizio ex abrupto.

Ora, non c'è dubbio che in un trattato serio sulle virtù dell'uomo è addirittura ovvio che non può mancare la giustizia. Ho già illustrato nell'incontro di Málaga (A. CAsanova 2010: 65-76) che la quadruplice divisione delle virtù proposta da Platone nel IV libro della Repubblica (sapienza, coraggio, temperanza, giustizia), ripresa e definita da Aristotele nell'Etica Nicomachea (nella Metafisica e in altre opere), è di fondamentale importanza in tutta la tradizione successiva. Le quattro virtù platoniche furono riprese anche nel pensiero cristiano e denominate "cardinali" da Sant'Ambrogio e poi ridefinite con maggiore spessore teorico da San Tomaso d'Aquino, che, riprendendo proprio la tradizione aristotelica, distingue nell'ordine le quattro virtù cardinali, cioè 'cardini' dell'etica umana (giustizia, fortezza, prudenza, temperanza), inferiori solo alle virtù teologali, che sono tre (fede, speranza, carità). Ebbene - tornando al nostro opuscolo - il maiale Grillo sa benissimo che, se vuol dimostrare la superiorità degli animali sugli uomini, deve parlare anche di giustizia: anzi, soprattutto di giustizia. Non per caso, nel cap. 3 la pone in prima sede - nell'ordine: giustizia, assennatezza, coraggio e poi tutte le altre (cf. p. 181). Come virtù "cardinale", cioè cardine dell'etica, la giustizia non può mancare.

Ancor di più: in un serrato confronto tra animale e uomo, non può mancare una trattazione di quel delicato problema che è la giustizia relativa tra uomo e animale. Non per caso, ma per ovvia necessità, nell'altro dialogo plutarcheo sugli animali, il cosiddetto De sollertia animalium, la discussione tra due persone vere e reali (Autobulo e Soclaro, rispettivamente padre e amico di Plutarco) sul tema importantissimo "se e quanto gli animali siano forniti di intelligenza e di raziocinio" (per usare ancora le parole di K. Ziegler 1965: 125) porta ben presto (nei primi capitoli) a prendere posizione sul fatto che gli animali hanno intelligenza e ragione, ma non l'aspirazione alla perfezione, cioè la virtù; e si afferma che gli uomini superano gli animali nella facilità dell'apprendere, nell'acume, nel senso di giustizia e nel buon senso comune, mentre gli animali possono essere superiori in grandezza, velocità, acutezza della vista e dell'udito; inoltre fra gli animali è importante l'amore per i figli, ma senza che sia dato loro il vero scopo di questo amore, che è la giustizia (cap. 4). Ma non per questo, si dice al cap. 7, si può - come fanno Stoici e Peripatetici - negare la ragione agli animali per riservare il concetto della giustizia e del diritto sociale al mondo umano, né si deve escludere un rapporto di giustizia e diritto verso gli animali. E questo, naturalmente, è un tema importante, non solo del De sollertia 
animalium, dove si osserva che servirsi degli animali non è ingiustizia di per sé, ma lo diviene se ce ne serviamo in modo cattivo, incurante o crudele (cap. $7)^{5}$, ma anche in un apposito trattato, egualmente plutarcheo, che va sotto il titolo di De esu carnium, purtroppo conservato in modo incompleto e lacunoso, diviso in due parti ${ }^{6}$, cui sono comunque da riferire anche in alcuni frammenti plutarchei attestati da Porfirio ${ }^{7}$. Il tema è in parte ripreso da Plutarco anche in un passo delle Quaestiones Convivales (2.3, 635E-638A)8.

Ebbene, in base a queste considerazioni sembrerebbe chiaro, palese, quasi ovvio che l'opera è incompleta, anzi largamente incompleta, come pensava Ziegler. In proposito però io userei una maggiore prudenza e farei piuttosto un altro tipo di riflessioni.

Il dialogo Gryllus non è un trattato serio, espositivo, dimostrativo; è una esercitazione retorica, divertente e divertita. Non dobbiamo trasformarlo in un trattato a tesi filosofica. $\grave{E}$ un dialogo mitico, del tutto fittizio, e il protagonista è un personaggio a sorpresa, assolutamente inverosimile, e sostiene una tesi retorica, paradossale: chi parla è Grillo, un maiale, e non Plutarco. È una tesi provocatoria.

Io osserverei nel testo due particolari importanti, finora - a mio avviso - non valorizzati abbastanza. Anzitutto il maiale Grillo ha annunciato fin dall'inizio che è pronto a parlare di tutte le virtù, a partire proprio dalla giustizia e a dimostrare la superiorità degli animali in tutte quante le virtù. Poi, per abilità dialettica (o, se vogliamo, sofistica), è partito dalla per sottolineare addirittura che gli animali sono i veri, non gli uomini, che non sanno nemmeno più che cosa sia il coraggio. A mio avviso, è chiaro e scontato che il maiale ha intenzione di parlare di tutte le virtù, ed ha lasciato alla fine la giustizia, perché è l'argomento fondamentale nella contrapposizione fra animali e uomini. $\mathrm{Ma}$ - e qui interviene la seconda osservazione, che non deve sfuggire nella lettura del testo - è Ulisse che nella discussione, impaziente di sottrarsi alla fiumana argomentiva di Grillo, nel tentativo di fermarla e batterla in maniera decisa, interrompe l'esposizione del maiale e getta in campo, all'improvviso, un argomento che dovrebbe a suo avviso troncare la discussione. È l'obiezione che, al di là delle virtù umane caratterizzanti, che noi chiamiamo "cardinali", ci sono

${ }^{5}$ K. Ziegler 1965: 128. Vd. in proposito la Introduzione di Giuseppina Santese, in L. Inglese; G. SAntese i 999: 15 ss. e 23 ss.

${ }^{6}$ Il testo è edito da Helmbold nel vol. XII della Loeb (W. C. Helmbold i 957). Ma vd., più di recente, L. Inglese; G. SAntese i999; e cf. D. Magini 2001.

${ }^{7}$ Fr. 193 SAndBach (vol. VII, pp. 119-122 nell'edizione Teubner; vol. XV, pp. 352-261 nella Loeb). Si veda quanto scritto in proposito da D. Del Corno, nella Introduzione a D. Magini 2001: 37 ss.

${ }^{8}$ Vd. A. Cainzza 2001; S.-T. Teodorsson 1989: 210-232. 
altre virtù, che riguardano la percezione del divino: in termini platonici e plutarchei, c'è la ; in termini aristotelico-tomistici potremmo dire che si accenna alla prima delle virtù teologali (fede, speranza, carità). Ovvero: l'uomo è superiore agli animali perché ha nozione che esistono gli dei. Su questo tutti sembrerebbero d'accordo: anche Epicuro diceva che tutti hanno una (Epic., Ep. ad Men. 123 ss.). Ma non è su questo che vorrei soffermarmi: vorrei invece ripetere che è Ulisse a deviare e fermare il discorso, non Grillo. Dunque è Ulisse che taglia corto e interrompe la dimostrazione prevista o prevedibile, e già programmata. Naturalmente bisogna chiedersi perché. Ovviamente Ulisse è un personaggio, non una persona reale: dunque bisogna chiedersi perché l'autore gli fa dire questo, cioè perché gli fa interrompere la fiumana della dimostrazione. E questa per me - è la base della soluzione dei nostri problemi nell'interpretazione del dialogo plutarcheo. Evidentemente Plutarco vuole che il suo dialogo rimanga un 'divertissement' limitato, e non diventi un lungo trattato dimostrativo, completo ed esaustivo. A mio avviso, qui si tocca il punto qualificante dell'opera: Plutarco non vuole che si arrivi alla questione centrale, nevralgica, importantissima, se c'è la giustizia fra gli animali, e nemmeno all'altra, egualmente campale per lui, quale sia la giustizia verso gli animali (di cui si parla nel De esu carnium). E quindi fa intervenire proprio il protagonista del dialogo, Ulisse, a dare una svolta decisiva alla dimostrazione, imponendo un drastico taglio: al di là delle virtù classiche, c'è l'intuizione teologica! Ciò che manca nel dialogo, cioè il duplice ampio discorso sulla giustizia tra gli animali e verso gli animali, è dunque omesso volontariamente dall'autore, non caduto "per una perdita secondaria" nella tradizione del testo. Questa a me sembrerebbe una conclusione di cui possiamo sentirci abbastanza sicuri.

C'è però da fare una postilla. L'obiezione di Ulisse, indubbiamente brusca e maligna, è respinta con una battuta feroce, non con un argomentazione sofisticamente elaborata e rifinita. La battuta è così tagliente che non è immediatamente chiara nella sua cattiveria, ma è stata ormai adeguatamente spiegata (da Reiske e gli altri) ${ }^{9}$. Atei sono piuttosto certi uomini, non gli animali: ad esempio proprio quel Sisifo che una certa tradizione, maligna, presenta come padre reale di Ulisse per affermare e spiegare la grande intelligenza ed astuzia di lui. La battuta si spiega con riferimento ad una versione del mito sicuramente post-omerica, forse risalente ai Cypria (secondo F. Jounn 1966:279, n. 5), ben attestata nella tragedia, sia in Eschilo (fr. 175 Radt: Armorum iudicium) che in Sofocle (Ai. 190, Phil. 417, 625, 1311; fr. 567 Radt: Syndeipnoi) e in Euripide (IA 524 e 1362; Cycl. 104). Ed

\footnotetext{
${ }^{9}$ Cf. p. 183 e n. 4.
} 
è una versione del mito ripresa e annotata come curiosità antiquaria dallo stesso Plutarco in Aet. Rom. et Gr. 43, 301D ${ }^{10}$, dove si spiega che secondo alcuni Anticlea concepì Ulisse perché violentata da Sisifo appena prima del suo matrimonio con Laerte: Ulisse era dunque intelligente e astutissimo per motivi genetici. A questo allude pesantemente Grillo: o non è vero che è "seme" di Sisifo (cioè non è intelligente), oppure dimentica che proprio il padre naturale a lui attribuito da certuni era notoriamente ateo. La battuta è tagliente, fortemente offensiva, e tronca quindi il discorso. Dopo, non si può immaginare che Ulisse si dichiari convinto, come pensava Ziegler: piuttosto sarà offeso e arrabbiato. Fosse irascibile come Achille, lo potrebbe uccidere all'istante; o forse, più probabilmente, si può immaginare che interrompa qui il suo tentativo di convincerlo e parta senza di lui.

Pertanto, alla luce di queste considerazioni, io non parlerei né di parte mancante perché perduta, né di argomentazione compiutamente e adeguatamente terminata. Di certo l'autore ha concluso bruscamente la sua opera volontariamente, per non portare fino all'assurdo (e alla noia) il suo gioco paradossale. Egli ha esposto a lungo il pensiero di Grillo, ispirato alla tradizione del cinismo ${ }^{11}$, sfruttando anche elementi epicurei ${ }^{12}$, e persino stoici ${ }^{13}$, anche se vari elementi rivelano la preparazione platonica dell'autore ${ }^{14}$, creando un 'pastiche'

${ }^{10}$ Edito nel vol. IV della Loeb, da F. C. BАввітт 1972.

${ }^{11}$ Che la fonte principale sia cinica è ammesso concordemente dalla critica: vd. e.g. R. Hirzel 1895 II: 128 ss.; K. Ziegler 1965: 132; U. Dierauer 1977: 187 ss.; G. Indelli 1995: 25; G. Santese 1999: 44, nn. 115-116, 49; J. A. Fernández Delgado 2000: 172, 176, 180; per un indice dei motivi cinici vd. J. Bergua Cavero 1991: 13-15.

${ }^{12}$ La componente epicurea è stata variamente valutata. Secondo H. Usener 1887: LXX ss. essa percorrebbe il dialogo da un capo all'altro ("argumenta omnia, et saepe quidem verbo tenus, ex Epicuro philosophia petita sunt”). La critica recente ha molto attenuato tale giudizio: G. InDELLi 1995: 22, si limita a rilevare nel dialogo una "presenza di materiale epicureo e venature antiepicuree"; F. ВесCH 2000: 218, n. 103, afferma che "nel Bruta animalia vi è ben poco di epicureo - al di là di espressioni abbastanza generiche e comunque non riferibili in modo esclusivo ad una precisa scuola di pensiero".

${ }^{13}$ Vd. F. Dümmler, nella recensione agli Epicurea di Usener, ristampata in F. DüMmLeR 1901: 316-318. Che l'opera sia rivolta contro gli Stoici è opinione di K. Ziegler 1965: 131-4; cf. D. Babut 1969: 62 ss.; G. Santese 1999: 44, n. 116.

${ }_{14}$ Ad esempio, la distinzione tra i vari tipi di è certamente epicurea (cf. Ep. ad Men. 127.8), ma anche platonica (Re. 558d-559c; Phdr. 254a-d). L'esempio della scrofa di Crommione (987F) riporta a Lach. 196d-e, dove è citato lo stesso aninale; 988B-C, dove si afferma che gli uomini affrontano pericoli solo per evitare rischi peggiori, può essere confrontato con Phd.68d-69e; 989C, dove è implicita l'idea che le città di mare sono particolarmente esposte alla corruzione dei costumi, può essere accostato a Pl. $\mathrm{Lg}$. 704d-707c; e in generale le osservazioni sugli effetti dell'irruzione delle esterne nell'anima, che evocano l'immagine della città invasa da un esercito straniero, riportano sicuramente alla nota tematica della Repubblica. Senza aggiungere, naturalmente, che tutta la tematica della discussione sulle virtù è spiccatamente di matrice socratico-platonica. 
filosofico che è eufemistico chiamare eclettico o sincretistico (in proposito magari mi soffermerò un'altra volta): ma non ha mai presentato veramente la voce di Ulisse. Di certo né l'autore né il lettore possono realmente condividere l'opinione di Grillo: questa può far sorridere in vari punti per la sua arditezza e per la sua stravaganza, ma alla fine si deve capire che l'autore ha lasciato al lettore il compito di proseguire nel cammino della riflessione in vista di una possibile conclusione. Come il suo maestro Platone, anche Plutarco si riserva di approfondire l'argomento e tirare le conclusioni nell'ambito dell'insegnamento orale svolto all'interno alla sua scuola. Come si può rispondere a Grillo, lo dovranno dire gli alunni - o forse anche i lettori stessi -, preparando una argomentazione seria, da opporre come adeguata antilogia.

In questa opera, certamente retorica (che molti ritengono giovanile ${ }^{15}$, perché fresca, divertente, inattesa, sorprendente, piena di bravura retorica), l'autore non vuole dimostrare una tesi seria, filosofica, coerente con tutto il suo pensiero complessivo di filosofo, ma solo proporre una provocazione retorica, un divertimento sofistico se vogliamo, una tesi paradossale, che dev'essere funzionale ad una vera riflessione filosofica sul tema della virtù animale.

${ }^{15}$ Cf. K. Ziegler 1965: 133; J. Bergua Cavero 1991: 17; W. C. Helmbold 1957: 490; G. Indelli 1995: 21; A. Barigazzi 1992: 301. Ma forse, in definitiva, ha ragione J. A. Fernández Delgado 2000: 181, che è totalmente scettico sulla cronologia di tutte le opere zoologiche di Plutarco. 


\section{Bibliografia}

Babвitт, F.C., Plutarch's Moralia, vol. IV, ed. with an English Translation, Cambridge-Mass., London 1972 (1935).

Babut, D., Plutarque et le Stoïcisme, Paris, 1969.

BARIgAzzI, A., "Implicanze morali nella polemica plutarchea sulla psicologia degli animali", in I. Gallo (ed.), Plutarco e le scienze. Atti del IV convegno plutarcheo, Genova-Bocca di Magra aprile 1991, Genova 1992: 297-315.

Becchi, F., "Biopsicologia e giustizia verso gli animali in Teofrasto e Plutarco", Prometheus 27, 2001: 119-135.

Becchi, F., "Irrazionalità e razionalità degli animali negli scritti di Plutarco, ovvero: il paradosso della superiorità razionale ed etica degli animali", Prometheus 26, 2000: 205-225.

Becchi, F., "Istinto e intelligenza negli scritti zoopsicologici di Plutarco", in M. Bandini; F.G. Pericoli (edd.), Scritti in memoria di D. Pieraccioni, Firenze, 1993: 59-83.

Bergua Cavero, J., "Cinismo, ironía y retórica en el Bruta ratione uti de Plutarco", in J. García López; E. Calderon Dorda (edd.), Estudios sobre Plutarco: paisaje y naturaleza. Actas del II Simposio Español sobre Plutarco, Murcia 1990, Madrid 1991: 13-19.

Cainzza, A., Plutarco, Conversazioni a tavola, libro II, Napoli, 2001.

Casanova, A., "Il 'Grillo' di Plutarco e la tradizione della figura di Ulisse", Ploutarchos n.s. 4, 2006/2007: 19-28.

Casanova, A., "Il 'Grillo' di Plutarco e Omero", in J. Boulogne (ed.), Les Grecs de l'antiquité et les animaux. Le cas remarquable de Plutarque, Lille, 2005: 97-109.

Casanova, A., "The Time Setting of the dialogue Bruta animalia ratione uti", in A. Pérez Jiménez; F. Titchener (edd.), Historical and Biographical Values of Plutarch's Works. Studies devoted to professor Philip A. Stadter by the International Plutarch Society, Málaga, Logan, Utah, 2005: 121-131.

Casanova, A., "Traduzioni e riusi del Grillo di Plutarco nel Rinascimento fiorentino: Machiavelli e Gelli", in A. Pérez Jiménez (ed.), Plutarco renovado. Importancia de las traductiones modernas de Vidas y Moralia, Málaga, 2010: 65-76.

Dierauer, U., Tier und Mensch im Denken der Antike. Studien zur Tierpsychologie, Anthropologie und Ethik, Amsterdam, 1977.

Dümmler, F., Kleine Schriften, I. Zur griechischen Philosophie, Leipzig,1901.

Fernández Delgado, J. A., "Le Gryllus, une éthopée parodique”, in L. van der Stockt (ed.), Rhetorical Theory and Praxis in Plutarch, Acta of the 
IV International Congress of the IPS, Leuven, july 3-6, 1996, Louvain, Namur, 2000: 171-181.

Helmbold, W. C.; Cherniss, H., Plutarch's Moralia, vol. XII, ed. with an English Translation, Cambridge, Mass., London 1957.

Hirzel, R., Der Dialog. Ein literarische Versuch, Leipzig, 1895.

Hubert, C., Plutarchi Moralia, vol. VI.1, Lipsiae, 1954.

Indelli, G., Plutarco, Le bestie sono animali razionali, Intr. testo critico trad. e comm., Napoli, 1995.

Inglese, L.; Santese, G., Plutarco, Il cibarsi di carne, intr. testo critico, trad. e commento, Napoli, 1999.

Jounan, F., Euripide et les légendes des Chants Cypriens, Paris, 1966.

Magini, D., Plutarco, Del mangiar carne. Trattati sugli animali, traduzione di Donatella M., con introduzione di D. Del Corno, Milano, 2001.

Russell, D., Plutarch. Selected Essays and Dialogues, A new translation by D. R., Oxford, New York, 1993.

Teodorsson, S.-T., A Commentary on Plutarch's Table Talks, vol. I (1-3), Göteborg, 1989.

Usener, H., Epicurea, Leipzig, 1887.

Ziegler, K., Plutarco, trad. it., Brescia 1965 (= "Plutarchos von Chaironeia", RE XXI.1, 1951: 636-962. 
(Página deixada propositadamente em branco) 


\title{
Animali parlanti e giustizia in Plutarco ed Omero
}

\author{
Marcello Tozza \\ Universidad de Málaga
}

\begin{abstract}
In his dialogue Bruta animalia ratione uti, Plutarch shows not only an incredible satirical vein, but also great knowledge of Homeric poems. The latter serve as a starting point for creating a surreal episode; moreover, they serve as a reference for the author, with literal quotes, to deepen the meaning of his speech. A wise use of the Homeric text allows Plutarch to place animals above men, from a physical, ethical and rational point of view. In veiled and ironical terms, Plutarch brings animals nearer the characteristics which the same deities are assigned. Like Gryllus in Plutarch, Xanthus in Homer imposes his role as mediator between the physical and metaphysical worlds. Achilles' horse, whom Hera endows with speech, but who loses this ability because of the Erinyes, who are the ministers of Justice, expresses the "right" according to Homer's categories, summarizing, in a few verses (Iliad 19.408-417), the structural order dominating the human condition.
\end{abstract}

Nel Grillo ${ }^{1}$ di Plutarco, Circe concede la parola ad un maiale che, trasformato da uomo in animale, preferisce questa condizione allidea di ritornare uomo, e mette dialetticamente in difficoltà un Ulisse demitizzato.

Già gli studi condotti da Angelo Casanova 2005: 97-109 hanno dimostrato come Plutarco non abbia semplicemente preso spunto, in maniera libera e vaga, da un episodio dell'Odissea per creare il suo dialogo: Plutarco ha voluto inserire questa parentesi in un momento preciso del poema, ed esattamente dopo la sequenza dei versi 37-141 del libro XII, in cui Circe, prima che Ulisse abbandoni definitivamente la sua isola, annuncia alleroe quali altri ostacoli dovrà affrontare per fare ritorno in patria; la dea dà consigli su come superare le Sirene, Scilla, Cariddi e il soggiorno presso l'isola Trinachia, e, mentre nell'Odissea Ulisse, ascoltati i consigli, si separa da Circe senza

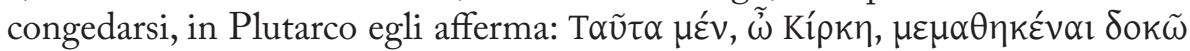

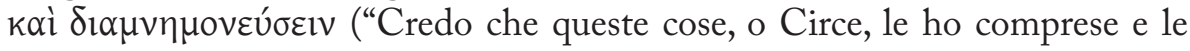
terrò a mente").

Questa battuta iniziale del Grillo, a cui segue immediatamente la richiesta, da parte di Ulisse, di essere informato sulleventuale origine umana degli animali dell'isola, vuole essere un anello di congiunzione tra il dialogo odissaico e quello plutarcheo.

Un Ulisse incapace di contrastare le argomentazioni del suo interlocutore si ritrova di fronte ad una pretesa di superiorità da parte dell'animale sull'essere umano, una superiorità di carattere fisico, etico e razionale, sostenuta da argomentazioni che capovolgono il sistema di valori su cui si basa l'epopea omerica e, in particolare, la figura di Ulisse.

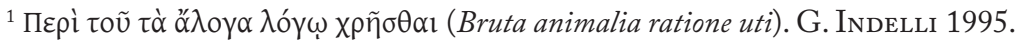


Grillo dà inizio al proprio discorso persuasivo menzionando le tre principali virtù per le quali, impropriamente secondo l'animale, gli uomini

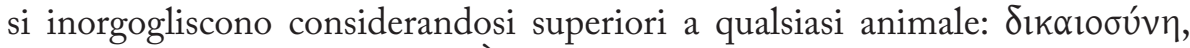
$\varphi \rho o ́ v \eta \sigma ı s ~ e ~ \alpha ̉ v \delta \rho \varepsilon i ́ \alpha(986 \mathrm{~F})$. È proprio quest'ultimo concetto, il coraggio, associato alla forza fisica, che il protagonista utilizza per attaccare in maniera diretta la figura di Ulisse: l'eroe diviene l'emblema di un'intelligenza umana che non si mostra "giusta" dal punto di vista etico, ma, al contrario, rivela un allontanamento da qualsiasi comportamento corretto o coraggioso; un sapiente utilizzo del testo omerico, attraverso citazioni letterali, consente di porre l'animale al di sopra dell'essere umano.

In $987 \mathrm{C}$ è rilevante la citazione degli epiteti omerici $\theta \rho \alpha \sigma u ́ c$ (“audace”) e $\pi \tau \circ \lambda i ́$ ío $\theta$ os ("distruttore di città"), che qui Grillo menziona allo scopo di sottolineare l'ingiusta attribuzione all'eroe di questi aggettivi.

Nel primo caso, si tratta di un epiteto che compare una sola volta nell'Odissea, riferito allo stesso Ulisse (10.436), mentre nell'Iliade compare più volte accanto ai nomi di Archeptolemo $(8.128,312)$, Laogono (16.604) e, soprattutto, Ettore (12.60, 210, 13.725, 22.455, 24.72, 786).

Riguardo al secondo epiteto, è utilizzato, nell'Odissea, per il solo Ulisse (8.3, 9.504-530 [ $\pi \tau \circ \lambda ı$ ı́óp nell'Iliade, affianca anche i nomi di altri personaggi (Achille, Oileo padre di Aiace, Otrinteo, Ares ed Eniò) ${ }^{2}$.

Gli epiteti menzionati mostrano di avere una funzione ben precisa: Grillo,

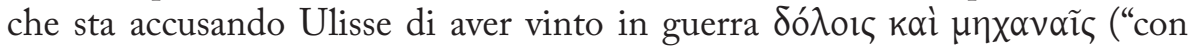
inganni e macchinazioni”: 987C), vuol sottolineare il fatto che meritano questi aggettivi soltanto divinità della guerra, quali Ares ed Eniò, o eroi che, come Ettore e Achille, si distinguono per la propria forza e si servono di essa, non dell'inganno, per avere la meglio.

In 988D Grillo cita altri epiteti con un fine abbastanza chiaro: fa notare all'eroe che, quando la poesia vuol segnalare uomini particolarmente valorosi

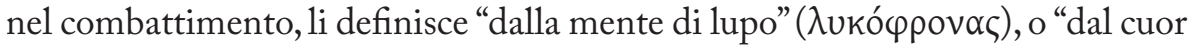

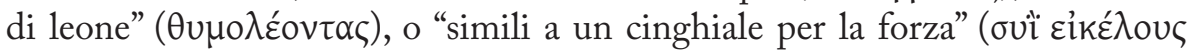

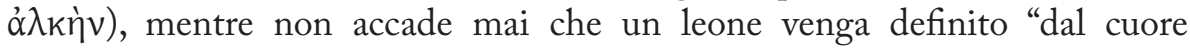

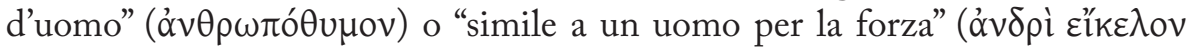

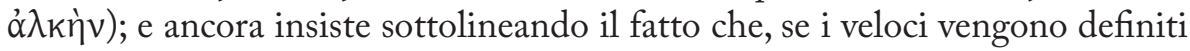

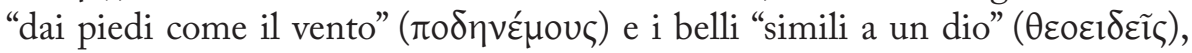
significa che i personaggi che si distinguono vengono paragonati a chi, nello stesso campo, è superiore. Il primo epiteto, in effetti, compare in Omero come nome proprio: è il nome dello scudiero di Aiace Telamonio, Licofrone, che

${ }^{2}$ Il. 2.278, 10.363 (Ulisse); 8.372, 15.77, 21.550, 24.108 (Achille); 2.728 (Oileo); 20.384 (Otrinteo); 20.152 (Ares); 5.333 (Eniò). 
nell'Iliade (15.430) muore trafitto dalla lancia di Ettore. Il secondo, "dal cuor di leone", è utilizzato da Omero per definire Eracle (Od.11.267; Il. 5.639), Ulisse (Od. 4.724, 814) ed Achille (Il. 7.228). Il terzo, "simile a un cinghiale per la forza", è utilizzato nell'Iliade per definire Idomeneo (4.253) e Aiace Telamonio (17.281). Gli ultimi due epiteti, "dai piedi come il vento" e "bello come un dio", sono frequentemente usati da Omero: il primo per definire, nell'Iliade, la dea messaggera Iride (Il. 2.786, 5.353, 368, 11.195, 15.168, 200, 18.166, 183, 196, 24.95.); il secondo per definire numerosi personaggi ${ }^{3}$, in particolare, nell'Iliade, Paride e Priamo, e, nell'Odissea, Telemaco e Teoclimeno.

Dunque, attraverso la citazione del testo omerico, viene messo in evidenza come gli uomini più valorosi, per essere segnalati, vengano paragonati agli animali e alle divinità, e come le stesse divinità, quando vengono collegate al concetto di forza fisica, vengano paragonate agli animali, ma non agli uomini. In questo modo, Plutarco non solo pone l'animale al di sopra dell'uomo, ma addirittura lo avvicina alle caratteristiche assegnate alle stesse divinità.

Anche nel dialogo De sollertia animalium, Plutarco cita Omero con il chiaro intento di enfatizzare le virtù animali associandole a caratteristiche divine: nel passo 978B Fedimo, nel suo tentativo di dimostrare la maggiore intelligenza degli animali marini rispetto a quelli terrestri, menziona una particolare caratteristica della seppia, ossia la sua capacità di liberare liquido nero, creandosi attorno una nube oscura che offusca la visuale dei pescatori; il personaggio plutarcheo paragona la seppia, per questa sua capacità, alle divinità omeriche, affermando che "imita gli dèi omerici che spesso avvolgono e nascondono qualcuno, se vogliono salvarlo, <<in una nube oscura >>"

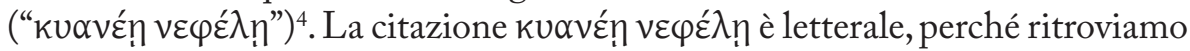
l'espressione nel libro V dell'Iliade (v. 345), in cui Apollo avvolge Enea "in una nube oscura" per sottrarlo al bronzo di Diomede.

Così il testo omerico, oltre che punto di riferimento, diviene lo strumento attraverso cui Plutarco pone l'animale in un piano intermedio tra essere umano e divinità: Circe si era già espressa sull'idea di ritrasformare in uomini gli animali, ricordando ad Ulisse, in 986A, che egli aveva "scelto male" ( $\kappa \alpha \kappa \tilde{\omega} \varsigma$ $\beta \varepsilon \beta 0 u \lambda \varepsilon \tilde{v} \sigma \theta \alpha \mathrm{l}$ ) riguardo a sé stesso e ai compagni (è evidente il richiamo al verso 387 del libro $\mathrm{X}$ dell'Odissea, in cui Ulisse chiede esplicitamente a Circe di liberare i suoi compagni); tuttavia, la dea preferisce utilizzare l'animale per

${ }^{3}$ Il. 3.16, 27, 30, 37, 58, 450, 6.290, 332, 517, 11.581, 13.774, 24.763 (Paride); 24.217, 299, 372, 386, 405, 483, 552, 634, 659 (Priamo); 2.623 (Polisseno); 2.862 (Ascanio); 12.94 (Deifobo); 17.494 (Areto); 17.534 (Cromio); 19.327 (Neottolemo). Od. 1.113, 3.343, 14.173, 16.20, 17.328, 391 (Telemaco); 15.271, 508, 17.151, 20.350, 363 (Teoclimeno); 4.628, 21.186 (Eurimaco); 6.7 (Nausitoo); 7.231 (Alcinoo); 10.205 (Euriloco); 21.277 (Antinoo).

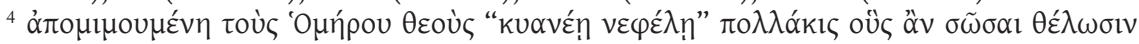

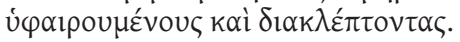


sostenere la validità della propria opinione, e quest'ultimo non solo si mostra adatto al proprio ruolo di mediatore, ma riesce addirittura a presentarsi come più degno, rispetto all'uomo, di essere relazionato al divino.

Anche in Omero assistiamo ad un insolito dialogo tra un eroe ed un animale, e, ancora una volta, una dea concede la parola all'animale perché critichi il punto di vista dell'eroe.

Il dialogo tra Achille e il suo cavallo Xanto avviene nel libro 19 dell'Iliade (400-423), nel momento in cui la narrazione s'incentra sul ritorno in battaglia dell'eroe greco; Achille è già salito sul carro, assieme al suo auriga Automedonte, e, poco prima di lanciarsi nella mischia, si rivolge ai suoi cavalli:

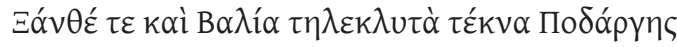

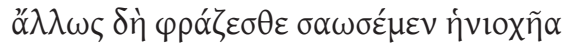

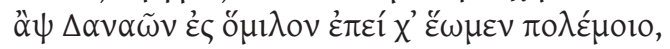

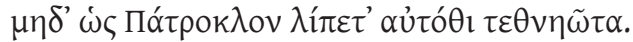

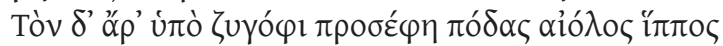

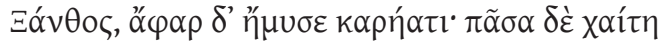

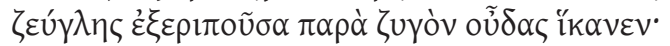

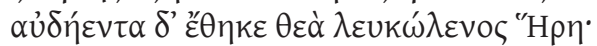

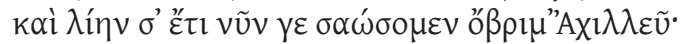

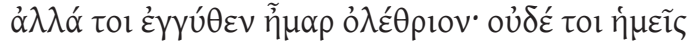

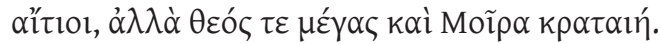

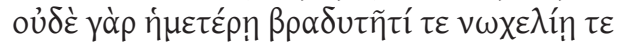

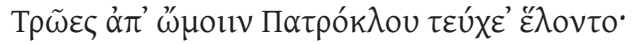

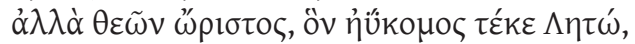

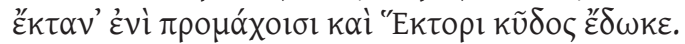

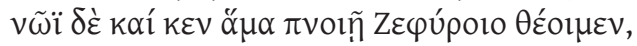

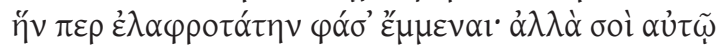

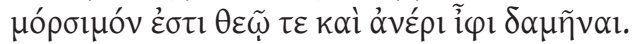

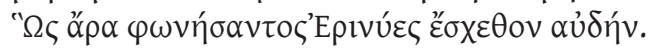

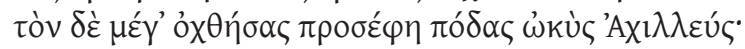

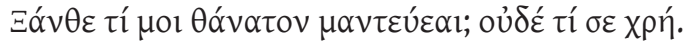

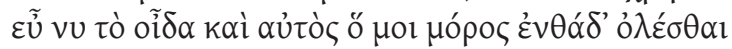

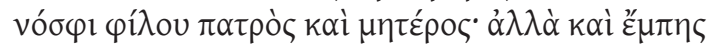

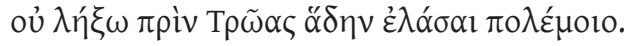

Xanto e Balio, illustri figli di Podarge, pensate di riportare in salvo il vostro auriga in mezzo ai Greci, quando saremo sazi di guerra, diversamente da come avete lasciato là Patroclo morto > . Da sotto il giogo, Xanto dagli zoccoli lucidi improvvisamente abbassò la testa, e la criniera, cadendo dal collare, arrivò a terra lungo il giogo, ed Era, la dea dalle candide braccia, lo fece parlare: 
"Sì, ancora una volta ti salveremo, fortissimo Achille, ma ti è vicino il giorno di morte: non ne siamo noi responsabili, ma un grande dio e la Moira feroce.

Non per nostra lentezza od incuria i Troiani hanno tolto le armi dalle spalle di Patroclo, ma il più forte degli dèi, il figlio di Leto dai bei capelli, l'ha ucciso in prima fila e ha dato gloria ad Ettore.

Noi potremmo anche correre come il soffio di Zefiro che, dicono, è il più veloce, ma il tuo destino è quello di essere ucciso da un uomo e da un dio $>$. Mentre così parlava, le Erinni fermarono la sua voce e, turbato, rispose il rapido Achille:

"Xanto, perchè mi predici la morte? A te non spetta.

Lo so anch'io che il mio destino è di morire qui, lontano dal padre e dalla madre, e tuttavia non smetterò prima di avere saziato di guerra i Troiani" ${ }^{5}$.

Detto ciò, Achille lancia i cavalli in prima fila. Dunque, Era concede la parola all'animale perché ricordi all'eroe l'impossibilità di trovare, nella realtà sensibile, la causa di un avvenimento: la morte di Patroclo era stata determinata dall'intervento di Apollo, il quale, "avvolto in una fitta nebbia" (’̉ $\kappa \varepsilon \kappa \alpha \lambda \cup \mu \mu \varepsilon ́ v o \varsigma$, Iliade 16.790), l'aveva colpito alle spalle, facendogli cadere di dosso l'elmo, la corazza, lo scudo e la lancia (vv. 791-804), rendendo così semplice l'attacco con la lancia ad Euforbo e, finalmente, ad Ettore (vv. 806821). Lo stesso Patroclo mostrerà la propria consapevolezza dell'intervento divino, chiarendo ad Ettore che hanno provocato la sua morte innanzitutto

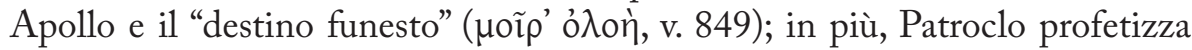

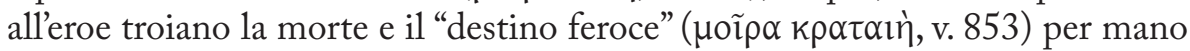
di Achille, e la reazione è la stessa a cui assistiamo nel dialogo tra quest'ultimo ed il suo cavallo, in quanto Ettore chiede all'avversario già morto: "Patroclo,

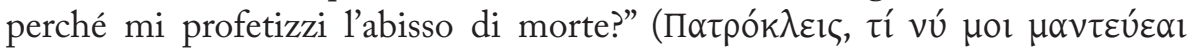

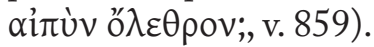

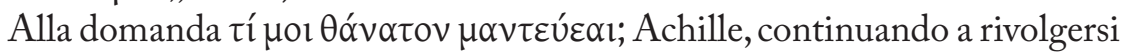

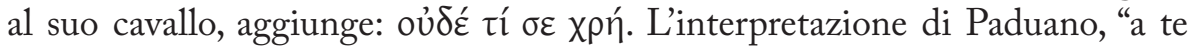
non spetta", si mostra efficace in quanto rinvia al senso dell'intervento delle Erinni, che tolgono la voce all'animale; le Erinni intervengono qui in quanto garanti dell'ordine naturale del reale, i cui limiti venivano oltrepassati dall'uso della parola da parte dell'animale: si tratta della stessa funzione delle Erinni che Eraclito sottolinea quando afferma, nel frammento 94 Diels-Kranz, che "il sole non oltrepasserà le misure: in caso contrario, le Erinni ministre della

\footnotetext{
${ }^{5}$ Viene riportata, in questa sede, la traduzione di G. Paduano 2007.
} 
Giustizia lo scoveranno" ("H入ı

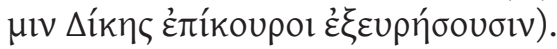

Così, in questo contesto, l'entità divina può rompere i limiti dell'ordine naturale, ma non quelli stabiliti dalla Moira: è per questo che in Omero assistiamo, in determinati casi, ad un autentico lutto della divinità, e vediamo lo stesso Zeus in una situazione di totale impotenza, nel libro 16 dell'Iliade, di fronte alla morte del figlio Sarpedonte; in quest'aspetto il mondo divino si mostra, nella maniera più profonda, come metafora della condizione umana.

Anche nella profezia di Xanto vengono menzionati, come futuri responsabili della morte di Achille, un uomo, un dio e la Moira: sarà Ettore stesso, in punto di morte, a chiarire ad Achille l'identità dell'uomo e del dio ("Paride e Febo Apollo t'uccideranno alle porte Scee, per quanto tu sia

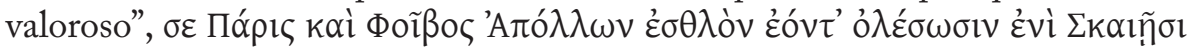

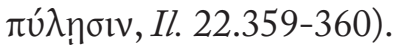

Insistendo sui tre piani, gerarchicamente strutturati, da cui scaturiscono le situazioni contingenti, Xanto descrive in sintesi le categorie attraverso cui la società omerica giudica il mondo fisico in relazione con il metafisico: la condizione umana si muove all'interno dei limiti stabiliti dal divino, che, a sua volta, segue la volontà del Destino. Il filologo tedesco Walter Otto ha concesso un ampio spazio, nel suo lavoro di ricerca su Gli dèi della Grecia forte nesso che si registra, nel linguaggio omerico, tra il concetto di "destino" e quello di "parte assegnata": analizzando la funzione dei sinonimi $\mu$ oĩ $\alpha$ e

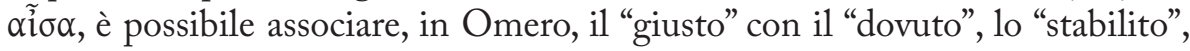
il "determinato", eliminando, di fronte al Destino, la contrapposizione giustoingiusto, sostituita da un'idea di "giustizia" che si identifica con la "necessità".

Da qui la domanda dell'eroe omerico, "perché mi predici la morte?"; la consapevolezza del determinato porta all'accettazione del destino, che però lascia spazio alla libertà che si esercita nell'attuare all'interno degli stessi limiti stabiliti: per questo Achille sceglie di continuare a lottare fino a "saziare di guerra i Troiani”.

Appare significativa, nel sintetizzare quest'ordine strutturale che domina la realtà, la scelta dell'animale: il cavallo Xanto viene menzionato direttamente solo in un'altra occasione da Omero, nel libro 16 dell'Iliade, quando Patroclo veste le armi di Achille e Automedonte gli aggioga i cavalli. Leggiamo nei versi 148-154:

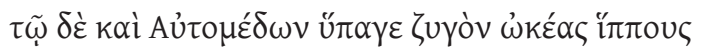

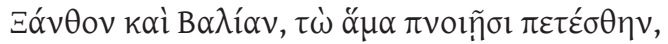

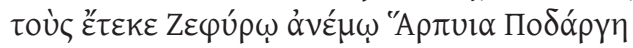

${ }^{6}$ W. F. Oтто 1929. 


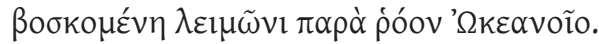

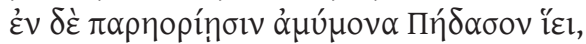

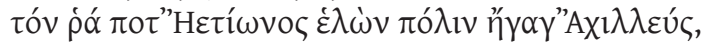

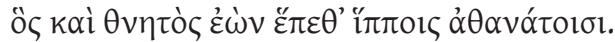

\section{E Automedonte gli aggiogò i cavalli veloci,}

Xanto e Balio, che volavano assieme al vento:

li generò a Zefiro l'arpia Podarge,

mentre pascolava sui prati presso le acque del fiume Oceano.

Al bilancino collocò il bellissimo Pedaso,

che Achille aveva portato dal sacco della città di Eezione,

e, pur essendo mortale ${ }^{7}$, seguiva i cavalli immortali.

Dunque, nel presentare Xanto e Balio, viene posto l'accento sulla natura immortale degli animali, associandoli alla sfera divina, ed in particolare a due entità che hanno a che fare con il concetto di rapidità (Zefiro in quanto vento, Podarge perché "dai piedi agili", come mostra l'etimologia del nome); si tratta di un aspetto che rappresenta, nel testo omerico, una delle molteplici tracce di un pensiero religioso pre-ellenico, di cui, in questo contesto, si conserva un chiaro ricordo: la sacralità del cavallo nel mondo miceneo viene messa in luce da varie testimonianze, che appartengono alla fase finale della tarda età del bronzo egea.

Lo studioso L. R. Palmer, analizzando le tavolette in Lineare B di Pilo Fa 16 ed Ea 59, ha ricondotto le forme $i$-qo e $i-q o-j o$, rispettivamente, al dativo

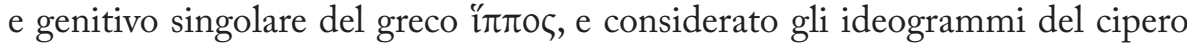
e del grano, presenti nel testo, come indicanti le offerte ad un "Dio Cavallo" .

Nelle nuove tavolette in Lineare B di Tebe, scoperte nel centro della città moderna da V. Aravantinos, tra l'autunno del 1993 e la primavera del 1995, sono presenti le forme $i-q o-p o-q o-i$ (in Fq 214, 252, 254+255, 272, 276, 305, 367) e $i$-qo-po-qo (in Fq 198, 247), che corrispondono rispettivamente al dativo

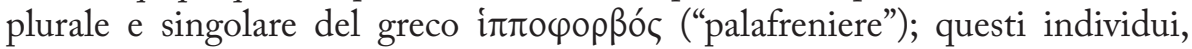
destinati alla cura dei cavalli, figurano nei documenti come destinatari di farina d'orzo, assieme a termini che indiscutibilmente rinviano alla sfera cultuale (quali $m a-k a$ e $k o-w a$, riconosciuti come i nomi micenei di Demetra e Kore, o $a-k e-n e-u-s i$, che corrisponde al dativo plurale del participio presente del verbo à $ү v \varepsilon u ́ \omega$, "essere puro").

Un altro dato testuale significativo è costituito dall'espressione, presente

\footnotetext{
${ }^{7}$ Pedaso incontrerà la morte poco più tardi per mano di Sarpedonte, che manca Patroclo ma colpisce il cavallo con la lancia (Il. 16.466-469).

${ }^{8}$ L. R. Palmer 1963; idem 1983: 283-296.

${ }^{9}$ V. Aravantinos; L. Godart; A. Sacconi 2001.
} 
nella tavoletta di Pilo An 1281, po-ti-ni-ja i-qe-ja, che corrisponde al greco

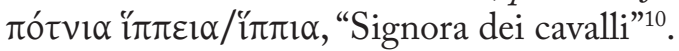

Possediamo, inoltre, un'unica ma importante testimonianza archeologica che mostra un nesso, nella cultura micenea, tra il cavallo ed una figura divina: si tratta di una statuetta in terracotta datata a cavallo tra i secoli XIII e XII a. C., rinvenuta in una tomba situata nei pressi di Kharvati, in Attica; si riconosce facilmente il motivo iconografico della dea micenea dalle braccia alzate, seduta in sella ad un cavallo ${ }^{11}$.

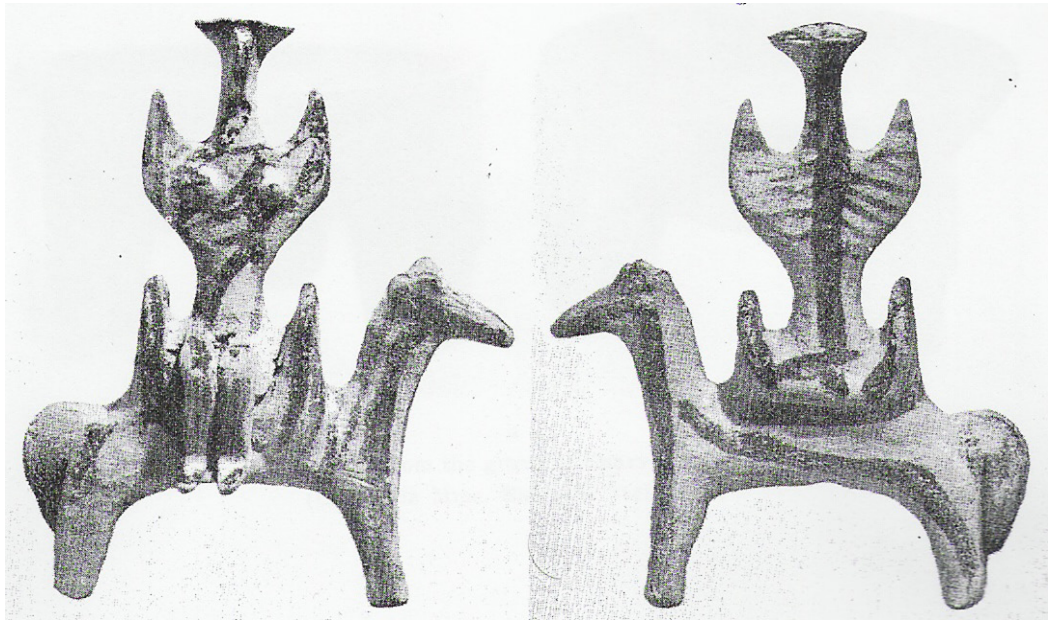

D. Levi 1951, tav. 4 a-b.

In Omero sono numerosi i passi in cui gli animali, in particolare gli uccelli, vengono presentati come intermediari tra mondo fisico e metafisico, ed associati alle stesse divinità, che sono solite manifestarsi, oltre che come fenomeni naturali ed esseri umani, sotto forma animale ${ }^{12}$; Plutarco rivaluta questo ruolo dell'animale, e, nei capitoli 74-76 del trattato De Iside et Osiride, utilizzando categorie antropologiche che sembrano anticipare lo strutturalismo di C. Lévi-Strauss 1962, considera le caratteristiche stesse degli animali come causa di un loro culto simbolico, giungendo alla conclusione che, come

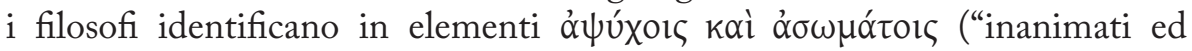
incorporei”) un â̌vı $\gamma \mu \alpha$ del divino, così gli animali costituiscono oggetto di

${ }^{10}$ M. GÉrard-Rousseau 1968: 118-120.

${ }^{11}$ D. Levi 1951: 108-125.

12 È emblematico il caso di Atena, che non solo utilizza gli uccelli come strumento attraverso cui inviare un segnale, ma adotta la forma degli stessi per compiere diverse apparizioni o sparizioni: Il. 5.778, 7.59, 10.274, 19.350; Od. 1.320, 3.372, 22.240. 
venerazione unicamente in quanto, attraverso di essi, si venera l'entità divina,

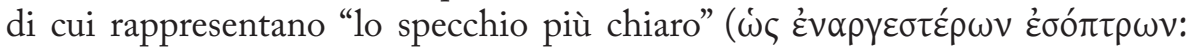
382A).

Dunque, sia in Plutarco che in Omero, è l'accostamento dell'animale alla sfera divina che giustifica l'utilizzo dello stesso per esprimere un'idea di "giustizia", che, nel primo caso, attraverso un linguaggio ironico ma intriso di sapienti citazioni, acquisisce un valore etico, nel secondo, attraverso l'ambivalenza del termine $\mu$ ĩ $\rho$, viene a coincidere con il concetto di "ordine cosmico". 


\section{Bibliografia}

Aravantinos, V.; Godart, L.; Sacconi, A., Thèbes. Fouilles de la Cadmée I. Les tablettes en linéaire $B$ de la Odos Pelopidou. Edition et commentaire, Pisa, Roma, 2001.

Casanova, A., Il "Grillo" di Plutarco e Omero, in J. Boulogne (ed.), Les Grecs de l'antiquité et les animaux. Le cas remarquable de Plutarque, Université Charles-de-Gaulle, Lille 3, 2005: 97-109.

IndelLi, G., Le bestie sono esseri razionali, Napoli, 1995.

Levi, D., "La Dea micenea a cavallo", in G. E. Mylonas (ed.), Studies presented to D. M. Robinson, Saint-Louis, Missouri, 1951: 108-125

LÉvi-Strauss, C., Le totémisme aujourd'hui, Paris, 1962

Paduano, G., Omero, Iliade, Milano, 2007.

Отто, W. F., Die Götter Griechenlands. Das Bild des Göttlichen im Spiegel des griechischen Geistes, Bonn, 1929.

Palmer, L. R., The interpretation of mycenaean greek texts, Oxford, 1963.

Palmer, L. R., “Studies in Mycenaean Religion”, in P. Händel; W. Meid (edd), Festschrift für Robert Muth, Innsbrucker Beiträge zur Kulturwissenschaft 22, Innsbruck, 1983: 283-296. 


\section{IV. \\ CONCEPTUAL TENSIONS AND JUSTICE IN THE AFTERLIFE}


(Página deixada propositadamente em branco) 


\title{
Eunomia in heaven and on earth. Plutarch's nomos BETWEEN RHETORIC AND SCIENCE
}

\author{
Luc VAN DER STOckT \\ Katholieke Universiteit Leuven
}

\begin{abstract}
Against the Epicureans, Plutarch holds that philosophy and religion are more important for society than statute laws. Given the analogy between the politician and the god-creator of the harmonious cosmos, rulers and their laws should, then, humbly imitate god and his divine law of Justice, thereby having only persuasion as a tool. It is argued that the rhetorical concept of persuasion plays an equally important role in the way the god, according to Plutarch (as a Platonist) has created the cosmos: divine persuasion overcame the laws of nature. The prescriptive character of this persuasion, however, conflicts with our modern concept of the descriptive character of physical laws.
\end{abstract}

\section{Statute law and divine law: prescribing ethics}

Statute laws, as a product of human legislation, are one of the cornerstones of democratic societies: they distinguish them from theocratic regimes, and, in that they are products of public debate, from aristocratic regimes that rule at their own discretion. Even more, according to Isocrates in his Nicocles 9, human legislation is a characteristic of, and even a condition for living in society: laws prescribe how individuals should behave when living together, and thus they set us free from the way of life of animals ( $\tau 0 \tilde{v} \theta \eta \rho i \omega \delta \tilde{\omega} \zeta \zeta \tilde{\eta} v$ ). The Epicureans would agree to that. Colotes at least, in Plutarch's Adversus Colotem (1124D), affirms:

Those men who appointed laws and usages and established the government of cities by kings and magistrates brought human life into a state of great security and peace and delivered it from turmoil ( $\theta o \rho v ́ \beta \omega v)$. But if anyone takes all this away, we shall live a life of brutes (Onpíov ßíov) ...

In this light, it would testify to a naïve optimism if one would uphold

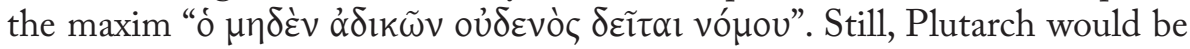
inclined to go with the motto to a certain extent, and not simply because he dislikes the Epicureans. In his opinion, even if there were no laws, we would still have philosophy to guide us on the road to virtue: "we would do freely at the bidding of our reason, as Xenocrates says, what we do now at the command of the law". Besides, "the very legislation that Colotes praises provides first and foremost for our belief in the gods" (1125). Philosophy and religion, then, are foundational for society. In To the uneducated ruler 5, just like the young philosopher in Progress in Virtue $§ 10$ is compared to the one who is initiated 
into the Mysteries and then sees a great light, so the ruler copies the light of justice god has established in the cities as an image of his Reason. The cardinal concept is expressed in the repeatedly quoted passage from Plato, Laws 4, $715 e^{-716 a^{1}:}$

God who, as old tradition tells, holdeth the beginning, the end and the center of all things that exist, completeth his circuit by nature's ordinance in a straight, unswerving course. With followeth Justice always, as avenger of those that fall short of the divine law; and she, again, is followed by every man who would fain be happy, cleaving to her with lowly and orderly behaviour; but he who is uplifted by vainglory, or prideth himself on his riches ..., and through his pride joined to youth and folly, is inflamed in soul with insolence, dreaming that he has no need of ruler or guide, etc.

Rulers and their laws should, then, humbly imitate god and his divine law. And then, the key concepts are that of the "excellent professional" and

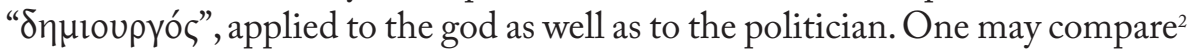
De communibus notitiis 1065F:

but Zeus the paternal and supreme and righteous and, as Pindar calls him,

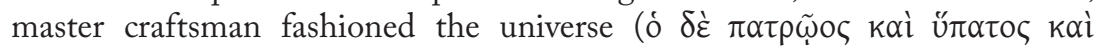

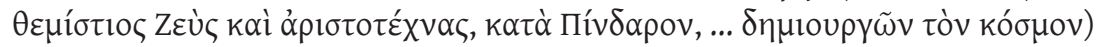
not ... as a drama but as a town common (Kolvòv óotv) to gods and men who should live lawful partners in right and virtue concordantly and blissfully

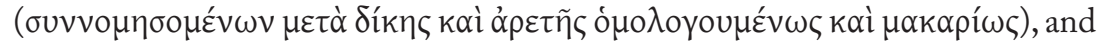

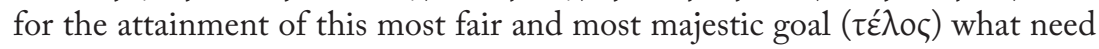
had he of pirates and murderers and parricides and tyrants?

\section{with Precepts of Statecraft 807B-C:}

For truly it is an outrageous and abominable thing if a pilot selects sailors and a ship's captain selects a pilot "well knowing how at the stern to hold steady the tiller etc." and an architect chooses subordinates and handicraftsmen who will not spoil his work, but will cooperate to perfect it, whereas the statesman, who is, with a term from Pindar, the artist par excellence and the creator of

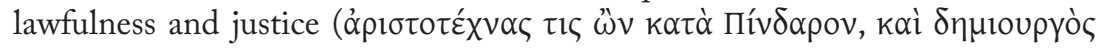

\footnotetext{
${ }^{1}$ For an analysis of the cluster of parallels to which this passage belongs, see L. VAN DER Sтоскт 2004: 137-149.

${ }^{2}$ For an analysis of the cluster of parallels to which this passage belongs, see L. VAN DER Sтоскт 2002: 115-140.
} 


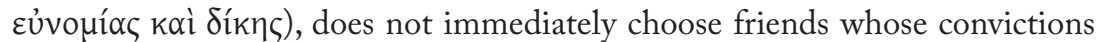
are like his own, who will aid him and share his enthusiasm for what is noble

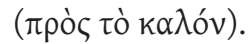

The analogy between the agent in the sphere of statute law and in that of divine law is almost perfect, except that the human ruler is only "a kind of" ( $\tau ı)$ artist par excellence. Since the perfect artist by definition reaches his goal, this implies that installing the law of justice on a human level is more problematic than on the divine, cosmic level; installing lawfulness and justice in human society is but a goal, whilst at the cosmic level, it is a fact, brought about by the divine agent. Apart from his character, the politician has but one tool, as Precepts of Statecraft $\$ 5$ argues; it is that of $\pi \varepsilon \imath \theta \omega$, capable of "softening by persuasion and overcoming by charms the fierce and violent spirit of the people"; the politician cannot "gain power and rule the multitude ( $\dot{\varepsilon} \xi 1 \sigma x \tilde{v} \sigma \alpha l$ $\kappa \alpha i ̀ ~ \kappa \rho \alpha \tau \tilde{\eta} \sigma \alpha 1 \tau \tilde{\omega} \nu \pi \circ \lambda \lambda \tilde{\omega} v)$ unless he possesses persuasion and attractive speech" (801E). The politician as an artist processes the people's (irrational ${ }^{3}$ ) spirit with the tool of persuasion. We must now examine the procedure of

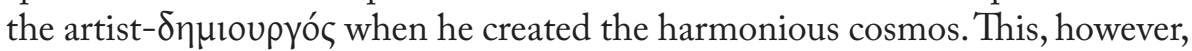
will involve another concept of lawful harmony.

\section{Precribing law and "law of nature"}

\subsection{Dual causation: explaining and understanding the cosmos}

The modern perspective in which science or scientific activity is undertaken is different from the one of the Ancients. From our contemporary point of view, science is an activity that seeks to acquire true and valid knowledge; acquiring this knowledge may be considered an end in itself, or, given the predicting value of physical laws, a means of controlling the course of events. By contrast, Aristotle - I refer to Aristotle because he is often regarded as the most 'scientific' of the classical philosophers - would emphasize that the 'theoretical' way of life is an end and a gratification in itself, that the pleasure or happiness that is experienced in the exercise of this intelligence is the fruit of the exercise of something divine in $\mathrm{man}^{4}$, and that the perfection of the theoretical life is wisdom 5 .

It is legitimate, then, to ask what are implications of the interference of an ethical category such as 'wisdom', and of a 'divine' agent, with Greek scientific activity. More specifically, one might suspect that those factors would blind the scientist when he scrutinizes Nature and seeks to discover 'how it works'.

\footnotetext{
${ }^{3}$ On the irrational character of the people, see J. CARrière 1984: 166, n. 4.

${ }^{4}$ Cf. P. Hadot 1995: 126.

${ }^{5}$ P. Hadot 1995: 137.
} 
Admittedly, the distinction between the spiritual and ethical on the one hand, and the material world on the other hand, is nowadays no longer clear-cut, and a definition of science as 'the study of the material world' would no longer $\mathrm{do}^{6}$. But we would not call the question 'To what end does the world exist?' a scientific question, but a philosophical (namely metaphysical) or religious one. Yet the answer to that question was the culmination of ancient philosophy:

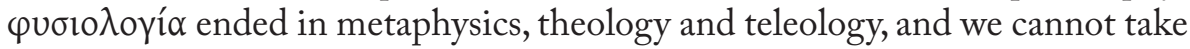
it for granted that teleological speculations did not interfere with the unbiased observation of how Nature works.

This legitimates the question whether Plutarch had any notion of what we call 'a law of nature', or 'a scientific law', or 'a physical law'. In our modern understanding, a scientific law can be formulated as a statement, based on observation, of a general and universal and eternal relation between natural phenomena. The statement is synthetic (not analytical) and expresses a causal relationship between observable facts. Scientific laws exist even without men knowing or formulating them; they operate solely and coercively on the basis of the natural characteristics of matter. They are descriptive and have predictive value; they are not prescriptive, like statute laws.

In Plutarch's Academic Platonism, things are more complicated, "the concept of dual causality" being "an essential component of Plutarch's Platonism". I point to only three important texts:

\section{a. Life of Pericles 6.2-3:}

A story is told that once on a time the head of a one-horned ram was brought to Pericles from his country-place, and that Lampon the seer, when he saw how the horn grew strong and solid from the middle of the forehead, declared that, whereas there were two powerful parties in the city, that of Thucydides and that of Pericles, the mastery would finally devolve upon one man, - the man to whom this sign had been given. Anaxagoras, however, had the skull cut in two, and showed that the brain had not filled out its position, but had drawn together to a point, like an egg, at that particular spot in the entire cavity where the root of the horn began. At that time, the story says, it was Anaxagoras who won the plaudits of the bystanders; but a little while after it was Lamprias, for Thucydides was overthrown, and Pericles was entrusted with the entire control of all the interests of the people.

Now there was nothing, in my opinion, to prevent both of them, the naturalist and the seer, from being in the right of the matter; the one correctly divined the cause, the other the object or purpose. It was the proper province of the

\footnotetext{
${ }^{6}$ J. Ziman 1980: 36-37.

${ }^{7}$ See J. Hospers 1980: 104-111.

${ }^{8}$ J. Opsomer 1998: 183.
} 
one to observe why anything happens, and how it comes to be what it is; of the other to declare for what purpose anything happens, and what it means. And those who declare that the discovery of the cause, in any phenomenon, does away with the meaning, do not perceive that they are doing away not only with divine portents, but also with artificial tokens, such as the ringing of gongs, the language of fire-signals, and the shadows of the pointers on sundials. Each of these has been made, through some causal adaptation, to have some meaning 9 .

In the Life of Pericles, Anaxagoras conducts a dissection and explains the anomalous phenomenon of the one-horned ram on the basis of natural

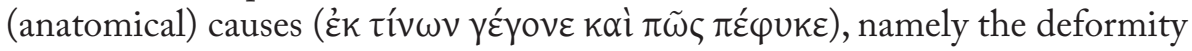
of the ram's brain; this is what Plutarch calls the oitía."However,P.'s description cannot be accurate. An animal so deformed would not have lived long enough to grow its "strong, solid" horn, nor is there in fact any relation between the horn and the skull (much less the brain)" ${ }^{10}$. But whether or not Anaxagoras could ever have made the impossible observation of the brain's deformity, is no problem for Plutarch: he simply regards the reported fact as historically true, and accepts Anaxagoras' explanation. Now Anaxagoras was not to be criticized: he did his job as a $\varphi$ voikós, and he was Pericles' teacher, and in that capacity responsible for the lofty grandeur of Pericles' mental disposition and of his eloquence.

But nor was there anything wrong with the explanation of the seer Lampron.

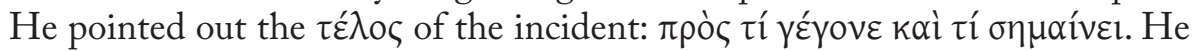
did his job as a $\mu \alpha v^{2} \tau \iota \varsigma$ : he interpreted the phenomenon as a divine omen. There is some stress on the validity of his prediction, because it conveniently foresees the historical fact of Pericles' rise to power. And apparently this must compensate for our surprise: the anecdote about Anaxagoras' $\varphi$ volo $\lambda$ oүí $\alpha$, we would have expected, was introduced as an example of Anaxagoras setting Pericles free from $\delta \varepsilon \imath \sigma \iota \delta \alpha \iota \mu \nu$ í $\alpha$, whilst what we get is a defense of a religious causation...

Anyway, there is no conflict here between $\varphi v \sigma 10 \lambda o \gamma i ́ \alpha$ and prophecy, between natural causes and divine teleology ${ }^{11}$. In other words: teleology does not prevent the world from having natural causes. Both are explanations in their own right.

b. De defectu oraculorum 435E-436A:

I shall defend myself by citing Plato as my witness and advocate in one. That philosopher found fault with Anaxagoras, the one of early times, because he

\footnotetext{
${ }^{9}$ All translations are from The Loeb Classical Library.

${ }^{10}$ See Ph. A. Stadter 1989: 85.

${ }^{11}$ See D. Babut 1969: 521.
} 
was too much wrapped up in the physical causes and was always following up and pursuing the law of necessity as it was worked out in the behaviour of bodies and left out of account the purpose and the agent, which are better causes and principles. Plato himself was the first of the philosophers, or the one most prominently engaged in prosecuting investigations of both sorts, to assign to God, on the one hand, the origin of all things that are in keeping with reason, and on the other hand, not to divest matter of the causes necessary for whatever comes into being, but to realize that the perceptible universe, even when arranged in some such orderly way as this, is not pure and unalloyed, but that it takes its generation when matter comes into conjunction with reason.

In De defectu oraculorum there is outspoken criticism of Anaxagoras, not

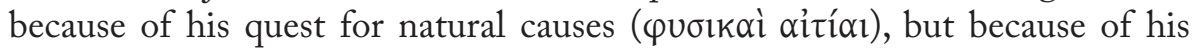
one-sided interest in them and his neglect of what is explicitly called "better

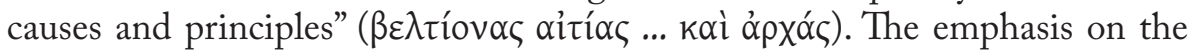
supremacy of those "better causes" can, again, be explained by the context: Lamprias is defending himself against the charge that, in his explanation of how the oracle works, he neglects them, and so he is eager to stress their importance!

The text hints at an element of what we would call "a scientific law", namely a description of the operation of natural laws: in talking of the physical causes, Lamprias explains by describing them as "the law of necessity as it was

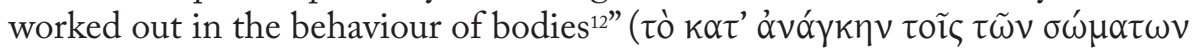

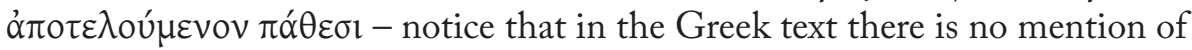

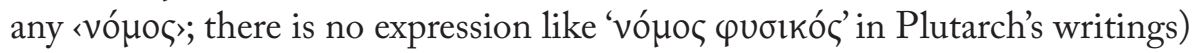
and "the causes necessary for whatever comes into being" ( $\tau \tilde{\omega} v \alpha \dot{\alpha} v \alpha \gamma \kappa \alpha i ́ \omega v$

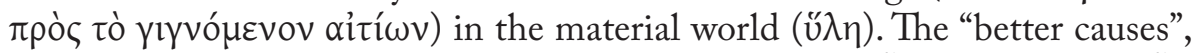

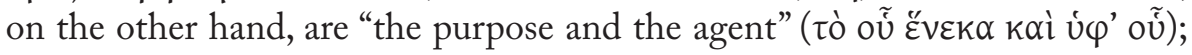
they concern "the origin of all things that are in keeping with reason" ( $\tau \dot{\eta} v$

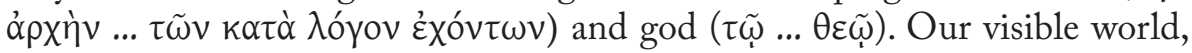
then, the cosmos as we perceive it, exists as a mixture: matter to which reason is interwoven, and, as a mixture, is to be explained on the basis of natural causes together with the better causes: reason, providence, god. This means that the physical world is insufficiently understood by pointing to its natural causes alone: such an understanding ( $\lambda$ óyos) through explanation of material

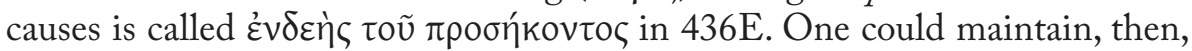
that the autonomy of the physical world as a cosmos of physical causation is preserved, but that, for the sake of a proper understanding of the cosmos, it is complemented by a theory of teleological causation. One might even say that

12 Later on (436E) Lamprias offers some examples: "clashes, transmutations and

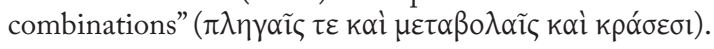


divine and teleological causes, in that they are "higher and better", supersede the natural causes. But there is no conflict between them.

There is a clear anti-Stoic tendency here: the younger generation (in opposition to the "very earliest theological writers and poets") of so-called natural philosophers (436D), who do away with the "beautiful and divine origin", are precisely the Stoics ${ }^{13}$. Furthermore, it is interesting to notice that Plutarch, just like he did in the Life of Pericles but now more elaborately than in that $L i f e^{14}$, illustrates the point by reference to artificial products ( $\tau \dot{\alpha} \tau \varepsilon \chi \nu \eta \tau \alpha^{\prime}$ in Per. 6.5, $\dot{\varepsilon} \pi i \tau \tilde{\omega} \nu \tau \varepsilon \chi \nu ı \tau \tilde{\omega} \vee$ in De def. orac. 436A sqq.). But in keeping with the theme of the dialogue, Lamprias in De def. orac. stresses the importance of the

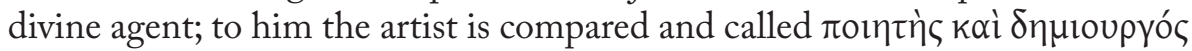
(436A-B). This is an expression elsewhere reserved for the god himself, who, in turn, receives the epitheton $\tau \varepsilon \chi v i ́ \tau \eta \varsigma$ (cf. supra).

c. The preponderance of the "higher, divine, better" principles implies the subordination of natural causes. This becomes explicitly clear in the Life of Nicias, $\$ 23^{15}$. Plutarch records that Anaxagoras was the first to offer a scientific explanation of the eclipses of the moon, but that in his days natural philosophers were distrusted "for that they reduced the divine agency down to

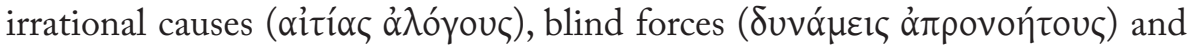

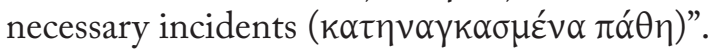

It was not until later times that the radiant repute of Plato, because of the

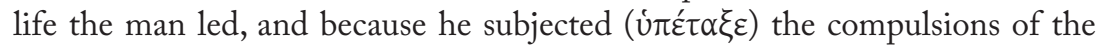
physical world to divine and more sovereign principles, took away the obloquy of such doctrines as these, and gave their science free course among all men.

The whole paragraph can be regarded as a pendant for the passage in the Life of Pericles. There, the scientific explanation of Anaxagoras should have illustrated Pericles' freedom from superstition thanks to Anaxagoras, whilst actually the story ends in a plea for the "higher" causes. Here it starts as a condemnation of Nicias' superstition, but it actually ends in a license for the scientific explanation such as that of Anaxagoras. Except that Plutarch continues with an explanation of the lunar eclipse as an omen: he needs those two legs to stand on!

It has become clear by now that the physical processes we would nowadays describe in terms of "physical laws", are to Plutarch's mind (merely)

\footnotetext{
${ }^{13}$ D. BABut 1969: 313, n. 1 .
}

${ }^{14}$ In the Life, the meditation on causation embroiders on an illustrative anecdote; Plutarch himself calls himself to order, and refers that subject matter to "another piece of writing". That may indeed be a reference to De defectu oraculorum: see PH. A. Stadter 1989: 87.

${ }^{15}$ For a discussion of this passage, see J. Hershbell 1982: 142-143 and J. Opsomer 1998: 182-183. 
compulsively mechanistic, irrational and purposeless movements. Moreover, they are subordinated to the rational agency of a divine agent who provides for the purpose and true meaning of those movements.

On the one hand, one can understand why this divine causation is so important for Plutarch. Especially the upward, discursive train of thoughts in De facie in orbe lunae makes that clear. There is no better way to put it than $\mathrm{H}$. Görgemanns ${ }^{16} \mathrm{did}$ :

Für Plutarch ist das übergreifende Thema offenbar [...] die kosmische Theologie. Das "Wozu?" der so fremd und fern erschienenden Himmelswelt bewegt ihm, und er versucht in verschiedener Weise, wissenschaftlich und mythisch, darauf zu antworten. Er folgt damit eine menschliche Bedürfnis nach Sinngebung, das von der strengen Wissenschaft nicht befriedigt wird"; "Mechanistisches Funktionieren wird ausgeschlossen; statt dessen wird eine sinnvolle Ordnung durch einen göttlichen "Werkmeister" angenommen".

And in that cosmos man has a destination. It is a destination that can fulfil his highest hopes and invest him with the peace of mind the essay $D e$ tranquillitate animi evokes. But, on the other hand, the question remains whether the scientific and the 'mythic' or 'religious' argument together explain the harmony of the cosmos without any hitch.

\subsection{Creating cosmos}

For an answer to the question how god managed to create the cosmos, we must turn to On the face in the moon again. 12-15 constitute a unit, in which Plutarch's brother Lamprias modifies the Stoic doctrine of the local separation and stratification of the elements, according to which earth, water, air and fire have 'natural' motions and locations. Thus earth, being heavy, will naturally have a downward movement. Now Lamprias believes that the moon is of an earthy substance, and so he has to explain why this earthy substance is above and thus seems to have an 'unnatural position'!

Lamprias refers to Empedocles' cosmology, arguing that the cosmos came

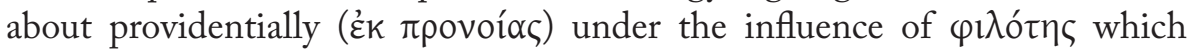
compelled the four principles to "change positions and interchange functions", so as to produce the concord and community of the universe ( $\alpha \rho \mu o v i ́ \alpha v$ k $\alpha \dot{i}$

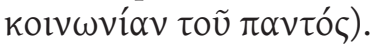

$\S 13$ starts with a paradox:

If not a single one of the parts of the cosmos ever got in an 'unnatural' condition, ..., I cannot make out what use there is of providence ( $\tau \tilde{\eta} \varsigma \pi \rho o v o i ́ \alpha \varsigma)$ or of what

\footnotetext{
${ }^{16}$ H. Görgemanns 1968: 10-11.
} 


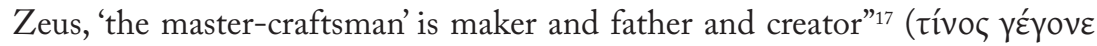

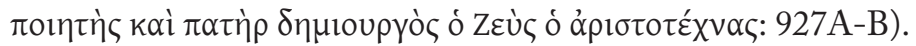

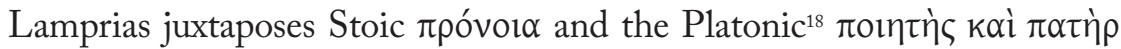
$\delta \eta \mu \imath o u p \gamma o ́ s$, thus suggesting that a mere mechanical operation of natural forces, even if permeated by a Stoic providence, will not suffice to explain the cosmos, unless we accept the operation of a supreme power, an artist par excellence" 19 .

Is it, then, the Empedeoclean ${ }^{20}$ god's $\varphi \imath \lambda$ ó ' 'naturnalness' of the elements? For surely there must be a tool, a procedure, a means to effectuate that. Lamprias' answer consists in a redefinition of what is 'natural': each particular part has its "natural position and motion and disposition" only "whenever it acts or is affected or disposed so that it contributes usefully

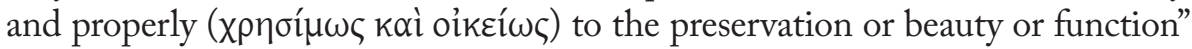
(927E) of that thing for the sake of which it has come to be. And this new teleological definition allows for the intervention of divine providence. But still, how did it operate? The answer is not explicitly in Plutarch, and thus, since Plutarch in all these matters is Plato's voice, it must be in Plato. And indeed, when discussing the nature of the cosmos containing the elements not as the

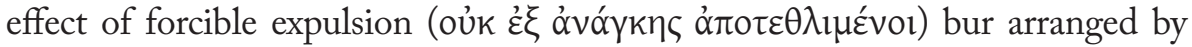

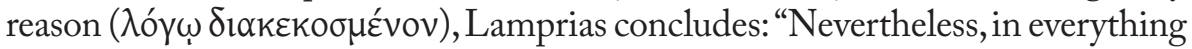
the better has control of the necessary" (928A). And that is Plato, Ti. 48a $\mathrm{a}^{21}$ :

For, in truth, this Cosmos in its origin was generated as a compound, from the combination of Necessity and Reason. And inasmuch as Reason was controlling Necessity by persuading her to conduct to the best end the most part of the things coming into existence, thus and thereby it came about,

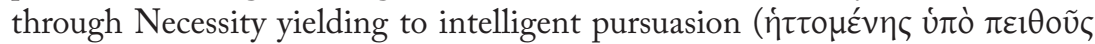

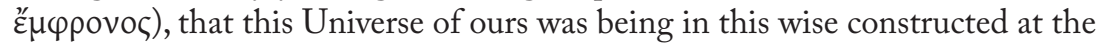
beginning.

${ }^{17}$ H. Görgemanns 1970: 104, n. 47 is right in supposing that we need something like koú

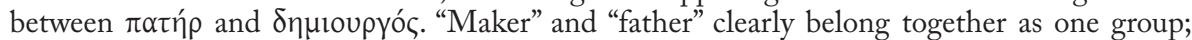
these terms are discussed at length in Plat. quaest. II. In that Quaestio, the epithet Ü comm. not. 1065E) appears as ơ $v \omega \tau \alpha^{\prime} \tau \omega(1000 \mathrm{E})$. In De facie Lamprias is accumulating the epithets by means of the polysyndeton because this Zeus will need 'supernatural' powers in order to force the elements to leave their 'natural' positions and to take on 'unnatural ones' (like the earthy moon above us).

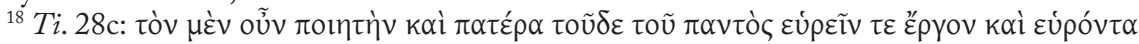

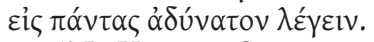

${ }^{19}$ L. VAN DER STOckT 2002: 119.

20 The answer cannot come from Anaxagoras, since he, regrettably, "did not really employ the concept of Nous in explaining the natural world, and thus in Plutarch's and Plato's eyes, he failed to provide teleological insights": J. Hershbell 1982: 146.

${ }^{21}$ See H. Cherniss 1968: 95, n. c. 
The analogy between the politician and the divine agent may be complete by now. But to our modern mind it is inconceivable that a law of nature would change its operation, and actually dissolve itself, because it is "persuaded" by human or divine (prescriptive) speech. And this is where the hitch is: in Plutarch's (Platonic) 'intelligent design', a divine agent 'overcoming' laws of nature by persuasion in order to create meaning. 


\section{Bibliography}

Babut, D., Plutarque et le Stoïcisme, Paris, 1969.

Cherniss, H., Plutarch's Moralia XII (The Loeb Classical Library), London, Cambridge, Mass., 1968.

Carrière, J., Plutarque. Oeuvres Morales. T. XI² (Collection des Universités de France), Paris, 1984.

Görgemanns, H., Das Mondgesicht (De facie in orbe lunae). Eingeleitet, übersetzt und erlaütert von -, Zürich, 1968.

Görgemanns, H., Untersuchungen zu Plutarchs Dialog De facie in orbe lunae (Bibliothek der klassischen Altertumswissenschaft, N.F. 2.33), Heidelberg, 1970.

Нadot, P., Quiest-ce que la philosophie antique (Collection Folio/Essays), s.1., 1995.

Hershbell, J., "Plutarch and Anaxagoras”, ICS 7, 1982: 141-158.

Hospers,J., "Law",in E. D. Kleke; R. Hollinger; A. D. Kline (edd.), Introductory Readings in the Philosophy of Science, Buffalo, 1980.

Opsomer, J., In Search of the Truth. Academic Tendencies in Middle Platonism (Verhandelingen van de Koninklijke Academie voor Wetenschappen, Letteren en Schone Kunsten van België, 60, nr. 163), Brussel, 1998.

Stadter, Ph. A., A Commentary on Plutarch's Pericles, Chapel Hill, London, 1989.

VAN Der Stockt, L., "With followeth justice always (Plato, Laws 716A): Plutarch on the divinity of rulers and laws", in Lukas de Blois et alii (edd.), The Statesman in Plutarch's works. Vol. I: Plutarch's statesman and bis aftermath: political, philosophical, and literary aspects. Proceedings of the $V I$ International conference of the International Plutarch society, Leiden, 2004: 137-149.

VAn der Stockt, L. “Karpos ek filias hègemonikès (Mor. 814C): Plutarch's observations on the old-boy network", in Philip A. Stadter; Luc Van der Stockt (edd.), Sage and emperor: Plutarch, Greek intellectuals, and Roman power in the time of Trajan (98-117 A.D.), Leuven, 2002: 115-140.

Ziman, J., "What is Science?”, in E. D. Kleke; R. Hollinger; A. D. Kline (edd.), Introductory Readings in the Philosophy of Science, Buffalo, 1980. 
(Página deixada propositadamente em branco) 


\title{
Ordre et désordre dans la pensée de Plutarque. Réseaux lexicauX et PROBLÉMATIQUES PHILOSOPHIQUES AUTOUR DE $\triangle \mathrm{IKH}, \mathrm{KO \Sigma MO \Sigma ,} \mathrm{NOMO \Sigma}$
}

\author{
Françoise Frazier \\ Université Paris Ouest - Nanterre La Défense
}

\begin{abstract}

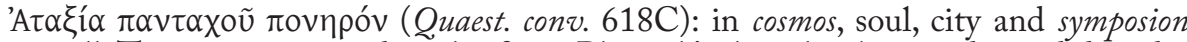
as well. This paper is aimed at clarifying Plutarch's thought about order and disorder

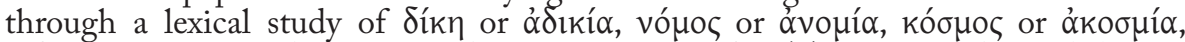
referring to a general concept and not to a peculiar fact. The main traditional themes

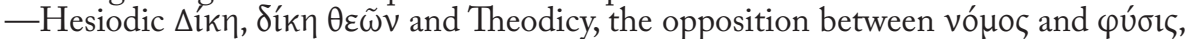
connections between order in the city and vópor, and the Hellenistic ideal of the

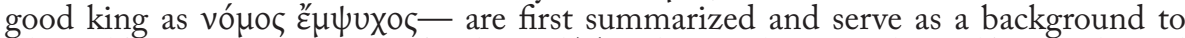
Plutarch's own conceptions of Dike and Theodicy at the metaphysical/ cosmological level, as well as his views on the good political order and the good ruler at the political/ ethical level. Finally a closer examination of the five occurrences of the Pindaric "Zzùs

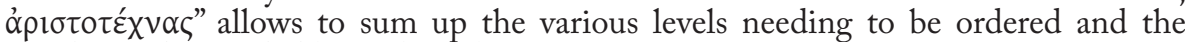
peculiar order needed by each of them.
\end{abstract}

L'importance de la notion d'ordre dans une civilisation où le mot adopté

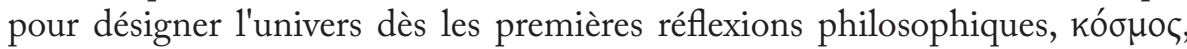
dénote un agencement, une organisation, impliquant ordre et beauté ${ }^{1}$, n'a rien que de connu: ordre, beauté, harmonie interviennent non seulement pour penser cet ordre de l'univers, mais aussi celui de la cité et de l'âme, mettant en jeu cosmologie, psychologie (au sens antique), politique, éthique. Chez un auteur comme Plutarque, nourri de la tradition et dont l'ouvre apparaît souvent comme une sorte de "conservatoire",oùl'on retrouve des échos de toutel'histoire de la philosophie - fruit sans doute pour partie de son enseignement - , il m'a paru intéressant de regarder de plus près la place tenue par des notions aussi importantes qu'ordre et désordre, exprimées avec prédilection par díkn et

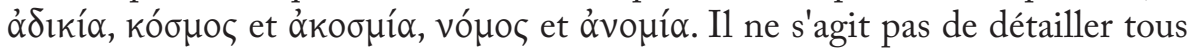
les cas concrets, mais de tracer un cadre conceptuel, si bien qu'une simple étude des occurrences, si elle a été un préalable nécessaire à ce travail, s'est vite révélée insuffisante. Pour donner quelque idée de ses difficultés et de ses insuffisances, cette approche purement lexicale fournit une centaine d'occurrences d' á $\delta ı \kappa^{\prime} \alpha^{2}$, dont près de la moitié —emploi au singulier avec une détermination ou emploi au pluriel —désigne un acte précis, donc en dehors de l'étude que je me propose,

${ }^{1}$ M. Casevitz 1989.

${ }^{2}$ La définition donnée dans les Définitions pseudo-platoniciennes (416a), est la suivante:

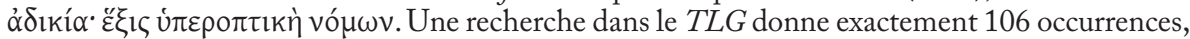
dont une bonne cinquantaine (18 dans les Vies, 37 dans les Moralia, dont 3 dans les fragments) ont une valeur générale. 


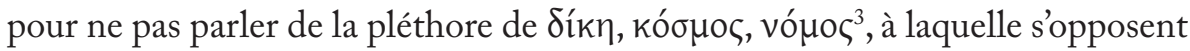

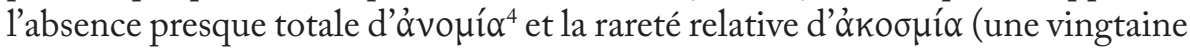
d'emplois dont une dizaine seulement peut nous intéresser ${ }^{5}$, en particulier ceux qui, dans l'ordre éthique ou, plus souvent cosmique, mettent en opposition

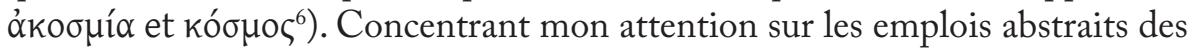
termes, j'ai choisi de partir des problématiques philosophiques traditionnelles,

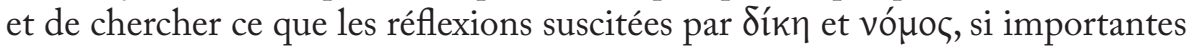
aux époques archaïque et classique, devenaient chez Plutarque, en prêtant une attention particulière aux passages où plusieurs des notions retenues sont réunies, dont certains posent de délicats problèmes d'établissement de texte et d'interprétation. Je m'attacherai ensuite aux emplois du paradigme cosmologique, puisque, aussi bien, les passages les plus riches mis au jour par

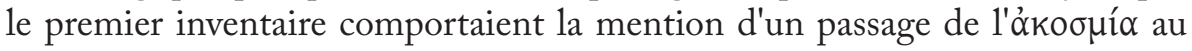

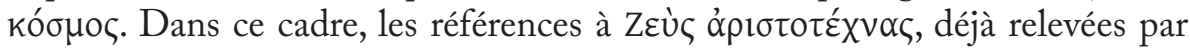
L. VAN DeR Stockt 2002 à l'intérieur d'un "Pindar-cluster", méritent un intérêt particulier et permettront, en conclusion, de préciser les déclinaisons du modèle cosmologique et d'en dégager une certaine logique.

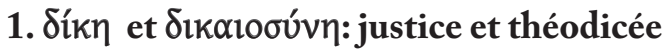

Rare dans les poèmes homériques, où elle désigne règle ou usage ${ }^{7}$, Dikè

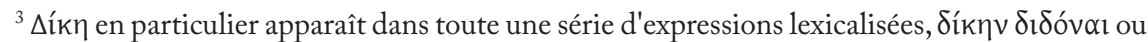

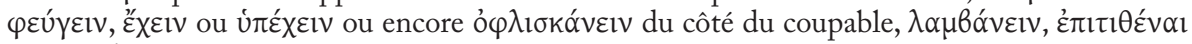

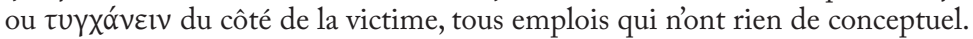

${ }_{4} 4$ occurrences seulement: Lyc. 2.5 (avec ó่ $\tau \alpha \xi \hat{i} \alpha$, pour marquer la situation de Sparte

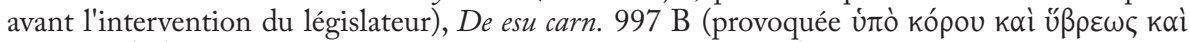
$\pi 0 \lambda \cup \tau \varepsilon \lambda \varepsilon i ́ \alpha \varsigma$ ) et dans deux contextes polémiques, Amat. 755B (Protogène stigmatisant ainsi le

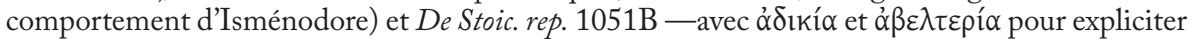

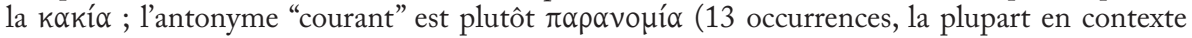
narratif).

${ }^{5} \mathrm{Il}$ y a 11 occurrences dans les Vies, dont 9 pour exprimer le désordre dans un groupe

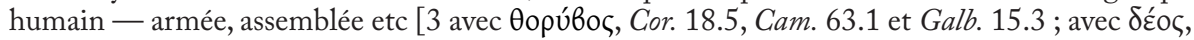
Crass. 24.3 ; avec oúyxuoıs, Ibid. 27.7; seul in Sert. 26.9 (banquet), Pomp. 54.4 (cité), Cic. 13.4 (théâtre), Oth. 13.5 (cavaliers)] et 9 dans les Moralia [dont 1 pluriel, pour les roses dépouillées de leurs pétales, Quaest. conv. 3.1, $646 \mathrm{D}$, mettant en valeur la critique contre les couronnes de

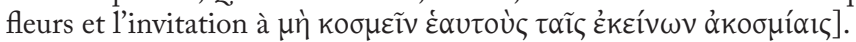

${ }^{6}$ Dio 11.2 ; De def. orac. 430E ; Quaest. conv. 1.2, 616 A ; De an. procr. 1014B; De lib. et aegr. 1.13; à quoi il faut ajouter une citation de Sophocle (Conj. praec. 141E) et l'interprétation des mythes des Titans et des Géants (De fac. lun. 926E), qui sera étudiée infra. Concernant la conduite, Ant. 11.4 (qui renvoie aux injures échangées par le héros avec Dolabella), Cons. ux. $609 \mathrm{E}$ (ce que pourrait provoquer un deuil) sont à la limite du cas particulier.

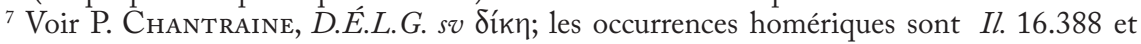

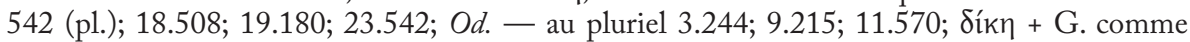

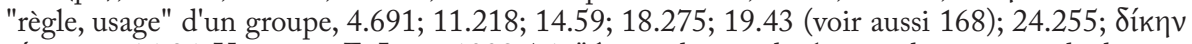

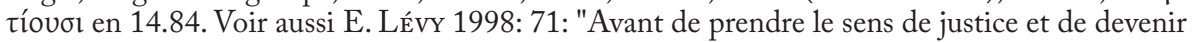
le principe organisateur de la société... dikè a appartenu au vocabulaire judiciaire, c'est-à-dire 
commence à prendre de l'importance dans la Théogonie (901-902), où elle apparaît comme fille de Zeus et de Thémis - le mot le plus usité par Homère -, sœur d'Eunomia et d'Eirénè, Heures qui "à toute heure prennent soin, pour les mortels, des travaux à faire"8. Puissances incarnant et explicitant des caractères majeurs de leur mère - continuité, stabilité, régularité - , marquant interdits, frontières à ne pas franchir, préséances à respecter ${ }^{9}$, elles exercent leur action prioritairement en direction de la collectivité humaine, appelées ainsi à patronner le futur ordre civique, dont elles esquissent les contours. Sans ses sœurs, sa figure s'accuse encore dans le poème consacré au monde des hommes, les Travaux, où la célèbre fable de l'épervier et de la rossignole la montre demandant réparation à Zeus quand on l'a bafouée ${ }^{10}$. Au cour de la réflexion sur l'ordre du monde des Présocratiques, qui, d'une certaine manière, reprend et modifie la démarche de la Théogonie, Jíkn est utilisée par Anaximandre ${ }^{11}$, Héraclite ${ }^{12}$ ou Parménide ${ }^{13}$, tandis que les textes poétiques plus soucieux de l'ordre humain dus à Solon, Pindare ou Eschyle lui réservent aussi toute sa place ${ }^{14}$. Elle a encore quelques occurrences intéressantes dans le Timée, où elle apparaît comme principe du "bien-vivre" au moment où le démiurge donne ses directives aux divinités secondaires ${ }^{15}$, ce qui n'est peutêtre pas sans importance pour le niveau auquel Plutarque la situe. Cependant, si l'on poursuit ce rapide survol historique, on ne peut manquer de relever

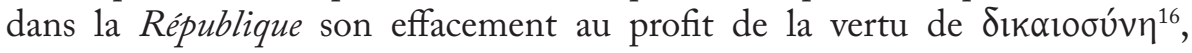

à celui qui s'intéresse aux techniques permettant de régler pacifiquement les différends entre individus ou entre groupes."

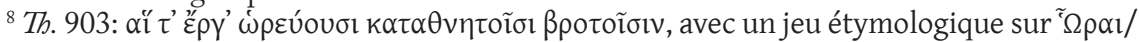

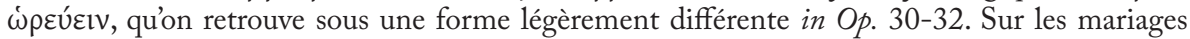
de Zeus et l'importance de ses filles pour l'ordre humain, voir A. Bonnafé 1985, en part. 97102 ("La descendance de Chaos, les mariages de Zeus et le sort des hommes") et 125-128 ("Utilisation des unions divines").

${ }^{9}$ Je reproduis ici l'analyse de J.-P. Vernant \& M. Detienne 1978: 104-106.

${ }^{10}$ Sur les ressemblances avec l'allégorie des Litai au chant 9 de l'Iliade et le remplacement de celles-ci, essentielles dans le système de réparations homériques, par l'intervention de la justice à l'époque archaïque, voir D. Aubriot 1984.

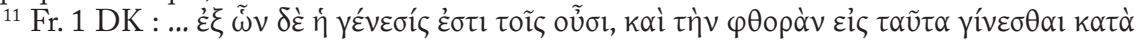

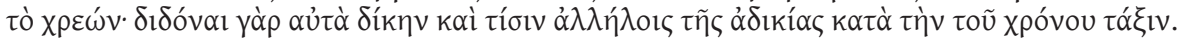

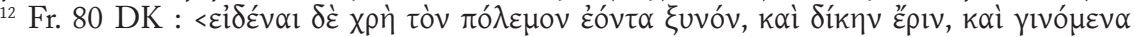

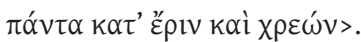

${ }^{13}$ Personnage figurant dans le fr. 1, elle apparaît comme force de maintien in fr. 8 DK: oủ $\delta \varepsilon$

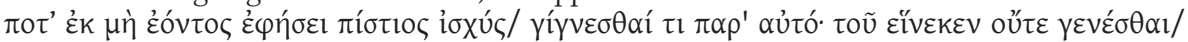

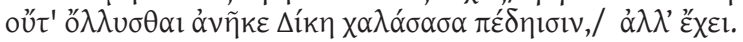

${ }_{14}$ Outre l'ouvrage classique de H. Lloyd-Jones ${ }^{2} 1983$, qui embrasse tous les auteurs, d'Homère aux sophistes, voir, plus spécifiquement, M. L. Zunino 2004.

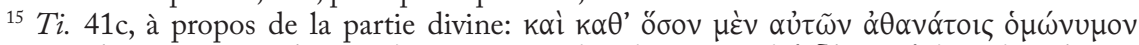

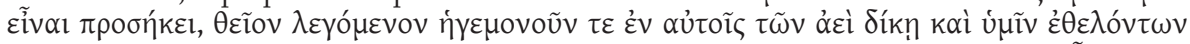

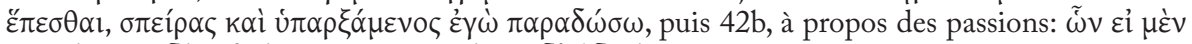

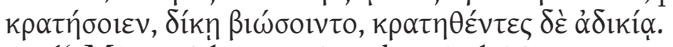

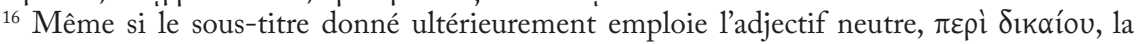

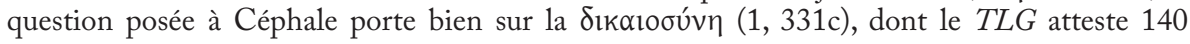


que confirment et les Définitions hellénistiques transmises dans le corpus

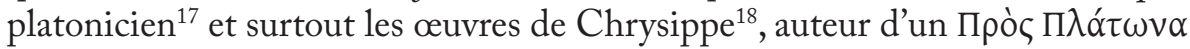

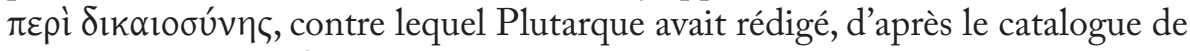

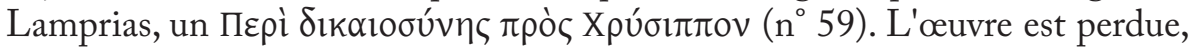
mais on trouve plusieurs mentions polémiques dans les traités antistoïciens ${ }^{19}$, dont l'une met en jeu notre $\Delta$ ík $\eta$ hésiodique.

Il s'agit du chapitre 32 des Contradictions stoïciennes, où, abordant la contradiction dont Chrysippe se rend coupable "quand il affirme d'une part que rien ne dépasse la Providence (des dieux), d'autre part que rien ne dépasse la misère (des hommes)" (31.1049A1-2),Plutarque cite d'abordles critiques quelui ont faites les Pythagoriciens sur "ce qu'il écrit dans ses livres Sur la justice au sujet des coqs", puis la réponse qu'il y a apportée et qui va permettre la mise en contradiction. Cette réponse, il va la

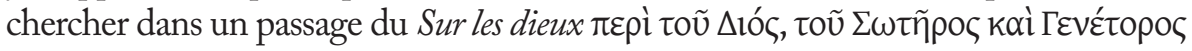

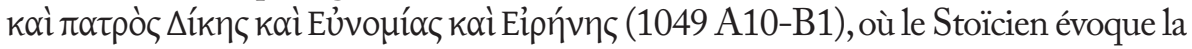
nécessité que la Divinité procure aussi dans certains cas des principes de destruction. Et Plutarque de dénoncer la contradiction entre les épithètes, toujours honorables et philanthropiques, dont il use pour la Divinité et les actes sauvages et barbares qu'il lui impute ainsi (1049 B10-C1). Le thème, développé tout au long des deux chapitres suivants, débouche sur cette "estocade" finale où les notions ordonnatrices qui nous intéressent se multiplient:

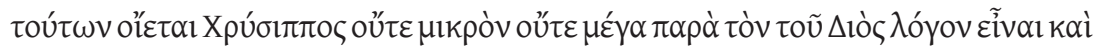

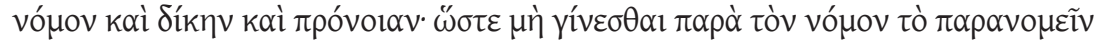

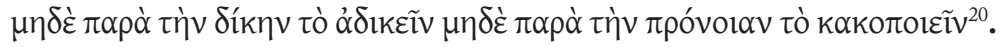

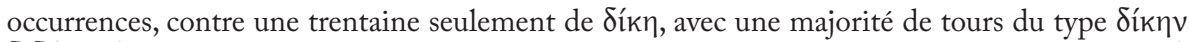
Sidóval (1, 330d, 2, 359a, 365d, 366a, 380b2 et 5, 4.445a, 5, 471b, 474a, 9, 591a, 10, 615a et e) ou synonymes $(3.405 \mathrm{c}, 7.520 \mathrm{~b}, 529 \mathrm{c}, 10.610 \mathrm{~d})$ et 7 emplois concrets au pluriel (4.425d, 4.433e, $5.464 d$ et e, 6.499a, 8.549c et 10.616b); on ne trouve que deux passages où la dikè apparaît

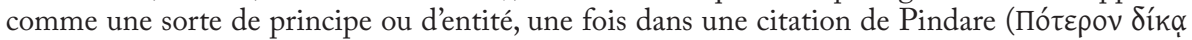

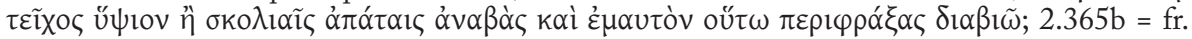
213), et une fois dans la bouche de Socrate, montrant l'importance de choisir les hommes bien

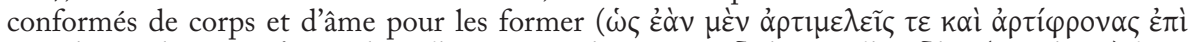

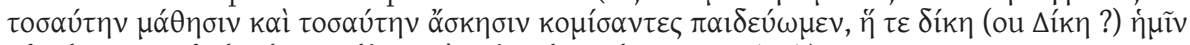

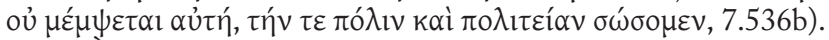

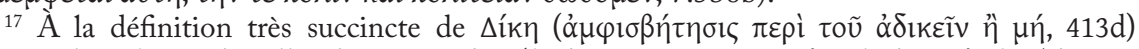

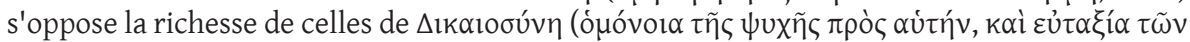

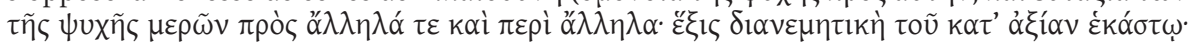

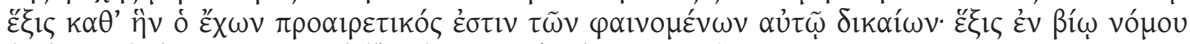

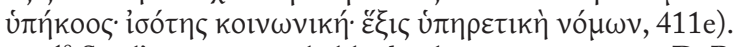

${ }^{18}$ Sur l'existence probable de plusieurs écrits, voir D. BAвUt 2004: 176, n. 205.

${ }^{19}$ De Stoic. rep. 12, 1038B, 15, 1040A sq; 16, 1041A-E, 32, 1049A, 36.1051A-B; voir aussi De comm. not. 25, 1070E-F.

${ }^{20}$ De Stoic. rep. 34.1050 D7-12: "De ces choses [vices, maladies et toute forme mauvaise], il n'en est aucune, selon Chrysippe, grande ou petite, qui contrevienne à la raison de Zeus, à la loi, à la justice et à la providence, d'où il s'ensuit que violer la loi ne contrevient pas à la loi, ni être 
Sans discuter l'argumentation de Plutarque et la pertinence de ses

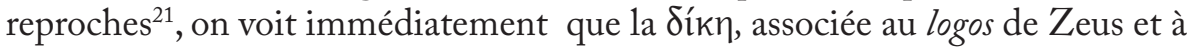
sa providence, se situe bien au niveau supérieur assigné dans le Timée : ce qui est plus net encore dans les passages de théodicée ${ }^{22}$.

Ce thème constitue le sujet même des Délais de la justice divine, où

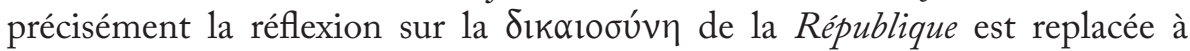
l'intérieur du plan de la Providence ${ }^{23}$. D'emblée, dans la définition même de la justice exercée par la divinité, est mis en avant le soin de l'âme que doit avoir le

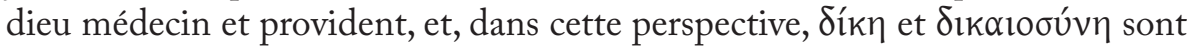
associées (De sera num. vind. 4, 550A):

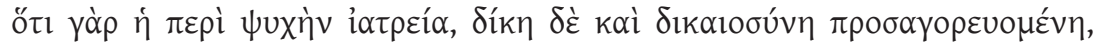

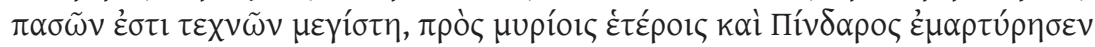

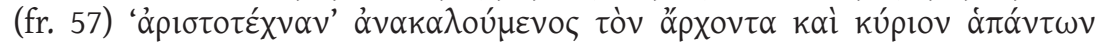

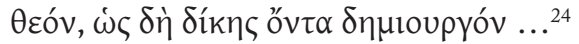

Par cette association - que le français peine à rendre - la justice se trouve définie sous ses deux aspects, l'un ( $\delta i ́ k \eta)$, plus "objectif", désignant le châtiment réparateur comme le principe ordonnateur, qui, mis en œuvre,

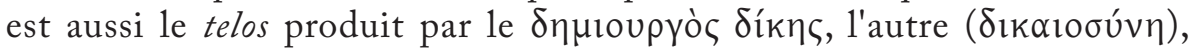
qui est vertu agissante et dessine, pour ainsi dire, en filigrane l'agent qui la possède. Or son possesseur suprême, celui qui en offre le modèle à l'homme, c'est Dieu, dont, réciproquement, elle constitue un des attributs essentiels, comme le montre le troisième texte important, la réflexion sur la Justice que suscite le surnom d'Aristide dans la Vie qui lui est consacrée.

Plus précisément, Plutarque y oppose ce glorieux surnom aux surnoms violents qu'ont affectionnés les rois hellénistiques, et il le met en rapport avec le modèle divin que ces rois se targuent d'imiter et ses trois attributs, indestructibilité, puissance et vertu — laquelle se confond avec la justice (Arist. 6.3):

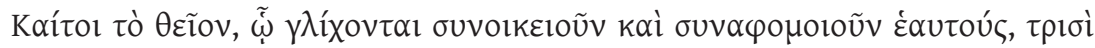

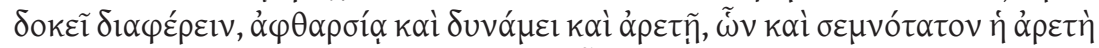

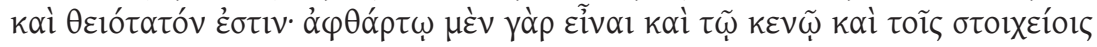

injuste à la justice, ni faire le mal à la Providence" (trad. D. Babut).

${ }^{21}$ Voir sur ce point D. Babut $2004: 289$, nn. 425 et 426.

${ }^{22}$ Cf. D. Babut 2004: 274, n. 382.

${ }^{23}$ F. Frazier 2010: 72.

24 "Que la médecine de l'âme, qu'on nomme justice et équité, soit le plus grand des arts, Pindare, à côté de mille autres, en témoigne, proclamant 'artiste suprême', ce maître et seigneur universel qu'est Dieu, en tant précisément qu'ouvrier de la justice...” (trad. F. Frazier) ; sur la référence pindarique, voir infra, pp. 237-240. 


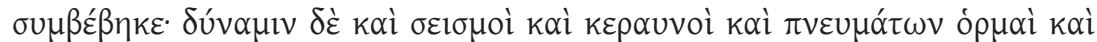

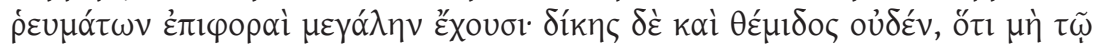

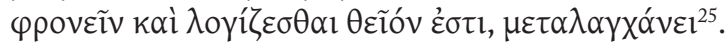

On retrouve bien, au niveau supérieur, les principes fondateurs et archaïques

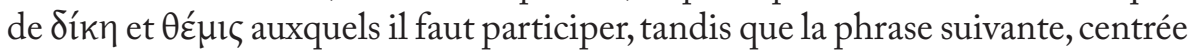
sur les sentiments suscités par ces attributs dans l'âme humaine, envie face à l'immortalité, crainte devant la puissance, vénération pour la vertu, ramène au

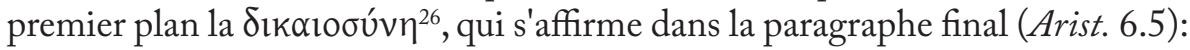

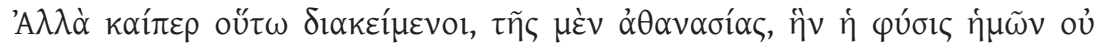

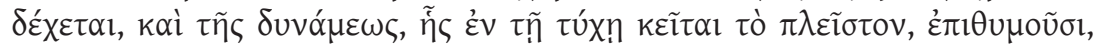

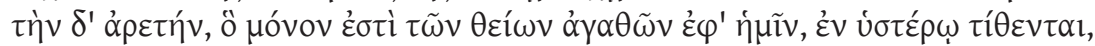

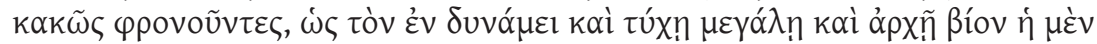

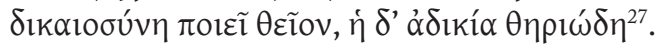

On trouve explicitée ici l'opposition entre justice et injustice, qui met en jeu

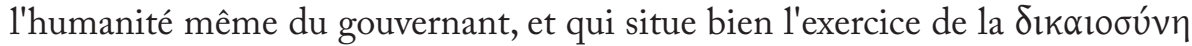
dans le domaine humain, dans le champ éthique, là où la référence à themis et dikè était mise significativement sur le même plan que des éléments physiques comme le vide, les séismes ou la foudre.

De cette répartition, on trouve le témoignage le plus net dans un dernier passage, tiré du De latenter vivendo, ouvrage qui ne saurait se comparer en importance au De sera, mais qui en partage du moins l'orientation anti-épicurienne. Ce passage a déjà attiré l'attention de son plus récent commentateur, G. Roskam, qui y voit même une des phrases essentielles de l'opuscule, où, à travers l'opposition à la doctrine épicurienne, se dessine en filigrane l'idéal éthique de Plutarque ${ }^{28}$ :

25 "Et cependant on pense que la divinité, à laquelle ils sont si désireux de s'assimiler et de ressembler, possède trois attributs distinctifs : l'incorruptibilité, la puissance et la vertu, dont la vertu est le plus auguste et le plus divin; En effet l'incorruptibilité appartient aussi au vide et aux éléments, et grande est la puissance des tremblements de terre, des tonnerres, des ouragans et des inondations, mais rien ne participe à la justice et à l'équité, en dehors de l'être qui est divin par l'intelligence et la raison" (trad. R. Flacelière) - je n'entre pas dans les problèmes de texte que

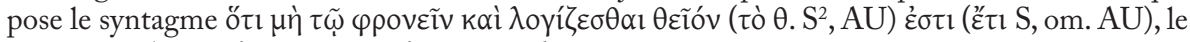
sens général qui m'importe ici n'étant pas douteux.

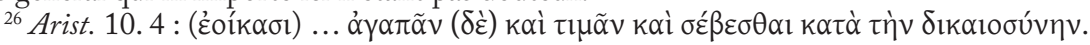

27 "Mais, en dépit de ces sentiments, ce que les hommes désirent le plus, c'est l'immortalité, qui est incompatible avec notre nature, et la puissance, qui dépend en majeure partie de la fortune; quant à la vertu, le seul des biens divins en notre pouvoir, ils la placent en dernier, bien à tort, puisque c'est la justice qui rend divine la vie passée au sein du pouvoir, d'une grande fortune et de la souveraineté, tandis que l'injustice la rend bestiale" (trad. R. Flacelière, légèrement modifiée).

${ }^{28}$ G. Roskam 2007: 121: "This is undoubtedly one of the most important sentences of the little work. It is not only diametrically opposed to the central tenets of Epicureanism, but also 


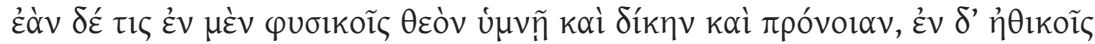

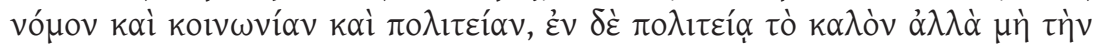

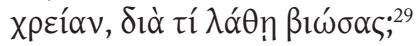

Importante, la classification paraît aussi de prime abord étonnante et

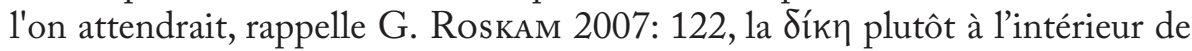
l'éthique que dans le champ de la physique. Il en voit cependant l'explication dans la théologie platonicienne de Plutarque, où bien et justice appartiennent à l'essence divine ${ }^{30}$. Si je souscris entièrement à cette explication, il me semble même que la présente étude permet d'aller un peu plus loin. Le concept éthique,

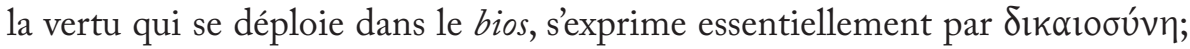
en dehors d'un exercice précis de la justice, procès, jugement, châtiment,

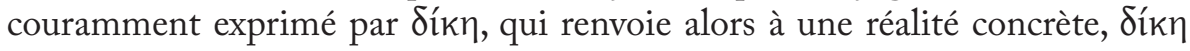
principe ordonnnateur s'inscrit dans l'ordre du monde et, à ce titre, s'associe volontiers à la $\pi \rho o ́ v o l \alpha^{31}$ —cest encore dans un opuscule anti-épicurien, l'Adversus Colotem, que Plutarque, confirmant le verdict de la Vie d'Aristide, flétrit comme une vie bestiale celle qui ne connaît que le plaisir et ignore la díkn $\theta \varepsilon \tilde{\omega} v$ comme la beauté de la vertu ${ }^{32}$. On comprend aussi, dans cette perspective, le recours à la figure de $\Delta$ íkn dans les mythes eschatologiques ou dans les citations

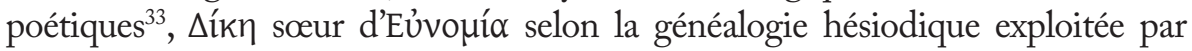

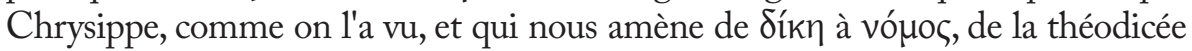
au monde humain ${ }^{34}$, où les problématiques développées autour du vó $\mu$ oৎ sont plus

contains in a nutshell the general outlines of Plutarch's own programme of the 'good life'."

${ }^{29}$ De lat. viv. 4, 1129B : " Si dans le domaine physique, l'on célèbre dieu, la justice et la providence, dans le domaine éthique, la loi, la communauté et la participation aux affaires politiques, et dans la vie politique, le bien et non l'utilité, pourquoi vivre caché ? " (ma traduction).

30 "That Plutarch also underlines the importance of justice in the domain of physics may come as a surprise, since one would a priori expect the mention of the element of Jík rather in the field of ethics. Its presence in the domain of physics could perhaps be explained by Plutarch's thoroughly Platonic theology, in which justice and the good in general are inherently and inextricably bound up with God's essence."

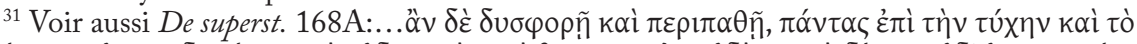

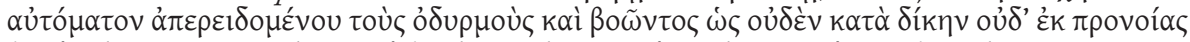

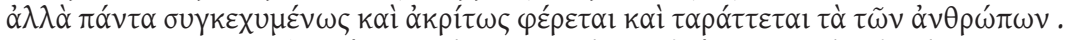

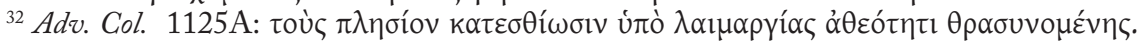

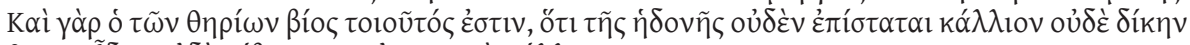

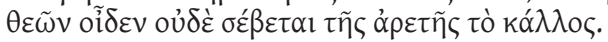

${ }^{33}$ Sans minimiser la culture du pepaideumenos et l'influence des mythes platoniciens, je ne trouve pas suffisante l'explication par la simple possession de la culture: il appartient au critique d'en préciser l'utilisation dans chaque contexte. Sur l'emploi précis de la $\Delta$ ík $\eta$ mythique, voir la contribution de Miguel Herrero de Jáuregui.

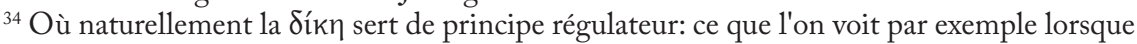
Plutarque évoque les fins propres auxquelles la nature porte l'homme, De am. prol. 495C:

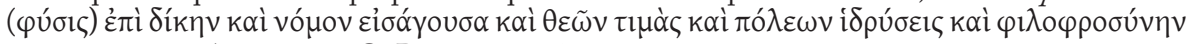
- passage signalé aussi par G. Rosкам 2007: 128. 
variées et vont faire l'objet d'une revue rapide avant que l'analyse se concentre sur le traité le plus riche sur la question, le Ad principem ineruditum.

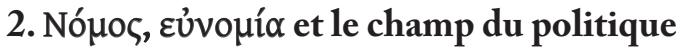

Une première série de textes réunit deux ou trois des sœurs hésiodiques pour désigner un état politique idéal: on les trouve ainsi associées pour peindre sous des couleurs favorables l'action organisatrice des vainqueurs romains ${ }^{35}$, mais c'est la Vie de Numa, conçu comme une sorte de législateur platonicien avant la lettre, qui offre les passages les plus intéressants. D'entrée, lorsque les émissaires romains veulent convaincre un Numa réticent, avant tout soucieux de

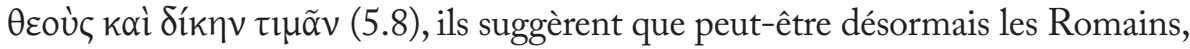

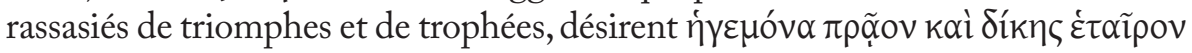

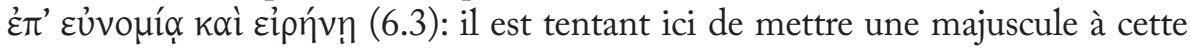
$\Delta$ íkn dont le Sabin est compagnon. En tout cas, son importance pour atteindre eunomie et paix est d'emblée évidente et se trouve pleinement confirmée à la fin de la Vie, lorsque Plutarque peint les beaux effets obtenus par les belles vertus de

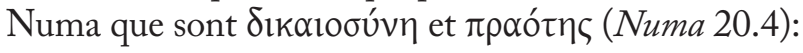

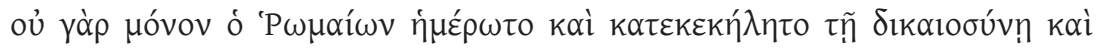

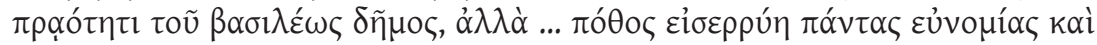

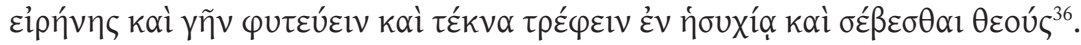

Un tel texte oriente vers la réflexion sur la figure du roi, qui s'amorce dès le $\mathrm{IV}^{\mathrm{e}}$ siècle, se développe à l'époque hellénistique et a une actualité évidente à l'époque de l'optimus princeps, quelque réinterprétaton personnelle qu'en puisse donner chaque auteur. Avant de s'y attarder, il faut cependant, après avoir vu rapidement les figures hésiodiques, revenir sur les problématiques qui ont dominé l'époque classique.

On songe d'abord à l'opposition fondamentale entre vó étroitement liée à la critique des sophistes, puis à la crise morale de la fin $\mathrm{du} \mathrm{V}^{\mathrm{e}}$ siècle $^{37}$, dont on trouve sans doute l'écho majeur dans le face à face de

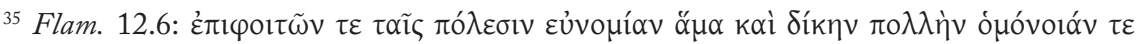

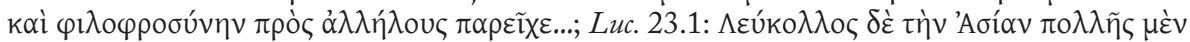

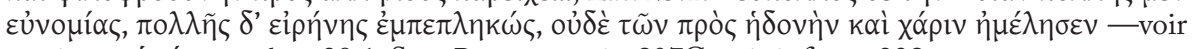
aussi avec ópóvola, Aem. 29.1. Sur Praec. ger. reip. 807C, voir infra, p. 238.

36 "Car le peuple romain ne fut pas le seul que la justice et la douceur du roi eût adouci et comme ensorcelé ... en tous [dans les villes alentour] s'insinua le désir de vivre sous de bonnes lois, en paix, en cultivant la terre, en élevant paisiblement leurs enfants et en vénérant les dieux" (trad. R. Flacelière, légèrement modifiée). Les deux vertus semblent si intimement liées que Plutarque les réunit même sous un seul article.

${ }^{37}$ On trouvera une présentation d'ensemble in J. DE Romilly 1971: 73-95 ("La critique des sophistes") et 97-114 ("La crise morale"), chapitre que lon peut compléter par E. LÉvy 1976: 
Calliclès et Socrate du Gorgias ${ }^{38}$. Or chez Plutarque, elle apparaît, à l'examen, passablement lexicalisée et sans grande fécondité philosophique. Sans doute peut-on retrouver sous son égide une adaptation du paradoxe du Gorgias ${ }^{39}$ dans la réponse prêtée à Dion en butte aux manœuvres d'Héraclide (Dio 47.8):

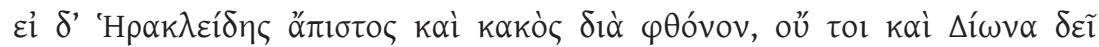

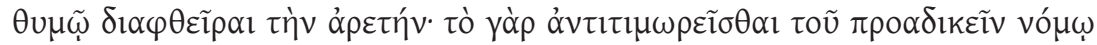

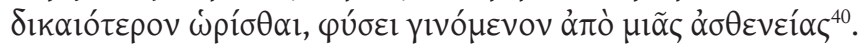

Si ce passage fait en quelque sorte culminer la tonalité platonicienne de ces principes, tout ce qui précède y a préparé, puisque Dion a rappelé en ouverture qu'il s'était exercé principalement, non à la guerre, comme les autres, mais, en disciple de l'Académie, à surmonter colère, jalousie et esprit de querelle

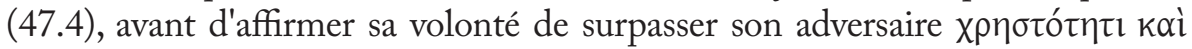

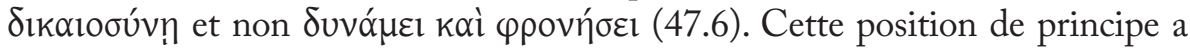
des conséquences pratiques immédiates et Dion, en qui le philosophe prime le politique, n'applique en effet pas la loi, qu'il minimise, dans toute sa rigueur: il relâche Héraclide, en faisant fond sur le pouvoir bénéfique de la clémence ${ }^{41}-$ grave erreur qu'il paiera de sa vie, car on est dans un des cas, rares, où le platonisme lui-même doit céder devant l'intérêt de l'État ${ }^{42}$, lequel ne se confond nullement avec les vópol, entendus comme expression d'un droit positif et conventionnel.

Mais, plus que l'opposition ${ }^{43}$, c'est la conjonction de la nature et de la loi que Plutarque se plaît à souligner quand l'occasion lui en est donnée. De manière factuelle, il montre les Romains qui, au moment de la fondation de

90-107 ("Contestation de la morale et de la loi").

${ }^{38}$ Voir, en particulier, le premier exposé de Calliclès, 482c-486d, et, pour les oppositions

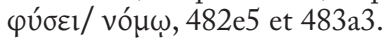

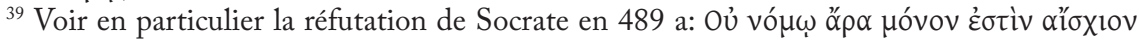

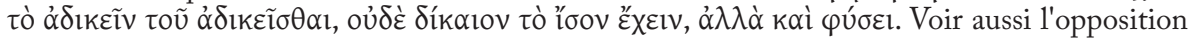
in Prt. 337 d et Lg. 889 e.

40 "Si l'envie rend Héraclide déloyal et méchant, ce n'est pas une raison pour que Dion ternisse sa vertu par la colère. Il est vrai que, selon la loi, il est considéré comme plus juste de se venger d'une injustice que de la commettre le premier, mais, selon la nature, ces deux actes procèdent d'une seule et même faiblesse" (trad. R. Flacelière).

${ }^{41}$ Même renchérissement sur la stricte justice légale chez les Pythagoriciens dans leur

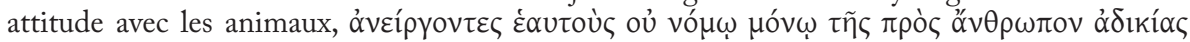

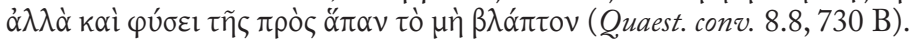

${ }^{42}$ Sur les quelques cas de ce genre, voir F. Frazier 1996: 164-166.

${ }^{43}$ Voir le mot de Denys — donc d'époque classique, Sol. 20.7 = Reg. et Imp. Apopht. 175F, les deux mobiles possibles de l'action de Crassus, Fab. 25.4, ou encore la comparaison, très ornementale, du An seni resp. 789E sur les cheveux blancs, correspondant naturel de la couronne accordée par les lois; voir aussi Aet. Rom. et Gr. 19,268C sur l'établissement du début de l'année;

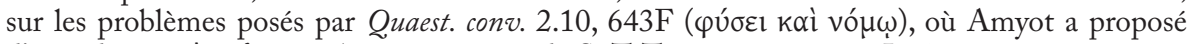

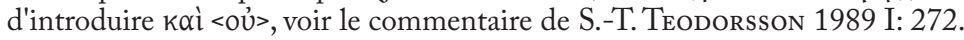


l'Urbs, jettent dans le mundus "tous les prémices de ce dont l'usage est légitimé par la loi ou rendu nécessaire par la nature" (Rom.11.2). Plus significativement, il souligne lui-même, dans le grand éloge de l'amour de l'Érotikos, au-delà de la simple dimension conjugale établie par la loi, la dimension cosmique donnée par la nature (Amat. 770A):

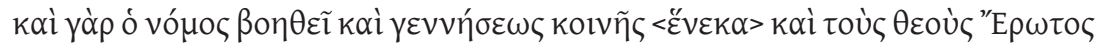

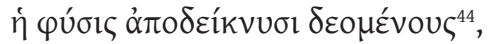

ou encore, dans le De facie 935C, il fait rappeler à son frère Lamprias les honneurs rendus à la lune par les hommes, comme il faut le faire pour les dieux:

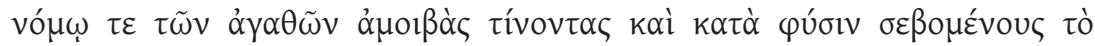

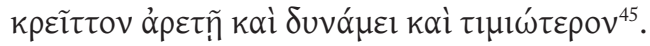

Ces quelques passages attirent l'attention sur l'importance que Plutarque

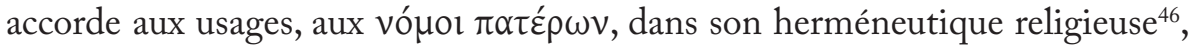
conformément à la theologia tripertita, dont les Opinions des philosophes livrent la définition la plus claire sous la rubrique au titre révélateur, Пó $\theta \varepsilon v$ Évvol $\alpha v$

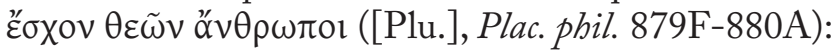

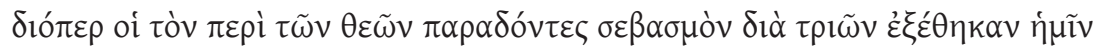

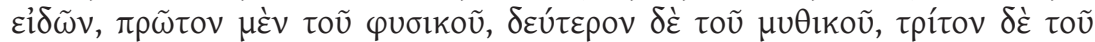

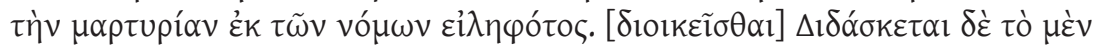

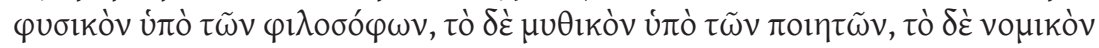

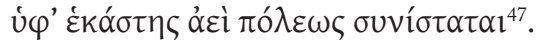

Si l'opinion est attribuée à Chrysippe (fr. 1009 SVF) et l'œuvre considérée

44 "La loi, d'une part, protège (les époux), et la nature, d'autre part, montre que les dieux eux-mêmes ne sauraient se passer de l'amour pour assurer la propagation générale de la vie",

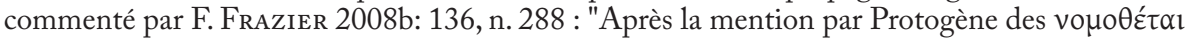
contraints par la nécessité d'encourager la reproduction (750C4) et l'évocation par Daphnée

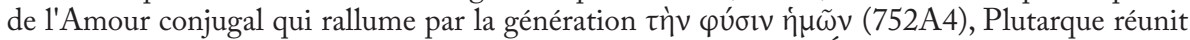

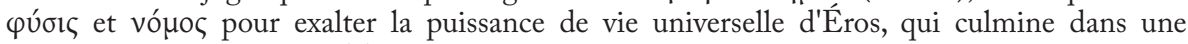
hiérogamie grandiose de la Terre et du Ciel."

45 "payant selon la loi les bienfaits reçus et révérant conformément à la nature ce qui est supérieur et plus honorable en vertu et en puissance" (ma traduction).

46 Comme je l'ai suggéré in F. Frazier 2005: 130-136 ("Wohlwollen Gottes und Hermeneutik der Tradition im Spätwerk").

47 "C'est pourquoi ceux qui nous ont enseigné le culte des dieux ont eu recours à trois types d'exposés, l'un fondé sur la nature, l'autre fondé sur le mythe, le troisième sur le témoignage des usages. L'enseignement fondé sur la nature est celui des philosophes, l'enseignement mythique est celui des poètes, et chaque cité pour sa part compose l'enseignement fondé sur les usages." (trad. G. Lachenaud). 
comme apocryphe, on trouve des traces de cette triple origine dans l'Erotikos ${ }^{48}$

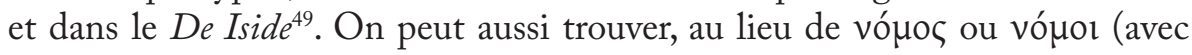

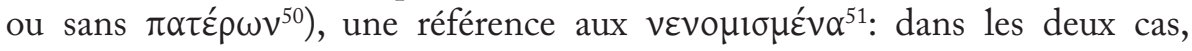
l'accent est mis sur la coutume et son ancienneté, plutôt que sur son caractère conventionnel, sur les relations traditionnelles avec les dieux, à conserver, plutôt que sur des règles proprement politiques. Dans ce domaine, Plutarque peut sans doute, à l'occasion, s'interroger sur telle ou telle loi bizarre et souligner l'obscurité des intentions du législateur ${ }^{52}$, mais les mentions de la loi n'en sont pas moins d'une remarquable rareté dans ses traités politiques, en particulier dans ceux qui s'attachent à la vie civique contemporaine, le An seni et les Praecepta gerendae reipublica $e^{53}$.

Ces derniers offrent une mention rapide de la nécessité pour l'homme d'État de ne pas s'en tenir à la stricte légalité quand l'intérêt supérieur de la cité l'exige,

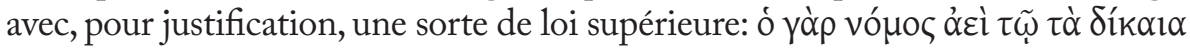

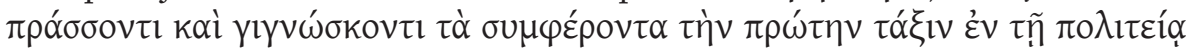
$\delta i ́ \delta \omega \sigma v^{54}$, mais c'est à propos du souverain que la relation avec la loi se pose

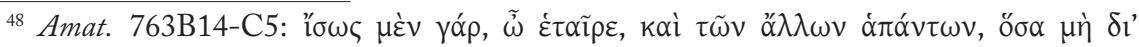

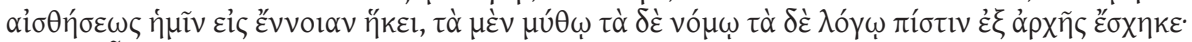

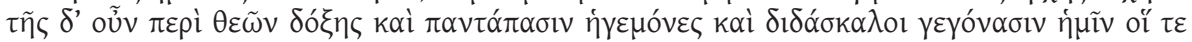

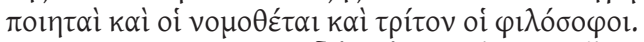

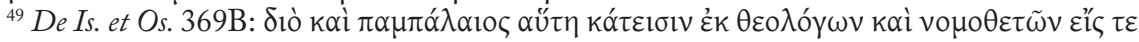

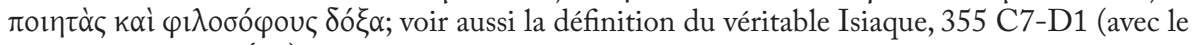
participe $v \varepsilon v o \mu \imath \sigma \mu \varepsilon v \alpha)$.

${ }^{50}$ Cf. De def. orac. $416 \mathrm{C}$ et $436 \mathrm{~F}$.

${ }^{51}$ De Is. et Os. $355 \mathrm{C}$ et 378D; De def. orac. 435E; Amat. 756B: sur ce thème, F. Frazier 2008a.

${ }^{52}$ Une des lois les plus discutées dans la tradition est celle de Solon obligeant à prendre parti dans une stasis — plusieurs fois citée (voir F. FrazIER 1996: 141-143), elle figure en dernier dans la liste des lois apparemment ridicules qui fondent le raisonnement a fortiori du début du De sera

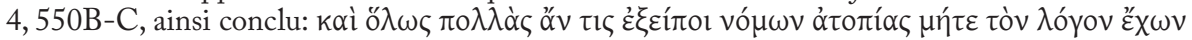

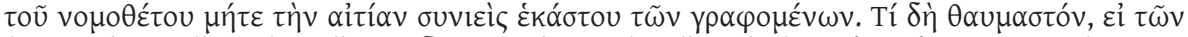

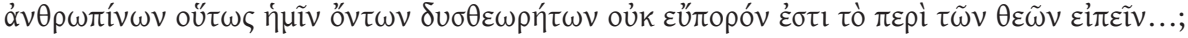
pour d'autres exemples particuliers, voir les contributions de Inés Calero Secal et de Stefano Amendola.

${ }^{53} \mathrm{Ne}$ me semblent pas mériter de longs développements deux mentions, assez banales, l'une dans le An seni, où, pour inciter à l'engagement, Plutarque oppose les circonstances difficiles de l'époque classique avec ses staseis aux conditions contemporaines beaucoup plus favorables,

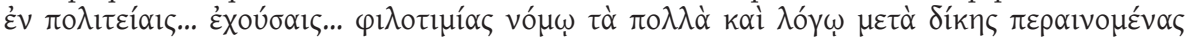

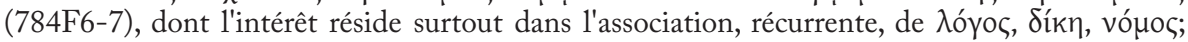

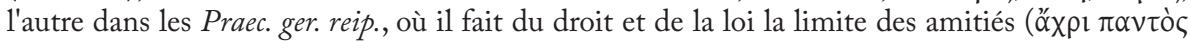

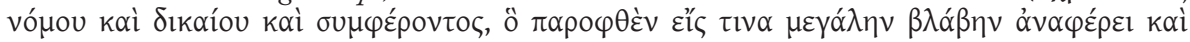
Koıvท́v, 808A9-B1 pour Périclès; voir aussi 808E11 pour Caton). J'ai laissé de côté le De unius, dont l'authenticité est discutée, mais où, en tout état de cause, il n'y a aucune occurrence de vóuoc.

${ }^{54}$ 817D7-9: "Aussi bien, la loi donne toujours la première place dans le gouvernement à celui qui agit selon la justice et sait ce qui est utile" (traduction J.-C. Carrière, CUF, t. XI-2, avec longue note, p. 197, n. 5). Voir aussi, sur le respect de la légalité, F. Frazier 1996: 160-161. 


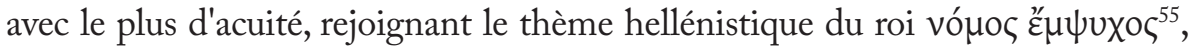
que Plutarque réinterprète dans les deux traités consacrés à la figure du prince. Les occurrences les plus nombreuses et les plus intéressantes se trouvent dans le Ad principem ineruditum, comme l'a souligné son dernier éditeur, Aldo Tirelli ${ }^{56}$, mais la conclusion du Maxime cum principibus offre aussi des lignes précieuses pour mieux apprécier les rapports du gouvernant et du philosophe, qui sont aussi ceux du gouvernant et de la philosophie. Complémentaires ${ }^{57}$, ces opuscules constituent en effet à eux deux, me semble-t-il, une actualisation de la réflexion platonicienne sur le philosophe-roi: si, en effet, comme l'a indiqué Aldo Tirelli, le Maxime cum principibus peut être lu comme un aggiormamento de la théorie $\mathrm{du}$ philosophe-roi, les circonstances contemporaines faisant désormais attribuer au philosophe le rôle plus modeste de conseiller ${ }^{58}$, le gouvernant du Ad principem entretient aussi des rapports privilégiés avec la philosophie qui en font une sorte de "variante moderne" du philosophe-roi, où les aspects moraux de maîtrise de soi, de praotès et de philanthrôpia envers autrui l'emportent sur la connaissance du réel et la sortie de la caverne.

Dans ce cadre, c'est en particulier l'interprétation platonicienne du vó $\mu$ o

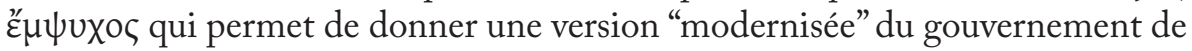
soi sur lequel insistent si fortement et l'affrontement de Socrate et de Calliclès dans le Gorgias et l'analogie entre justice de la cité et justice de l'âme de la République. Il s'agit donc moins de considérer le souverain comme une loi "vivante", "animée", une sorte "d'hypostase terrestre de la Loi divine ${ }^{59}$ ", ainsi que l'ont fait les Pythagoriciens, que de regarder ce qui se passe en son âme. C'est à ce point que sont précieuses les dernières lignes du Maxime cum principibus, où Plutarque rappelle le désir des philosophes d'inscrire leurs logoi dans l'âme des gouvernants pour leur donner force de lois - ce qui précisément motiva le voyage sicilien de Platon $^{60}$. Cela suppose "une âme qui n’est jamais laissée

${ }^{55}$ Pour les grands traits de cet idéal du bon roi, on pourra se reporter commodément à A.J. Festugière 1972; pour les textes, voir L. Delatte 1942.

${ }^{56} 1,779 \mathrm{D} 1,3,780 \mathrm{C}$ et 780E4-781A5, 4, 781B7.

${ }^{57}$ A. BARIgAzZi 1982: 70, a suggéré d'y voir deux morceaux d'un même ouvrage

${ }^{58}$ A. Tirelli 2005: 19-20: "... in cum princ. philos., attraverso un aggiornamento del progetto platonico (non piú il governo dei filosofi ma, piú modestamente, i filosofi consiglieri di governo) si teorizza la necessità che l'uomo di cultura si accosti al ceto politico con finalità paideutiche - legitimando cosí la figura del filosofo consiglier, benefattore del genere umano...".

59 A. Tirelli 2005: 27-28, et 2007: 327-332, où sont répertoriés un certain nombre

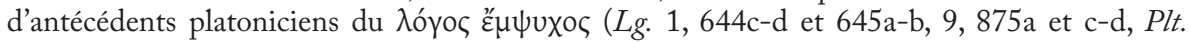
294a-b et le célèbre passage $P h d r .275 d-276 a)$.

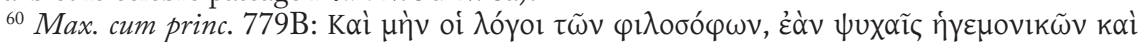

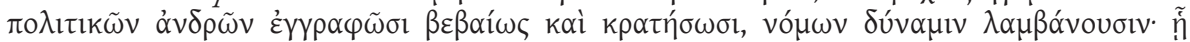

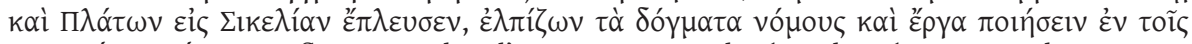

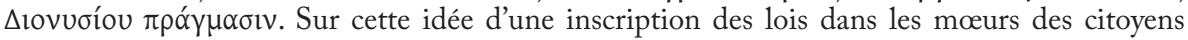
et non sur un support matériel, voir Lyc. 13. Le Ad principem s'ouvre de même sur Platon et la 


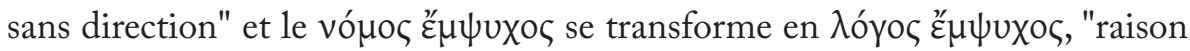
(philosophique) inscrite dans l'âme". C'est ce que souligne le préambule du $A d$ principem (3, 780C5-9):

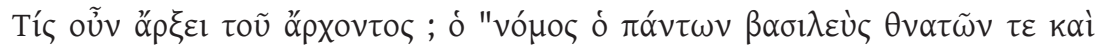

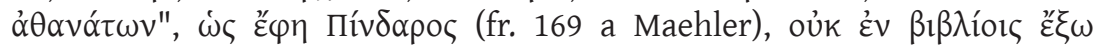

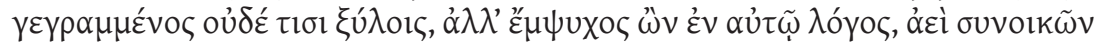

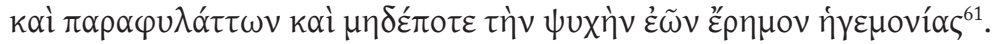

On retrouve ici, au singulier, le logos philosophique ${ }^{62}$, qui se concrétisait et se particularisait dans les logoi que les philosophes du Maxime cum principibus s'attachaient à inculquer aux gouvernants. La réflexion se déploie en effet à un niveau plus général et abstrait, dont témoignent et l'emploi récurrent du singulier, $\lambda$ ó $\varsigma^{63} \varsigma^{63}$, et les occurrences de $\delta i ́ k \eta$, principe supérieur et régulateur comme on l'a vu plus haut.

Pour en rappeler le véritable sens, Plutarque met aussi à profit le contreexemple d'Anaxarque, adultération du conseiller philosophe, prodiguant à Alexandre, plein de remords après le meurtre de Cleitos, des encouragements

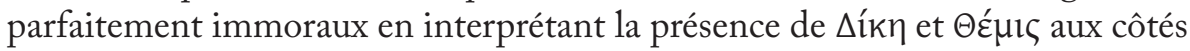
de Zeus, comme la garantie que, quoi qu'il fasse, l'acte du souverain ne saurait être que $\theta \varepsilon \mu ı \tau o ̀ v ~ k \alpha i ̀ ~ \delta i ́ k \alpha 10 v^{64}$, que c'est donc son bon plaisir qui aurait force de la loi, au lieu qu'évidemment, aux yeux du platonicien, il doit se soumettre à la justice supérieure avant d'y soumettre les autres. Et Plutarque de rectifier (Ad princ. iner. 4, 781B5-7):

demande à lui faite par les Cyrénéens "de rédiger et de leur laisser un corps de lois (vó $\mu$ ouৎ $\tau \varepsilon$

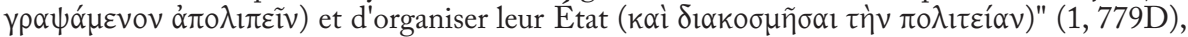
mise en ordre que l'arrogance de leur prospérité rendrait impossible aux yeux du philosophe athénien et qu'il refuse.

61 "Qui donc sera le maître du maître? 'La loi qui règne sur tous, mortels et immortels' comme a dit Pindare. Il ne s'agit pas d'une loi visible écrite dans des livres ou sur des stèles de bois, mais de la raison qui vit dans l'âme du souverain, qui habite constamment en lui, y monte la garde et ne laisse jamais son âme sans gouverne" (trad. M. Cuvigny).

${ }^{62}$ A. Tirelli 2005: 28, le distingue soigneusement du logos des Stoïciens: "in lui vive ed opera il logos, che però non è da intendere come Anima dell'universo, Ragione che penetra e ordina il tutto, alla maniera degli esponenti del Portico, bensí come capacità di discernimento morale installata nel suo intimo dall' educazione filosofica."

${ }^{63}$ Outre les passages étudiés infra (3, 780E7-8 et F5; 5,781F8), voir aussi 1,779E12-F1: 'O

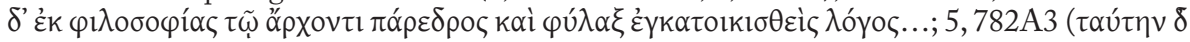

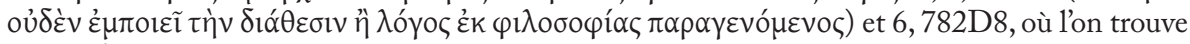

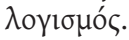

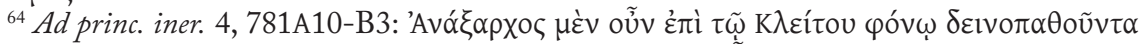

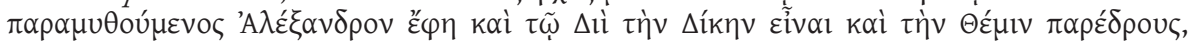

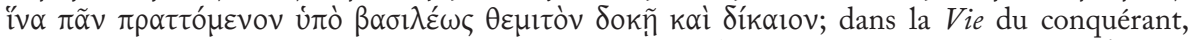
Plutarque dit, avec le vocabulaire qui nous intéresse, qu'Anaxarque le rendit ainsi xauvó $\varepsilon \rho \rho v$

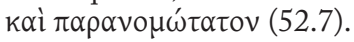




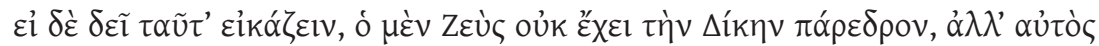

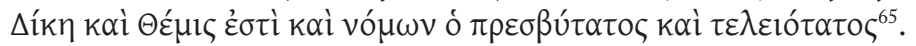

Ainsi sont traduits en termes mythiques les liens du divin et du juste, qui font de la divinité le modèle du gouvernant, l'archétype de la loi, que le gouvernant doit représenter et réaliser dans le monde politique. Ces notions étaient déjà traitées d'un point de vue plus conceptuel dans le chapitre précédent, sur lequel il nous faut revenir.

Ayant d'abord défini l'archè, en la situant dans la marche du monde, dans

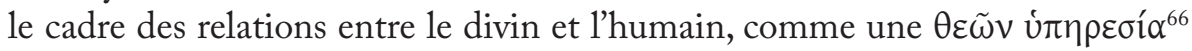
chargée de répartir les biens dispensés par les dieux, "dont il n'y a ni jouissance

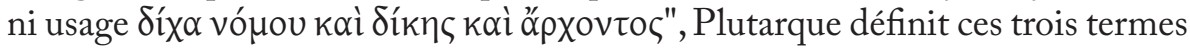
$(3,780 \mathrm{E} 4-\mathrm{F} 2)$ :

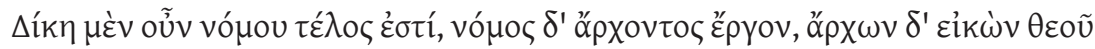

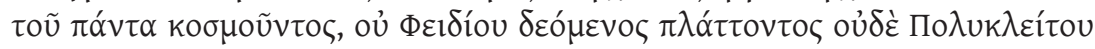

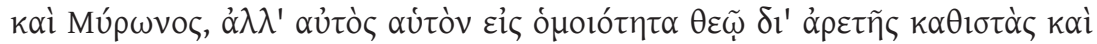

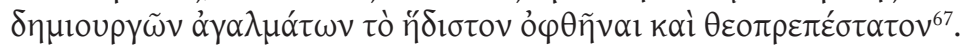

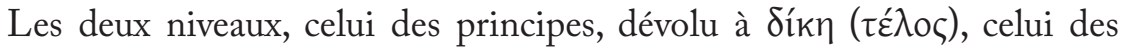
réalisations concrètes, qui revient au vópos (ह̌pyov), se retrouvent, enrichis ici de la conception de l'agent de cette réalisation, l'ó $\rho x \omega v$, qui est aussi le

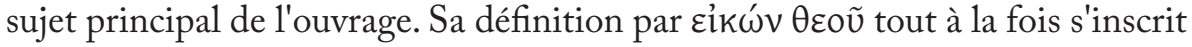
dans la conception platonicienne générale des relations entre le divin et le sensible - rappelant la distance ontologique qui sépare les deux ${ }^{68}$ — et dans

65 "En fait, s'il faut former des conjectures sur cette matière, Zeus n'est pas assisté par Justice : il est lui-même Justice, Droit et la plus ancienne et la plus parfaite des lois" (trad. M. Cuvigny, légèrement modifiée).

${ }^{66}$ Voir, derechef, le commentaire de A. Tirelli 2005: 28: "In tale orizzonte si iscrive la

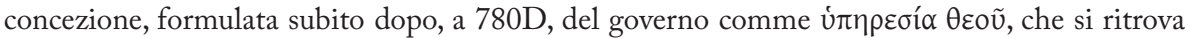
anche in praec. ger. reip. $823 \mathrm{~F}$ e in Num. 6.2, una biografia che presenta notevoli tratti di affinità con il nostro opuscolo, celebrando nell'antico re sabino l'incarnazione ante litteram dell'ideale politico di Platone."

67 "La justice est la fin de la loi, la loi l'ouvrage du souverain, le souverain l'image de Dieu qui ordonne toutes choses. Nul besoin pour modeler une pareille image d'un Phidias, d'un Polyclète, d'un Myron: c'est le souverain lui-même qui, par le moyen de la vertu, cherche à se rendre semblable à la divinité et à créer, de toutes les statues, la plus agréable au regard et la plus digne d'un dieu." (trad. M. Cuvigny légèrement modifiée pour donner toute leur valeur conative aux participes présents).

${ }^{68}$ Voir aussi, destinée à éviter tout malentendu, la critique de l'immanence stoïcienne au chapitre 5, avec une référence explicite à Platon, qui précède une seconde occurrence du

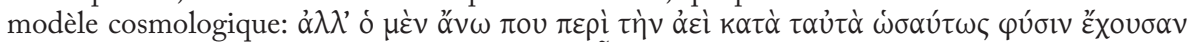

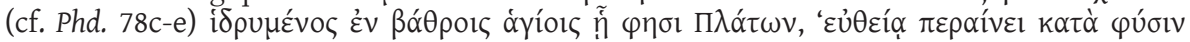

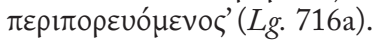


le développement sur la maîtrise de soi et le bon comportement royal entamé au chapitre précédent et nourri du contraste entre les rois et chefs (les plus

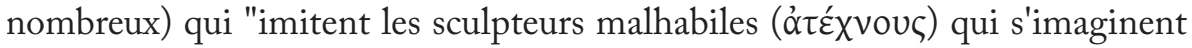
que leurs colosses donnent une impression de force et de grandeur" (779F) et le bon archôn. La "statue", l'óy $\alpha \lambda \mu \alpha$, qu'il doit façonner lui-même au lieu de se faire représenter en orgueilleuse majesté par les grands sculpteurs, est le fruit

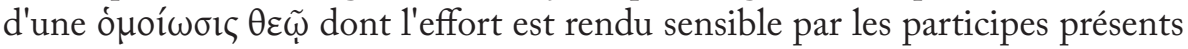
et le but mis en valeur par l'hyperbate qui réserve la place finale au superlatif $\theta \varepsilon о \pi \rho \varepsilon \pi \varepsilon ́ \sigma \tau \alpha \tau o v$.

En quoi consiste cette image, c'est ce que tente de préciser la phrase suivante, où apparaît pour la première fois le comparant solaire. Elle pose des problèmes d'édition et d'interprétation délicats:

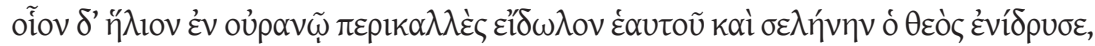

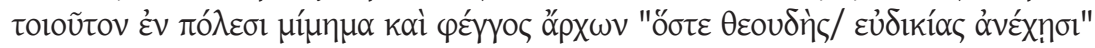

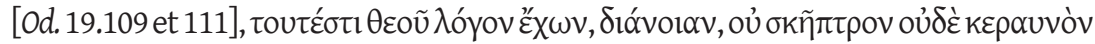

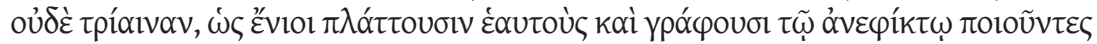

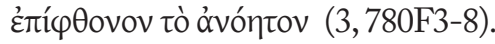

La subordonnée, avec le comparant, est claire: "comme la divinité a placé dans le ciel comme splendide image d'elle-même le soleil et la lune", mais les choses se gâtent dans la principale, elliptique du verbe et où les éditeurs successifs ont été embarrassés par la fonction à donner à l'accusatif $\delta ı \alpha ́ v o ı \alpha v$, qui n'est coordonné ni à ce qui précède, ni à ce qui suit. De toutes ces discussions, Aldo Tirelli donne un compte rendu précis et exhaustif dans son édition et, sans prétendre trancher entre deux solutions dont aucune ne me paraît pleinement satisfaisante, je voudrais insister, moins sur les détails grammaticaux et stylistiques, soigneusement exposés par le savant italien ${ }^{69}$, que sur les implications pour la pensée de Plutarque des deux possibilités majeures.

Pour commencer par la dernière proposition en date, Aldo Tirelli, rétablissant un parallélisme strict des deux propositions ${ }^{70}$, propose de sousentendre dans la principale le même verbe que dans la subordonnée, દ̇vı $\delta \rho u ́ \varepsilon l$, dont $\delta$ ó́volav serait le complément, placé après la glose du vers homérique: "c'est comme une telle image splendide qu'est placée dans les cités par le gouvernant qui 'vénérant la divinité, maintient les jugements droits', c'est-à-dire

\footnotetext{
${ }^{69}$ A. Tirelli 2005: 110-113, n. 23.

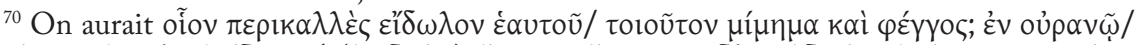

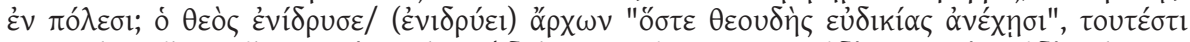

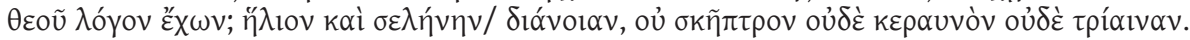
Notons que l'on trouve bien un parallélisme parfait dans la seconde occurrence du paradigme solaire, en 5, 781A (voir note ad loc. CUF, XI-1, p. 132), où le prince est sans aucun doute l'analogue du soleil.
} 
qui possède la raison divine, la dianoia, et non le sceptre, la foudre ou le

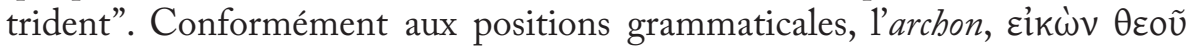

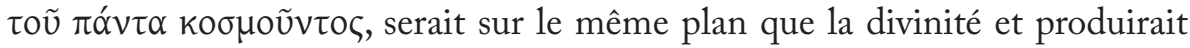
lui aussi dans la cité une certaine image de lui-même brillante et ordonnatrice, vision active qui cadre bien avec l'accent mis sur l'effort d'imitation dans la phrase précédente. Néanmoins "installer la dianoia" paraît une expression bizarre, et si, à la rigueur, on l'admet, "sceptre, foudre et trident" seraient aussi "installés": l'ellipse du verbe peut éventuellement faire passer cette bizarrerie pour n'imposer à l'esprit du lecteur que l'opposition entre pensée et force, mais l'emploi de É $\chi \omega \nu$ dans cette allusion aux statues tenant ces attributs du pouvoir paraîtrait plus naturel.

Si l'on revient à l'interprétation plus traditionnelle, le verbe sous-entendu

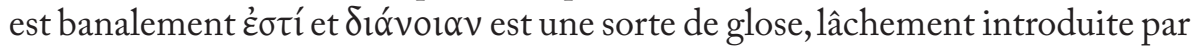
Plutarque ou indûment insérée par un copiste, l'ensemble se comprenant ainsi " telle est la splendide image que constitue dans la cité le gouvernant 'qui, plein de respect des dieux, maintient les jugements droits', c'est-à-dire doté de la raison divine, la dianoia, et non du tonnerre, de la foudre ou du trident..." On

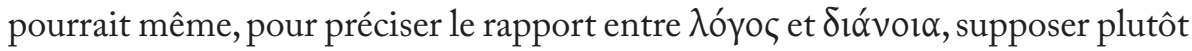
une construction attributive et comprendre quelque chose comme "qui possède le logos divin qu'est la dianoia", ou mieux, "qui a le logos divin sous forme de

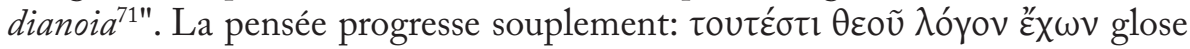

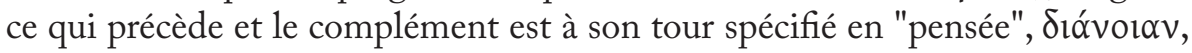
réalité immatérielle que Plutarque oppose aussitôt aux grossiers attributs du pouvoir déjà stigmatisés plus haut. L'archôn est dans ce cas l'analogue du soleil dans le monde humain, image dont il importe, non qu'elle ait été placée par la divinité, mais qu'elle détienne le logos divin et puisse l'appliquer dans la cité. Plus précisément, c'est la possession de cette raison divine qui en fait l'image de la divinité - et c'est peut-être pourquoi a été choisi le tour $\theta \varepsilon o \tilde{v} \lambda o ́ \gamma o v$, rare chez Plutarque et qu'on ne trouve guère que dans le De Iside, rapporté à la divinité elle-même ${ }^{72}$ - rareté qui peut aussi expliquer qu'il ait besoin d'être spécifié en ठıóvola.

On le voit, aucune des hypothèses ne donne un résultat totalement satisfaisant et, dans ce contexte - contrairement au chapitre 5 -, on n'arrive pas à trancher si l'archôn est l'image de la divinité, sur le même plan que le soleil, ou l'agent qui donne une image de l'activité du dieu ordonnateur. Deux

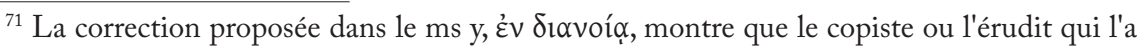
introduite était conscient de la difficulté syntaxique, mais cette variante est incompatible avec la reprise oủ $\sigma \kappa \eta ́ \pi \tau \rho o v ~ \kappa \tau \lambda$ qui ne peuvent pas être dans la pensée.

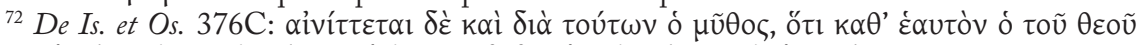

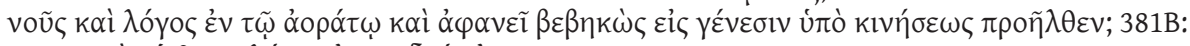

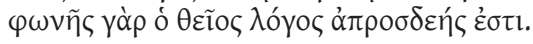


points sûrs se dégagent néanmoins, l'importance majeure du logos et, qu'il soit présent ou non dans cette phrase, l'accent porté sur l'effort imitatif humain, qui réapparaît dès la phrase suivante, où l'on repasse sous le regard de la divinité:

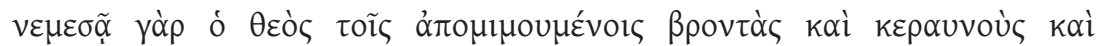

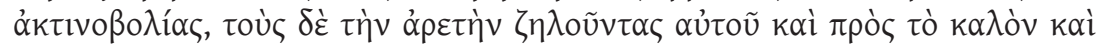

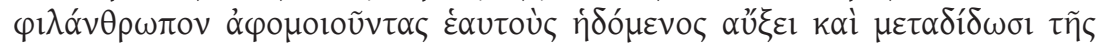

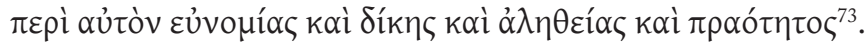

Cette importance de la mise en ordre se retrouve dans l'emploi du paradigme cosmique vers lequel nous ont déjà orientés et la comparaison solaire et la

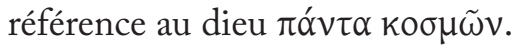

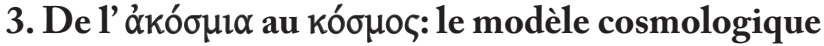

Un premier signe, ténu sans doute, mais non négligeable, de l'importance, non seulement de l'ordre, mais plus précisément de la mise en ordre à laquelle invite le paradigme cosmique, réside dans la mention fréquente du désordre

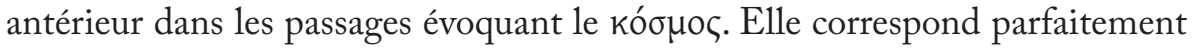
à l'interprétation littérale, temporelle, que Plutarque donne de la formation du monde, et à la conception, dont il fait état dans son commentaire au Timée, d'un premier mélange de divisible et d'indivisible, antérieur à l'association avec le Même et l'Autre. C'est le divisible qu'il identifie à l'âme précosmique, désordonnée et harmonisée seulement dans un second temps, ce second état de l'âme n'impliquant cependant pas une disparition totale de la tendance précédente au désordre, rémanence qui est la source du mal ${ }^{74}$. Ce qui est vrai au niveau de l'âme du monde se retrouve à celui de l'âme humaine, où la vertu éthique, qui a pour matière les passions, est elle-même conçue en termes de "mise en ordre", qui discipline, mais n'élimine pas l'irrationnel (oủk oũ $\sigma \alpha$

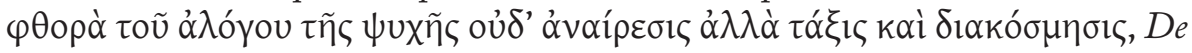
virt. mor. 444D).

Dans les développements cosmologiques stricto sensu, qu'on prenne l'exégèse du De procreatione animi $i^{75}$ ou la réflexion sur la pluralité des

73 "Car la divinité se courrouce contre ceux qui copient ses tonnerres, ses foudres, les rayons qu'elle lance. Mais pour ceux qui cherchent à imiter sa vertu, à se modeler sur sa perfection et son amour des hommes, elle y prend plaisir, elle les élève et leur fait part de son équité, de sa justice, de sa vérité et de sa douceur" (trad. M. Cuvigny).

${ }^{74}$ Voir J. Opsomer 2004 et 2007.

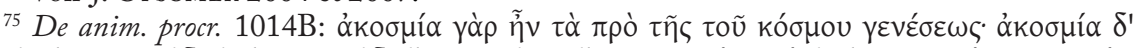

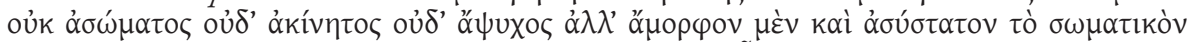

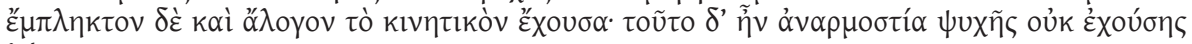

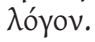


mondes du De defectu $u^{76}$, "hommage à Platon" qui s'oppose à l'illimitation des Epicuriens comme à la nécessité stoïcienne de faire correspondre un monde unique à une Providence unique ${ }^{77}$, on retrouve, toujours les

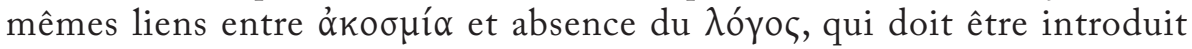

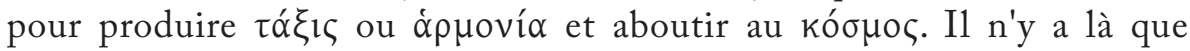
confirmation de ce qui est bien connu et je voudrais plutôt m'attarder sur un passage polémique du De facie, où Lamprias met en garde Pharnace, le Stoïcien, contre les conséquences d'une théorie qui aboutirait à

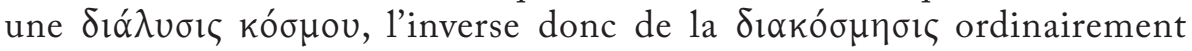
évoquée. Cette dissolution, ce retour au désordre, est assimilé à la phase dominée par le veĩkos d'Empédocle ou encore, dans un style plus

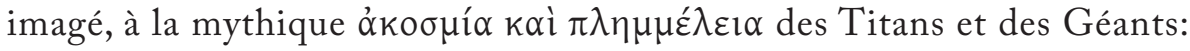
la comparaison, qui nous fait remonter aux temps primitifs, superpose adroitement l'image d'une troupe désordonnée, l'idée morale d'un

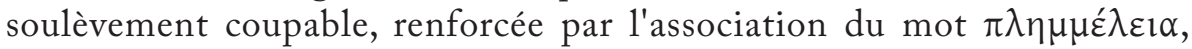
et l'évocation d'un univers sans ordre ${ }^{78}$, où les éléments errent chacun de son côté et suivant son propre mouvement. Et cette belle description, toujours inspirée d'Empédocle, débouche sur une référence à Platon: cet

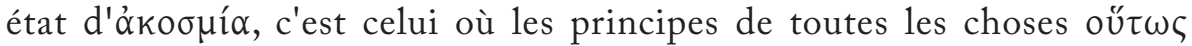

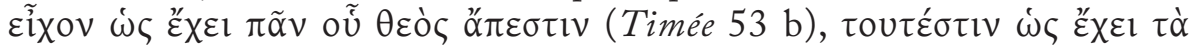

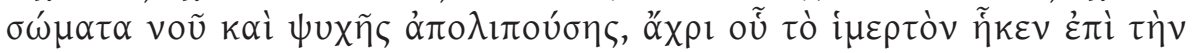

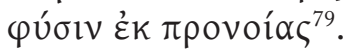

La mention de la providence mérite d'être soulignée: intervenant ici dans un passage polémique et imagé dirigé contre des philosophes aussi convaincus que Plutarque de son existence, les Stoïciens, dont les lignes suivantes ${ }^{80}$ vont mettre au jour une contradiction, elle apparaît plus souvent encore dans l'opposition avec les Épicuriens, qui la nient. Ainsi il n'y a rien que de très

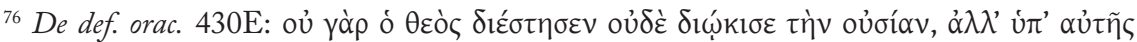

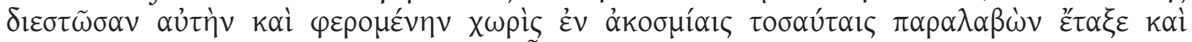

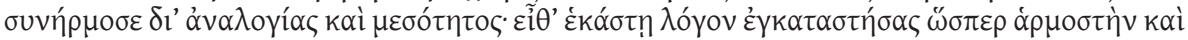

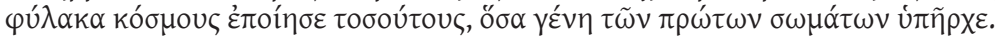

77 Voir De def. 30, 426D9-E5; pour l'hommage à Platon, accompagné du rappel de la prudence académique, 37, 430E10-431A3.

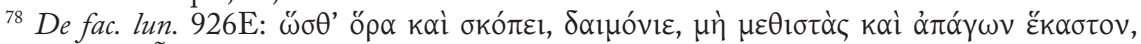
ö

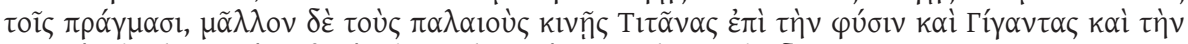

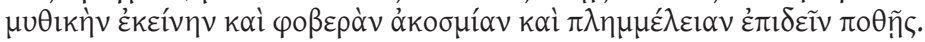

${ }^{79}$ De fac. lun. 926F6-9 (Cherniss): (les principes) "étaient dans l'état dans lequel, selon Platon, se trouve tout chose dont dieu est absent, c'est-à-dire dans lequel sont les corps quand esprit et âme font défaut, jusqu'à ce que le désir s'introduise dans la nature du fait de la providence".

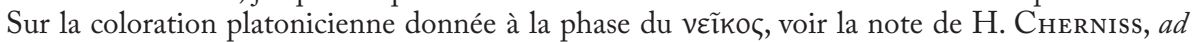
loc (Loeb, t. XII, p. 84).

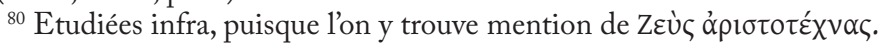


attendu à voir le plus bel emploi du paradigme cosmique, nourri du Timée et des Lois, ouvrir la théodicée que constitue le De sera (5, 550C12-E2):

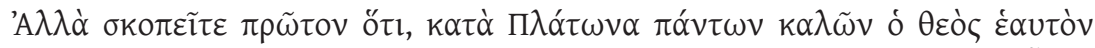

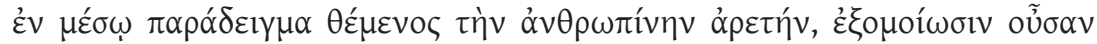

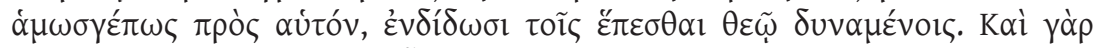

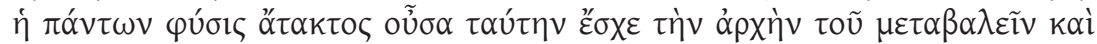

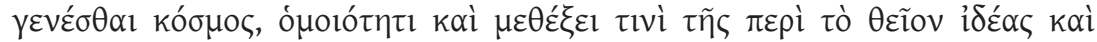

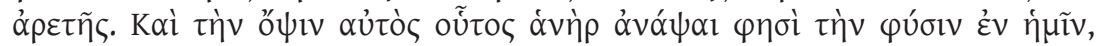

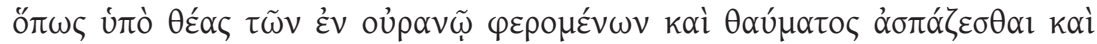

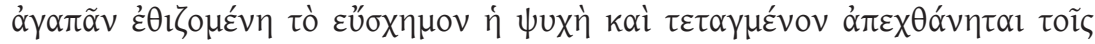

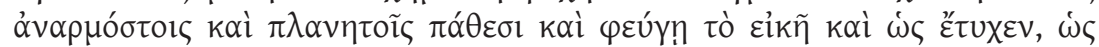

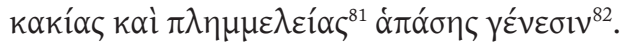

L'explicitation de la manière dont Dieu a "mis au milieu", offert à tous, le paradigme à suivre pour qui veut accéder à la vertu, se fait en deux temps: Plutarque évoque d'abord la mise en ordre du monde, métamorphose de la matière désordonnée (l'âme précosmique du De procreatione) en cosmos, qui suppose une participation à la forme et à la vertu divines, avant de s'attacher aux effets de la contemplation de cet ordre sur l'âme. L'opposition avec l'épicurisme, dans les domaines cosmologique et éthique à la fois, transparaît nettement dans les qualifications des principes et passions à fuir énoncés dans les dernières lignes, tandis que, dans la contrepartie positive, on retrouve le même vocabulaire, et, surtout, le même effort éthique, souligné par l'emploi de

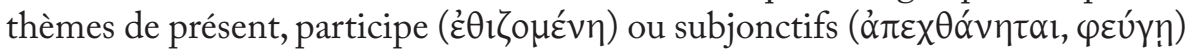
- cette récurrence me semble d'autant plus remarquable qu'elle ne touche pas aussi directement le thème de la réflexion que les conseils prodigués au " chef mal éduqué ", implicitement invité à s'éduquer: si le temps intervient dans le De sera, c'est comme le cadre possible d'un changement, comme l'espace où Dieu seul peut définir le kaıpós du châtiment, voire comme le lieu d'un châtiment immédiat et perpétuel, infligé par le remords, mais l'effort pour s'amender importe peu à la réflexion et n'y apparaît pas en dehors de ce passage

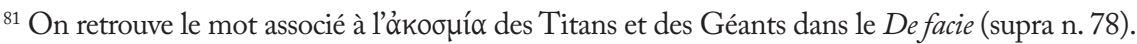

82 "Songez donc d'abord que, selon Platon, Dieu, en se présentant à tous comme le paradigme de tous les biens, met la vertu humaine, qui est en quelque sorte une assimilation à lui-même, à la portée des êtres capables de 'suivre Dieu'. En effet, la nature universelle, qui ignorait tout ordre, a trouvé le principe de sa métamorphose en monde organisé (cosmos) dans une certaine ressemblance et participation à la forme et à la vertu divines. C'est encore cet auteur qui affirme que la nature a allumé en nous la lumière de la vue afin que notre âme, par la contemplation émerveillée des astres qui cheminent dans le ciel, s'accoutume à aimer et chercher l'ordre et l'harmonie, à prendre en horreur les passions livrées à l'errance et à la dysharmonie et à fuir ce qui 'se fait à l'aventure' et 'comme cela se trouve', considéré comme lorigine de tout mal et de toute discordance." Pour un commentaire plus détaillé, voir F. Frazier 2010: 77-78. 
initial. Preuve que l'effort sur soi est à ce point consubstantiel à la vie morale aux yeux de Plutarque qu'il ne saurait l'omettre dans une peinture générale de la réalité, de dieu, du monde et de l'homme.

A plus forte raison, le modèle cosmique et l'effort qu'il suscite et guide tout à la fois dans l'âme humaine, se retrouvent-ils dans le contexte pédagogique hautement platonicien que constitue la Vie de Dion. De nouveau le texte pose quelques difficultés, dont la première concerne directement la "mise en ordre" du caractère. Voici ce que Dion attend de Platon, qui devra s'employer auprès de Denys le Jeune — un bel exemple de princeps ineruditus (Dio 10.2-3):

ö

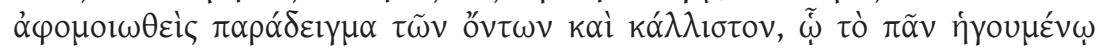

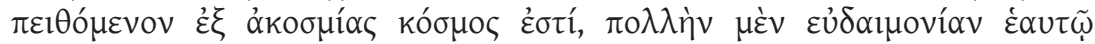

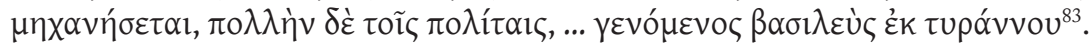

Les manuscrits transmettent majoritairement l'inacceptable $\delta 1 \alpha k o \sigma \mu \eta \theta \varepsilon i \varsigma$

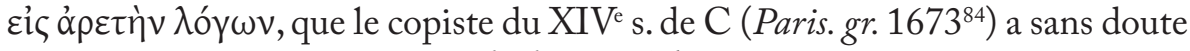

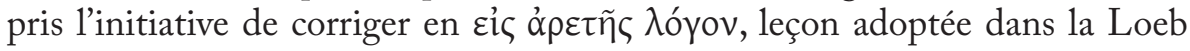
comme dans la CUF, alors que, dans Teubner, Ziegler, dont j'ai repris le texte, a préféré la correction du génitif pluriel en datif singulier, $\lambda o ́ \gamma \omega$ au lieu de $\lambda o ́ \gamma \omega v$. Un tel texte s'accorde bien avec les thèses du Adprincipem et confirme le rôle du logos dans une "mise en ordre visant la vertu" qui passe derechef par l'imitation du principe le plus divin. La relative reprend le parallèle entre la

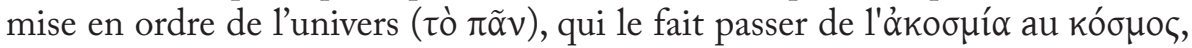
et la "mise en ordre" éthique, mais celle-ci, s'attachant à l'âme d'un gouvernant, se double d'une transformation politique - peut-être préparée par l'accent mis, dans le comparant cosmique, sur l'obéissance au principe directeur, qui évoque et la domination de la partie hégémonique, rationnelle, dans l'âme du gouvernant, et l'obéissance qu'à son tour il va obtenir, puisque, dans sa pratique du pouvoir, il va désormais passer de l'état de tyran (en proie à l'ỏkoouía des passions ${ }^{85}$ ) à celui de roi.

83 “afin que, ayant disposé son caractère à la vertu grâce à la raison et l'ayant conformé au plus divin et au plus beau modèle des êtres, à la direction duquel l'univers se soumet pour sortir du désordre et devenir monde ordonné, il procurât beaucoup de bonheur à lui-même et beaucoup aux citoyens ... devenant ainsi roi de tyran qu'il était" (ma traduction).

${ }^{84}$ Voir la présentation de M. Juneaux, Vies, CUF, t. I, XLIX-L: "...le copiste du Parisinus, agissant comme un éditeur, prend de temps en temps des libertés avec le texte, corrigeant ou inversant un mot, susbtituant parfois au texte un commentaire ou une interprétation personnelle."

${ }^{85}$ J'adapte ici une description qui recourt aussi au paradigme cosmique, et que l'on trouve dans le De libidine, frg. contesté, dont F. H. Sandbach souligne qu'il présente des ressemblances de fond avec la pensée de Plutarque, les différences stylistiques pouvant s'expliquer si l'on admet qu'il s'agit d'un abrégé de l'œuvre. Un des passages très proches de la pensée de Plutarque et

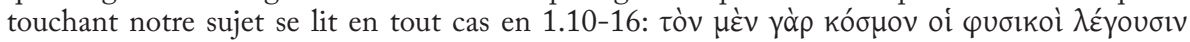


Le glissement se fait dans Dion tout naturellement de l'éthique au politique et montre, en acte (avec, cette fois, des participes aoristes), ce qui était recherché dans le Ad principem. Si l'on descend encore davantage dans la pratique politique et sociale, la mise en ordre conserve toute son importance: en témoigne un mot célèbre de Paul Emile dont Polybe (30.14-15) ${ }^{86}$ se fait l'écho avant Plutarque ${ }^{87}$ et qui associe comme les deux aptitudes d'une même âme la mise en ordre de bataille des soldats et l'organisation du banquet, soit deux activités majeures, l'une en temps de guerre, l'autre en temps de paix. Le Romain est alors en terre hellénique, après sa victoire sur Persée, pour un séjour que Plutarque qualifie d'है $v \delta \circ \xi o v ~ \alpha ̊ \mu \alpha ~ k \alpha i ̀ ~ \varphi ı \lambda \alpha ́ v \theta \rho \omega \pi o v ~(28.1)$ et qui le fait apprécier des $\mathrm{Grecs}^{88}$. Or ce mot de Paul Emile se retrouve dans un des Propos de Table "sympotiques", c'est-à-dire discutant des usages du banquet et portant plus précisément sur la question de savoir "Si celui qui reçoit doit lui-même placer les convives, ou s'il doit les laisser choisir". Une controverse s'est élevée entre le père et le frère de Plutarque, Timon, après le départ furieux d'un étranger "nouveau riche" ulcéré de "ne point voir de place libre qui fût digne de lui", ce qui, par le biais d'une scène de comédie, donne à la discussion une certaine épaisseur sociale; le père, favorable au placement qui eût évité l'esclandre, se tourne alors vers Plutarque (Quaest. conv. 1.2, 615E-616A):

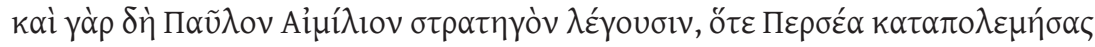

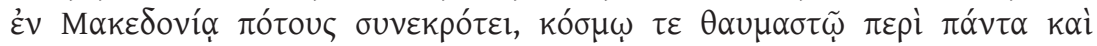

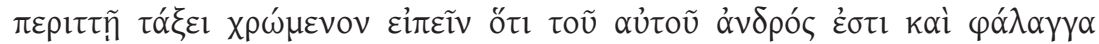

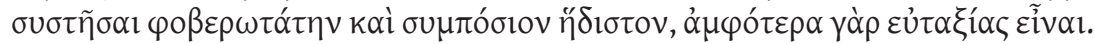

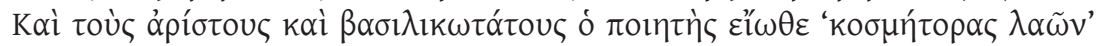

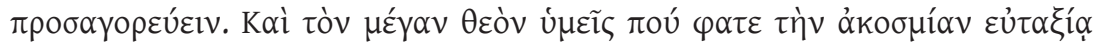

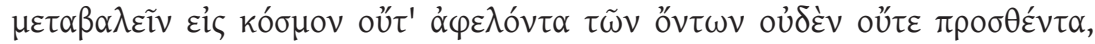

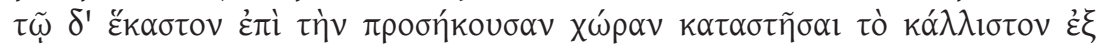

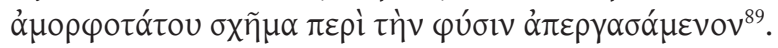

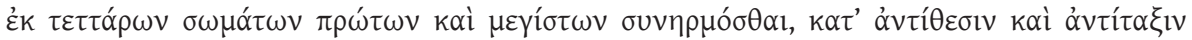

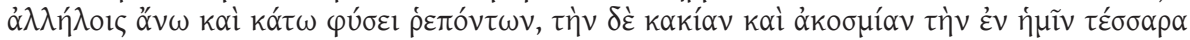

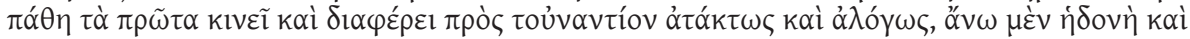

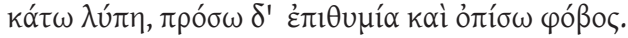

86 "O

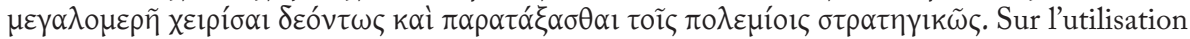
du banquet aussi par Philon dans la peinture du politique Joseph (De Josepho 202-206) et

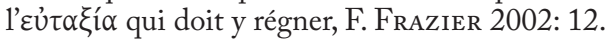

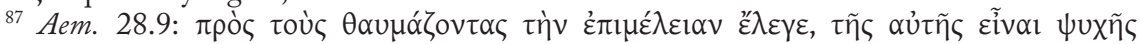

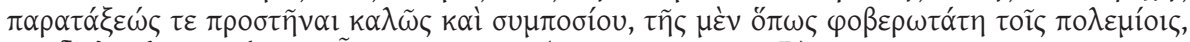

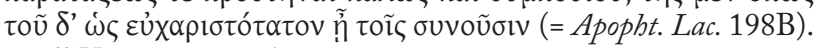

${ }^{88}$ Voir supra n. 35.

89 "Ne rapporte-t-on pas en effet que Paul-Emile, le général, quand il organisait des banquets après sa victoire sur Persée en Macédoine, voulait que tout fût admirablement ordonné et soigneusement réglé, disant que le même homme devait aussi bien savoir donner au front 
Autoboulos est un homme cultivé et le banquet est le lieu même où faire assaut de culture : d'où la double référence, au vocabulaire homérique et à la cosmologie platonicienne, particulièrement adaptée

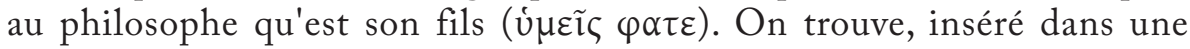
controverse familiale policée, ce que l'on avait aussi dans la polémique plus virulente du De facie et, s'il faut prendre ici le paradigme cum grano salis, il n'en faut pas moins souligner l'importance de la notion d'ordre dans tous les domaines, qui justifie cette sorte de déclinaison de la mise en ordre, passant du cosmique au psychique, de l'éthique au politique et social -les deux ne se séparant guère dans l'Antiquité, où le banquet est, dès l'époque archaïque, lieu du koinon ${ }^{90}$. La meilleure preuve de cette sensibilité particulière des Grecs à la mise en ordre et de la place qu'ils lui attribuent dans la vie politique et sociale ressort avec encore plus de clarté si l'on se reporte à la forme que prend le même mot de Paul-Emile chez Tite-Live (45.32.11):

Vulgo dictum ipsius ferebant et convivium instruere et ludos parare ejusdem esse qui vincere bello sciret.

Certes un dérivé de struo, constructio, a pu servir de traduction à $\sigma u ́ v \tau \alpha \xi ı \varsigma^{91}$, mais la notion d'ordre n'est guère prégnante dans le verbe instruere, et surtout, en bon Romain, Tite-Live ajoute au banquet, dans les festivités du temps de paix, les ludi, effaçant d'autant plus le parallélisme entre les deux "ordres" que, du côté de la guerre, il n'est pas question de savoir "ranger" les armées, mais seulement d'obtenir la victoire. Si l'on revient maintenant du côté grec, Lamprias, au milieu de comparaisons avec des techniciens humains qui agencent et assemblent ${ }^{92}$, se réfère

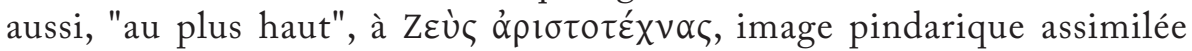
à la figure du démiurge platonicien, c'est-à-dire à celui qui constitue le кóouos.

de bataille sa forme la plus redoutable et au banquet sa forme la plus agréable? Car l'un est l'autre reposent sur le principe d'un arrangement judicieux. Le Poète a coutume d'appeler "bons ordonnateurs de guerriers" les hommes les plus remarquables, les plus aptes à régner. Et vous, vous dites bien que c'est par un arrangement général que le grand dieu substitua l'ordre au désordre, sans rien enlever de ce qui existait et sans rien ajouter, et que c'est en plaçant chaque chose à l'endroit convenable qu'il tira d'une extrême confusion la forme la plus belle pour la nature" (trad. F. Fuhrmann, légèrement modifiée).

${ }^{90}$ Voir P. Schmitt-Pantel 1992, en part. 45 sqq. ("Symposion et partage sacrificiel: 2 modèles pour la cité archaïque").

${ }_{91}$ A. Ernout ; E. Meillet, D.É.L.L, 4e éd., Klincksieck,1967, sv. struo.

${ }^{92}$ Cela correspond pleinement aux emplois premiers de kó $\mu \circ \varsigma$, antérieurs à son usage "cosmique": voir G. Neumann 1995. 


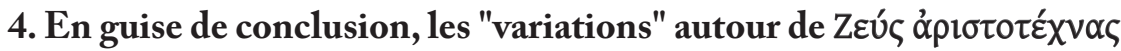

Cette citation récurrente, qui figure dans cinq passages (De sera num. vind. 4, 550B; Quaest. conv. 1.2, 618B-C; Praec. ger. reip. 807C; De fac. lun. 927B; De comm. not. 1065E), a déjà été relevée et analysée par L. VAn der Stockt 2002: 117-125 (et Tables 1-2) comme élément d'un "Pindar-cluster", d'inspiration platonicienne, dans lequel reviennent

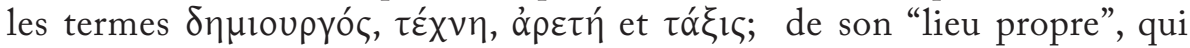
serait la discussion cosmologique du De facie, elle s'introduit, avec le $D e$ communibus notitiis et le De sera, dans le domaine éthique, tandis que les Propos de Table en donnent une utilisation quelque peu humoristique où l'éthique se spécifie en étiquette et que les Préceptes politiques la tirent dans un sens métaphorique ${ }^{93}$. On ne peut que souscrire à cette analyse, mais la réflexion sur ordre et désordre dans la pensée de Plutarque permet de l'affiner encore, de même que, réciproquement, la revue des cinq passages permet de synthétiser les grandes lignes de notre étude.

Dans la citation comme pour notre thème, les deux termes sont importants, Zzúc, qui nous situe au plus haut, au niveau du divin créateur et

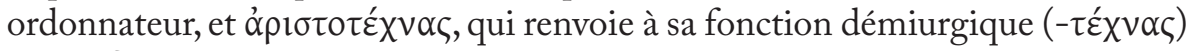

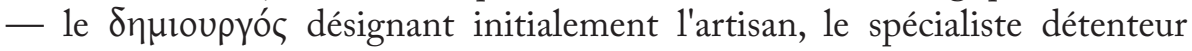

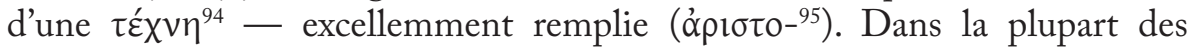
citations, l'épithète pindarique est pour ainsi dire glosée par un groupe apposé ou coordonné qui en spécifie le sens contextuel. Sur ces bases, on peut déjà

${ }^{93}$ L. VAn der Stockt 2002: 125: "To sum up: the Pindar-quote is part of a Platonically

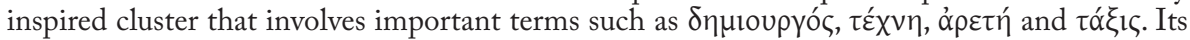
proper habitat is most probably the cosmological discussion in De facie, whilst De comm. not. and De sera go into its ethical implications. It found a playful application in the domain of ethics and etiquette in the Quaest. Conv., and became the source of a powerful metaphor in Praec. ger. reip."

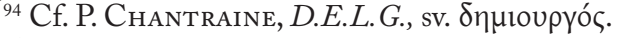

95 Pour ce type de composés, on peut hésiter entre deux interprétations: $1^{\circ}$ celle par un composé de type possessif, d'où "à l'art sans pareil", soit, plus joliment, "qui excelle dans son art", ou $2^{\circ}$ celle par un composé à rection verbale, avec nom d'agent au second élément, nom d'agent en - $\alpha \varsigma$ non attesté au simple dans le lexique, mais d'un type bien représenté en composition

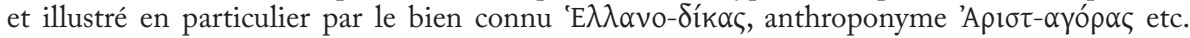

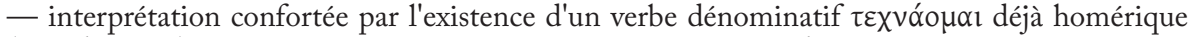

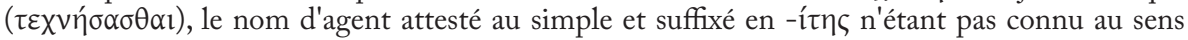
d' "artisan, ouvrier" avant l'époque classique, d'où ici le sens "qui construit, fabrique le mieux", soit "meilleur artisan". C'est la première solution que retient E. RüEDI 1969: 40-41 et en particulier 171-172 pour le composé pindarique, considérant comme l'une des caractéristiques de la langue poétique l'emploi d'Epitheta ornantia avec des théonymes, ce qui est du reste corroboré dans

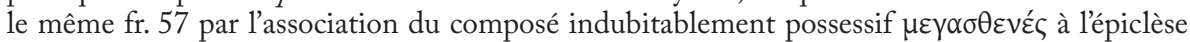
de Zeus $\Delta \omega \delta \omega v \alpha \tilde{\imath} \varepsilon$. Mais quel que soit le sens voulu par Pindare, il est clair que Plutarque l'interprète dans le deuxième sens. Je remercie vivement ma collègue et amie Sophie Minon, dont la science m'a fourni ces précisions linguistiques. 
mettre à part la citation des Préceptes politiques ${ }^{96}$, qui ne reprend que l'adjectif,

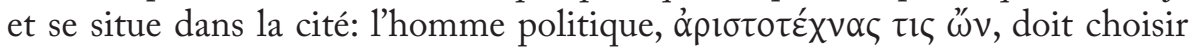
judicieusement ses amis, qui sont, dans son action et pour la réussite de celle-

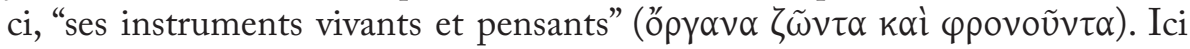
c'est donc par la notion d' "instrument" que se fait le rapprochement avec les artisans détenteurs d'une technè, maçon ou charpentier. Et le "bon ordre", réalisé dans le cadre civique, est exprimé par les notions traditionnelles qui ont

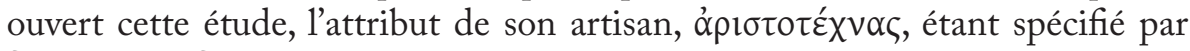

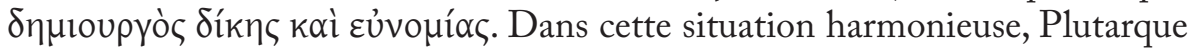
insiste moins sur un certain ordre constitutionnel que sur l'harmonie des relations humaines - aspect en effet essentiel dans la cité de son époque, où il faut "régler" amitiés et inimitiés à l'intérieur, et assurer de bonnes relations avec les autorités romaines pour éviter toute intervention de leur part.

Avec la mention de Zeus, on quitte le domaine de la cité pour prendre un point de vue cosmique, qui va jouer à deux niveaux, celui du cosmos stricto sensu, celui où intervient le démiurge du Timée, et celui du monde mortel, confié dans le dialogue platonicien aux dieux secondaires - mais où c'est la part immortelle par lui semée qui doit commander et assurer l'ordre de la justice. Le premier niveau, qui concerne astres et planètes, se trouve dans le De facie $e^{97}$, comme le fait attendre le sujet

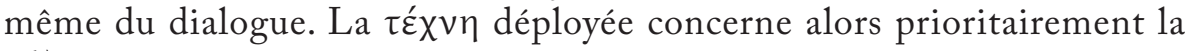

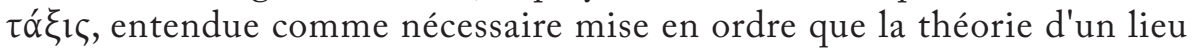
que chaque élément occuperait d'emblée, par nature, rendrait superflue

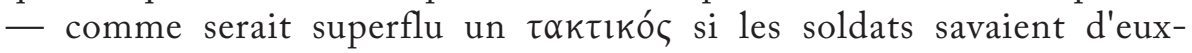

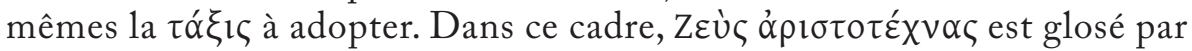

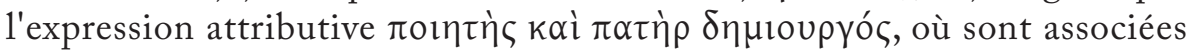
l'expression de Timée 28a ( et la "traduction" habituelle de l'épithète pindarique, $\delta \eta \mu$ ıoupүó $\varsigma$, dont l'objet devient ici problématique, voire inexistant ( $\tau$ ívos;). Ce qui est en jeu, élément essentiel et de la polémique avec les Stö̈ciens et de la

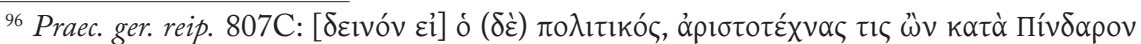

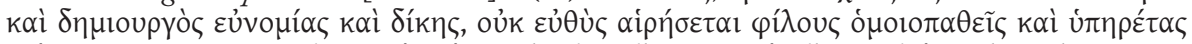

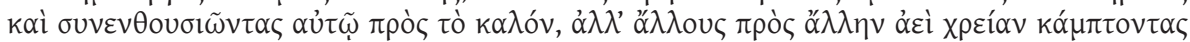

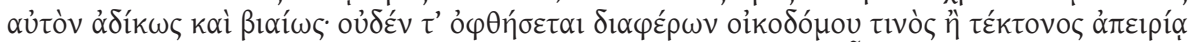

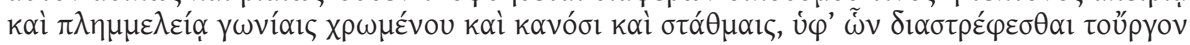

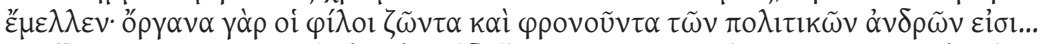

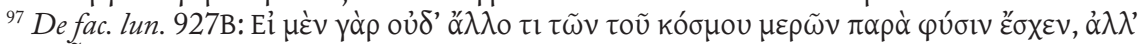

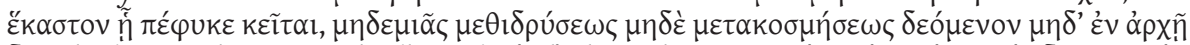

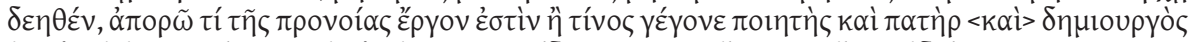

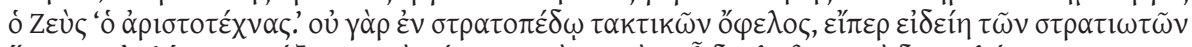

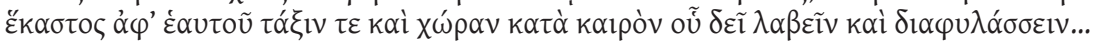

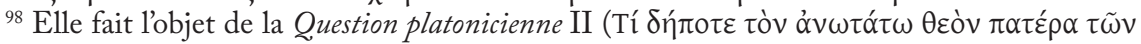

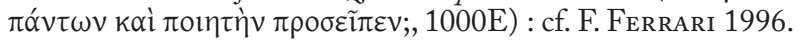




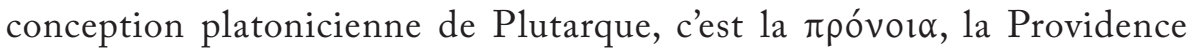
qui prévoit et pourvoit à l'ordre du monde.

C'est elle qui sous-tend aussi les emplois de la citation dans les Notions communes $^{99}$ et les Délais ${ }^{100}$, passages que L. Van der Stockt définissait, de façon large, comme "éthiques" et que l'on peut préciser, je crois, au terme de cette étude, comme relevant de la théodicée. Le traité antistoïcien ${ }^{101}$ critique la comparaison établie par Chrysippe entre les épigrammes ${ }^{102}$ de peu de qualité, mais qui contribuent à la fin de la comédie - susciter le rire - et le rôle

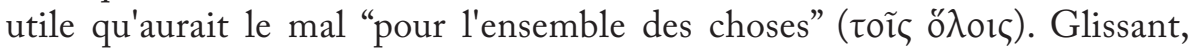
dans sa discussion, de "l'œuvre" à l'auteur, Plutarque fait donc intervenir

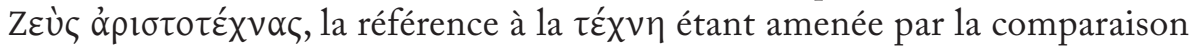
avec l'art du poète, et il glose cette fois l'épithète par le participe $\delta \eta \mu 10 u p \gamma \tilde{\omega} v$

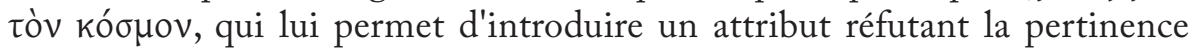

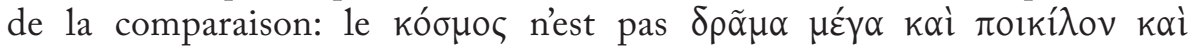

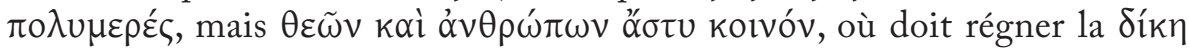

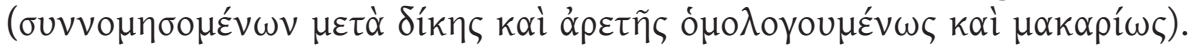
S'expliquent ainsi a posteriori les épithètes attribuées à Zeus et, pour ainsi dire,

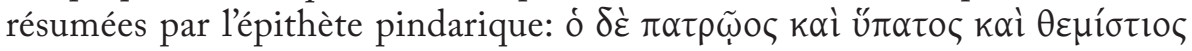

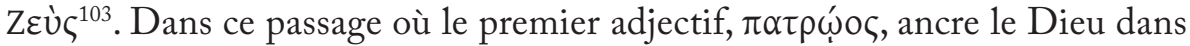

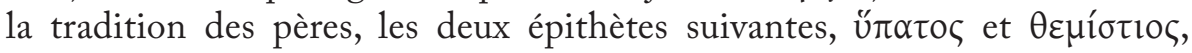

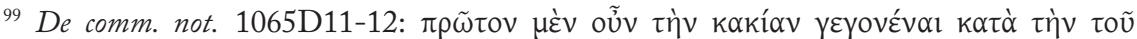

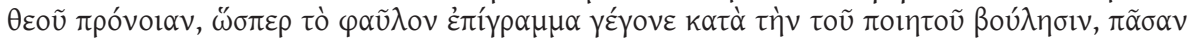

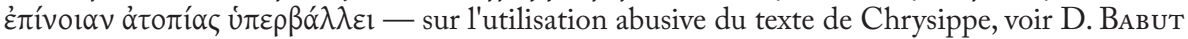
2002: 175, n. 191.

${ }^{100}$ De sera num. vind. 3, 549B9, où, d'emblée, Olympichos souligne les conséquences

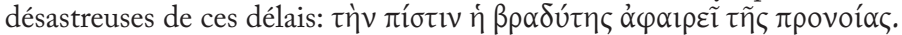

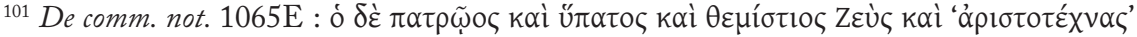

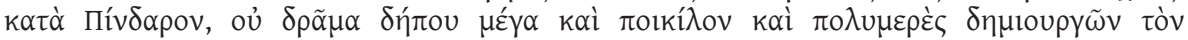

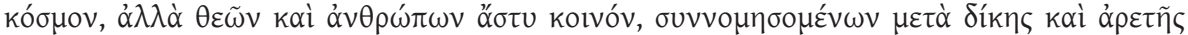

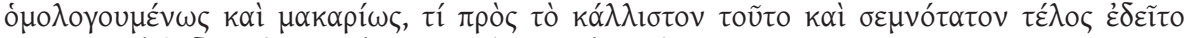

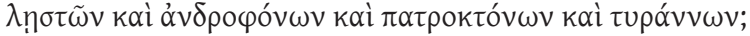

${ }^{102}$ Sur les difficultés d'interprétation que suscite le terme (sans incidence pour le thème ici traité), voir D. BAвut 2002: 174, n. 188.

${ }^{103}$ De nouveau, l'examen général des occurrences permet de préciser les choses et de revenir sur l'assertion de D. BABUt 2002: 175-176, n. 197 — qui, dans un domaine qui n'est pas le sien, ne fait qu'entériner les reconstructions de Pindare tentées par les spécialistes de poésie lyrique à partir des citations de Plutarque et écrit: "Quant aux autres épithètes [scil. que l'épithète pindarique] de Zeus retenues ici, leur choix est déterminé par le contexte du poème perdu de Pindare, comme cela ressort des des textes de P. ... où figure également la citation". Rapprocher dans cet esprit le $\pi \alpha \tau \eta ́ \rho ~ d u ~ D e ~ f a c i e ~ d u ~ \pi \alpha \tau \rho \tilde{\omega} о \zeta$ qu'on trouve ici, en disloquant l'expression

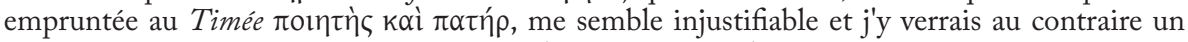
exemple indubitable de glose personnelle (et platonicienne) de Plutarque, à partir duquel on peut proposer l'hypothèse, confirmée, je crois, par cette étude, qu'il donne dans tous les cas une glose personnelle adaptée à chaque contexte - d'où il appert que ma propre note au De sera $(\mathrm{F}$. FrAZIER 2008b: 12, n. 29) mériterait aussi d'être révisée et précisée. 
dessinent la figure d'une divinité suprême garante de la justice, démiurge d'un monde où coexistent dans la justice et la vertu hommes et dieux. Ces derniers disparaissent des Délais ${ }^{104}$, où la lumière se focalise sur la justice qui doit régner dans les âmes comme dans le monde. Pindare est invoqué en préambule comme un des nombreux garants de la définition (platonicienne) de la justice comme "médecine de l'âme": sa qualité de technè suprême amène la référence à Zzù $\alpha_{\alpha} \rho 1 \sigma \tau o \tau \varepsilon ́ \chi v \alpha \varsigma$ et l'adjectif est cette fois glosé par

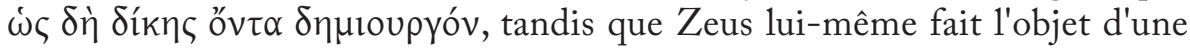
périphrase qui rappelle sa toute-puissance de dieu provident ( $\tau$ òv ö $\rho \chi 0 v \tau \alpha$

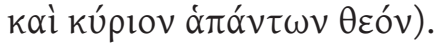

Enfin la dernière citation, tirée des Propos de Table ${ }^{105}$, suivant la "déclinaison" que nous a déjà fait suivre l'examen du paradigme cosmologique, nous ramène au banquet, où l'ordre et l'harmonie dépassent la simple question "d'étiquette" et reflètent la vision grecque du monde et son exigence d'ordre: dans ce

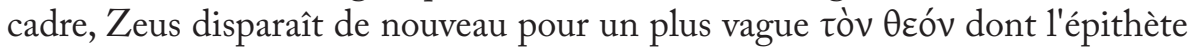

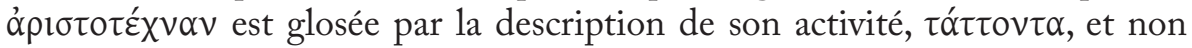
par l'objet de sa "démiurgie" - il s'agit bien cependant, à un autre niveau, de savoir comme dans le De facie quelle est la place appropriée où ranger chaque élément ou chaque convive. C'est sur ce modèle que le symposiarque est invité à montrer les qualités "d'un homme ayant le sens de l'ordre et de l'harmonie"

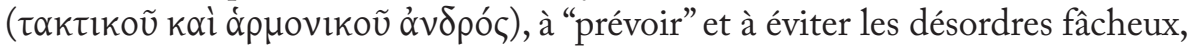
au nom d'un principe partout prévalent et qui pourra nous servir de conclusion:

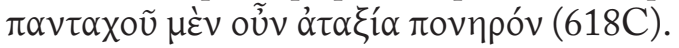

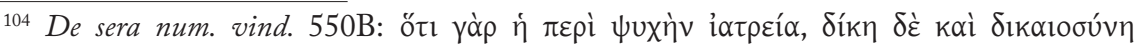

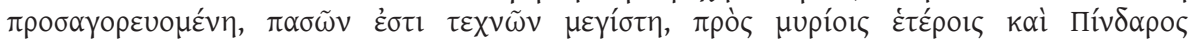

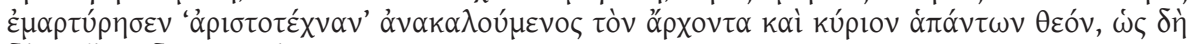

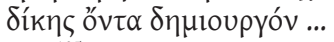

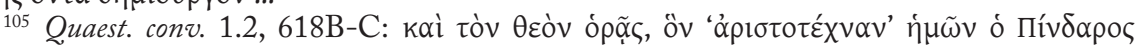

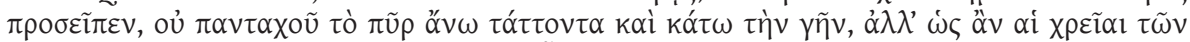

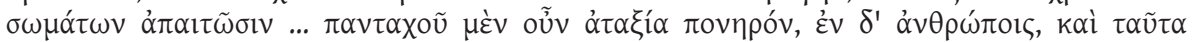

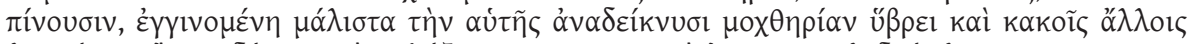

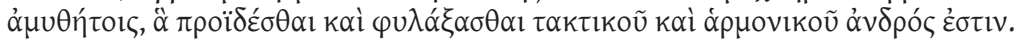




\section{Bibliographie}

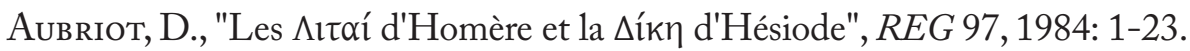

Babut, D. ; Casevitz, M., Plutaroue. Traités antistoïciens, CUF t. XV-1 et 2, Paris, 2004 et 2002.

Barigazzi, A., "Note critiche ed esegetiche agli scritti politici di Plutarco II", Prometheus 8, 1982: 61-79 (= Studi su Plutarco, Firenze, 1994: 263-286).

Bonnafé, A., Eros et Eris. Mariages divins et mythe de succession chez Hésiode, Lyon, 1985.

CAsevitz, M., "À la recherche du Kosmos. Là tout n'est qu'ordre et beauté", Le temps de la réflexion 10, 1989: 97-119.

Delatte, L., Les traités de la royauté d'Ekphante, Diotogène et Sthénidas, Paris, 1942.

Ferrari, F., "Dio: padre e artefice. La thelogia di Plutarco in Plat. Quaest. 2", in I. Gallo (cur.), Plutarco e la religione, Napoli, 1996: 395-409.

Festugière, A.-J., "Les inscriptions d'Asoka et l'idéal du roi hellénistique", in Études de Religion Grecque et Hellénistique, Paris, 1972: 210-225.

Frazier, F., Histoire et Morale dans les Vies Parallèles de Plutarque, Paris, 1996.

Frazier, F., "Les visages de Joseph dans le De Josepho", The Studia Philonica Annual 14, 2002: 1-30.

Frazier, F., "Göttlichkeit und Glaube. Persönliche Gottesbeziehung im Spätwerk Plutarchs", in R. Hirsch-Luipold (hsg), Gott und die Götter bei Plutarch. Götterbilder-Gottesbilder - Weltbilder, Berlin, New York, 2005: 111-137.

Frazier, F., "Philosophie et religion dans la pensée de Plutarque. Quelques

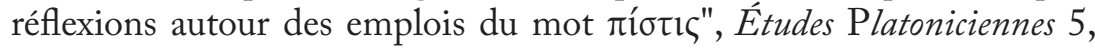
2008: 41-61 (= 2008a).

Frazier, F., Plutarque, Érotikos, Classiques en poche n 85, Paris, 2008 (= 2008b).

Frazier, F., "Le De sera, dialogue pythique. Hasard et Providence, Philosophie et religion dans la pensée de Plutarque", in F. Frazier ; D. Leão (edd.), Tychè et Pronoia, La marche du monde selon Plutarque, Coimbra, 2010: 69-89.

LÉvy, E., Athènes devant la défaite de 404. Histoire d'une crise idéologique, BEFAR 225, Paris, 1976.

LÉvy, E., "Dikè chez Homère: entre privé et public", Ktèma 23, 1998: 71-79. 
Lloyd-Jones, H., The Justice of Zeus, California, ${ }^{2} 1983$.

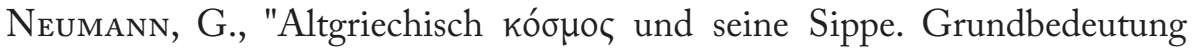
und Etymologie", in Verba et Structurae. Festschrift für Klaus Strunk, Innsbruck, 1995: 203-210.

Opsomer, J. "Plutarch's De animae procreatione in Timeo: Manipulation or Search for consistency?", in P. Adamson et alii (edd.), Philosophy, Science and Exegesis in Greek, Arabic and Latin Commentaries, coll. BICS. Suppl. 83, 1, London, 2004: 137-162.

Opsomer, J., "Plutarch on the One and the Dyad", in R. Sorabji et R. W. Sharples (edd.), Greek and Roman Philosophy 100 BC-200 AD, vol. II, coll. BICS Suppl. 84, London, 2007: 379-396.

DE Romilly, J., La loi dans la pensée grecque, Paris, 1971.

Rosкam, G., A commentary to Plutarch's De latenter vivendo, Leuven, 2007.

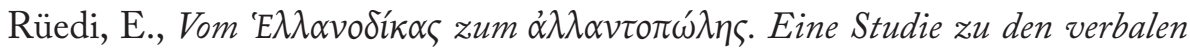
Rektionskomposita auf- $\alpha \varsigma /-\eta \varsigma$, Zürich, 1969.

Schmitt-Pantel, P., La cité au banquet. Histoire des repas publics dans les cités grecques, Rome, 1992.

Teodorsson, S.-T. , A Commentary on Plutarch's Table Talks, 3. vol., Göteborg, 1989-1996.

A. Tirelli, Plutarco. Ad un governante incolto, $C P M \mathrm{n}^{\circ}$ 41, Napoli, 2005.

A. Tirelli, "Dal nomos empsychos al logos empsychos: potere e responsabilità nel pensiero politico di Plutarco", in P. Volpe Cacciatore e F. Ferrari (cur.), Plutarco e la cultura della sua età, Napoli, 2007: 311-336.

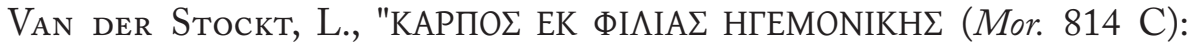
Plutarch's observations on the 'old-boy Network', in P. A. Stadter and L. Van der Stockt (edd.), Sage and Emperor, Leuven, 2002: 115-140.

Vernant, J.-P.; Detienne, M., Les ruses de l'intelligence. La mètis des Grecs, Paris, 1978.

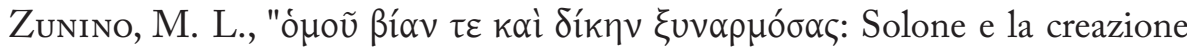
della giustizia", Klio 86, 2004: 5-15. 


\title{
Jueces, premios y castigos en el Más Allá de Plutarco ${ }^{1}$
}

\author{
Ana Isabel Jiménez San Cristóbal \\ Universidad Complutense de Madrid
}

\begin{abstract}
Plutarch mentions in his writings the existence of three judges, Minos, Rhadamanthys, and Aeacus. They judge people in Hades and decide whether they must be condemned in Tartarus or can live happily on the Isles of the Blessed. Rewards and punishments depend on the moral behaviour of the souls during their lives. The aim of my work is to analyze the background against which Plutarch elaborates his idea of justice in the Netherworld. He suits and reworks traditional motifs but also leaves a personal mark on his netherworldly imagery.
\end{abstract}

\section{La existencia post mortem}

Plutarco aborda en diversas obras la cuestión de la inmortalidad del alma y las posibles formas de existencia post mortem ${ }^{2}$. En el Escrito de consolación a Apolonio trata de confortar a su amigo por la pérdida de su hijo recurriendo a un relato atribuido a "los antiguos poetas y filósofos" (120B), según el cual, los muertos que han sido piadosos disfrutarán de cierto honor y privilegio y sus almas habitarán un lugar apartado. Plutarco cita entonces unos versos de Píndaro (120C-E, cit. Pi. fr. 129 Maehler [= 58 Cannatà Fera], portavoz de los poetas, para ilustrar las delicias de ese lugar. A continuación, en representación de los filósofos, reproduce literalmente un extenso pasaje del Gorgias platónico en que se expone cómo la conducta de los hombres en vida condiciona el destino de las almas tras la muerte (120E-121D, cf. Pl. Grg. 523a-524a).

Para desarrollar su concepto de vida tras la muerte Plutarco se inspira efectivamente en la escatología platónica ${ }^{3}$, pero dispone además de un amplio

${ }^{1}$ Este trabajo forma parte del Proyecto de Investigación "Cosmogonía y escatología en la antigua Grecia. Influjos y paralelos con el Próximo Oriente”, financiado por el MEC (FFI 201017047). Agradezco a Rosa Aguilar, A. Bernabé, F. Frazier y A. Pérez Jiménez sus sugerencias, indicaciones bibliográficas y correcciones.

${ }^{2}$ Aquí nos centraremos en Plu. Cons. ad Apoll.120E-121D, De sera num. vind. 563B-568A, De gen. Socr. 589F-592E, De fac. lun. 940F-945D; fr. 178 Sandbach; Comp. Cimon. et Luc. 1.2. Véanse además: Plu. Cons. ad Apoll.107D-110E, De sera num. vind. 560A-F; Cons. ad ux. 611D y ss.; De fac. lun. 942D, Non posse suav. 1104A-1107A; Rom. 28; fr. 177 Sandbach. Sobre este particular, véanse R. Aguilar 1981; I. P. Culianu 1983: 43-47; F. E. Brenk 1986: 2117-2130; F. E. Brenk 1987: 275-294; A. Pérez Jiménez 1993: 108-114; F. E. Brenk 1994; J. Boulogne 1994; G. Roskam 1999: 468-474; J. Boulogne 2008; F. Frazier 2010.

${ }^{3}$ Para la influencia platónica, véase R. M. Jones 1916: 48-56, 58-60, 69ss; W. Hamilton 1934; W. Hamilton 1934a; G. Soury 1942: 7, 73-82, 177-210; Y. Vernière 1977: 95101, 119-121, 124-129; R. Aguilar 1981: 13-22; F. E. Brenk 1987: 262-275; P. Donini 
repertorio de catábasis y viajes celestes que abordan la existencia ultramundana desde una perspectiva literaria, filosófica y religiosa ${ }^{4}$. El propósito de este trabajo es pasar revista a los antecedentes sobre los que Plutarco elabora su concepto de justicia en el Más Allá, adaptando y reelaborando relatos y motivos tradicionales, pero sin renunciar a sus propias convicciones e ideas y dejando su impronta personal en la manufactura de la imaginería ultramundana.

\section{Los jueces del Hades}

En el pasaje del Gorgias citado por Plutarco (Cons. ad Apoll.121C-121D, cf. P1. Grg. 523e-524a [Orph. Fr. 460]) se menciona la presencia en el Hades de tres jueces, Minos, Éaco y Radamantis, nombrados por Zeus. Son los encargados de juzgar a los hombres y decidir si han de ser condenados en el Tártaro o habitar felices en la Isla de los Bienaventurados ${ }^{5}$, según haya sido su conducta moral. Radamantis juzga a los de Asia, Éaco, a los de Europa y Minos dicta sentencia definitiva en caso de duda. Plutarco destaca en varios de sus escritos las virtudes éticas que los tres tuvieron en vida y que les capacitan para ejercer como jueces en el Hades ${ }^{6}$. Éaco sobresalió como buen padre y sobre todo fue piadoso hasta el extremo de recibir culto tras su muerte (Plu. Par. min. 311E, 312B; Thes. 10.3; Dem. 28.4, 5). Radamantis descolló como juez y guardián de las normas fijadas por su hermano Minos (Thes. 16.4, cf. Od.19.179), de quien, a su vez, se elogia su condición de rey, legislador y especialmente discípulo de Zeus (e.g. Max. cum. princ. 776E, De sera num. vind. 550B) ${ }^{7}$.

La elección por parte de Plutarco del pasaje del Gorgias no parece casual ${ }^{8}$. Los jueces infernales no están atestiguados en la literatura griega de los siglos V-III a. C., salvo en una breve mención de Píndaro (O. 2.58-60 [Orph. Fr. 445]) y en varios pasajes platónicos ( $R$. 614b [OF 461], Grg. 523e-524a [Orph. $F r .460])^{9}$. Píndaro hace una vaga referencia al juicio de las almas, menciona a

1988: 128-129, 142-143; A. Pérez Jiménez 1993: 113, n. 31; F. E. Brenk 1994: 9-21; M. A. Durán López 1994; J. Boulogne 1999; A. Pérez Jiménez 2001: 201-203; F. Frazier 2010. Sobre los premios y castigos en la escatología platónica, cf. A. BERnABÉ 2011: 155188.

${ }^{4}$ Véanse especialmente Y. Vernière 1977: 153-194, 284-294; A. BernabÉ 1996, 78-79; M. A. Santamaría Álvarez 2007.

${ }^{5}$ Sobre la presencia de este concepto en Platón y Plutarco, véase M. Martínez 1999: 98-106.

${ }^{6} \mathrm{La}$ función legisladora de Minos y Radamantis ha sido estudiada por K. J. HöLKeskamp 1999: 44-59; sobre su presencia y papel en el Hades, véase C. Sourvinou-Inwood 1999: 32-34, 54-55, 87-88; E. Coelho 2007.

${ }^{7}$ Otras menciones relativas a las actuaciones, crueldad y benevolencia de Minos pueden verse en Thes. 15.1, 19.5-10, 25.3; Aet. Rom. et Gr. 299A; De tuend. san.132E.

${ }^{8}$ Las causas han sido bien estudiadas por M. A. Durán López 1994, quien muestra cómo Plutarco utiliza un mito protréptico como elemento consolatorio.

${ }^{9}$ En la Apología de Sócrates (Apol. 41a, Orph. Fr. 1076 I), se menciona a Minos, Radamantis y Éaco, pero no se especifica si juzgan las almas de los muertos, o simplemente dirimen pleitos 
los jueces, pero no los nombra y, sobre todo, centra su atención en las almas de los no piadosos ${ }^{10}$, cuestión que se aleja notablemente del propósito de Plutarco. Por su parte, Platón en el mito de Er narrado en la República (614cd) menciona la presencia de jueces infernales, pero sin ahondar demasiado en sus atribuciones y sin dar sus nombres ${ }^{11}$. En qué consiste el juicio de las almas lo detalla un pasaje del Axioco $(371 c)^{12}$, un diálogo cuya autencidad es cuestionada $^{13}$, pero que en cualquier caso presenta una visión escatológica inspirada en descripciones del Más Allá platónico. En el Axíoco sí se nombran los jueces, pero no se distinguen sus funciones. Cabe pensar que Plutarco ha elegido el pasaje del Gorgias por ser uno de los más detallados que conoce y por la innovación que representa el sistema de juicios allí descrito. Según Platón, el procedimiento actual deriva del propio Zeus y trata de solventar el sistema vigente en tiempos de Crono, cuando el juicio se realizaba el mismo día en que moría la persona a quien se juzgaba y los jueces eran también hombres vivos. Zeus nombra ahora a sus propios hijos, que son mortales, y a diferencia de los jueces terrenales, los infernales juzgan desnudos, desprovistos de intereses materiales e inmunes a todo tipo de corrupción ${ }^{14}$. Del mismo modo deben estar desnudas y desprovistas de riqueza las almas a quienes se juzga para garantizar la objetividad de los jueces (Grg. 523 b-e, apud Plu. Cons. ad Apoll.121A-C) $)^{15}$.

Por otra parte, hemos visto que Plutarco atribuye este ideario a un "relato de antiguos poetas y filósofos”, entre los que se encuentran Píndaro y Platón, pero el recurso a esta fórmula tradicional puede implicar otras fuentes. Platón emplea expresiones semejantes para referirse a doctrinas atribuidas a Orfeo y Museo, que el filósofo adapta y transforma sabiamente hasta hacerlas suyas ${ }^{16}$. En los testimonios órficos más antiguos no se menciona el juicio en el Más Allá ${ }^{17}$, pero en su tránsito ultramundano el iniciado ha de superar una serie de

entre ellos, función que tiene ya Minos en Homero (Od. 11.568-571), cf. C. SourvinouInwOod 1999: 87-88; A. BERNABÉ 2011: 159-163.

${ }^{10}$ M. A. Santamaría Álvarez 2003: 265-271.

${ }^{11}$ Sobre el mito de $\operatorname{Er}(\mathrm{Pl}$. R. 614b-621b) y la escatología de la República, cf. especialmente H. Richardson 1926 y A. Bernabé 2011: 172-178 con bibliografía.

${ }^{12}$ Cf. Y. Vernitère 1977: 291-292. Sobre la escatología de este diálogo, véase A. Bernabé 2011: 178-188, con bibliografía. Platón menciona también el juicio de las almas en la Carta Séptima (P1. Ep. 7, 335a; Orph. Fr. 433 I) y en las Leyes (P1. Lg. 959b), pero sin detallar en qué consiste.

${ }^{13}$ Cf. el estado de cuestión de P. Gómez Cardó 1992.

${ }^{14}$ Sobre el mito del Gorgias, véanse E. R. Dodds 1959: 372-379; L. Bescond 1986; J. Dalfen 2002: 223-225; D. Sedley 2009; A. Bernabé 2011: 157-163.

${ }^{15}$ Cf. M. A. Durán López 1994: 647. Sobre la idea de la desnudez de las almas en Plutarco, cf. G. Soury 1942: 215-216.

${ }^{16}$ Cf. A. Bernabé 1998: 39-57, 91-93; A. Bernabé; A. I. Jiménez San Cristóbal 2008: 53-55; A. Bernabé 2011: 7-15.

${ }^{17}$ Pero se trata de una creencia asociada al orfismo y pitagorismo desde antiguo. Platón (Ep. 7, 335a, [Orph. Fr. 433 I]) menciona ciertos escritos antiguos y sagrados, probablemente atribuidos a Orfeo y Museo, que ilustran sobre el juicio post mortem. Con Pitágoras y su secta lo 
pruebas, como beber de la fuente apropiada o no equivocarse de camino, y debe demostrar además a unos guardianes, a Perséfone y a otras divinidades infernales que ha cumplido con sus obligaciones rituales y merece, en consecuencia, un destino dichoso ${ }^{18}$. Plutarco, por su condición de homo religiosus, conoce bien estas doctrinas y su literatura y es consciente de que la escatología platónica es deudora en ocasiones de la órfica ${ }^{19}$. Así, en el Gorgias la idea de los dos caminos recuerda la encrucijada con dos fuentes, a la derecha y a la izquierda, que aparecen descritas en las laminillas órficas desde finales del s. V a. C. ${ }^{20}$ Plutarco sigue la doctrina platónica, como él mismo indica con el vocablo 'filósofos', pero con el recurso a la fórmula tradicional de los 'antiguos poetas' parece sugerir que el propio Platón debe mucho a su vez a otras doctrinas. En el fondo, lo que hace Plutarco es apoyar el prestigio de la cita platónica con el prestigio de la poesía antigua y revelada.

El pasaje de la Consolatio es el único en que Plutarco cita juntos a los tres jueces del Hades, si bien otras veces se refiere a ellos de forma individual. En la biografía de Catón el Mayor (23.2) hay una alusión implícita al juicio de las almas que encabeza Minos. El texto es poco relevante, pero muestra una visión escatológica en que cada cual retoma la función que tenía durante su existencia terrenal: Minos fue juez en vida y lo sigue siendo en el Hades; del mismo modo, Isócrates y sus discípulos, oradores y logógrafos, ejercerán como tales a su muerte. En otro pasaje (fr. 201.6 Sandbach) Plutarco recurre a Homero para mostrar que Radamantis habita la llanura Elisia y los confines de la tierra donde moran los enviados por los dioses ${ }^{21}$. En principio, la mención de Radamantis es puramente poética, por su relación con la Elisea ${ }^{22}$, y no se habla del juicio de las almas, sino más bien del lugar reservado a quienes han vivido piadosamente. El propio Plutarco añade en su comentario que la llanura Elisia es el nombre que se da a la superficie de la luna. Sabemos por el mito de Sila narrado en el Sobre la cara que aparece en el orbe de la luna (942D) que para Plutarco la luna se identifica con la morada de Perséfone y es el lugar al que llegan los espíritus nobles tras una primera muerte y en el que se disuelven tras la desunión de alma e intelecto que supone la segunda muerte ${ }^{23}$.

En el Sobre la imposibilidad de vivir placenteramente según Epicuro

relacionan Arist. EN 1132b 21ss. y Iamb. VP 86, 155, 179; DK 58c 3, ap. D. L. 8.35, cf. M. A. Santamaría Álvarez 2003: 268.

${ }^{18}$ Cf. A. Bernabé; A. I. Jiménez San Cristóbal 2008: 171-174.

${ }^{19}$ Y. Vernière 1977: 154-157; A. Bernabé 1996.

${ }^{20}$ Orph. Fr. 474-484a, cf. A. Bernabé; A. I. Jiménez SAn Cristóbal 2008: $19-52$.

${ }^{21}$ Cf. Od. 4.563, pasaje que se cita también en De fac. lun. 942F, 944C.

${ }^{22}$ Cf. C. Sourvinou-Inwood 1999: 32-34.

${ }^{23}$ Sobre la segunda muerte, véase infra, n. 50 . 
(1104A-1107A), Plutarco ataque la doctrina epicúrea sobre la muerte y aboga por la concepción platónica de que la conducta moral en vida determina la existencia ultraterrena ${ }^{24}$. El miedo a los juicios y castigos del Hades, dice Plutarco, contiene en cierta medida a los que son injustos y malvados. En cambio, prosigue más adelante $(1104 \mathrm{~B}, 1104 \mathrm{D})$, poco efecto tiene la figura de Éaco para la mayoría descreída, que no cree en los terrores del Hades.

El veredicto de Minos, Radamantis y Éaco determina si las almas han de tomar el camino que lleva a la Isla de los Bienaventurados, donde gozarán de premios o, por el contrario, el que conduce al Tártaro en que yacerán sometidas a suplicios. A estos caminos se suman el de la reencarnación, que significa una vuelta al mundo actual, y el camino que conduce al mundo superior, al que se llega por el trance de la segunda muerte expuesta en el De facie ${ }^{25}$. Aquí vamos a centrarnos en los premios y castigos que aguardan al alma en el Hades, sin abordar los aspectos de la reencarnación o las consecuencias de la segunda muerte. Al igual que Platón, Plutarco recurre al mito para exponer las retribuciones y suplicios del alma en tres de sus diálogos. En el De la tardanza de la divinidad en castigar, introduce el mito de Tespesio; en el De facie, el de Sila, y en el Sobre el demón de Sócrates, el de Timarco ${ }^{26}$.

\section{Divindades vengadoras y castigos en el Más Allá}

La suerte de las almas condenadas se expone principalmente en el De Sera (563B-568A) al hilo del mito de Tespesio ${ }^{27}$. En su experiencia ultramundana, inspirada sobre todo en el mito de Er platónico y localizada en el cielo ${ }^{28}$, Tespesio contempla distintos tipos de almas: unas puras y brillantes que

${ }^{24}$ Cf. H. Adam 1974: 67-70; F. Albini 1993: 24ss; G. Roskam 1998: 470-472.

${ }^{25}$ Sobre los caminos en la escatología de Plutarco, véase M. A. Durán López 2001.

${ }^{26}$ Estudios de conjunto de los tres mitos pueden verse en G. Soury 1942; F. E. Brenk 1977; Y. Vernière 1977; R. Aguilar 1981; F. E. Brenk 1994; R. Aguilar 1996a. La bibliografía más relevante de cada uno está citada en las notas 27, 37 y 49.

${ }_{27}$ Sobre este mito, véanse G. Soury 1942: 211-227; J. Hani 1975: 111-115; Y. Vernière 1977: 108-112, 201-203; R. Aguilar 1981: 1-26; Y. Vernière 1986: 340-352; R. Aguilar 1993: 20-23; M. A. Durán López 1999; H. G. Ingen kamp 2001: 134; A. Pérez Jiménez 2001; I. Gallo 2003-2004: 202-204; M. A. Santamaría Álvarez 2007; F. Frazier 2010; M. TAufER 2010.

${ }^{28}$ Sobre la inspiración platónica, véanse Y. Vernière 1977: 288; F. E. Brenk 1977: 136139; M. A. Durán López 1999: 215-217; M. Taufer 1999; J. Sirinelli 2000: 406-410; C. Wiener 2004; F. Frazier 2010. Y. Vernière 1977: 285-293 y M. A. Santamaría Álvarez 2007: 879-886 señalan paralelismos y motivos coincidentes entre la aventura de Tespesio y las nekyiai de la Odisea (Od. 11 y 24) y la del cínico Menipo (D. L. 6.101), la catábasis de Dioniso en las Ranas de Aristófanes, los relatos de viaje al Hades atribuidos a Heráclides Póntico y Clearco de Solos, e incluso la catábasis de Eneas (Verg. Aen. 6). Sobre los ecos dionisíacos en la descripción de Tespesio, véanse Y. Vernière 1964; Y. Vernière 1986: 351; F. E. Brenk 1987: 287-288 y M. A. Durán López 1999: 211-214, 218-219; para los motivos de inspiración órfica, cf. A. Bernabé 1996: 78-79; M. A. Santamaría Álvarez 2007: 879-881. 
ascienden derechas, y que deben ser las almas justas, y otras, probablemente las condenadas, marcadas por manchas o llagas, que giran en círculo inclinándose hacia arriba y hacia abajo y lanzando gritos inarticulados (564A-E). Las almas injustas han de rendir cuentas ante unas divinidades vengadoras y someterse a castigos para purificarse de las faltas cometidas en vida que probablemente atentaban contra la ética o la justicia vigentes $(564 \mathrm{E}-565 \mathrm{~B})^{29}$.

Adrastea, hija de Ananke y Zeus, es la vengadora suprema de todas las injusticias. Le auxilian en su labor, Poine, Dike y Erinis. La primera se ocupa de quienes han sido castigados en vida con penas que sólo atañen al cuerpo pero no corrigen al alma. Dike recibe a quienes no fueron castigados ni purificados en vida por delitos de gran envergadura, hace visibles sus culpas a todos y les obliga a purificarse liberándose de sus pasiones con dolores y sufrimientos intensos. A medida que se van purificando las almas van desapareciendo las manchas, llagas y cicatrices, secuela de sus pasiones ${ }^{30}$. Algunas almas, sin embargo, no logran purificarse y se ven abocadas a un nuevo nacimiento. Por último, Erinis, la colaboradora más severa de Adrastea, persigue a quienes son absolutamente incurables y los aprisiona en un lugar indecible e invisible. Plutarco retoma una serie de divinidades que vengan los crímenes de sangre, bien atestiguadas desde época clásica, especialmente en los trágicos ${ }^{31}$. La novedad principal es que las presenta como un conjunto, a cuya cabeza está Adrastea, y delimita su esfera de actuación al mundo de los muertos ${ }^{32}$. La clasificación de las almas del $D e$ Sera guarda importantes reminiscencias del Fedón platónico $(113 \mathrm{~d}-114 \mathrm{~b})^{33}$, en que se distingue entre quienes han vivido moderadamente y han de purificarse hasta que son absueltos, aquellos que son irremediables y se ven arrojados para siempre al Tártaro por la magnitud de sus crímenes, quienes han cometido delitos graves pero curables y, finamente, quienes vivieron de forma piadosa $y$ habitarán una morada pura.

Tespesio avanza en su camino y ve la sima de Lete, una gruta similar a los antros báquicos, por la que Dioniso condujo arriba a Sémele, y en la que las almas se humedecen y emborrachan para olvidar antes de reencarnarse

${ }^{29}$ Véase F. Frazier 2010: 155-156.

${ }^{30}$ Sobre el simbolismo de los colores asociados a los diferentes tipos de almas, cf. G. Soury 1942: 217-220; Y. Vernière 1977: 147; I. P. Culianu 1983: 46-47; J. Boulogne 1994: $223-$ 224, 227-229, 233 y n. 97; F. Frazier 2010: 154-155.

${ }^{31}$ Poine y Dike aparecen en A. Ch. 947; Dike y Erinis, en A. Eu. 510, Ag. 1432; S. Ai.1390, Tr. 808; E. Med. 1389; PDerveni col. IV 9; y Dike es invocada en S. Ant. 451. Por su parte, Adrastea castiga la soberbia en A. Pr. 936 y P1. R. 451a.

32 Sobre su función, véanse G. Soury 1942: 214-215; Y. Vernière 1977: 234-241; R. Aguilar 1986: 6-7 y n. 10; R. Aguilar 1996: 159 y n. 132; R. Aguilar 1996a: 286-288.

${ }^{33}$ Cf. F. Frazier 2007: 195-196; F. Frazier 2010: 152-153. Sobre la escatología del Fedón, cf. A. Bernabé 2011: 163-172. Categorías similares de condenados pueden verse en P1. Grg. $525 \mathrm{c}, 526 \mathrm{~b}$, R. 615a-b. 
(566A-B) $)^{34}$.Tespesio pasa también por la sima de los tres démones y el oráculo ${ }^{35}$ antes de volver al lugar los castigos (566E-567D). Contempla los suplicios de cuantos vivieron disimulando su maldad y con fama de virtuosos en vida. E1 espectáculo de tormentos es ahora más atroz y duro si cabe. Los condenados han de sacar fuera el interior del alma y se contorsionan y retuercen de forma anormal. Para purificar las almas unos démones las sumergen sucesivamente en tres lagunas cercanas, una de oro hirviendo, otra helada de plomo y la última áspera y dura de hierro $(567 \mathrm{C}-\mathrm{D})$. Las almas allí sumergidas van cambiando de color, aspecto y consistencia hasta que recobran su luminosidad original (565C). A continuación, las que van a reencarnarse en animales son golpeadas por artesanos que las adaptan a sus nuevas formas $(567 \mathrm{~F})$. Los procedimientos empleados para regenerar las almas recuerdan a los que usa la alquimia para transformar los metales viles en nobles. La imagen, ausente en la escatología platónica, tal vez se inspire en escritos gnósticos que describen la creación del alma del mundo como una mezcla de tipo alquímico ${ }^{36}$.

Encontramos nuevas referencias a los castigos en el mito de Timarco, narrado en el De genio $(589 \mathrm{~F}-592 \mathrm{E})^{37}$, si bien Plutarco se interesa aquí más por presentar una doctrina sobre la naturaleza del alma que por los aspectos escatológicos. El protagonista contempla una sima de la que escapan aullidos, llantos y gemidos innumerables de personas y animales. El lugar ha sido interpretado, no sin controversia, como el mundo inferior en que residen las almas que van a reencarnarse $(590 \mathrm{~F})^{38}$. Un poco más adelante se habla del Hades como lugar de castigo que arrebata las almas mancilladas e impuras que deben nacer de nuevo (591C) $)^{39}$. En cambio, las almas que ya han cumplido su ciclo de nacimientos son acogidas por la luna. Sus concavidades son lugar de purificación y castigo de las culpas y puertas por las que las almas circulan de la luna al cielo o bien hacia la tierra. El propio movimiento de las almas revela cuál es su condición: se mueven de forma recta y ordenada las almas

${ }^{34}$ Cf. G. Soury 1942: 217 y n. 1; Y. Vernière 1964; Y. Vernière 1977: 185-188, 221; R. Aguilar 1981: 7-11; Y. Vernière 1986: 351; F. E. Brenk 1987: 287-288; A. Pérez Jiménez 1993: 114; R. Aguilar 1996a: 288-289; M. A. Durán López 1999; A. Pérez Jiménez 2001: 204-206; R. Aguilar 2010: 9-10.

35 Y. Vernière 1977: 188-190; R. Aguilar 1981: 11; R. Aguilar 1996a: 289-290; M. A. Durán López 1999: 214-215; A. Pérez Jiménez 2001: 206-208.

${ }^{36}$ Cf. J. Boulogne 1994: 218, 227-234; J. Boulogne 2008: 60-61. Agradezco a A. Pérez Jiménez la sugerencia de la posible relación con la alquimia, así como las referencias bibliográficas.

37 Sobre el mito, cf. W. Hamilton 1934a; G. Soury 1942: 153-175; G. MÉautis 1950; Y. Vernière 1977: 105-108; J. Hani 1975; R. Aguilar 1981: 27-44; Y. Vernière 1986: 340-352; R. Aguilar 1993: 23-24; R. Aguilar 1996a: 292-293; I. Gallo 2003-2004: 200-202.

${ }^{38}$ Como el Tártaro lo ven F. Cumont 1966: 136, n. 3; Y. Vernière 1977: 182-183. Con la tierra lo identifican R. M. Jones 1916: 57; G. MÉautis 1950: 208; véase R. Aguilar 1981: 35 y R. Aguilar 2010: 7-8, con bibliografía.

${ }^{39}$ Cf. R. Aguilar 1981: 36. 
que por crianza y educación tienen una parte irracional no demasiado dura ni obstinada, mientras que se inclinan hacia arriba y hacia abajo las que tienen un carácter indómito (592A). Son evidentes los ecos del Fedro platónico (247b) en que la situación de las almas está ligada a su capacidad de controlar las pasiones en vida ${ }^{40}$.

En esa dicotomía entre lo racional y lo irracional incide también el $D e$ facie. Aquí todas las almas, racionales y pasionales, al morir están abocadas a errar durante cierto tiempo entre la tierra y la luna, pero su condición no es la misma ya que las injustas y disolutas pagan por sus ofensas, mientras que las buenas se purifican del miasma del cuerpo en un lugar llamado pradera del Hades del que luego partirán hacia la luna $(943 C)^{41}$. Desafortunadamente Plutarco no explicita cómo pagan las almas injustas esas ofensas. En todo caso, lo que determina una vez más la situación del alma es la capacidad de raciocinio que le ayuda a vencer las pasiones.

Hallamos también referencias a los castigos en un fragmento del tratado Sobre el alma (fr. 178 Sandbach) ${ }^{42}$. Al hilo de la comparación entre lo que experimentan los iniciados en el ritual y en el momento de morir ${ }^{43}$, Plutarco describe el panorama que acoge al alma a su muerte. El fiel tiene visiones sagradas y experimenta efectos físicos típicos del terror y la angustia provocados tal vez por la incertidumbre o, mejor, porque el alma contempla allí los "terrores del Hades" ${ }^{4}$. El panorama de los profanos resulta desolador: una multitud impura que se hunde en el barro, pisoteándose y empujándose unos a otros. En este ejemplo la idea de justicia está ligada al ideario religioso y a la práctica cultual: quienes se inician y participan en los misterios disfrutarán en el Hades de una existencia privilegiada, frente a los profanos que yacerán en el fango. No es relevante determinar si Plutarco se está refiriendo a los misterios de Eleusis, a los órficos o a los de Isis ${ }^{45}$, porque probablemente el imaginario es compartido por los misterios en general. Lo importante es que testimonia la supervivencia de una concepción de la justicia ligada a la iniciación y al cumplimiento de ritos, propia de cultos mistéricos como el orfismo, y de la que ya Platón ( $R$. 363cd, 364b, 364e, 366a; Phd. 69c, Grg. 493a-c) se hacía eco siglos atrás fundamentalmente para denunciarla ${ }^{46}$.

${ }^{40}$ Cf. R. Aguilar 1981: 40-41.

${ }^{41}$ Cf. G. Soury 1942: 185-186; Y. Vernière 1977: 190; A. Pérez Jiménez 2011.

${ }^{42}$ Cf. G. Soury 1942: 186-188; R. Aguilar 1981: 91-94; Y. Vernière 1986: 349-350; A. BERnABÉ 2001.

${ }^{43}$ Sobre el particular véanse Y. Vernière 1977: 196-197; F. Díez de Velasco 1997: 413422; A. Bernabé 2001: 10-21.

${ }^{44}$ Véase también PDerveni col. V 5ss; cf. A. Bernabé 2002.

${ }^{45}$ Véase A. Bernabé 2001: 11-12, con bibliografía sobre la discusión.

${ }^{46}$ Otros tormentos pueden verse en $\mathrm{P} 1$. Axioc. 371d. Sobre la concepción religiosa de la justicia, cf. H. G. Ingen kamp 2001; A. I. Jiménez San Cristóbal 2005; A. Bernabé 2011: 188-204. 
El análisis de los textos analizados muestra que las almas son condenadas por un comportamiento en vida que atenta contra la ética o la justicia (en el De sera), por su incapacidad para controlar las pasiones (en el De genio y en el De facie) o por causas estrictamente religiosas, a saber el hecho de no estar iniciado. Todos estos motivos se encuentran ya en la escatología platónica y en la de los cultos mistéricos, de los que Plutarco es, por tanto, deudor ${ }^{47}$. Si comparamos los castigos que Platón augura a los condenados con los de los escritos plutarqueos, observamos similitudes, pero también notables diferencias. En el Fedón y en la República los condenados yacen en el barro, el mismo castigo que cita Plutarco en el De anima ${ }^{48}$. En el Gorgias (493b) Platón describe que los insensatos y no iniciados son castigados a llevar agua en un cedazo a una tinaja agujereada, un castigo que Plutarco no menciona, pese a citar pasajes textuales del Gorgias en la Consolatio. Por último, en el Axioco (371d) los condenados son lamidos por fieras salvajes o quemados por las divinidades vengadoras, castigo comparable a las manchas o llagas que estigmatizan las almas condenadas en Plutarco. Da la impresión de que el de Queronea se aleja en ciertos aspectos del filósofo ateniense. Mientras en los escritos de Platón el alma se ve obligada a realizar actividades penosas, en los de Plutarco tiene una actitud más pasiva y sufre los tormentos "en carne propia”. Así es sumergida en lagunas, golpeada por artesanos y constreñida a moverse en círculo o retorcerse. En general, Plutarco prescinde de las detalladas descripciones platónicas de los terrores del Hades y opta por una imagen más abstracta y aséptica del castigo. Habla de sufrimientos intensos, gemidos o lamentos, pero rara vez explicita su causa o procedencia y evita en gran medida el lado cruel y violento. Parece que Plutarco prefiere no incidir demasiado en ciertos aspectos, bien porque los considera de sobra conocidos, bien porque piensa que los castigos son más simbólicos que reales.

\section{Los premios en el Hades}

Los premios que aguardan las almas de los buenos se exponen fundamentalmente en el De facie, en la narracción del mito de Sila $(940 \mathrm{~F}-945 \mathrm{D})^{49}$. Leemos allí que ningún individuo mezquino o impuro puede

${ }^{47}$ En el Fedón (69d), Platón dice que los iniciados son los filósofos y se desmarca de una visión "ritualista". En cambio, Plutarco, de acuerdo con lo que leemos en Cons. ux. 611D, valora las iniciaciones y participa activamente junto con su mujer en el culto, cf. Y. VERNière 1977: 220-225; Y. VERNIÈRE 1986: 336-339. Sobre la transposición de la imaginería tradicional, cf. Y. VERNIÈRE 1977: 178-194.

${ }^{48}$ Pl. Phd. 69c, R. 363c-d; véanse también Pl. Phd.113d-114b, R. 615a.

49 Sobre el mito, cf. W. Hamilton 1934; G. Soury 1942: 176-210; Y. Vernière 1977: 102-105; R. Aguilar 1981: 45-64; Y. Vernière 1986: 346-352; P. Donini 1988; A. Pérez 
subir al extremo límite de la tierra, el lugar donde los nobles llevan una vida apacible hasta la segunda muerte $(942 \mathrm{~F})^{50}$. Más adelante dice que las almas nobles pasan un tiempo en la zona más suave del aire a la que se denomina "las praderas del Hades" para librarlas de las impurezas del cuerpo (943C-D) ${ }^{51}$. Algunas de ellas no consiguen superar esa fase intermedia y son rechazadas. Otras, en cambio, logran llegar a la luna y son tocadas como vencedoras con coronas de plumas que se llaman coronas de la rectitud porque esas almas lograron someter y adiestrar su parte irracional en vida. El premio supremo

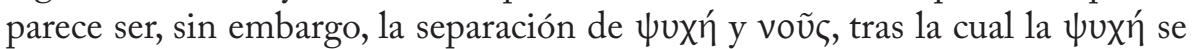
disuelve en la luna y el voũ alcanza el sol $(944 \mathrm{E})^{52}$.

La idea de la estancia feliz en la pradera, probablemente de raigambre indoeuropa, es frecuente en la escatología griega desde Homero y tiene gran fuerza en los órficos y, por supuesto, en Platón ${ }^{53}$. En cuanto a la corona tenemos ejemplos desde Píndaro en que las almas de los bienaventurados se adornan con coronas en el Más Allá como símbolo de victoria sobre la muerte ${ }^{54}$. Plutarco menciona también la pradera y corona en relación con la suerte de las almas bienaventuradas en el fr. 178 Sandbach, al que ya nos hemos referido a propósito de los castigos. Leemos allí que el iniciado disfruta de un destino feliz entre hombres purificados de su misma condición. El rasgo que define esa condición es haber participado en los misterios. Una luz asombrosa, lugares puros y praderas acogen al iniciado que llega purificado y coronado. La corona, además de simbolizar el triunfo sobre la muerte, le sirve al difunto de seña de identidad que lo identifica como iniciado, frente al resto de muertos profanos ${ }^{55}$.

Plutarco se refiere también a los premios en el Hades en un pasaje de la Comparación entre Cimón y Lúculo (1.2). Allí se hace eco de un texto de la República, al que antes nos referimos, en el que se afirma irónicamente que una corona y un estado de embriaguez sempieterna son las recompensas

Jiménez 1991; A. Barigazzi 1994; S.-T. Teodorsson 1994; R. Aguilar 1996a: 290-292; A. Pérez Jiménez 1998; H. G. Ingenkamp 2001: 133-135; A. Pérez Jiménez 2002; I. Gallo 2003-2004: 204-206; A. PÉrez Jiménez 2011.

${ }^{50}$ Sobre la segunda muerte, cf. G. Soury 1942: 196-203; Y. Vernière 1977: 213-214; A. Pérez Jiménez 1993: 10-11; S.-T. Teodorsson 1994: 116-117; A. Pérez Jiménez 1998: 285, 290-294.

${ }^{51}$ Cf. G. Soury 1942: 187-188; R. Aguilar 1981: 54-57.

${ }^{52}$ Cf. R. Aguilar 1981: 69-70; A. PÉrez-Jiménez 2002: 469-478.

${ }^{53}$ Od. 11.539, 24. 3-14; P1. R. 616b, Grg. 523e-524a. En varias laminillas órficas datadas en el s. IV a.C. (Orph. Fr. 487, 5-6; Orph. Fr. 493) el destino final de los iniciados son las praderas de Perséfone, cf. A. Bernabé; A. I. Jiménez San Cristóbal 2008: 174-177. Sobre la pradera en la tradición indoeuropea, cf. M. H. Velasco López 2001.

${ }^{54}$ Cito algunos ejemplos distantes en el tiempo: Pi. O.2.74ss, P1. R. 363c, Ar. fr. 504, 6 K-A, laminilla órfica de Turios (Orph. Fr. 488, 6, s. IV a. C.), Suppl. Hell 980, Verg. Aen. 6.665. cf. A. Bernabé; A. I. Jiménez San Cristóbal 2008: 124.

55 Sobre la coronación de las almas en Plutarco, véase también G. Soury 1942: 189. 
prometidas a los iniciados órficos y dionísiacos ${ }^{56}$. Platón utiliza la metáfora de la borrachera eterna para poner de manifiesto la absurdidad, en su opinión, de prácticas rituales en que el vino, símbolo de Dioniso, tiene vital importancia en vida y tras la muerte. Plutarco con su comentario supo captar perfectamente la ironía del filósofo ateniense: si el iniciado órfico aspira a la comunión con Dioniso, dios del vino, qué mejor manera de lograrla que la embriaguez eterna en un banquete junto al resto de iniciados.

\section{Conclusiones}

Plutarco asume el postulado de que el comportamiento de los hombres en vida condiciona el destino del alma tras la muerte. La conducta puede valorarse atendiendo a criterios morales, jurídicos y racionales o bien de acuerdo con parámetros estrictamente religiosos, como estar iniciado o no. En la pintura escatológica se advierten trazos de raigambre platónica, junto a imágenes tomadas de cultos mistéricos, pero sin que Plutarco renuncie a su propio aporte original, como la legitimidad de los jueces, la topografía lunar-celeste, la clasificación de las almas o las lagunas de metal.

El alma ha de someterse al veredicto de Éaco, Minos y Radamantis, que determinan si han de ser premiadas o condenadas. El dictamen queda garantizado por las virtudes éticas de los propios jueces y por la ecuanimidad que les confiere el hecho de juzgar en el Hades y ser inmunes, por tanto, a intereses crematísticos. Las almas se distinguen fundamentalmente por su tonalidad y por su movimiento. Las condenadas son clasificadas por colores según la gravedad de sus delitos. Divinidades vengadoras las someten a penas diversas para purificarlas, aunque algunas son incurables y quedan aprisionadas para siempre. Otras son sumergidas en lagunas de oro, plomo y hierro, imagen que recuerda los métodos alquímicos recogidos en escritos gnósticos. En la mayoría de los casos el alma tiene un papel pasivo, es decir, es receptora de los castigos y marcas que la identifican como culpable. En general, Plutarco se aleja del lado violento que el castigo tiene en las descripciones platónicas y opta por una visión contundente pero aséptica de las almas condenadas. Sí se hace eco, en cambio, de elementos como la corona y la pradera, que son recurrentes en la imaginería tradicional que describe la bienaventuranza de las almas justas, y que sitúa en la fase inmediatamente anterior al premio supremo que parece ser la disolución de la $\psi u x \eta ́$ en la luna y la llegada del voũ

En definitiva, los mitos que Plutarco idea para exponer su visión de la existencia postmortem logran fusionar perfectamente concepciones escatológicas

${ }^{56}$ P1. R. 363c-d. F. CAsadesús 1999 ha analizado el pasaje platónico y el texto de Plutarco. Véase también A. Bernabé 1996: 67. 
platónicas con elementos procedentes de la propia experiencia iniciática de su autor. La filosofía no cede su espacio, pues se apela constantemente a las virtudes morales y éticas del alma, pero convive con prácticas y creencias religiosas. En este sentido la amalgama plutarquea recuerda la que encontramos en el Papiro de Bolonia, datado en los ss. II/ III d. C., aunque también se ha vinculado con el ambiente judaico del helenismo alejandrino ${ }^{57}$. El papiro refleja la creencia en que tras la muerte del cuerpo el alma es guiada al Hades, donde se la juzga y obtiene un destino en consonancia a su comportamiento en vida. La geografía infernal del papiro y la concepción de un Hades dual con premios y castigos coinciden con la imaginería de los cultos mistéricos. Sin embargo, los condicionamientos éticos requeridos para alcanzar el destino dichoso apuntan a un ideario que desdeña la concepción puramente ritualista. No podemos entrar ahora en el análisis del texto del papiro pero los paralelismos entre la escatología plutarquea y el itinerario infernal, las categorías de almas y los castigos allí descritos merecerían una comparación más detallada.

${ }^{57}$ Editan el texto O.Montevecchi; G. B. Pighi 1947; R. Merkelbach 1951; A. Vogliano 1952; O. Montevecchi 1953: nr. 4; H. Lloyd-Jones; P. J. Parsons 1978 y A. Bernabé 2007, OF 717, con bibliografía. Véanse también los detallados análisis de A. SETAioli 1970, 1972, y 1973. 


\section{Bibliografía}

Adam, H., Plutarchs Schrift non posse suaviter vivi secundum Epicurum. Eine Interpretation, Amsterdam, 1974.

Aguilar, R., La noción del alma personal en Plutarco, Madrid, 1981.

Aguilar, R., "El vuelo del ama”, Fortunatae, 5, 1993: 11-25.

Aguilar, R., Obras morales y de costumbres. Moralia VIII, Madrid, 1996. (1996).

Aguilar, R., "Elementos religiosos en los mitos de Plutarco", in Gallo, I. (ed.), 1996: 285-295. (1996a).

Aguilar, R., "La visión del mundo según las revelaciones. De Sera, 563f-568a

y De genio, 589f-592e", in Frazier, F.; Leão, D. F. (edd.), Tychè et Pronoia. La marche du monde selon Plutarque, Coimbra, 2010: 3-12.

Albini, F., Plutarco. Non posse suaviter vivi secundum Epicurum. Introduzione, Traduzione, Commento, Genova, 1993.

Barigazzi, A., "L'arresto della freccia del tempo (De facie in orbe lunae 941A ss.)", in García Valdés, M. (ed.), 1994: 57-69.

Bernabé, A., "Plutarco e lorfismo", in Gallo, I. (ed.), 1996: 63-104.

Bernabé, A., "Platone e l'orfismo", in Sfameni Gasparro, G. (ed.), Destino e salvezza: tra culti pagani e gnosi cristiana. Itinerari storico-religiosi sulle orme di Ugo Bianchi, Cosenza, 1998: 37-97.

Bernabé, A., "La experiencia iniciática en Plutarco", in Pérez Jiménez, A.; Casadesús, F. (edd.), 2001: 5-22.

Bernabé, A., "Los terrores del más allá en el mundo griego. La respuesta órfica", in Díez de Velasco, F. (ed.), Miedo y religión, Madrid, 2002: 321-329.

Bernabé, A., Poetae Epici Graeci Testimonia et Fragmenta, Pars II Orphicorum et Orphicis similium Testimonia et Fragmenta, Fasciculus 3, Berolini, Novi Eboraci, 2007.

Bernabé, A., Platón y el orfismo. Diálogos entre religión y filosofía, Madrid, 2011.

Bernabé, A., Jiménez San Cristóbal, A. I., Instructions for the Netherworld. The Orphic Gold Tablets, ed. revised and enlarged, Leiden, Boston, Köln, 2008.

Bescond, L., "La doctrine eschatologique dans le mythe du Gorgias", in Dumond, P.; Bescond, L. (edd.), Politique dans l'Antiquite, Lille, 1986: 67-87. 
Boulogne, J., “L'enfer ouranien de Plutarque”, in Thomas, J. (ed.), L’imaginaire religieux gréco-romain, Perpignan, 1994: 217-234.

Boulogne, J., "Les couleurs du ciel ou la réécriture par Plutarque des mythes escathologiques de Platon", Euphrosyne, 27, 1999: 17-29.

Boulogne, J., "Plutarque et l'hermétisme", in Ribeiro Ferreira, J.; Van der Stockt, L.; CÉu Fialho, M. (edd.), Philosophy in Society. Virtues and Values in Plutarch, Leuven, Coimbra, 2008: 53-64.

Brenk, F., In Mist Apparelled. Religious Themes in Plutarch's Moralia and Lives, Leiden, 1977.

Brenk, F., "Demonology in the Early Imperial Period", ANRW II, 16,3. Berlin, New York, 1986: 2068-2145.

Brenk, F., "An Imperial Heritage: The Religious Spirit of Plutarch of Chaironeia", ANRW II, 36, 1, Berlin, New York, 1987: 249-349.

Brenk, F., "The Origin and the Return of the Soul in Plutarch", in García VALDÉs, M. (ed.), 1994: 3-24.

Casade sús, F., "La borrachera eterna como premio. El testimonio de Plutarco", in Montes Cala, J. G.; Sánchez Ortiz de Landaluce, M.; Gallé Cejudo, R. J. (edd.), 1999: 161-170.

Coelho, E., Los jueces infernales en la literatura griega, Tesis doctoral inédita, Universidad Complutense, Madrid, 2007.

Culianu, I. P., Psychanodia. A Survey of the Evidence Concerning the Ascension of the Soul and its Relevance, Leiden, 1983.

Cumont, F., Recherches sur le symbolisme funeraire des Romains, Paris, 1966.

Dalfen, J., "Platons Jenseitsmythen: Eine 'neue Mythologie'?", in Janka, M.; Schafer, C. (edd.), Platon als Mythologe. Neue Interpretationen zu den Mythen in Platons Dialogen, Stuttgart, 2002: 214-230.

Díez de Velasco, F., "Un problema de delimitación conceptual en Historia de las Religiones: la mística griega”, in Plácido, D.; Alvar, J.; Casillas, J. M.; Fornis, C. (edd.), Imágenes de la Polis, Madrid, 1997: 407-422.

Dodns, E. R., Plato. Gorgias. A Revised Text with Introduction and Commentary, Oxford, 1959.

Donini, P., "Science and Metaphysics: Platonism, Aristotelianism, and Stoicism in Plutarch's On the Face in the Moon", in Dillon, J. M.; Long, A. A., The Question of "Eclecticism". Studies in Later Greek Philosophy, Berkeley, 1988: 126-144. 
Durán López, M. A., "El mito del Gorgias en la Consolatio ad Apollonium”, in García Valdés, M. (ed.), 1994: 643-650.

Durán López, M. A., "Una escena báquica en el mito de Tespesio: contenido y función”, in Montes Cala, J. G.; Sánchez Ortiz de Landaluce, M.; Gallé Cejudo, R. J. (edd.), 1999: 211-219.

Durán López, M. A., "Encrucijadas en el mundo místico de Plutarco", in Pérez Jiménez, A.; Casadesús, F. (edd.), 2001: 99-106.

Frazier, F., "Une relecture du mythe final du Phédon. Le philosophe et son logos", in David, S.; GÉny, E. (edd.), Troikka. Parcours antiques. Mélanges offerts à M. Woronoff, vol. I, Presses Univ. de Franche-Comté, 2007: 189201.

Frazier, F., "Quand Plutarque actualise le mythe d'Er. Delphes, la justice e la providence dans le mythe de Thespésios (De Sera 22. 563B-33. 568A)", in Van der Stock, L.; Titchener, F.; Ingenkamp, H. G.; Pérez Jiménez, A. (edd.), Gods, Daimones, Rituals, Myths and History of Religions in Plutarch's Works. Studies Devoted to Professor Frederick E. Brenk by the International Plutarch Society, Málaga, 2010: 145-162.

Gallo, I., "Funzione e significato dei miti nei dialoghi 'morali' di Plutarco", in López Férez, J. A. (ed.), Mitos en la literatura griega helenistica e imperial, Madrid, 2003-2004: 197-208.

Gallo, I., (ed.), Plutarco e la Religione. Atti del VI Convegno plutarcheo, Ravello, 29-31 maggio 1995, Napoli, 1996.

García López, J.; Morales Ortiz, A., Plutarco. Obras morales y de costumbres XIII. Sobre la música (Pseudo Plutarco). Fragmentos, Madrid, 2004.

García VAldés, M., (ed.), Estudios sobre Plutarco: ideas religiosas. Actas del III Simposio Internacional sobre Plutarco, Oviedo, 30 de abril a 2 de mayo de 1992, Madrid, 1994.

Gómez Cardó, P., "Axíoco", in Platón. Diálogos VII. Dudosos. Apócrifos. Cartas, Madrid, 1992: 389-425.

Hamilton, W., “The Myth in Plutarch's De facie (940F-945D)”, CQ, 28, 1934: 24-30. (1934).

Hamilton, W., "The Myth in Plutarch's De genio (589F-592E)”, CQ, 28, 1934: 175-182. (1934a).

Hani, J., "Le mythe de Timarque chez Plutarque et la structure de l'extase", $R E G, 88,1975: 105-120$. 
Hölnes кamp, K. J., Schiedsrichter, Gesetzgeber und Gesetzgebung im archaischen Griechland, Sttutgart, 1999.

Ingen Kamp, H. G., "Juridical and Non-Juridical Eschatologies and Mysteries", in Pérez Jiménez, A.; Casadesús, F. (edd.), 2001: 131-142.

Jiménez San Cristóbal, A. I., "El concepto de dike en el orfismo", in Alvar Ezquerra, A.; Gónzalez Castro, J. F. (edd.), Actas del XI Congreso Español de Estudios Clásicos, Madrid, I, 2005: 351-361.

Jones, R. M., The Platonism of Plutarch, Chicago, 1916.

Lloyd-Jones, H.; Parsons, P. J., "Iterum de Catabasi Orphica", in Kyklos. Festschrift Keydell, Berlin, 1978: 88-108 (= The Academic Papers of Sir. H. Lloyd-Jones, Oxford, 1990, 333-342).

Marcos Montiel, J. F., Plutarco. Obras morales y de costumbres XII. Tratados antiepicúreos, Madrid, 2004.

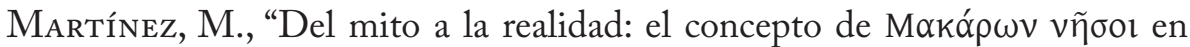
Platón, Aristóteles y Plutarco", in Pérez Jiménez, A.; García López, J.; Aguilar, R. (edd.), 1999: 95-110.

MÉAutis, G., “Le mythe de Timarque”, REA, 1950: 201-211.

Merkelbach, R., "Eine orphische Unterweltsbeschreibung auf Papyrus", $M H, 8,1951: 1-11$.

Montes Cala, J. G.; Sánchez Ortiz de Landaluce, M.; Gallé Cejudo, R. J., (edd.), Plutarco, Dioniso y el vino. Actas del VI Simposio Español sobre Plutarco, Cádiz, 14-16 mayo de 1998, Madrid, 1999.

Montevecchi, O., Papyri Bononienses I, Milano, 1953.

Montevecchi, O.; Pighi, G. B., "Prima ricognizione dei papiri dell'Università di Bologna”, Aegyptus, 27, 1947: 175-183.

Morales Otal, C.; García López, J., Plutarco. Obras morales y de costumbres II, Madrid, 1986.

Pérez Jiménez, A., "Plutarco y el paisaje lunar", in García López, J.; Calderón Dorda, E. (edd.), Estudios sobre Plutarco:paisaje y naturaleza. Actas del II Simposio Español sobre Plutarco, Madrid, 1991: 307-317.

Pérez Jiménez, A., "El viaje sidéreo de las almas”, Fortunatae, 5, 1993: 101123.

Pérez Jiménez, A., "Ciencia, religión y literatura en el mito de Sila de Plutarco", in Brioso, M.; González Ponce, F. J. (edd.), Actitudes literarias en la Grecia romana, Sevilla, 1998: 283-294. 
Pérez Jiménez, A., "Plutarco versus Platón: espacios místicos en el mito de Tespesio”, in Pérez Jiménez, A.; Casadesús, F. (edd.), 2001: 201-210.

Pérez Jiménez, A., "Valores literarios del mito de Sila: anotaciones estilísticas a la antropología de Plu. De facie 943a-943b”, in Torraca, L. (ed.), Scritti in onore di Italo Gallo, Napoli, 2002: 463-478.

Pérez Jiménez, A., "En las redes de xpóvoc. La peregrinación inicial de las almas contaminadas", in Herrero de JÁuregui, M.; Jiménez San Cristóbal, A. I.; Luján Martínez, E. R.; Martín Hernández, R.; Santamaría Álvarez, M. A.; Torallas Tovar, S., Tracing Orpheus, Berlin, Boston, 2011: 205-211.

Pérez Jiménez, A.; Casadesús, F., (edd.), Estudios sobre Plutarco: misticismo y religiones mistéricas en la obra de Plutarco. Actas del VII Simposio español sobre Plutarco, Palma de de Mallorca, 2-4 de noviembre de 2000, Madrid, Málaga, 2001.

Pérez Jiménez, A.; García López, J.; Aguilar, R., (edd.), Plutarco, Platón y Aristóteles. Actas del V Congreso Internacional de la I. P. S., MadridCuenca, 4-7 de mayo de 1999, Madrid, 1999.

Richardson, H., "The Myth of Er (Plato, Republic 616b)", CQ, 20, 1926: $115-131$.

Roskam, R., "Le pari de Plutarque'. Computing pros and cons in the face of death”, in Pérez Jiménez, A.; García López, J.; Aguilar, R. (edd.), 1999: 463-474.

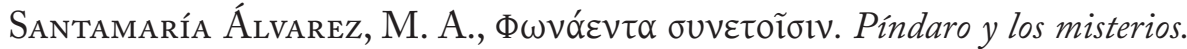
Edición y comentario de la Olimpica segunda, Tesis doctoral inédita, Salamanca, 2003.

Santamaría Álvarez, M. A., "El motivo literario del viaje al Hades en el mito de Tespesio (Ser. num. vind. 563C-568A)”, in Nieto Ibáñez, J.M.; López López, R. (edd.), El amor en Plutarco. IX Simposio Internacional de la Sociedad Española de Plutarquistas, León, 28-30 de septiembre de 2006, León, 2007: 877-887.

Sedley, D., "Myth, punishment and politics in the Gorgias", in Partenie, C. (ed.), Plato's Myths, Cambridge, New York, 2009: 51-76.

Setaioli, A., "Nuove osservazioni sulla 'descrizione dell'oltretomba' nel papiro di Bologna”, SIFC, 42, 1970: 179-224.

Setaioli, A., "L'imagine delle bilance e il giudizio dei morti", SIFC, 44, 1972: $38-54$. 
Setaioli, A., "Ancora a proposito del papiro bolognese n. 4", SIFC, 45, 1973: 124-133.

Sirinelli, J., Plutarque de Chéronée. Un philosophe dans le siècle, Paris, 2000.

Sourvinou-Inwood, C., 'Reading' Greek Death. To the End of the Classical Period, Oxford, 1999.

Soury, G., La démonologie de Plutarque. Essai sur les idées réligieuses et les mythes d'un Platonicien éclectique, Paris, 1942.

Taufer, M., "Er e Tespesio. Plutarco interprete di Plutarco", Lexis, 17, 1999: 303-318.

Taufer, M., Il mito di Tespesio nel De sera numinis vindicta di Plutarco, Napoli, 2010 (non vidi).

Teodorsson, S.-T., "The Psychology of De facie and De virtute morali", in García Valdés, M. (ed.), 1994: 115-122.

Velasco López, M. H., El paisaje del Más Allá. El tema del prado verde en la escatología indoeuropea, Valladolid, 2001.

Vernière, Y., "Le Léthé de Plutarque”, REA, 66, 1964: 22-32.

Vernière, Y., Symboles et mythes dans la pensée de Plutarque. Essai d'interprétation philosophique et religieuse des Moralia, Paris, 1977.

Vernière, Y., "Initiation et eschatologie chez Plutarque”, in Ries, J. (ed.), Les rites d'initiation, Louvain-La-Neuve, 1986: 335-352.

Vogliano, A., "Il papiro bolognese Nr. 3", Acme, 5, 1952: 385-417.

Wiener, C., "Kurskorrektur auf der Jenseitsfahrt. Plutarchs ThespesiosMythos und Kolotes' Kritik an Platons Politeia", WJA, 28, 2004: 49-63. 


\section{INDEX LOCORVM}

ADESPOTA TRAGICA

fr. $421 \mathrm{~K} .: 173$

Aelianus

De natura animalium

6.61: 56

Aeschines (Orator)

1.13: 57

1.28: 57

Aeschylus

Agamemnon

521: 87 n. 1

1432: 248 n. 31

Choephoroe

947: 248 n. 31

Eumenides

510: 248 n. 31

Persae

400: 87 n. 1

Prometheus

936: 248 n. 31

Fragmenta (ed. Radt)

175: 185

Alcinous

Didask. 29.182 .32 ss.: 142 n. 19

Alcman

fr. 105 Calame: 165

Anaxagoras (fr. D-K)

72A 5: 173 n. 26

AnAXarchus: 165
Anaximander

Fragmenta Diels-Kranz

1: 217 n. 11

12A 10 D-K: 87

Anaximenes

fr. 13B 2 Diels: 87

Apuleius

De Platone 2.7: 142 n. 19

Aristophanes

Acharnians

524-527: 29 n. 25

530: 28 n. 22

Birds

1331: 87 n. 1

Clouds

858-859: 32 n. 38

914: 88 n. 3

Frogs: 247 n. 28

Pax

605: 31 n. 34

Fragmenta (ed. Kassel-Austin)

504.6: 252 n. 54

Aristo Chius

Fragmenta West

20: 45

Aristotle: 26, 71 n. 11,95 n. 16, 143, 154 and n. 4, 155, 205

De anima: 251

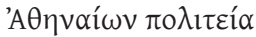

9.63-68: 33 n. 44

21-22: 45

22.7: 48 n. 19 
23.3: 45

26.3: 59

27.4: 28 n. 18

52.2: 61 n. 20

55.3: 57

56.6: 56

De caelo

280a 21: 88 n. 2

Ethica Eudemia

1234a 31: 144 n. 35

Ethica Nicomachea: 116 n. 29, 142, 143

n. 22,183

1094b: 155

1103b: 44

1114b: 44

1124a: 88 n. 3

1129a 5: 25 n. 6

1129a 32: 143 n. 31,144 n. 36

1129a 32-1129b 10: 146

1129a 33 ss.: 143 n. 32

1129b: 159

1129b 26-31: 143 n. 24

1130a 3: 143 n. 27

1130a 26: 143 n. 31

1132 b 21 ss.: 246 n. 17

1133b 30: 143 n. 25

1133b 32-33: 143 n. 26,146

1134a 31-32: 143 n. 27

1134b: 157 n. 14

1134b 5: 143 n. 27

1135a 16: 143 n. 25

1136a 4: 143 n. 25

1136a 19: 143 n. 25

1172b 24: 143 n. 25

1173a 21: 143 n. 25

Magna moralia

1182a 11: 142

1185b 6-8: 144 n. 36, 146 n. 41

Metaphysica: 183

Meteorologica

339a 20: 88 n. 2

De mundo

401b: 163 n. 6

Politica

1253a 16: 25

1253a 29-30: 143 n. 27

1253a 37: 164 n. 9

1255b 10: 143 n. 30

1256b-1274a: 33 n. 44

1275b: 59

1283a 38-40: 143 n. 29

1284a: 48 n. 18

1289b 29: 144 n. 36
Rhetorica

1357b 27-30: 89 n. 8

1360b 24: 26 n. 10

1366b: 26

1366b 9-10: 25 n. 6

1367a 17-22: 31 n. 36

1373d: 157 n. 14

1375a: 159

De virtutibus et vitiis

1250b 24: 144 and n. 35

1251a 33-34: 144 n. 36

Fragmenta (ed. Rose)

539: 15 n. $35,122,128$

Aspasius

In Ethica Nicomachea comm.

40.9: 145 n. 37

139.26: 145 n. 37

Athenaeus

4.65: 58

Aulus Gellius

Noctes Atticae

20.8: 123 n. 9

BibLE

Ev. Matt. 16.26: 88 n. 2

Cassius Dio

65.3: 97 n. 18

Cebes: 163

Chrysippus

On the Gods: 166, 172

Fr. 1009 SVF: 224

Cicero

De divinatione

18.42: 76

De Inventione

3.6: 157 n. 16

De natura deorum

3.91: 77 n. 30

Leges

1.6.18-19: 154 n. 6

1.60: 156

Republic

3.6: 157 n. 16

3.22, 33: 154 n. 6

Clearchus (Historicus): 247 n. 28 
CRITIAS: 74, 76, 77

fr. 19 Snell: 74 n. 23, 78, 183

CYPRLA: 185

Demosthenes (orator)

24.103: 56

57.32: 58 n. 10

60.36: 88 n. 3

Diodorus Siculus

7.12: 78 n. 36

12.39.3: 31

Diogenes Laertius

1.55: 56

6.101: 247 n. 28

7.131: 155 n. 9

7.139: 88 n. 2

8.35: 246 n. 17

Dionysius of Halicarnassus

2.61.2: 78

8.48: 87

Duris of Samos

FGrHist. 76 F65: 29 n. 24

Empedocles: 161, 211, 232

fr. 134 Diels: 87

EpHoRus

FGrHist. 70F 193: 32 n. 38

FGrHist. 70F 149: 78 n. 36

Epicurus: 95 n. 16, 143

Ep. 2.37: 88 n. 2

Ep. ad Men. 123 ss.: 185

Ep. ad Men. 127.8: 186 n. 14

R.S. 31: 143

R.S. 33: 143 n. 32

fr. 531 Usener: 143 n. 32

EURIPIDES

Cyclops

104: 186

Iphigenia Aulidensis

524: 186

1362: 186

Iphigenia Taurica

468: 177 n. 35

Medea

1389: 248 n. 31
Fragmenta

979 Kannich.: 122 n. 6, 173

Galen

Anim. Pass. 5.11 K: 156 n. 13

De propriorum animi... 1.9.13: $149 \mathrm{n}$. 52

Heraclides Ponticus: 247 n. 28

Heraclitus: 172, 217

Fragmenta Diels-Kranz

30: 87 n. 2

80: 217 n. 12

94: 167 and n. 17, 195-196

Hermogenes

ap. Stobaeus 1.49.44: 88 n. 2

Herodotus: 76,174 n. 30

1.65: 87 n. 1

2.52: 87 n. 1

7.36: 87 n. 1

7.163-166: 141 n. 14

8.60: 88 n. 3

8.77: 141 n. 12

8.79.1: 49

8.86: 87 n. 1

8.142: 88 n. 3

9.59: 87 n. 1

9.66: 87 n. 1

Hesiod: 71 n. 10, 121, 153 n. 3, 161, 215

Opera et Dies: 123 n. 9, 141, 217

30-32: 217 n. 8

122: 111 n. 7

197 ss.: 170 and n. 21

217-224: 141 n. 9

240: 154

255-256: 139 n. 5

256: 157,173 and n. 27

256-262: 141 n. 9

270-272: 154 n. 7

275: 141 n. 10

279-280: 141 n. 9

286 ss.: 44

287-288: 146

289 ss.: 43

724-726: 128

Theogony: 217

900 ss.: 166,174

901-902: 23

902: 139 n. 5

903: 217 n. 8 
Index locorum

'Homer'

Iliad

1.238 ss.: 140 n. 7

2.214: 87 n. 1,88 n. 3

2.278: 192 n. 2

2.728: 192 n. 2

2.623: 193 n. 3

2.786: 193

2.862: 193 n. 3

3.16: 193 n. 3

3.27: 193 n. 3

3.30: 193 n. 3

3.58: 193 n. 3

3.450: 193 n. 3

4.253: 193

5.333: 192 n. 2

5.345: 193

5.353: 193

5.368: 193

5.639: 193

5.759: 88 n. 3

5.778: 198 n. 12

6.290: 193 n. 3

6.332: 193 n. 3

6.517: 193 n. 3

7.59: 198 n. 12

7.228: 193

8.12: 88 n. 3

8.128: 192

8.179: 88 n. 3

8.198: 170

8.312: 192

8.372: 192 n. 2

9: 217 n. 9

10.274: 198 n. 12

10.363: 192 n. 2

10.472: 87 n. 1

11.195: 193

11.581: 193 n. 3

12.60: 192

12.94: 193 n. 3

12.210: 192

12.225: 87 n. 1

13.121: 170 n. 21

13.725: 192

13.774: 193 n. 3

15.77: 192 n. 2

15.87: 139 n. 4

15.93: 139 n. 4

15.168: 193

15.200: 193

15.430: 193

16: 196

16.148-154: 196-197
16.387-388: 140

16.388: 216 n. 7

16.466-469: 197 n. 7

16.542: 216 n. 7

16.604: 192

16.790: 195

16.791-804: 195

16.806-821: 195

16.849: 195

16.853: 195

16.859: 195

17.281: 193

17.494: 193 n. 3

17.534: 193 n. 3

18.166: 193

18.183: 193

18.196: 193

18.502-506: 153

18.508: 153 n. 1,216 n. 7

19.180: 216 n. 7

19.327: 193 n. 3

19.350: 198 n. 12

19.400-423: 194-195

20.5: 139 n. 4

20.152: 192 n. 2

20.384: 192 n. 2

21.550: 192 n. 2

22.359-360: 196

22.455: 192

23.542: 216 n. 7

24.72: 192

24.95: 193

24.108: 192 n. 2

24.217: 193 n. 3

24.299: 193 n. 3

24.372: 193 n. 3

24.386: 193 n. 3

24.405: 193 n. 3

24.483: 193 n. 3

24.552: 193 n. 3

24.634: 193 n. 3

24.659: 193 n. 3

24.763: 193 n. 3

24.786: 192

Odyssey

1.113: 193 n. 3

1.320: 198 n. 12

2.68: 139 n. 4

3.138: 88 n. 3

3.244: 216 n. 7

3.343: 193 n. 3

3.372: 198 n. 12

4.563: 246 n. 21 
4.628: 193 n. 3

4.691: 216 n. 7

4.724: 193

4.814: 193

6.7: 193 n. 3

7.231: 193 n. 3

8.3: 192

8.179: 87 n. 1

9.106: 140

9.112: 141

9.215: 216 n. 7

9.274: 140

9.504-530: 192

10.135-399: 181

10.205: 193 n. 3

10.387: 193

10.436: 192

11: 247 n. 28

11.218: 216 n. 7

11.267: 193

11.539: 252 n. 53

11.568: 122

11.568-571: 244 n. 9

11.570: 216 n. 7

12.37-141: 191

12.142: 181

13.77: 87 n. 1

14.59: 216 n. 7

14.84: 216 n. 7

14.173: 193 n. 3

14.447: 192

15.271: 193 n. 3

15.508: 193 n. 3

16.20: 193 n. 3

16.442: 192

17.151: 193 n. 3

17.328: 193 n. 3

17.391: 193 n. 3

18.275: 216 n. 7

18.356: 192

19.43: 216 n. 7

19.168: 216 n. 7

19.178-179: 121

19.179: 244

20.350: 193 n. 3

20.363: 193 n. 3

21.186: 193 n. 3

21.277: 193 n. 3

22.240: 198 n. 12

22.283: 192

24: 247 n. 28

24.3-14: 252 n. 53

24.119: 192

24.255: 216 n. 7
Hyperides (Orator)

Against Athenogenes

10.11-16: 60

IAMBLICHUS

VP 9.46: 164 n. 9

VP 179: 74 n. 22

VP 30. 172: 142

VP 86: 246 n. 17

VP 155: 246 n. 17

VP 179: 246 n. 17

INSCRIPTIONS

Inscriptiones Creticae

IV.41.I 1-7: 62

IV.41.I 12-17 - II 2: 62

IV.47.1-8: 62

IG Rom. 4.982: 88 n. 2

OGI 458.40: 88 n. 2

$S I G$ 814.31: 88 n. 2

ISOCRATES: $71 \mathrm{n} .11$

4.179: 88 n. 2

8.32: 57

Busiris 24.25: 74

Nicocles 9: 203

LAW OF THE TWELVE TABLETS: 62

VIII.6: 62 n. 22

XII 2b: 62 n. 22

Libanius

Declamationes

11.1, 14: 56

Livy: 13

1.18-21: 78

45.32.11: 236

Lysias (Orator)

10.19: 61

Orphic Fragments (ed. Bernabé)

14: 173 n. 25

32-33: 173 ก. 25

433 I: 245 nn. 12,17

445: 244

460: 244

474-484a: 246 n. 20

485-486: 177 n. 35

487.5-6: 252 n. 53

488.6: 252 n. 54

493: 252 n. 53

1076 I: 244 n. 9 
Orphic Hymns: 161-178

61-64: 161,170

64: 165

Parmenides: 87, 161, 217

Fragmenta Diels-Kranz

1: 217 n. 13

8: 217 n. 13

Pherecrates (Comicus)

fr. 145 CAF: 164 n. 8

Philolaus (philosopher)

21: 87

Phocylides: 141 n. 14

Pindar: 141, 217, 227 n. 61, 240, 245, 252

Olympian odes

2.58-60: 244

2.74 ss.: 252 n. 54

13.6-11: 141 n. 12

Pythian odes

3.82: 87 n. 1

Fragmenta (ed. Maehler)

57: 141 n. 12,237 n. 95

129: 243

169: 165

169a: 157

213: 218 n. 16

Pitagoras: 142, 246

Plato: passim

Euthyphro

12c 10-12e 8: 142 n. 21

Apologia Socratis

41a: 244 n. 9

Crito

50d: 57

53c 7: 142 n. 17

Phaedo: 92, 109, 114, 248 n. 33

68d-69e: 186 n. 14

69c: 250,251 n. 48

$69 \mathrm{~d}: 251$ n. 47

78c-e: 228 n. 68

107d: 113

108a: 93 n. 14

109b-e: 113

113d: 113,114 n. 16

113d-114b: 248

117d: 116 n. 27
Theaetetus

145e 6: 142

Politicus: 17

277d 1-2: 89 n. 8

294a-b: 226 n. 59

296d-e: 155 n. 10

297d: 155

Symposium: 92

180d-182a: 93

187d-e: 93

188c: 93

190e: 93 n. 14

202d-e: 113

209a: 26

Phaedrus: 92, 104

246a-248b: 113

247b: 250

248a: 113

254a: 104 n. 8

254a-d: 186 n. 14

275d-276a: 226 n. 59

Laches

196d-e: 186 n. 14

Protagoras

300c: 44

320c-322d: 25 n. 7

323a 5-7 ss.: 141 n. 15

337d: 223 n. 38

Gorgias: 223, 226, 244, 245, 246

464b-465e: 78

472e: 25 n. 7

482c-486d: 223 n. 38

482e-483d: 44

482e 5: 223 n. 38

$493 a-c: 250$

483a 3 ss.: 141,223 n. 38

483c 3 ss.: 144 n. 36

489a: 223 n. 38

493b: 251

504d: 93 n. 14

507c 1-3: 142 n. 21

508a: 88 n. 2

523a-524a: 243,252 n. 53

523b-e: 245

523e-524a: 244

525c: 248 n. 33

526b: 248 n. 33

Meno

90a: 93 n. 14

Respublica: 8, 92, 114, 226

books 1-2: 139 n. 1

book 4: 183

330d: 218 n. 16

330d-332c: 25 n. 7 
331a 4-5: 142 n. 21

331c: 217 n. 16

338e 1 ss.: 142

343c 3: 143 n. 27

343c-e: 44

343 e ss.: 143 n. 29

349b 8-349c 9: 144 n. 36

350d 4 ss.: 142 n. 17

353e 7-8: 142

359a: 218 n. 16

361a 5-361b 1: 147 n. 44

361a 4-5: 147 n. 45

362a: 177 n. 35

363a: 177 n. 35

363c: 252 n. 54

363 c-d: 250,251 n. 48,253 n. 56

$364 \mathrm{~b}: 250$

$364 \mathrm{e}: 250$

365b: 218 n. 16

365d: 218 n. 16

366a: 218 n. 16, 250

367a ss.: 143 n. 29

367c 2-3: 142

380b 2: 218 n. 16

389b: 67

389c-d: 74,78

405a-410b: 78

405 c: 218 n. 16

411e: 218 n. 17

413d: 218 n. 17

414d: 75

416d-417b: 34 and n. 51

425d: 218 n. 16

433a: 159

433e: 218 n. 16

434c: 26 n. 7, 159

435a: 26 n. 7

435c: 159

435e: 159

436a-b: 159

445a: 218 n. 16

451a: 248 n. 31

459d-e: 75

464d: 218 n. 16

464e: 218 n. 16

471b: 218 n. 16

474a: 218 n. 16

487e: 79 n. 41,156 n. 11

493a-e: 77

497c-d: 75

499a: 218 n. 16

501e: 156 n. 11

520b: 218 n. 16

529c: 218 n. 16 536b: 218 n. 16

549c: 218 n. 16

558d-559c: 186 n. 14

586b 1: 144 n. 36

591a: 218 n. 16

602b: 75 n. 26

610d: 218 n. 16

614b: 244

614b-621b: 245 n. 11

614c-d: 245

615a: 218 n. 16

615a-b: 248 n. 33

615e: 218 n. 16

616b: 218 n. 16,252 n. 53

617c-d: 111 n. 8

617d-e: 113,116 n. 28

620d-e: 113,116 n. 28

621b: 112 n. 10

Timaeus: 96, 113, 114, 115, 217, 231, 233, 238

27a: 88 n. 2

28a: 238

28c: 211 n. 18

30b: 115 n. 22

31a: 115 n. 22

37c: 72 n. 12

41c: 217 n. 15

42b: 217 n. 15

48a: 211

53b: 232

69c: 115 n. 22

70a: 115 n. 22

90a: $112-113$ n. 13

Minos

318e-319f: 121

319c: 121,122

319d: 122

Leges: 7, 15, 75 n. 25, 92, 233

614a-b: 121

630e: 155 n. 8

631c: 42

644c-d: 226 n. 59

645a-b: 226 n. 59

704d-707c: 186 n. 14

711E: 79 n. 41

712a: 156 n. 11,204

715b: 10 n. 18

715e 7-716a 3: 139 n. 6

716a: 173 and n. 25,228 n. 68

718e 5-719a 2: 146

760c: 127 n. 18

774a: 56

875a: 226 n. 59

875c-d: 226 n. 59 
889e: 223 n. 38

906c 3: 144 n. 36

936d: 61

936e: 61

959b: 245 n. 12

964b 3-6: 26 n. 10

Epinomis [Dub.]

987b: 88 n. 2

Epistulae

335a: 245 nn. 12, 17

357a: 177 n. 35

Definitiones: 218

416a: 215 n. 2

Plotinus: 114 n. 19, 116-117

3.4.3, 3-4: 116 n. 27

3.4.3, 8-10: 116 n. 28

5.3.7, 25-28: 117

6.6.8, 12-14: 117

6.8.18, 4-7: 117

\section{Plutarch}

Vitae: passim

Theseus: 76

1.3: 76

6.4: 145,147

10.3: 244

15.1: 244 n. 7

16.4: 244

19.5-10: 244 n. 7

25.3: 244 n. 7

Romulus: 6, 76

11.2: 6 n. 2,224

28: 243 n. 2

28.10: 6 nn. 2,3

30(1).5: 145

Comparatio Thesei et Romuli

6.2-3: 18

Lycurgus: $67-80$

2.5: 216 n. 4

3.6: 145

4.3: 78

4.5: 70

5.2: 78

6.5:71

7.2: 76

13: 226 n. 60

13.1: 71

13.1-3: 8 n. 11

14.1: 71,79

15.2: 55

21.1: 71

24.2: 58

28.13: 36 n. 58
29.1: 71,76

29.6: 67

30.5: 156

32.2: 72

Numa: 67-80

3.4: 72 n. 14

3.8: 73

4.2: 67,73 n. 18

4.6: 72

4.7: 69

4.7-8: 69

4.11: 122 n. 4

5.5: 174

5.8: 222

6.2: 228 n. 66

6.3: 166 and n. 14, 174, 222

8.3: 73

8.7: 73 and n. 17

15.1: 73,75

20.4: 36 n. $58,145,222$

20.5: 144 n. 34

20.7: 79

20.9: 156

20.11: 145

20.11-12: 41

22.3-4: 73 n. 19

Comparatio Lycurgi et Numae

4.5: 67

4.9: 8 n. 12

Solon: 55

2.1-3.2: 148

5.4: 148

5.4-5: 5, 143 n. 25,146 n. 43

$5.6: 6$

6.4: 145

14.5: 145,148

15.1-2: 6 n. 1

20.4: 54

20.7: 6 n. 2,223 n. 43

21.2: 6 n. 1

22.1: 56

22.3: 57,158 and n. 21

22.4: 101

23.2: 56

24.3: 60, 62

Publicola

21.7: 145

23.3: 148

24(1).8: 148

Comparatio Solonis et Publicolae 9

39.7: 9 n. 15

Themistocles

1.1: 58

2.2: 45 n. 12 
20.1-2: 46

27.3: 6 n. 2

Camillus

10.5: 11

13.1: 172,173

17.4: 11 and n. 20

18.2: 145

24. $4: 13$ n. 26

36.3: 13

63.1: 216 n. 5

Pericles: $23-38$

2.4.1-2.4.4: 24 n. 3

2.5: 145

2.5.1-9: 24

2.5.5: 23

3.2: 33

4.1-5: 27

4.6-6.1: 27 n. 16

5.1: 35

5.3: 28

6.1: 29

6.2-3: 206-207

6.5: 209

7.1: 28 n. 22

7.2: 28 n. 22

7.3-6: 28 n. 17

8.1: 28 n. 22

8.4: 28 n. 22

8.6: 28 n. 22

9.1: 28

9.3: 28

9.3.2: 25

9.4: 28

10.3: 28

10.4: 28 n. 21

10.6: 30

10.7: 30

10.10.7: 29 n. 26

12.1: 32

12.2: 28,32

12.3: 148

13.15: 28

13.16: 28

14.1: 32

15: 37

15.1: 31

15.3: 32,35

16: 35

16.1: 28

16.3.10: 25,34

16.3.4-5.1: 34 and n. 50

16.7: 149 n. 51,158

18.1: 27

19.3.6: 27
21.1: 27

22.2: 27

22.2-3: 32 n. 37

24.1-2: 32

24.2: 29

25.1: $25,29,31$

25.2-3: 35

28.2: 29

28.6: 31

29.1-2: 32

29.4.5: 25

30.1: 16 n. 38

30.3.2: 25

30.4: 29

32.3.5: 25

32.4.2: 25

32.5: 30

32.5.4: 25

32.6: 30

32.6.2: 25

33.3: 35

33.7.1-8.3: 33 and n. 45

36.9: 30 n. 32

37.3: 59

37.4.3: 25

37.5: 29

38.2: 29

39.1: 29

39.1.1-2.1: 37 and n. 61

Fabius Maximus

2.4: 80 n. 45

4.4-5.1: 70 n. 8

7.2: 80

10.2: 158 n. 21

14.6.2: 25 n. 4

21.3.7: 25

24.9: 158 n. 21

25.4: 223 n. 43

Comparatio Periclis et Fabii Maximi

3.5.1-3.6.5: 36 and n. 54

Alcibiades

8.3: 55

Marcius Coriolanus

1.3: 148

1.4: 145

1.5: 147

15.4: 147

18.5: 216 n. 5

Timoleon

5.1: 145

6.1: 148 n. 48

6.2: 27

6.7: 156 n. 12,158

37.5: 145 
39.7: 9 n. 16

41.1: 145

41(2).1: 145

Aemilius Paullus: 171

22.3: 171 n. 22

28.9: 235 n. 87

29.1: 222 n. 35

30.1: 145

37.1: 145

41(2).8: 148

Comparatio Aemilii Paulli et Timoleontis

2.7: 13 n. 27

Pelopidas

3.2: 149 n. 51

3.4: 149 n. 50

4.4: 148

24.6: 6 n. 2

25.2: 18 n. 48

25.4: 145

26.8: 145,148

Marcellus

1.3: 145

20.1: $49-50$

20.1-2: 148

Aristides: 24, 26, 41-50, 219, 221

1.1: 148

2.1: 44 n. 7

2.2: 144

2.3-4: 45 n. 12

2.6: $45-46$

4.1: 47

5.6: 44

6.1:27

6.1.1-6.3.3: 26 n. 9

6.2: 48

6.3: 147,165 n. $12,219-220$

6.5: $146,147,220$

10.4: 220 n. 26

13: 46

13.2: 18

13.3: 46

22.3-4: 19, 46-47

24.1: 44

24.3: 49 n. 20

25.1-3: 19, 47-50

25.3-9: 44

25.3.4: 32 n. 40

25.3-10: 33

25.7-8: 149

27.1-7: 44

Cato Maior: 41-50

1.5: 49

2.3: 44 n. 7

3.3: 44 n. 9
3.4: 44 n. 7

3.8: 157

4.1: 49

5.1-7: 145

5.2: 49

5.2-7: 147

6.4: 49

12.1: 44 n. 8

23.2: 246

30.3: 157

30(3).1: 145 n. 39

30(3).2: 148

31(4).2: 149

31(4).3: 149

31(4).5: 149

Comparatio Aristidis et Catonis: 41-50

3.3: 32

3.2-4: 44

3-4: 44

Philopoemen

1.3: 147

3.1: 147

12.4, 6: 18 n. 49

12.5: 6 n. 2

18.3: 171 n. 23

Titus Flamininus

1.5: 147

2.5: 145

11.4: 42, 145, 146

12.6: 166,222 n. 35

20.1-2: 147

21.1-2: 147

Comparatio Philopoemenis et Titi

Flaminini

3: 18 n. 49

3.1-3: 19 n. 55

Pyrrbus

8.10: 145

12.3: 149

12.4: 147

12.12: 147

22.3: 27

Marius

10.2: 171 n. 22

12.1-2: 16 n. 37

22.1: 171 n. 22

23.1: 171

28.3-4: 16 n. 40

29.2: 15 n. 36

42.4: 18,19 n. 56,41

42.7: 19 n. 56

43.3: 17 n. 41

46.5: 149 
Lysander

2.6: 148

7.1: 145

7.1-2: 16 n. 39

7.5: 147

30.5: 55

30.6: 145,148

Sulla

8.2-3: 15 n. 34

12.7: 14 n. 31

Comparatio Lysandri et Sullae

1.1: 14 n. 32

1.2: 14 n. 33

2.1: 27

\section{Cimon}

4.1: 58 n. 11

6.5-7: 175 n. 33

14.5: 30 and n. 30

Lucullus

2.4: 10 n. 17

4.1: 145

23.1: 166,222 n. 35

29.6: 145

36.5: 145

Comparatio Cimonis et Luculli

1.2: 243 n. 2,252

Nicias

1.5: 53 n. 3

9.1: 148

Crassus

2.1: 150 n. 53

24.3: 216 n. 5

27.7: 216 n. 5

34(1).2: 150

34(1).4: 149

37(4).3: 150

Comparatio Niciae et Crassi

4.3-4: 18

Eumenes

1.2: 145

8.1: 145

9.1: 145

Sertorius

26.9: 216 n. 5

Agesilaus

23.2-3: 47 n. 15

23.5: 26,43 n. 5

23.8: 145

30.2-6: 18

30.5: 18 n. 49

32.11: 18 n. 49

Pompeius

16.2: 145

54.4: 216 n. 5
Comparatio Agesilai et Pompeii

2.3-4: 18

Alexander

4.7: 145

4.8: 145

21.7: 145

30.10: 145

30.13: 171 n. 22

41.2: 145

52: 173 n. 26

52.5: 79 n. 43

52.7: 227 n. 64

Caesar

14.2-10: 17 n. 44

15.4: 145

33.1: 17 n. 43

35.6: 17 n. 42

Phocion: 50 n. 22

3.7-8: 42

10.7: 145

14.1: 145

19.1: 145

29.5-30.5: 148

30.5: 148

36.1: 145

38.1: 145

Cato Minor

5.2: 145

8: 12

8.4: 12 n. 24

9.9: 145

14.3: 145

16.6: 145

44.12-13: 146

44.14: 144

47.2: 18 n. 50

21: 12

21.10: 12

57.6: 12 n. 25

Agis et Cleomenes

9.3-6: 121-131

10.1: 145

10.2: 145

11.2: 59

21.5: 36 n. 59

30(9)1-5: 11 n. 22

30(9)3: 15 n. 35

Tiberius et Gaius Gracchus

3.1: 145,148

9.2-3: 143 n. 31,144 n. 35,148

20(1).2: 148

20(1).3: 147 n. 46

20(1).6: 149

20(1).7-8: 148 n. 49, 149 
Index locorum

Comparatio Agidis et Cleomenis cum

Tiberio et Gaio Graccho

1.7: 148

Demosthenes

1.2: 27

1.4: 144,146

14.1: 148

Cicero

6.1: 43,145

$6.5: 43$

13.1: 7

13.4: 216 n. 5

28.4: 244

28.5: 244

31.4: 173

52(3).5: 145

Demetrius: 7

1.1: 144

1.4: $26,43,145$

4.5: 144,145

42.8: 7 n. 4

42.9: 140 n. 7

Antonius: $101-106$

10.5-10: 102

11.4: 216 n. 6

13.3: 13 n. 28

25.6: 101,106

26: 104 n. 10

28.1: 102

28.2: 105

30.1-6: 102

31.3: 102

31.5: 102 n. 5

35: 102 n. 4

36.1: 103

36.7: 101

44.5: 171 n. 23

53.9-10: 105

54.1: 103

71-85: 104 n. 10

83.1: 106

Dion: 7 n. 3,235

1.3: 145,146

1.4: 148 n. 47

4.3: 145

7.1: 145

10.2-3: 234

10.4: 146

11.2: 216 n. 6

17.6: 145

24.1-10: 70 n. 8

32.1: 145

47.4: 223

47.5: 145
47.6: 145, 223

47.6.1-7.1: 43 n. 5

47.6-7: 26

47.8: 7 n. 3,223

52.1: 145

52.1-4: 148

52.4: 145

55.2: 167

Brutus: 13-14

2.3: 145

29.3: 145

29.4: 14 n. 30

30.6: 145

32.2: 145

35.3: 14 n. 29

Comparatio Dionis et Bruti

3.6: 14 n. 30

Aratus

10.5: 148

14.4: 148

19.3: 148

46.1: 145

Artaxerxes

23.5: 79 n. 43

Galba

15.3: 216 n. 5

22.7: 149

Otho

1.3: 169

13.5: 216 n. 5

Moralia: passim

De liberis educandis

7E: 11 n. 21, 62

Quomodo adolescens poetas audire debeat 26A: 43 n. 6

32C: 170 n. 21

Quomodo adulator ab amico internoscatur

50E: 147

57C: 150

Quomodo quis suos in virtute sentiat profectus

chap. 10: 203

75C-D: 156 n. 13

75D-F: 158 and n. 19

77D: 43

De capienda ex inimicis utilitate

99E: 158 n. 18

De amicorum multitudine

De fortuna

97E: 144 and n. 34

De virtute et vitio

440F-441A: 156 
Consolatio ad Apollonium

102C: 148

107D-110E: 243 n. 2

119D: 148

120B: 243

120C-E: 243

120E-121D: 243 and n. 2

121A-C: 245

121C-121D: 244

De tuenda sanitate praecepta

132E: 244 n. 7

Conjugalia praecepta 87-89, 97

138D: 54 n. 4

139C: 92 n. 11

140C: 91

140E: 54 n. 4

141E: $88-89,88$ n. 3,216 n. 6

142C: 89 n. 7

145A: 88 n. 3

145E-F: 89-90

Septem sapientium convivium: 7,9

151F: 8 n. 12

151F-152A: 9 n. 14

154E: 7 n. 5,12 n. 23

154F: 7 n. 5

155F: 125

161F: 173

De superstitione: 80 n. 46

164E-165C: 148

165C: 70

165E: 70

165F: 169

168A: 221 n. 31

Regum et imperatorum apophthegmata

175F: 223 n. 43

Apophthegmata Laconica

198B: 235 n. 87

218E: 89

Mulierum virtutes 97 and n. 18

225A: 89 n. 7

227E-F: 89 n. 7

243B-D: 42

257E-258C: 97

259D-260D: 89 n. 7

Aetia Romana et Graeca

268C: 223 n. 43

277A: 169

299A: 244 n. 7

301D: 186

Parallela minora

chap. 38: 171 n. 22

311E: 244

312B: 244

De fortuna Romanorum: 76-77
318A: 166 n. 13

324E-F: 13 n. 26

De Alexandri magni fortuna aut virtute

330D: 79 n. 43

330F: 143 n. 31,144 n. 35

332C: 145

332C-D: 145

332D: 143 n. 31,144 n. 35

333B-C: 148

De Iside et Osiride: 80 n. 46, 225

chaps. 74-76: 198

352A: 164 n. 8

355C: 225 n. 51

369B: 225 n. 49

370D: 167 n. 17

376C: 230 n. 72

378D: 225 n. 51

382A: 199

De defectu oraculorum

413: 170

414F: 114

416C: 225 n. 50

420F-421E: 114

421C: 165 n. 10

426D 9-E 5: 232 n. 77

430E: 216 n. 6,232 n. 76

430E 10-431A 3: 232 n. 77

435E: 225 n. 51

435E-436A: 207-208

436A ss.: 209

436A-B: 209

436D: 209

436E: 208 and n. 12

436F: 225 n. 50

An virtus doceri possit

439B: 158 n. 18

De virtute morali

440F: 144 n. 34

444D: 231

445A: 144 n. 34

451D-E: 144 n. 35

De cohibenda ira

458C: 47 n. 16

463E: 44

De tranquillitate animi: 210

465D: 148

468C-D: 148

475D: 148

De amore prolis

493E: 55

495C: 221 n. 34

De garrulitate

510A: 167, 168, 176

De sera numinis vindicta: 91 n. 9, 162 
and n. $2,169,170,172,174$ n. 30 , $175,176,177,178,220,247$

549A: 174

549B 9: 239 n. 100

549D: $174-175$

549D-550C: 121

549E: 121

550A: 121 and n. 2, 141 n. 12,144 n. $33,164,175,219$

550B: $120-131,237,240$ n. 104, 244

550B-C: 225 n. 52

550C 12-E 2: 233

551C: 158 n. 20

555C: 168 n. 18,175

558F: 175

560A-F: 243 n. 2

561C: 175

563A: 175

563B-568A: 243 n. 2,247

563E: 110

563F-564A: 112 n. 9

564A-E: 248

564C: 115 n. 24

565C: 249

564E-565B: 248

564F: 166, 168, 169, 176

566A-B: 249

566D: 165 n. 10

566E-567D: 249

567C-D: 249

566F: 176

567A: 176

567F: 249

De genio Socratis

575C: 76

579F: 80

580A: 77

580A-B: 80

581F-582C: 110

584E: 148

584F: 149 ก. 52

585F-586A: 114 n. 16

588C-589F: 110

588E-589C: 114 n. 15

589B: 114 n. 15

589F-590B: 110

589F-592E: 243 n. 2,249

590B: 110

590B-592E: 109-117

590F: 110, 249

591A: 111 and n. 7

591B: 111 n. 8

591C: 111,249

591D: 112 n. 10
591D-E: 112 n. 11

591F: 115 n. 26

592A-C: 113,250

592C: 113

593A: 77

593A-594A: 110

593D-594A: 114 n. 16

594A: 114

De exilio

600E: 148

602E: 148,167

604A: 167 n. 17

Consolatio ad uxorem: 87, 91

608C: 91

608F: 91

609E: 91,216 n. 6

609E-F: 148

611D: 251 n. 47

611D ss.: 243 n. 2

Quaestiones convivales

615E-616A: 235

616A: 216 n. 6

618B-C: 237,240 n. 105

618C: 215

635E-638A: 184

643F: 223 n. 43

646D: 216 n. 5

719B: 172

730B: 223 n. 41

Amatorius: 87, 92, 225

750C 4: 224 n. 44

750F: 59 n. 15

752A 4: 224 n. 44

753D: 93,97

755B: 216 n. 4

755D: 93

756B: 225 n. 51

763B 14-C 5: 225 n. 48

764B-765D: 93

766E-F: 94-95

766E-768F: 93

767A: 94

767B: $94-95$

767E-F: 95

767F-768A: 96

768B-D: 97

769A-B: 95 n. 15

769B-C: 42 n. 2

770A: 224

770C: 95 n. 15

770D-771C: 97

Amatoriae narrationes

774B: 168 n. 18 
Maxime cum principibus philosopho esse disserendum: 226,227

776E: 145 n. 38,146 n. 43,244

776E-F: 121 n. 3

777A: 145 n. 38

779B: 226 n. 60

Ad principem ineruditum: 222, 226 and n. $60,234,235$

chap. 5: 203

779D 1: 226 n. 56

779E 12-F 1: 227 n. 63

780C: 7 n. 7, 10 and n. 19, 78, 165, 226 n. 56

780C 5-9: 227

780D: 228 n. 66

780E: 7 and n. 7, 144, 165

780E 4-F 2: 228

780E 4-781A 5: 226 n. 56

780E 7-8: 227 n. 63

780F 5: 227 n. 63

780F: 9 n. 13

780F 3-8: 229

781A: 229 n. 70

781A 10-B 3: 227 n. 64

781B 5-7: 227-228

781B: 140,141 n. $9,163,165,173$ and n. 27

781B 7: 226 n. 56

781E: 157

781 F 8: 227 n. 63

782A 3: 227 n. 63

782D 8: 227 n. 63

An seni respublica gerenda sit

784F 6-7: 225 n. 53

789E: 223 n. 43

790A: 155 n. 9

791D: 146 n. 43

792D: 146 n. 43

796C: 146 n. 42

797A: 44, 50 n. 22

Praecepta gerendae reipublicae

chap. 5: 205

798C: 146,155

798E: 146

799B: 146

800B: 146

800B-C: 41 n. 1

801E: 205

802B: 165 n. 11

805E: 44 n. 7

807B-C: 204-205

807C: 166,222 n. 35, 237, 238 n. 96

808A 9: 7 n. 6

808A 9-B 1: 225 n. 53
808E 11: 225 n. 53

813B-C: 78 n. 34

814A-C: 68

817C-E: 17

817D: 17,47 n. 16

817D 7-9: 225 n. 54

817F: 18 n. 48

818A: 146 n. 43

819E: 173 n. 27

821B: 145 n. 38

823C: 146

823F: 228 n. 66

De unius in republica dominatione, populari statu, et paucorum imperio 826C: 155

827B: 155 n. 9

De Herodoti malignitate

860D: 165 n. 10

Aetia physica (911c-919e)

De facie in orbe lunae: 210, 211 n. 17, 236, 247, 250

chaps. $12-15: 210$

926E: 216 n. 6, 232 n. 78

926F 6-9: 232 n. 79,233 n. 78

927A-B: $210-211$

927B: 237,238 n. 97

927E: 211

928A: 211

935C: 224

940F-945D: 243 n. 2, 251

942D: 243 n. 2,246

942F: 246 n. 21,252

943A 30: 115

943B: 111 n. 7

943C-D: 252

944C: 111 n. 7,114 n. $17,115,246$

n. 21

944E: 252

945C-D: 111 n. 8

945E: 115

De sollertia animalium: 182, 183, 184

964D-E: 158 n. 18

Bruta animalia ratione uti: 181-187, 191-199

978B: 193

986A: 193

986F: 23 n. 1, 181, 192

987C: 192

987F: 186 n. 14, 192

988B-C: 186 n. 14

988D: 192

989C: 186 n. 14

De esu carnium: 184,185

997B: 216 n. 4 
Platonicae quaestiones

1000E: 211 n. 17,238 n. 98

1009A-B: 158 n. 20

De animae procreatione in Timaeo: 233

1014B: 216 n. 6, 231

De Stoicorum repugnantiis

1048E: 158 n. 21

1033A-B: $158-159$ n. 21

1038B: 218 n. 19

1040A ss.: 218 n. 19

1041A-E: 218 n. 19

1043B: 159

1049A: 166, 172, 218 n. 19

1050D 7-12: 218 n. 20

1051A-B: 218 n. 19

1051B: 216 n. 4

1056C: 166

De communibus notitiis adversus Stoicos 1065D 11-12: 239

1065E: 211 n. $17,237,239$ n. 101

1065F: 204

1070E-F: 218 n. 19

Non posse suaviter vivi secundum

$$
\text { Epicurum }
$$

1101C: 168 n. 19

1101D: 70 n. 8

1104A-1107A: 243 n. 2, 246-247

1104B: 247

1104D: 247

Adversus Colotem: 221

1119C: 158 n. 20

1124D: 203

1124F: 172

1125: 203

1125A: 221 n. 32

1125F: 168,176 n. 34

De latenter vivendo: 220

1128F: 70

1129B: 221 n. 29

De libidine et aegritudine

1.10-16: 234-235 n. 85

1.13: 216 n. 6

Parsne an facultas animi sit vita passiva

De Musica

1141D-F: 164 n. 8

Placita Philosophorum

2.1.1: 87

2.1.3: 88 n. 2

879F-880A: 224

Fragmenta (ed. Sandbach)

21: 166

31: 170 n. 21

36: 154
38: 154 n. 7

90: 122-131, 153-159

102: 123 n. 9

177: 243 n. 2

178: 243 n. 2, 250, 252

193: 184 n. 7

201.6: 246

Polyaenus

Strategmata

8.39: 97 n. 17

Polybius

6.8.10: 68

6.56.2-13: 79

9.10: 49 n. 21

10.2.8-10: 75, 78, 80

16.12.9-11: 75

28.1: 235

30.14-15: 235 and n. 86

Porphyry: 184

In Arist. Categ. 4.1.135: 164 n. 9

Proclus: 123 n. 9, 130 n. 27, 174 n. 30

Pythagoras: 87

Seneca

Epistulae

7: 159

7.1-2: 154 n. 4

97.15: 143 n. 32

De bebeficiis

3.18: 158

Seneca-THe-Elder

Suoasoriae

1.6: 103

Simplicius

In Arist. Categ. 8.264: 164 n. 9

Solon: 141, 217

Fragmenta

3.14 D.: 141 n. 11

24 D.: 33 e nn. 46-47

Sophocles

Ajax

190: 185

293: 88 n. 3

1390: 248 n. 31

Antigone: 139 
450 ss.: 153 n. 2

451: 248 n. 31

495-508: 71 n. 10

Philoctetes

417: 185

625: 185

1311: 185

Trachiniae

808: 248 n. 31

Fragmenta

567 Radt: 185

762 Nauck $^{2}: 88$ n. 3,89

Stobaeus

2.7.25: 146 n. 40

45.29: 159

Stoics (von Arnim)

SVF III 174: 159

SVF III 175: 155 n. 9

SVF III 308: 143

SVF III 314: 156

SVF III 315: 154 n. 6

SVF III 658: 156 n. 13

Strabo

10.14.19: 78 n. 36

SUDA

s.v. ¿́́ov : 32 n. 38

Suetonius

Augustus

69.2: 104 n. 9

TAcitus

Historiae

4.67: 97 n. 18

Theognis

145-148: 141 n. 14

Theophrastus: 87

Thucydides: 28 n. 20,29

1.5: 88 n. 3

1.9: 76

1.96: 49 n. 20

1.114.2: 32 n. 37

2.21.1: 32 n. 37

3.108: 87 n. 1

4.76: 87 n. 1

8.48: 87 n. 1

8.67: 87 n. 1
Trasymachus: $141-142$

85 [78]. B 8: 141 n. 15

VS II 326. 14-18 DK: 141 n. 15

VIRGIL

Aeneid

4.125-126: 105 n. 15

4.172: 105 n. 15

4.338-339: 105 n. 15

6: 247 n. 28

6.426-429: 111 and n. 6

6.665: 252 n. 54

8.688: 105

Georgics

1.242-243: 111

VItRUVIUS

6. praef. 3: 57

Xenophon: 71 n. 11

Cyropaedia

6.4.3: 88 n. 3

Hellenica

2.4.41: 60

Memorabilia

1.1.11: 88 n. 2

1.4: 74 n. 22

2.2.13: 57

Respublica Lacedaemoniorum

1.2: 78 n. 36

8.1: 126

8.4: 126,130 
(Página deixada propositadamente em branco) 


\section{Volumes Published in the Collection Humanitas SUPPLEMENTUM}

1. Francisco de Oliveira, Cláudia Teixeira e Paula Barata Dias: Espaços e Paisagens. Antiguidade Clássica e Heranças Contemporâneas. Vol. 1 Linguas e Literaturas. Grécia e Roma (Coimbra, Classica Digitalia/ $\mathrm{CECH}, 2009)$.

2. Francisco de Oliveira, Cláudia Teixeira e Paula Barata Dias: Espaços e Paisagens. Antiguidade Clássica e Heranças Contemporâneas. Vol. 2 Linguas e Literaturas. Idade Média. Renascimento. Recepção (Coimbra, Classica Digitalia/CECH, 2009).

3. Francisco de Oliveira, Jorge de Oliveira e Manuel Patrício: Espaços e Paisagens. Antiguidade Clássica e Heranças Contemporâneas. Vol. 3 História, Arqueologia e Arte (Coimbra, Classica Digitalia/CECH, 2010).

4. Maria Helena da Rocha Pereira, José Ribeiro Ferreira e Francisco de Oliveira (Coords.): Horácio e a sua perenidade (Coimbra, Classica Digitalia/ $\mathrm{CECH}, 2009)$.

5. José Luís Lopes Brandão: Máscaras dos Césares. Teatro e moralidade nas Vidas suetonianas (Coimbra, Classica Digitalia/CECH, 2009).

6. José Ribeiro Ferreira, Delfim Leão, Manuel Tröster and Paula Barata Dias (eds): Symposion and Philanthropia in Plutarch (Coimbra, Classica Digitalia/CECH, 2009).

7. Gabriele Cornelli (Org.): Representações da Cidade Antiga. Categorias bistóricas e discursos filosóficos (Coimbra, Classica Digitalia/CECH/ Grupo Archai, 2010).

8. Maria Cristina de Sousa Pimentel e Nuno Simões Rodrigues (Coords.): Sociedade, poder e cultura no tempo de Ovídio (Coimbra, Classica Digitalia/ $\mathrm{CECH} / \mathrm{CEC} / \mathrm{CH}, 2010)$.

9. Françoise Frazier et Delfim F. Leão (eds.): Tychè et pronoia. La marche du monde selon Plutarque (Coimbra, Classica Digitalia/CECH, École Doctorale 395, ArScAn-THEMAM, 2010).

10. Juan Carlos Iglesias-Zoido, El legado de Tucídides en la cultura occidental (Coimbra, Classica Digitalia/CECH, ARENGA, 2011).

11. Gabriele Cornelli, O pitagorismo como categoria historiográfica (Coimbra, Classica Digitalia/CECH, 2011).

12. Frederico Lourenço, The Lyric Metres of Euripidean Drama (Coimbra, Classica Digitalia/CECH, 2011). 
13. José Augusto Ramos, Maria Cristina de Sousa Pimentel, Maria do Céu Fialho, Nuno Simões Rodrigues (coords.), Paulo de Tarso: Grego e Romano, Judeu e Cristão (Coimbra, Classica Digitalia/CECH, 2012).

14. Carmen Soares, Paula Barata Dias (coords.), Contributos para a bistória da alimentação na antiguidade (Coimbra, Classica Digitalia/CECH, 2012).

15. Carlos A. Martins de Jesus, Claudio Castro Filho, José Ribeiro Ferreira (coords.), Hipólito e Fedra - nos caminhos de um mito (Coimbra, Classica Digitalia/CECH, 2012).

16. José Ribeiro Ferreira, Delfim F. Leão \& Carlos A. Martins de Jesus (eds.), Nomos, Kosmos E'Dike in Plutarch (Coimbra, Classica Digitalia/CECH, 2012). 
IMPRINT:

Simões \& Linhares, Lda.

Av. Fernando Namora, n.o 83 - Loja 4 3000 CoImbra 
(Página deixada propositadamente em branco) 


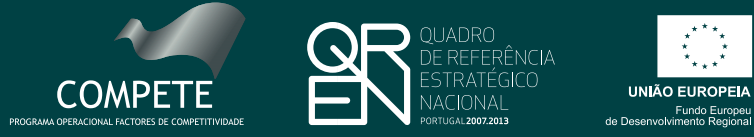

\section{OBRA PUBLICADA \\ COM A COORDENAÇÃO}

CIENTÍFICA

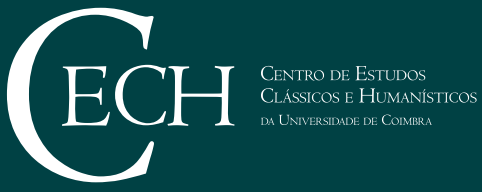

- $\mathbf{U}$

C •

1

IMPREVSA DA LNIERSDADE DE COMBRA

U 